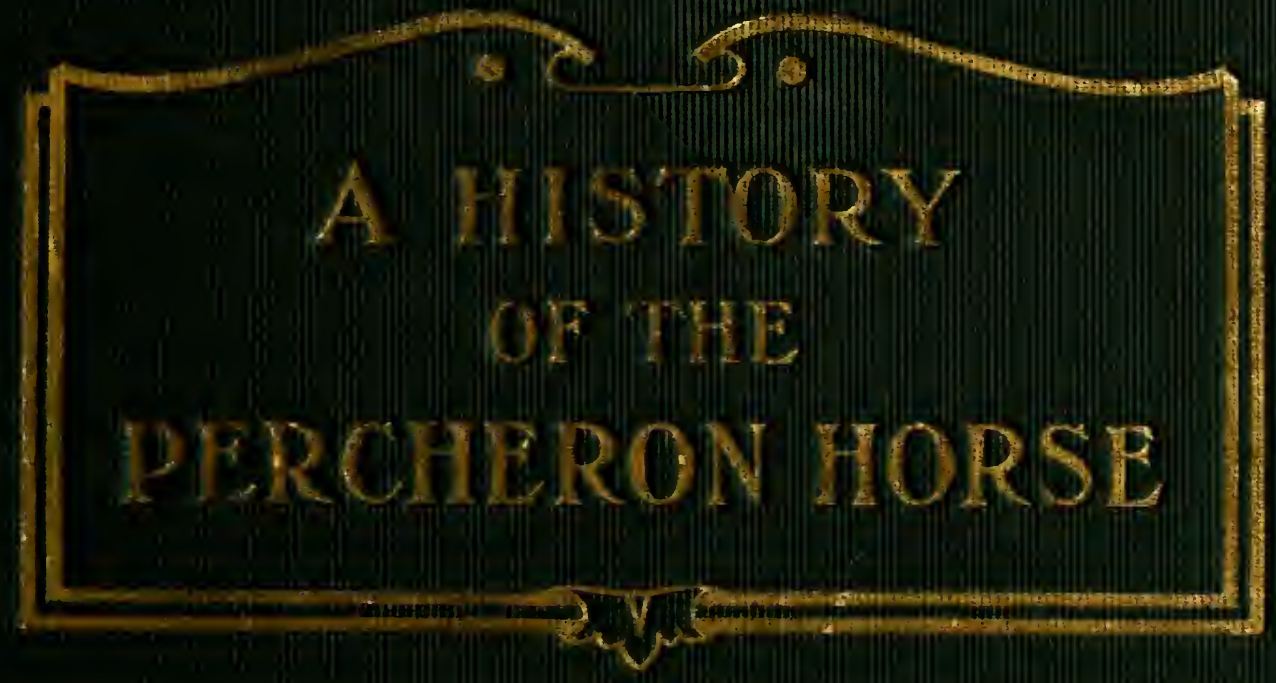

(i) 1 


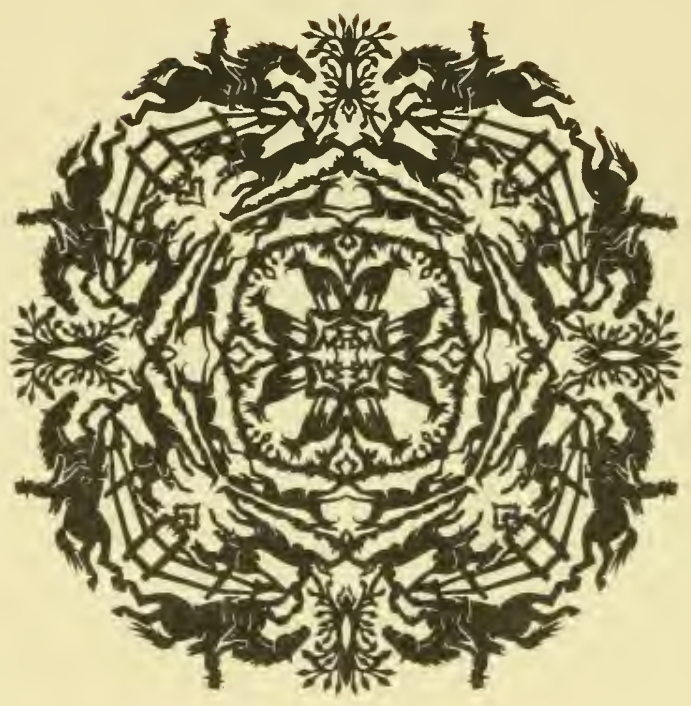

JOHN A.SEAVERNS 
Webster Family Library of Vetennary Medicine Cummings School of Veterinary Medicine at Tufts University 200 Westboro Road North Grafton, MA 01536 


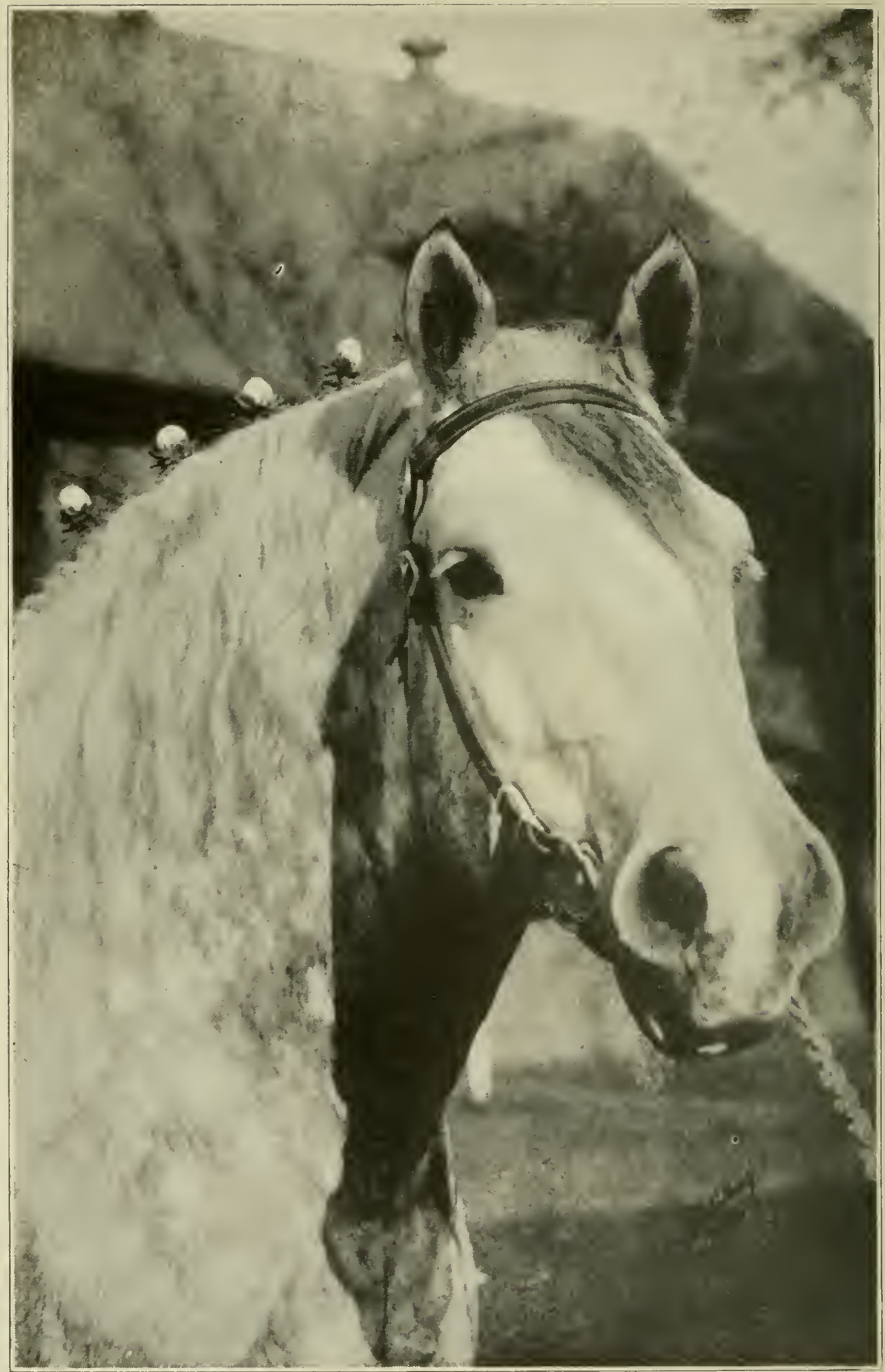

FIRST IN IVAR, FURST IN PEACE AND FIRST IN THE HEARTS OF OUR COUNTRYAIEN. 


\section{A HISTORY OF THE PERCHERON HORSE}

Including hitherto unpublished data concerning the origin and development of the modern type of heavy draft, drawn from authentic documents, records and manuscripts in the national archives of the French Government, together with a detailed account of the introduction and dissemination of the breed throughout the United States, to which is appended a symposium reflecting the views of leading contemporary importers and breeders touching the selection, feeding and general management of stallions, brood mares and foals.

Compiled under the personal direction of

\section{ALVIN HOWARD SANDERS, D. AGR., LL.D.}

Editor "The Breeder's Gazette," author of "Shorthorn Cattle," "At the Sign of the Stock Yard Inn" and "The Story of the Herefords."

In collaboration with

WAYNE DINSMORE, M. S. A. Secretary of the Percheron Society of America. 
COPYRIGHT, 191\%,

SANDERS PUBLISHING CO

All rights reserved. 


\section{PUBLISHER'S ANNOUNGEMENT.}

This volume has been compiled in response to a widespread demand for information touching the origin, evolution, development and distribution of the modern heavy draft type of Percheron horses. It was undertaken originally by Mr. Sanders as individual research work along lines similar to his well-known histories of the Shorthorn and Hereford breeds of cattle, but press of work incidental to the conduct of "The Breeder's Gazette" made it necessary that assistance be secured in tracing the long story beginning with the early days in the Perche, and ending with the Chicago International Live Stock Exposition of 1916.

A determined effort has been made to throw new light upon the foundation history of the type in the Perche itself. Mr. John Ashton, Continental European correspondent of "The Breeder's Gazette," was commissioned by Mr. Sanders to search French agricultural literature from the earliest periods for references to the Pereheron horse, and if possible secure permission from the French anthorities to examine all books, records and documents contained in the Government archives at Paris, including the official entries detailing the registration and inspection of stallions bought for the Government stud at le Pin, together with lists of stallions officially approved and subsidized by the Govermment prior to the Stud Book period for service in the region in which the modern Percheron was evolved.

Fortmately this extensive and painstaking inquiry met 
with the hearty cooperation of French librarians and the Ministry of Agriculture, every facility being extended, even to the point of permission to photograph original entries of great historical importance. The condensed results of months of patient investigation along this line are presented in this rolume; and it is confidently believed that this portion of the work constitutes one of the most valuable contributions made in many years to the history of any of the existing improved breeds of live stock. It is demonstrated that the Percheron horse has existed as a distinct type from very ancient times, and that much that has been accepted-on insufficient evidence-in the past relating to the development of the breed since the beginning of the nineteenth century must now be discarded as mere tradition.

The facts, brought to light here for the first time, seem to contradict flatly the part so long alleged to have been played by Arabian blood in the production of the latterday Percheron; and while this diligent study of old records-apparently never heretofore examined by those assuming to write early Percheron history-may be regarded as destructive to that extent in its operation, the student will not fail to note that in place of what now goes by the board as unsubstantiated there is supplied a complete, constructive, tangible, authentic official set of facts that place underneath the foundations of the Percheron Stud Book of France the solid rock of verified Govermment records, indisputable and convincing. If any doubt has heretofore existed as to when, where and by whom the increase in weight of the Percheron horse was undertaken, such questions need no longer be raised.

This portion of the story should be of absorbing interest to all students of the derelopment of Pereheron types, and represents a sincere and exhaustive effort to get at the 
truth regardless of what the facts might show. Breeders and owner's of Percheron horses not only in America, but in France as well, will no doubt welcome the results of this study.

Mr. Sanders' own personal recollections of the American Percheron trade go back to his boyhood days on an Iowa farm, his father, the late James H. Sanders, having been one of the earliest introducers of the blood in the trans-Mississippi country, and subsequently compiling the initial rolumes of the Percheron Stud Book of America. In the rork of gathering material for the early American period the aid of the late James H. S. Johnstone, author of "The Horse Book', was asked and obtained, many interesting facts relating to the pioneer breeders, importers and equine celebrities of the old days being developed as a result of extended traveling in various parts of the United States.

As the present day was approached the serrices of $\mathrm{Mr}$. Wayne Dinsmore, Secretary of the Percheron Society of America, were invoked, and with the permission of the directors of that organization he utilized the records and the facilities of his office to collect, analyze and arrange a great mass of important and interesting data detailing the wide expansion of Percheron breeding in America during the past forty years.

It will of course be understood that this work is compiled primarily for the benefit of American readers. Consequently the details of French production since the establishment of the Percheron Stud Book of France in 1883 have not been extensively discussed.

The anthors are aware that their work is by no means perfect. Errors of omission and commission are bound to creep into any volume of this sort, involving as it does explorations in new fields, and the handling of an almost 
Dewildering array of names and figures. It has been the intent and purpose throughout, however, to present the facts exactly as found; and if the work shall be regarded as adding somewhat to the general store of knowledge concerning the most popular draft horse type in North America, the compilers and publisher's will be pleased and gratified. 


\section{FOUR CYCLES OF PERCHERON HISTORY.}

The following pen picture covering four distinct periods in the evolution of the breed of which we write, presenting first the famous French "chargers" of the middle ages, their successors on the heary coaches of the ante-railway days, the demands of the plow for a weightier type as the arts of peace advanced, and now the "ton horse" of modern commerce is taken from the sketch of the late Mark W. Dunham, written by Mr. Sanders and published last year in his book "At the Sign of the Stock Yard Inn." It is republished here by request.

"Under a gray old castle's frowning walls a drawbridge falls across the moat. The trumpets sound. A glittering cavalcade emerges. Pennons gay and guidons flutter in the breeze. Steel and silver-corselet, hilt and morionglisten in the morning sun, and noble chargers, mostly white and gray, prance proudly, bearing out into the medieval world brave beited linights and their retainers faring forth to meet what ere betides.

"Generations pass: in the far distance the rhythmic beating of heavy hurrying hoofs! It is a highway builded by the kings of France. To the sound of the horn and the sharp note of the lash, the great diligence bearing the royal mails and laden deep with passengers and their gear comes into view. A rush, a roar of wheels and the great freighted coach is gone.

"Agriculture calls: down the long furrows see the shining plowshares deeply driven. The mellow earth awakens, and lo, the stored up riches of a fertile field await the seed. Long is the journey and repeated oft. From 'early morn to dewy eve' the living shuttles travel, back and forth; but weight that wearies not is harnessed.

"And yet again, last scene of all: a busy modern city street. Huge vans and trucks are rumbling ever on the granite blocks. Big grays and blacks march proudly to the music of a nation's commerce. Power, patience, dignity personified. Glory be to men who can produce such prodigles!" 



\section{TABLE OF GONTENTS.}

CHAPTER I-THE ANCIENT PROVINCE OF THE PERCHE.

Topography of the District-Geological Formation-Water Courses-Climatic Conditions-Ancient History-Fotrou and the Counts of The Perche-Modern Records BeginLive Stock Husbandry Important-Under the "Grand Monarque"-The Eighteenth Century-Long Famous for Its Horses-A People Devoted to Their Own-The

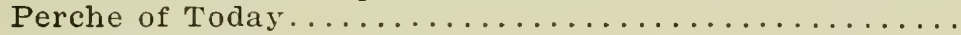

CHAPTER II-PERCHERON PROTOTYPES.

Some of the Fairy Tales-The Saracenic Rout-Mounts of the Crusaders-War Horses of the Middle Ages-The Probable Foundation-Normandy Invades The PercheWhence the Percheron?-The Arabian Tradition-An Historic Discussion- "The Legendary Iradischi"-Modern Arab Crossing Not Mentioned-Is the Percheron a Primitive Type..$\ldots \ldots \ldots \ldots \ldots \ldots \ldots \ldots \ldots \ldots \ldots \ldots \ldots$

CHAPTER III-THE RENAISSANCE FOLLOTING THE REVOLUTION.

Delestang and His History-Lamagdelaine's Prizes-A Draft Type at Montdoubleau-Unverified Tradition Exploded-Godolphin an English Saddler-Gallipoly a Small Turkish Saddle Horse-Error Easily Perpetuated -Jean-le-Blanc-The Eridence Summarized-The Breed "Modifies Itself"-M. Fardouet Was Right-The Government Stud-First Draft Stallions at the Haras du Pin-Official Notes-Directors and Inspectors Disagree

\section{CHAPTER IT-EVOLUTION FROM WITHIN.}

Prizes Stimulate Effort-The National Archives in Evidence-First Approved Stallions Near Nogent-Grand Pierre, Bijou and Le Coq-Liberally Patronized-Big Horses in Service-Le Coq Goes to Belgium-More Big Gray Horses-Other's in Nogent District-In the Department of Orne-Service for 12 Francs-At Mortagne in the Early '30's-In La Sarthe-Loir-et-CherA Broad Constructive Policy Continued-Outcrossing Exaggerated-As to Color-Passing of the Diligence Type-Some Conclusions..................... \$2-106

CHAPTER V-FIRST FRENCH HORSES IN AMERICA.

Authentic Records Begin-Alexander's Norman-First Importation to the States-Ohio Importations of 1851Normandy, or Pleasant Valley Bill-A Great CareerThe Holman Horse-Louis Napoleon-Taken to Illinois - Acquired by the Dillons-Maryland Importation of 1853-Rollin Imported in 1856-Darby Plains Importation of 1857 - Kentucliy Importation of 1859-Massachusetts Importation of 1864 -Gray Duke-Eastern Imports of 1866-First Direct Importation into Illinois-Ohio Ac-

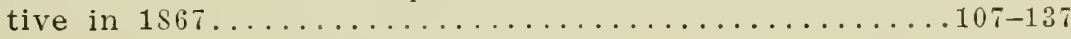




\section{CHAPTER VI-THE IIIPORTING RECORD TO 1870.}

A Profitable Business-Activity in Ohio-The Walters Percherons-Old Success Imported-M. WT. Dunham Enters the Business-Napoleon Bonaparte-A Lull in 1869 -Across the Continent-Good Buying for Illinois-Duke de Chartres Brings $\$ 4,000$ - First of the Blood in Wisconsin-Dillons' Big St. Laurent-Recapitulation..... 138-158

CHAPTER VII-MID-TIEST PIONEERS.

Leaders of the Period-Oaklawn in Front-Home Breeding Emphasized - Some Celebrities Described - Drawing from the Fountain Head-The Dillons-Ohio Breeders of the ' 70 's-The East and the Far West-On the Pacific Coast-Dr. Tr. H. Trinter-Daniel Dunham-Eli Hodgson-Stubblefield Importations-Percheron Breeding in Other States-James H. Sanders-A Campaign of Education-Foundation of the Stud Book-The Peoria Con-

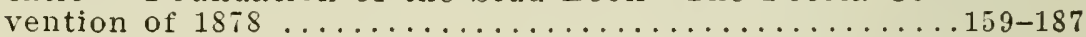

\section{CHAPTER VIII-THE FRENCH STORI RESUIED.}

Practical Promotive Work-More Pre-Stud Book RecordsM. Cheradame-Toulouse, "The Magnificent"-Chocolat -The Ducoeurjolys-Pelletier-Moisand-Jouset and Mitau-Old Records Brought to Light-Fardouet and Caget-Michel Fardouet-Celestian Caget-The Chouanards and La Touche-The Perriots-The TacheausCharles Paul Aveline-Credit Due These PioneersFounding of the Stud Bools-Meager Data at First Available-The Case of Jean-le-Blanc...............1ss-232

CHAPTER IX-THE GREAT ENPANSION OF THE '80'S.

Distribution by States-Oaklawn Breeding Operations-The Brilliant Blood-The Story of Old Erilliant-Brilliant 1271-Prepotency of Brilliant Blood-Developments at Oaliawn-Results Despite Difficulties-Great Mares of Oaklawn Stud-Oaklawn Influence-Oaklawn Sales of 'S0's-Mr. Dunham's Influence-Ellwood Green-Sires Used by Mr. Fllwood-Cheri and Seducteur-Mares in Stud-Influence on Other Studs-Noted Sires SoldSummary of Ellwood Operations-Daniel Dunham's Tork-The Dillons-Sires Used-Dillons in the Show-

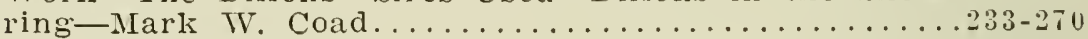

CHAPTER X-OTHER PROMINENT FIGURES OF THE PLRIOD.

Log Cabin Farm-Edgewood Farm-John T. Akin-Minnesota Breeder's-Leonard Johnson-Founding Maple Point Stud-Leading Sires Used-The Johnson MaresShowyard Record-Minnesota Percheron Horse Company -George E. Case- Wisconsin's Leadel's-Trauwatosa Farm-Kellogg Stock Farm-The Kellogg StallionsNoted Mares-Influences on Other Studs-Reserve Forces in Illinois-Stetson \& Sons-Mares Owned and Colts Raised-The Stetson Sires-Taluable Brood Mares -Degen Bros.-George S. Hanna--E. Hodgson \& SonOhio Breeders-Jones Bros.-Samuel Kendeigh-M. T. Bates-E. J. Condit-Iowa's Percheron Breeders-Iowa Breeder's of the 's0's-MIaplehurst Stock Farm-J. H. 
Barnett-Other Breeders-Further Consideration of Illinois-Pre-eminence of McLean Co., Ill.-In Tazewell-In LaSalle-Other. Minnesota Breeders-Other Breeders in Wisconsin-Other Michigan BreedersOther Breeders in New York-Percheron Breeding in Pennsylvania-Progress in Indiana-In the Sunflower State-In Missouri-Other States..............271-337

CHAPTER XI-AN ERA OF PROFOUND DEPRESSION.

What the Figures Show-Oaklawn Farm-Brilliant-Other Oaklawn Sires-Oaklawn Mares and Colts-Oaklawn Sales and Leases-The Great Leader-Other Illinois Breeders-New Blood-Progress in Iowa-Lakewood Farm-Developments in Ohio-Pleasant Valley FarmOther Ohio Breeders-In Minnesota-Belleview FarmWillard \& Fuller-In Wisconsin-In Kansas.........33s-3s4

CHAPTER XII-THE NEW CENTURY DATNS AUSPICIOLSLY.

The Actual Increase-Pedigree Publication Suspended-New Association Formed-Old Records Acquired-Influence of Dealers and Importers-The Development by States -In Illinois-Important Illinois Dispersions-New Studs Founded in Illinois-Progress in Iowa-Ohio's Contributions-Progress in IFansas-Progress in Minnesota-The Hoosier Horsemen-Wisconsin's WorliersTrork in Nebraska-North Dakota's Great Range Project-Progress in South Dakota-In Other States -Michigan-Missouri-Pennsylvania-Tirginia-O. E. Jordan-Selma Farm-California-Colorado-NontanaWashington-New York-Growth of the Percheron Society of America-A Canadian Association-Percheron

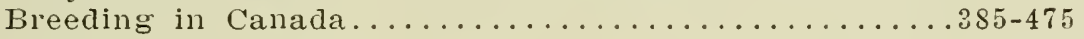

\section{CHAPTER XIII-DISTRIBUTION AND STATISTICS OF} PROODLCTION IN THE UNITED STATES.

Percherons in the South-Horse Stock of the United States - Percherons the Leading Draft Type-War ExportsFrench Embargo on Exports-American Breeding Stimulated-Commercial Narket for Draft Horses-

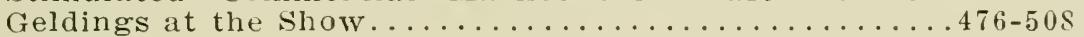

CHAPTER XIV-SELECTION, CARE AND MANAGEMENT.

Edmond Perriot-James 11. Fletcher-II. E. Prichard-E. B. Thite-J. L. DeLancey-J. O. Singmaster-W. S. Dunham-J. B. McLaughlin-W. S. Corsa-A. L. Robison \& Son-Lee Brothers-Dan Augstin's Story-U. L. Burdick-On the Northwestern Fange-Management of Foals and Yearlings-Feeding Alfalfa-Importance of Soundness-Growing Purebred Percheron Fillies-Buying. Feeding and Selling Draft Geldings-Permanent Marks for Percherons.....................509-58s

\section{CHAPTER IV-BLOODLINES IN THE SHOWRING.}

The Breeding of Leading Winners-Breeding of Prizewinners at French Shows-Breeding of International Prizewinners .................................... 58902 



\section{INDEX TO ILLUSTRATIONS.}

American buyers in the Perche, 385.

Amorita 61314, 587.

Armour six-horse team, 505.

Augstin, D., $3 \$ 1$.

Aveline, Charles, 224.

Aveline, Charles, residence at LaTouche, 228.

Aveline, Joseph, colts at pasture, 102.

Aveline, Joseph, 232.

Aveline. Joseph, farm at Dorceau, 198.

Areline, Louis, 224.

Aveline, Louis, farm at La Crochetiere, 226 .

Avery, Henry, 333.

Ayres, M. L., 363.

Bamboucheur (62018), 407.

Bar U Ranch, 473 .

Beckett, James D., 288.

Bellême forest, 21.

Bell, Samuel, 467 .

Bell, William, 467 .

Besigue (19602), 395.

Bigelow, Timothy C.. 116.

Bigelow, Timothy L., 116.

Big Jim, 499.

Bignon, A., farm at Aulnays, 192.

Bonheur's studies of Toltaire, Jupiter and Confident, 246 .

Bonheur's study of Brilliant 1271, $2 \pm 2$.

Boullay-Chaumard, M., 190.

Bourdin, E., 230.

Bowman, T. B., 333.

Branding irons, 583.

Briggs, H. A., 260.

Brilliant 1271 and group of get, 240.

Burdick, U. L., 497.

Calypso 25017 (44577), 393.

Carnot 66666 (66666), 411.

Castile $\lceil \$ 956$ (64553), 513.
Chappels, Anatole, 232.

Chappels, A., farm at La Plessis, 202.

Chouanard, Charles, 210.

- Chouanard, Charles, farm at Ia Bretonnerie, 226.

Chouanard, Emile, 210.

Chouanard, Jules, 210.

Chouanard, Maurice, 210.

Chouanard, Maurice, residence at La Roustiére. 194.

Colegrore, Arthur, 497.

Coleman, C. R., 315.

Cook, A. W., 315.

Corsa, IT. S. 415 .

Crouch, G. R., 441.

Crouch, J., 441.

Curtiss, Charles F., 415.

Danforth, William, 497.

DeLancey, J. L., 260.

DeLancey, T. I., 260.

Delchester Farms, mares in hayfield, 509.

Diligence, 110.

Diligence horses of $1 \$ 30,17$.

Dillon, Ellis, 136.

Dillon, Isaiah, 136.

Dillon, Levi, 136.

Dorothy B. $122 \pm 55,521$.

Dragon 52155 (63516), 425.

Ducoeurjoly, D., farm of, 228.

Ducoeurjoly, Desiré, 196.

Dunham, Daniel, 164.

Dunham, Mark W., 160.

Dunham, T. S., 160.

Ellwood, I. L., 256.

Ellwood, TT. L., 256.

Erica (68318), 407.

Fair Hope $117379,577$.

Fardouet, Alphonse, 72.

Fardouet, Michel, 72.

Fardouet, M., farm at Le Bois Joly, 206. 
Feeding" colts, rack for, 567 .

Feuillard, Ansbert, 196.

Fletcher, James M., 164.

Fullington, Charles, 12̈S.

Fullington, James, $12 \mathrm{~s}$.

Gallipoly entry in Government records, i2

George P. 82495, 529.

Georgiana $28622, \quad 451$.

Girard, Alphonse, 230.

Godolphin entry in Government records, 62 .

Govermment certificate of 1822 , 87.

Gray Billy, 118.

Grenat so714 ( 71632$), 553$.

Guy, Henry, 126.

Helen Helix 97206, 521.

Hamelin, Adrien, 196.

Haras du Pin, chateau and courtyard, 76.

Haras du Pin, stallions in service, 88.

Harris, Edward, 108.

Hermine 102198 ( 76134$), 587$.

Hodgson, Eli, 130.

Hodgson, M. C., 130.

Hodgson, William, 130.

Holbert, A. B., $\$ 15$.

Horace 7884, $35 \%$.

Huisne, pasture on the; 19.

Humbert, L. H., 41 j.

Hurt, C. II., 321.

Hurt, William, 321.

Huston, John, $3 \$ 1$.

Hysope, 573.

Ildefonse 79307 ( 83004$), 521$.

Imprecation 79304 (79214), 425.

Indivise, French prize-winning mare, 480 .

Intime 87219 (83153), 399.

Iran $10 \$ 146,545$.

Jalap $\$ 0583 \quad(85614), 601$.

Jasmine 88573 (85983), 589.

Joan and colt Julie, 112.

Joie 105878 (\$3942), 513.

Johnson, Leonard, 164.

Jones, C. M., 126.

Jones, Milton E., 321.

Jones, Thomas, 126.
Kieiser, Charles, 495.

Keiser, S. I., 495.

leota Insight $107242,577$.

lieota Jalap 106186 , 54 J.

liontact 87277 (95804), 529 .

La Belle 34982, 451.

Lactine 101472 (100912), 559.

Lagos 99093 (1023\$9), $5 \$ 9$.

LaFerté 5144,347 .

LaFerté Bernard-Place Saint Julien, 55 .

Lane, George, 471.

Lee, J. H., 333.

Legitime 98978 (99389), 537.

Louis Napoleon, 120.

Lycee 105934 (102746), 589.

Mack, 499.

Martin, Erastus, 126.

Mauldin, James, 363 .

MicCormick, L. J., $2 \delta 8$.

MeLaughlin, J. B., 467.

Mc.Millan, H. G., 389.

Mortagne, roadway at, 55.

Moulinet (6S017), 480 .

Moulin, L., farm at La Grand Champrond, 206.

Moulin, L., 232.

Nave, A. P., 381 .

Nicodemus, Ed, 467 .

Nogent-le-Rotrou-army officers inspecting horse stock of district, 58 .

Nogent-le-Rotrou-C h a t e a u de Saint Jean, 21.

Nogent-le-Rotrou, market day, 80.

Nogent-le-R o tro u-Rue de la Charronnerie, 66.

Nogent-le-Rotrou-Rue Saint Hilaire, 66 .

North, C. M., 333.

Oakley, Charles, 122.

Orr, W. C., 363.

Pabst, Fred, 288.

Palmer, T T., 272.

Paul Potter's "Great Horse," 36.

Pellitier, H., of La Bernuche, Orne, 92.

Pelleray, C., 196.

Perche, a farm home in the, 32 . 
Perche, typical village in the, 29. Rigot. MI., 230.

Perche, mares at work in field, S2. Roseland $87467,53 \pi$.

Perche, sccnes in the, 96.

Perche, mares at work in liaglield, $33 \mathrm{~s}$.

Perche, two-year-old colts at Edmond Perriot's, 344.

Perche, map showing modern boundary lines, 25.

Perche, two snapshots by Mr. Sanders in the, 220 .

Percheron mare and colt in an Illinois pasture, 359.

Perriot, Edmond, 212.

Perriot, Edmond, chateau of La Ronce, 104.

Perriot, Ernest, 214.

Perriot, Jr., Ernest, 214.

Perriot, Jr., Emest, farm and residence at L'Archie, 194.

Perriot. Edmond, farm at Champeaux, 216.

Perriot, Ernest, residence at $\mathrm{L}$ : Orme, 21s.

Perriot, Louis, 212.

Perriot, Louis, residence at La Borde, $21 s$.

Phillips, G. W. 495 .

Pink 24765 (47513), 399.

Pink Brilliante 5โS97, јт3.

Pleasant Valley Bill, 114.

Poindexter, P. H., 363 .

Powerful 6670 (Bayard 7519 ), . 94.

Prichard, WV. E., 260.

René, Charles, 190.

Richard, E., farm at La Gêromerie, 100.

Sanders, James Harvey, 176.

Seducteur ss50 (7085), 25s.

Selma Farm, mares at work, 461 .

Singmaster, C. F., 315 .

Singmaster, J. O., 315.

Slack, Louis, 497.

Stetson, Ezra, 272.

Stubblefield, George $\Pi$., 389.

Stubblefield, L. F., $3 \$ 1$.

Suzanne $(\$ 1567), 395$.

Tacheau, A., breeding farm at La Pellois, 198.

Tacheau, Auguste, 22.2.

Tacheau, Jr., A., residence at Le Burin, 200.

Tacheau, Jr., Auguste, 222.

Taylor, Charles R., 321.

Thibault, M., 232 .

Thibault, MI., farm at La Bourdonniêre, 202 .

Tomnac Tilleneure-director of Haras, 74 .

Turquoise $110346,559$.

Tallé, M., farm of, 107.

Vendome $1161.51,553$.

Villette-Gaté, M., 2230.

Walters, $\Pi$. T., Percherons, 140 , $142,144,146,14 \mathrm{~s}$.

Walters, W. T., $13 \mathrm{~S}$.

War horses of the Middle Ages, $38-40$.

White, E. B., 471.

IIilson, J. E., $28 S$. 


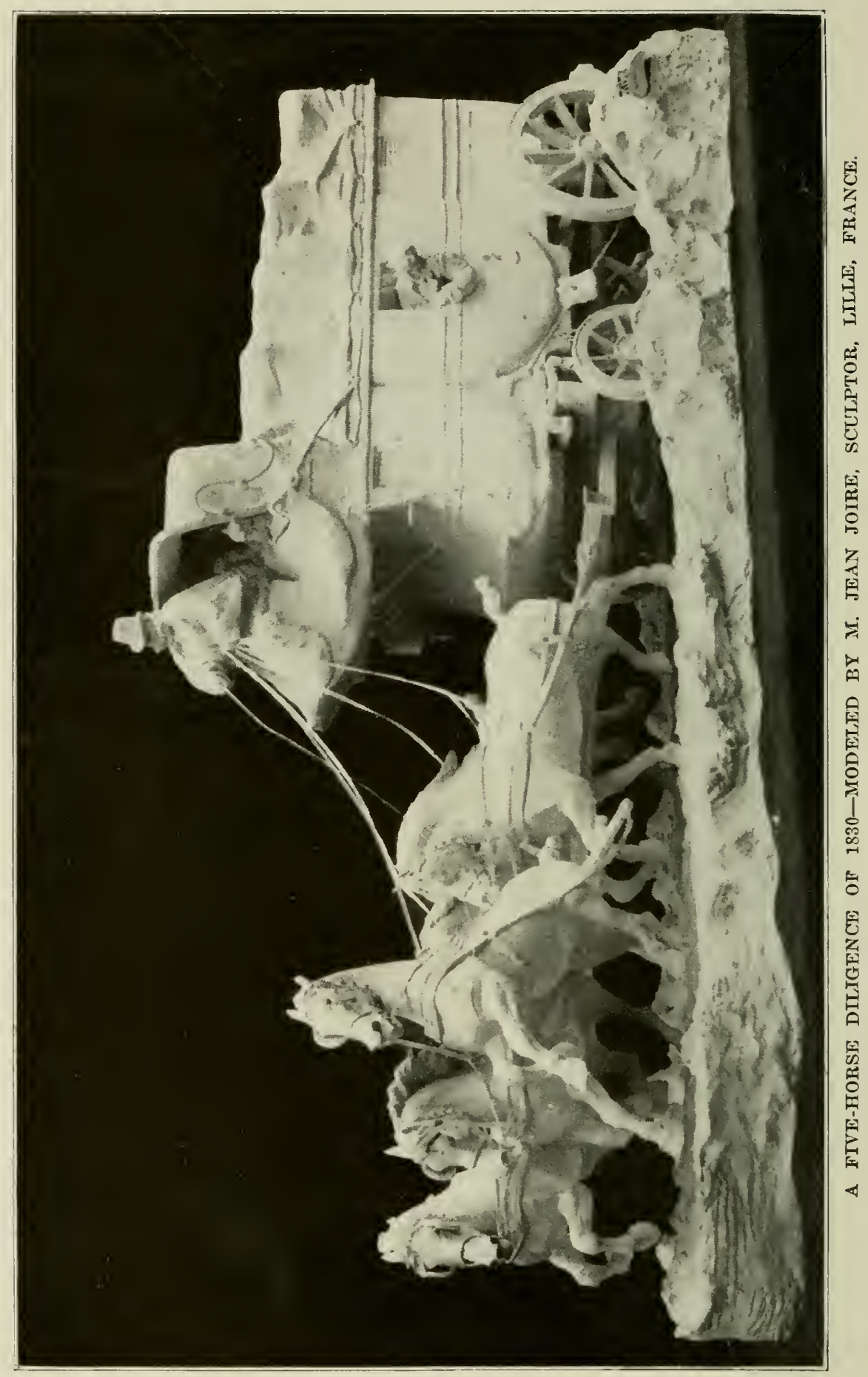




\section{GHAPTER I.}

\section{THE ANCIENT PROVINCE OF THE PERCHE.}

One of the smallest provinces of old France, the district known as The Perche, derived its name from the ancient forest, Perticus Saltus, which originally covered almost the entire region. Vestiges of this great wooded tract exist today in the forests of Bellême, Reno and Du Val. What is now known as The Perche Forest in Normancly was also once a part of it. During the time of the Gauls the province was too thickly. wooded to permit of much settlement. Some time about the beginning of the ninth century the monks are said to have made clearings in the forests; but long before this period it is probable that restricted tracts had been brought under cultivation in some of the more farored valleys.

Topography of the District.-The Perche really comprises a region lying between Normandy on the north and west, Maine on the southwest, Vendome and Dunois on the sonth, and the Beauce country, the so-called granary of France, on the east. If viewed from an aeroplane, one would observe that the relatively prominent relief of the district, compared with the level countries that surround it, helps to solve the problem of how the Percheron breed came to be evolved within such a comparatively 
small region. The lowest point of the territory is at 'Theil on the Huisne, about 270 feet above sea level, and the highest town is Mortagne, at an altitude of about 750 feet. The shape of The Perche is that of an ellipse, the dimensions about 53 by 66 miles. Within this elliptical tract there are now fifty cantons. Only foals which are the progeny of registered dams and sires of the Percheron breed and born in one of these cantons are eligible for registration at the present time in the Pcrcheron Stud Book of France.

Geological Formation.-Geologically speaking, this territory is characterized essentially by cretaceous formations of the Cenomanian Stage, and is a part of the Secondary Aureole Period, circumscribed by the Tertiary deposits of the Paris Basin. This Cenomanian Stage, which dominates all over The Perche, is subdivided into sand and Ronen chalk. It is the Rouen chalk that plays so important a roie in the geological formation of the region. It forms all the length of the broad valley of the Huisne, as well as that of the Sarthe in its upper reaches. Of course the bottom-lands of all the valleys are composed of alluvial soils and are very fertile. Going westward from Mortagne and Bellême, Jurassic formations are encountered, and it is a curious fact that on these soils we are apt to meet with Percheron horses having lighter frames than those raised in the Huisne and Sarthe vallers. While the soils of The Perche vary somewhat in the varions districts, they are chiefly of clayey and clayey-loam texture. Sandy 



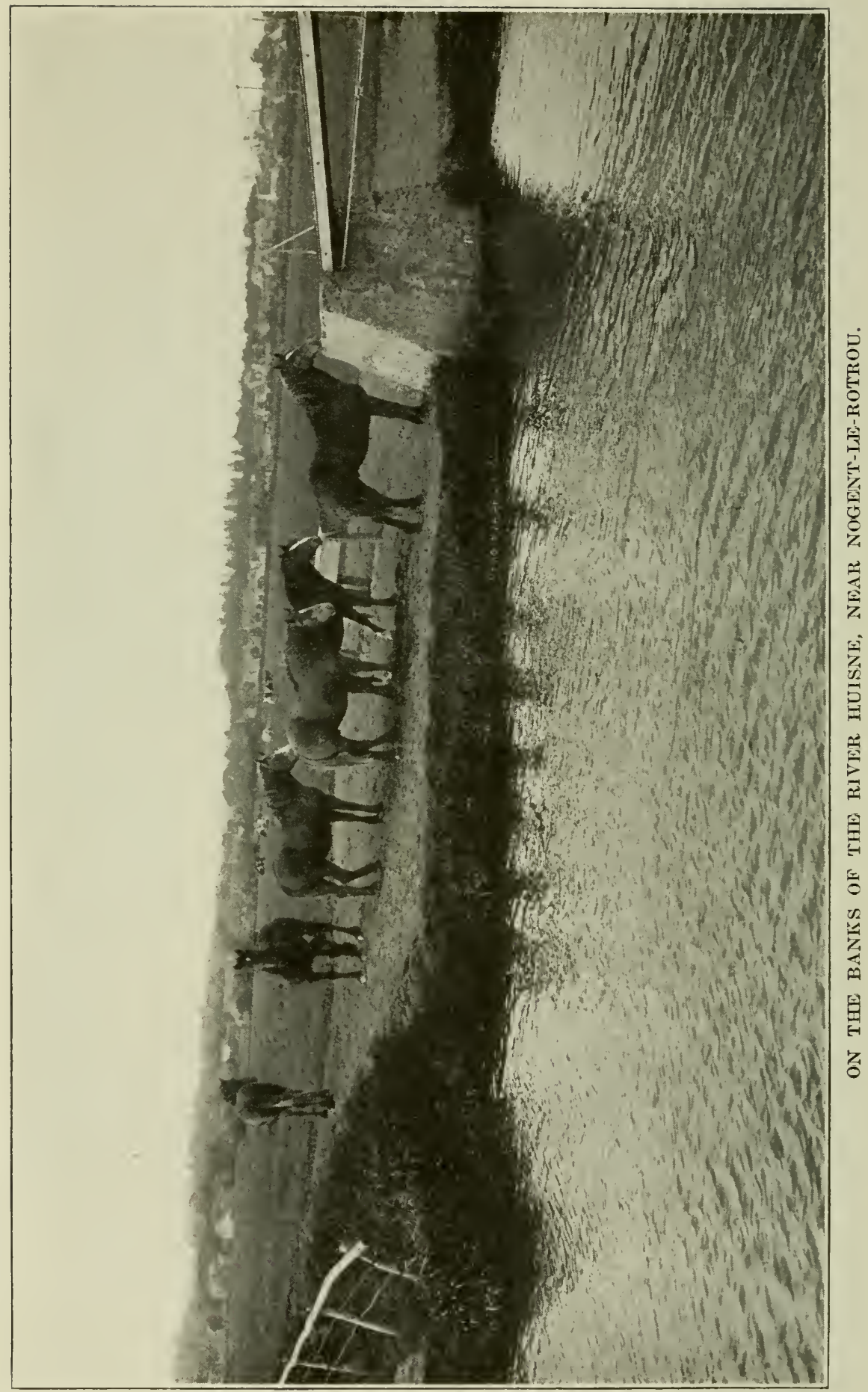


soils are met with occasionally. In color they vary from black to a ruddy chocolate.

Near Bellême a limestone suitable for building purposes is found. Free-stone or sandstone is quarried at various places in The Perche. A considerable quantity of marl is also available, and it has been a custom for hundreds of years for the farmers to spread this over their fields. Formerly there were many iron mines, chiefly at Logny, but they are now exhausted. The sandstone quarries of Regmalard and Logny are still worked, this stone being used for building purposes. Lime-kilns are operated in some districts.

Water Courses.-The Perche is especially well watered. It is rare that one encounters so many flowing streams in such a small country. This fact contributes in a great measure to the excellence of its pastures. There are six rivers: The Huisne, which rises to the north of Bellême, and flows into the Sarthe, near the torn of Le Mans, is about $i 7$ miles long; the Sarthe empties itself into the Loire, after a course of 165 miles; the Eure is 82 miles long, the Avre 41 miles, the Iton about 60 miles, and the Loire about 12:3 miles. Not all the mileage of these rivers is in The Perche. There are no less than twenty-seren small tributaries or river's of the second class. Many of these streams would be designated merely as creeks in the United States. It is the Huisne, in its meandering semi-circular route around Bellême, Pervenchères, Corbon, Nogent-le-Rotrou and La Ferté Bernard, which serves as the chief col- 
lecting medium of the waters that descend the green hills of The Perche. A study of the map will reveal the tortuous course of this river; it receives many rivulets in its passage, and after it leaves Nogent its volume increases perceptibly until it empties itself into the Sarthe.

Climatic Conditions.- The surface of the land is considerably broken, being traversed by numerous valleys, chicf of which are the basins of the Huisne and the Sarthe. There is some timber along the banks of the streams and on the numerous low hills. The forests which border the rim of The Perche serve to condense the atmospheric vapors, and consequently the precipitation is abundant. The climate is rather humid and conducive to the growth of grass. The mean precipitation is $88 \pm$ millimeters. The mean annual temporature, according to the Scientific Commission of the Department of Orne, is 49.1 Fahrenheit. The wooded area forms 16 per cent of the total land, a proportion which corresponds to the average of all the area of France. The natural "prairies", where most of the horses are pastured, occupy the bottom-lands of the valleys.

Ancient History.-The records of the first settlements of this region, Bellême, Mortagne and Nogentle-Rotron, are lost in remote antiquity. The most ancient Count of The Perche was Agombert, who lived during the time of Louis the Debonair, about 830 or 840 A. D. Then the Romans overran Gaul The Perehe was conquered by one of the lieutenants of Caesar, who in his "Commentaries" mentions 


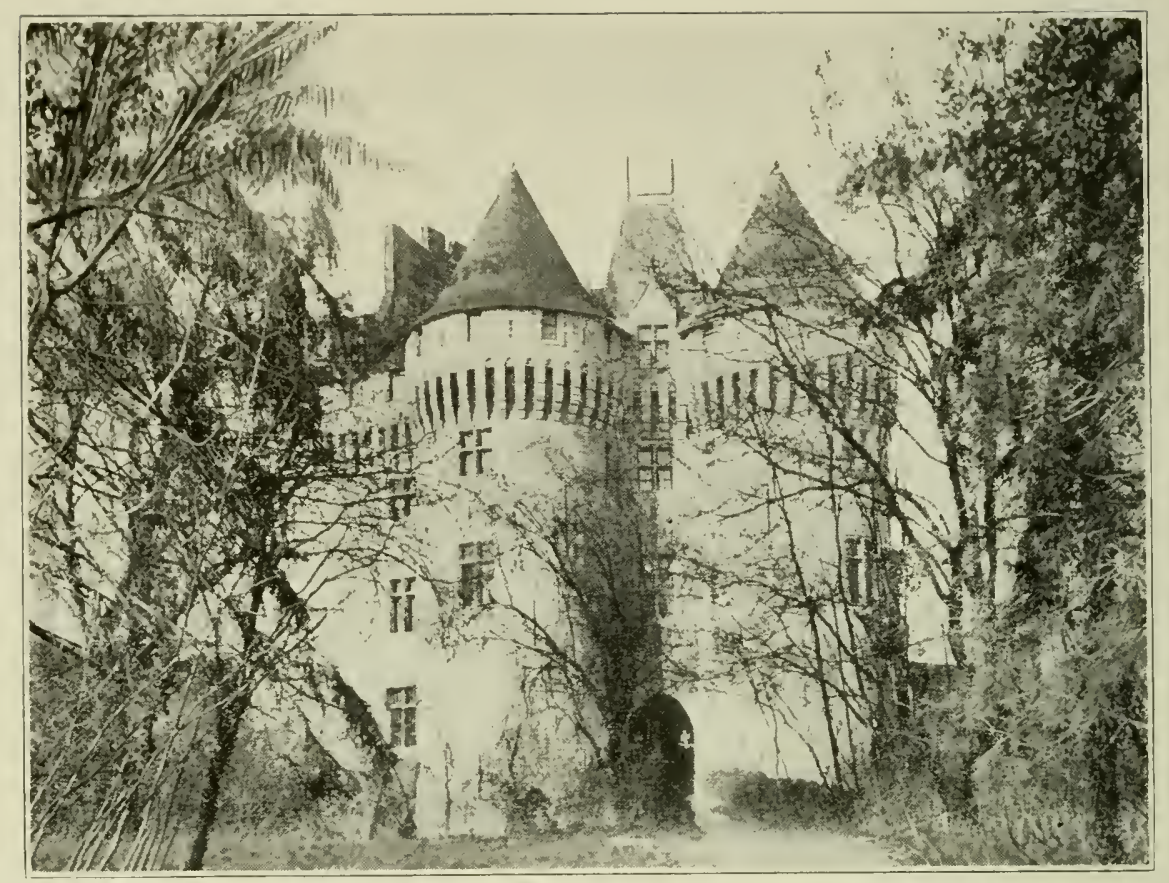

NOGENT-LE-ROTROU-CHATEAU DE SAINT JEAN.

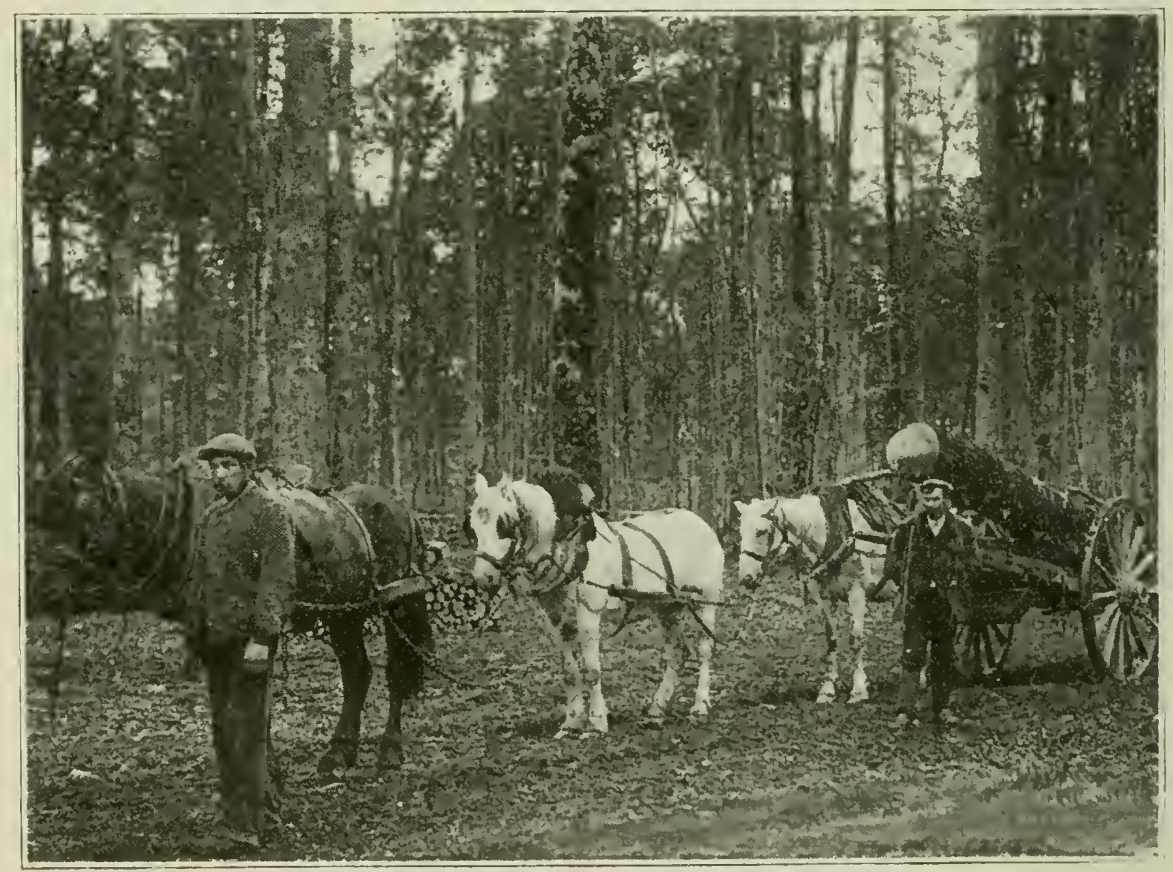


particularly the warlike character of its inhabitants under their chief, Veridiouix, who caused the Roman generals no little work. In the middle of the ninth century the Norsemen invaded The Perche and laid waste the country.

In 1135 Nogent, at that time built of wood, was destroyed by fire. About 1358 it fell into the hands of the English, but the Treaty of Bretigny on May 8, 1360, gave the town back to the French, and in 1361 it was turned over once more to its seigneurs. Once or twice after that date the English obtained possession of it. It was not until the year 1230 that The Perche came uncler the French crown. From the end of the sixteenth century up to the time of the French Revolution-a period of about 200 years - the province enjoyed a profound peace, and agriculture and stock-breeding made much progress. *

Rotrou and the Counts of The Perche.-The Counts of The Perche were first known under the title of Seigneurs de Bellême. During the Middle Ages the history of the province was characterized by continuous strife and bloodshed. During a part of the eleventh century there was internal warfare waged by Robert II of Bellême against the Rotrous, Counts

*The Abbé Fret, the best known historian of The Perche of modern times, in his "Antiquités et Chroniques Percheronnes" relates that after about two centuries of profound peace an insurrection took place at Mortagne, the capital of The Perche, on the 23rd of July, 1789, the mob taking possession of all the registers of the excise and burning them in the market place. He then relates how a handful of rioters did terrible things at Nogent, destroying by fire, among other articles in the public square, precious manuscripts and authentic documents, charters and other matter indispensable to the history of the town. $\mathrm{He}$ affirms that the origin of Nogent goes back to the greatest antiquity, and every other historian of The Perche corroborates that statement. 
of The Perche and Mortagne. According to Odolant-Desnos, the Rotrous, Seigneurs of Nogent, date from before 853. The chief of these was Rotrou III, whom the historians call Rotron II. He was first Count of Mortagne and Seigneur of Nogent, became later Count of The Perche, and has been surnamed The Great. As a warrior he distinguished himself by his feats against the Saracens in Spain, conquering sereral cities and taking many castles in the year 1089. In 1095 he left for the Crusades with Robert III, Duke of Normandy, who left his duchy in pawn with Henry of England for the sum of 10,000 silver pounds. Rotrou commanded the tenth corps of the army of the Christians at the siege of Antioch. On the 15th of July, 1099, he took part in the siege and capture of Jerusalem. The following year he returned to The Perche.

When Rotrou III came back he soon got into trouble with his mortal enemy, Robert of Bellême, known later to history as "Robert the Devil." In spite of the fact that Rotrou had allied himself with Henry, King of England, by marrying one of his daughters, he could not avoid falling into Robert's hands on two occasions. Later he went once more to fight the Infidels in Spain. When he returned in 1109 he founded the Abbey of Tyron, which became in 1140 the celebrated Abbey of La Trappe. He founded other religions orders in The Perche. Fighting in Normandy, he was killed at the siege of the Grosse Tour of Rouen. The body was brought to the chureh of St. Denis at Nogent, and buried. This ancient town, 


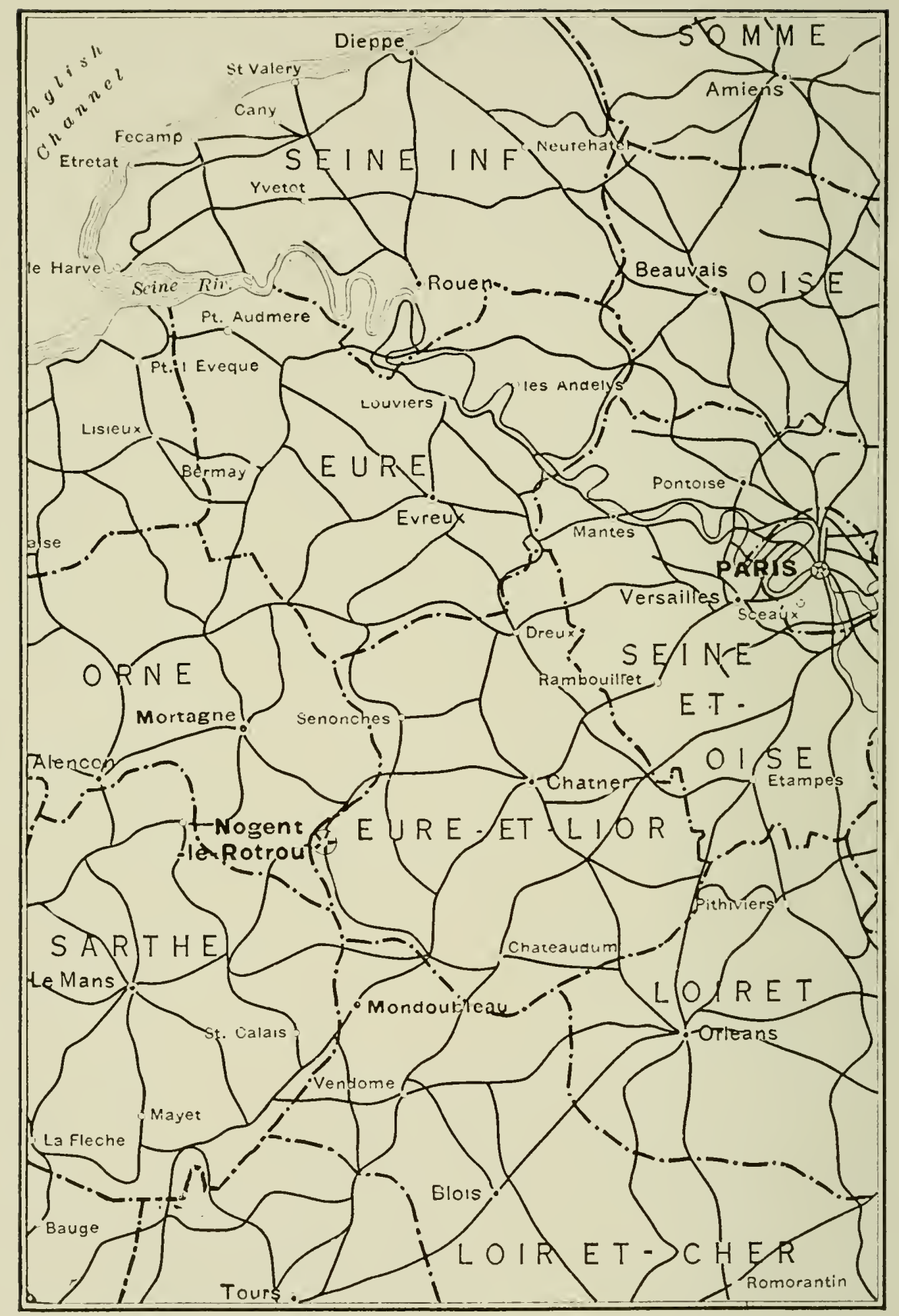

MAP OF A SECTION OF NORTHUESTERN FRANCE, SHOWING LOCATION OF NOGENT-LE-ROTROU AND THE PERCHERON COUNTRY IN REFERENCE TO THE SEACOAST AND THE CITY OF PARIS. 
now known as Nogent-le-Rotrou, is, and for years past has been, the Percheron capital.

Charles Du Haÿs, Master of Horse to Napoleon III, in his "Le Cheval Percheron,' quoting from the Abbé Fret, the author of a history of the province of The Perche, and accepting as correct the statement that Rotrou and other nobles participating in the Crusades brought back stallions from the Holy Land, asserts that they were largely used. This may be true. Indeed, it is by no means improbable, and yet a careful reading" of the "Suite Chronologique des Seigneur's de Nogent-le-Rotrou" by Odolant-Desnos, published in 1785, which includes a detailed account of the homecoming of that knight, yields no reference to his having brought back Arabian holses. Indeed, we have searched in vain in early French literature for any specific statements to substantiate the generally accepted dicta on this point.

Modern Records Begin.-As war gradually ceased to be the chief business or diversion of the great nobles and landed proprietor's the gentler arts of agriculture naturally received more attention, and it followed, as a matter of course, that efforts wers finally made to increase the value of the horse for farm purposes. Louis XI (1461-1483) first curbed the power and fighting spirit of the great feudal barons and war lords who had for so long made France a hotbed of internal strife, and he asserted the majesty of centralized authority.

Although we have made diligent search through 
a great variety of old books and mamuscripts relating to the past history of The Porche, we have only been able to find occasional definite references to agricultural operations as related to horse-breeding. There is an original manuscript in the National Library entitled "Memoire sur la Comté du Perche en l'année 1698,' from which wo may quote as follows:

"The moadows and pastures are very good, especially in the following places: Oirs, Conilimert, St. Quentin, I a Mesnière, St. Julien and Barville on the Herimne and the Sarthe; and Regmalard, Dorceau, Conde, Condeau, Mesle and Theil, several of which are on the river Huisne. But the high lands are not very good. . . . These lands, liowerer, are not. altogether useless, for in some cantons sheep are fattened on the higher lands, while in other cantons such as those of Logny, Lemage and Neuilly, where this rough land is better than in the other cantons, cows and oxen are fattrned thereon. The sheep and cattle fattened in The Perche aro driven to Paris, to the markets of Sceaux and Poissy.',

"The county is so ancient that its origin cannot be found. It was one of the first provinces to be established by our kings after the conquests of the Gauls.

"The Election of Mortagne comprises almost all of the province of the Perche; it was created by Charles the Nintl, King of France, Aug., 1572.

"The Manor's of Bollême and Nogent.-Bellême has 57 parishes. Nogent is composed of a large borough and 40 parishes. There are 1,300 men in the borongh. There are in all the parishes of the Election of Mortagne 62,692 souls.'

Live Stock Husbandry Important._-On page 396 
of this old manuscript we find the following interesting paragraph:

"The Raising of Colts and other" Animals.Money enters the province by the following channels: the sale of colts, fat cattle and sheep, butter, poultry and eggs which are taken to the Paris markets. As the province of The Perche is only three days from Paris (by road), there is no difficulty in transporting supplies. The wool which the sheep produce is also a great help. All this brings in more than 100,000 pounds a year. The majority of the inhabitants work at plowing and cultivating the land."

The document also tells of big fairs and markets at Maures, Logny, Regmalard and Bellême, and three important market days every week at Nogent: Tuesday, Thursday and Saturday. We quote again:

"Maures is another large borough admirable for the fertility of its soil and its situation. The Huisne nearly surrounds it to make an island. This is a very ancient town to judge from its deeds. Mortagne has four fairs a year, and markets every TVednesday and Saturday. The Lord of the Manor (Seigneur) of Nogent has the right to hold two fairs a year. [But he did not do so, we learn, as he was content with his three market days a week.-Ed.] The women and girls spin flax and wool at home, for the manufacture of cloths at Nogent and Mortagne.'

According to the dictionary of de la Martinier, published in 1768, The Perche was well peopled at that date, and a great business was done in wheat and cattle, the grain being transported to Alençon and Brittany by horses. The chief manufactures at that time were textiles produced at Mortagne and Nogent. These were carried to Paris, Rouen and 
St. Quentin. It is stated that the breeding of horses had at that time reached great proportions, and that four famous fairs were held at Mortagne, and other's at Bellême, Tourouvre, Logny, Regmalard and Nogent. Also, that the famous fair of St. Andrew at Mortagne attracted buyers from all the surrounding provinces.

Under the "Grand Monarque." - When we arrive at the golden age of Louis XIV, evidence that a demand for a somewhat heavier horse had set in is presented by a manuscript of that period found among the documents pertaining to the government haras (or studs) in the National Archives at Paris. References appear in this to the character of the king's stallions in service at that time in the Percheron country. Such information as is given concerning them is reproduced in the footnote." Of these horses it will be noted that one was a Barin, one a "large bay," two were gray and one a sorrel, the blood not being mentioned except in the case of the "dun-colored" Barb.

*A list signed by H. Duplessix, Commandant of the Haras, containing the names, residences, parish, etc., of "private persons with whom the stallions of the King of France were placed for their safe keeping" :

In the Election of Mortagne, Jacques Billard, cattle dealer, Mortagne, is charged with the keeping of a Barb, dun-colored, 17th June, 1673.

M. René Pezé, surgeon and apothecary at Bellême, is charged with a gray stallion, aproved May 15 th, 1676 .

M. André Fristel, St. Julien-sur-Sarthe, is charged with a road horse, dapple-gray, Oct. 15th, 1677.

Michel Dreux, Nogent-le-Rotrou, is charged with a sorrel with white mane and tail, April $15 \mathrm{th}, 16-\mathrm{s}$.

René Bouillon, farmer at Beauvais, parish of Iton, is charged with a large bay horse, very old and broken-winded. There is a note following this entry saying that the latter stallion must not be allowed to serve mares as the Intendant has ordered it to be replaced. This is dated May 23, 1674 . 
In that part of the Department of Orne lying in Normandy Italian, Barb, and Spanish stallions are mentioned, but no reference is made of Arabs. From the same document we learn that "M. de Morangis has visited all the stallions in the district," finding' that "there are many beginning to show signs of old age, and that it would be better to replace them by more vigorous and heavier sires; the mares of the region are too small." He remarks that "as soon as the colts are six months old the farmers sell them to buyers coming from outside districts," and that "this method results in the money staying in the country." This report was then made to the Secretary of State:

"He has visited all the stallions. There are some fine ones descended from the stallions of the King that would soon populate the region if the farmers rould not sell them at 30 months old. Nothing stays in the country except those which certain gentlemen are careful to raise and mature. The majority of the King's stallions are too old; a few private persons have replaced them by others.

"It would be very desirable if the King would furnish about six more stallions of heavier build. The Barbs are getting colts with too weak limbs."

Notwithstanding this criticism of the royal stallions it is asserted that under Louis XIV The Perche still maintained that high reputation as a nursery of good horses which it had apparently enjoyed since the Middle Ages, and the stage-coach and carrying companies were steadily increasing thein purchases in the district. Speed with heavy loads was of course the prime requirement in front of the 


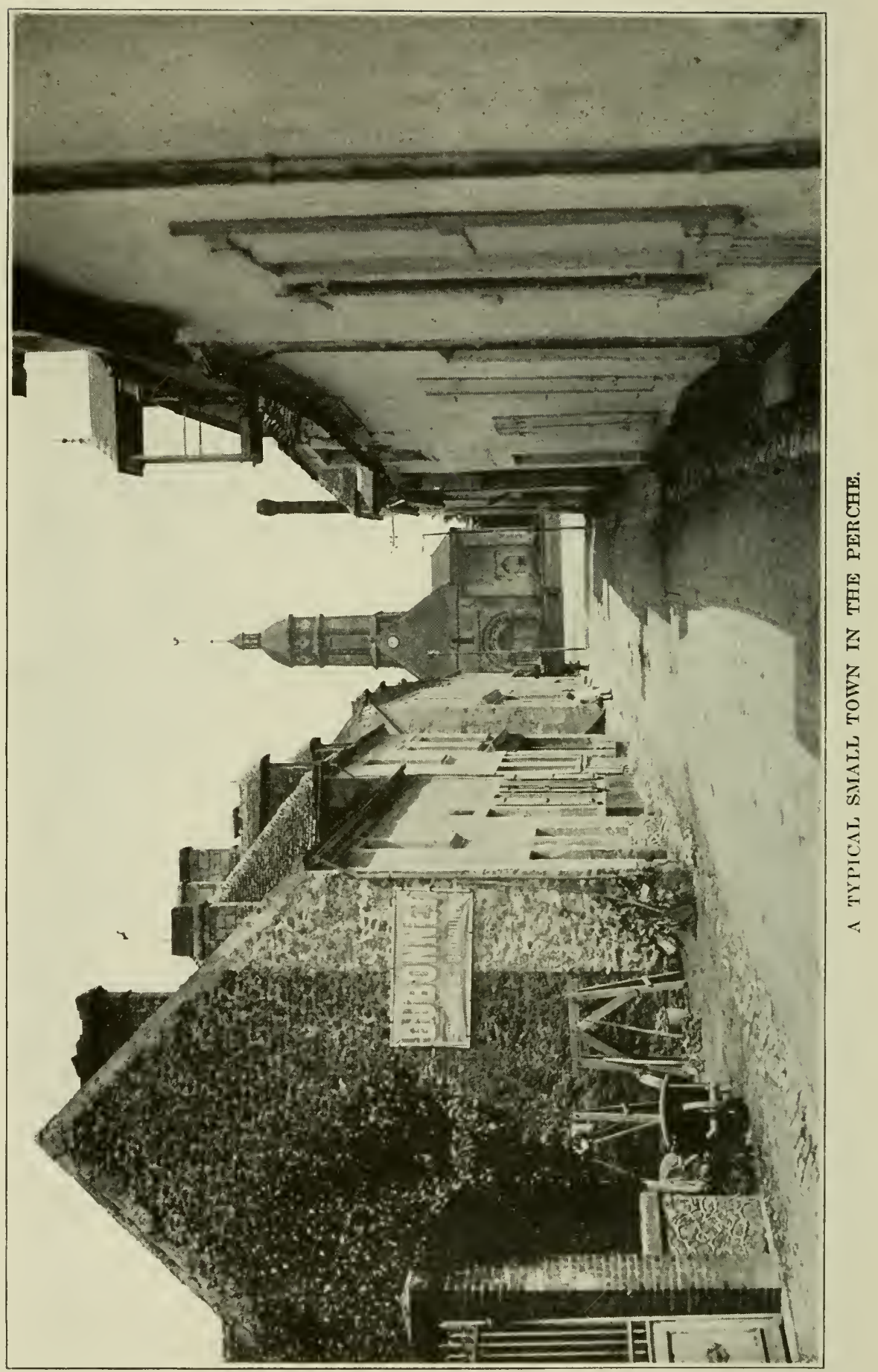


ing hands each week. At the fair held at Laigle, July 11, 300 head of horses were disposed of, and at the fair held on the first Friday in September 220 head were sold. At a third fair at the same place on the 12th of November no less than 550 horses were sold.

In an old brochure by P. Bruyant entitled, "Nogent-le-Rotrou et ses environs," it is stated that the chief local industry, the manufacture of bolting cloth, began to decline in 1774 , due primarily to the shipwreck of the "Nogent-le-Rotrou", with a cargo of cloth, the son of the owner of the vessel and of the industry, René Gullier, being drowned and his father ruined. "But," says the author, "fortunately the derelopment of the breeding of Percheron horses commenced to compensate for the decline of this local industry."

Long Famous for Its Horses.--Old letters written by residents of The Perche and still conserved in the government archives at Paris show that from very early periods the province has been courted as a producer of good horses. In fact, its fame in this regard led to frequent spoliation, numerous raids being made by marauders who evidently knew in advance where good mounts were to be had. During the civil war known as the Fronde, under the minority of Louis XIV (1648-1653), both the party of Mazarin and that of the nobles mare frequent incursions into this region, primarily for the purpose of carrying off horses. History tells us that Beaufort, the warlike grandson of Henry IV of France, entered 
The Perche in 1652, "striking ter"ror everywhere and stealing horses."

In a letter in the National Library, Paris, dated March 7, 1628, and written by one Michel Denyau, a notary of Montcloubleau, we read: "The Perche has suffered very much; the army has carried off the majority of our mares." In another written June 7, 1651, the writer complains: "The gendarmerie has ruined everything' in The Perche, and publicly stolen everything it came across in the way of horses. - . M. de Villir informs me that the gendarmerie has ruined everything in the Chartres country and stolen the hor'ses."

Still further confirmatory of the assertion that The Perche has always been pre-eminently a region fitted to the raising of live stock, and especially horses, we find the following eighteenth century letter from the Intendant of Alençon to the Intendant of Tours on the subject of rumors relative to the cornering of the wheat crop:

"Have no faith, sire, in the reputation for" an abmulance of wheat which we are said to possess. I have already had the honor of calling your attention to the fact that in all the Election of Alençon there is not produced enough wheat to feed us three months. Our culture consists in grass and hay to fatten our steers, which we get from Poitou, and to raise very fine horses, which make our principal commerce."

\section{A People Devoted to Their Own.-All the world} has wept with Longfellow orer the fate of the Acadian farmers of Grand Pré. The attachment of 
the French people to the soil upon which they have lived and loved is indeed proverbial. We in America have before us the fine illustration of the thrifty, home-keeping habitants of the lower St. Lawrence. This trait is strongly marked among the expatriated French, but when we come to those actually born and bred under the lilies of Old France it assumes the form of that passionate devotion to country which finds ready and tragic demonstration whenerer the call to arms is souncled.

From time whereof the memory of man rumneth not to the contrary this adherence to things which have been their own for generations has marked particularly the character of the farmers of provincial France. The Abbé Fret, one of the chief historians of The Perche, referring to the habits of the people of this province before the revolution, said:

"Each village family, free from all ambition, oceupied itself with its purely domestic affairs, and rarely lost to view the church sterple of its own respective parish. Each indiridual, content with the lot apportioned by Providence, desired neither greatness nor riches and the village church-rard held within its bosom the ashes of ten generations; for it was an honor to share the last resting place with one's forefathers just as they had shared their legacies."

The Perche of Today.-After the Revolution The Perche, together with all the other ancient provinces of France, was dividerl into departments. Thus we find The Perche today comprises the departments of Orne, Sarthe, Eure-et-Loir and Loir-et-Cher. Orne 
and Sarthe include the greater part of the territory, but Eure-et-l soir, in which the city of Nogent-lc. Rotrou is situated, is perhaps of the greatest importance so far as the Percheron breed is concerned. Loir-et-Cher has the least territory in The Perche, and yet the neighborliood of Montdoubleau and Sarigny-sur-Bray has always been famous for producing fine draft mares of true Percheron character. The birthplace of the modern type is found within a radius of 18 or 20 miles around Nogent, a territory which includes a little of all four of the departments. It should here be observed that not one of these departments in its entirety is found in The Perche. For example, a part of Orne is situated in what has long been known as Normandy. The great breeding centers of the Percheron race at this date, and in fact for many years past, have been Nogent-leRotrou in Eure-et-Loir, La Ferté Bernard in the Sarthe, and Mortag'ne in Orne.

What the farmers of The Perche were in the olden times so are they today, in so far as relates to their devotion to home and land and horses. Their horses are a part of their inheritance particularly prized and accustomed to the affectionate attention of the entire household. Their docility, growing out of this intimate human companionship, is therefore an inbor'n trait.

Such is, in brief, the cratle of the breed of which we are to write-at region of green hills and verdant vales, populated by a patient, persistent, kindly, frugal, slirewd, home-loving people rooted firmly to 


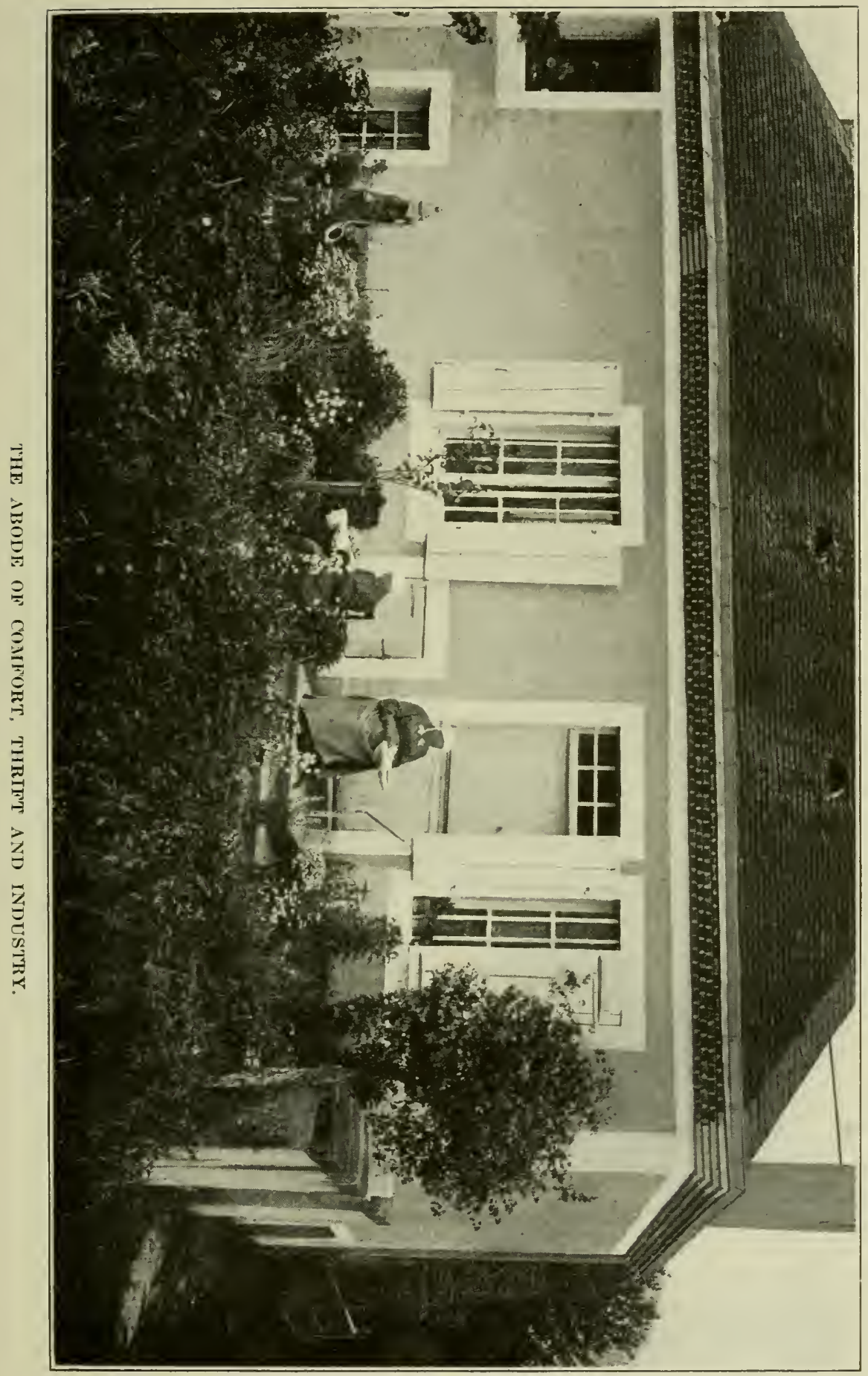



the soil of their fathers and always loyal to the old traditions. Around their white ancestral walls oldfashioned flower's grow and sweet-scented roses bloom, and with each recurring advent of spring through dreamy sumny days and under skies of rarest blue the apple blossoms fill with beauty all the land and spread their fragrance.

Quaint and picturesque, and true always to itself, is this ancient province of The Perche. 


\section{GHAPTER II.}

\section{PERCHERON PROTOTYPES.}

The author of a "History of Ancient Perche," M. Odolant-Desnos, remarks that the F'rench are "more inclined to make history than to write it." They have developed the Percheron horse, but his real origin is involved in almost total obscurity. Only speculation can be indulged in concerning his remote past, and strange to relate, until now few facts have been available touching the evolution during the past century of the heavy draft type, which, it must be understood, is distinctly a modern creation. Prior to the Napoleonic wars the Percherons were practically all of the diligence type, and it was not until about 1820 that a demand for heavier horses for agricultural purposes manifested itself sufficiently to induce a studied effort at increasing the size and weight of the breed. The French gorernment gare this morement support, as will be shown presently, and the farmers of The Perche persisted in their efforts in this direction until the foundation was laid upon which was made possible the production, at a still later date, of the 2,000-pound horse ultimately called for by the American trade.

This one thing we know: that through centuries of ricissitudes the farmers of The Perche clung to 
their good horses, morlifying the type from time to time to meet changing conditions. From the earliest times 'The Perche farmer has been a producer of horses, and not often a buyer from elsewhere. The whole temper of The Perche people is opposed to the miscellaneous introduction of material from the outside. They were a little world unto themselves in this matter of their horses, and relied mainly upon their own ability to mold the type from within the limits of their own country as new demands were made. They were always free sellers of colts and horses to the adjacent provinces and central cities. The usual morement was from within outward, and not from the outside into the district. An understanding of this fact is of fundamental importance in attempting to grasp the reasons for the Percheron's latter-day popularity. It establishes a basis for his prepotency in crossing upon mares of mixed breeding, such as were commonly found in the adjacent provinces of France and especially such as were in use in the United States at the time the great extension of Percheron breeding in America began.

Some of the Fairy Tales.-Almost every possible equine ancestry has been suggested to explain the existence of the Percheron horse. For a long time -and eren to this day one may find this explanation given in encyclopedias and other books of general information-it was maintained that the Percheron was a descendant of the Brittany draft horse. Some writers have gone so far as to adrance the theory that the Percheron is of English ancestry; other's 
state that the gray color has been obtained by liberal crossings with the Bonlonnais; many have hinted that Flemish blood has entered into its make-up. Some writers tells us that the old Bourbonnais horse has played a prominent part in the evolution of the Percheron; others hint of a possible Spanish source. It has even been asserted that the black color which became popular about 1880 was due to Nivernais blood, while still other's have exaggerated the use of Picardy mares, introduced to a small extent ne:rr Montdoubleau near the beginning of the nineteenth century, proclaiming them the progenitors of the heavy Percheron type. And last, but by no means least, there is the commonly accepted teaching that the Percheron is of Oriental origin and that even as late as the nineteenth century his latter-day excellence, as well as his preclominating color, is to be ascribed to the powerful influence of two Arabian stallions from the government haras at Le Pin!

It would be idle to discuss all these in detail. Traditions are anybody's creation. Legendary tales must pass at their own value. Authentic French government records, however, cannot well be got around. We shall present some that have apparently been heretofore overlooked.

The Saracenic Rout.-Historians affirm that on the day in which Charles Martel, a king of Old France, met and overcame the Moslem host of $\mathrm{Ab}$ derame upon the field of battle between Tours and Poitiers 300,000 Saracens were slanghtered. The fate of Christendom was at stake. This was A. D. 


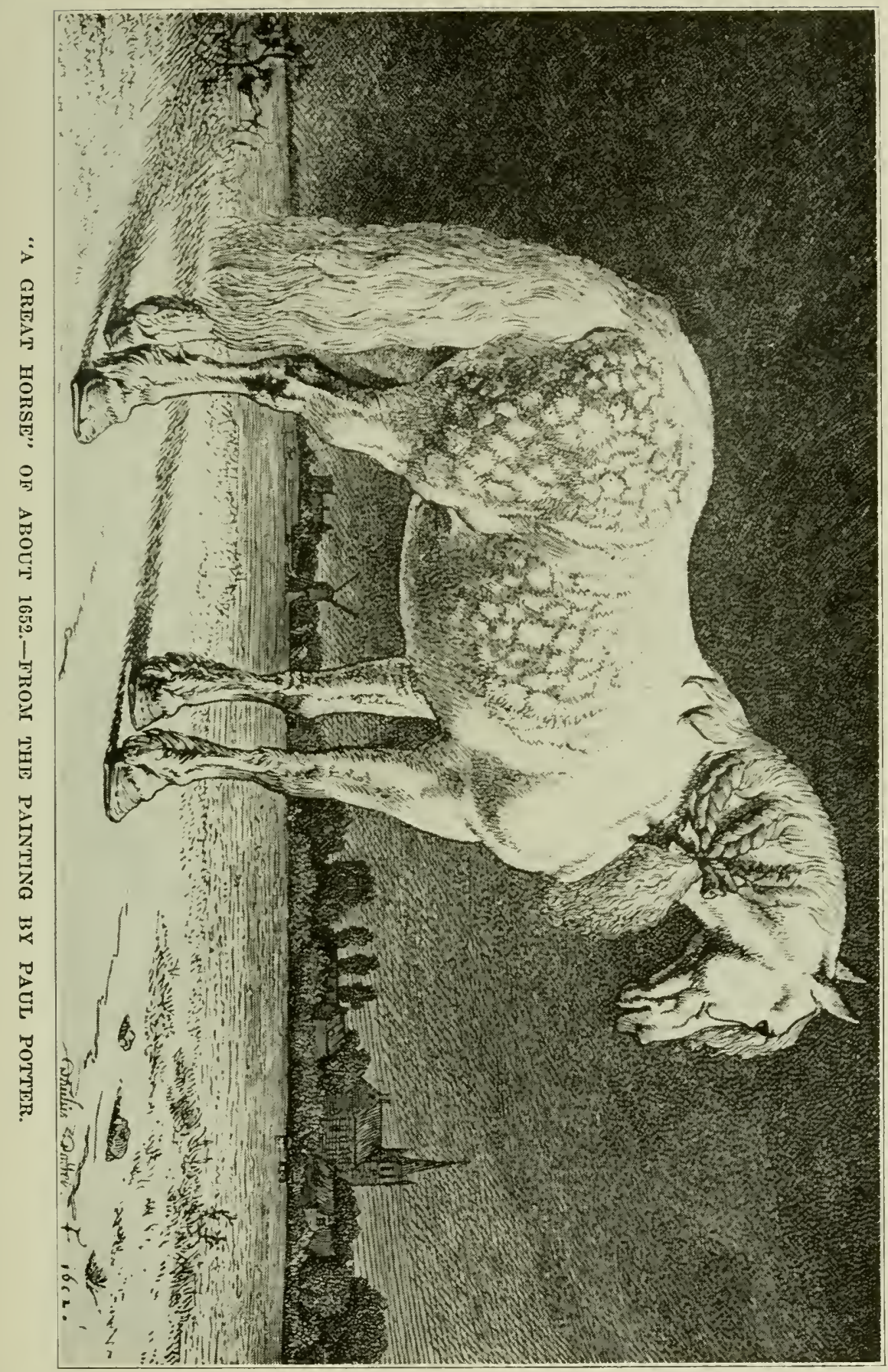



732. There is more than a suspicion that the number slain was placed by the old chroniclers at a figure large enough to cover all possible contingencies. Howerer, that is not the point. It has always been claimed that in this overwhelming rout the invaders left behind them many horses of the desert breed, and that these were distributed among the troops of the French monarch, many of whom lived in the regions since known as the Orleanais, Normandy and The Perche.

That Arab blood was left belind at the time of this crowning disaster to Oriental arms in western Europe no one need doubt; and looking down the long vista of the centuries that have come and gone since then, we may find in this a possible explanation of the combined style and substance of the gray and white chargers so numerous in the middle ages - a possible cross of the eastern blood-horse upon a weightier western type.

Mounts of the Crusaders.-After the lapse of some centuries came the Crusades, when the very flower of European chivalry, rallying to the standard of the cross, invaded the Holy Land. Numerous expeditions followed in which the French monarchs and nobles took a conspicuous part. It has been said that The Perche received liberal introductions of Arabian blood following the return of the Crusaders, who are alleged to have brought back stallions that were freely used to the great profit of the horses of the district. Certain writers go so far as to name Geoffroy IV, the lord of Montdoubleau, 
Count Roger of Bellesmer, Goroze, the lord of Saint Cerney, Courville and Courseroult, and Rotrou, Count of The Perche, as personages of high degree who aided in this undertaking. It is further alleged that while the blood -was also brought into other provinces it was nowhere so carefully conserved or in-bred as in The Perche. All of which may be true, or it may be pure invention. The fact is, that if the traditions as to the type of horses used by the Crusader's and the knights of the feudal ages handed down from one generation of artists to another are to be relied upon in any degree whatsoever, it is more probable that the Crusaders waged war with horses of their own production much better adapted to their needs than was any desert stock.

In concluding his discussion of the effects of these expeditions upon European progress the great French authority, Michand, in his "History of the Crusades," speaking of various benefits accruing to the participating nations, takes up in detail the contributions to the arts and industries growing ont of those conflicts. Among other things he mentions the effect of the Crusades on European agriculture and tells of wheat and of various fruits and plants that were brought back to Europe. But the only reference he makes to the horse in this connection is in the following sentence:

"A short time after the first expedition of Louis IX Birbar sent to Mainfrey, son of Frederick II, several Mogul prisoners with their horses, which were of Tartar breed." 


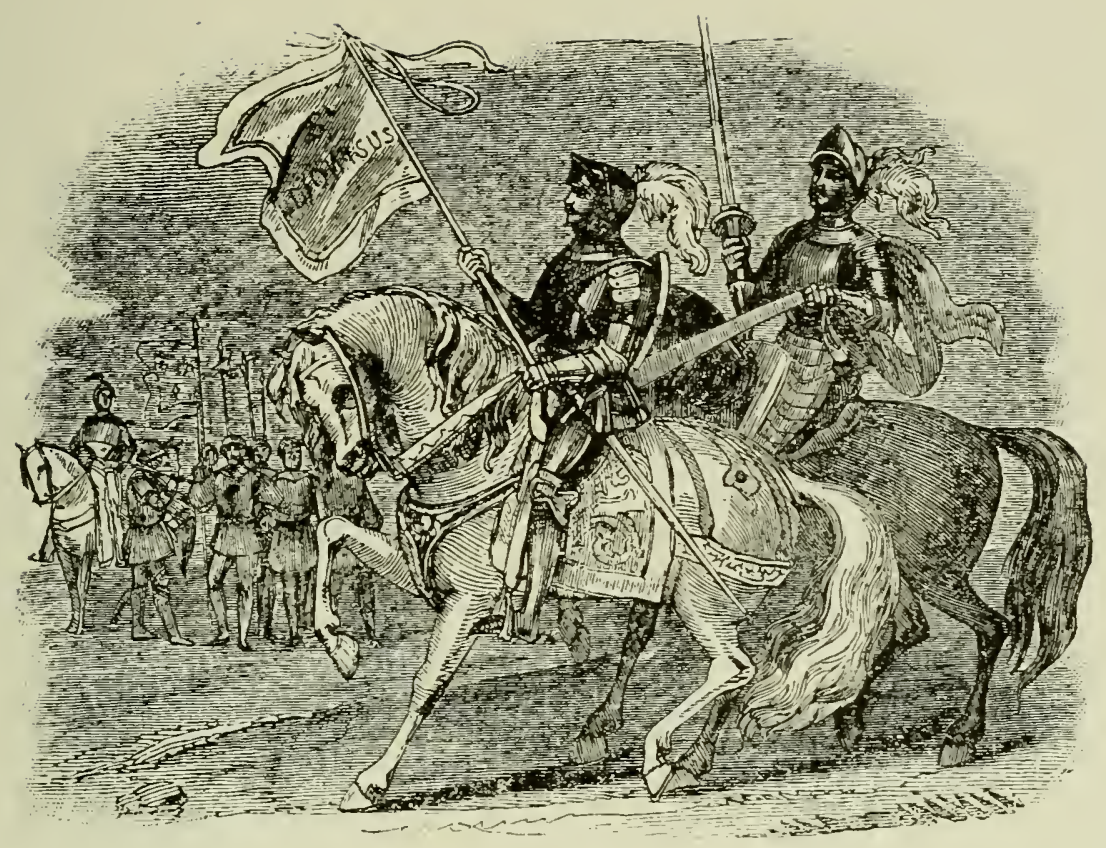

UNFURLING THE SACRED ORIFLAMME OF OLD FRAYCE.-FROM FROISSIRT'S "CIIRONICIES."

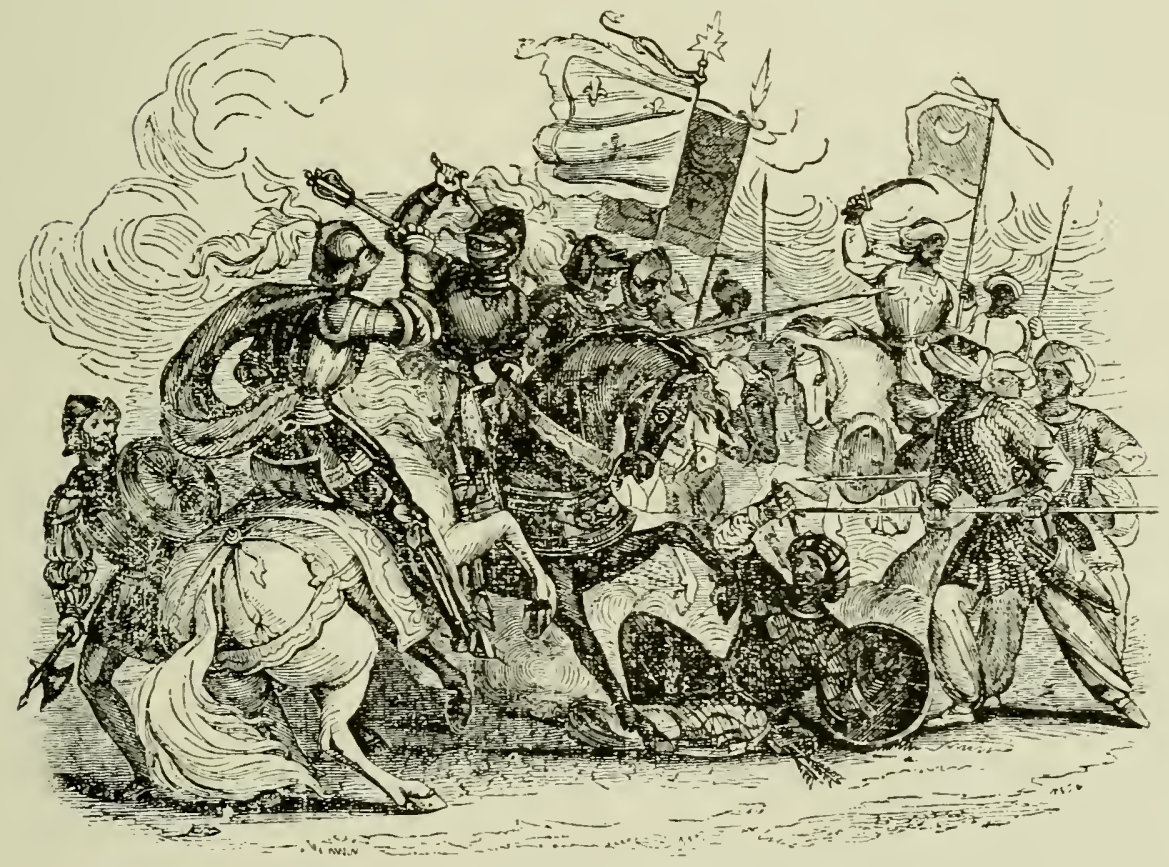

CRUSADERS IN CONBAT.-FROM FROISSART'S "CHRONICLES." 

No mention is made of the introduction of Arabian stallions. Curiously enough, in a fine edition of this work published some years ago, profusely illustrated with drawings by the celebrated artist Gustave Doré, the French and the English knights, and even royalty itself, when mounted are invariably shown astride stoutly built white or gray chargers. On such a horse Doré delineates Richard Coeur de Lion himself in his famous conflict with the Sultan Saladin. Another drawing, entitled "Glorious death of Jacques de Maillé," shows that famous Knight of the Temple going to his death as a noble steed of the same type sinks to the earth pierced by many arrows. Again in the plate entitled "The Battle of Antioch," the European knights are seen galloping into action mounted on great wide-quarterer horses of the same general conformation. So in the picture of "200 Knights Attacking 20,000 Saracens" the big, white chargers are everywhere in evidence. Most curious of all, perhaps, is the fact that Doré in drawing upon his imagination to illustrate the celebrated "Apparition of Saint George on the Mount of Olives" depicts the patron saint of England mounted on a white horse of the same type and fitted out-very properly for a steed used in navigating the air-with a pair of wings!

War Horses of the Middle Ages.-Histories dealing with the Dark Ages are lamentably lacking in horse lore. Breeds were not discussed much in those days; only types were mentioned. The draft horse had then no place. The war horse dominated every- 
where. Plowing was done chiefly by oxen. The carrying trade was done either by oxen or by pack animals. Even as recently as about 200 years ago we find from the old manuscripts on The Perche that the native horses in that province transported on their backs wheat and manufactured goods to Paris (three days by road), to Ronen, Brittany and other centers. There were three classes of horses used-the destrier, or war charger, the palfrey, or parade horse, and the roussin, or road horse. These designations were in rogue until the beginning of the nineteenth century.

The horse that could serve successfully the purposes of the mail-clad warrior's of fendal times had to be up to carrying a lot of weight. With the burdens put upon them, no weakling steeds would long survive the shock of joust or tournament or the more serious work of the field of battle. Not only was the charger himself sometimes loaked down with his own gear-metal-ornamented caparison, with perchance steel breast-plate and hearl-piece-but in the saddle was an athletic rider with his load of iron and lance or battleaxe in place. Substance withont sluggishness was a prime consicleration. Activity in hand-to-hand combat meant losing or gaining ail. A horse with prond carriage was demanded to meet the state and dignity of nobility and royalty. In brief, only a grand good type of horse could meet the imperative requirements of those whose lives depenter so largely mpon the weight and mettle of their mounts. 


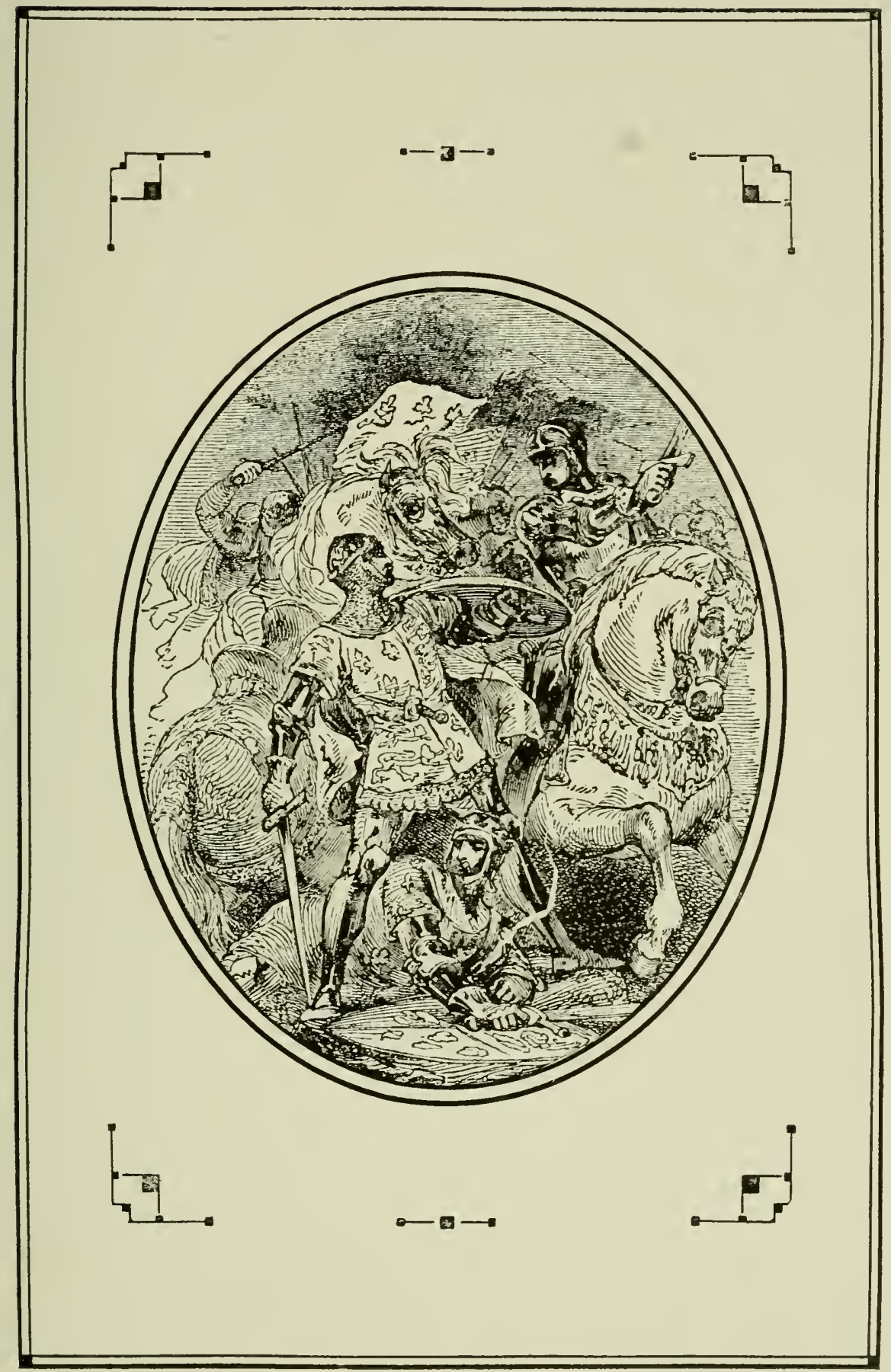

A WAR HORSE OF THE MIDDLE AGES-REPRODUCED FROM FROISSART'S "CHRONICLES OF ENGLAND, FRANCE AND SPAIN." 

We have before us as we write a rare old edition of that famous literary landmark of the feudal ages, "The Chronicles of England, France and Spain," written by Sir John Froissart, "the Herodotus of a barbarous age." In it are recounted the most daring deeds performed by the belted knights of the thirteenth and fourteenth centuries. There are practically no references in the text to types of horses, but there are many quaint wood engravings, reproductions of old-time delineations, that are not without interest in this comnection.

Crude as these old drawings may appear, there is this to be said about them: they apparently demonstrate, in the first place, that gray and white were the prevailing, or at least the farorite, colors with the French noblesse of that period; and in the second place, that the artists were endearoring to draw horses that were not only refined, clean-limbed and of good style, but that also possessed marked substance. Stout middles and generally thick bodies are almost invariably shown.

It can of course be said that neither Doré nor the earlier artists who undertook to depict the type of horses in use in the old days had any technical knowledge of breeds or types. That is probably true. Animal delineation was not their specialty. Nevertheless, the fact that many different artists working at different periods and illustrating different phases of the military operations of the Crusades and the Middle Ages, seem to have fixed upon practically the same type of horse in nearly every 
instance, to wit, a gray or white with clean-cut head, heavy shoulders, wide back and quarters and, usually, clean limbs, is significant.

Corroborating the work of the artists, at least in respect to the color, may be cited a verse from the old-time ballad recounting the deeds of valor performed by one Charles de Trie, a valiant knight of The Perche. It was sung by the wandering minstreis and ran as follows:

\section{"Ce biau sire de Trie, \\ Sur son blanc destrier, \\ Contre gent ennemie \\ S'en va guerroyer."}

This old French has been freely translated:

"On charger white the sire of Trie

Against the foe has gone to war."

M. Du Haÿs, whose great affection for the Percheron led him to prepare his beautifully-written history of the breed, remarks that in his childhood he had often been rocked to sleep to the tune of this old song, embodying as it did one of the old traditions of the province.

The Probable Foundation.-That the blood of the Arab, derived from the spoils of the great Saracenic rout, may have been the source of the style and beauty of the war hor'ses used several centuries later by the Crusaders against the Moslems, is not a violent assumption. That the French nobles brought back Arabian stallions from the Holy Land is not at all improbable. That these were used upon the mares of The Perche and other provinees is easily possible. But upon neither point is there any real 
proof. On the other hand, if the testimony handed down by artist and historian is of any value whatsoever, we may safely assert that gray horses of noble character and stout conformation were in universal favor in France at the time of the Norman conquest of England and continued to be popular throughout the centuries preceding the introduction of the diligence. We conclude, therefore, that the strong, active grays with which those heavy vehicles were horsed were in all probability the lineal de. scendants, the logical successors, of the splendid horses that graced the age of chivalry in western Europe. This, then, is the likely prototype of the Percheron of pre-Napoleonic times, the fountainhead of that courage, soundness, stamina and color which has long been his heritage.

Before passing to our examination of the records of the French Government, which throw such a flood of light upon the modern type of the breed, we present the report of a discussion which took place in The Perche many years ago touching the mooted question of the remote derivation of the race. This has not heretofore been accessible to the general public, but was uncovered in the course of our extended exploration of the agricultural literature of France. In view of its historical importance we here give it place.

Normandy Invades The Perche-We refer to a congress of agriculturists held at Mortagne in 1843, a full account of which we find in the official "Annuaire de l'Association Normande," the only report 
extant. It may be stated in passing that this "Association Normande" was an organization that met at different towns in Normandy at stated periods. While it was customary to holl the annual congress at some town within the borders of the ancient province of Normandy, this meeting of 1843 was held in the Arrondissement of Mortagne, which is wholly in The Perche and has always formed a part of the Generality of Alençon, the capital of the present Department of Orne, in which the town and Arrondissement of Mortagne are situated. This detail explains the reason why the Nolmandy association, including as it did many members living in The Perche, took up the question of the breeding and origin of the Percherons, which at that time was exciting much interest. We mention this in order to record the fact that a certain part of Normandy and The Perche encroached the one upon the other, and it was only by following up the bibliography of French agriculture under the head "Normande" that we were able to locate this important report of the Mortagne congress of 1843, which we believe has not heretofore been presented in connection with the study of this subject. In fact, so far as we know, this is the first time that the letter of the Abbe Fret has been given to the Percheron breeding public of the present time in its entirety. We are indebted to the "Société des Savants" for the privilege of examining the publications of the "Association Normande."

Whence the Percheron?-Under the head, "Race 
de Chevaux Percherons," we find the question introduced as follows:

"M. de Caumont haring put questions concerning the breeds, and respecting the Percheron breed in particular, a discussion took place upon this subject.

"M. Oliver, veterinarian, has the floor. He pointed out that formerly the Percheron breed comprised two well defined varieties or types; the lighter type was known as a 'light draft horse,' and the other, which was larger and more material, was called a 'draft horse.' He complained that the introduction of Picardy mares in the neighborhod of Montdoubleau, about 1815, had altered the primitive trpe of the Percheron. He thought that by making the breed larger in size they had closed one of their most important outlets, viz., the sale of army horses, which had been, under the Empire, their most assured outlet. He thought also that eren the service of diligences must suffer from the alteration in trpe which he had mentioned, and he expressed a wish that the government would take the necessary steps to establish the ancient Percheron breed in all its purity.

"M. Gautier, veterinarian, replying to M. Oliver thought that the changes complained of had not brought about differences so important in the Percheron breed as he (M. Oliver) had supposed, because if the breed really had become heavier by means of the mares of Montrloublean, these mares are none the less Percherons. M. Gautier thought that the railroads would canse great modifications in the horse trade, and that in the future the number of horses required for diligence purposes would diminish according to the development of new railways, and that it was necessary for the farmers of that region to apply themselves to the production of army horses. 
"M. de Blampré remarked that castration was not in usage in The Perche, and, if Percheron horses supported the operation like horses of other breeds, it would appear that, according to a generally adopted opinion, a profound alteration took place in their qualities, etc.

"M. Bigot thought that the farmers of The Perche should assure themselves respecting the effect of the railroads on the horse trade. The same fears had been manifested in Belgium, now covered with a network of railroads."

The Arabian Tradition.-M. de Blampré then read a letter" "from M. l'Abbé F'ret, member of the Association," regarding the origin of the Percheron horse. The priest had mentioned the Percheron in his well known history of The Perche, but in so doing he had quoted from the writing's of Delestang. It was not until this Mortagne congress of 1843, in the letter herewith reproduced, written to be read upon that occasion, that we find anything mentioned as to the bringing of Oriental stallious back from Palestine by Perche noblemen or as to the part such horses possibly played in the history of the Percheron. Neither Du Haỵs nor his followers have given any quotations from this letter, nor has any of them given any account of the debate that occurred between the members of the association which took place upon that occasion. The letter follows:

"Within the confines of the ancient province of The Perche is raised a breed of horses known by the name of Percherons, very distinct both in exterior and aptitudes; they have the size, some have 
fine conformation, and they are, for the most part, excellent draft horses. In many of the manor houses in the lower Porehe there is a tradition that has been handed down for six centuries to the effect that the beauty of this breed was due primitively to its crossing with the Arab, of which breed good juclges find today, in the shape only of certain indiriduals in The Perche, several characteristic traits.

"At the time of the Crusades, influenced like other's by the religious zeal which, in this period of chivalry, compelled them, as a duty, to arm themselves against the infidels, a large number of the Percheron Seigneurs started out for the conquest of Palestine, and stared for more or less time in the ()rient. Sereral of these raliant knights errant brought back from this far off country some Arabian horses of the strain 'kadischi,' which were employed in the improvement of the native breed. Geoffroy IV, Seigneur of Montdoubleau, was one of the Crusarlers who showed the most zeal in propagating this breed.

"Tradition has left us a pretty good irlea of this improved breed, formerly in great demand as coach horses, which for elegance, conformation, energy, style and long service could be compared to the breed known as the Limousine. But, by its crossing with breeds less perfect, it has successively degenerated, and almost entirely fallen owing to the negligence and apathy of the landowners, who have done nothing whatever so far as selecting indirichals for breeding purposes is concerned. Howerer, this breed is today in such demand by buyers from the adjacent departments that it is becoming a branch of commerce of great benefit to the region, and for that reason it is necessary that it should be improved.

"The possession of Algeria by France renders the importation of Arabs of the 'kadischi' strain extremely easy. Assuredly the mixing of this blood 
with the Percheron blood would produce the same results as during the eleventh and twelfth centuries. "We ardently trust that the rich landowners of The Perche will take the initiative in this worthy cause, so that the province, which has produced for France this fine breed to which it has given its name, will not be disinherited of the glory of having rendered it its primitive purity."**

\section{An Historic Discussion.-Inasmuch as the abbé's}

* This document is deemed of such historic interest that we herewith supplement our translation of it by presenting the original French:

"L'ancienne province du Perche élève dans son sein une race de chevaux connu sous le nom de percherons, très distinct par leur forme et d'un bon service; ils ont de la taille, quelques-uns de la figure, et sont la plupart d'excellents cheraux de trait.

"Une tradition, conservée depuis six siècles dans plusieurs chateaux du bas Perche, prétend que la beauté de cette race était due primitivement à son melange avec la race arabe, dont les connaisseurs retrouvent encore aujourd'hui, dans la figure seulement de quelques individus plusieurs traits caracteristiques.

"A l'epoque des croisades, entraînés comme les autres par le zèle religieux qui, dans ce temps chevaleresques, leur faisait un devoir de s'armer contre les infidèles, grand nombre de seigneurs percherons partirent pour la conquête de la Palestine, et restèrent plus ou moins de temps dans l'Orient. Plusieurs de ces preux paladins ramenèrent de ce pays lointain quelques chevaux arabes de la race "kadischi", qui furent employés a l'amelioration de la race indigène. Geoffroy IV. Seigneur de Montdoubleau, fut un des seigneurs croisés qui mirent le plus zèle à propager cette race.

"La tradition nous a laissé une idée avantageuse de cette race perfectionnée, qu'on recherchait autrefois pour les attelages de luxe, et que l'on comparait pour la grâce, l'élégance, la figure, la vigueur, la finesse, et la durée, à la race connue sous le nom de limousine.

Mais, par son mélange avec des races molns parfaites, elle a successivement dégénéré, et presque entièrment tombée par la négligenc? et le defaut de lumière des propriètaires, qui n'ont apporté aucun soin dans le choix des sujets propres à la perpétuer dans le pays.

"Il serait cependant d'autant plus important de perfectionner cette race, qu'elle est aujourd'hui très recherchée des departements voisins, et qu'elle prend une branche de commerce très arantageuse pour le pays.

"La possession de l'Algerie par la France rend extrêmement facile l'importation au Perche des chevaux arabes de la race de "kadischi." Assurément le melange des ce sang avec le sang percheron produira les mêmes resultats qu'aux XI et XII siècles.

"Nous formons des voeux ardents pour que quelques riches propriétaires du Perche prennent l'initiative dans cette honorable entreprise, afin que la province, qui a procuré à la France cette belle race chevaline et qui a donné son nom, ne soit pas deshéritée de la glorie de l'avoir rendue à sa pureté primitive." 
letter has been made the basis of so much that has been handed down to our day and generation, it will now be of interest to set forth the discussion which it provoked among those who were present. Particular attention should be given to the remarks of M. Gautier, whose standing at the time may be fairly gauged from the fact that he not only opened but closed the discussion. We again quote verbatim:

"M. Gautier said he had no knowledge of any documents which would cause one to think, like the Abbé Fret, that the Percheron was descended from the Arab; or from the Brittany horse, as some others thought. As for himself, he had the conviction that this breed (the Percheron) was a primitive type, and that the introduction of the English half-blood, as a sire, had brought in modifications rendering it suitable for an army horse.

"M. Blanpré thought that the crossing of Percheron mares with half-blood horses had caused bad results. The half-blood is a mixed breed, and it would be contrary to all principles to admit a horse incapable of impressing character on its products. He thought that the conservation in the region of fine Percheron stallions, carefully selected, suitable, if one wished, of rendering the breed lighter and liberally encouraged by government prizes would be the best means of maintaining the horse of this breed as a commercial proposition. The crossing with stallions that did not show any primitive type had nearly destroyed all the French breeds.

"M. Le Roy thought that there mas too much dissimilarity between the Thoroughbred stallion and the Percheron mare to give any hope of success in such a combination. He feared, also, that the tenant farmers would be afraid of the lightness of the Thor- 
onghbreel, and that the half-blom was preferable, for if they gave their mates to a 'Thoroughbred stallion cortain qualities wonld he inlserited from the sire and other's from the dam, which would result in 'misfits.'

"M. de Clinchemps spoke warmly against any crossing with the demi-sang. . . . He thought that it was necessary, just as had been done by the English, to go back to the source and buy Arabian hor'ses as stallions, an opinion in liarmony with all principles, confirmed by experience and crowned by success in the case of our neighbours (the English).

'M. Gautier speaking' about the origin of the Percheron horse said: "The origin is still within the domain of probabilities. Every man, who has up to this time written on French and foreign breeds, says that the Percheron is of Brittany origin. As proof, nothing. Each writer, in consulting his predecessor, has reproduced the same opinion. One writer has said that the Percheron was of English origin. ()thers say that the Percheron is descended from the Arab. For me, if I may give my opinion: I believe that the Percheron is a primitive breed, singularly altered, improved by crossings at different periods with Arabian and Einglish horses."

"The Legendary Kadischi." - It will be observed that the writer of this letter is careful to set forth that what he tells of the introduction of the Arabian blood rests, not upon any existing records, but on "tradition" lianded down among" "the manor houses of the lower Perche." This then is the foundation upon which the Arabian story rests. It has been generally accepted; and yet not all the intelligent men of The Perche have given it credence, as is eridenced by the following from the "Annuaires Nor- 
mandes" of 1909, in the report of an agricultural show held at Mortagne where one of the local notables, M. de Longuemar, who made the principal discourse, said in speaking of the origin of the Percheron:

"The very nature of the soil itself, the environment-that is the primordial reason; much more certain than the hypothetical crossings of the native mares with Arabian stallions, the legendary 'kadischi.'

\section{Modern Arab Crossing Not Mentioned.-It will} also be observed that while there were various views expressed relating to the origin and crossing of the breed, there was no disposition to attach special importance to the Arabian phase of the proposition. It will also be noted that while this took place in 1843 , no reference whaterer was made to modifications of the breed by the use about 1820 of the alleged Arabian stallions Godolphin and Gallipoly, to be referred to further on. On the other hand, the probability of remote Oriental crossing's was apparently conceded, a fact which conforms to what we have already intimated in preceding pages touching the part possibly played by the Oriental blood in the production of the gray charger's used by the old French nobility.

Before dismissing this reference to the congress of Mortagne it should further be pointed out that at the time when it was held the army was a large buyer of horses in this district. This explains the talk about crossing with stallions of lighter types, 
with a view towards furnishing horses suitable for military purposes. In strong opposition to this, however, we find the farmers themselves, the mare men of The Perche, who were best able to judge for themselves what kind of a horse was best adapted for their own service. They preferred a heavier type, and, as we shall show in another chapter, the foundations of the modern heavy-draft Percheron had been firmly laid by the use of government-approved stallions, mostly of gray color and in many cases standing 16 hands and over in height, upwards of 25 years prior to the holding of this congress.

Is the Percheron a Primitive Type?-We draw special attention to M. Gautier's expression of his belief that the Percheron was in reality a primitive breed, from time to time crossed with other types. We do this for the purpose of introducing at this point the testimony of M. André Sanson, late Professor of Zoölogie at the National School of Agriculture, Grignon, France, and at the National Institute of Agronomy, Paris. In his book, 'L'Origine des races Francaises de chevaux,' page 95, Vol. 3, he says:

"The Percheron breed, like all the others, is contemporaneous with the mammoth of the alluvial. It goes back to the Deluge, and, in the presence of such antiquity, the epoch of the Crusades, by comparison, only dates from yesterday.

"The Percheron . . . had its origin in the basin of the Seine, and that is the reason why we give to this type the scientific name of Sequanien, 
derived from the name which the Seine had during the Gallo-Romano epoch.'

He then goes on to say:

"In the sandy alluvial deposits of the Seine Basin at Grenelle, so rich in fossils, several skeletons of horses were discovered in 1868. Among these was a skull almost complete.

"This skull (now conserved at the Museum of Natural History at Paris), although broken at the time by the pick-axes of the excavators, has been reconstituted perfectly, and is the only perfect skull of its epoch that science possesses, and as such is extremely precious. Having been enabled to examine this skull before it was restored, we were struck by the resemblance that each bone had to the cranial bones of the Percheron of the present day. Since then a methodical comparison of the two skulls has permitted us to establish their complete identity."

If a typical Ethiopian and a Chinaman were to be buried side by side, skilled anatomists could a thousand years hence establish their complete identity by an examination of their skulls alone, if conserved intact. It is said that the race of any given species demonstrates in the head, more than in any other part of its anatomy, the specific characters inherent in the race. Whenever a breed has been extensively crossed with another, such crossing is supposed to dirulge itself unmistakably, to the trained eye, in a modification of the cranial bones.

The Percheron is said to possess a dolichocephalic cranium. The Arabian horse is decidedly brachycephalic. Among other dolichocephalic equine races 
may be mentioned the old Flemish breed, but the median depression which distinguished the Flemish horse is reported to be absent in the skull of the Percheron. Further, it is said that there is a peculiarity about the head of the Pereheron distinst from all other breeds, in that near the half-length of the frontal bone of a typical Percheron there is a small re-entering curve, imparting to the physiognomy a specific aspect.

From a brochure entitled, "Les Habitants Primitifs de la Basse Orne," being a eopy of a lecture delivered by Dr. E. T. Hamy before the Association Française pour l'Adrancement des science at the Congress of Rouen in 1883, we learn that among the human and animal fossils discovered in an excavation made at the bridge of Vaucelles in 1787 was a skull of a horse of remote prehistoric antiquity. This skull was pronounced to be dolichocephalic, and from the indications of the surrounding strata it was established that the fossil clated from the Neolithic or Polished Stone Age.

Whatever bearing all this may have on the theory of Arab crossing mpon the mares of The Perche it gives color to Gautier's contention at Mortagne as to the Percheron's being a primitive type. 


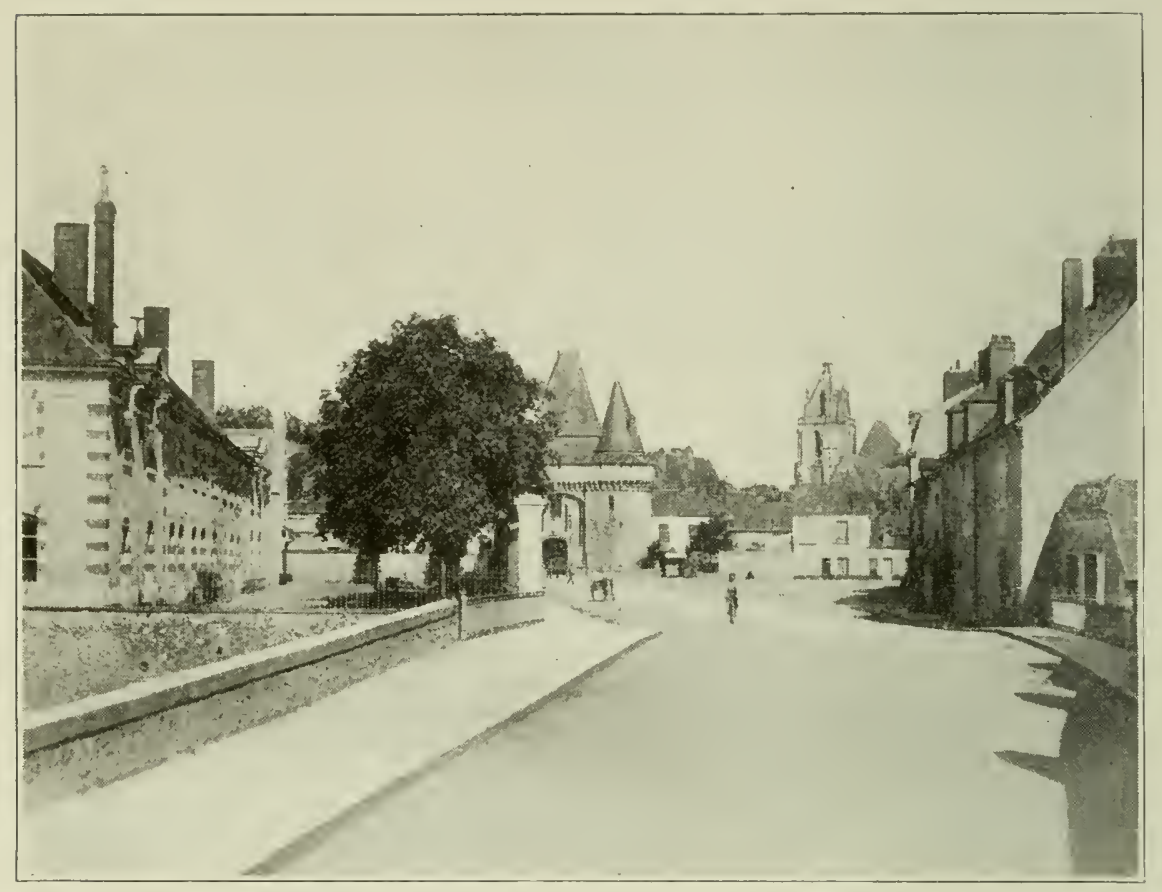

LA FERTÉ BERNARD-PLACE SAINT JULIEN.

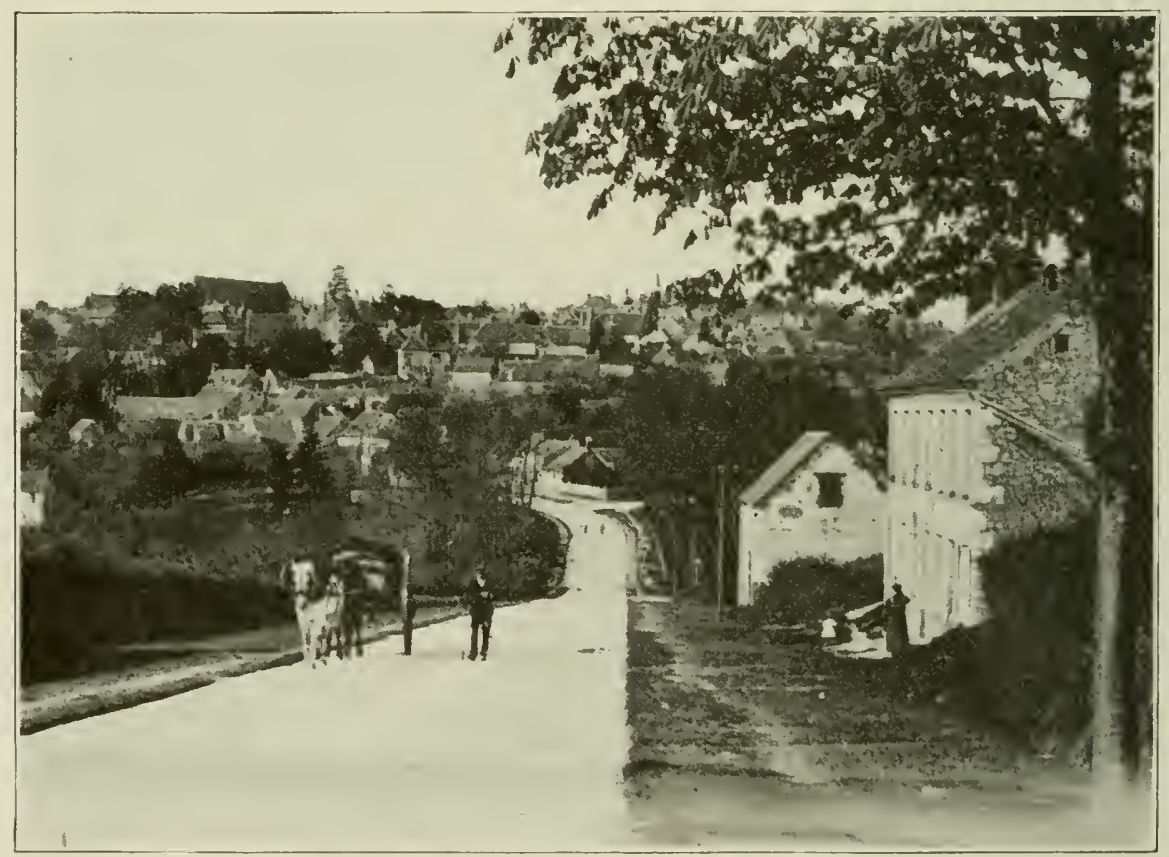

ROADWAY LEADING INTO MORTAGNE. 


\section{GHAPTER III.}

\section{THE RENAISSANCE FOLLOWING THE REVOLUTION.}

In a rare old book published at Mortagne in 1801, the ninth year of the French Republic, we find these paragraphs:

"The breed of horses known as the Percheron is destroyed; it is absolutely annihilated; the suppression of the haras has contributed to its dying out. This breed was precious for its courage, its vigor, and its longevity. It was more valuable for its wearing qualities than eren for its splendid conformation. It had excellent hips, fine hocks, round in rib, free-moving shoulders-though a trifle heary-a neck too leavily muscled, a head a little coarse, perfect legs and everlasting feet.

"Perhaps the Percheron breed, whose qualities are, without doubt, due to the climate and character of the pastures, can be reestablished by distributing the best stallions all orer the district, and confiding them to the care of rich landowners and respectable farmers."

The first paragraph is indeed valuable and interesting for its description of the Percheron as he existed prior to the great Revolution. "Everlasting feet" surely constituted the best of all foundations upon which to reconstruct a breed of horses that had suffered grievously from the effects of internecine strife. The second paragraph of course con- 
flicts with the first in that it shows that the breed was not literally "destroyed" nor "absolutely annihilated,"' because the author points the way whereby it is to be rehabilitated. Evidently Citizen Fontenay, who used this strong language, merely intended to express, with Gallic exuberance of language, a feeling of overwhelming regret that the native race had been so grievously injured. The reference is of sufficient importance, as learling up to the modern history of the Percheron, to warrant our making it the starting-point of our story of how the old breed rose Plooenix-like from the fiery ashes of the Revolution, and was transformed from a race of saddlers, humters and diligence stock into the moder'n horse "de trait," or heavy draft. The increasc in weight began to be clearly manifested, as we shall soon relate, arount 18:0.

Delestang and His History.-So far as we are aware, no writer on the Percheron horse lias quoted, or even mentioned, the author of the first really inportant publication or document in which the word "Percheron" is userl, as applied to the native breed of horses in The Perche. Tre refer to the work entitled, "Essai de Chorographic du IV Arrondissoment du Department de l'Orne. Chef lieu; Mortagne. Thermirlor, an IX," printed in July, 1801, and written by M. Delestang, the first T'nder-Prefect of the Arrondissement of Mortanne, a division corresponding practically to a county in the United States. True, Gallier, in lis work on the French breeds, has some idea that such a volume exists be- 
cause he reproduces a paragraph from the Abbè Fret relating to the Percherons and adds, "This is equally the opinion of Oclolant-Desnos, first UnderPrefect of Mortagne." Now Odolant-Desnos is one of the great historians of The Perche, but he was not "first Under-Prefect of Mortagne," nor indeed of anywhere else, but lived at Alençon and was by profession a doctor of medicine. And in passing it may be remarked that nearly all French writers have reproduced the paragraph on the Percheron hor'se in the Abbé Fret's history, but none seems to have been cognizant of the fact that the priest had copied it, almost word for word, from Delestane's book which had been published about 30 years previously.

Delestang had procured his information from the best local sources arailable, inviting the coöperation and collaboration of the citizens of Mortagne and the farmer's of the surrounding country, and the quoted paragraphs with which this chapter opens, he obtained from a "Memoire sur l'agriculture par le citoyen Fontenay." Delestang was the author of several books, largely compilations of statistics relating to his district, all of which was in The Perche. These are full of interest, and yet they seem to have escaped modern writers on the Percheron horse. On page 17 of his "Notice Statistique de la sous prefecture de Mortagne," published in 1801 under the head of "Animal Production," he says:

"This consists principally of horses, cattle and sheep. The horses, known inder the name of Per- 
cherons, were celebrated as saddlers and hunters, but they were employed chiefly as diligence and express horses. There are about 13,520 horses, mares and colts [in his district, of course]. Included in this number 5,200 horses and 5,280 mares are employed in agricultural work; 1,380 horses and mares are employed in other work than agriculture; and 1,560 are colts and fillies."

\section{Lamagdelaine's Prizes.-In his "Chorographie,"} published in 1803, Delestang speaks again of the Percheron horse, using in part expressions similar to those he had previously employed. But from this it appear's that it was afterwards discovered that conditions were not nearly so bad as Citizen Fontenay had originally stated, for under a caption, "Additional Information,', Delestang says:

"The breed of horses called Percherons owes its restoration to the solicitude of the Prefect of the Department, J. V. A. Lamagdelaine, who, desirous of regenerating this breed, has begun to offer prizes to the land owners and farmers who present, at the fair of Dec. 11, 1803, the finest brood mares and male colts of the Percheron breed. These prizes will be publicly distributed, on the fair ground, by the Prefect. This fair, called St. Andrew's, is renowned for the quantity of colts sold. The fair of St. Martin, held at Laigle, is also famous as a great colt fair. The commerce in horses at all the fairs of the Arrondissement of Mortagne is valued at about 550,000 pounds sterling, and that of the markets at about $£ 70,000$ weekly.'

In view of the fact that the purchasing power of money at that epoch was considerably greater than at present, it will be seen that the restoration had 


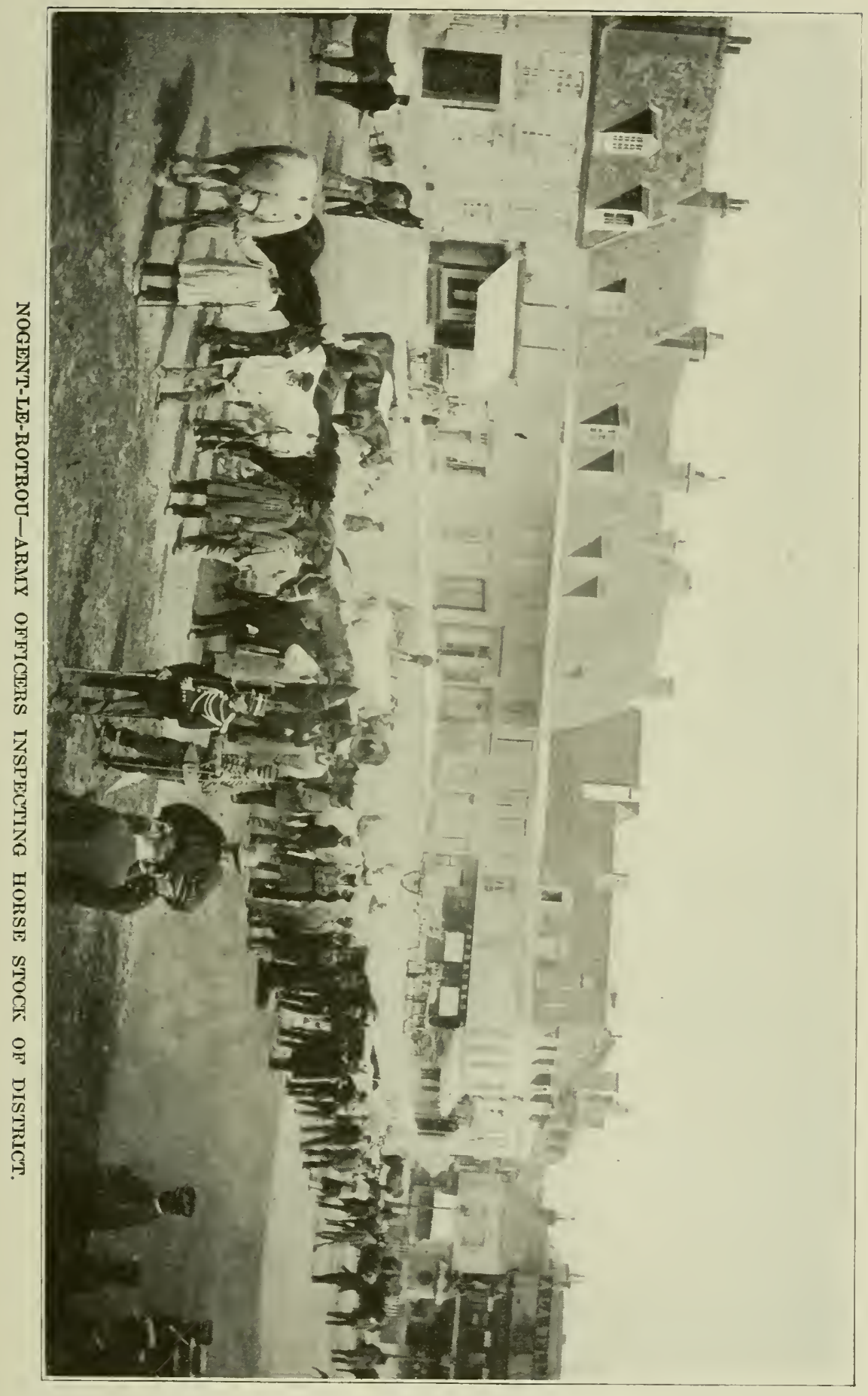



not only progressed rapidly, but that the type was in great demand from other districts, as the major part of the product was sold to burers hailing from outside points.

In 181:3, the "Conseil Général th Department d'Eure-ct-Toir" began to offer 1,000 franes a rear. divided between the Nogent and Courtalain fairs. At each two prizes, one of 300 franes and another of 200 franes, were offered for the finest brood mare and filly respectively. About the same epoch Orne began to offer 1,600 franes at the fairs of Alencon and Je Pin, but only Normandy horses are spoken of at these fairs. As a matter of fact it was the Normandy mares that were kept almost exclusirely near these latter places at this periorl, and these were bred to the demi-sang, Fuglish and other blooded saddle stallions kept for that purpose. Isa Sarthe also began about this time by giving 1,200 francs in bonuses.

A Draft Type at Montdoubleau._A complaint was voiced from the ricinity of Montrloubleau in 1818 that there were not enough stallions of the heavier sort arailable, showing that the objection of the farmers to the government's policy of faroring the lighter types was eren then officially noticed. We quote from the "Deliberations du Conseil Général de Loir-et-Cher", for 1818, under the head, "Elevage des Chevaux',

"The encouragement given to this class of improvement (the question of horses) offers in general satisfactory results. The canton of Montrloubleau, 
however, whose mares are only suitable for either heavy cavalry or draft purposes, would like to find at the depot of Blois, enough stallions analogous to the heavy type of mares found in the said region; in default of which the farmers will procure stallions to serve their mares wherever they can, in many cases sires which serve a great number of mares, because the service fees of these stallions are inferior to those charged by the government.

"The liberty of owning a stallion or recurring to that of one's neighbour cannot textually be destroyed; therefore it is necessary to combat this state of things by competition, and it is only by offering. to the said canton, eminently suitable for horse breeding, sufficient stallions appropriate for its particular class of mares and at the regular service fee obtaining in the region, that one can succeed in destroying the custom which has given rise to the necessity . . . etc."

Unverified Tradition Exploded.-Whether the horses captured at the battle of Tours from the Saracens furnished the basis of horse-breeding in The Perche or not none can say. That the Crusaders brought back Arabian stallions from Palestine to The Perche is a fairly reasonable assumption, although there seem to be no authentic records to that effect. That the gray and white chargers popular in France during the Middle Ages probably carried Oriental blood is of course possible. We now come, however, to a comparatively recent phase of the Arabian proposition which seems to demand special attention. We refer to the commonly-accepted statement that the modern Percheron owes not only a great part of his excellence, but the gray color as 
well, to the extensive use of "two Arab horses from the stud stables of Pin-Godolphin and Gallipoly.", The expression quoted is from "Le Cheval Percheron' by M. Chas. du Haÿs, the generally accredited modern historian of the Percheron in France. He says:

"These two valuable stock-getters, both gray, again gave tone and ardor to the Percheron race, and transformed definitely into gray horses the stock of the entire country, which had, it is said, become less uniform, and of all colors.'

It seems incredible that a mriter so generally wellinformed conld have been in error in a matter of such historical importance. The story of Godolphin and Gallipoly has been arlopted and incorporated into practically every rork dealing with the Percheron that has appeared during the past fifty years. None has doubted, none disputed, probably because of the rank and standing of the author. And yet his positive statements in other essential points have already been denied point blank by the Percheron Society of France.

It will be observed that Du Haÿs states that both of these horses were Arabs, and that both were gray. He also locates them definitely as coming from the government stud at Le Pin. He also says that they stood at the chateau of Count de Mallart near Bellême, and places the date at "towards" or "about" 1820. This latter" statement seemed to us to indicate a little uncertainty in regard to the date, at least. With no other idea, therefore, than merely 

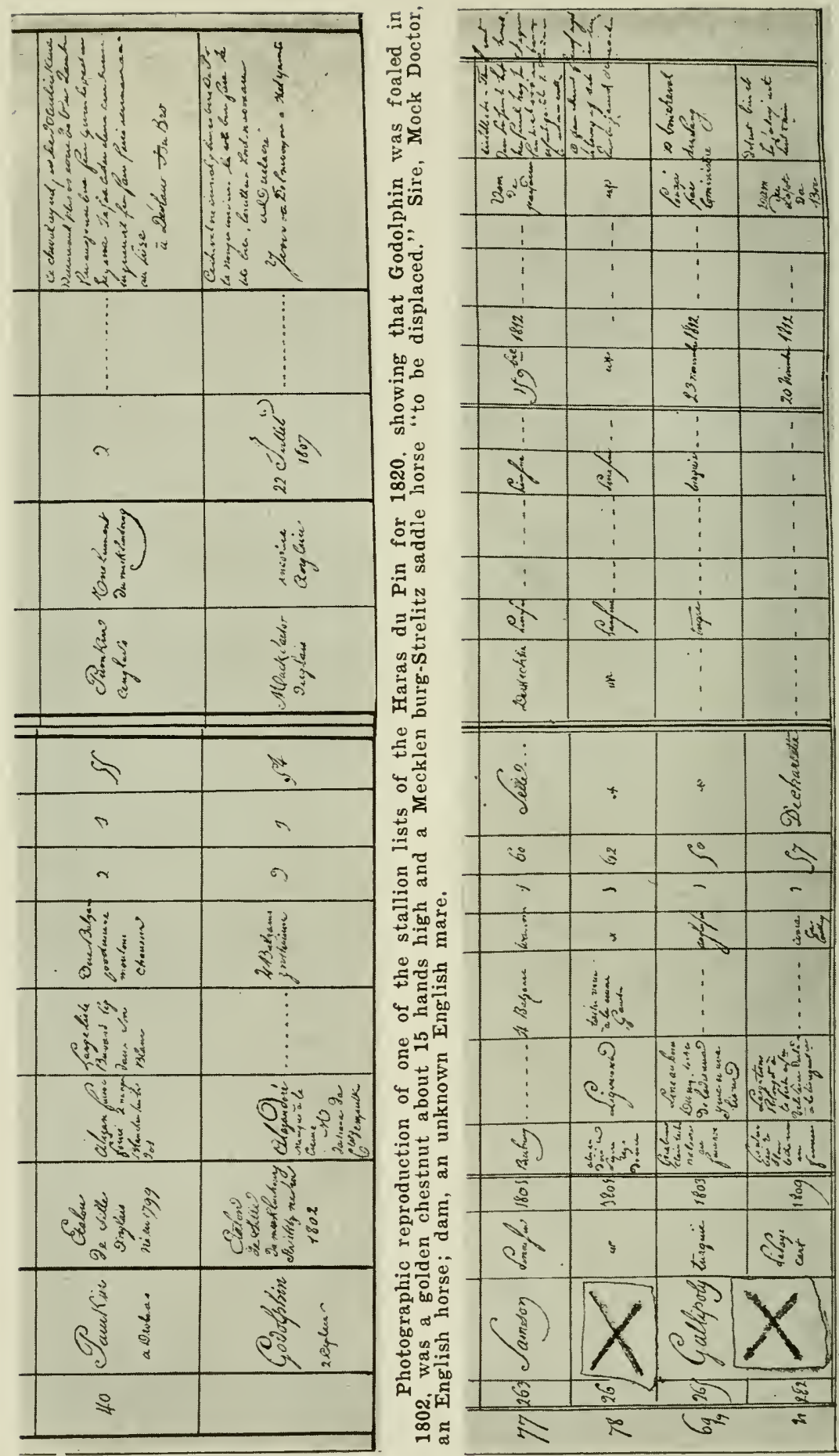

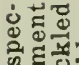

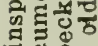

윰 के क

†

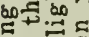

过

ठ․ㅠ

- 3

(स

⿷匚

क्षี

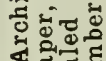

4 व

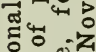

In $n$

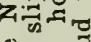

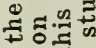

동훙혀

蛇宁

कर्य

현

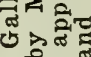

ह …

훼

on 3

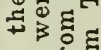

फै nफ

련영

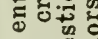

구요도.

당됴

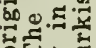

oै $>5$

‡.

पि口 0 ह

कि

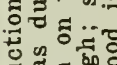

흘 동. 응

跘

Ф

○卉

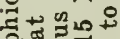

⿶凵

我范

묵ㅇㅇㅇㅇㅇ

대에

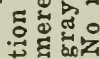




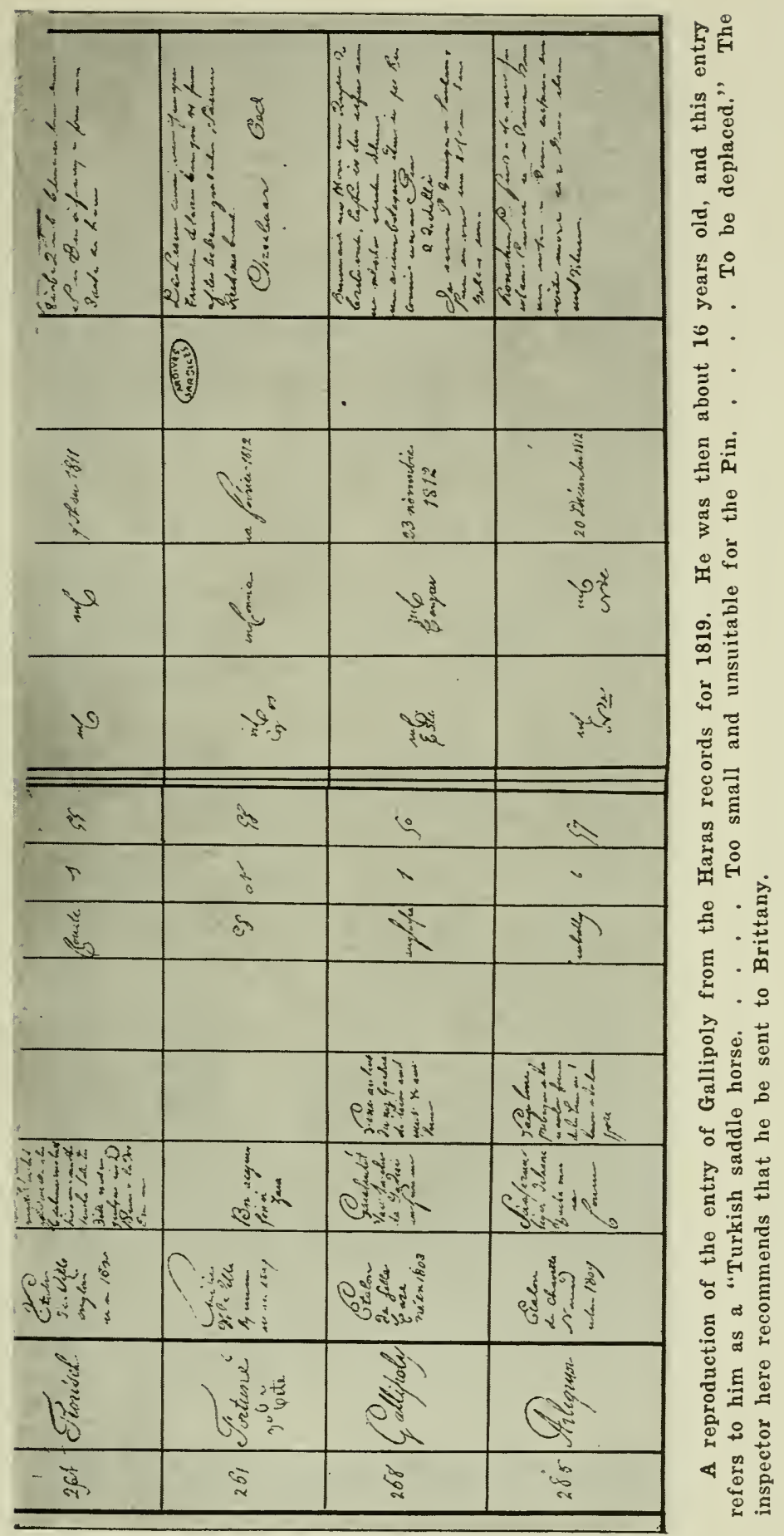


undertaking to reduce to specific terms a proposition of such interest to students of Percheron history, we have had the govermment archives at Paris searched in quest of details as to this supposedly epochmaking event. The results of this research are amazingly at variance with the above statements.

Permission was kindly given by the authorities not only to examine all the records, but to make plotographs of the original entries in substantiation of the facts now to be set forth. And lest any question of mistaken identity be raised, let us say at the outset that the two stallions bearing these names, concerning which we shall now give full particulars, are the only horses possessing those names mentioned in the list of stallions at Te Pin in all its history.

Godolphin an English Saddler.-We first meet Godolphin at the stallion inspection of 1810 . The record may be thus translated:

"No. 20, Godolphin; born 1802; height 1 meter, 54 cm. (about 15.1 hands) ; from the stable of Count de Maulke, Mecklenburg-Strelitz. Observations: good horse, but marked at the croup M.; inferior to the preceding horse in the list (also a MecklenburgStrelitz horse). Sire: Mock Doctor, English blood horse; Dam: Unknown English mare. When entered: 12.July, 1807. Description: Saddle horse.'

It appears that he was secured for the stud by $\mathrm{M}$. D'Avangour, who also brought in several other Mecklenburg horses in the same year, 1807. All these were classed as "saddle horses." At the inspection of 1812 we find the following observations relating 
to Godolphin: "Figure commune; jarrets droits et mauvais; vaillaine croup; il trot mal. (Conformation ordinary; hocks bad and straight; ugly croup; he trots badly.) The inspection of 1813 revealed that he was "common horse and without quality." Inspection of 1815 was followed by this report: "Godolphin, Mecklenburg saddle horse; nothing' distinguished about lim; low croup; strong limbs; action passable."

At the inspection of 1819 we find this of Godolphin: "This horse has ceased to serve at the Haras du Pin; his croup is common; middlepiece well-made; head good; action altogether bad. To be deplaced. I propose to send him to Abbéville." This horse does not appear again in the inspections of succeeding years. His color is given as "alezan doré", (golden chestnut)! It appears, therefore, that it was not until after 1818 that Godolphin ceased to serve at Le Pin. He was then sixteen years old, and was about to be "deplaced" as no longer suitable, and it was proposed that he be sent to Abbéville in the department of La Somme.*

*Lest a query be raised in this connection as to possible confusion with the celebrated stallion Godolphin Arabian, of English fame, the following particulars are submitted. Attention is called to the dates. These, of course, show that the Godolphin Arabian died long years before the Godolphin of our story came upon the scene.

Godolphin Arabian, like the Byerly Turk and the Darley Arabian, was one of the main sources of improvement which led to the establishment of the Thoroughbred as a breed. His earlier career is shrouded in more or less mystery, but it is fairly well established that he was a Barb of rather common origin and appearance, and not a true Arabian. Though there is no authentic account of his foaling, he is supposed to have seen the light in Barbary in 1724, his age having been clearly stated as seven in 1731. It is not known who originally took him from his native 


\section{Gallipoly a Small Turkish Saddle Horse.-This} stallion first comes to light in govermment records at the inspection of 1813 . We quote, and again give a photographic reproduction, from the original documents:

"Gallipoly, Turk; light speckled gray; height, 1 meter, $50 \mathrm{~cm}$ : classification, saddle horse: sire, a Turk; dam, a Turk; born 180:3; entered haras Nov. 23, 1812. By whom bought: sent by the Minister. Observations: good blood horse."

Here we have a speckled-gray saddle stallion barely 15 hands high, and ten years old at date of entry! He was not an Arab and scarcely a type, one would say, to build up the Percherons "around 18:20," among which, as we shall shortly show from these same authenticated records, there were many big approved gray stallions in actual service and founding the modern draft type from within the limits of the native breed itself.

To resume Gallipoly's record: At the inspection of 1815 he is referred to in complimentary terms as an "excellent stallion, woll conserved; produces well, good action." It must be remembered that these inspectors had ever in mind the requirements of the

country, but it is said that a Mr. Coke, an Englishman, being in Paris, was attracter by the appearance of the stallion in the street and bought him despite the fact that the menial labor of hauling a cart was then being exacted of him. At first he was not much thought of in England, where Mr. Coke sare him to a Mr. Williams, who in turn presented him to the Earl of Godolphin.

Godolphin Arabian was a brown-bay in color, of about 15 hands, with an unusual development of crest and some white on his off hind heel. He seems to have had but the three owners in England, passing each time as a rift. From the Earl Godolphin he took his erroneous title, and in his possession he died at Gogmagog in Cambridgeshire in 1753 , being then, as gạuged by his seven-year-old mouth in 1731, in his 29 th year. 
army and not of the farm. After four years more of service we find him still at Le Pin under the inspection in 1819. Of the little old horse it was then said: "Well bred and plenty of blood, very pretty head, short coupling; the buttocks are short, and the tail not well attached; he trots lightly and with vigor; he is too small and musuitable for le Pin. To be deplaced. I propose to send him to Brittany." The game old saddler is still there, howerer, the following year, but is going to be sent away, and that is the last we hear of him. Too small to get cavalry remounts, and yet regenerator and prototype of the modern Percheron! Is it possible? Is it probable? And yet how could Du Haÿs make a mistake in a matter to which he attaches so much importance? Did he or any of his successors take the trouble, as we have, to delve among those old dusty documents? Perhaps not.

There were many other Mecklenbur's-Strelitz saddle horses and horses of English breeding, as well as Normandy saddle horses, at Le Pin at this time. What was their mission? Undoubtedly to serre the Normandy and demi-sang mares in the Merlerault country, which was full of light mares at that time producing cavalry colts.

Error Easily Perpetuated.-It is not so remarkable that we find so many articles and treatises on the Percheron breed wherein the Arabian blood is credited with having wronght important changes as late as 1820 , by writers who apparently either from lack of time or means or other reasons have not under- 
taken to verify the statement, since we find in the preface of the first volume of the Percheron Stud Book of France the following reference. It will be observed, however, that the Percheron society was by no means in accord with Charles Du Haÿs on other vital particulars. We quote from the stud book:

"It is known that the finest specimens of the Percheron breed existing today can be directly attributed to the regenerating influences of the Arab, the primitive horse, the first origin of the Percheron breed. The authorized historian and the faithful friend of the Percheron breed, Charles Du Haÿs, supported, many years ago, this doctrine. This author has shown his great knowledge of horsebreeding in establishing that Jean-le-Blanc, the horse which excited so much his admiration, was a direct descendant of the Arabian stallion Gallipoly, which was owned by the Haras du Pin. This horse has been the most powerful element in perfecting the Percheron breed since this epoch. Nearly all the most highly estimated stallions may be considered as the direct descendants of this horse.

"The Perche owes much to M. Du Haÿs for his precious teachings, and we feel that we cannot do better for our own cause and at the same time render the latter merited homage than to cite, in this first volume of the stud book, his ideas on the Percheron breed and its development.

"However, we would like to state that Charles Du Haÿs has committed a grave error in one of the passages of his book, page 45 , in saying that the Perche threw its barriers wide open to all the big mares that came along in order to make the breed more weighty. On page 47, he also states that Brit- 


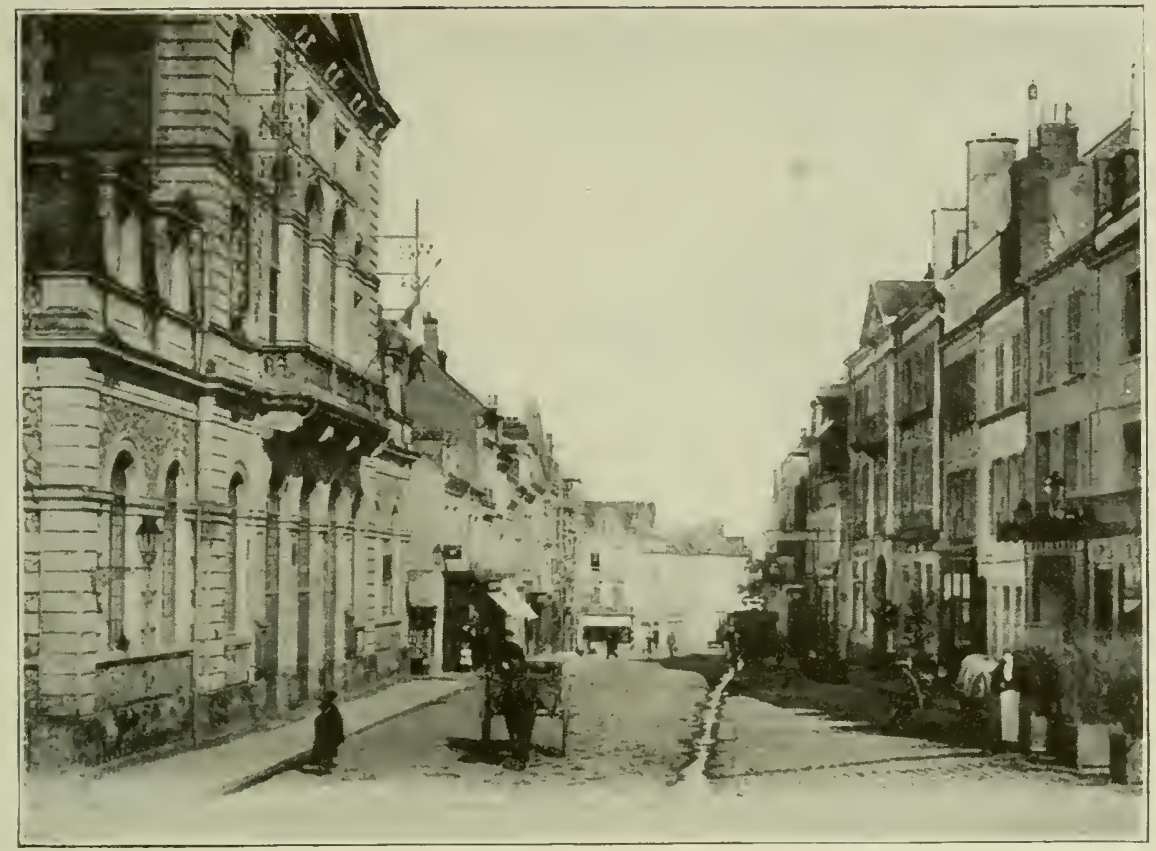

NOGENT-LE-ROTROU-RUE DE LA CHARRONNERIE.

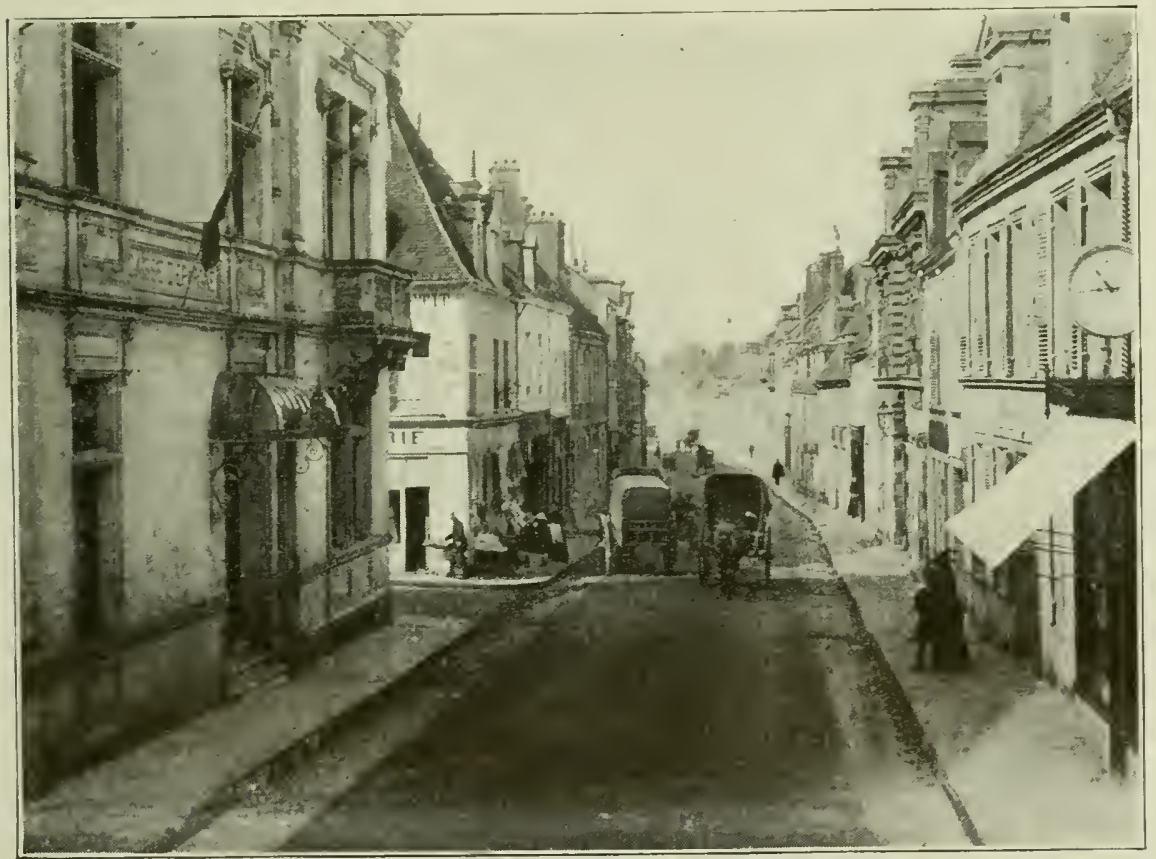

NOGENT-LE-ROTROU-RUE SAINT HILAIRE. 

tany draft, Picarty, Cauchois and Boulonnais stocks have been emploved. We regret that we are obliged to refute these involuntary errors on the part of the honorable writer, who has been deceived by false indications. The Percheron breed has not been enlarged in size except by its own blood, just as we shall be able to prove by a notice on the Percheron breed which we shall publish later.'

We shall shortly provide the proof that it is not necessary to look to either Godolphin or Gallipoly, nor indeed to any other out-crossing, to account for the pre-stud-book Percheron and his color. He was big and he was gray at the rery time these saddle horses were in service. In the meantime it need only be said that those who incorporated this "tradition" into the initial volume of the stud book are not to be faulted for so doing. The story was given currency by a writer who knew and loved the Percheron, and who would not knowingly mislead anybody in respect to their derivation. There was none to deny or disprove it. Du Haÿs was unquestionably sincere in his belief in the tales someone had told him as to these horses. The Société Hippique Percheromne had no special reason for doubting the truth of the statements made. At the time of the publication of the first stud book, its sponsors were simply seeking to place on record the names of latterday breeding horses. They rery naturally did not undertake any detailed investigations tonching a matter so remote and of purely academic interest. In other words, they were not writing history; they were making it. 
Jean-le-Blanc.-In the first volume of the French Stud Book is the following entry:

"Jean-le-Blanc, white, No. 739 ; bor'n in Orne about 1823 or 1824; owned by M. Miard, Sr., Villiers-en Ouche (Orne). It is to this remarkable stallion, more than any other, that we owe a great improvement of the breed. He was recognized as a true Percheron, and, nevertheless, was a descendant of the famous Arab stallion Gallipoly, of the Haras du Pin, that stood at the chatean of Coësme, near Bellême. (For further information on this remarkable horse see the book, 'Cheval Percheron,' Charles Du Hä̈s.)

"Jean-le-Blanc died at the advanced age of 32 years, exempt from all blemish. In going through this book one will find a great number of horses raised in The Perche during the last 50 year's that had Jean-le-Blane as ancestor. This fact demonstrates that the superiority to which the Percheron breed has attained, surpassing all other draft breeds in excellence, is due in a great part to the regenerating influence of the Arab, fortified by consanguineous and judicious mating.'

At the very time this entry was being made there were data lying buried under piles of other matter at the Ministry of Commerce-the central Bureau of the Haras was formerly under the administration of that ministry previous to admitting the Minister of Agriculture to cabinet rank-that would have overturned these unsubstantiated but accepted presumptions. At least, there seems no other construction to be placed upon the facts we have adduced. Let us recapitulate:

The Evidence Summarized.-We have shown by 
an examination of the original documents of the inspections of the Haras du Pin, and by photographing them, that neither Gallipoly nor Godolphin was an Arab, Gallipoly being a small Turkish saddle horse, and Godolphin a Mecklenburg-Strelitz saddle horse of English breeding. Further, that far from Godolphin being a "gray," he was a "golden chestnut." We are told that these two horses went to Coësme, near Bellême, in 1818 and following years. Neither documents nor deductions are attested in proof. The facts are, that in 1818 both of these stallions were still in service at the haras. Godolphin was then 16 years old and Gallipoly was 15 years old. In 1819 at the annual inspection we read that Godolphin "has ceased to serve at Le Pin," and that he is going to be "deplaced" as no longer suitable, it being proposed to send him to Abbéville (Department of La Somme). In the same year, 1819, Gallipoly is going to be "deplaced" as no longer suitable. It is proposed to send him to Brittany. But in the following year we find the name of Gallipoly still on the list of stallions doing service at Le Pin, although the name of Godolphin is absent. After 1820 we never hear of Gallipoly again; he is then 17 years old, and has probably been sent to Brittany.

So far as the statement that these two stallions were the means of giving the gray color to the Percheron breed is concerned, all one has to do to demonstrate such a fallacy is to read the accounts of the approved heavy draft stallions serving simultan- 
eously all orer The Perche, beginning about the year 1820 , full particulars as to which will presently be given. Practically all these stallions were dapplegray in color, and they are all classed as "Percheron." If either of the two stallions mentioned had been used on Percheron mares the colts would certainly have been smaller in size than their dams, whereas the general tendency at this epoch all over The Perche, following the general prosperity and busy times after the Revolution, was to improve the weight and stature of draft horses to meet the great demand for heary hor'ses for agricultural and industrial and commercial purposes. Then, again, if Gallipoly was sent away as being "too small" as a sadclle stallion, is it possible that such a horse would be found large enough and strong enough at 17 years old to sire heary draft colts?

If we could find any evidence that would assist us in deducing that either of these two stallions was used to ameliorate the Percheron breed, or even used on real Percheron mares at all, we should be glad to support such a hypothesis, especially when we consider the fact that such statements have been accepted and given official comtenance for so long a period. As it is, we can only say that if these two horses had not been giren prominence by Du Haỵs as "Arabs" - to follow up the latter's acceptance of the Abbé Fret's traditions respecting the Arabian stallions of the Crusades-they would probably never have been mentioned in connection with the Percheron breed. 
The Breed "IVIodifies Itself." - In a memoir' written in 188:3, M. Michel Fardonet, one of the distinguished breeders of his time, and the first President of the Percheron Society of France, presented an absolutely correct statement concerning the development of the heary-weight Percheron of modern days. Although without facts, names and particulars to sustain his assertions, and admittedly resting some of them upon remarks he had heard his father make many years previously, M. Fardonet could not have done better had he possessedthough apparently he lid not-a copy of the old government records which we are now to reproduce. This is what he said:

"I have heard my father", who was a breeder, say that the haras deteriorated the Percheron breed with its demi-sang stallions, instead of improving as it pretended to do. The breeders liave renounced the colts said to be improved, to raise only colts the product of big horses, well proportioned and of pure origin.

"It may be bollly said that if the heart of The Perche-that is to say the environs of Nogent-leRotrou within a radius of 18 to 20 miles-has conserved the purest type of its race of heary Percheron, it is thanks to the breeders and stallioners of the region, such as Messr's. Perriot, father and grandfather, Ducoeurjoly, Sr., the Vineaults, etc., etc. [Of course M. Fardouet was too modest to mention his own name, but really he would come very near the head of the list.-Eid.]

"It was about 1820 to 1840 that the Percheron breed, the breed of horses that trotted quickly, commenced to modify itself. It has definitely refused to 
cross with the demi-sang, believing it to be harmful; it has also, despite the assertions of Charles Du Haÿs, equally rejected the Brittany draft, Picardy, Cauchois and Boulonnais horses which have too often and fraudulently been introduced into The Perche, but which have never been invited to enter.'

M. Fardouet Was Right.-The reference to the attitude of the government in connection with the concluct of the Haras du Pin is easily interpreted. That establishment was being maintained mainly with a view towards encouraging the production of horses suited to the requirements of the military service. The stud is situated near the boundary line between the old provinces of Normandy and The Perche. As will be shown further on, the stallions first bought by the government for this purpose were mainly of various demi-sang (half-blood) English types usually carrying infusions of the Thoroughbred blood, and classified as saddle or coach stallions. These were liberally patronized by the Normandy farmers and by some of the mare owners of The Perche, with the effect stated by M. Fardonet.

Later on, as we shall show, the government, apparently yielding to pressure from The Perche for weightier horses for agricultural purposes, added a few draft stallions; but had the farmers of that district been dependent entirely upon the Haras du Pin for sires of horses big enough to meet their needs, this story probably would never have been written. However, while this statement holds good as to the types of stallions bought and kept in service by the 


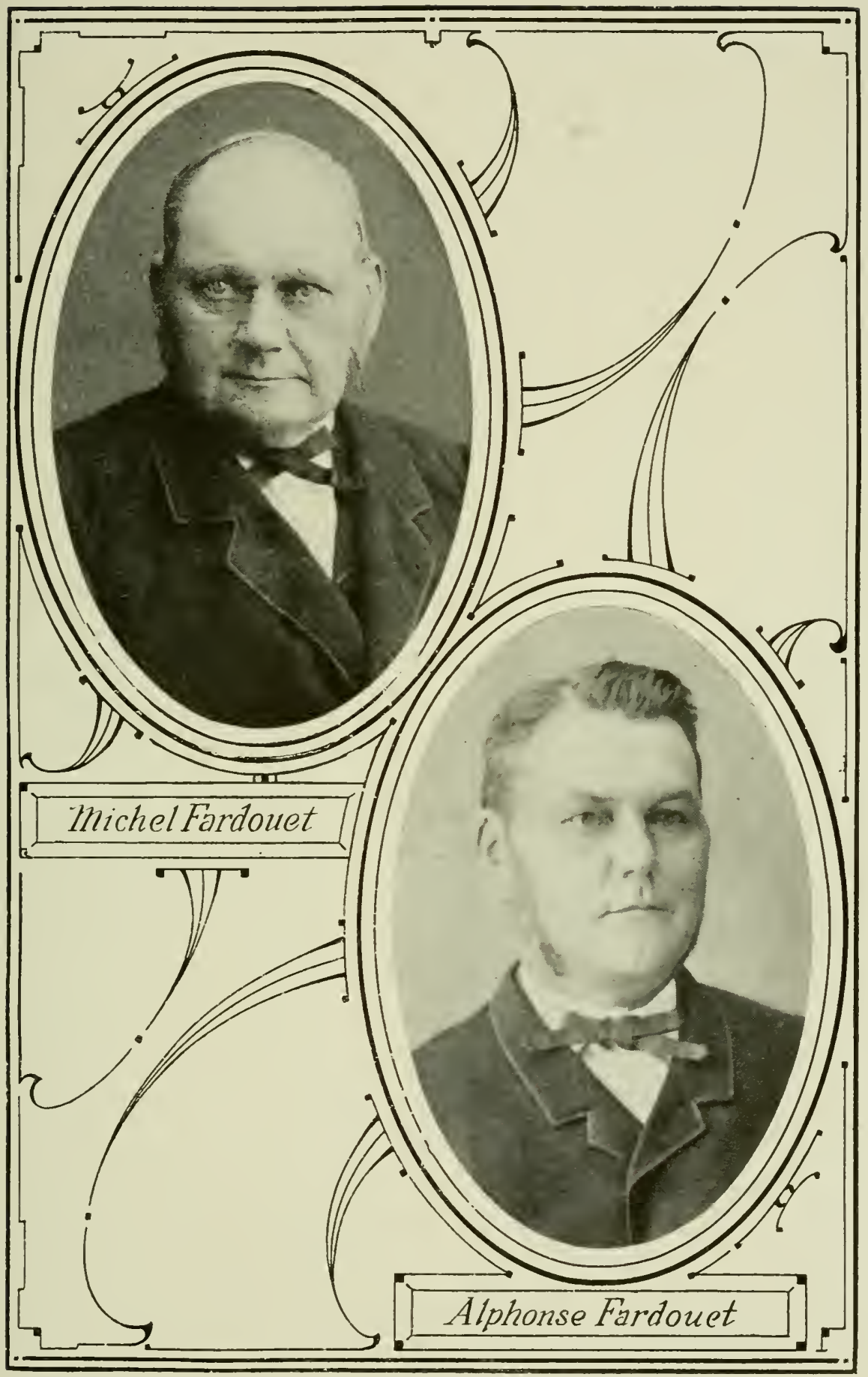



govermment, it must be said to the everlasting credit of the authorities at Paris, that while they were primarily and properly looking first after the interests of the army at I e Pin, they at the same time actively and efficiently promoted in a practical way, as we shall presently prove, the aspirations of the people of The Perche in their ambitions to increase the size of the Percheron horse.

The credit for this work of converting the old-time trotting Pereheron into a heary horse is clue, as M. Fardonet truly sars, to the breeders of the district themselves. Not only is that statement correct, but the date at which this important work was inaugmrated is also giren in accordance with the actual fact. And most important of all, M. Fardonet soundad the entire depth and breadth of the whole proposition tonching the composition of the modern Percheron when he said that "about 1820 to 1840 " the breed "commencerl to morlify itself." These assertions, unsupported as they were at the time by the presentation of facts and figures, and murerified eren in the initial rolume of the Percheron Stud Book of France, are now to be rested upon the rock of the archives of the French government.

We shall first take up the record at the Haras du Pin, and then present the long roll of honor of gorerument-approred and subsirlized Percheron statlions, through the services of which the breed so effectually modified itself during the eventful rears referrer to in M. Fardonet's singularly accurate narration. 
The Government Stud.-It was not until the nineteenth century was well on its course that the French government stud known as the Haras du Pin began to interest itself in draft stallions. An examination of the documents shows that in the purchases made for the national haras from 1765 to 1789 Norman and English blood greatly predominated. There were many Poitevins, a few Vimeux and Limousins, some Spanish, and but one or two Arabian stallions bought during this period. In fact, the documents of the Haras du Pin show that very few stallions of the Arabian breed have ever been kept there. At one time there was a fair number of Barbs,* but one rarely finds the word "Arab." The breed of every stallion used is given, almost withont exception. Before the dates mentioned, Danish, Cotentin and Italian stallions had been greatly in vogue. All these were used almost exclusively on the mares in the Merlerault district adjacent to Normandy. The government was chiefly concerned in encouraging the production of cavalry horses.

\section{First Draft Stallions at the Haras du Pin.-Te} shall now give the record of the breed at the Haras du Pin from the time the first draft stallions were introduced.

*The type of horse known as the Barb derives its name from the ancient Barbary states of North Africa adjacent to the Mediterranean coast, including Morocco, Algeria, Tunis, etc. While the type has undergone more or less change, quite a number of the French colonial cavalry troops engaged in the great European war are mounted on horses of Barb type. As breeding horses the stallions are reputed to sire larger colts when crossed with other breeds than when mated with mares of their own blood. 
In the list of stallions kept by the French government at this establishment one may search in vain for draft stallions during the eighteenth century. It was not until about 1808, according to the haras documents, that the authorities commenced to purchase heavy draft stallions, and then only on a very restricted scale. For instance, we find in the list for 1809 mention made of Le Pierrot, standing about 15.3 hands, "dapple-gray" (g'ris pommelé), and classed simply as a "draft stallion." It seems to have been general during the initial years of the introduction of draft stallions at this stud to class these horses merely as "draft", (de trait), without mentioning the breed. There can be little doubt, however, that these early dapple-gray horses were Percherons. Situated in the borders of the Percheron country, it is but reasonable to take this view, and this deduction is corroborated by the fact that on the rare occasions on which a Cauchois or Boulonnais stallion was employed he was invariably designated as such in the records. From 1809 up to the year in which we find the word "Percheron" mentioned for the first time in the list, those designated simply as "draft stallions" appear with increasing frequency, and nearly all of them are described as "grays."

Curiously enough, the first instance found where a Percheron stallion is specifically classed as such is in the "Contrôle des étalons du Pin," sent by the director, the Count de Maillé, to the director-general of the haras at Paris, under date of Aug. 17, 182.2. The entry is that of Desarmé 538: "Percheron draft, 
bor'n in 1815; color: bay with long tail; sire and dam: unknown Percherons; height: 15.2 liands." He entered April 5, 1821. The director's observation referring to this horse is "bon cheval de trait." In the report from which the preceding detail is extracted practically all the stallions are described as saddle and coach horses-of Anglais and Normandy breeding.

As a matter of fact, the haras management had very little use for a draft stallion at that time. In $18: 3$ there were several in the list, however, as well as mares and fillies of the draft type, but the word "Percheron" is not used-merely "de trait." However, in the following year, 1824, we find a second mention as follows: "Timbalier, Percheron draft; dapple-gray; short tail; 16 hands; sire and dam unknown; boinn 1818." Also: "Polisson, Percheron draft; dark dapple-gray; slightly orer 15 hands; sire and dam unknown; born 1818." There is a note opposite this horse's name: "To be sent to Auxerre." He was perhaps too small. There is also reference in that year to Geant, an "enormous Boulonnais," and some Cauchois draft stallions are mentioned.

At the 1826 inspection we hear of Desarmé again, as follows:

"Desarmé covered 45 mares last year at Chanday; 32 of these were fecundated, resulting in the birth of 13 colts and 13 fillies, all alive. The progeny of Desarmé are reputed to resemble very much their sire; they are all good. Desarmé has served this year $4: 3$ mares at Chanday. I wish to keep Desarmé.' 


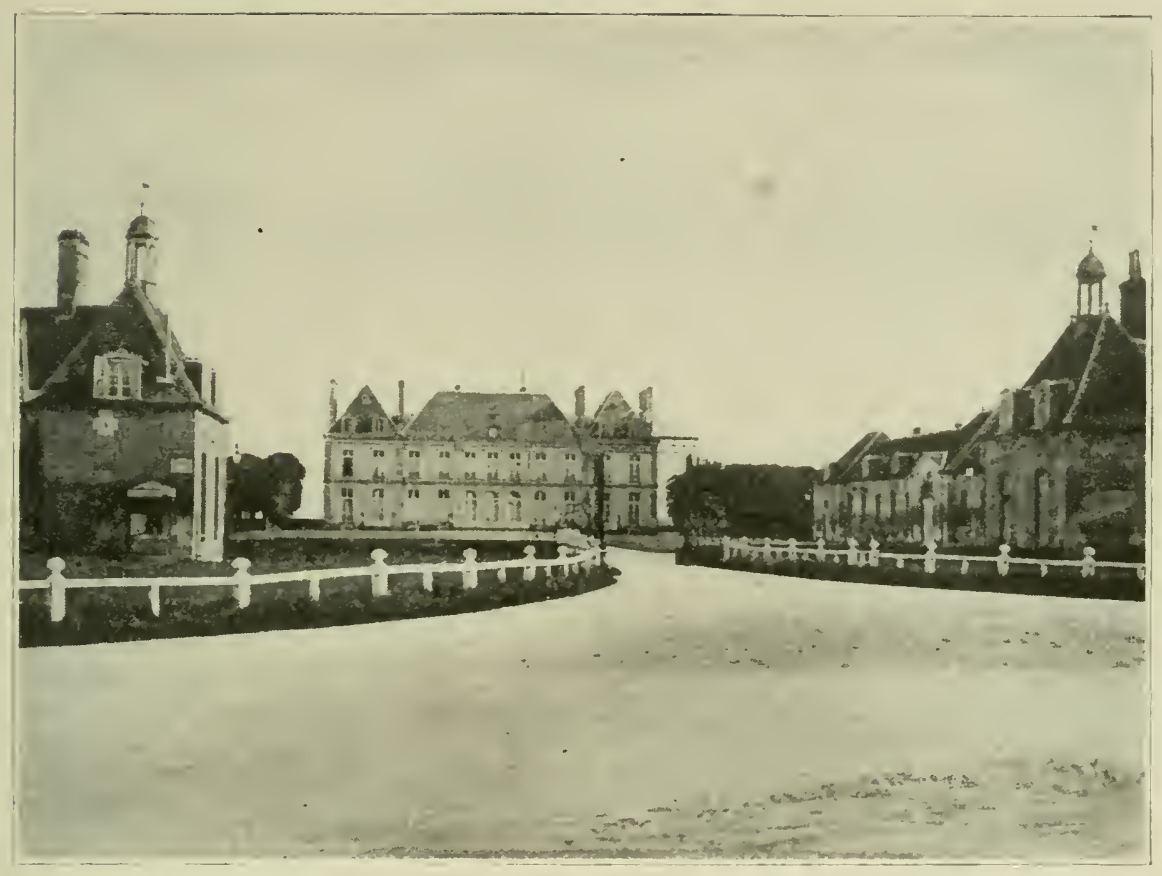

THE CIITEAU AND GLIMPSE OF THE STABLING AT LE PIN.

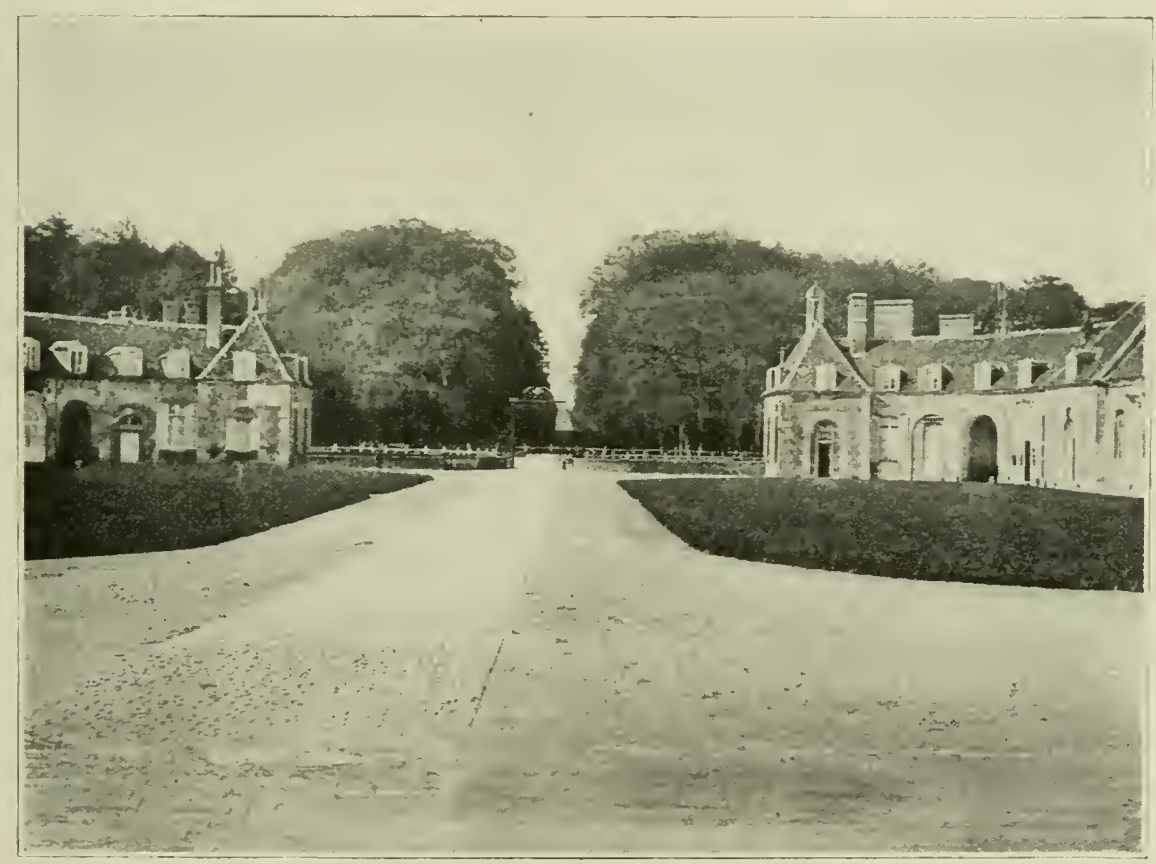

INSIDE THE COURTYARD AT I.E PIN. 

This note was written by the director of the stud. However, the inspector gave very little encouragement to draft horses at that time, for we find in different handwriting: "Ce cheral est trop commun pour Le Pin. (This horse is too common for Le Pin.)",

A big horse called Jocko is mentioned in 1826a dapple-gray, standing about 16.2. He entered March 19, 1826. We here find also the first mention of Herbager, a famous stallion. There was a certain laxity in classifying; perhaps it was thought superfluous. It is fair to presume that the dapplegray Le Pierrot, in the list of stallions at the stud in 1809, was a Percheron, although simply described at that time as "de trait" (draft). Herbager, for instance, in 1826 was classed as "de trait," no mention being made of breed, but later we find him classed as a "Percheron," as also was Jocko. Herbager was about 15.2, dapple-gray, with a long tail and dark mane. He was born in 1822 and entered Oct. 11, 1825. He served 35 mares at Bellême during his first year.

Official Notes.-In 18.27 we find this director's note concerning Desarmé: "He has covered 43 mares at Chanday; 8 colts and 17 fillies resulted. Desarmé's colts are strongly built, and may be employed in farm work. I still ask that I may keep Desarmé." Nevertheless, the inspector recommended Desarmé's removal. In this year we hear also of Remorquer, undoubtedly one of the finest of the early Percheron stallions used at the Pin, as will be seen from the 
records. His color is given as "white-gray", with a long tail. He stood 16.2 hands, full. His sire and dam were unknown Percherons. We read in the director's handwriting: "Remorquer made his first season (1826) at La Ferté Bernard, where he served 42 mares. I wish to keep Remorquer, who sires strong colts." The inspector's notes are: "Fine draft horse; good worker; to be conserved." This horse was worked in the shafts after the breeding season was orer. Joly is another "lheary draft" horse we hear of in this same year. He was slightly under 16 hands.

At the inspection of 1809 we find the following note of the director respecting the Percheron Jocko: "In 1828 Jocko served 24 mares; 8 colts and 15 fillies resulted. Jocko is a good draft stallion; his colts are good. Jocko has served this year 39 mares at Beaumont." Another entry on same page: "Jocko is useful for doing the farm work at the haras. I ask that he may be kept." Inspector's note: "Useful for doing the work on the estate." Director's notes on Herbager made in 18:8: "Herbager served 32 mares at Nogent and Bellême in 18.27; 23 were fecundated, resulting in 8 colts and 10 fillies. Herbager is a good breeder; that is the reason he is in such great demand by the farmers. He has served 54 mares this rear at Bellome." Another note in different handwriting states: "Herbager is in great demand around Belleme, because lie is such a sure breeder. This draft stallion does uscful work." (He 


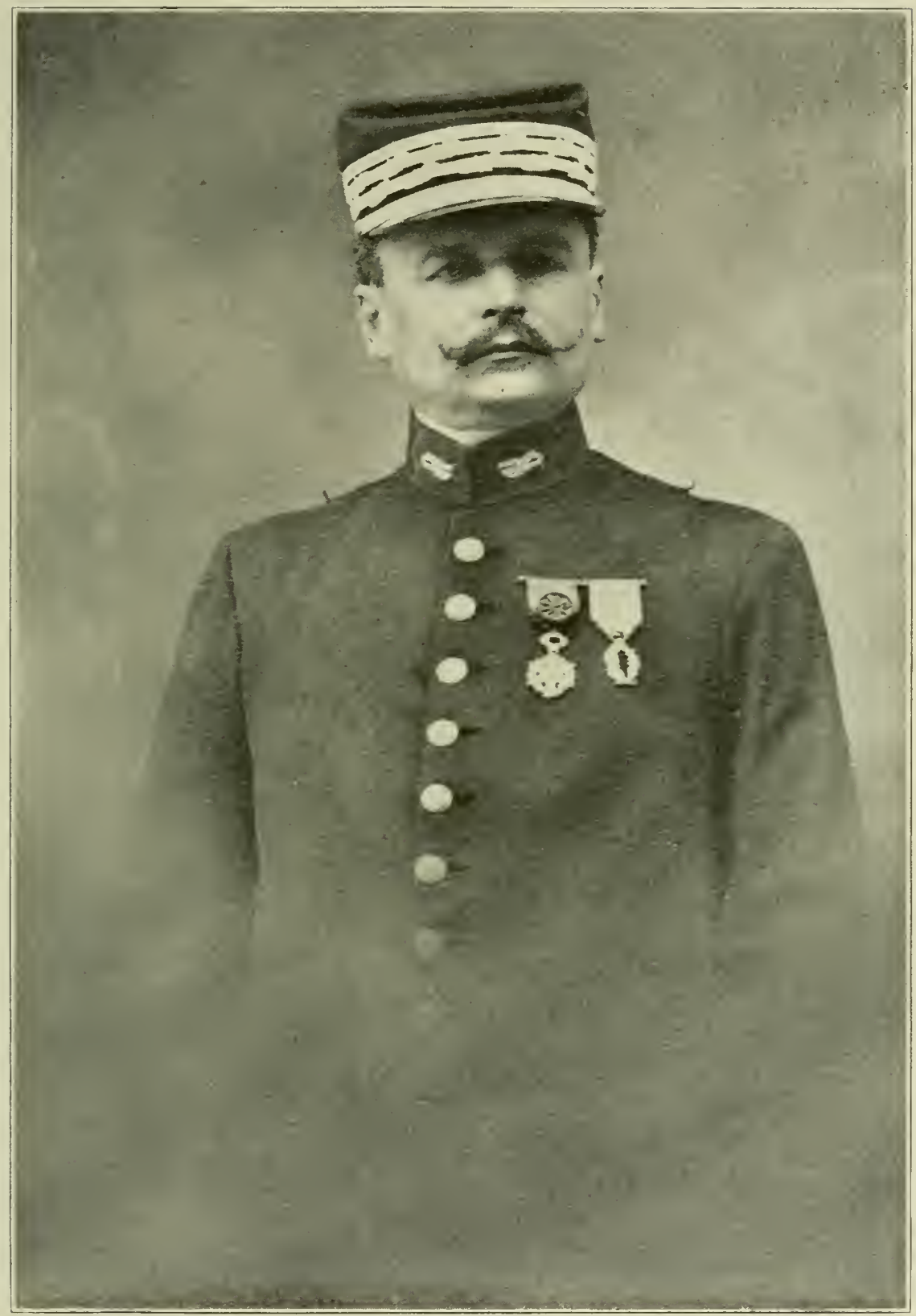

VISCOUNT DE TONNAC VILLENEUTE-DIRECTOR OF THE HARAS DU PIN SINCE 1911-PRIOR TO THAT SUBDIRECTOR AND RIDING MASTER FOR A PERIOD OF FIFTEEN YEARS-AN EXPERT JUDGE AND FERVENT ADMIRER OF THE PERCHERON HORSE. 

worked on the estate as a draft horse.) Inspector's note: "Useful for farm work."

Remorquer "covered 44 mares at the haras in 1827; of these 23 were fecundated; 8 colts and 11 fillies resulted. Remorquer gets good colts; he has served 41 mares this year at the haras. This draft stallion is a good worker in the shafts; very useful for work on the estate." Mention is made this year of Inconstant, a draft stallion slightly under 15.2, born in 18.3; he was light gray, slightly dappled. He served at Courtalain and Brabadanger in 1827. Of him it was said: "This stallion is well liked around Chanday. The farmers are pleased with the foals he gets. This year he has served 46 mares at La Ferté Bernard. He is useful for work on the estate; I wish to keep him." Inconstant served 41 mares at Chanday in 1828. In 1827 Joly got 18 foals out of 25 mares at La Ferté Bernard. He was well liked. In 1828 the same horse served 42 mares at Chanday, and in 18.9 he had 50 mares at La Ferté Bernard. The inspector's note on Remorquer, 1829: "A draft horse of great power."

From the inspection of 1830 we take the following: "In 1828 Jocko covered 22 mares; 6 colts and 2 fillies resulted. Jocko does not get many foals. However he works very hard as a draft horse (on the estate); his colts are good ones. This year Jocko has served 39 mares. Besides doing the season at the stud, he is employed at all kinds of work on the estate. I wish to keep Jocko.' In 1828 Herbager served 54 mares at Bellême, and in 182955 mares at the same 
place, getting 18 colts and 17 fillies. Note: "This stallion is very sure; his products are good and as a draft horse he fulfills every conclition as a sire that gets colts which sell well; for this reason it is greatly regretted at Bellême because he was not sent there in 1830. He has served at the haras this year, having covered 37 mares, besides working as a draft horse on the estate. To be conserved." Herbager was a great horse. A further note on Remorquer: "He works very hard and does the season at the stud besides. Farmers say that he gets good colts. In 1829 he had 45 mares at the haras.' Joly served 28 mares in 1828, and in 18.9 he had 50 mares at Chanday. Note: "The colts got by Joly are wellformed.", In 1830 .Joly had 45 mares at La Ferté Bernard.

Superior entered the haras in February, 1828. He was a little lower than 16 hands. He did the season at Nogent, getting 13 colts and 10 fillies out of 35 mares. His record reads: "His colts are good, but as he has sired some sorrels and a certain shade of gray which does not please the farmers, he is not in so great demand as his merits warrant." In 1829 he served 39 mares at Nogent, and in 1830 besides being employed as a work horse he served 39 mares at Chandayon.

Directors and Inspectors Disagree.-As showing the prejudice which the government inspectors sent from Paris had against these early draft stallions, it appears that in almost every case at the annual inspection, where draft animals were concerned, the 


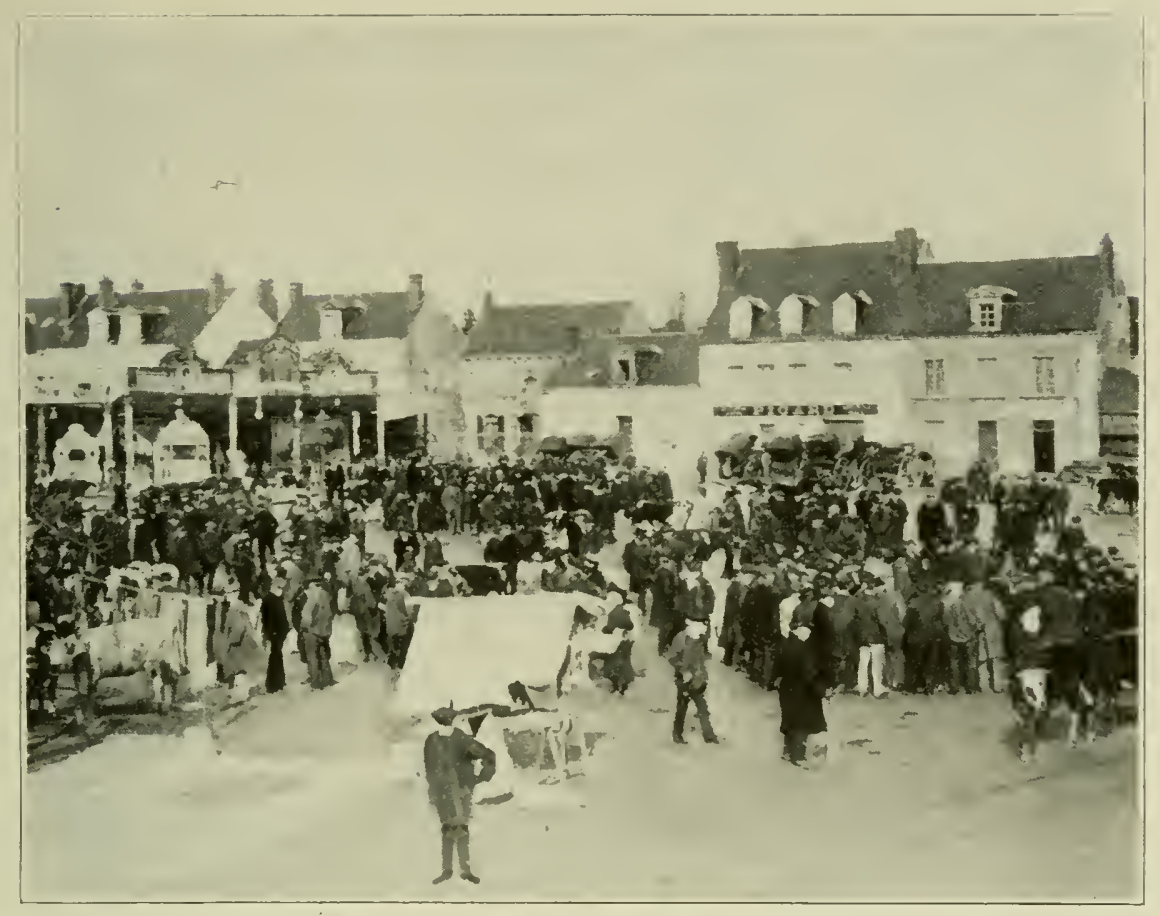

A MARKET DAI AT NOGENT-LE-ROTROU.

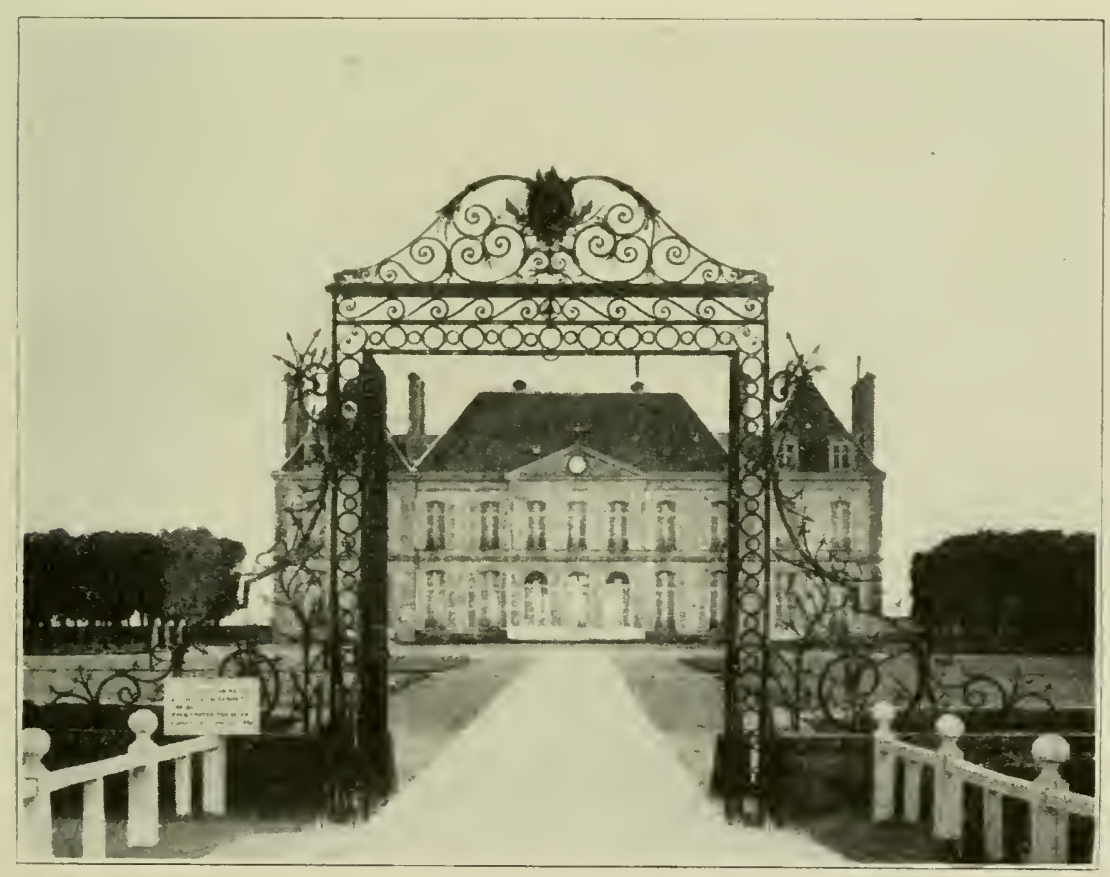

ENTRANCE TO THE HARAS DU PIY. 

inspector's note recommends that these draft stallions be kept only as work horses and should not be allowed to serve-this in spite of the high recommendation of certain horses by the director of Le Pin, who was best able to judge their merits. The truth is, that the government inspectors discountenanced the use of draft horses. They wanted all the mares in the country to be served by blood hor'ses. They were always obsessed by the necessity of finding cavalry remounts. However, we find that the director continued to use these Percheron stallions for breeding purposes just the same, despite the inspector's recommendations. It is amusing to observe the director's note, year after year: "I wish to keep this horse," and then the inspector's note under it: "To be used as a work horse only; should not serve mares." Then the next year we read that the stallion had served mares and done work on the estate besides. And so it continues year after year. The obvious fact is that the farmers were pleased with the colts they were getting from this draft blood. They were increasing the size of their horses, which were doing good service in the fields and probably bringing better prices at this period than army horses. 


\section{GHAPTER IV. \\ EVOLUTION FROMI ITITHIN.}

We have seen that about 1809 the government began adding draft stallions to the coach and sarldle types maintained in the Haras dn Pin, and that theso did considerable service as well as the heary hauling about the establishment. Work was apparently about all that the army officers thought they were fit for, and from their standpoint the inspector's were doubtless right enough. The farmers of The Perche, however, were not to be turned from their now clearly apparent determination to produce a bigger horse. Normandy might breed all the army remounts she liked. The Perche had other plans, seeing which the departmental and central govermment authorities set forces in motion that soon brought important results. This aid took the form of gorernment inspection and approval of certified stallions and a bonus to the owner. We find the first reference to this epochmarking step in 1818.

Prizes Stimulate Effort.-The "Annuaire Statistique et Administratif du Dept. d'Eure et Loir pour 1819," after reciting the fact that "formerly, from the province of ancient Perche, horses suitable for the dragoons and hussars were obtained, and also excellent cobs for the stage-coach service," refers to 


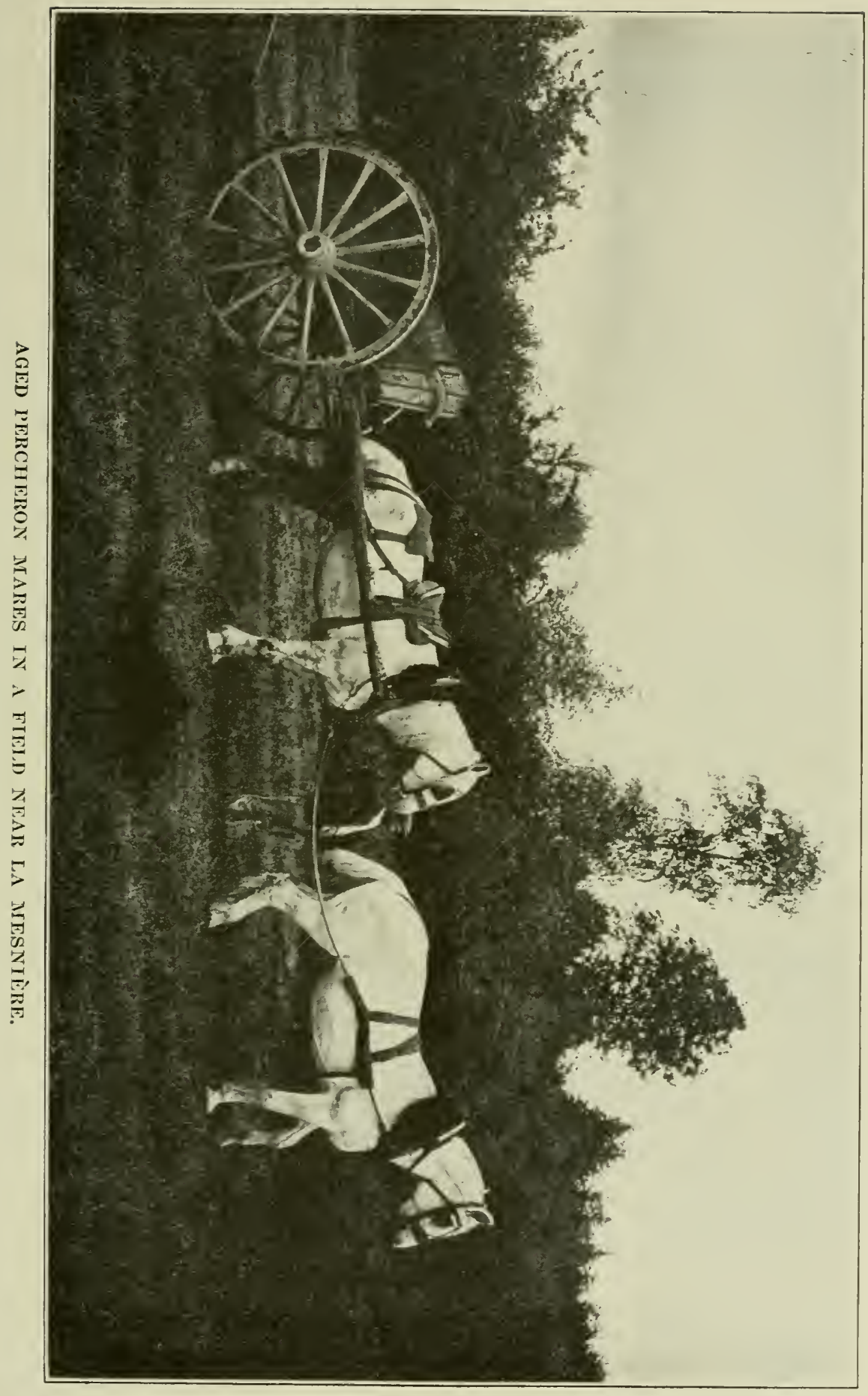



the desire of the authorities and intelligent breeders to "improve the species of horses natural to the country, suitable for withstanding prolonged fatigue, and on that account very much in demand." We quote:

"The Count of Breteuil has taken effective measures to improve the horses in The Perche, and, incidentally, to better the breeding establishments. His decree of the 27th of August, 1818, approved the 16th of September following by His Excellency the Minister of the Interior, empowers an inspector to visit all the stallions destined for service and to indicate those having the necessary qualities rendering them fit for the purpose, and also to see that only those mares suitable for coupling with such stallions are allowed to be covered. Each stallion owner will receive a booklet containing the names of his horses. The list of entires appropriate for public stud work will be published and exposed at the prefect's office."

In the same publication for 1820 we find the following:

"The excellent breed of Percheron horses belonging to the Department is appreciably improved since a selection of the stallions has been practised and prizes awarded to the finest brood mares. Owners of approved stallions receive from the government, for each year the horses are kept at stud, 100 to 300 francs as a pension, according to the quality of the stallion.

"At the Courtalain fair, held on the 25th of Norember, and at the Nogent market on the Saturday preceding St. Andrew's Day, prizes are awarded to the farmers possessing the best brood mares that have been served by the stallions approved by the government, or by stallions owned privately, pro- 
vided they have been declared suitable for public service. $\dot{M}$. Barré, farmer at Maintenon, has just received a medal from the govermment in recognition of his great care given to his horses.

"Nogent-le-Rotrou has four fairs, which attract great gatherings. Many horses are sold there."

Notice should be taken of the fact that in these original inspections not only had the stallions to be certified before being permitted to serve, but the mares offered for service had also to be approver. This brings us to the presentation of the incontrovertible proof of the correctness of M. Fardonet's statements already quoted.

The National Archives in Evidence.-Clearly the original manuscripts in the National Archives at Paris are not to be disputed, and they reveal a story of splendid service rendered to The Perche by the government of France in the days when the horseloring people of that province were seeking to lay the fonndations of an industry that was destinerl to add millions to the wealth of French and American farmers. In these archires the detailed story of the creation of the Percheron horse of heary draft, so long untold is revealed, and we need not say that it gives us much pleasure thus to be able to clear away misconceptions heretofore hancled down, substituting fact for fiction, and authentic records for mere traditions; thus placing underneath the records of the Percheron societies of France and the United states the data that anchors their foundations in the bed-rock of an official registration clating back now nearly one hundred years. 
It will be shown in the following pages that the splendid work of the French gorernment in giving bonuses or prizes to approved stallions of the Percheron breed dates simultaneously from about 1820 in the Departments of Eure-et-Loir (Arrondissement of Nogent), Orne (Arrondissement of Mortagne), and Loir-et-Clier (Arrondissement of Vendôme)-the very cradle of the Percheron breed. Later, the Department of La Sarthe entered upon the same good work. We have already shown that the beginning of Percheron breeding at the Royal Haras du Pin commenced about the same time. We quote now exclusively from the original documents (manuscripts) in the National Archires at Paris, corering the formative period of the modern Percheron.

First Approved Stallions Near Nogent.-The first three approved stallions in the Nogent district were Superb, Le Curieux, and Le Percheron. Superb belonged to M. Debray, Margon, just outside of Nogent. He was a dapple-gray, and was approved on the 14th of August, 1820. His bonus was fixed at 300 francs a year, and he was considered the best stallion at that time. In 1822 he served 42 mares, from which 29 foals were born. In 18:3 he har 58 mares. Five of the mares were described as "Percheron-Norman," the others were "Percherons."

Le Curieux was owned by M. Chevet, Condray. He obtained first prize as an approved stallion in 1821. He was four years old, and is described as a "Percheron suitable for draft purposes," dapplegray, with a light-colored head; he was got by a 
horse called Bonhomme, "out of a mare of M. Cochin." These particulars, besides others, are given on the certificate issued to the owner. In height this horse was about 16.1 hands. Le Curieux was again approved in 1822 and in that year had 60 mares. In 1823 he served 110 mares, 23 of which belonged to one owner, a M. Lemême. Five Picardy mares were served by Le Curieux in 1823; there were also several Normans, but about five-sixths were Percherons. In 18:4 he served 47 mares in the communes of Bazoches-Gouez, Chapelle-Royal, Charbonières, St. Bomert, Souance, Bethonvilliers, Vichères, Coudray, Etilleux and St. Lubin, all in Eureet-Loir. In addition he served 74 mares in the Department of Orne (communes of Masle and Ceton) in the same year. From the 47 mares served in Eureet-Loir, 31 foals were born; 19 of these were gray in color. In 1825 Le Curieux served 101 mares in all; 34 were in Eure-et-Loir, and of these 13 were gray, 7 black, 6 red-roan, 2 brown, 4 bay and 2 chestnut.

In 1825 Aubert, belonging to Cotterean of Coudray, not far from Nogent, served 90 mares, 25 of which were gray, 8 black, and 19 bay. This stallion obtained an approved bonus of 240 franes.

Le Percheron was approved on Aug. 14, 1820. He is described as a seven-year-old bay, of the Percheron breed. He belonged to M. Guillemain Conie, and served only two years. He received an annual bonus of 100 francs. In 1821 he served 47 mares.

Grand Pierre, Bijou and Le Coq.-We next come 


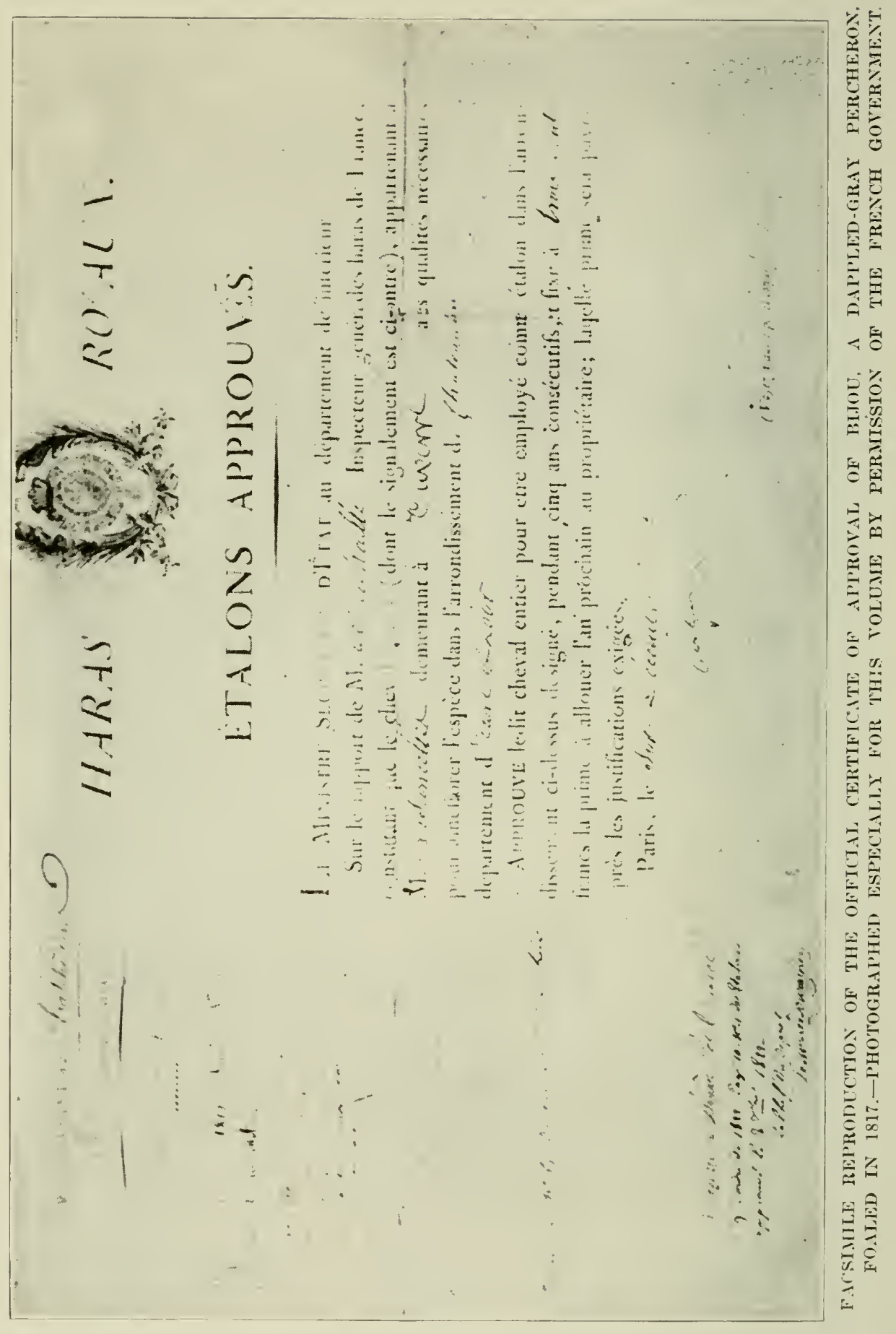


to Grand Pierre, owned hy Dien, of Coudray. This horse was born in 1818 and was a clapple-gray. He served 60 mares in 15.24, among them one belonging to M. Ducoeurjoly, a probable ancestor of Ducoeurjoly, one of the first members of the French Percheron Society. The mare was a gray and she bore a filly foal, also gray. Grand Pierre got 37 foals from the 60 services. In $18 \% 5$ he had 61 mares and in 18:6 he served 64. We next find Bijou, owned by M. Vasconcelles, Houssaye (commune of Anverre). In 18.2t he had jt mares, and the result was 36 foals. Then comes Le Coq, a great stallion belonging to Benoit, Illiers. In 18:t he served 101 mares and 70 foals resulted. In 18.55 and 1826 he served 75 mares each year. This stallion was dapple-gray, and stood a little over 16 hands. Bijou was also dapple-gray, but only 15.11/2 hands high, though he is lescribed in the certificate as "Percheron, heary draft.' He was evirlently in great demand, in the years 1825, '.26, and '27 serving' 116, 124, and 135 mares.

Liberally Patronized.-In 18.7 we find that a letter was sent from the Minister of the Interior (Bureau des Haras) to the Prefect of Eure-ct-Loir ordering 1,070 francs to be paid to the following stallioners: Benoit (2 stallions), 400 franes; 240 franes to Cottereau, of Coudray; 100 francs to Dien, Condray; 180 francs to Monnier Vasconcelles, Anverre; and 180 francs to Maréchal (sometimes written Marchal), St. Germain-le-Gaillard.

Aubert, one of the horses already mentioned, was 
a strawberry-roan born in 1820 and standing slightly over 15.3 hands. He served 90 mares in 1825 and 91 in 18:6. He belonged to Cottereau. In 1827 he had 77 mares. Lecoeur belonged to Benoit. He was a light-gray, about 15.3 hands high, and was born in 1819. In 1825 he had 65 mares and 115 in 1826. There were many blacks and grays among the mares served by this horse in 1826. Maréchal owned a horse called Le Percheron (not the one previously mentioned). He stood about 16.2 hands high, a dapple-gray. In 1825 he had 108 mares, among them being 8 belonging to one Labiche. In 1826 he served 117 mares and in 1827 he had 88. According to the Minister of the Interior's letter, dated 18th of June, 1828, we find that Cottereau's stallion Aubert was not allowed to serve mares after that date. In 1827 he had 88 mares. Mention is made of an approved stallion, Le Braillard, which served 73 mares in 1826. Maréchal's Pierrot, a dark dapple-gray born in 1822, was approved the 25th of November, 1826. Pierrot got 82 living foals in his first season out of 113 mares.

Big Horses in Service.-That the big stallions were popular in those days is instanced by the list of mares served by the "heavy draft" stallion Le Grand, that stood 17 hands high and was dapple-gray in color. He was owned by Toutay, of Coutretôt, and served in the Nogent district. In 1826 he had 112 mares, and in 1827 he served 91 . In the list of mares served by the approved stallions about this period we find that the dapple-grays are becoming more numerous and bays occur less frequently. In 1829 le Grand had 


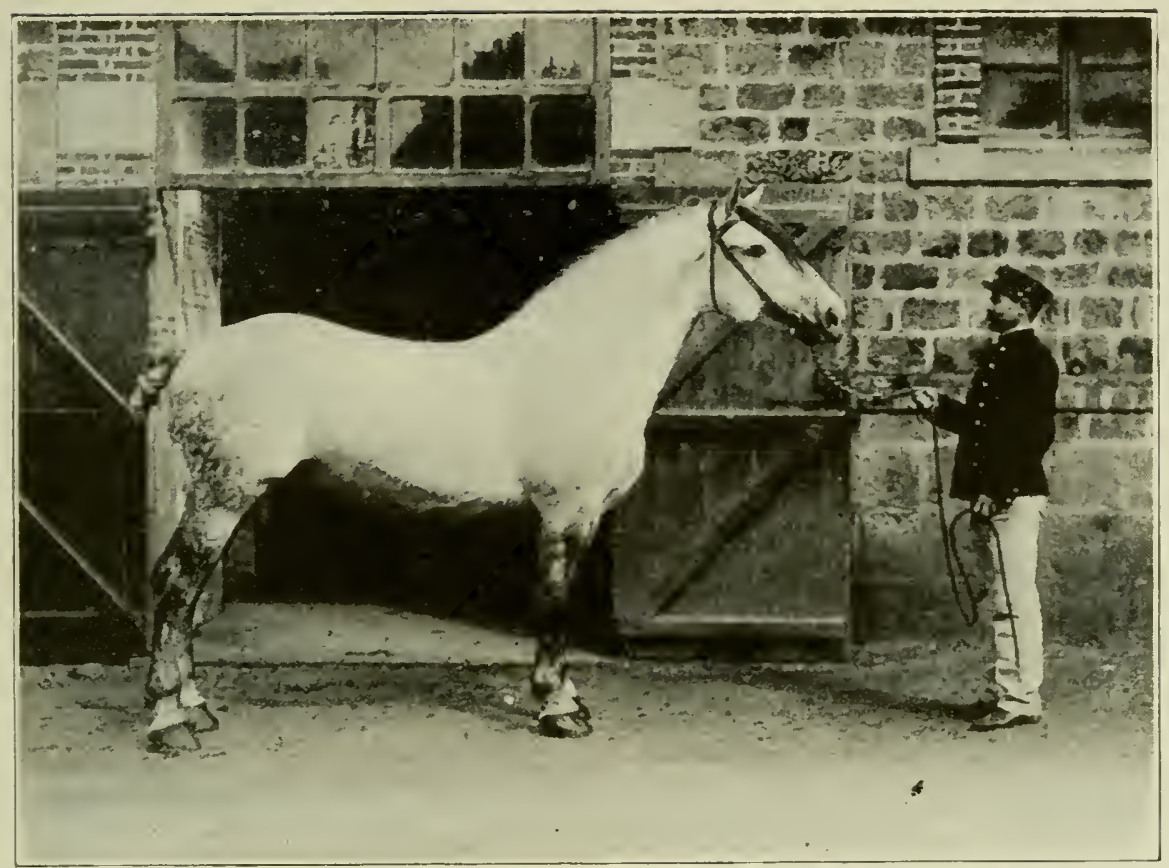

TRITON, TYPE OF PERCHERON STALLION USED AT THE GOVERNMENT STUD.

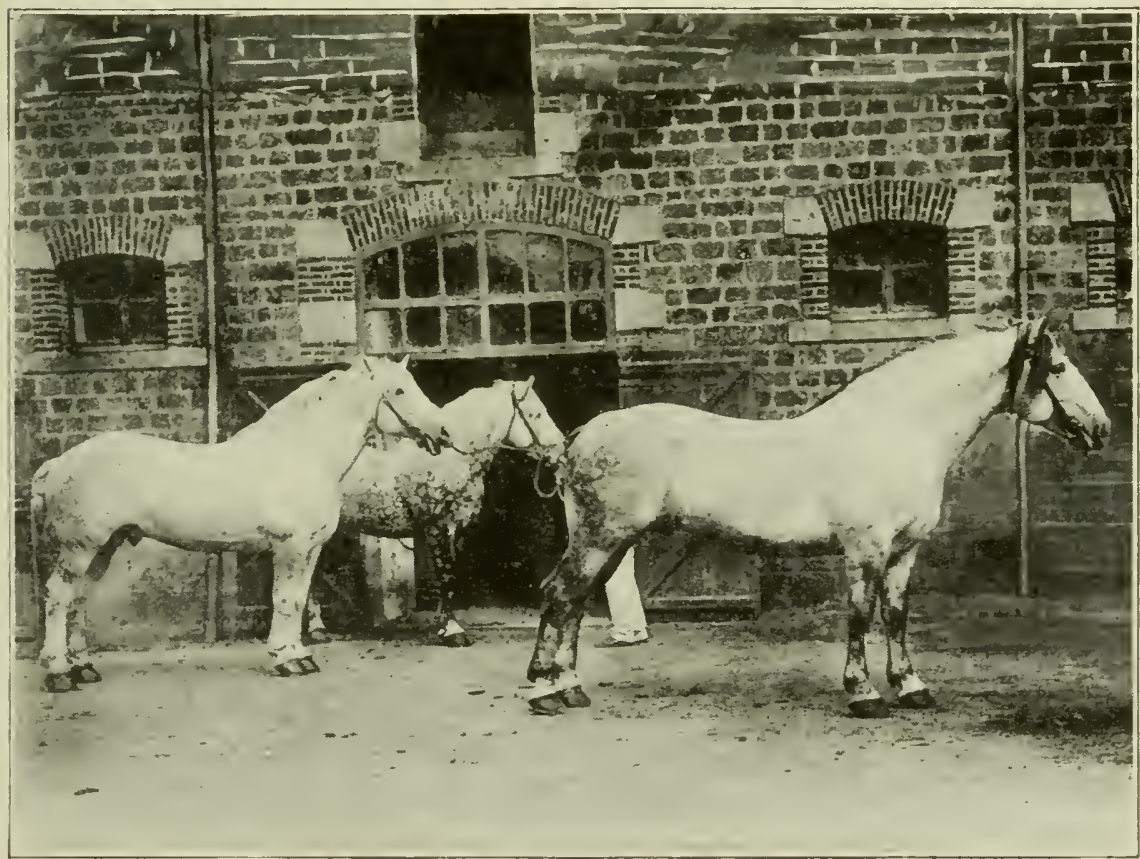

PERCHERON STALLIONS AT IE HARAS DU PIN. 

60 mares, and in 1830 he had 63, 16 of which were dapple-gray and 9 of other shades of gray. There were also 9 blacks among the number. Toutay had another stallion, approved the 18th of November, 1828, called Charles, dapple-gray, and described as "heavy draft." He stood 16 hands high. Beausang (Madame Toutay) and l'Eveille, (serving in the Châteaudun district) are two other stallions mentioned at this time. Beausang stood 15.3 hands high, and was dapple-gray. L'Eveille was also dapplegray, measured a little orer 16 hands, and was borm in 1823. He served 109 mares in 1828. In 1830 he had 78 mares, "gris pommelé"-dapple-graygreatly predominating among these colors. He was authorized, but not approved at this time. In 1831 he had 85 mares.

We next hear of Cottereau's 16-hand white-gray stallion Franconni. He had 82 mares in 1829 and 101 mares in 1830. Bijou, already mentioned, served 120 mares in 1829 and a still larger number in 1830. We note also that Le Cadet, born in 1824, dapple-gray, 16 hands high, served 117 mares in 1829 and 136 in 1830. Margot, a dark gray of about 15.3 hands, belonging to M. Facheux in the Châteaudun district, served 53 mares in 1828, 54 in 1829, and 64 in 1830. Benoit had a stallion at this time, Le Robuste, a 16.2-hand dapple-gray born in 1823 that served 107 mares in 1829 and 111 in 1830.

Le Coq Goes to Belgium.-In 1829 the fine stallion Le Coq was purchased by the director of the St. Paul Riding Academy, Brussels. This is the horse that 
was owned by Benoit. According to a letter found among the documents relating to the approved stallions, 2,540 francs was offered for Le Coq at the fair of St. André before he was approved. The letter is written by the Prefect of Eure-et-Loir to the Minister of the Interior. In 1828 Le Coq served 154 mares and in 1829 had 116 mares. Bijou had 130 mares in 1828. Cottereau's stallion, Braillard, served 64 mares in 1828 and the same number in 1829. At the end of the 1829 season this stallion broke his thigh while serving a mare, as attested by affidavit made out at Coudray on the 7 th of October, 1829. Le Grand had 81 mares in 1828, 60 in 1829, 72 in 1830, and 52 in 1831. The owner of Le Grand (Toutay) had also another approved stallion at this time, called Le Vean Rayé. He had 60 mares in 1828, 61 in 1829, and 55 in 1830. This stallion, born in 1824, was dark gray and 16 hands high.

In 1831 the owners of the approved stallions in Eure-et-Loir were Benoit, Madame Toutay (Beaumont), Guillaumin, Gaubert, Cottereau, Toutay, and Maréchal. Toutay and Maréchal had each three stallions. Benoit had two stallions; one, Le Cadet, served 120 mares in 1831 and 145 in 1832, while the other, Le Pommelé, born in 1827, and standing 16.1 hands full, had 95 mares in 1831 and 108 in 1832.

More Big Gray Horses.-Maréchal's Le Bijou (another Bijou, probably a son of the first), born in 1826, had 112 mares in 1831 and 61 in 1832. The same owner's Le Pierro, a dapple-gray of 16 hands, born in 1826, had 106 mares in 1832. Maréchal's 
third approved stallion was Le Courtois, dapplegray, born in 1828. He served 68 mares in 1832. There is also a stallion mentioned at this time, Le Devé, 16 hands in height and a dark dapple-gray, born in 1828, that served 61 mares in 18:32. Gaubert's stallion, Largneux, served in the Chartres district. He was dapple-gray, 15.2 hands high, and had 57 mares in 18:31, 50 in 1832, 53 in 1833, and 51 in 1834. Guillaumin had also a stallion named Le Coq (not the Benoit stallion) that served at this time. He had 101 mares in 1831 and 111 in 1832. Toutay's Le Grand, the 17-hand stallion previously mentioned, that served near Nogent had 59 mares in 1832; lie was then ten years old and Ducoeurjoly had a gray mare served by him in that year. Toutay's Le Charon, a 16-hand dapple-gray bor'n in 1828, had $6: 3$ mares in 18:2. The same owner had another stallion, Dorchène, which died from colic. This fact is attested by the mayor of the commune. One of the witnesses was a M. Chouanard (8th of June, 18:32), a probable ancestor of the well known Chouanard family of breeder's near Nogent. Dorchène served 60 mares before he died in 183:2. Franconni had 64 mares in 18.31, the same number in 1832, and $55 \mathrm{in}$ 1833.

Others in Nogent District.-In 1835 the amount of bonuses given to approved stallion owners in Eureet-Loir was 1,580 franes, as follows: 400 franes to Toutay (2 stallions), 340 to Benoit ( 3 stallions), 200 to Guillaumin, 150 each to Maréchal and Dieu, 120 each to Cottereau and Gaubert, and 100 francs to 
Darid, making a total of 10 stallions, the majority of them in the Nogent district. Toutay's stallions this year were Le Grand and Le Percheron. In 1833 Le Grand had 72 mares, and in 1834 he served 60 mares. Benoit's Le Pommelé served 109 mares in 1833, and 111 mares in 1834. The same owner's Le Coquet had 82 mares in 18:34, while his third stallion, Le Cadet, had 107 mares in 1833 and 68 mares in 1834. Guillaumin's Le Coco received a prize of 200 francs and was probably a very fine stallion. In 1832 he had 90 mares, in 1833 he had 91 mares, and in 183463 . Largneux served 53 mares in 1833 and 51 in 1834 . Dieu's Le Poulet had 53 mares in 1833 and 56 in 1834. We should have mentioned also Le Bijou, belonging to a M. Thion, that had 60 mares in 1833. Cottereau's Franconni, now described as "white" in color, had 50 mares in 18.34. Darid's stallion (name not given) served 82 mares in 1834, and from lis services in 1833 we are told by the records that he got 49 living foals.

In the Department of Orne.-From the documents relating to the Department of Orne the splendid work of these early approved stallions runs concurrently with those in Eure-et-Loir. We first hear of a dapple-gray stallion belonging to M. Launay, Mauvaisinière, near Mortagne. This horse got 23 foals from the 1824 season. Touis Pelletier, tenant farmer at Corbon, had a stallion, Le Bijou, that made the 1825 season, serving 38 mares. Just as in the case of Eure-et-Loir the full list of mares is given together with date of service, height of mare, color, age, the 


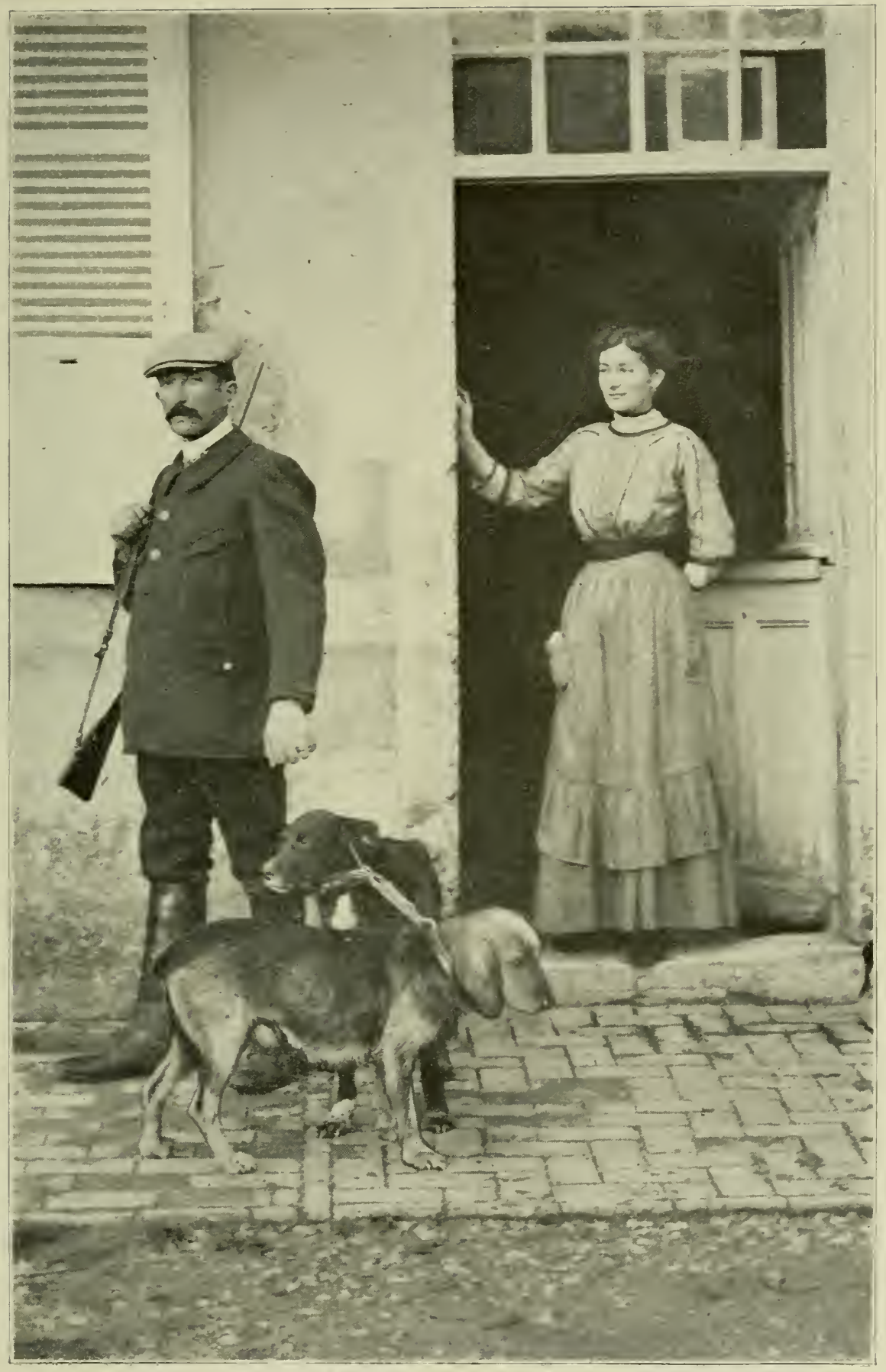

H. PELlETIER OF LA BERIUCHE, ORNE. 

name of owner, etc., certified correct and stamped with all the seals of the mayors in the several communes in which the mares were served.

All the mares, with hardly an exception, are described as "Percherons." The first list will give a correct idea of the colors prevailing at that period. Among the mares served by Pelletier's horse in 18:5 there were 13 grays, 9 bays, 1 brown-bay, 4 blacks, and 3 chestnuts. The mares were not so high as those in the Nogent district; hardly any were over 15.2 hands. Some mares were served in Eure-et-Loir by Launay's horse, and he also served mares in La Sarthe. Launay's old stallion book is found among the records; it is bound in sheepskin, with a raw-hide lace attached to close it. On every page appears the stamp of the mayor of the different communes. That is why we can state that his horse served a few mares out of his own department, as we find the mayor's stamp of Buissaye (3 mares) and Reveillon (1 mare), both places in Eure-et-Loir. It seems that Launay's horse began serving in 1822, but the list is lacking. We find, however, a statement that he got 26 living foals out of 31 mares. It should have been mentioned that the first full list of Launay's mares was in 1823-91 mares-but the observations made respecting the colors apply to 1825 . It is a very simple matter to find the colors of any given year, however, if greater detail is deemed necessary.

In 1823 all the mares are described as Percherons except 9 Brittany mares, and one Normandy mare. We find the name of Areline for the first time in 
1823 at Mont Gaudray. He had a brown-bay mare served by Launay's horse.

Service for 12 Francs.-In Launay's notebook for' 1822 we read the following interesting detail: "Mares to be served three times, after which payment of 12 franes for the service shall be made, and 1 franc, 50 centimes for the groom." Several of the farmers had two or three mares served. Some of these men are described as land-owners, while other's are tenant farmers. Launay's horse received a bonus of 200 francs a year, as shown by a letter from the directorgeneral of the haras at Paris to the Prefect of Orne transmitting money to be handed over to Launay. Pelletier's horse got 33 foals from the 1825 season, and 32 from the 1826 season. This horse was a dapple-gray, standing 17 hands high, and his prize money was 150 francs a year. M. Lefort had a dapple-gray, described as "Percheron, heary draft,"' bor'n in 1821 . In 1826 he served 26 mares, and in 1827 he had 32 mares. He stood 16 hands high.

At Mortagne in the Early '30's.-In 1830 there were three approved stallions in the Arrondissement of Mortagne. Two belonged to Pelletier', and the other to Jacques Geru. Geru's horse, Hercule, was a dapple-gray, 16-hand, heavy draft, born in 1825. He served 52 mares in 1830, and 58 in 1831. Pelletier's stallion, Le Bijou, born 1825, was dapple-gray; he served 35 mares in 1830, and the same number in 1831. Most of the mares were under 15.2 hands at this time in that part of The Perche. They are, 
however, all described on the stallion sheets as "Percherons."'

In 1833 the approved-stallion owners in Orne were Pelletier (2 stallions), Dutheil of Eperraix, Herrissay and Guerrée. Guerrée's horse was about 15.3 hands high and dapple-gray in color. Dutheil's horse was described as "heavy draft," standing 16 hands high, a gray-slightly dappled. In $183 \pm$ he served 51 mares, and in 1835 he had 35 mares. There is also another stallion mentioned, Bijou, which served 30 mares in 1834, and 38 mares in 1835 . He was 17 hands high, was born 1829, and was dapple-gray in color. Herrissay's stallion, born 1830, a 16-hand dapple-gray, served 34 mares in 1834 and 32 mares in 1835. He had another horse, described as "white" in color, which served 35 mares in 1834 and 32 in 1835.

The owners of approved stallions in Orne in 1834 and '35 were Leconte, of Veuville ( 2 stallions, 350

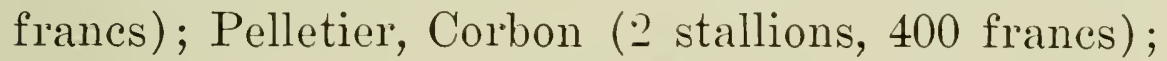
Herrissay, St. Germain de Martigny (200 franes); Guerrée, Fremongène (100 franes). Herrissay's Bijou served 53 mares in 1835, and 60 mares in 1836. Bijou (Guerrée's) served 60 mares each year in 1835 and '36, while L'Ami (Pelletier's) had 32 mares in each of those years. The mares served by Herrissay's horse measured from 15 to 16 hands. Already there seems to be an improvement in the size. Leconte's Cuirassier was not a Pelcheron. He is described as a heavy coach horse, dark chestuut in color and served in the coach-horse district-around Argentan, that part of Orne lying in Normandy. He served 56 
mares in 1836. The other Leconte horse was a saddler, and served only 19 mares in 1836. All of these stallions liad to serve a minimum of 30 mares in order to obtain the bonus.

In La Sarthe.- We first find record of La Sarthe's figuring among the departments having approved stallions in 1832. M. Cousin, commune of Peray, had a (lapple-gray stallion, born 18: $\overline{7}$, slightly under 16 hands, which served 40 mares in 1832, 43 mares in 1833, and 42 in 1834. We find the names of Aveline and Hamelin among the owners of mares served by this horse. Another approved stallion was M. Pierre Abot's horse Mouton, "dapple-gray, heavy draft," born 1828, 16 hands high. He had 57 mares in 1833, but in the following year was not allowed to serve.

Loir-et-Cher.-In the department of Loir-et-Cher, in that part of the department lying in The Perche (Arrondissement of Vendôme) very intensive breeding of Percherons took place, beginning about the same date as in the other departments, and we find, just as in the case of the stallions in the other districts mentioned, that those in Loir-et-Cher were practically all grays of different shades.

The first approved stallion we find record of in this district belonged to a M. Ferrand. He was a silver-gray, of 15.2 hands, and was described as heavy draft. In 1827 he served 103 mares. Then we find a record of Coco, a slate-colored gray with four white feet, belonging to M. Richandean, St. Gourgon. He stood about 16 hands. In 1830 there were two approved stallions. One of these was Coco, and 


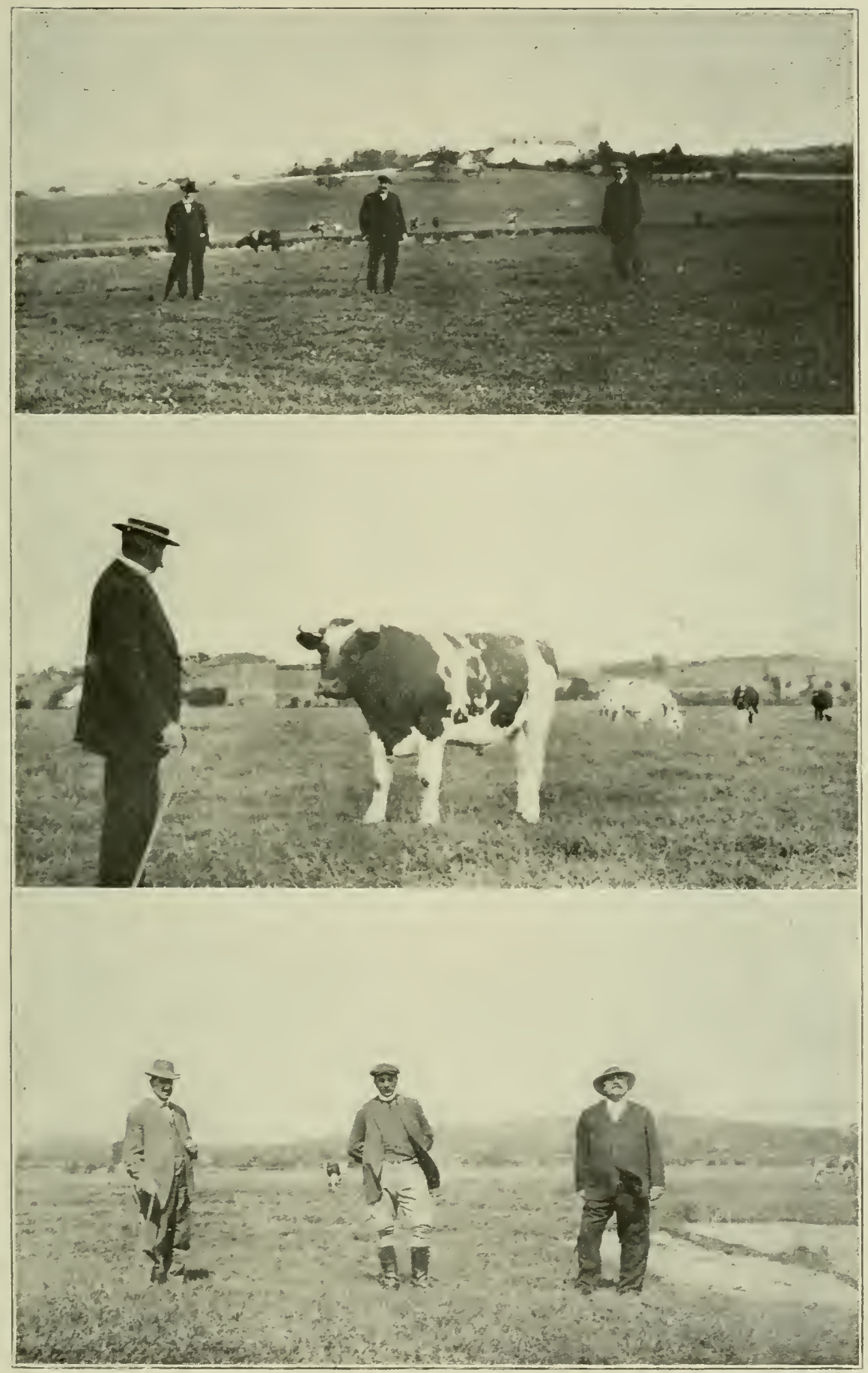

'Tnp-Chas. Areline, Louis Areline and M. E. Jones in Chas. Areline's pastures. Ifiddle-Paul Chouanard lcoking at cattle at Ir. Tacheau's. Bottom-Same indiriduals as seen in top picture--SCENFS IX THE PERCBF. 

45 foals were born as the result of his first season. Ferrand's horse served 94 mares in 1830, and 106 in 1831. In 1831 more bonuses were given for approved stallions. T. Tardiveau's Moulinet, a dapplegray of 16 hands, bor'n in 18:23, served 140 mares in 1831. Another dapple-gray belonging to Tardiveau is reported to have served 181 mares in 1831. There was another stallion belonging to a M. Crignon, Merainville.

In 1832 we find a growing interest in Percheron breeding in this section. Ferrand had three lorses, and Richandeau, Tardiveau and Crignon one each. Crignon's horse served 32 mares in 1832. Moulinet had 151 mares in 1832. Ferrand's horse served $86^{\circ}$ mares in 1832. Another of his hor'ses (name not given), born 1823, a heavy draft of 16 hands, gray, served 102 mares in 1831 and 94 in 1832. His third stallion was also 16 hands high, white in color. He served 98 mares in 1832. Tardireau's horse served 108 mares in 1832. A stallion belonging to Tardiveau, authorized but not approred, 17 hands high, gray, served 85 mares in 1831 and $8 t$ in 1832.

In 183:3 there were about seven or eight approved stallions, and 1,150 francs was distributed in bonuses. Ferrand had three horses, and T. Tardiveau, Richandean, Crignon and P. Tardivean one each. All these stallions were either white, dapple-gray or silvergray with white manes and tails; all were "Percherons." Gray greatly predominated everywhere in this country among the mares served, according to the lists; and the stallions are remarkable, not only 
for the number of mares served, but also for their fecundity, as evidenced by the attested lists of living foals from the seasons' services. In 1834 Ferrand had three approved stallions, which served 101, 105 and 103 mares. The other stallioners were T. Tardiveau, P. Tardiveau, Contançeau, Chevet (Montdoubleau), and Thereau. None of these stallions served fewer than 80 mares, while some of them had considerably more than a hundred.

This part of The Perche has always been noted as a mare country, although buyers-Americans, at least-do not visit the centers like Montdoubleau, Savigny-sur-Bray and Droué as frequently as formerly. Nevertheless, a great many colts from that region get into the hands of the stallioners around Nogent and are ultimately sold for export to America.

A Broad Constructive Policy Continued.-It might be interesting, although somewhat wearisome, to undertake to extend this sort of data further, but we have already brought it down through the formative period named so accurately by M. Fardouet. Moreover, this carries the French side of the narrative well down towards the beginnings of the export trade with the United States, and we must now be turning our attention to our own side the Atlantic. Suffice it to say, therefore, that this same system of bonuses and inspection was continued in The Perche, and with happy results.

Speaking of the policy pursued during the years succeeding those so fully covered by the foregoing 
notes, the Abbé Fret, from whom we have so frequently quoted, says:

"Since 1836 the desire to ameliorate agriculture in The Perche has made great strides among the farmer's. A noble emulation has been set by creating' 'prizes of encouragement,' an agricultural committee having been established at Nogent, which unites ammually under the presidency of the Count de Bussy. This committee has already justified the hopes of its founders and is spreading its influence over the region. A depot of stallions has been established at Nogent, at the barracks of St. Denis, by the Haras du Pin, which has greatly improved the horses of the Percheron breed. They have distributed prizes at Nogent to the owners of the finest brood mares."

A few more records and we shall conclude this discussion. In the "Bulletin de la Société Royale de Mans" is an interesting account of an agricultural show held at Mamers in 1838. Prizes were given for the best draft mare having foaled during the year, age 4 to 9 years; also for the best colt, two to three rears, and the best filly, same age. All were to be of the Percheron breed. Agricultural shows at which Percheron horses were exhibited also took place at Saint Calais, Beaumont-le-Comte, Saint Pater, La Ferté Bernard and Marolle-les-Braults.

At a show held at La Ferté Bernard on the 19th of September, 1841, a M. Torsay won the first prize on a light flea-bitten gray mare, about 16.2 hands high and eight years old. Second prize went to M. Vincent on a steel gray, five years old, of about the same height. A black mare, six years old, measuring about 16.1, received honorable mention. It will be 
seen from this that there were big drafty mares in The Perche even in those days. M. Richard won the first prize on fillies with a brown bay of about 15.2 hands, and second prize went to M. Prudhomme on a filly of similar color, about the same height.

In stallions first prize went to M. Pennetier, and second to M. Flemriada. These stallions had no competition, as evidenced by the following:

"Although these stallions had no competitors, the judges nevertheless thought they ought to be awarded prizes as presenting in the highest degree the qualities which constitute a stallion suitable for the production of draft colts, and it is probably owing to the superiority of these two individuals that one must attribute the absence of competitors."

At the show in the same town in $1842 \mathrm{M}$. Pennetier again won first prize in stallions with a horse of 16.3 hands, dapple-gray, six years old. In the following year M. Tacheau, probably the grandfather of the present noted stallioner and breeder, won first prize in fillies.

Outcrossing Exaggerated.-Had the Percheron, then, during this evolution, received no crosses from other breeds? Very likely experiments were tried, but it is entirely clear that misguided alliances with extraneous blood were never permitted specially to influence the race in its entirety. The specific and inherent qualities of the type were always conserved intact. Unsatisfactory colts, the product of occasional infusions of blood from other breeds, were promptly set aside as work horses and not allowed to reproduce their kind. No men are more 


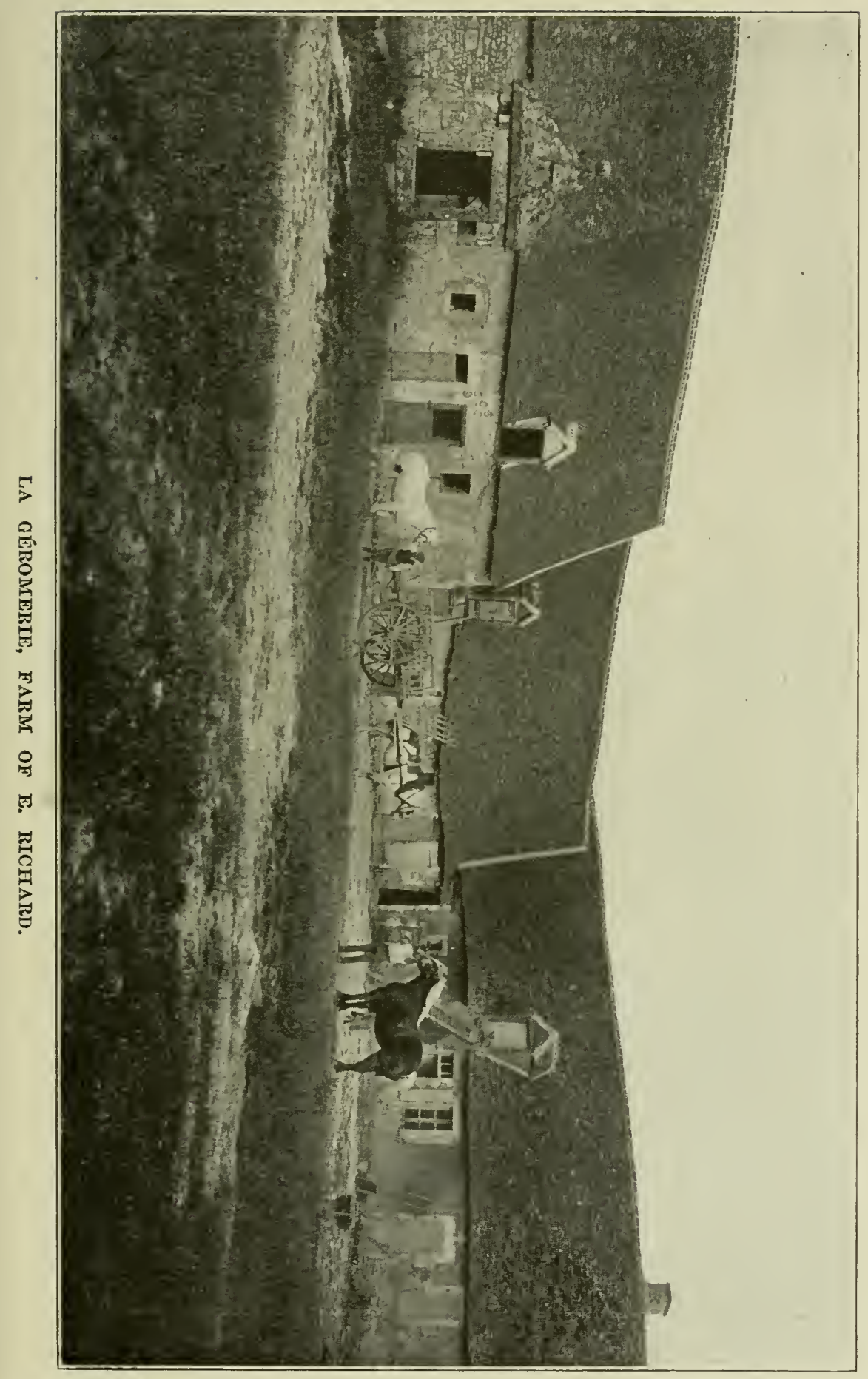



tenacious than those of The Perche. None knows better than the Percheron farmer himself which type of horse suits his needs best.

The possible influence of an introduction of a few Picardy mares near Montdoubleau about the beginning of the 19th century has been grossly exaggerated. We have had an examination made of the original sheets containing full descriptions of the native mares served in The Perche by the approved Percheron stallions from the time these approved stallions first began their work, and only in a few instances do we find the name "Picardy," as applied to the "provenance" of the mares, mentioned. This blood was quickly eliminated, as is shown by reference to later documents. But long before the organization of the stud book the purity of the breer was almost guaranteed by the fact that only the most typical sires were allowed to serve mares. Each department had very stringent rules to assure the purity of the breed. No stallion could serve mares without official permission first having been obtained.

As to Color. - With respect to the black color. which became popular some years ago much has been said by way of insinuating that this came from an outside source. There have always been plenty of black mares in The Perche. Precise information touching this is to be found in the government service sheets. Every stallion sheet that we have har examined, beginning about 1820, alludes to black mares of the "Percheron" breed. The breeders of The Perche, like other men, cater to their customers, 
and they were easily able to produce blacks in considerable numbers from within the breed itself by natural selection.

When the special demand for blacks abated, stallions of that color were discarded and the farmers began to put their mares again to grays. Similarly, if a craze for bays had sprung up years ago, it would have been possible to produce bay colts all over The Perche. The first Percheron specifically mentioned in the records of the government stud, as has already been set forth, was of that color. The gray color, however, has always been common to the Percheron, and it was through the influence of the approved stallions which we have listed that this color became predominant. The stallions used in The Perche, almost without exception, during the early formative period were grays, and of these nearly all were dapple-gray ("gris pommelé").

That was the period when the popularity of the Percheron as a stage-coach or diligence horse had reached its zenith. Three important turnpike roads from Paris to the coast passed through The Perche, and as the railroads had not yet come traveling was by diligence. Some of these coaches also carried the mails, and good time had to be made regularly. The lighter Percheron of those days was considered ideal for this work, and the gray color pleased the proprietors because the teams could be seen more distinctly at night. The introduction of railroads caused the Percheron later to be drafted into omnibus work, principally at Paris, where thousands of these dap- 


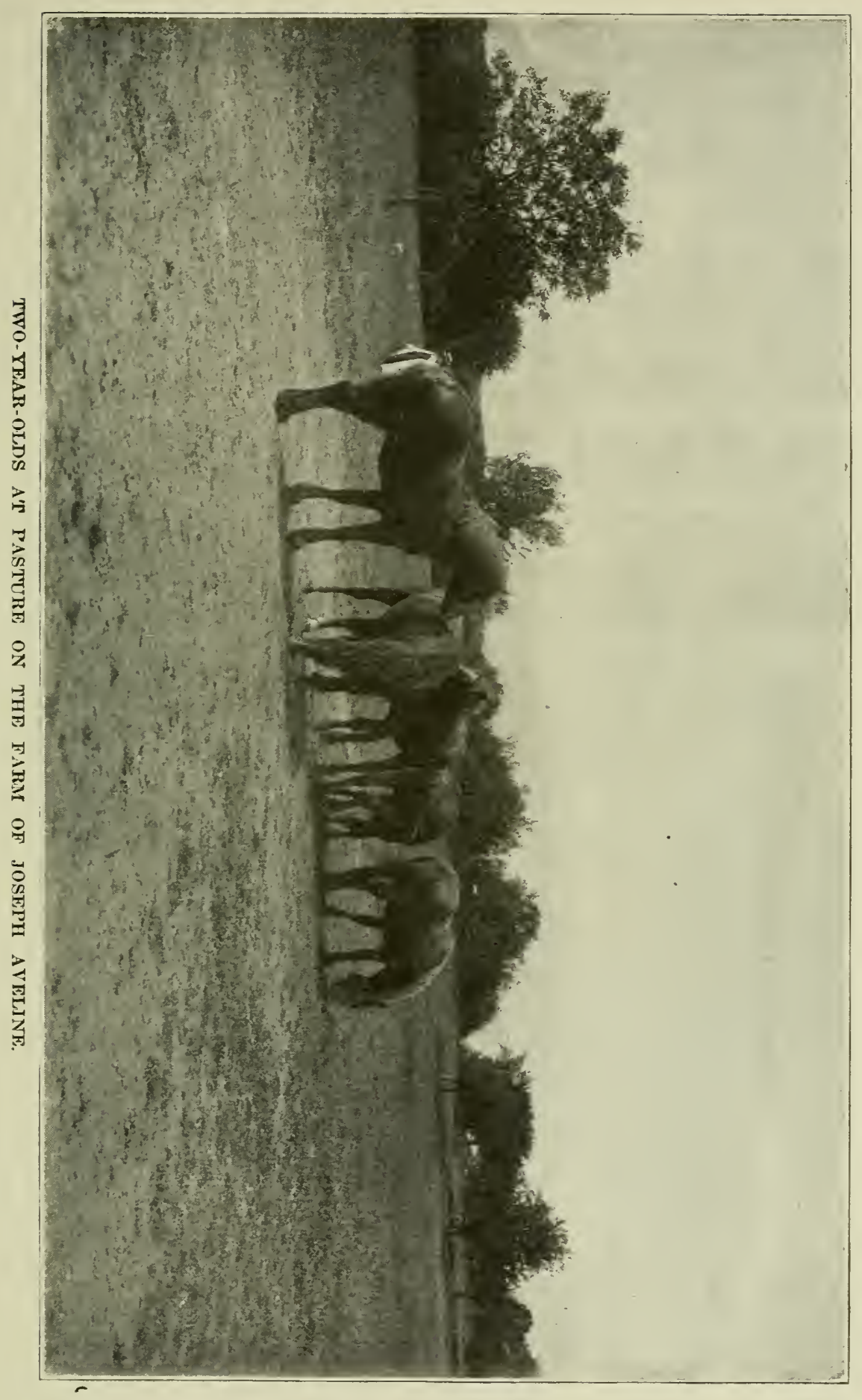



ple-gray horses in matched couples.and threes were until very recent years a familiar sight.

Passing of the Diligence Type.-But even before the railways came, under the influence of the service of the large approved stallions we have mentioned the breed was becoming more drafty, a fact which called forth some protest, as is evidenced by a report made at a meeting of the Agricultural Society of Mans, on Feb. 5, 1845, from which we quote:

"It is an incontestable fact that the stallion shows of this department (Sarthe) have produced satisfactory results. But, really, what do we want today? Light, vigorous draft horses for our artillery, mail coaches and diligences, the number of which has been doubled since twenty years ago. We need horses capable of doing about 7 to 10 miles an hour, at least, in harness. Shall we obtain these results with heavy horses, only suitable for heary draft work and large exploitations?"

The Beauce was asking for larger horses to do the plowing and to prepare the land for the wheat crop. This region is contiguous to The Perche, and is called the "granary of France." The growing population of Paris, which has always taken most of the Beauce wheat, compelled more modern methods of culture on the part of the grain-growing farmers of that fertile region. Oxen were gradually being discarded and heavy horses were being used in greater numbers throughout all France. The call upon The Perche for material of this sort was not only persistent but it came from many different districts.

Some Conclusions.-The more profoundly one 
studies The Perche and its history, the more firmly one is persuaded: first, that the Percheron horse is a product of this ancient province and indigenous to the basin of the Seine, and second, that he has been developed and has acquired his most distinguishing characteristics through judicious breeding within the territorial limitations of The Perche itself. Centuries of evolution in a small country where the soil, the climate, the forage, and the very air itself conduced in the highest degree to the production of good horses have accomplished the result so admired today.

Modifications of type have taken place in the past, and no doubt will appear in the future. All draft breeds have undergone mutations to meet the changing exigencies of the times. During the Dark Ages the native horse of The Perche was in demand as a war horse. Later we know that in the 17 th century depredating bands frequently entered The Perche, primarily for the purpose of appropriating the fine horses known to be there. Although we have no historical facts to prove that Rotrou III sallied forth from Nogent with his numerous retinue of knights and vassals, all mounted on the light type old-time Percherons, when he went to fight the infidels in the Holy Land in 1095, history does not tell us, on the contrary, that other than native horses were employed in this expedition, or in the second Crusade, or in the campaign against the Saracens in Spain. To all of these martial exploits many of the seigneurs of The Perche contributed their quota. 


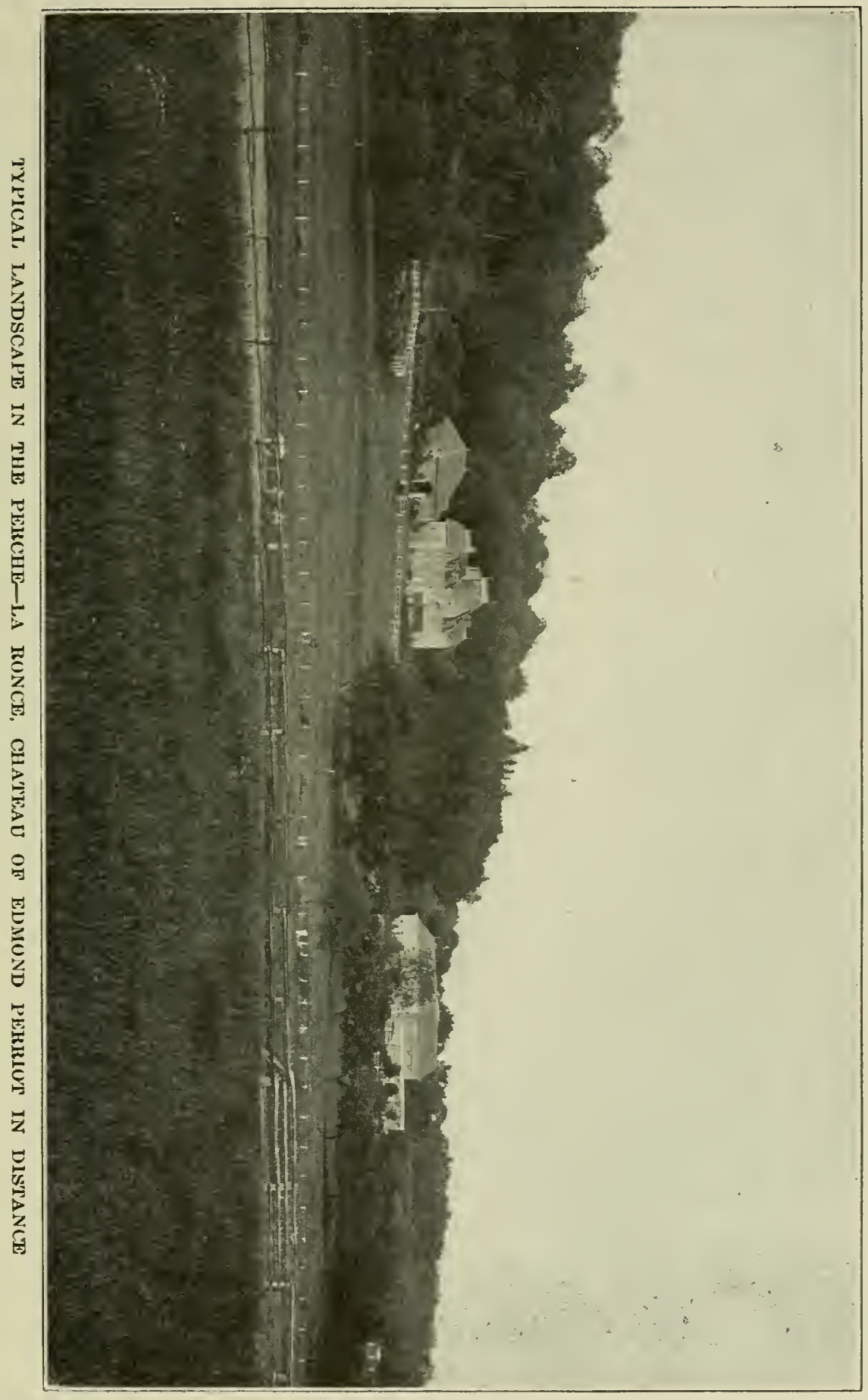



Through many generations during various periods of the Percheron's history the same old families have been engaged in producing colts in this wonderful nursery of good horses. The names of some of those who have contributed largely to the making of Percheron progress will be mentioned in a subsequent chapter. The specially rapid maturing qualities of the Percheron, and the extraordinary plasticity of the breed have served these persistent breeders admirably in their eminently successful effort to produce larger horses. All this lias been brought about under the stimulating influence of foreign gold by a rigorous selection of the breeding materials, rational working of the brood mares, and liberal feeding of the young stock with suitable grain and forage.

This, then, is a fair account of the original evolution of the modern type in France, so far as can be ascertained by an exhaustive examination of all available records pertaining to it. The famous stallions appearing in the first volume of the Percheron Stud Book of France were undoubtedly the direct descendants of the government-approved stallions listed in the foregoing pages. It will be observed that the long record so carefully examined at the expense of much time and labor yields the name of but one stallion in service during this period described as a "Boulonnais," and he was not owned by a Percheron farmer but belonged to the government. The Perche was increasing the weight of its own horses by free recourse to the services of the 
larger stallions and mares selected and mated with this particular object in view, under official inspections. The stallions named in this chapter, and they alone, are the true historic forbears of the heavy draft Percherons of the years that followed their use. 



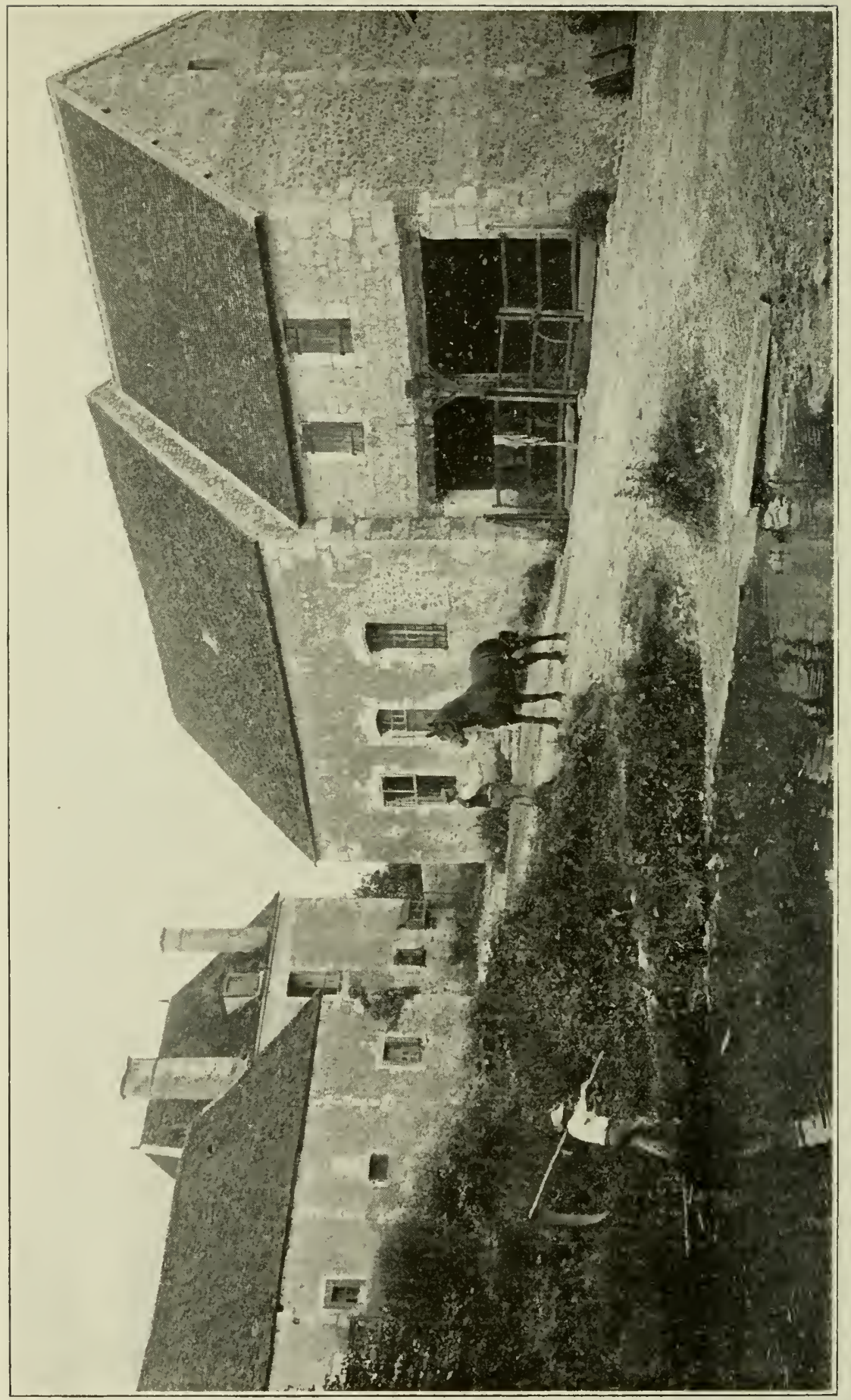

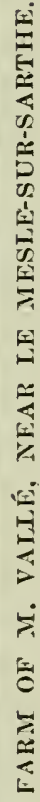




\section{GHAPTER V.}

\section{FIRST FRENCH HORSES IN AMERICA.}

Somewhere on the shaggy shores of the mighty seaward outlet of the Great Lakes, quite probably at Quebec, the first horses brought from the old to the new France were debarked. Doubtless within the crypted chests of the churches and monasteries of Canada records of horses imported in the seventeenth and eighteenth centuries lie buried deep in the dust of time, but in none of the public documents of the Dominion, church or state, is there mention of such shipments. Louis XIV sent some mares and a few stallions from the Royal stables in 1665, 1667 1670 , but they were not of a sort well suited to the purposes of agriculture. Other stallions besides the few donated by the king must have been imported by the colonists themselves and these in all probability were of a sturdier, more useful type. After the cession to Britain in 1760 the insular types assumed the ascendancy, save in the old French settlements.

The primeval forests of the Lower St. Lawrence were first seen by Jacques Cartier, the French explorer, in the year 1535, but it was not until 1609 that Champlain began building upon the now historic rock of Quebec. This event marked the beginnings of Canadian agriculture, and to this day the horses 
of the province of Quebec, in the hands of the descendants of the first "habitants," reveal in their activity and endurance, if not in size, something of the character of the sturdy, fast-traveling, longdistance trotters for which France had been famous for generations. More than a century ago the native horses of eastern Canada offered in their conformation indisputable proof of a Gallic origin, but so altered to meet the exigencies of a new country as to be entitled to recognition as a distinct type.

Authentic Records Begin.-The first stallions imported into North America from France of which there is record in all probability did not come from The Perche. The so-called "McNitt Horse," brought into Canada in 1816, was a dapple-gray standing from 15.2 to 15.3 hands high. At the time he was imported the French government, as we have already shown, was just beginning at the Haras du Pin to give a more or less grudging support to the idea of developing heavy drafters in The Perche. While the breeding and origin of the McNitt Horse, or European, as he was sometimes called, cannot now be fixed, it is clear that he was of a type then in favor in France. He weighed around 1,200 pounds and was a trotter of renown. Moreover, he proved a successful and prolific sire. His sons were, as a rule, so superior to the native stock of the time that many of them were kept entire and used in the stud. At a rather advanced age he was brought into Washington County, New York. Both he and several of his sons were popular in the Empire State 


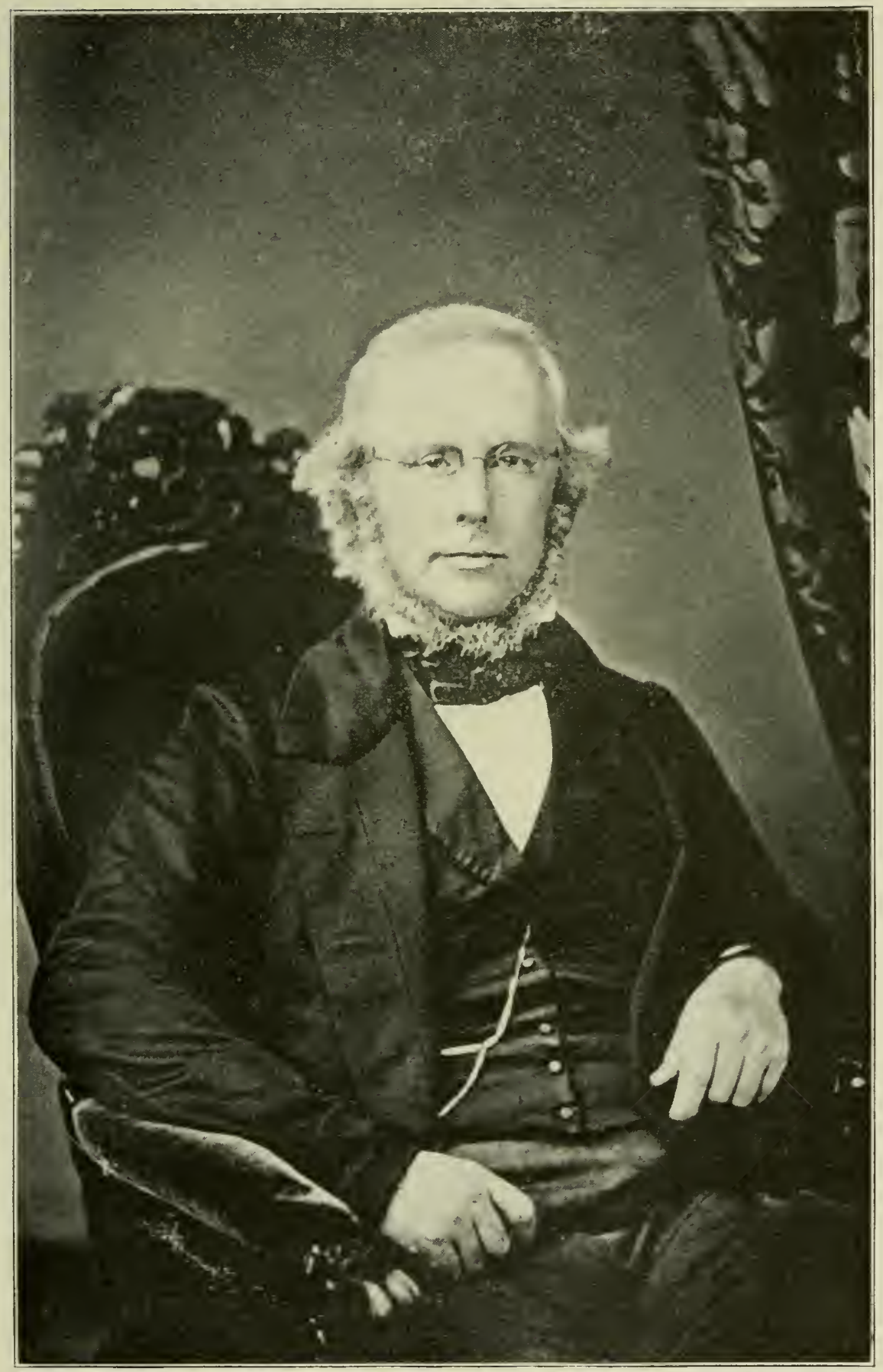

EDWARD HARRIS OF NEW JERSEY-PIONEER IMPORTER OF PERCHERONS. 

and New England, but whatever mark they may have left upon the horses of that portion of the United States was later effaced by the stronger blood of imp. Messenger, a Thoroughbred and also a gray, whose stock even to the second and third generations proved popular in the east.

Alexander's Norman.-One son of the MeNitt Hor'se gained a measure of renown in this country. This was the gray Morse Horse, sire of Alexander's Norman, a noted stallion taken from New York state to Robert A. Alexander's famous Woodburn Farm in Kentucky some time during the ' 50 's of the last century to sire work horses. This he did with success, and incidentally he founded a small and comparatively unimportant family of trotters. The name of this horse would indicate that the French type probably had been preserved in his case.

Diligent search of old newspaper files and such public documents as are available reveals no proof of further importations from France for a long series of years. There is a tradition that at some time between 1820 and 1831 gray French horses were imported into Maryland, but if so all traces of them, their owners, and their history have vanished.

First Importation to the States.-In 1831 Edward Harris, a resident of Moorestown, N. J., was traveling for pleasure in northern France and became so impressed with the excellence of the hardy horses that hauled the heavy diligences in which he traversed the country that he determined to ship a few 
specimens to the United States. It was not, however, until 1839 that he succeeded in putting this determination into effect, and then bad luck pursued his venture; only one of the first four head shipped reached America alive, and this sole survivor was a mare. Nothing daunted, Mr. Harris immediately took ship again for France, and returned this time with two stallions, one named Diligence, and two mares, one of which died shortly after landing. This importation, it would appear, had only a passing influence on the native stock of New Jersey. One of the stallions went blind during his first year in this country and was permanently retired from service. One of the mares named Dapple proved a non-breeder, while the other, Joan, a gray, produced a gray colt, a chestnut filly, and a bay colt at successive foalings, all being got by the gray Diligence. Joan's next and last foal, born in 1856, was a bay by Harmer's Norman, a stallion said to have been imported and not hitherto located, but which will be definitely referred to later on. Diligence was a compactly built horse standing about 15 hands high, and according to his owner he begot about 400 foals. He died in 1856. One mare, Julie, foaled in 1851, and two stallions, Diligence $2 \mathrm{~d}$ and Louis Philippe, all by Diligence, were entered among the foundation animals accepted for registry in the first volume of the American Stud Book.

Ohio Importations of 1851.- - In another volume the author has shown that the cattle stocks of the midwest states were profoundly influenced by the im- 


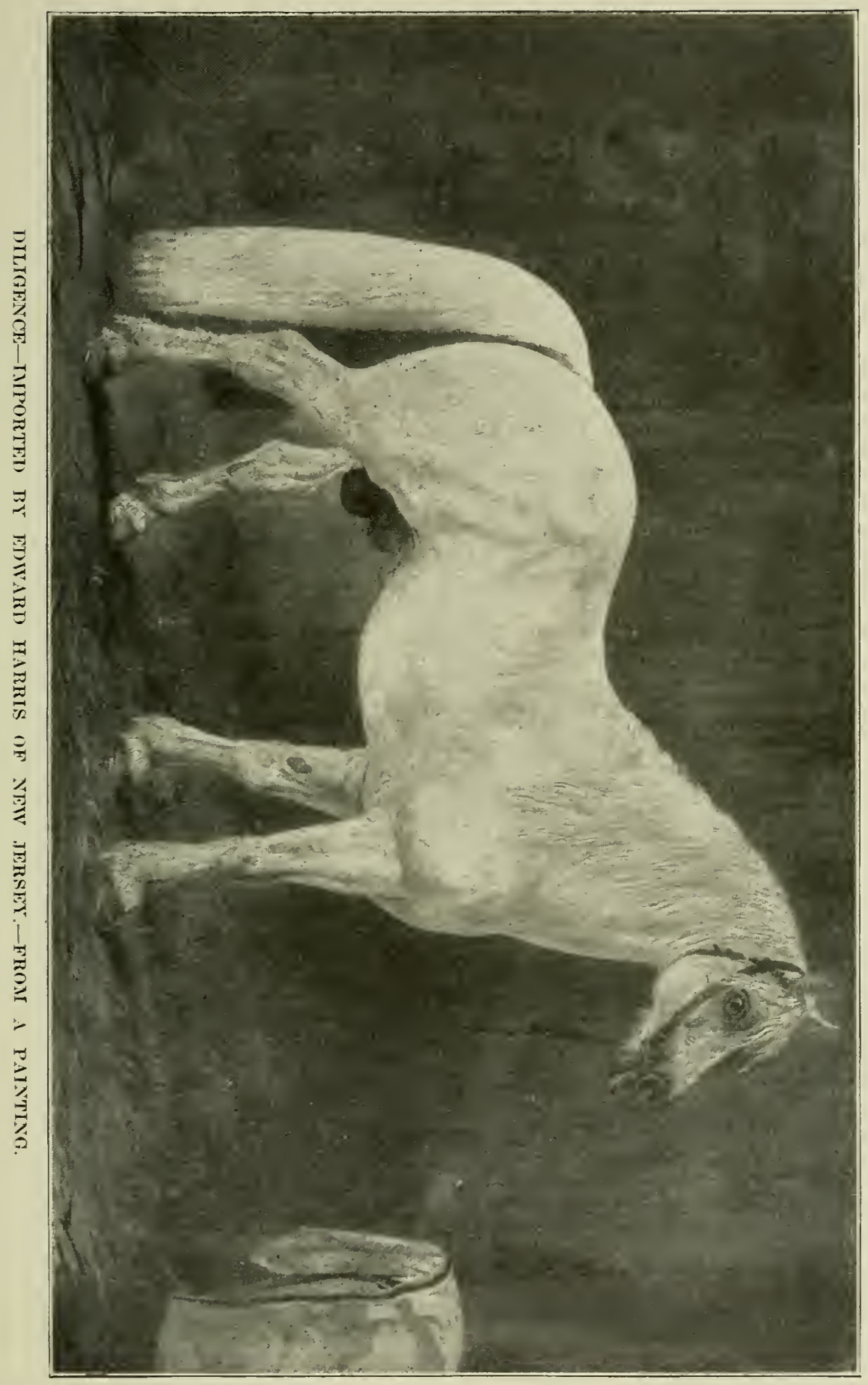



porting operations of the enterprising farmers of south-central Ohio carried on at intervals during a long series of years beginning in 1834. These men were mostly of Virginia extraction and never could abide inferior domestic animals. Their attention was first given to their herds and flocks, which acquired in due course a nation-wide celebrity. Their love for a good horse was proverbial, but it first expressed itself in an attachment to the English Thoroughbred or blood horse and to those wonderfully gaited saddlers which are still the pride of all men and women of Virginia stock. Nevertheless, we have here to credit to these same public-spirited Ohioans of the old school the bringing in of the original seed from whence the great Percheron harvest of our own times has been reaped. In short, we have now to record that the importation into Ohio in 1851 of the two French stallions Normandy and Louis Napoleon was followed by results of which their importers little dreamed, and that in the career of the one in Ohio and of the other in Illinois we have revealed the solid base upon which the subsequent popularity of the French horse of heary draft throughont the United States really rests.

It would be interesting if we could trace the exact origin of these two successful stallions, but this is now impossible. We know that they were not bought in The Perche by the men who imported them. The importers probably never had heard the name. It is a fact, nevertheless, that at that date 
The Perche was a prolific producer of horses of this type, and that, as we have already shown, the farmers of that province were free sellers of colts to outside buyers.* It will never be positively known, however, whether or not these horses were of the true Percheron blood. What little is known about the breeding of Normandy is vague and of Louis Napoleon's ancestry nothing whatever is available. We know that both were bought in the vicinity of Rouen and that Normandy was bred near that city, but from what sort of ancestry tradition sayeth naught. Their importers had not penetrated as far as The Perche. Here are the known facts:

\section{Normandy, or Pleasant Valley Bill.-Hitherto it} has been popularly supposed that in 1851 two stallions only were imported from France, the one being Louis Napoleon 281 and the other Normandy 351, or Pleasant Valley Bill, as he was well-nigh universally known during his lifetime. So far tradition has been right as to the importations, but wrong as to the number of horses. Dr. Mareus Brown, Circleville, O., really imported two stallions, so that in 1851 three entire horses came from the northern part of

* In a book entitled "European Vineyards," written more than fifty years ago, Mr. Wm. J. Flagg, speaking of the heavy horses in harness in the Bordeaux district, says:

"Two farmers, whom I afterwards met while traveling in Normandy, told me the Perche country was really the home of the breed and that it was their custom to buy there six months' colts, which they raised and broke, working them from two years old, and selling them when they got to be five or six years old, the prices obtained for full-grown and well-broken animals ranging from $\$ 200$ to $\$ 250$. I am glad to learn they are at length bringing them to America, where a late importation sold for prices which averaged $\$ 2,500 . "$ 


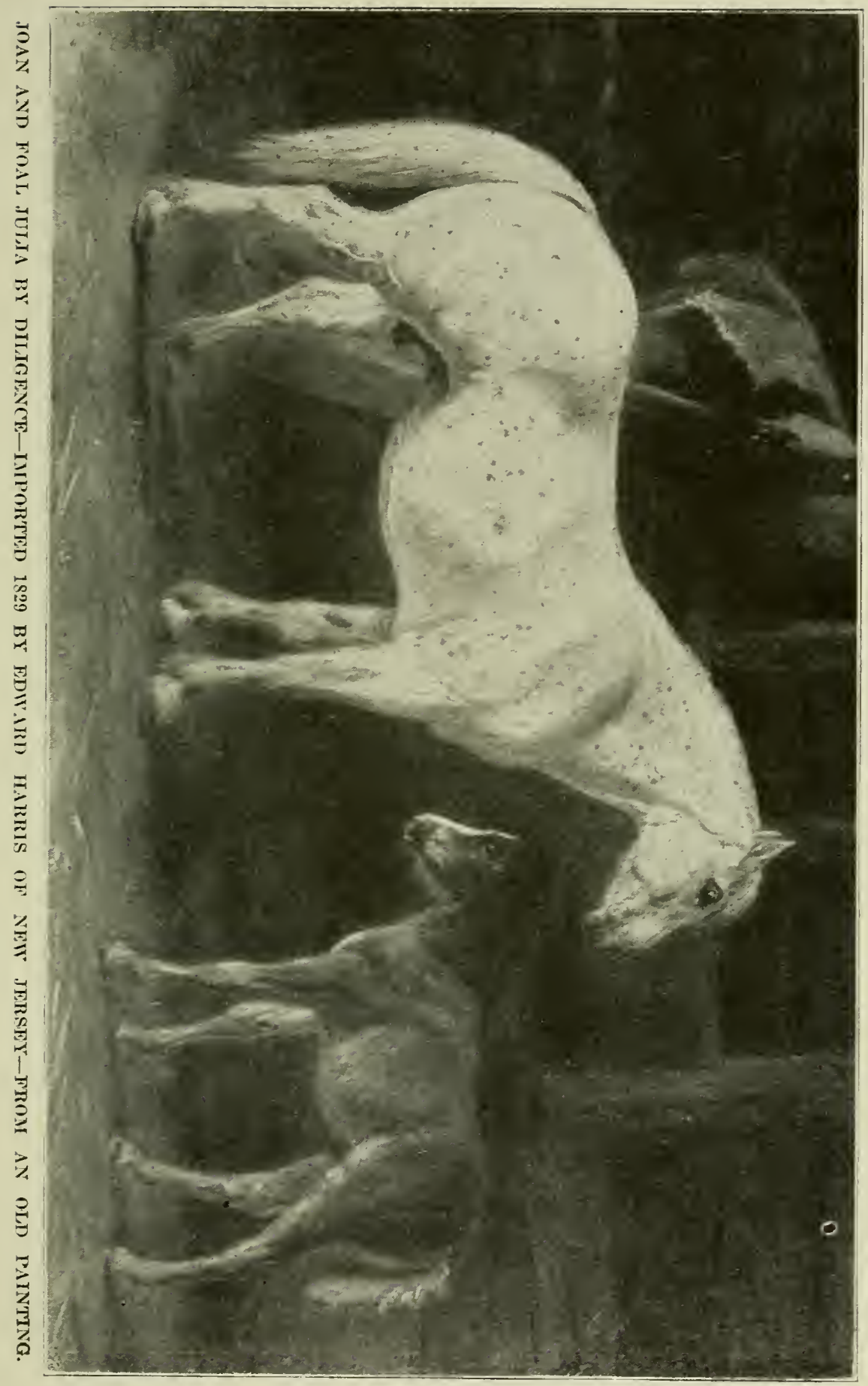



France to Ohio. Proof that Dr. Brown imported two stallions is complete, or rather that Samuel Holman, Chester Springs, Pa., who was entrusted by Dr. Brown with the task of procuring for him a French horse, bought two with Dr. Brown's money and took one of them for himself.

Among Dr. Brown's papers turned over in connection with the sale of a half-interest in "Old Bill" to the late T. C. Bigelow, Columbus, O., there is a letter from Samuel Holman dated at London, England, July 10, 1851, which reads:

"I leave these few lines to inform you that I have used the $£ 100$ got of you for the purchase of a horse. I have bought two, one for you and one for myself. The one is a two-year-old and the other three years old. They are strong able colts. I suppose will weigh 1,200 to 1,400 pounds each now. The color does not please me exactly and another objection I had to them was that they cut all their foals' tails off as soon as they are foaled in this country and consequently both are short-tails. 'Their colors are darkish silver, black legs, manes and tails. However, I concluded to risk them."

The remainder of the letter goes into details concerning shipping. Attached to this are the original French certificates of sale and identification, interesting mainly as descriptive of the breed to which these horses belonged, thus:

$$
\text { "Rouen, .July 1, } 1851 .
$$

"I do hereby certify that the two Diligence colts purchased from me by $\mathrm{Mr}$. Sam'l Holman of the United States of America were bred and raised by me and from my best brood mares. The stock is 
pure and I consider them as fine as I ever sold and I doubt whether a better pair of colts can be found in all Normandy.

Follows then this certificate:

\section{“Z. PIMONT.',}

"Havre, July 16, 1851.

"This is to certify that I shipped the two Norman colts bought by Mr. Samuel Holman of Z. Pimont of Rouen on the 8th day of July, 1851, on board the ship Scianne, Capt. Williams, consigned to R. W. Hopkins \& Co., New York. I am well acquainted with M. Pimont and his stock of horses and know they are of the finest diligence stock, as he keeps no other kind on his farm. This stock of horses is held in high estimation here on account of their great bone and muscular power, quick action and durability and I consider the pair sent as a fair sample of the stock.

\section{"Y. BARBE."}

Next comes the statement of the import agents in this wise:

\section{"New York, August 30, 1851.}

"We do hereby certify that the two gray horses consigned to us by Mr. Samuel Holman when received on board the packet ship Scianne, Capt. Williams, on the 12th day of August, 1851, in good condition, and delivered them according to his orders, one to his brother F. Holman, and the other to Doct. Brown of Ohio.

"R. H. HOPKINS \& CO."

These letters readily attest the fact that two diligence stallions were imported by Dr. Brown and Samuel Holman in 1851. Further reference will be made to the Holman horse. These letters and certificates prove that Pleasant Valley Bill, or Nor- 


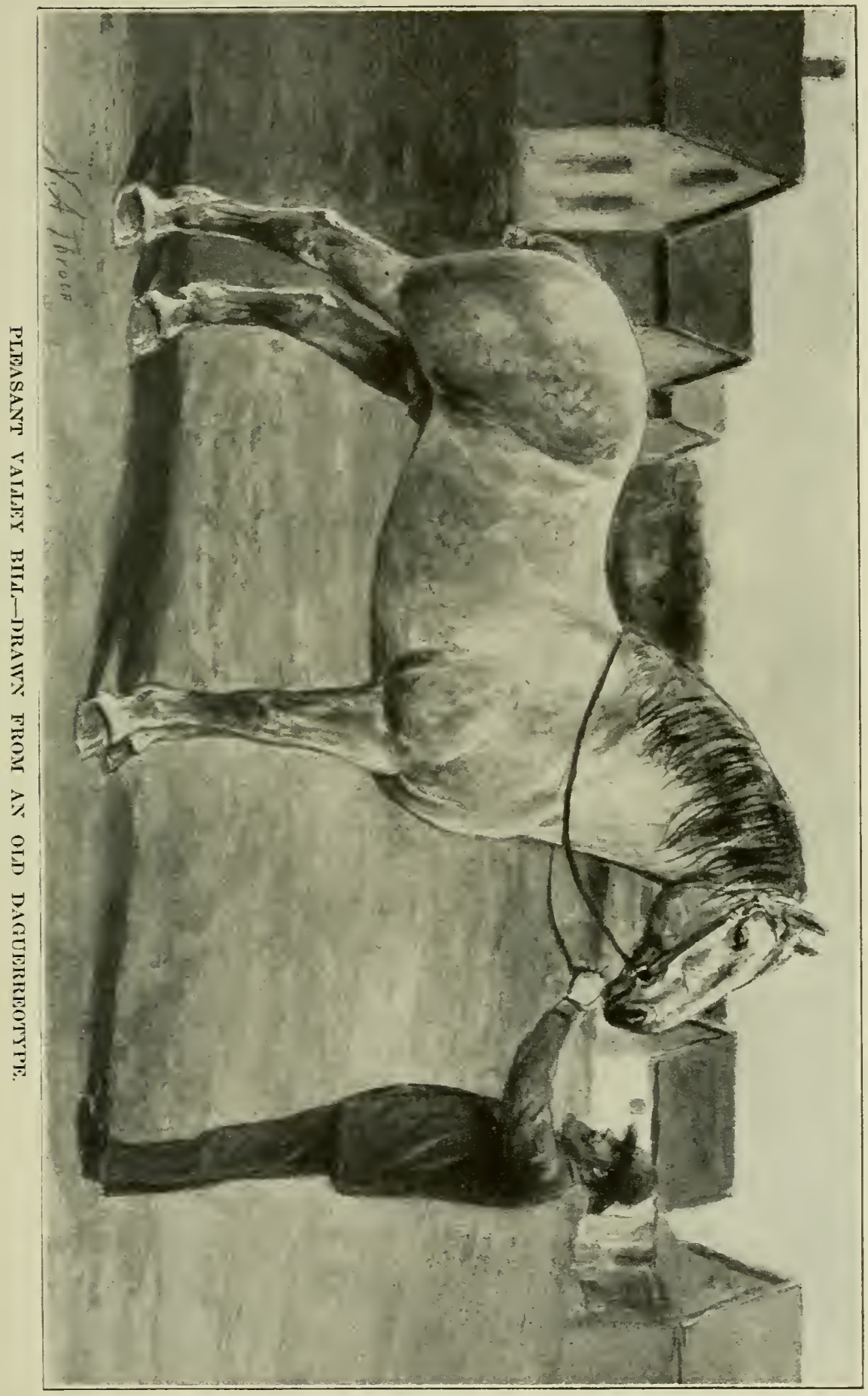



mandy, and his mate were of the "true diligence type." Fortunately we can even at this late date tell, approximately at least, what the type was like from the illustration of Normandy presented herewith. This cut was made from a large and very clear daguerreotype in the possession of T. L. Bigelow, Columbus, O., son of and successor in business to the late owner of the horse, and to whom we desire to express our thanks for his aid in reaching the exact history of this importation. It will appear that Louis Napoleon and Pleasant Valley Bill were of two distinct types, though imported from the same district of France in the same summer.

A Great Career.-Just past two years of age when imported, Normandy 351 was located by Dr. Brown at his home town of Circlerille, O., and at first was not very popular in the stud as a country stallion. Dr. Brown has left no written statement among his papers intimating whether he intended when he started for Europe that spring to buy a stallion or not. He was an enthusiastic adrocate and supporter of all improved methods of agriculture and stock breeding, hence it is considered more than likely that he had such an importation in mind when going abroad in the spring of 1851. For years he owned the Pickaway County fair grounds at Circleville, and gave their use free of charge to the Pickaway County Agricultural Society. He once offered to donate Normandy to that organization provided it would stand him for public service at the fair grounds, but that offer was curtly declined and in 
1856 Dr. Brown sold the horse to Bigelow \& Marshall, who removed him to the town then called Pleasant Valley but now known as Plain City. There the stallion achieved a splendid reputation, begetting an amazingly numerous progeny and finally passing into the hands of the late Thomas Jones, father of C. M. Jones, now treasurer of the Percheron Society of America and resident on the old homestead. In his possession Normandy died in 1874 full of years and honors, having been owner by Mr. Jones just ten years. Many good stallion colts as well as fillies remained after him, and his descendants were widely disseminated.

While at Plain City Normandy became variously known as "Pleasant Valley Bill," "Old Bill," and "The Valley Horse," the title by which he is best remembered being the first of these. Few people knew that his real name was Normandy 351. He did more than any other horse to popularize the French type in the state that reaped the benefit of his services. He was extraordinarily prolific and is known to have begotten as many as 110 colts for which the fees were paid in a single season. Of his extreme fertility the late Thomas Jones is quoted in Volume 1 of the Percheron Stud Book of America as having said:

"It is safe to say that he averaged sixty colts a year for eighteen years and that they sold at three and four years old for an average of $\$ 200$, many of them having brought $\$ 500$ each, and some as much as $\$ 1,000$. It was when the United States government began scouring the country for good horses 


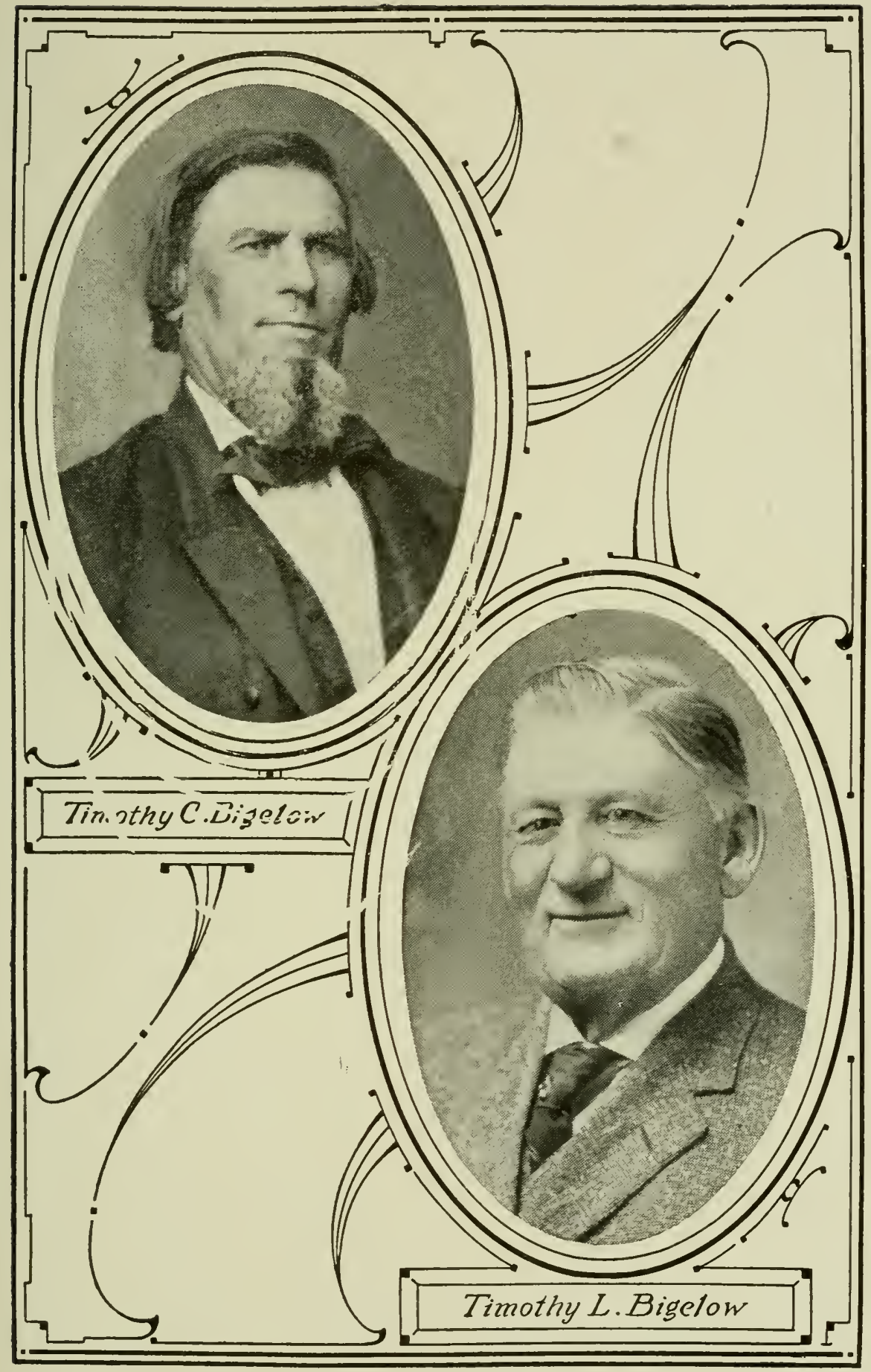



during the War of the Rebellion that the seal of fame was set upon Valley Bill for all time. His get readily brought from $\$ 50$ to $\$ 125$ more than the common stock of the country where he stood, the general belief being that those who had Bill's colts to sell to Uncle Sam received on an average $\$ 80$ per head for them more than was paid for other varieties."

His get were wonderfully uniform, none of them very large, and the great number of red-roans which followed his cover has given rise to a belief quite general in some quarters that he was when young of that ruddy hue, shedding out to white at a comparatively early age. As a matter of fact, however, in his youth he was a silvery gray with dark legs, mane, and tail and later became well-nigh snow white. Nothing need be said here descriptive of his conformation. Our illustration shows more clearly what he was like than could be told in words. He stood about 15.3 hands and weighed between 1,300 and 1,400 pounds.

The Holman Horse.-Not nearly so much is known of the three-year-old gray diligence colt that accompanied Pleasant Valley Bill on his journey from Havre to New York. Lewis E. Holman, son of Samuel Holman, the importer, Phoenixville, Pa., takes up the thread of the story from the time the two colts reached New York in 1851 in the following statement:

"Gray Billy, as we called our horse, was shipped to the home of my father's brother, Frederic Holman. to await my father's arrival. From there he was 
brought to our farm on which we still live and always have lived. The reason we do not know his age when he died is that after keeping him many years we sold him to a Mr. Bird of New Jersey. How long he lived after that we do not know. His weight was between 1,300 and 1,400 pounds. His colts were fine and he was a sure foal-getter. He was not popular at first, but it was not long before he was appreciated, though not in our immediate neighborhood. Buyers came from New York and many places of distance to buy his colts as they were remarkably fine and far superior to the colts by ordinary horses. He was a dark silver, dappled, three years old, one year older than Valley Bill. He was perfectly gentle and for his size very active, as were all of his colts."

The illustration of Gray Billy is from a curious old oil painting in the Holman home near Phoenixville, Pa., our engraving being a facsimile reproduction, without effort to correct its manifest crudities. Gray Billy is thus identified with the hitherto unplaced Harmer's Norman, Holmes' Norman, Holman's Norman, and Duke of Normandy 172, recorded under that number without date of birth or importation, or other lata.

Louis Napoleon.-In 1851 in the course of a trip abroad three Ohio men-Erastus Martin of Woodstock, Pearl Howard of the same place, and young James Fullington of Milford Center, a member of a family distinguished in Ohio agricultural historywent from England to France in quest of Merino sheep. Somewhere in the neighborhood of Rouen Martin saw a gray stallion with which he was deeply impressed-a big one possessing the distinction of 


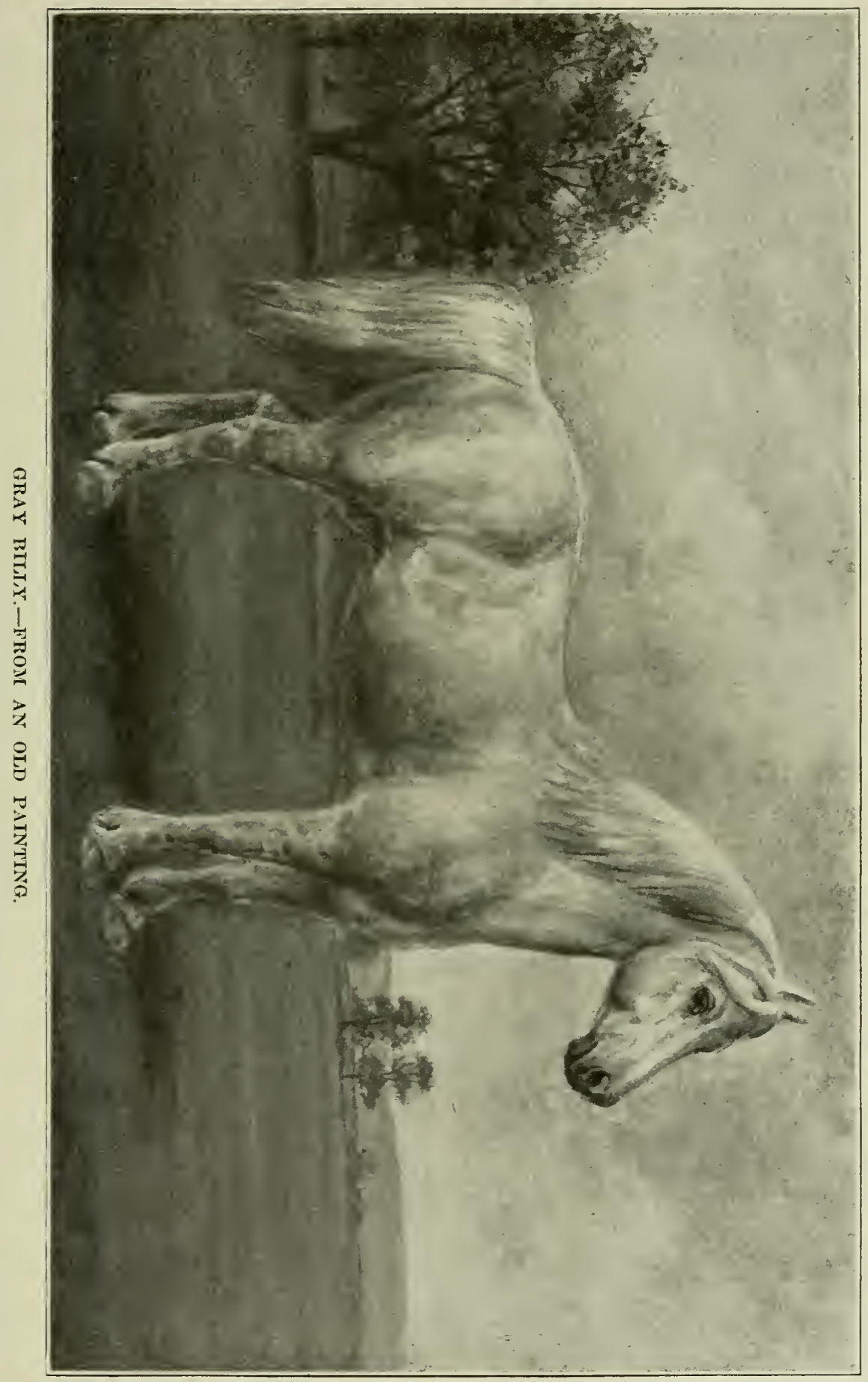



being kept for stud service alone. As to where he came from history is silent. This horse took $\mathrm{Mr}$. Martin's fancy, but all efforts to buy him proved futile. Not to be foiled entirely, however, he did the next best thing and bought a three-year-old full brother described at that time as "a raw, unfinished colt" but promising to attain good size.

Mr. Martin paid $\$ 350$ for the colt and on rejoining his comrades told them what he had done, expressing his belief that such a stallion would do a goor business in the part of Ohio from which they came. Besides, it would not cost much to get him home with the rest of the stock. Pearl Howard declined point blank to invest any of his money in so big a stallion, but young Fullington, who was merely traveling with the party on a pleasure jaunt, committed his brother Charles, then a well-known figure in Ohio stock-breeding circles, to pay for a half interest in the horse.

Landed safely in the Darby Plains country of Ohio, Louis Napoleon, as this French-bred colt had been named, met with a chilly reception. The late James H. Sanders, founder of the American Percheron Stud Book, who was born and lived as a roung man in central Ohio, has left the following statement concerning this horse:

"Louis Napoleon was a gray three-year-old of good size, but not of the largest type, short-legged, closely ribbed, blockr, and compact, with a neck rather short and head a little too large for elegance, but withal clearly cut, about $151 / 2$ hands high, and 
weighing, in full flesh, about 1,600 pounds. At that time he was a dark iron-gray, but long before his death, he became perfectly white.

"At this time the writer was living within a few miles of Messr's. Fullington and Martin, and well does he remember the jokes that were hurled at Charley Fullington for what was called his folly in bringing such a horse all the way from France. The chunky, short-legged, gray colt and his importers were the butt of every horseman in that country; but the Fullingtons believed in him firmly, and bred several mares to him in the spring of 1852. His service fee that season was put at $\$ 10$ to insure, yet such was the prejudice against him that only ten mares were bred to him, and seven of this number belonged to his owners. In the meantime, Mr. Erastus Martin had come to the conclusion that the horse was destined to prove a bad investment, and accordingly, he embraced an opportunity of selling his interest to $\mathrm{Mr}$. Gordon, one of his neighbors.

"In the spring' of 1853 it was thought best to try a new field with the big gray colt, and accordingly he was sent to Dayton, and his service fee was fixed at $\$ 15$; but he did very little better there than he had done during the previous season in Union County. Early in the summer of 1853 , the few colts that he had got in Union County during the previous season began to show signs of that remarkable excellence that was destined soon to make the despised French horse famous throughout the entire west, and then came a demand that he should be returned to that county. Accordingly, during the next season (1854) he was again kept at Milford Center, Union County, and although his fee was placed at \$15-a price hitherto unheard of in that region-he was well patronized by the people who had two years before ridiculed him." 


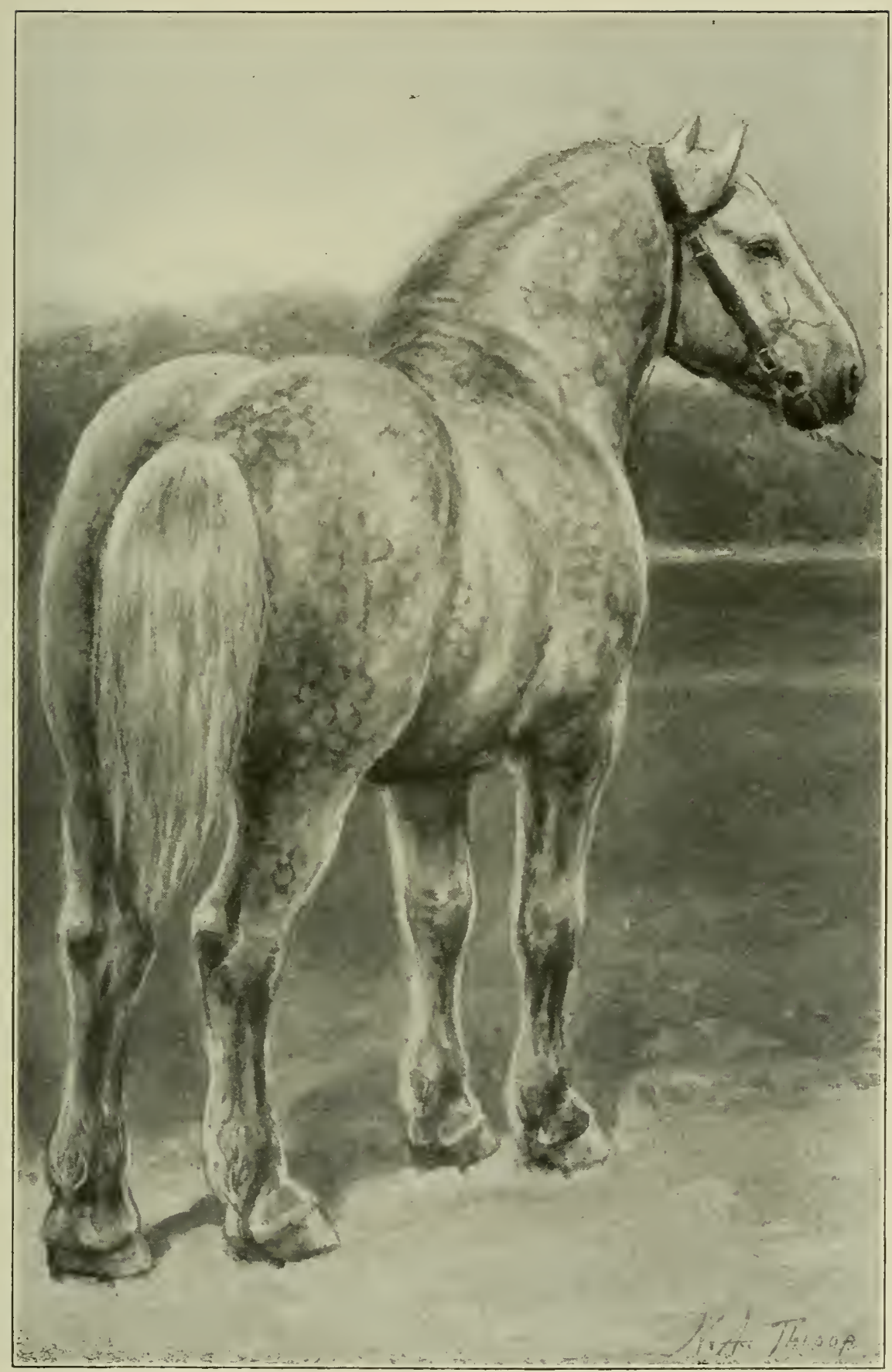

LOUIS NAPOLEON.-DRAWN FROM AN OLD PHOTOGRAPH. 

It is related that Howard had remarked when the purchase of a one-third interest in the colt had first been suggested to him that "when he wanted to breed his mares to a bull he would choose one with horns," and that sentiment, implying that the horse was too big and clumsy, was very general at first among the owners of mares around Woodstock, Milford Center, and contiguous territory.

Taken to Illinois.-A. P. Cushman of DeWitt Co., Ill., a trader widely known in his day, while visiting in central Ohio that fall saw for the first time "The French Horse,"' as Louis Napoleon was then generally known. At a glance his practiced eye grasped the potentialities inherent in the big dark-gray stallion, then turning six years of age. To him it seemed merely a matter of sufficient size in the mares, and Tazewell, DeVitt, Logan, and other Illinois counties had many big ones sired by Oakler's English Cart Hor'se Samson and his sons. So for $\$ 1,500 \mathrm{Mr}$. Cushman acquired "The French Horse," and "roaded" him to his new home in the Prairie State.

Acquired by the Dillons.-Louis Napoleon made the season of 1855 at Waynesville, and within the next three rears various undirided interests in him were traded and sold until finally in the fall of $185^{\circ}$ Ellis Dillon acquir d a one-fourth interest in addition to the half already owned by Isaial and Leri Dillon, thus giving them a controlling interest. The Dillons, afterwards to acquire such prominence in the trade, were at that time residents of Tazewell county, and to their home Louis Napoleon was moved 
and there he made the regular season of 1859. His success was not great that spring and on July 4 he was sent to the farm of Eli Hodgson in Grand Ridge township, La Salle county, to stand during the fall. These details are offered to show how lacking the horse was at first in popularity. His colts from the Samson mares had not yet begun to show their worth. Purchase of the odd one-fourth interest in the horse had been precipitated by the declaration by Cushman that he would move him to Kentucky in search of fields more easy of conquest. During the fall season of 1859 Louis Napoleon covered but seven mares, five of them the property of $\mathrm{Mr}$. Hodgson.

Early in the spring of 1860 the fast-whitening stallion was returned to the Dillon headquarters, and as his foals developed his business in the stud increased. By mid-summer the demand for his services had become pressing and great secrecy was maintained regarding the date at which he was to be moved again to the Hodgson farm in La Salle. Young Martin Horlgson-still a prosperous breeder, and for many years a member of the firm of Prichard \& Hodgson, now dissolved-rode the white horse home in the dead hour of the night following the celebration of the national holiday. But so keen had been the scouting that when the journey was ended at a little before dawn, it is related that no less than forty-two mares were tied to the fences surrounding the Hodgson homestead awaiting their chance to be bred or booked. He had served but seven the season before. It is at this point, therefore, that we un- 


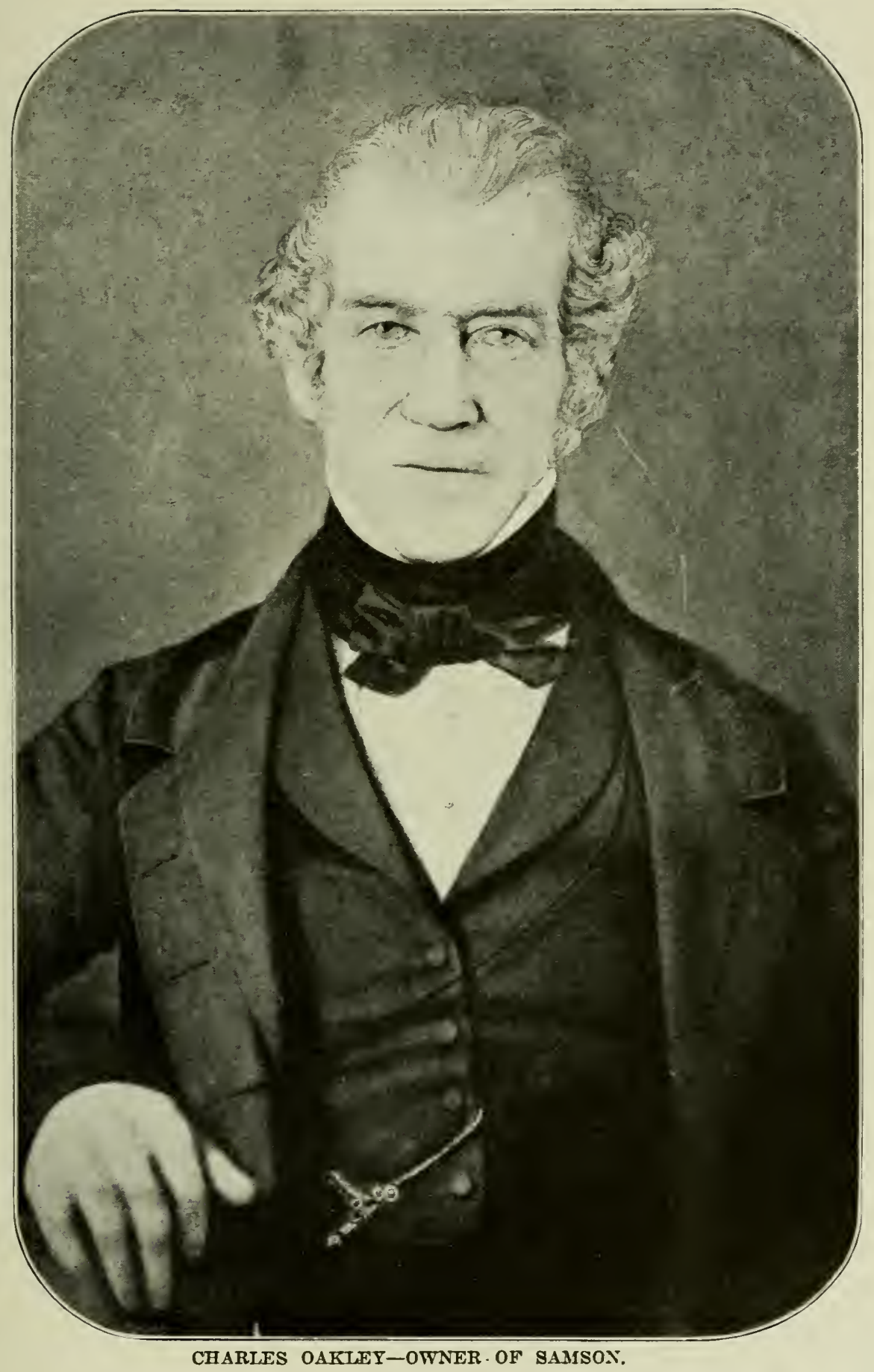



cover the real foundation of the popularity of the French horse of heavy draft in the western states. Louis Napoleon made several spring seasons in Tazewell county and fall seasons at the Hodgson farm in La Salle. In $186 \pm$ he was moved by the Dillons to Normal, in McLean county, where some two years later he became so badly infected that the operation of penotomy was resorted to in the hope of partially preserving his utility in the stud. After this, it is related, he sired three foals, dying in 1871 on the farm of B. Caldwell in Woodford county to whom the Dillons had presented him. First and last, it is believed, Louis Napoleon begot some 400 foals, not one of which was out of a purebred mare. Only the merest traces of his blood are discovered among our registered stock, a few recorded ria the topcross route descending from him. His number in the Percheron Stud Book is 281.

There is no question whatever that to the excellence of his colts and fillies from mares of Samson (English) blood was due the high degree of popularity which Lomis Napoleon achieved in Illinois. He did far better with them than with any others. Practically all of his male progeny were maintained entire, quite a few of them selling for $\$ 800, \$ 1,000$, and even longer prices. He bred fairly true to his own color, and in the hands of so shrewd a federation as the Dillons no stone was left unturned to keep him in the limelight. Displays of his grade colts were for years features of the Illinois State and other fairs. It is doubtful if there is another region 
in the whole United States in which we could have met mares of better weight or conformation. Many of these weighed 1,400 pounds, some as much as 1,500, and a few even up to 1,600 pounds-big, roomy, shapely, solid matrons, admirably fitted to mate with a stallion of Louis Napoleon's size, build, and type.

Various alleged portraits of this famous horse have in the past enjoyed a meretricious vogue, but all doubt as to his appearance at maturity is now definitely removed by the illustration herewith presented, prepared from an enlargement of a small daguerreotype taken in 1852 when the horse was four years old and dapple-gray in color. In height at full maturity he stood between 15.3 and 16 hands, and his greatest weight was 1,630 pounds.

Maryland Importation of 1853.-In Volume I of the Percheron Stud Book of America Col. Charles Carroll, Baltimore, Md., is credited with having imported the stallion Chartres 88 , but no statement is made as to color or date of birth. In that volume, too, J. Howard McHenry, Pikesville, Md., is named as the importer of two mares-Lily 572 and Snowdrop 607-gray and white in order written, but without certainty as to age. To Snowdrop the production of two purebred colts is assigned, both being. stallions and both by Duke of Normandy 172-the Gray Billy imported in the ship Sciamne along with Pleasant Valley Bill. Nothing further of the history of these importations of 1853 has been reached. Both of the mares died at a comparatively early age, the two stallions by Duke of Normandy 172 out 
of Snowdrop being the only progeny alleged to have descended from them. Nothing more is related of the stallion Chartres and as the compiler of the stud book working indefatigably forty years ago was unable to unearth other data, no more space need be occupied in their behalf. The bare facts, however, are interesting as showing that the home-raised stock of purebreds was slowly being augmented and as tending to fix definitely the identity of Duke of Normandy 172 and Gray Billy. Of the Maryland importations of 1853 it may then be fairly said that they left no sign so far as has been discovered up to this late day.

Rollin Imported in 1856.-By the spring of 1856 the few colts left by Louis Napoleon in Ohio had begun to display their merit and Erastus Martin, who had originally purchased the gray stallion near Ronen, in company with John Gordon, also of Woodstock, O., conceived the idea that a bay French horse would take well where the lighter color had failed of popularity. Accordingly an order for a bay stallion was dispatched by some of the stock buyers searching for Merino sheep in France and in due course of time the dapple-bay stallion Rollin 418 landed at Woodstock. Great preparations had been made for his reception on the Gordon farm, a new stable having been built during the summer for his occupancy. This shows that a hearty welcome awaited the newcomer and high hopes were entertained that he would prove a mighty success. Mr. Gordon had been associated in the last Ohio ownership of 
Louis Napoleon, when sooth to say the big gray horse had come to be looked upon more or less as "trading stock," which is well proved by the terms of the long-time deal on which he was acquired by a professional trader in an era when good horses were easily cashed. Sentiment had begun to veer, however, in favor of the imported horse.

Rollin was somewhat larger than Louis Napoleon, very thick at both ends and in the middle, not at all high-headed or stylish, but short-legged and drafty, and an impressive sire, a peculiar rotundity of barrel persisting in his get and descendants for generations, as well as a tendency to the production of red-roans. H. Dorr Martin, a banker of Woodstock, O., and son of the late Erastus Martin, says of Rollin:

"He left a lot of good colts. I remember some of them-mostly bays and browns, good blocky fellows. When the rebellion broke out we had some of his stock and they sold like hot cakes. They had good action for such large horses."

Despite his increased popularity, however, Rollin was not destined to remain long in the Darby Plains country. Inter-ownership trouble of some sort forced his sale and in 1859 the big bay horse left the new barn that had been built for him on a journey west to Onarga, Ill., L. Russ, later of the firm of Russ, McCourtey \& Slattery of that point, having purchased him at a price recalled by Mr. Martin as $\$ 3,000$. Rollin stood in Onarga and nearby towns for several seasons, doing a fine business, and in 1865 was bought by Jas. L. Owen, Mokena, Ill., as 


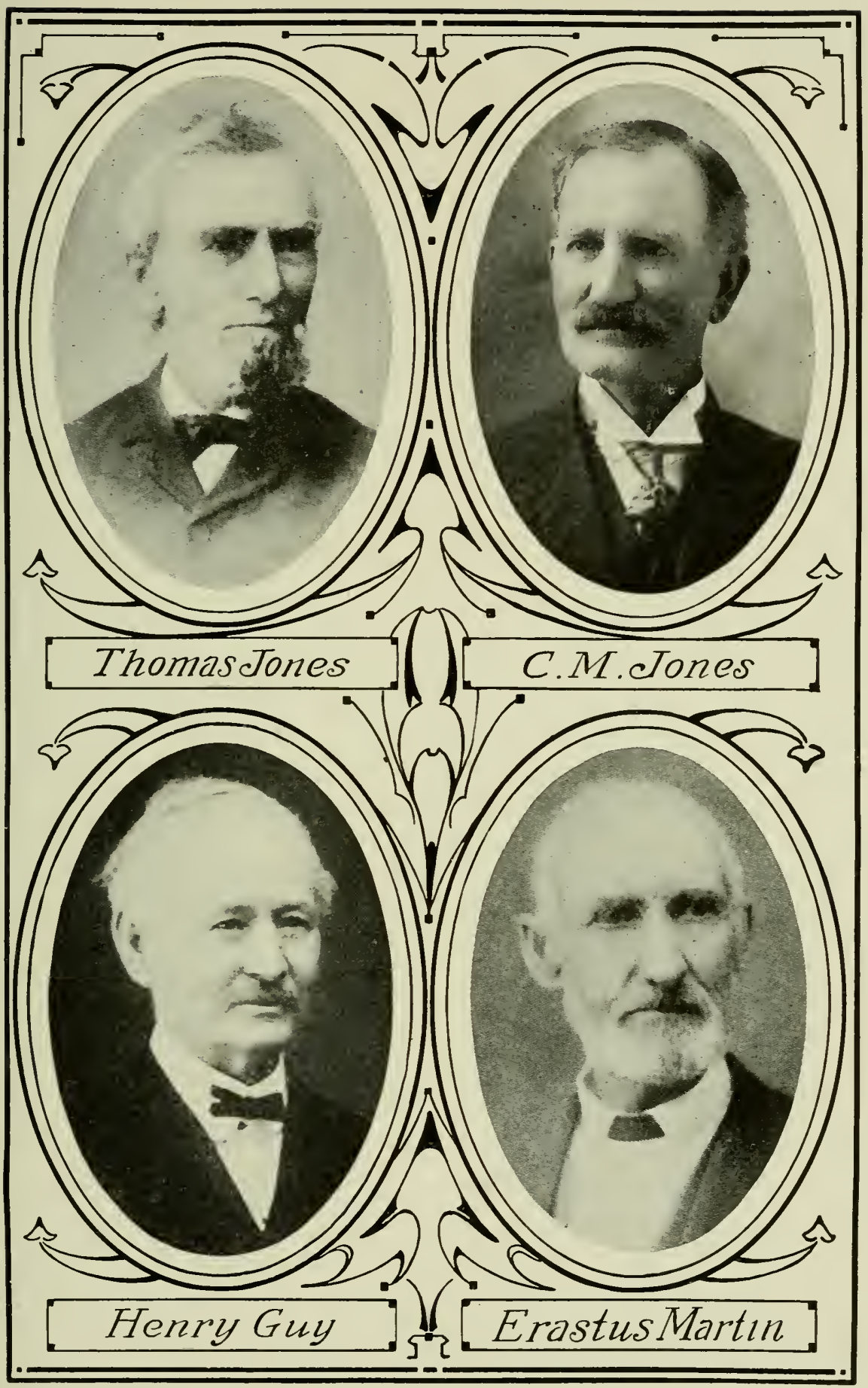



whose property he died six years later. He was the second imported stallion in Illinois and quite a number of mares by Louis Napoleon were sent from Tazewell, McLean and La Salle counties to be bred to him. His get included few grays, bays and browns persisting strongly except when the red-roan cropped out, so that his descendants could not be readily followed, except by records privately kept, among the native stock of the region where he stood for service. It is certain, though, that Rollin was a successful sire and did much to improve the farm horses of northern Illinois.

Darby Plains Importation of 1857.-Along in the later ' 50 's Ohio stockmen were very active in the effort to improve their sheep and cattle and in 1857 the Darby Plains Importing Co., the membership of which included stockmen in Union, Madison and Champaign counties, dispatched representatives to Europe. In this delegation were Henry Guy, Mechanicsburg, and Charles Fullington, Milford Center. After they had acquired cattle and other stock in Britain they crossed the channel to France in quest of Merino sheep and horses. Journeying together to Rouen Mr. Fullington left Mr. Guy and continued further afield after sheep.

Mr. Guy relates personally that having taken up a coign of vantage in front of an inn in Rouen he sat for days watching the horses as they were driven to town from the surrounding country. Finally he saw a four-horse outfit, the leaders of which just filled his eye. After much haggling he succeeded in 
buying these at $\$ 500$ for the pair. The wheelers Mr. Guy describes as having weighed probably a ton apiece and entirely too big for his purpose. They were held at $\$ 500$ each, or just twice as much as the smaller leaders. All were gray, but the pairs were of quite distinct types. A few days later a third stallion was bought, and also the mare Doll 540 , the first ever brought directly from France west of the Alleghanies. One of the pair of leaders died on the ocean, the survivor being the famous Baker Horse 21. His shipmate was Nonesuch 346, otherwise and in his day better known as Old Bob. This was probably the last importation ever made on a sailing ship and a terribly rough voyage was encountered. Though badly battered the two stallions and the mare after a time reached the Darby Plains alive and each won way to high renown. Doll went through many hands and proved prolific.

Put up at auction by the importers, the unnamed gray leader bought right out of the harness in the streets of Rouen was purchased by Dr. Baker, from whom he took his name, for lack of a better, and from that year (1857) he passed through many ownerships but always did well. The Baker Horse was not a big one by any means, weighing about 1,500 pounds. He was of the diligence type and a remarkably fertile and impressive sire. In 1864 he was purchased by Abram Curl of Woodstock, O., and he stood there until 1867. Of the Baker Horse H. Dorr Martin writes:

"He was a finely shaped horse and left some of 


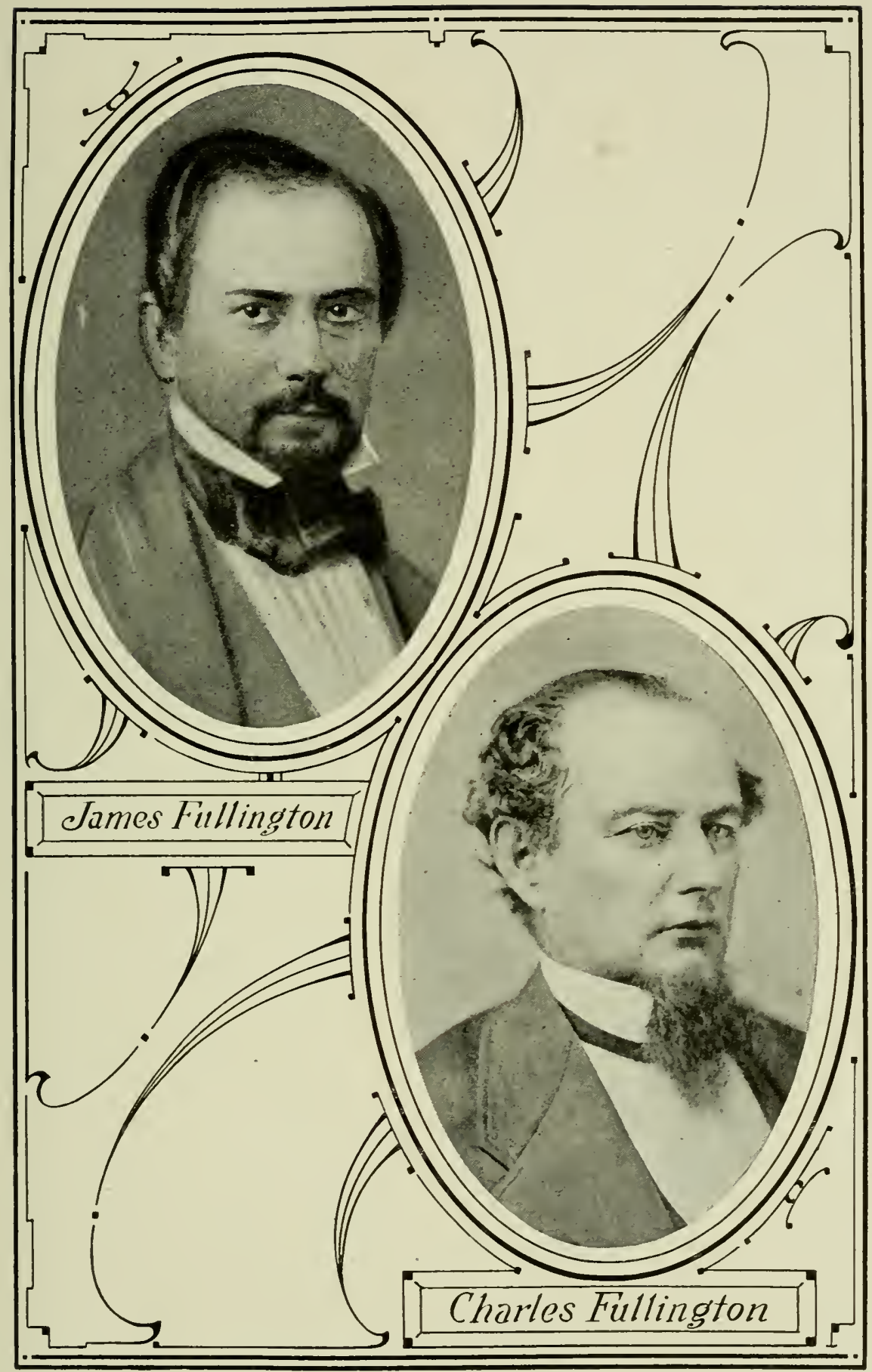



the best draft colts of any of the early importations. They were very tough and lived to a good old age. Mr. Curl had a team of horses by the Baker Horse which I remember very well that lived to be about 25 years of age and worked every. day. I personally owned a mare of this stock that raised me thirteen colts straight. Some of them sold as high as $\$ 300$ and $\$ 500$ apiece."

To Nonesuch 346, or Old Bob, is due the original popularity of the French horse in Delaware Co., O., a county that has since that time been a leader in Ohio draft horse production. At the sale held by the Darby Plains Importing Co., in 1857, "Bob" was bought by Peter Bland, Milford Center, one of the staunchest supporters of the type from the earliest days, and by him was resold to Lewis Lee of Delaware, at which place the stallion stood until the year before his death in 1875. Old Bob was about the same size and type as the Baker Horse and during his sojourn in Delaware had all he could do in the stud. Assuredly he made plain the path trodden by the breed in later times.

Doll 540 was the largest of the three animals imported by the Darby Plains Co. in 1857. She stood 16.3 hands at the shoulder and weighed upwards of 1,700 pounds, being of a larger, more rangy type than the two stallions that accompanied her across the ocean. She was possessed of the characteristic "Frenchy" or "creasy" rump, then a marked feature of the horses being brought over from France. She was rather short and droopy in her quarters, had heavy bone with some feather and in color was 
gray. In the spring of 1866 Charles Fullington, who by that time had acquired her, sent her to the Thomas Jones farm at Pleasant Valley to be bred to Old Bill. Prior to that year she had produced four foals by the Baker Horse 21, those of 1858 and 1859 dying young and those of 1860 and 1862 surviving and being named respectively Doll 541 and White Rose 613. In 1866 the late Thomas Jones bought old Doll 540 and the filly at her side by the Baker Horse 21, later named Rose 604. The price for the pair was $\$ 400$. In 1867 she foaled the filly Eugenia 13000 by Pleasant Valley Bill and during that summer she and the foal were sold to A. Gill and K. L. Wood for $\$ 1,000$. In 1869 old Doll produced the filly Josephine 1502 by the big horse Conqueror 109, a five-year-old gray of great scale imported in 1867 by Wallace, Watkins \& Co., Marion, O.

Shortly after this Gill \& Wood dissolved their partnership, Gill retaining the old mare and Wood the filly Eugenia, which afterwards produced several foals for him. In 1870, again to the cover of Conqueror, old Doll produced the stallion Thompson 461, probably the heaviest French colt bred in the United States up to that date, but phenomenally crooked in his hind legs. Despite that fact he is said to have proved a fairly successful sire. He and Josephine, both by Conqueror 109, were considerably larger than the others of old Doll's progeny, both exceeding a ton in weight. Poor old Doll did much for her various owners and for the breed at large, but Gill, who was a dour and crabbed citizen 


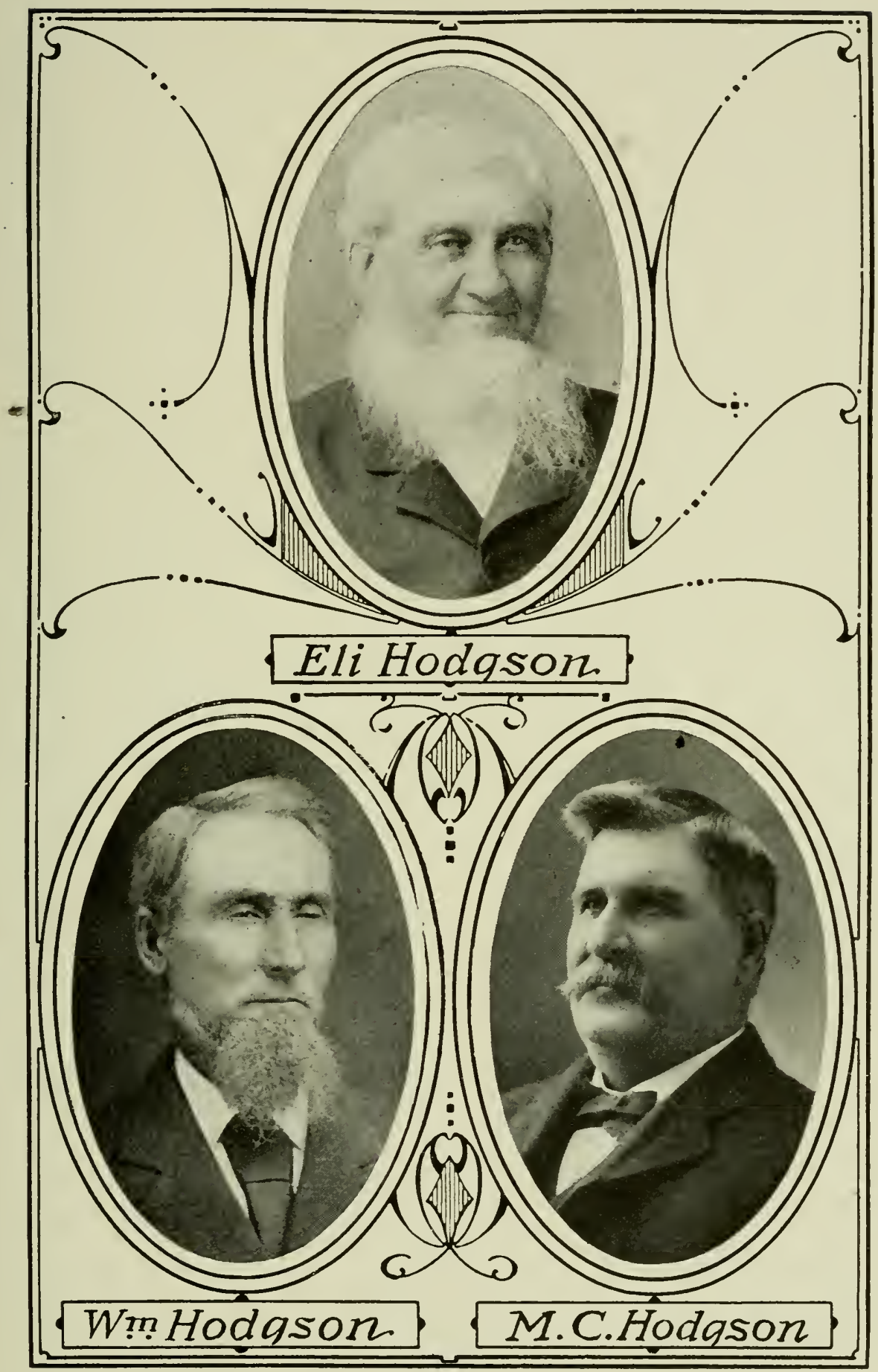



with peculiar notions as to horse improvement, when she became his exclusive property bred her to a Belgian horse, after which her usefulness came to an end. The filly Rose 604 by the Baker Horse 21 was bred as a two-year-old to Pleasant Valley Bill and produced three fillies in successive years to his cover. All of these were prolific, so that the descendants of old Doll 540 are very numerous.

Kentucky Importation of 1859.-Following the Darby Plains Importing Company's venture of 1857, the Kentucky importation of 1859 takes chronological precedence. This consisted of a stallion named Napoleon 4th 1723 and a mare named Marie Antoinette. This importation was made by Dr. Nove, or Nave, for the Jessamine Importing Co., Nicholasville, $\mathrm{Ky}$., and the horse was later transferred to Gen. W. C. Preston, Lexington, as whose property he died in 1878. The mare died in 1863 and here once more we find no lasting impression left upon the native equine stock.

Massachusetts Importation of 1864.-About the end of the sixth and opening of the seventh decades of the nineteenth century prospects in agricultural America were not such as to encourage private investment of large sums in any kind of live stock; indeed it was not until 1864 that further importations were attempted. In that year the Massachusetts Agricultural Society imported the stallions Conqueror 108 and Orleans 255 and the mares Empress 542, Lyons 574, and Normandy 587. Here again we run up against the dead wall of oblivion, 
the sole progeny eredited to this band of five being a roan filly dropped in 1866 by Lyons to the cover of Orleans. And there their history stops.

Gray Duke.-The horsemen of Ohio began anew in 1865. The shipment of that year consisted of but a single stallion-Gray Duke 1724, a gray foaled in 1863-and was made by the Galion Importing Co., of which J. M. White, Cardington, O., was the leading spirit. Mr. White was a passenger conductor on one of the early western railways and an enthusiastic horseman during his entire career. To his enterprise may be credited the first importation of French blood into the Galion district and the resumption of the business after the close of the war. He personally sent money to France for the purchase of a gray colt and then sold one-third interest in the youngster to two of his friends, the three forming the nucleus of the later prosperous Galion Importing Co.

Eastern Imports of 1866.-Three stallions and the same number of mares were brought across the ocean in 1866, S. W. Ficklin, Charlottesville, Va., importing the stallions Bienvenu 37 and The Colonel 459 and the mares Constance 530 and Eugenia 802. Both of these mares proved prolific and left recorded progeny behind them.

In the same year Dr. J. Pembroke Thom, Baltimore, Md., imported the mare Charlotte Corday 529, but later sold her to J. W. Hunt, Reynolds, Ky., where all trace of her is lost. In 1870 and 1871 she produced gray fillies to Little Corporal 274, a home- 
bred horse got by Duke of Normandy 172 (Gray Billy), imported in 1851 with Pleasant Valley Bill, out of Snowdrop 607, imported into Maryland in 1853.

First Direct Importation into Illinois.-It has been popularly supposed that it was not until 1868 that horses were imported direct from France into Illinois, but the records show that in this year of 1866 Dr. A. G. Van Hoorebeke brought the black stallion Lucifer 285 to Monmouth, which advances the date of direct importation into the great Prairie commonwealth some two years. Indeed Dr. Van Hoorebeke is to be credited with being the pioneer importer of Illinois as he brought over Lucifer 285 in 1866, the gray Leon 266 in 1868, the black Norma 348 in 1869, and the gray Laurent 709 in 1870. Unfortunately, Norma died the same year that he was imported.

Ohio Active in 1867.-Ohio importers had it all to themselves in 1867, Brown, Bigelow \& Co., of Columbus, and Wallace, Watkins \& Co., and Gilmore \& Houser, of Marion, being the only firms recorded as having engaged in the importing business that season. Brown, Bigelow \& Co. included in its membership Dr. Marcus Brown, of Circleville, importer of Pleasant Valley Bill in 1851, and the late T. C. Bigelow, in his time the leading team owner in the Ohio capital and one of the foremost horsemen of his time. It was surely the irony of fate that his death should have been caused by injuries sustained in an attack made upon him by one of the stallions 
he imported. It is to the courtesy of his son and successor, T. L. Bigelow, that this history is indebted for the portrait of Pleasant Valley Bill and for much authentic information gathered from his own personal recollections and the papers belonging to the old firm, dating back to 1851 and including the original documents in French relating to the purchase by Mr. Holman of Old Bill and Gray Billy at Rouen in 1851.

Brown, Bigelow \& Co. imported in that year Napoleon 325, Black Robert 54, and Duke of France 165. Wallace, Watkins \& Co. brought Conqueror 109, a big gray horse already referred to in connection with the history of old Doll 540, and Gilmore $\&$ Houser had Napoleon 2d 335, later sold to E. Dillon \& Co., Normal, Ill. The two Ohio firms last mentioned were later amalgamated into the Marion County Importing Co., which at one time was classed as handling better stallions on the average than any one in the business at the time. "Wat" Watkins was the brains of the coalition, but quit before the ball had been fairly set a-rolling. There is a story told of him in connection with the Illinois State Fair of 1872, which throws light on the state of live stock improvement in that era:

Decatur was the place of holding the Illinois show that season and substantially all the men interested in draft horses were on hand, the count showing a total of forty-two imported and grade animals on exhibition. These were all lined up in some sort of a parade and "Wat" Watkins happened to be stand- 
ing next W. E. Prichard, now, as then, a resident of Ottawa, Ill.

"Prichard," quoth Watkins, "look at that, fortytwo head, count 'em. Tell you what; this business is going to be overdone and I'm going to stand from under before the bottom drops out of it." And stand from under he did, getting out of the business shortly afterwards, and though the family was right at the top of the ladder at the time, the name of Watkins is hardly remembered now in its old home location in connection with any such important position.

Regarding the three stallions imported by the Columbus firm in 1867 T. L. Bigelow gives the following descriptions:

"Black Robert 54, black, weight about 1,500 pounds, of pure Norman blood, wonderful action and endurance.

"Duke of France 165, bay, weight 1,750 pounds, fair success in stud at fee of $\$ 20$. Sold to go to Galena, Delaware Co., O. Bay Duke (as we called him) was a beautiful Norman-French horse, fine style but not possessing the action of the pure Norman or diligence breed of horses.

"Napoleon 325, dapple-gray, weight 1,650 pounds, fair success in stud only. Stood mostly at Chillicothe and in Ross Co., O. This stallion was awarded first premium at the World's Fair held at Rouen, France, 1866 , in competition with some 500 stallions. As was the custom, the owner considered him sold to the Imperial Stud and would not put a price on him on that account for export. Messrs. Brown \& Bigelow, however, through the influence of a member of the court, secured a personal audience with the Emperor, 
Napoleon III, obtaining from him an order for the horse, later paying an enormous price."

These details supplied by Mr. Bigelow in connection with the stallions included in this and other importations made by the firm are of great value as showing the weight of the stallions then obtainable in France and proving the existence of at least two well differentiated types at that day. The name "Norman" was apparently given to the diligence or quick-moving, smaller pattern of Pleasant Valley Bill, while the larger, slower, more drafty sort, to which Louis Napoleon had belonged seems to have been referred to merely as "French."

Up to the end of 1867 twenty stallions and eleven mares had been imported from France, practically all of them having been purchased at or near the town of Rouen. In so far as can be ascertained the diligence type was preferred and had done better with the eastern mares than the heavier horses imported.

- Louis Napoleon and Rollin, the first French stallions brought to Illinois, had the advantage of meeting larger mares than those arailable farther east, or indeed anywhere else. It is presumable that Duke of France, the stallion referred to by $\mathrm{Mr}$. Bigelow as of "Norman-French" blood, was one of the heaviest retained in Ohio up to that time and probably about the same size as Rollin. That both these horses were bay and hailed from the same locality suggests a racial connection between them. Their ruddy coats and superior scale would suggest also 


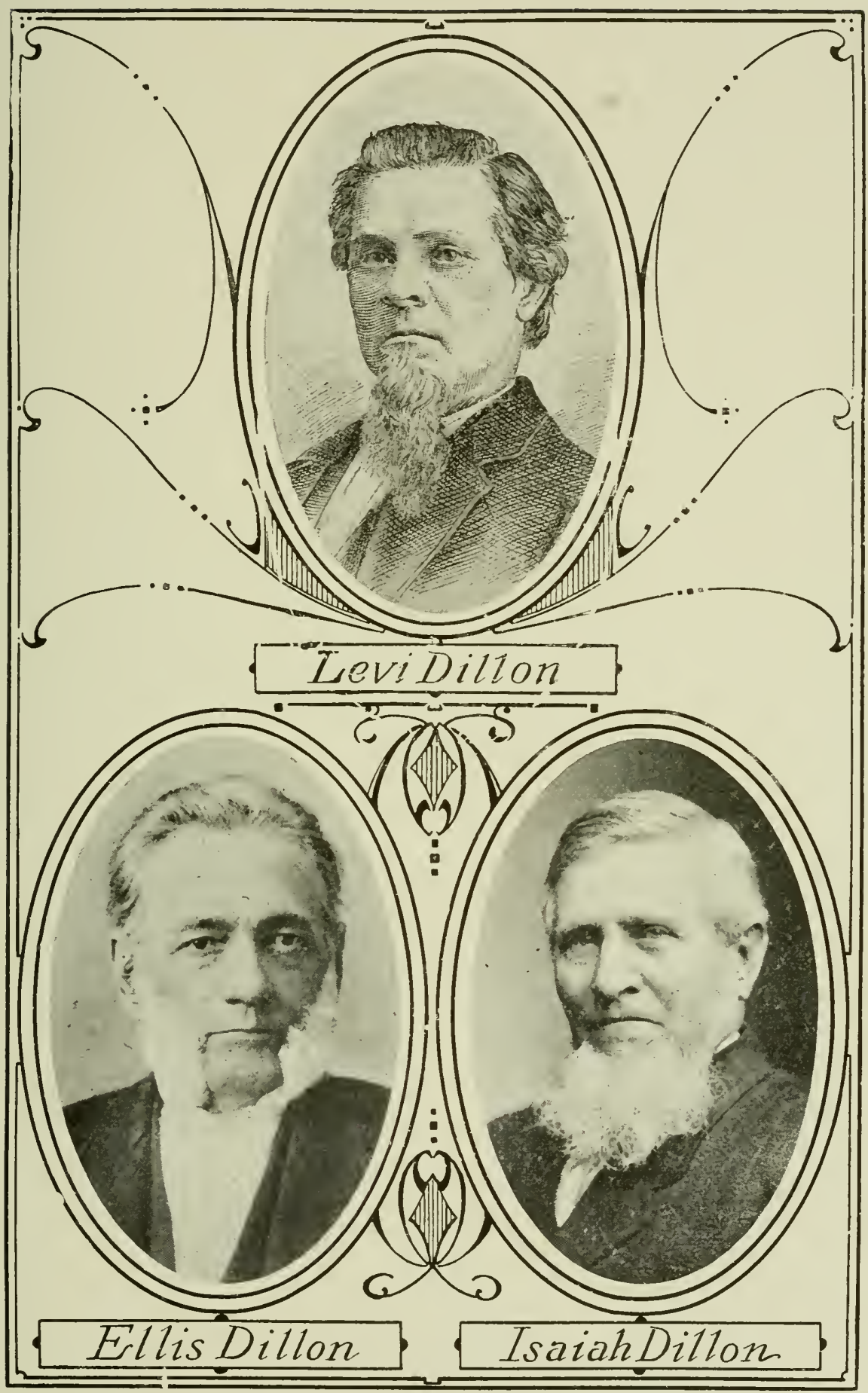



possession of some blood distinct from the diligence type. Up to the close of 1867 only three imported stallions had been brought into Illinois and none had been located in any other state west of Ohio. 


\section{GHAPTER VI.}

\section{THE IMPORTING RECORD TO 1870.}

More stallions and mares were imported into the United States from France in 1868 than during all the previous seasons, the figures being 31 stallions and 8 mares. Seven of the mares were brought across the sea by the late Gen. W. T. Walters, Baltimore, Md., and the remaining one by Jeff C. Clark, Normandy, Mo.

Importers of stallions in 1868 included, besides the two already named, the Galion Importing Co., Galion, O.; Wallace, Watkins \& Co. and the Marion County Importing Co., Marion, O.; Brown, Bigelow \& Co., Columbus, O.; Dwight Gay, Columbus, O.; Fullington, Phellis \& Co., Irwin Station, O.; A. G. Van Hoorebeke, Monmouth, Ill., and TV. J. Edwards, Clifton, Ill. Territorial expansion was the order of the day and greater size seems to have been sought in France by most of the importers. Practically all the stallions were bought in the towns of Rouen, Amiens, Elboeuf, Boulogne, and Havre. The Paris dealers' stables were also resorted to. The exact origin of the imported horses of this period will never be known, and this statement will apply with equal truth to many a good horse brought to America from France in subsequent years. It is clear that those 
It 7 Maleers 
who brought out the earlier Ohio stallions were not men who had made any special study of the business. The Perche, as such, was to them more or less a terra incognita. They knew nothing of what had been going on in that district for fifty years preceding their visits. The buyers of Louis Napoleon and other horses were not even in quest of horses. There were no stud books. No pedigrees were obtained, and none of these early buyers appears to have made any effort to seek out the real fountain head of the type that was destined to play such an important part in the development of draft horse breeding in the United States. In good time, however, this was discovered and commonly recognized.

Of the Missouri importation, consisting of two stallions and one mare, no information can now be secured further than that conveyed by the records. In Illinois the case is far different, because on the importation of Success and French Emperor by W. J. Edwards was raised by the late Mark Wentworth Dunham the most magnificent success ever achieved by one man in the heary horse business.

A Profitable Business.-By this time the importation and sale of imported stallions had settled down to the level and dignity of an established trade and prices ranged in this country between $\$ 2,000$ and $\$ 3,500$. In France prices remained on about their old scale. Among Dr. Marcus Brown's papers is a memorandum showing that the five stallions he bought in 1868 for Brown, Bigelow \& Co., cost laid down in Columbus, O., an average of $\$ 578.68$. One 
of the five was a Belgian which proved so utterly unreliable in the stud that he never succeeded in getting a mare with foal. In consequence he was never recorded. Another member of this importation, Black Leopard 50, had considerable Belgian blood in his veins; he was of medium stature and a fine mover. It was this horse that killed Mr. Bigelow. With the expansion of the business westward and the development of the fillies by earlier imported stallions, there arose an insistent demand in some quarters for more weight. Importers found it also to their advantage to be choice in the matter of individuality when making their selections abroad. Profits were very satisfactory. Sales were quite generally for cash and guarantees of reasonable sureness as foal-getters had not yet been exacted by purchasers. Service fees had reached a remunerative level and were going higher. In short the whole business had begun to take on that air of prosperity in which it was swathed a decade later.

Activity in Ohio.-In almost all of the importations of 1868 one or more stallions of outstanding merit were included. For instance, in the Galion company's lot of half-a-dozen, the largest importation brought over that year, no less than threeNapoleon 733, Puelo 752, and the oddly named Pluribustah 747-gained something more than local renown in the stud. While most of the imported stallions still ranged in weight between 1,600 and 1,700 pounds several imported that year were much heavier. 


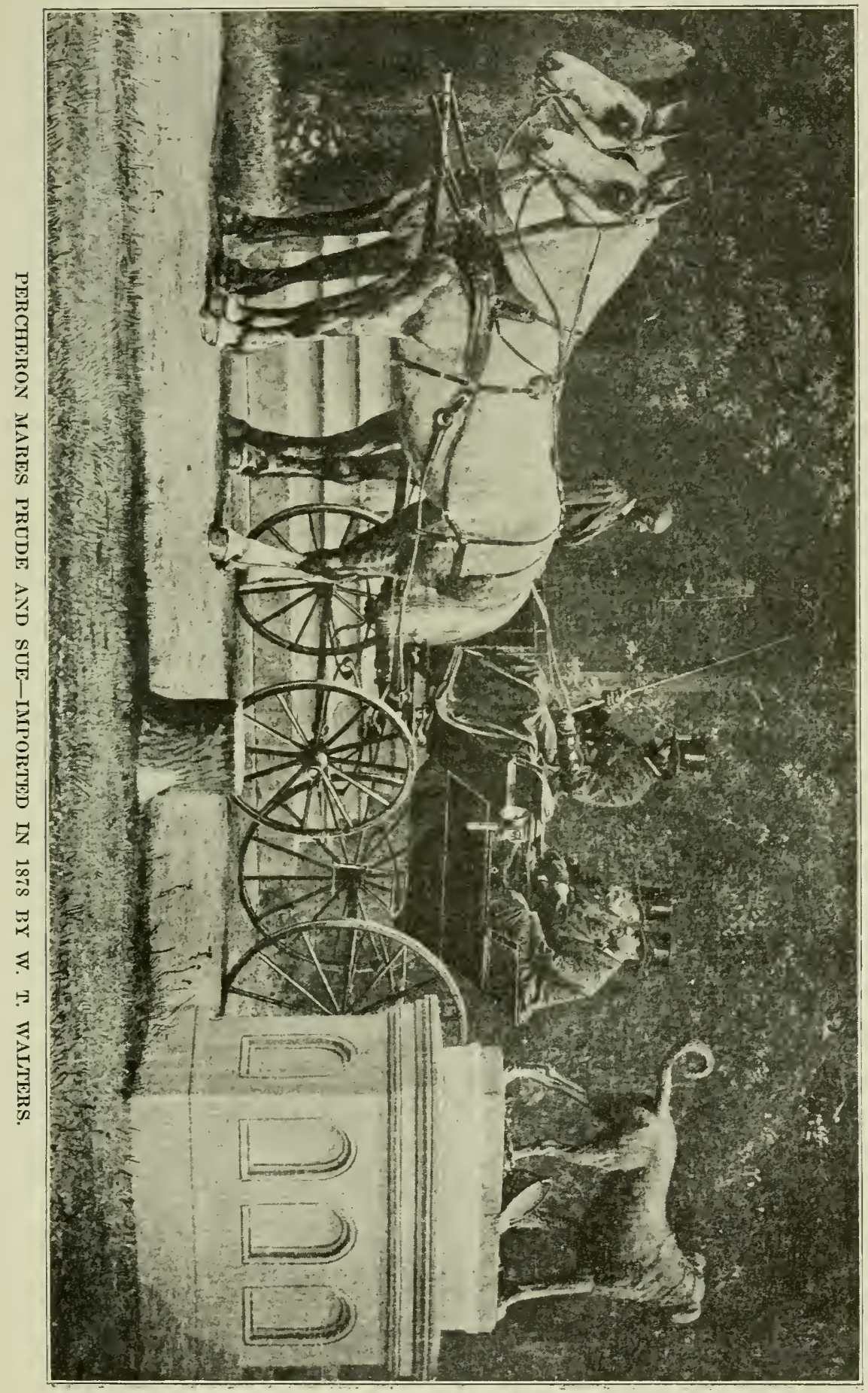


The transactions of Brown \& Bigelow that season will serve to illustrate the nature of the business as carried on in that distant day. Importers of the present time will be interested in the following particulars:

Black Leopard 50 was the dearest horse of the lot, costing 3,020 francs, or $\$ 604$, in France. He was considered by Mr. Bigelow the best horse he ever saw and after making many very profitable seasons at $\$ 20$ the mare he was sold at the age of sixteen for $\$ 1,000$. Diligence 137 cost $\$ 364$, was sold for $\$ 2,500$, and stood all his life at $\$ 20$. Coburg, the stallion that covered 100 mares and never got one of them with foal, cost \$264 in France and brought \$2,500. Twothirds of this price was on time and the notes were returned. Dictator 134 cost $\$ 620$. An offer of $\$ 3,000$ was refused for him. He made ten big seasons at $\$ 20$ a mare. Vigorous 486 was acquired for $\$ 204$ and found a buyer at $\$ 2,200$. There seems to have been no direct connection between size and price, as the two highest priced stallions in this lot, Dictator and Black Leopard, were in the order written the largest and the smallest in it. The average price paid for the five stallions abroad was $\$ 413$, but as gold was at a premium they actually cost the average previously named.

From all accounts the three lighter stallions in this lot, Black Leopard, Diligence and Vigorous, all weighing from 1,600 to 1,650 pounds, did quite as good business in the stud as the larger Dictator, which scaled 1,900 pounds. The heavier sorts were 
yet very much in the minority, the proportion of three light to one heavy in this importation probably holding good for all the others. The figures for the Brown \& Bigelow lot tell the story of the business at that time.

In the importation brought over by the Watkins federation of Marion, O., was the never-to-be-forgotten Napoleon 2d 337, purchased that fall shortly after landing by the firm of Llewellyn \& Prichard, Ottawa, Ill., which consisted of W. E. Prichard, still of that place, and his brother-in-law. Napoleon 2d was a very shapely gray horse of superb quality. He sprang into instant popularity when brought to Illinois. He was later commonly known as "Old Poley", and that sobriquet soon became familiar throughout La Salle and adjoining counties. Mares were brought, so great was his renown, over 40 miles to his court. Later his fame extended all over the state and his sudden death in 1877 deprived the budding heavy horse industry of the Prairie commonwealth of its best foal-getter. He cost $\$ 3,300$.

Of the Fullington-Phellis lot no less than three distinguished themselves more or less as sires in central Ohio. These were Duke of Normandy 168, Prince Albert 385, otherwise known as "Jim," and Prince Imperial 388, better remembered locally as "Old Charley." This firm was composed of Charles Fullington, back in 1851 part owner of Louis Napoleon, and Charles Phellis, one of the best known stockmen and one of the most advanced of Ohio agriculturists of his day. 


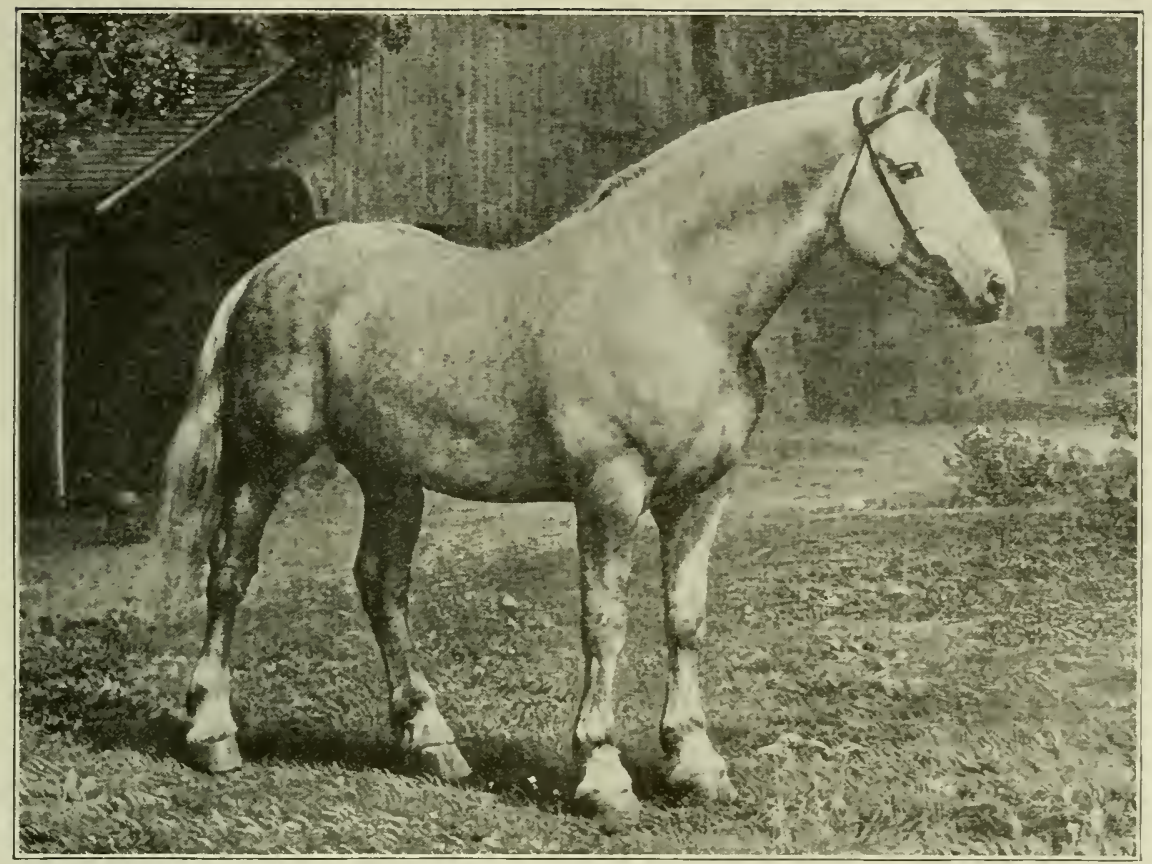

PERCHERON STALLION HERCULES-IMPORTED IN 1868 BY W, T, WALTERS.

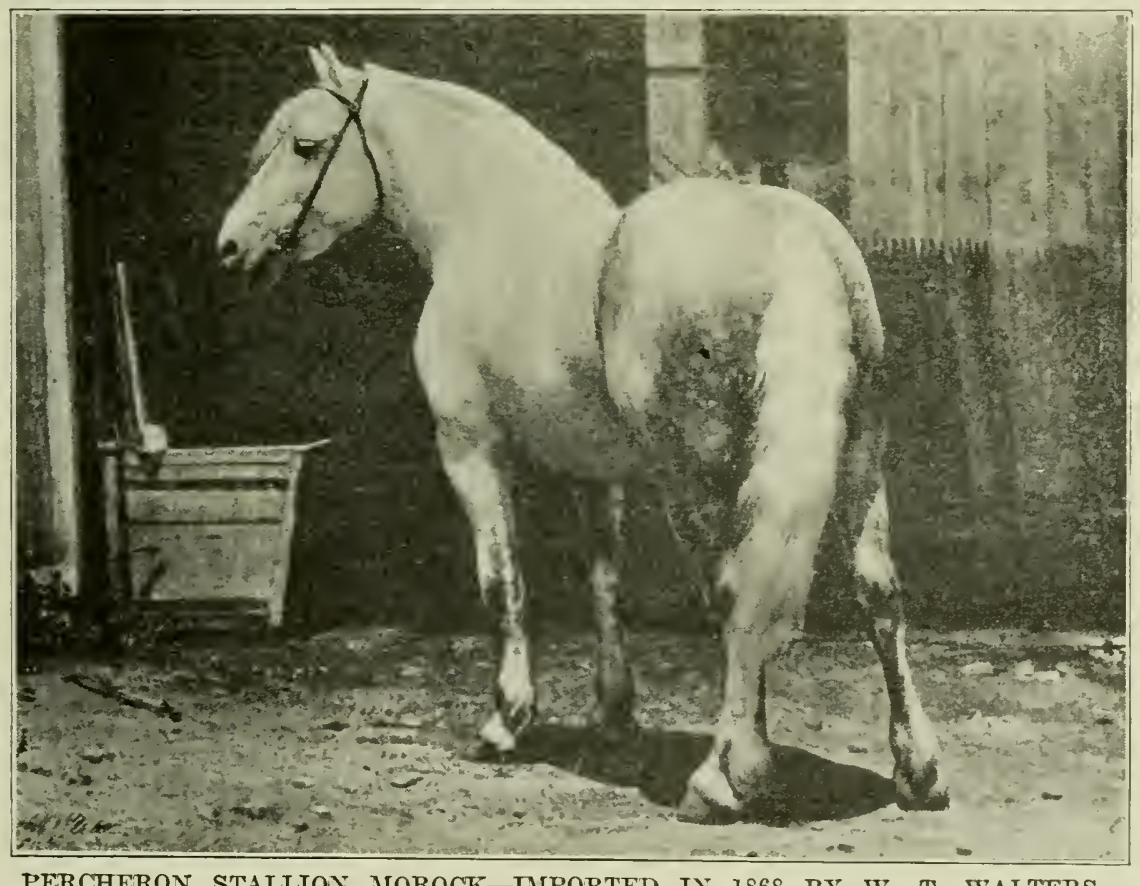

PERCHERON STALLION MOROCK-IMPORTED IN 1868 BY W. T. WALTERS. 

The Walters Percherons.-To Gen. W. T. Walters, Baltimore, Md., clearly belongs the credit of having been the leading importer and breeder of the Atlar. tic Coast country of the early day.

In 1868 he brought across the ocean four stallions and seven mares, establishing them on his estate just outside Baltimore. It may be said fairly that the gray diligence horse of France became an obsession with him. He was a man of wealth, position and large affairs. He resided in France for a considerable period and during his sojourn in that country became deeply impressed with the adaptability of the Percheron to American conditions. He formed a connection with one of the officials of the French government stud who assisted him in making his selections. He contended that the diligence type was suitable in every way for use before a gentleman's carriage. He sought generally the lighter weights, and seated in his platform spring wagon or double carriage drawn by a pair of what he always called Percheron mares, driven by a colored coachman, he was a familiar figure on the Baltimore drives.

Gen. Walters never overlooked an opportunity to promote public interest in his Percherons, and having ample means at his command he was in a position to go as far as he liked. He caused a translation of Du Haÿs' history of the Percheron horse to be made and published at his own personal expense. He distributed among his friends a splendid quarto volume profusely illustrated with plates of stallions and mares made from photographs by Schreiber of Phila- 
delphia, then and for long years afterwards the foremost live stock camera artist of America. The reproductions herewith of plates from Gen. Walters' privately circulated book disclose at a glance the type of horse he favored.

The late Dr. Ezra Stetson, Neponset, Ill., procured some of the Walters mares, and their descendants proved among the most useful horses of the early days of Percheron breeding in the middle west.

Old Success Imported.-W. J. Edwards, Clifton, Ill., was a patentee and manufacturer of improved road-construction machinery, a traveler, a gentleman, and the possessor of untiring energy. In 1868 he journeyed to Europe and when he returned to Clifton brought with him three imported stallions - a bay which was the largest of the trio, French Emperor 203, and the gray Success 452. Just where he acquired the bay and what became of that big horse diligent research has failed to reveal. These three stallions made seasons in Clifton in 1868, and that fall the two grays were purchased by the Fletcher Co., Wayne, Ill., which took its title from its first president, the late Mark Wentworth Fletcher, father of James Moore Fletcher, who some years later in connection with Oaklawn, and afterwards on his own account, became a leader in Percheron circles. Success attained great celebrity, as will be noted further on.

M. W. Dunham Enters the Business.-In this Fletcher company, as one of its members, was the late Mark W. Dunham, Wayne, Ill., one of the most 


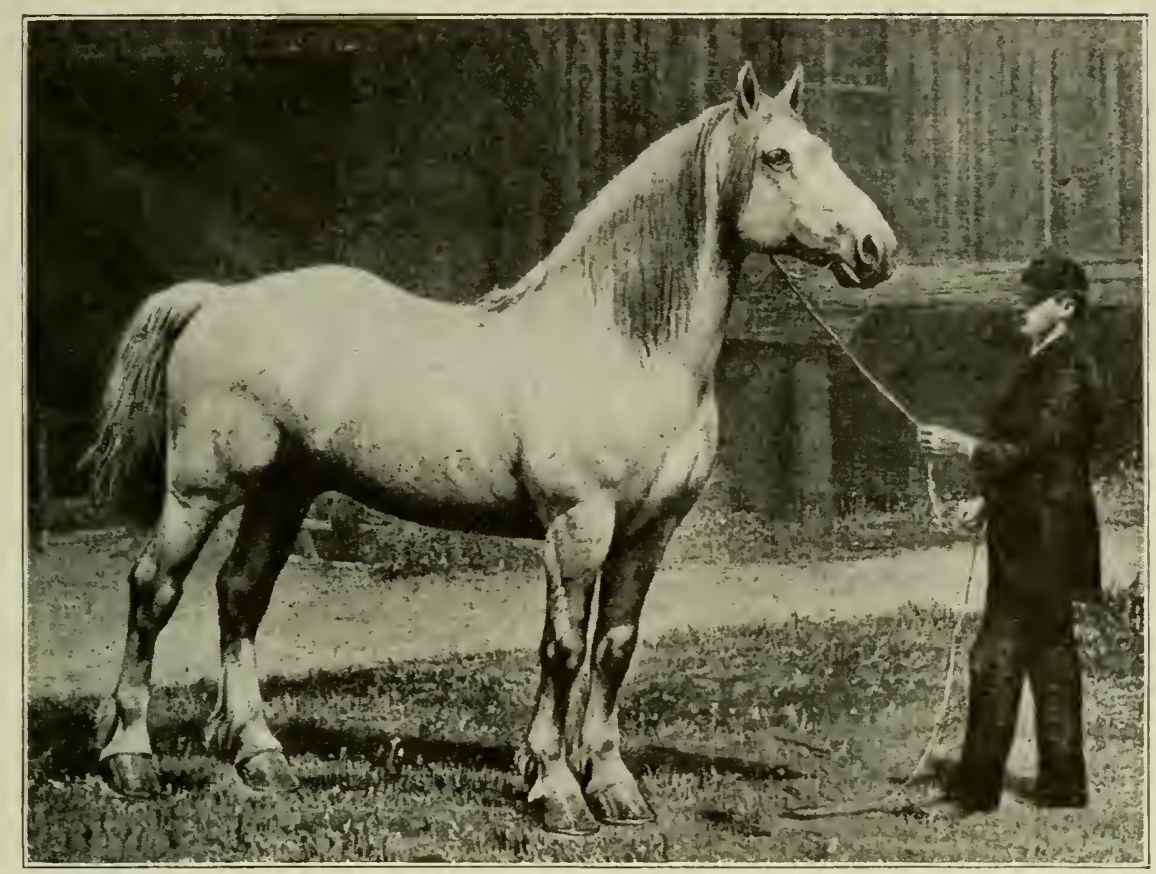

PERCHERON STALLION SULTAN-IMPORTED IN 1881 BY W. T. WALTERS.

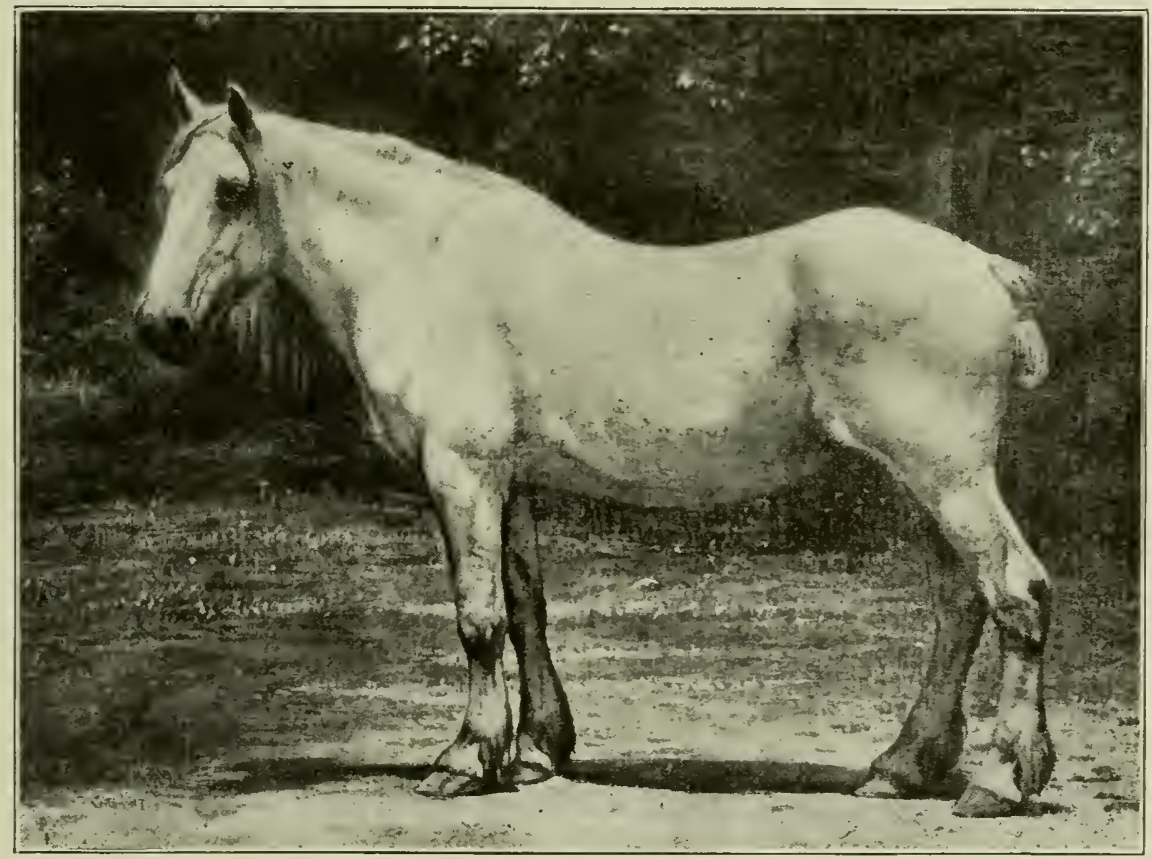

PERCHERON MARE ALENE-IMIPORTED IN 1866 BY W. T. WALTERS. 

resourceful and far-sighted men ever identified with animal breeding in North America. Firm in the conviction that a great future lay before the French horses in the United States, Mr. Dunham bought out his colleagues in this enterprise and there and then founded the great importing and breeding enterprise which has made the names of Dunham and Oaklawn household words among the draft horse breeders of two continents. His subsequent stupendous success will necessarily come in for frequent reference as our story progresses.

Napoleon Bonaparte.-While no very direct account can be given of the events which followed the introduction by Jeff C. Clark of French blood into Missouri, further than as contained in the records, the facts seem to be clear enough. Eugenia 802, the gray mare imported by $\mathrm{Mr}$. Clark that year as a four-year-old, proved prolific, though unreliable as to the color of her progeny. Mr. Clark seems to have held on to his imported horses for some seven years, when he disposed of Eugenia to Henry V. P. Block, Aberdeen, Mo., and the stallion Napoleon Bonaparte 334 to the Pike Co., Mo., Hor'se Association, Louisiana, Mo. Of this gray horse it is of record that while weighing close to 1,600 pounds he was possessed of coach horse conformation, style and beauty, quality and action. Moreover he was quite fast at the trot. There is a tradition, of sufficient moment at the time to induce the discriminating compiler to record it in Volume I of the Percheron Stud Book, that Napoleon Bonaparte 
trotted a mile over the old St. Louis fair grounds track in 3.42, pulling a four-wheeled coupe containing four men. Bismarck, the stable companion of this fast traveler, in 1874 became the property of Dr. Stetson of Neponset, Ill., but apparently he did not meet his views, as in the year following he passed to the same company that owned Napoleon Bonaparte.

This covers quite closely the main facts which transpired in 1868, the most memorable year since the inception of the importing business. Almost as many mares were imported as had thitherto crossed the ocean-8 as compared with 11 head-and the number of imported stallions had been increased 150 per cent, the figures from 1839 to 1867 inclusive being 20 as compared with 31 in 1868. Imported horses had penetrated as far west as Missouri and the second and third direct importations had been made into Illinois. By far the most important feature of the year was the entrance of Mark W. Dunham into the ranks following the banner of the French horse. Unpretentious and inauspicious though that beginning may have been it marked the opening of the era during which the breed was destined to assume the dominance of the American draft horse breeding industry, with M. W. Dunham as its leading exponent.

A Lull in 1869.--In the season following the boom of 1868 importations were greatly reduced, general commercial dullness and financial stringency being given as the causes. In 1869, too, we note the giving 


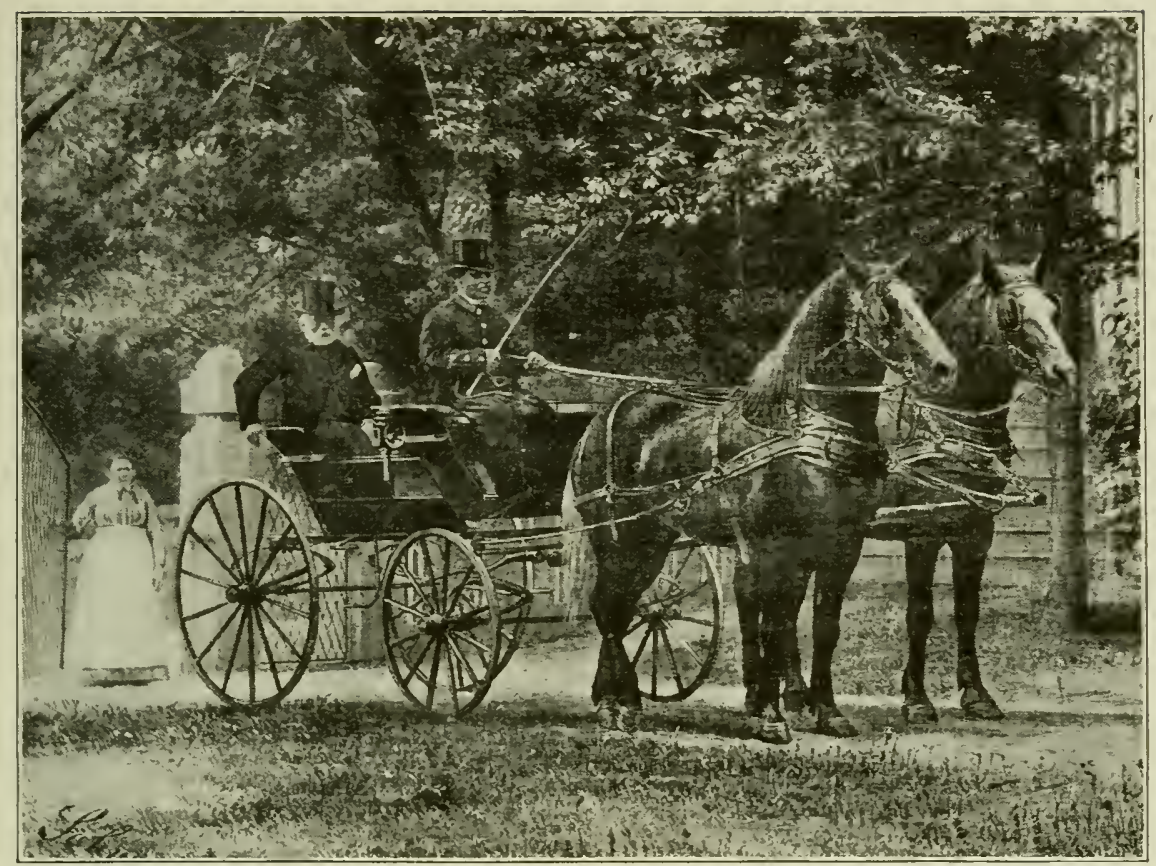

PERCHERON STALIIONS TRIBUNE AND SALYATOR-IMIPORTED BY $T$. T. IVALTERS,

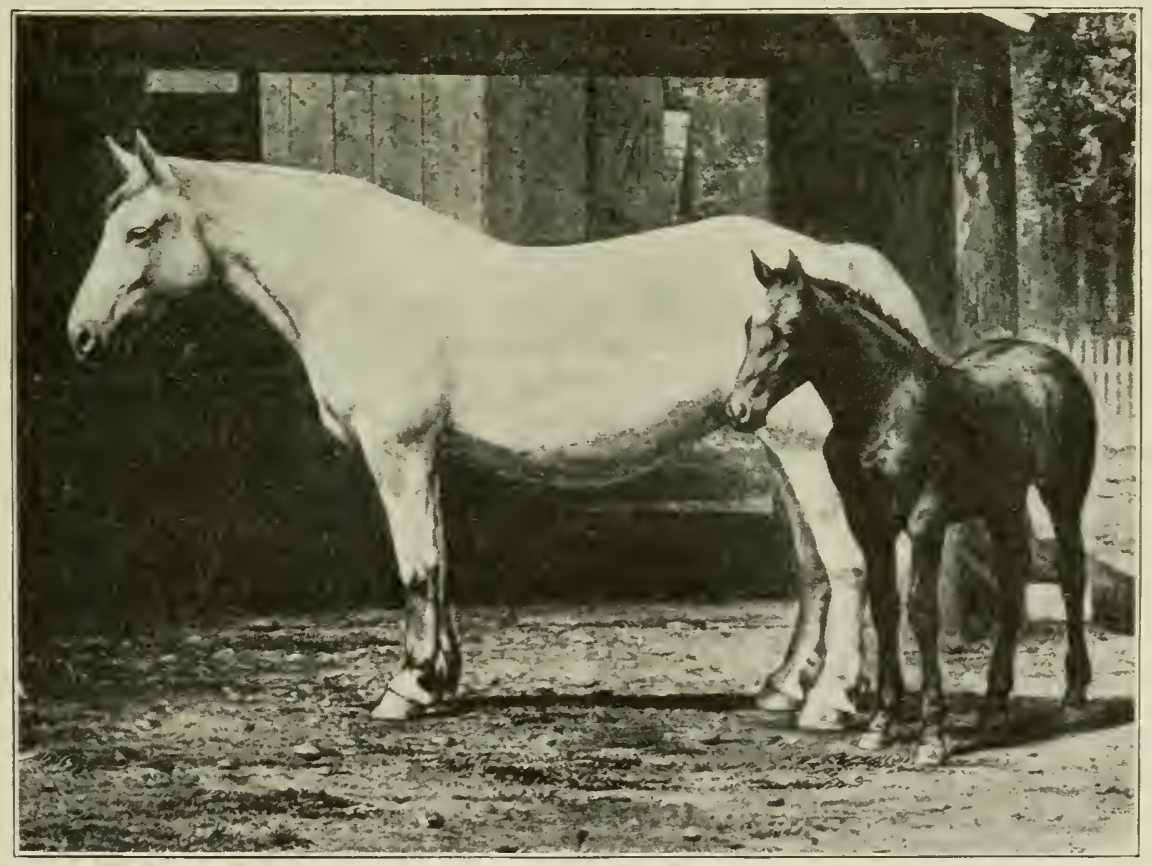

PERCHERON MARE KATE-IMIPORTED IN 1896 BY W. T. WALTERS. 

way of the Ohio contingent as the leader in the irnporting business, and the promise of the rise of Illinois to the proud position of prominence it was soon to assume and which it has held ever since.

Not one of the previously prominent Ohio firms is named as having brought horses across the ocean in 1869, the only importer of record in that state for that season being F. D. Dunham of Cincinnati, whose lot consisted of two stallions which do not seem to have made any impression on the equine affairs of the state. Hume \& Short of Brighton and A. G. Van Hoorebeke of Monmouth are the Illinois operators listed in the records. With three residents of Pennsylvania they comprise the roster of those actively engaged. The Pennsylvanians were E. W. Shippen, Meadville, who brought out three stallions, Edward Schreiber, Allentown, who brought five stallions and one mare, and John $\mathrm{S}$. Parker, West Chester, who brought two stallions. The total importations for the entire year amounted to fifteen stallions and one mare. No mark worthy of prominent mention seems to have been left by any of these animals. Only one foal is recorded as having been produced by the mare imported that season, Eugenia 803. It was a colt, color not given, sired by Prince Imperial 748 (imported the same year) and foaled in 1876.

It was in this year of 1869 that the state of Iowa received its first imported stallion. In the fall of 1868 Peter Bland, one of the earliest converts to the draft horse faith and a resident of the Darby Plains 
country of Ohio, bought from Fullington, Phellis $\&$ Co. the five-year-old gray Duke of Normandy 168, locally known as John Sheridan. One year later Mr. Bland sold this stallion, which was of the diligence type and weighed not more than 1,600 pounds at full maturity, to A. W. Cook, Charles City, Ia., who kept him until 1874 and then sold him to Jacob Erb \& Co. of Ames. Pride of Perche 382, imported by the Watkins federation of Ohio, reached the Iowa Agricultural College this same year. John Sheridan was not long destined for his work in Story county, his death following in August of the same season in which he was taken there.

Across the Continent.-The year 1870 saw the hub of the country's draft horse importing and breeding industry pass westward to Illinois, where it has ever since remained. Kansas received its first direct importation from France in the gray stallion Napoleon 736, imported by M. J. Parrott, Leavenworth, but fated not long to be retained in the Sunflower state. In 1872 Napoleon was sold to W. C. Meyer, the pioneer breeder of the Pacific slope, who in that year took his second lot over the Rocky Mountains. Mr. Meyer's first purchase, made in this year of 1870 , included the stallion White Prince 496, Doll 541 (by the Baker Horse 21 out of old Doll 540 , imported in 1857) and some grade mares with three crosses of imported blood in their veins. From these grade mares he was able in 1878 under the new top-cross rule to register the fillies Jane 812 and Josie 815, the former by Pride of Perche 380 and 


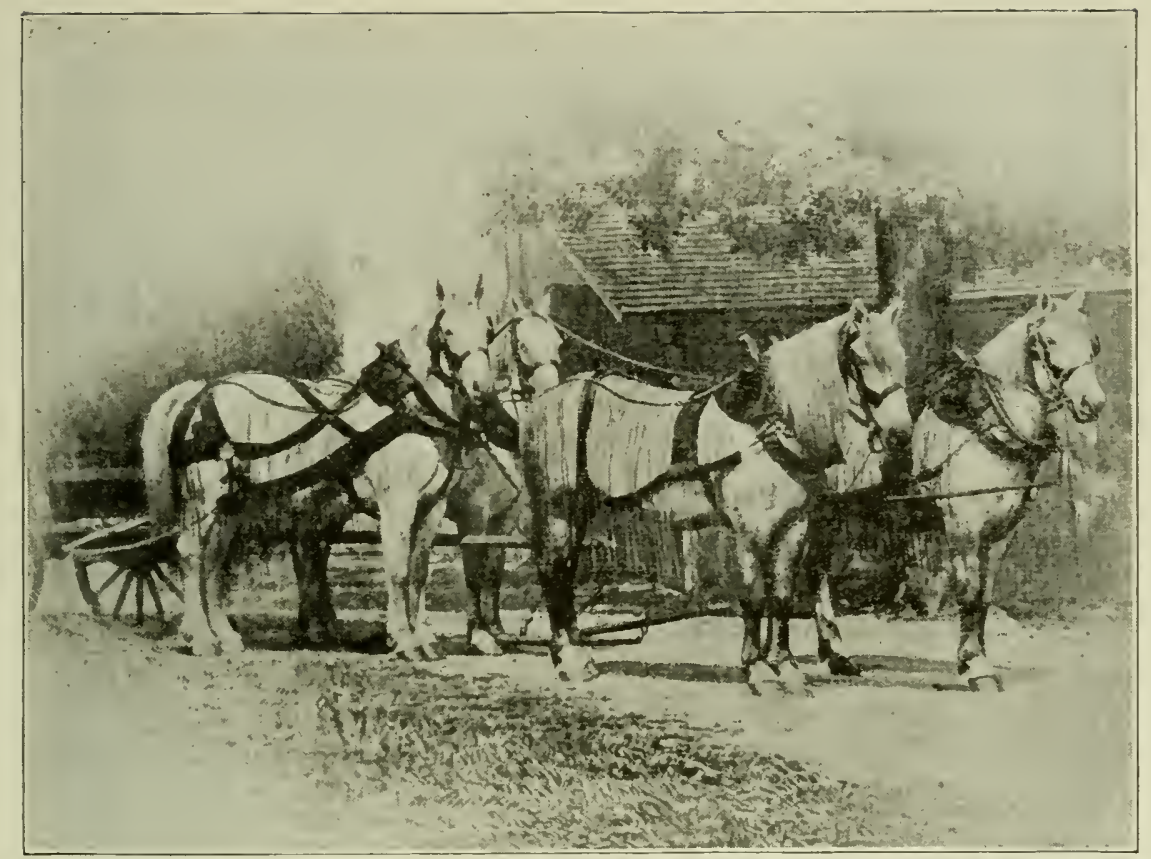

PERCHERON MLARES JAQUELINE, TOPSY, BELLE AND ALENE-IMIPORTED IN $186 S$ BY W. T. WALTERS.

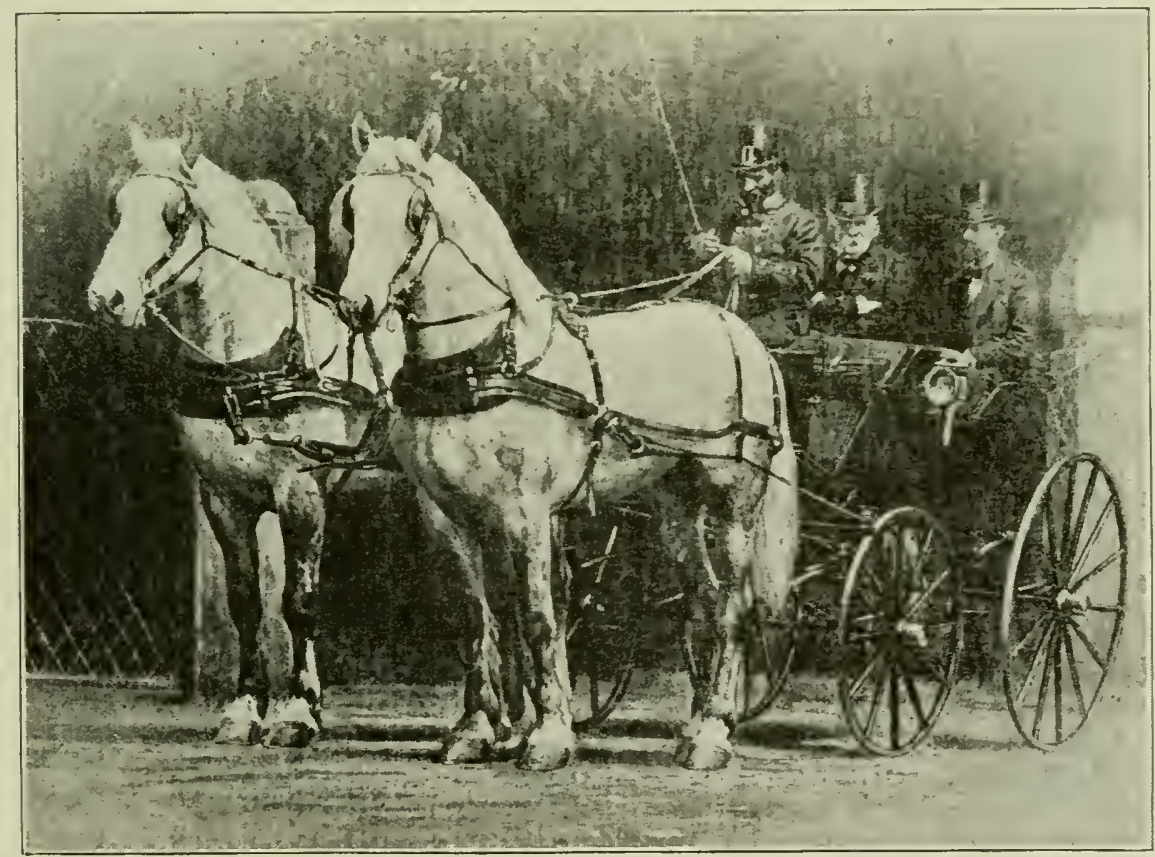

PERCHERON STALLIONS SULTAN AND VICTOR-IMIPORTED AND OWNED BY W. T. WALTERS. 

the latter by Gen. Fleury 846, their pedigrees otherwise being the same-dam Jennie by Prince Imperial 388 (Old Charley), grandam by Normandy 351 (Pleasant Valley Bill), third dam by Nonesuch 345 (Old Bob), fourth dam by Louis Napoleon 281.

White Prince 496 was the first imported horse ever taken west of the Rocky Mountains, and it will be observed that even as early as 1878 we had American-bred horses of high breeding graded up from the native stock. White Prince was a fine individua! and an extraordinarily successful sire, never a big: one, weighing around 1,600 pounds, and remembered as a typical specimen of the true diligence breed in its highest estate. His get followed his own pattern closely as to both type and color. Indeed he was regarded as exactly the horse that should have been chosen to make a start in a region where the improvement of the native stock had not previously been attempted. Unfortunately he was poisoned in 1878 , foul play in that manner removing perhaps the most impressive getter ever used on the common run of mares in the early days in that country.

Good Buying for Illinois.-Fullington, Thompson \& Co., Irwin Station, and the Marion company still held the fort in Ohio, each firm importing three stallions in 1870. All the other importers of that year, with the exception of Mr. Parrott, already mentioned as hailing from Kansas, were residents of Illinois. They were: Hume \& Short, Brighton; Russ, McCourtey \& Slattery, Onarga; Westfall, Moore \& Rexroat, Macomb; A. G. Van Hoorebeke, 
Monmiouth; Jas. A. Perry, Wilmington, and last but not least, E. Dillon \& Co., Normal, which had been identified with the business since the purchase of Louis Napoleon in 1858. Illinois' delegation consisted of 17 out of the 24 stallions imported that season. Josephine 814, brought across by Mr. Parrott, is the only mare listed for 1870 . She was disposed of the following spring to Mr. Meyer, but died before she could be shipped.

Duke de Chartres Brings $\$ 4,000$.-Among the stallions imported in 1870 were several celebrities. In the quartette brought by James A. Perry, Wilmington, Ill., was Duke de Chartres 150, a four-year-old gray conceded to have been the handsomest imported stallion of his day, and extraordinarily successful in. the showring at the Illinois State and other fairs. He earned the further distinction of being the first imported horse to be taken to California, William Hill \& Co., Petaluma, being the buyers at a price reported to have been $\$ 4,000$, or the highest paid up to that date. Diligent inquiry has failed to develop information touching Duke de Chartres' career after reaching the Golden State. Vidal 784, another stallion in the same importation, was later sold by $\mathrm{Mr}$. Perry to the Degens of Ottawa, his acquisition marking the entrance of that Illinois family into the business in which they were prominent for some years.

Pride of Perche 382, a four-year-old gray imported by the Marion company in Ohio, was probably the second imported stallion taken into Iowa, having 
been purchased by A. G. Howland, Otisville, the same year lie was imported. He made several seasons at the Iowa Agricultural College, Ames, but like John Sheridan died in 1877. Most of the stallions imported by Russ, McCourtey \& Slattery, Onarga, and Westfall, Moore \& Rexroat, Macomb, seem to have done yeoman service in the improvement of the native Illinois stocks, proving in the main long-lived, prolific, and impressive. One of the stallions imported by Westfall, Moore \& Rexroat was sold to A. V. Brookings, Macomb, Ill., marking the beginning of a connection that persisted prominently in that portion of the state for a great many years.

First of the Blood in Wisconsin.- Whether to Simon Rublee or to H. B. Sherman, both now members of the great silent majority, belong's the credit of having taken the first imported stallion into Wisconsin the records are not altogether clear. It is the tradition that Mr. Sherman bought a stallion in Olio of 1870 importation, but finding him wanting in some essential particular later obtained another in exchange for him--Pride of Perche 380. But it is certain that Mr. Rublee bought Mahomet 291, imported in 1870 , from the Dillons. He was one of their first lot of four head. In just which year the first imported horse was taken into the Badger state the records do not make clear, but the honor of blazing the trail in that commonwealth belongs to one or the other of these two men.

Dillons' Big St. Laurent.-With the importation 
of four head, which marked the beginning of the Dillons' importing career, there came certainly the weightiest stallion that up to that time had entered this country, and quite likely as big as any that has followed him. This was St. Laurent 435, a gray foaled in 1866, and said to have weighed near 2,400 pounds. He was loosely put together, and a somewhat uncertain getter, but there is no question as to his mastodonic dimensions.

Recapitulation.-Beginning with the Harris importation of 1839 and closing the first era of the importing business with the end of 1870 , we find a total of 90 stallions and 21 mares definitely recorded as having been brought to these shores from France. It is generally believed that a few animals besides those mentioned here were actually imported within the period described, but the data concerning them and the points of their origin were too indefinite for the compiler of the stud book some forty and more years ago to recognize their claims. At the best they could be but few in number. Some of the early imported stallions of the diligence type bred remarkably true to form, and there is little room to doubt that on removal far from the point of production some of their sons with age, whitening coat, and growing success in the stud gradually assumed the dignity, by local reputation, of "imported stock." If a few genuinely imported stallions were overlooked it is no more than must have been expected in the circumstances, but without doubt a place was found for every animal whose history 
could be traced without break or flaw. Naturally, too, there was considerable duplication of names, but that also was unavoidable. It is possible when the affairs of a stud book organization are in running order to prevent two animals being registered by the same name, but that is impossible in gathering together materials for a retrospective volume. Names under which stallions have been known for many years can not be changed for the purposes of making a more intelligible record. In reading the history of the earliest importations it is necessary, then, to sense properly the number following the name when tracing the career of any given individual. Of Napoleons, Dukes of Normandy, Prides of Perche, and Princes of various realms there were many and unless the stud book number is carefully noted in connection with the name confusion must ensue.

Of the 90 stallions imported between 1839 and 1870, Ohio had 42, Illinois 24, Pennsylvania 10, Maryland 5, Massachusetts, Virginia, Missouri and New Jersey 2 each, and Kansas 1. Owing to the activity of Gen. W. T. Walters, Maryland easily leads among the mares with a total of 10 out of 21 , followed by Massachusetts with 3, Virginia and New Jersey with 2 each, and Pennsylvania, Kansas, Missouri and Ohio with 1 each.

Starting once more with the landing of the Harris stallions and mares in New Jersey, we have the spread westward in chronological order to Maryland, Pennsylvania and Ohio, Illinois, Kentucky, Missouri, 
Kansas, Iowa and Oregon. Michigan received its first blood also in 1870, when Hon. Z. T. Chandler, Lansing, bought Mark Anthony 296 from Gen. W. T. Walters, Baltimore. Oddly enough, although every stallion taken into Illinois and further west necessarily had to pass through Indiana there is no mention made of the location of any imported stallion in that state within the period of 32 years just reviewed. Mahomet 292, a five-year-old gray stallion imported in 1868 by the Watkins confederacy in Ohio, is recorded as having made several seasons in Illinois and Indiana, but that is as close as we can come to discovering any early awakening in Indiana to a sense of the merits of these imported horses.

By the close of 1870 draft horse breeding had been established in Illinois as a commereial industry on a sure and solid basis, though as yet no purebred mares had been owned within the state. Up to this time a large percentage of the male progeny of the imported stallions, especially if gray in color and descended from the Samson mares, were kept entire and used in the stud, some of these grades being high-class individuals and often really not to be distinguished from the imported article. Weights as high as 1,800 and even 1,900 pounds had been achieved in this line of breeding and prices up to and beyond the $\$ 1,000$-line had been paid for the best specimens. Four hundred and $\$ 500$, and even $\$ 600$, $\$ 700$, and $\$ 800$ were prices constantly quoted for young gray horses possessing the characteristic "Frenchy" form, even though only half-bred. Stal- 
lion fees were liberal, reaching as high as $\$ 25, \$ 35$, and even to $\$ 40$ and $\$ 50$ in the top register. No line of live stock endeavor was so popular and at the fairs big and little the owners of French horses vied strenuously with one another in making displays of the colts and fillies begotten by their stallions. Of course these young things were all grades. In New Jersey all trace of the early importations was gradually swept away, the mark left by Gray Billy, stallmate of Pleasant Valley Bill on the journey across the ocean, being perhaps the hardest to efface, owing no doubt to the superior purity of his blood and his prepotence as a sire. Despite the social and personal prominence of Gen. W. T. Walters and the care and money he lavished on his Percheron breeding renture, little benefit accrued to the state of Maryland. Indeed, save that in some localities the weight of the native farm stock was measurably increased, it is questionable if the equine interests of the commonwealth received any lasting benefit. Much the same is true, on the best authority, of the earliest importations into Virginia, and all vestiges of the Kentucky importations of 1859 have vanished completely.

In Pennsylvania no doubt the war of $1861-5 \mathrm{swal}-$ lowed up most of the grades old enough to go to the front, the state at that day being famed as the breeding ground where the best big horses in the Union were produced. Indubitably the heavy demands made on the newly improved equine possessions of Pennsylvania for military purposes gave 
the work of amelioration so grievous a setback that before the machinery of improvement had again been set in motion the tide of agricultural advancement and settlement was flowing westward in such overmastering volume and strength that the ground lost could never be quite regained. Nevertheless Pennsylvania remained for years one of the dominant factor's in the American heavy horse breeding industry.

To a lesser extent the same is true of Ohio. In the Buckeye state perhaps the farmers' yards were not raked quite so clean as in Pennsylvania, and though the prices offered by the agents of the War Department tempted many breeders to sell their grade mares for army uses a larger percentage remained after the close of hostilities with which to begin anew the making of the native-bred drafter. Old Doll 540, imported in 1857 by the Darby Plains Co., proved a tower of strength to the budding purebred industry, not only in her own career but also in the prolificacy of her several daughters. They gave the Ohio fanciers a start in the breeding of purebred stock and the constant supply of unrelated imported stallions from 1851 onward gave them the opportunity to put successive crosses upon the native foundation until registration under the top-cross rule of 1878 had been achieved. TVe find no evidence that this new rule was taken advantage of in that day by the breeders in Maryland or Virginia.

Just how Indiana escaped from being infected with the desire to improve its work horses by the use of 
the imported blood will never be explained, but that not a single imported stallion had up to 1870 ever been taken for service within the boundaries of the state is proved beyond a doubt by the records. How such a priceless boon came to be overlooked entirely in the main line of western travel must remain an unsolved mystery.

Illinois seems to have been shaped by destiny to be the center of the American draft horse breeding industry. As already stated, the existence of the big mares carrying the blood of Samson contributed to the early success on the broad prairies of Tazewell and adjacent counties, and there is a tradition that even as early as 1835 grades of another draft breed had been used to better the work stock of that region. Moreover, Illinois with its deep rich soil and its wonderful grazing was from the very first an ideal horse-breeding ground.

As early as 1820 or thereabouts the Dillons, Hodgsons, and other well known old Illinois families had achieved fame as horse breeders in the localities back east from which they originally hailed. About that year several of these families sent scouts west with instructions to look up a new location, the representatives of the Dillons and the Hodgsons being charged specifically to locate lands where horse breeding could be made a specialty. They came on horseback and the practical judgment of these hardy pioneers is well demonstrated by their original choices of location along the Illinois River in Tazewell and La Salle counties. They brought good 
horses of the Dragon and Conestoga stocks with them, and the portion of the state where they settled has ever since been within the best breeding ground for draft horses in the west.

It was into Tazewell county that tradition alleges the very first stallions of draft blood brought to Illinois were taken about 1835 . It was into that same county that Samson was imported in 1843, and it was there again that Louis Napoleon made the "hit" that paved the way for all that has since transpired in this great branch of American animal husbandry. 


\section{GHAPTER VII.}

\section{MID-IVEST PIONEERS.}

The production of French horses in America from imported ancestry on both sides was so limited prior to 1871 as to be of little consequence. As a matter of fact only 23 animals since recorded in the American Stud Book were foaled during the years from 1871 to 1874 . More rapid headway was made after 1875, however, as a considerable number of mares had meantime been imported. Summarizing the situation, we find that 874 stallions and 152 mares were imported between 1871 and 1880, and that 104 stallions and 115 mares were bred in America during that same time.

Restricted as home-breeding may seem to have been, a solid foundation had nevertheless been laid. The value of the French horses in improving the common stock of the country, already demonstrated by Louis Napoleon, French Emperor, Success, Pleasant Valley Bill, and numerous others, had been more than sustained by the importation and use of Apollo 14, Vidocq 483 (732), St. Laurent 435, Nogent 738 (729), Dieppe 135, Malbranche 293, and numerous other sires of more than average merit. Actual breeding had begun in fifteen states. Last but not least, a number of firms had passed through the 
pioneer stages of importing and breeding and were leading the way to rapid improvement in our draft hor'se stock.

Leaders of the Period.-Mark W. Dunham, E. Dillon \& Co., James A. Perry, Daniel Dunham, A. W. Cook, Virgin \& Brown, Degen Bros., B. H. Campbell, James H. Sanders, R. B. Chisholm, and the Onarga Importing Company were leading figures in the trade during the period of which we speak. All but Cook and Sanders were located in Illinois. They were carrying the colors to the front in Iowa. There were, however, seventy-seven other men who are credited with importations during this time, and some excellent horses were brought over by some of the minor operators. In some cases importations were made by men who did not go abroad, but who bought their horses through accredited agents in France.

The leading breeder's of the early '70's, as shown by entries subsequently made in the American Stud Book, in order of importance were M. W. Dunham and E. Dillon \& Co., both of Illinois; S. W. Ficklin of Virginia; Thomas Jones \& Son and C. M. Jones, of Ohio; W. T. Walters of Maryland; W. H. Winter and Daniel Dunham of Illinois; W. C. Myer of Oregon; George W. Stubblefield \& Co., and Ed. Hodgson of Illinois. Thirty-two other breeders produced from one to four animals each during the years mentioned, and their product was distributed over the states named and ten others.

Oaklawn in Front.-Mark W. Dunham was not 


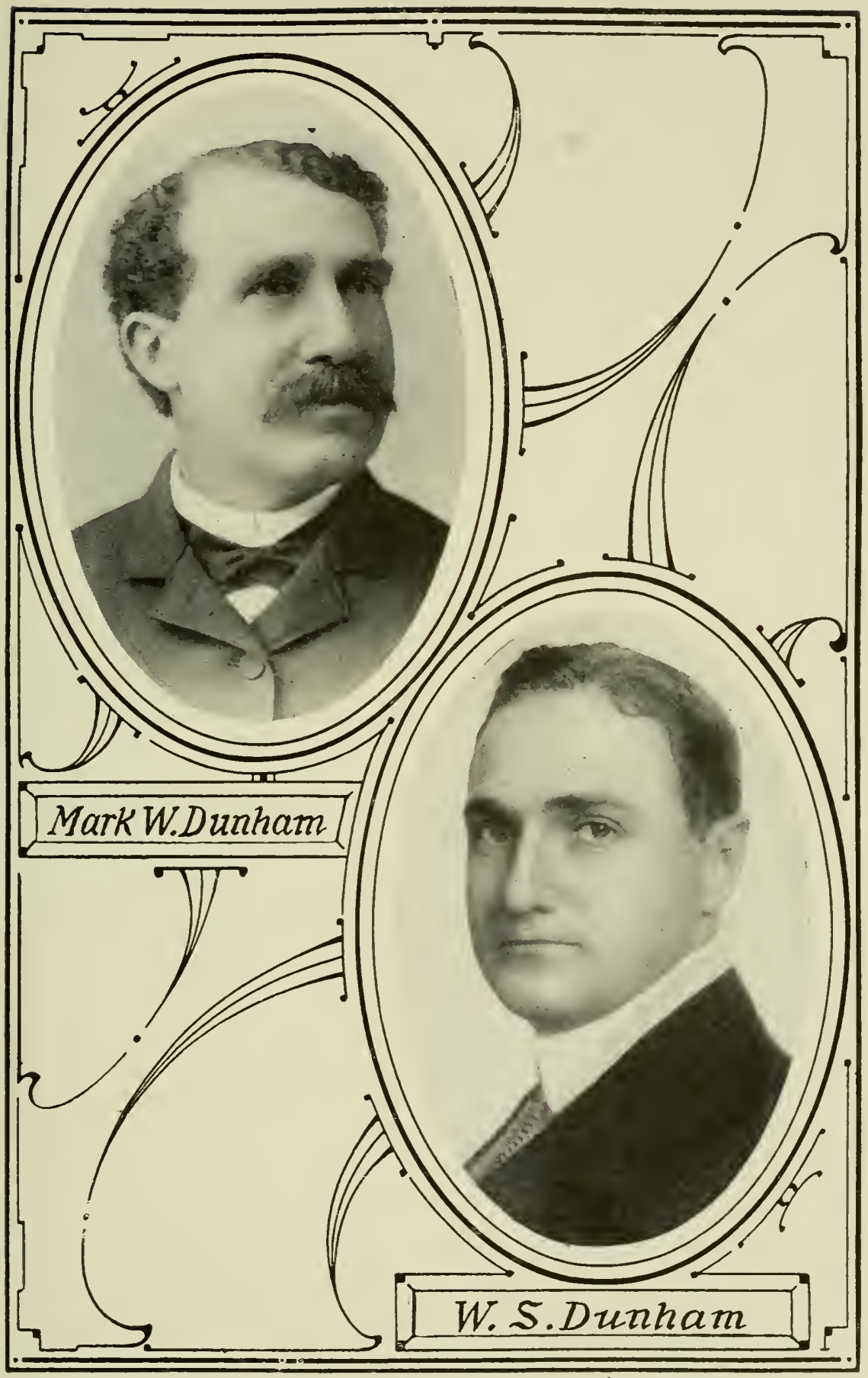



only the principal importer, but easily the leading breeder of his time, both in point of numbers and in the excellence of animals produced. Between 1872 and 1900385 mares and 353 stallions (a total of 738 Percherons) were bred at Oaklawn, more than in any five other breeding establishments operating during the '70's, '80's and '90's. Aside from this, the character of the animals produced was such that Oaklawn took the premier position at the outset, and its leadership was never seriously disputed during the lifetime of its founder.

Born in 1842 of New England parentage Mark W. Dunham succeeded in 1865 to the farm which his father had purchased from the government in 1833 . His education was obtained in the local schools and on the farm, under the guidance of a father who was a good farmer and a raiser of livestock of more than average merit. The father died when Mark was only 23 , and he at once assumed the management of the place which then comprised but about 300 acres, located near Wayne, Ill., where the buildings now stand.

Mr. Dunham as a practical farmer had bred good livestock from the outset, and as has already been briefly mentioned he had entered upon his career as a horseman by becoming a member of the Fletcher Horse Co., headed by his uncle, M. W. Fletcher. This was the company that had bought Success and French Emperor in 1868, shortly after their importation by W. J. Edwards. A few years later Mr. Dunham bought Success from the company for 
$\$ 3,300$. The excellent character of the colts sired by this stallion out of the small, nondescript mares then common in northern Illinois, and the decidedly greater value of the colts for work or sale (they brought twice as much at the same age as any other colts sired in the county) together with the fact that very few such horses were in service convinced Mr. Dunham that an excellent business opening was here presented. He lacked means, but had the confidence of his bankers, who financed his initial venturean importation of 6 stallions in 1872. He did so well on these that he brought over 17 stallions and 4 mares in 1873, and steadily increased his importations in both stallions and mares, until by the end of 1880 he had imported a total of 300 stallions and 75 mares.

Home Breeding Emphasized.-From the very be. ginning Mr. Dunham encouraged the breeding of Percherons in America, as is amply attested by the fact that he brought over 75 of the 152 mares imported during the ' 70 's. The other 77 mares were brought over by 17 different importers, the Dillons bringing 18 and Daniel Dunham 17.

Mignonette 584 (1447) was the best of the mares imported at this time. She is described as " 16 \% hands high, weight over 2,000 pounds in fair order, dapple-gray." She was six years old when imported in 1876, was champion mare at the Centennial Exposition at Philadelphia that year, and was a noted winner in France prior to importation. She was retained in the stud and was considered one of the 
best brood mares at Oaklawn. She was the dam of Nyanza 869, sold to head the stud of Henry Avery, Wakefield, Kans., in 1881. Ophelia 590, Minerva 585, Countess 537, Adelaide 519, and Midocean 583 were other mares that proved to be good producers at Oaklamn. By the end of 188020 stallions and 28 mares had been bred and reared by $\mathrm{Mr}$. Dunham as an earnest of his belief in the production of American-bred Percherons. Success 452, Apollo 14, and Vidocq 483 were the sires used, in order named, during this period.

Some Celebrities Described.-As a matter of interest a detailed description of these horses is here given:

Success 452, foaled in $186+$ and imported in 1868, was 16 hands high; weight 1,700 pounds. He was vigorous, hardy, an easy keeper, compact and symmetrical, with unusual elegance and attraciveness in general appearance and movement. His get were described as uniformly large-sized, compactly built, clean-limbed, stylish and active, whether from large or small mares.

Apollo 14, foaler in 1868, imported in 1875, was $163 / 4$ hands high, weighed 2,000 pounds, and was a dark dapple-gray. He was very symmetrical and stylish and excellent in quality. Grand champion at the Centennial in 1876, he sired but 5 purebred colts at Oaklawn before his untimely death early in 1878. Such colts as he did sire were very large, massive, and excellent in character.

Vidocq 483 (732), foaled in 1869 and imported in 
1874 stood 161/4 hands high, weighed 1,850 pounds, and was dapple-gray in color. He was very compact, symmetrical and stylish, with extreme spirit and courage. He was second at the Société Hippique Percheron Show at Nogent in 1872, being beaten by his half-brother, Duke de Chartres 162 (721). He was sold to Leonard Johnson of Minnesota shortly after importation, but the colts sired by him in France proved so good and were such consistent winners when imported that Mr. Dunham bought him back to head the Oaklawn stud in 1878 . Here he remained in service till 1885; he was the chief stock horse until superseded by Brilliant 1271 (755). He sired 36 purebred colts, most of which were bred by Mr. Dunham and Mr. Johnson. His greatest son, Nogent 738 (729), was placed at the head of the Dillon stud in 1877.

Drawing from the Fountain Head.-Mr. Dunham's pioneer service as an importer and breeder was notable for his insistence upon purchasing only horses of true Percheron breeding and character. He was not long in locating the source of the best draft horses in France. He sought his material in the very heart of The Perche. He early determined that the Percheron combined the necessary size and quality with unusual symmetry, style, action, spirit, and courage. His earliest purchases were made from such men as M. Cajet, M. Fardouet pere, M. Dupont, M. Miard and Ernest Perriot, Sr., all located in The Perche, and all leaders in Percheron breeding. His deliberate selection of the best stallions and mares 


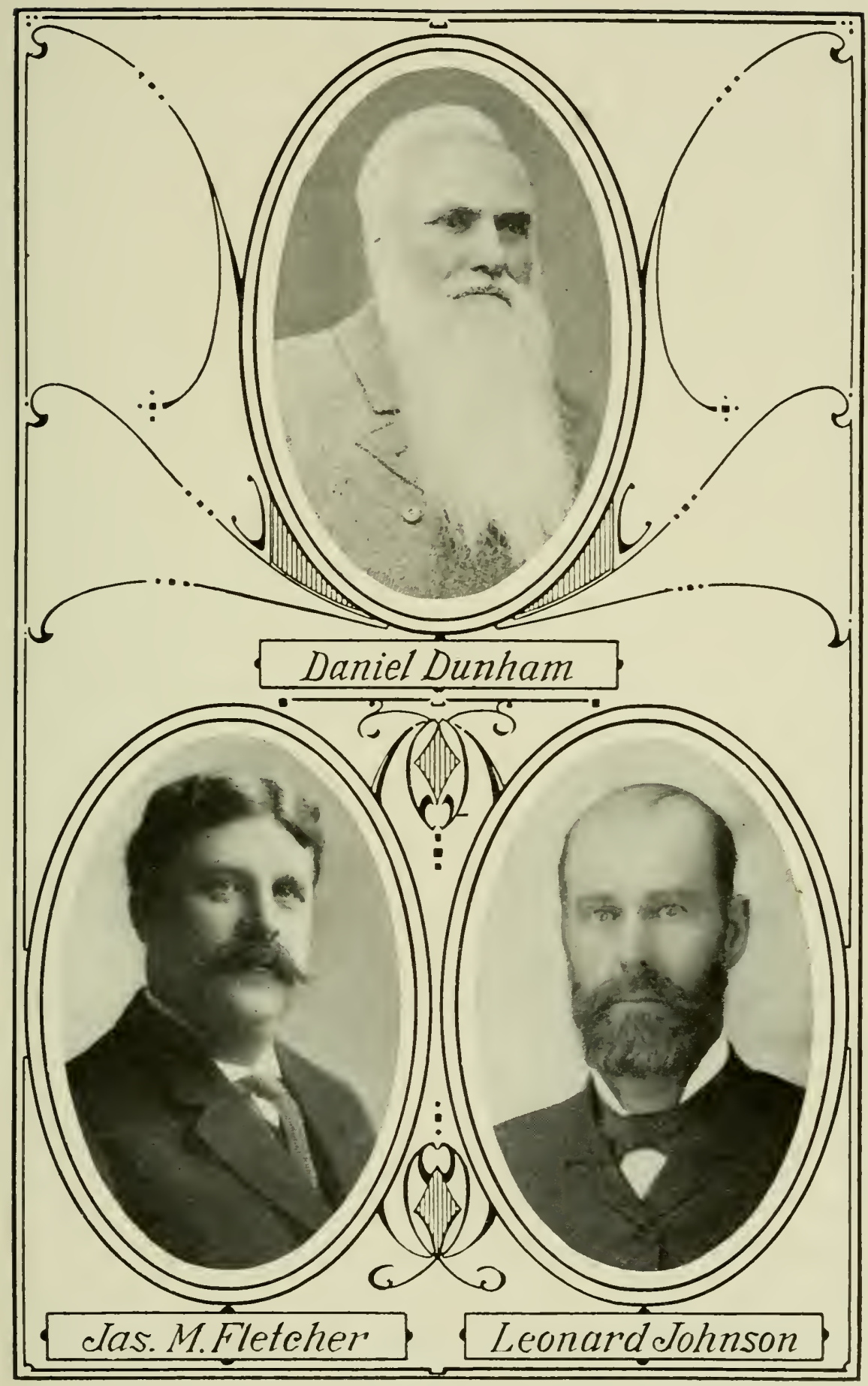



obtainable in France for use in his own breeding operations at Oaklawn set a high standard for other American breeders to follow; last but not least, his aggressive advertising through the agricultural press and at fairs and expositions, together with well-planned circular and catalog distribution, did more to bring Percherons to the front in these early days than any other factor. In his adrertising Mr. Dunham placed emphasis on the greater value of the colts begotten by Percheron sires, and repeatedly scored by pointing out that the colts sired by his Percheron stallions were selling for twice as much at the same age as the colts sired by the common grade or mixed-bred sires then in general use. The utility value of the draft horse was his theme, whether for work or sale, and he drove this point home so aggressively that his sales of Percherons in 1875 and '76 aggregated almost \$200,000-eloquent testimony, even at so early a date, as to the high character of his selections.

The Dillons.-Ellis Dillon and his nephews, Levi and Isaiah Dillon, operating under the name of E. Dillon \& Co., were first located in Tazewell, and later in McLean county in Illinois. The Dillons were the first family to locate in Tazewell county, and came there from Ohio in 1823. They brought with them horses larger than the average descended from English draft stock. Subsequently they had the services of old Samson, an imported English draft stallion, probably a Shire, brought over by Col. Oakley in 1843. They continued the use of this blood 
and bred mares of more than average size at a time when most farmers were frittering away what draft stock they had by mating their mares to trotting sires.

As already related, the Dillons obtained Louis Napoleon in 1857, and his phenomenal success as a sire finally led them to decide on direct importations. Four stallions were brought over in 1870, and from 1872 to 1880 importations were anmually made, except in 1878. From 1872 to 1880 they imported 84 stallions and 18 mares.

The breeding operations of the Dillon firm were restricted because of the limited number of mares available, but some very valuable sires were in use during this time. St. Laurent 435, their first sire, was a horse of tremendous scale; and while he was not a great breeding horse some of his get sold at long prices at early ages. Nogent 738 (729) was imported in 1877 by the Dillons, and was used by them in the late ' 70 's and early ' 80 's, supplementing St. Laurent 435 in the stud. He was a horse of exceptional quality and merit as a sire, and while he begot only 5 purebred colts after importation to America, the colts sired by him in France, many of which were later imported, were so excellent as to stamp Nogent 738 (729) as the greatest son of Vidocq 483 (732) and one of the ranking sires of the ' 70 's.

All told the Dillons bred 28 stallions and 13 mares between 1871 and 1880, most of them produced after 1876. They bred some very high-class animals, especially in mares, were aggressive exhibitors in the 
showring and good advertisers, and by reason of their prestige and influence in central Illinois in a business and political sense they exerted a strong influence on draft horse breeding. They were not particular, however, to hold strictly to Percheron type and bought many useful horses of other French derivation. They emphasized great weight, massiveness, and ruggedness, and placed rather less importance upon quality, finish, and action. They led the faction which held that all horses coming from France should be grouped as one breed, to be called "French Draft," and this divergence in views later caused a split in the ranks of the men who were forwarding Percheron horse-breeding interests in America.

Ohio Breeders of the '70's. - While the most aggressive Percheron campaign was being waged in Illinois, Ohio's breeders were not idle. Andrew Gill and Thomas Jones \& Son, at Plain City, and H. L. Wood, at Piqua, bred a total of 17 Percherons during this decade. Thomas Jones was the leading breeder. His operations were really started in 1864 by the purchase of Normandy 351 (Pleasant Valley Bill) from Timothy Bigelow. Doll 540 (imported) was bought in 1866 and her filly , Rose 604, foaled in 1866, was retained, though Doll and her next foal, a filly, were sold in 1867 to Gill \& Woods for $\$ 1,000$. From Rose 604 came three recorded fillies, foaled in 1869, '70, and '71, all sired by Normandy 351. These four mares were subsequently bred to Ajax 5, a very good big horse, imported in 1871 by the Delaware Import- 
ing Co., and bought in $187+$ by Joness. By 1880 the firm had bred and reared 5 stallions and 8 mares, of more than average merit.

Ajax 5 was about 17 hands high and weighed approximately a ton when in good flesh. He made a tremendous improvement in the size of the Percherons in Ohio, and was a very prepotent sire, both as to size and color. In the 18 years during which he was used at Pleasant Valley Stock Farm he never sired a colt that was not gray in color. Belle 522 was the best brood mare of those owned by the Jones firm at this time. She produced altogether 5 stallions and : mares, most of them foaled before 1880, and her descendants are to be found in all parts of Ohio.

The other Ohio breeders operating during this decade produced but two animals each, but they had laid the foundation for more extensive work and had, through the use of Percheron sires, made notable improvement on the common horses of their districts.

\section{The East and the Far West.-The men who stood} third and fourth in number of Percherons bred during this period were S. W. Ficklin of Virginia with 13, and W. C. Myer of Oregon with 12. Both were pioneers in their respective states, and must be given

${ }^{*}$ C. M. Jones, the son, then associated with his father, states that the farmers in his part of Ohio had the value of draft horses driven home to them most forcibly during the Civil War, when the descendants of Louis Napoleon, Pleasant Valley Bill, and the Baker Horse brought twice as much as common horses and were eagerly sought for by army buyers. The lesson struck home and the farmers gave liberal patronage to draft sires thereafter. 
great credit for campaigns waged against odds. Farming on a large scale, which quickly forced the greater utility value of the draft horse upon the attention of cornbelt farmers, was not general where these men lived, and the farmers and horsemen were less numerous and less able to buy.

Mr. Ficklin's start was really made in 1866, by the importation of 2 stallions and 2 mares. One of these mares produced a filly in 1867, and from these 3 mares he produced 13 colts during the period under consideration. The stallions produced were lost to sight in the common stock of Virginia, but the female line persisted and is today represented by more than 60 descendants, in the studs of T. L. White, F. B. Albert, D. T. Martin, C. H. King, D. M Cloyd, and others, all of Virginia. More than 40 of these trace through Constance 8th 8215, foaled in 1879 . Mr. Ficklin's Percheron breeding ceased in 1888.

On the Pacific Coast.-In December, 1870, William C. Myer of Ashland, Ore., bought White Prince 496. His place was located in a valley tributary to the Rogue River. Here, within sight of mountain peaks and with Indian pony mares as the chief mates in his harem, that imported horse started the work of improvement. The colts were uniformly good in color, compact, well-proportioned, with style, symmetry, and size. The progeny, even from pony mares not exceeding 800 pounds, weighed 1,200 pounds and over. Such results were exactly what the western ranchmen wanted, and as a consequence Mr. Myer established a stud by bringing out 2 more stallions 
and 4 producing mares, 2 of which came from Ohio, one from Pennsylvania, and one, of Ohio breeding, from Wisconsin. The stallions were Pride of Perche 380, imported in 1874, and Gen. Fleury, imported in 1875. Both were brought over by Fullington \& Co. of Ohio. Marked impetus was given to the growing popularity of the Percheron by these shipments of Mr. Myer, and he is justly credited with the most important pioneer work on the Pacific Coast.

Dr. W. H. Winter.-WV. II. Winter of Princeton, Daniel Dunham of Wayne, G. W. Stubblefield \& Co. of Bloomington, and Eli Hodgson of Ottawa, all of Illinois, were other leaders, with $11,10,8$, and 5 American-bred Percherons to their respective credits by the close of 1880 .

Dr. Winter was of English descent and came from Pennsylvania to Princeton in 1850 . He was engaged in the drug business, but was by inheritance a farmer and soon established Edgewood Farm. Here he bred Shorthorn cattle and draft horses. In 1874 he made his start in Percherons by purchasing Malbranche 293, imported in 1873 by the Princeton Horse Co., and in 1874 he had the mares Jeanne 560 and Joan 562 imported through N. C. Buswell. The mares both proved to be good breeders and by the close of 1880 he had 3 stallions and 8 mares descended from this modest foundation.

Malbranche 293 is described as a large gray, about 17.1 hands high, weighing over a ton. He was a deep-bodied, wide-chested horse with two good ends and a good middle. He was considered the best sire 
ever used at Edgewood Farm, although many of his colts were bays and sorrels-colors that were none too popular. Bernadotte 36 , a bay bred by Dr. Winter, sired by Malbranche 293 out of Jeanne 560, was also used, supplementing his sire.

Dr. Winter was a man of high character and considered a very good judge of horses. He exerted a wholesome influence on horse breeding in his district, but this was largely local at the time. Dr. Ezra Stetson of Neponset, Ill., was one of his contemporaries who bred a few horses during this early period; his operations will be dealt with later.

Daniel Dunham.-Mark Dunham's elder brother Daniel's operations during the decade under review require but passing comment. He bred 10 altogether, from mares purchased at Oaklawn, using the sires which were at the head of his brother's stud. In 1880 he imported 3 stallions and 17 mares, selected with particular view to his own Percheron breeding operations, so that his foundation was properly laid at the close of the time we are considering.

Eli Hodgson.-Mr. Hodgson had used Louis Napoleon during' the early '60's. He owned some good grade draft horses, and in 1874 made an importation of 3 stallions and 1 mare. Of the stallions Bob Havre 57 proved most valuable. He sired but few purebred colts, for purebred mares were scarce in his time, but his get out of common grade mares were so good that he earned over $\$ 10,000$ for his owner in 10 seasons and was then sold at the age of 13 for $\$ 2,500$ to W. P. Corbin, Pontiac, Ill. The 
mare, Pride of Paris 593, proved to be a regular producer, but she and her descendants were coarse and so lacking in both quality and symmetry that Mr. Hodgson discarded all of them after a few years.

Hodgson's operations between 1870 and 1880 served to develop great interest in draft horse breeding in La Salle county, and as a direct result a number of purebred studs were established there in the next decade, of which we shall have more to say anon.

Stubblefield Importations.-George TV. Stubblefield \& Co., Bloomington, Ill., made importations in 1874, '75, and '80, and bred altogether 8 Percherons by the close of this period. Henry Abrahams 224, imported in 1874, was the only sire of consequence used by Mr. Stubblefield during this time. He was an upstanding horse, a little over 17 hands, weighing around 1,800 pounds. He was a light gray, with fine head and neck, short back, and heavily muscled quarters. He had extra quality, good style and action. As a sire on the common mares of McLean county he proved extremely popular and did much to increase the demand for Percheron sires in that section.

Percheron Breeding in Other States.-A detailed discussion of the work of the 32 other breeders who contributed to Percheron breeding during this pioneer period is hardly necessary, for in most instances they were merely laying the foundations for later work, and while so doing aroused interest in draft horse breeding and convinced the average 
farmers who came in contact with the get of Percheron stallions out of common mares of the tremendous value to accrue through the use of such sires. The missionary work done by these early breeders was such that their names are worthy of mention on the pioneers' roll of honor, together with the number of their productions.

They were: R. W. \& T. T. Stubblefield, Bloomington, Ill., 2; Henry Avery, Wakefield, Kans., 2; C. Billborrow, Paw Paw, Mich., 1; James Dunn, Waseca, Minn., 3; Andrew Gill, Plain City, O., 2; Ezra Stetson, Neponset, Ill., 4; H. V. P. Block, Aberdeen, Mo., 3; C. Cameron, Brickersville, Pa., 4; J. J. Parker, West Chester, Pa., 1; J. W. H. Reynolds, Frankfort, Ky., 1; H. A. Babcock, Neenah, Wis., 1; A. W. Cook, Charles City, Ia., 4; Jeff C. Clark, Normandy, Mo., 2; Ed. Hodgson, Ottawa, Ill., 5; Rogy \& Trimble, Walnut, Ill., 2- H. M. Aldrich, Orland, Ind., 1; C. W. Pierce, Boston, Mass., 1; W. W. \& Al. Power, Pulaski, Ia., 1; Reuben Wright, Normal, Ill., 1; Bangs \& Billborrow, Paw Paw, Mich., 1; Bang's \& Co., Paw Paw, Mich., 1; Dickinson Bros., Ridgeway, Pa., 2; E. O. Hills, Bloomingdale, Ill., 1; T. Skillman, Petaluma, Cal., 1; Charles K. Harrison, Annandale, Md., 1; L. M. Hartley, Salem, Ia., 1; Avery \& Murphy, Detroit, Mich., 1; F. J. Schreiber, Moorhead, Minn., 3; W. H. Hubbard, Evanston, Ill., 1; K. L. Wood, Piqua, O., 2; S. Murphy, Detroit, Mich., 1; Poindexter \& Orr, Dillon, Mont., 1.

The popularity of Percherons was materially hastened by the importations made by horsemen who 
brought over only stallions, and whose work was purely that of dealers. While these men cannot be considered to have contributed so directly to the upbuilding of Percheron breeding as those who proved their faith in horse breeding by investing capital in breeding mares to be retained in their own studs, their work was nevertheless extremely valuable in that it placed numerous Percheron sires of merit in communities where draft horse improvement was being earnestly sought.

The uniformly good results obtained by crossing such Percheron sires on the common stock of that time created a strong demand for Percherons, made possible the tremendous expansion of the following period, and poured hundreds of thousands of dollars into the pockets of American farmers through increased values of colts produced. Among the men of this class who were especially active prior to 1880 were James L. Perry of Wilmington, Ill., A. W. Cook of Charles City, Ta., Virgin \& Brown of Fairbury, Ill., Degen Bros. of Ottawa, Ill., R. B. Chisholm of Elgin, Ill., the Onarga Importing Co. and Russ, McCourtey \& Slattery, both of Onarga, Ill., Fullington, Phellis \& Co. of Irwin Station, O., the Delaware Importing Co. of Delaware, O., N. C. Buswell of Princeton, Ill., Dan McCarthy of Ames, Ia., the Marion County Importing Co. of Ohio, M. D. Covell, first of Ohio and later of Kansas, and numerous others scattered over more than fifteen states. These are mentioned in the order of their importance as to number imported. 
James H. Sanders.-Contemporaneous with the entrance of these men into the field of Percheron importing and breeding, the late James Harvey Sanders, founder of live stock journalism and compiler of the first Percheron Stud Book ever projected, commenced as early as 1868 in the state of Iowa activities destined to have a far-reaching influence in the middle west.

Reared upon a farm in central Ohio, Mr. Sanders had accompanied some of the pioneers across the western prairies prior to the outbreak of the Civil War. Locating in Keokuk Co., Ia., he embraced the first opportunity to indulge an inborn fondness for good horses. He had personal knowledge of the superiority of the descendants of the French stallions imported into his native state over the ordinary farm stock of the western country, and in 1868 he went back to his old Ohio home and bought a four: year-old gray known as Victor Hugo, sired by imp. Count Robert, commonly known as the Baker Horse, imported by the Darby Plains Co. in 1857, and-as he tells us in an old hand bill printed after this colt was taken to Iowa-"universally admitted to be the best trotter ever imported from France into that region, now 18 years old, sound and hearty, and making a fortune for his owners." The dam of Victor Hugo was by "Old Bill," imported by Dr. Brown of Circleville in 1851-the "Valley Horse" of such celebrity as has already been mentioned, "now 21 years old and so highly valued that his owner refuses to put a price upon him." Victor Hugo's 
grandam was a mare by old Louis Napoleon, then still living at the age of 23 years, the property of the Dillons, the sum of $\$ 1,000$ having been offered for him only 12 months previous by Mr. Fullington of Ohio.

Thus it will be seen that this stallion was a seveneighths-blood horse, and individually he was in every way worthy of the three splendid sires whose blood coursed in his veins. He stood about 161/4 hands, weighed about 1,550 pounds, and was put in service at Sigourney in the spring of 1869 at a fee of $\$ 20$ to insure a mare with foal. He was fairly well patronized from the start even at that figure, and $\mathrm{Mr}$. Sanders encouraged farmers to breed to the horse by offering to buy the choice of the foals to be dropped at $\$ 125$ at weaning time, and the second best foal at $\$ 100$. Ifter several years of good work in the stud Victor Hugo died from a ruptured blood vessel." He was one of the first stallions of his type taken into the state of Towa, and his success paved the way for the profitable introrluction of the valuable imported horses Dieppe, Diligence, and Tempest, subsequently purchased by $\mathrm{Mr}$. Sanders. Dieppe and Diligence were imported by E. Dillon \& Co. Dieppe proved one of the greatest sires of his day in the central west. Mr. Sanders paid the sum of $\$ 3,000$ for Dieppe, and it proved a fine investment.

* Victor Hugo was the first draft stallion the compiler of this volume ever saw, and our recollection of this fine big horse is entirely clear. He had the traditional activity of the Percheron race, easily doing five miles an hour at the walk. He was worked in heavy harness every winter, and was the pride and admiration of the entire community in which he was owned. 


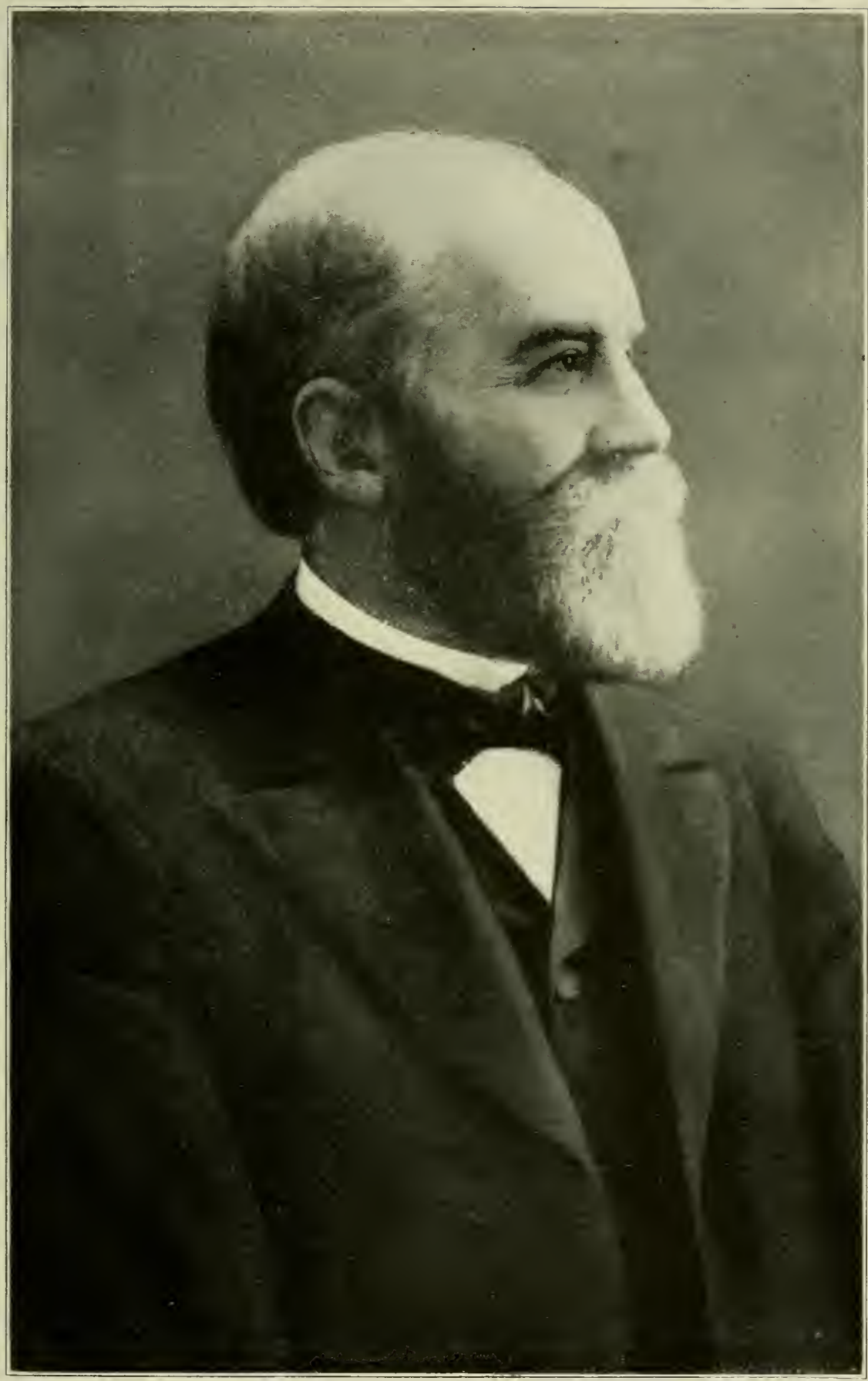

JAMES HARVEY SANDERS, FOUNDER OF THE AMERICAN PERCHERON STUD BOOK. 

This horse lived to a ripe old age, and did more for the improvement of the farm horses of Keokuk and adjoining counties than any other stallion of his time.

A Campaign of Education.-Mr. Sanders was not only one of the pioneer introducers of Percheron blood west of the Mississippi River, but he set in motion educational influences that greatly facilitated the subsequent successes of the Percheron throughout the United States. He was first of all a student. In liis library were the works of Charles Darwin, Herbert Spencer, Huxley, Francis Galton, and other scientists specializing on the laws governing the transmission of hereditary qualities. He read everything he could find in print relating to animal breeding. He felt the rising of the great tide of live stock improvement that swept through the mid-west states during the years immediately following the close of the Civil War. The state fairs were beginning to attract good exhibits. Shorthorn cattle, "Norman" and trotting horses, as well as "Magie" swine, were seen and talked about. Nobody knew much about any of the "new" breeds, but many were interested and were seeking light. There was no medium of communication between those who owned or were considering the purchase of better animals to replace the native types. Little information was available. Why not a newspaper, a periodical devoted especially to the discussion of animal breeding and management, and the news of the business in general? With J. H. Sanders to think was to act. 
In the month of May, 1869, Mr. Sanders began the publication of a 16-page monthly, which he personally edited and issued at his own expense from the then primitive printing plant of the local newspaper known as the "News." He was at the time engaged in banking and railway construction, besides trying to wake up the farmers of his state to the desirability of better blood. His purpose in founding the "Western Stock Journal" was purely altruistic. But it met with a cordial reception, and after a successful career of a few years its possibilities were so obvious that a Chicago syndicate took it over and made it the basis of the monthly magazine known as the "National Live Stock Journal," Mr. Sanders assuming by request of the publishers the editorship of the horse department to be conducted by mail from Iowa. Then came the great fire of 1871 , the financial panic of 1873 , the sweeping away of his private fortune, the enforced sale of the country place that had been the pride of his heart, removal to Chicago, and the assumption of the duties of editor-in-chief of the powerful magazine that was being builded upon his little Iowa venture as a foundation.

And so it came to pass that when the western draft horse breeding interest began about 1875 to feel the first great impulses of the boom that was now impending the necessary coöperation for a successful campaign of publicity and promotion in behalf of Percheron interests was assured. Mr. Sanders had the personal knowledge, the ability, and 
the medium of communication with the public that combined to render his services invaluable at this juncture; the more so because he had the confidence of the western people, and had already proved his breadth of view by adding to his own stud in Iowa, by purchase from Hon. George Murray of Racine, Wis., at a cost of $\$ 5,000$ the celebrated imported Clydesdale stallion Donald Dimnie. His sympathy with and advocacy of all the improved breeds promising to be useful to the American people was a matter of common knowledge.*

Foundation of the Stud Book. - With the great. expansion of the importing business following the entrance into it of the Dillon confederacy and M. W. Dunham the necessity for the establishment of a stud book was sensed by those most in interest. Up to that time "The General Stud Book" of England, wherein the pedigrees of, and other data concerning, the Thoroughbred horse were preserved, had been the sole register of the kind in existence. Neither in France nor in Britain had a similar record been

*In further illustration of Mr. Sanders' desire to work disinterestedly for the improvement of our American draft horse stock as a whole, may be cited the following announcement appearing in the editorial columns of the "National Live Stock Journal" for December, 1876:

"A Clydesdale Register.-At the urgent request of many of the leading breeders and importers of Clydesdale horses in the United States and Canada, the editor of THE Journal has commenced the compilation of a Clydesdale Register, which will be published as soon as the work can be completed. It will contain an account of the various breeds of cart or draft horses in Great Britain, the origin of the Clydesdale breed, and, ś far as can be ascertained, a complete list of the imported and prominent native-bred Clydesdale horses and mares in the United States and Canada, with their pedigrees."

Only great pressure of work that accumulated shortly afterward prevented the carrying out of this sincere intent. 
founded for any of the draft breeds, though some agitation of the subject had been started in both England and Scotland in connection with the English Cart Horse (as the Shire was then known) and the Clydesdale. "The General Stud Book' was begun as a private venture. There was no organization responsible for its arrangement, rules or publication, its chief utility lying in the aid it gave the Jockey Club in keeping the British turf free from fraud and originally in the stamp of official approval it gave to the private records of breeders kept and conducted in accordance with its few and simple regulations. It was plain, however, that a different policy must be pursued with registers in which the pedigrees of drafters should be preserved. Private ownership was impossible on the face of things. A society must be formed by the breeders and importers for the protection and promotion of their mutual interests and the verification and registration of pedigrees.

Therefore late in 1875 this proposal to establish a stud book for imported heavy French horses, their progeny and descendants took shape in the issuance of a call for a meeting of importers and breeders. In pursuance of that call, which W. E. Prichard, the only surviving member of the gathering, believes was sent out by the Dillons, a meeting was held in the old Briggs House, Chicago, in December, 1875the very first of its kind ever convened with the same object in view. Present on that most memorable occasion were M. W. Dunham, Ellis, Levi and Isaiah 
Dillon, James A. Perry, W. J. Edwards, James L. Owen, W. E. Prichard and J. H. Sanders, all of Illinois, and Simon Ruble of Wisconsin. Two sessions were held without definite result, but a few weeks later-in February, 1876-at a meeting held in the Transit House, Union Stock Yards, Chicago, with a larger number present, the "National Association of Importers and Breeders of Norman Horses" was finally launched on the troubled waters of pedigree registration and breed promotion. A full report of the discussion had upon this occasion has not been handed down, but it is a matter of record that the following resolution was passed:

"Resolved, That in the opinion of this meeting the Picardy horse, the Bolougne horse, the Percheron, and the Normandy horse are essentially the same race or breed, and should be designated as the Norman horse."'

This resolution was introduced by James A. Perry, Wilmington, Ill., and was unanimously adopted. A constitution and by-laws were also adopted, providing that "any person owning an imported or native full-blood Norman stallion or mare may become a member of this association." As a matter of fact, this meeting was not an altogether representative one, even for that early day. It was true that the term "Norman" had been in very general use in this country from the earliest importations. As a matter of fact, it had no significance at that time, nor at any other time so far as indicating a fixed breed of draft horses known as such in France was concerned, for the simple reason that no such type as 
a Norman draft horse was ever known in that country. Our people knew that most of the original importations, and many of the later ones as well, had been bought within the borders of the ancient province of Normandy. Little or nothing was known at that date as to the part which the province of Perche had really played in the production of the best horses of this stamp on the other side. There were several different types of draft horses used and bred in the Normandy district, but there was no draft horse originated and perpetuated under the name of "Norman', in that province.

Naturally the early American importers were first attracted by the horses seen in the streets of the commercial centres near the coast of northern Normandy, such as Rouen, and it was here that they began making their first purchases. They did not at first penetrate as far inland as The Perche. Just what proportion of Percheron blood was carried by Louis Napoleon, the Valley Horse, and others of the early celebrities can never be known, but from the prepotency which the best of these stallions afterwards demonstrated when crossed upon the native mares of the United States it is safe to assume that they were strongly bred horses, and that in all probability some of them at least had their origin in the Percheron country proper. That is at this late day, however, a purely academic consideration.

It is easy to understand why those who were largely interested in these horses in 1876 should prefer to stand by a name which had become so well estab- 
lished on this side the Atlantic, even though it were known to be a positive misnomer. It was purely a title of convenience, and this small conference of importers and breeders undoubtedly had in mind the idea that it mattered little as to what these horses were called in this country so long as they were of a good sort and were rendering the service for which they had been introduced. However, there were others who took a different riew and who thought. that it would be unwise, and in the long run unfortunate, if a purely American invention of this sort should be perpetuated. The more the history of the type was studied, the more convinced were those who had most regard for the facts of history, that the word "Norman" should ultimately be abandoned. Prominent among those who held this riew at this time were M. W. Dunham, B. H. Campbell, and Mr. Sanders. They knew of course that the term "Norman" was in general use, and had indeed employed it themselves in accordance with the prevailing usage in the west. This did not prevent them, however, from undertaking to bring about a modification of the term.

Long before the meeting in question had been called Mr. Sanders had been engaged in gathering authentic data concerning the earlier importations and their descendants of the pure blood, with a view towards laying the foundation for an Americar breeding interest. In the month of June, 1876, in an editorial published in the "National Live Stock Journal," he announced that he had undertaken the 
compilation of a "Norman Stud Book" as a private enterprise. While personally not in favor of the adoption of this name, he apparently at first deemed it best to follow the lead of those who had attended the February conference above mentioned. The work of preparing the initial volume progressed rapidly, and the book was issued from the "National Live Stock Journal" press late in that year, but fortunately a second edition was soon required and in this revision Mr. Sanders, upon his own motion, decided to adopt as the title for the volume "The Percheron-Norman Stud Book."* He believed he was justified in so doing. He had become convinced in his own mind, and rightly enough, that the real parent stock in France was the Percheron, and upon his own initiative he adopted the hyphenated title. This was of course a compromise between historical fact abroad and American usage at home, and like all compromises was not particularly satisfactory to anybody concerned. Nevertheless, it stood for some years.

The Peoria Convention of 1878.-At the original meeting at Chicago in 1876 there were but three states represented, and these by only 14 individuals. In the meantime, Volume 1 of the Percheron-Norman Stud Book had appeared-the first draft horse pedigree register ever issued on either side the Atlantic. On Feb. 14, 1878, another meeting of the association

* Originally Vol. I of the Percheron-Norman Stud Book was bound in green covers, and though it had 145 pages as against 212 for the revised edition-bound in the familiar brown boards-it was actually little more than one-half the size of the latter book. 
that had been formed at Chicago two years previously was called, at which the attendance numbered nearly 100 . Fifty of these were active members representing 8 different states and territories. At this meeting, which was presided over by Ellis Dillon, it was moved by Dr. Ezra Stetson that the constitution be amended so as to change the name of the organization to "The National Association of Importers and Breeders of Percheron Horses." Col. B. H. Campbell, who acted as secretary of this historic conference, moved to amend by substituting the words "Percheron-Norman," as used by Mr. Sanders in the first volume of the register. This amendment was accepted by Dr. Stetson, and after an extended discussion participated in by Mr. Dunham, Mr. Sanders, Mr. Virgin, Mr. Isaiah Dillon, and others, the motion as amended was unanimously adopted.

A motion to reaffirm the action of the Chicago meeting of two years previously, wherein it was declared that the various types of draft horses to be found in France under different names were substantially all of the same breed, provoked a spirited discussion and was finally tabled. A motion was adopted suggesting that for the future entries for the stud book showing five crosses of purebred horses on a native foundation should be accepted for registry. Officers were then elected as follows: President, Daniel Dunham, Wayne, Ill.; treasurer, T. C. Sterrett, Warrensburg, Ill.; secretary, B. H. Campbell, Des Moines, Ia. The following resolutions were unanimously adopted: 
"Resolved, That the history of the PercheronNorman horse, published by Mr. J. H. Sanders, as an introduction to his Stud Book, is the most valuable contribution to the literature pertaining to this matchless breed of horses which has ever been written in this country or Europe; and that for the labor and ability which he has bestowed upon his work, Mr. Sanders has placed the National Association of Importers and Owners of Percheron-Norman horses, as well as all others interested in the improvement of our horses, under great and lasting obligations to him.

"Resolved, That while the registry of animals contains some errors, mostly typographical, the work, on the whole, gives evidence of much labor and care; and that, both as a history and a record, the Stud Book is worthy of the entire confidence of the public.

"Resolved, That the Stud Book is calculated greatly to increase the popularity of the PercheronNorman horse in this country; and that it is not only to the interest, but it is the duty of all importers and owners to aid in its circulation.

"Resolved, That Mr. Sanders has not only labored conscientiously in our behalf, but in performing his task he has adhered substantially to the spirit of the covenant made between him and our Association."

Naturally this action was very gratifying to $\mathrm{Mr}$. Sanders, who as a matter of fact had devoted many months of time, and had expended considerable money in an earnest effort to put upon its feet a public registry that should be entitled to general confidence. He announced that he would proceed at once in the preparation of a revised edition of the volume that had already been issued, for the purpose of correcting any errors that had crept into the 
first edition, and also to add to the record the names of horses and mares that had in the meantime become available for registry.

At a meeting of the board of directors held in Chicago on July 10, 1878, the following additional resolutions were adopted:

"Resolved, That we reaffirm the resolutions passed by this Association at Peoria, in February last, endorsing the Stud Book prepared and published by Mr. Sanders, and respectfully request that he proceed with the publication of the revised edition at his earliest convenience.

"Resolved, That we assure the public that Mr. Sanders has the hearty co-operation of this association in his work, and that we denounce, as base and malicious slanders, all representations to the contrary.',

Unfortunately, more or less feeling had grown out of these extended discussions as to the name under which these horses should be known in the United States, and at a later date the adrocates of the idea that all heary horses imported from France should be registered in one book and under one title perfected an organization and began the publication of a second stud book known as "The National French Draft Horse Register." This book had the active support of the Messrs. Dillon and others among those who had been earnest and successful in promoting the interests of the French horses in the United States during the preceding years. 


\section{GHAPTER VIII.}

\section{THE FRENCH STORY RESUMED.}

Before proceeding with an account of the great expansion of Percheron breeding in America which characterized the decade beginning with 1880 and closing in 1890, let us return to France, and take note of the further progress of events in the home of the breed.

We have already shown by copious extracts from the national archives of France, preserved in Paris, that beginning with about 1815 the government extended systematic support to the aspirations of the breeders of Percherons through the medium of official inspection of stallions offered for service, and a system of subsidies paid out of the national treasury to the owners of the approved horses, besides purchasing and maintaining at the government stud at Le Pin stallions regarded as specially valuable for service in connection with the work in hand. This resulted in the establishment of a type better suited to agricultural uses than the ancient trotting and diligence stock for which the district had for so long been famous.

Practical Promotive Work.-A royal ordinance of Dec. 21, 1833, created in France several new government stallion depots, and reorganized some of those 
that had been in existence for many years previously, such as the Haras du Pin. As has already been shown, the Percheron breeding district, of which Nogent-le-Rotrou is the capital, had from the earliest periods benefited by the government's initiative at the stud just mentioned. Every year approved stallions from Le Pin were located in the old barracks of St. Denis at Nogent, where now stand the town college and court of justice.

In the year 1836 a committee of prominent men, including most of the best farmers of this district, organized a committee for the purpose of holding exhibitions or meetings known as comices in various localities, for the purpose of awarding prizes to the best animals and incidentally of encomraging agriculture and good farming through the continued maintenance and improvement of the Percheron breed. These comices exist at the present day, and are held in addition to the annual central show maintained under the auspices of the Percheron Society of France.

In 1836 we find that the president of the council of Nogent was the Count of Bussy, and among the members were Messrs. de Maurissure, de Chabot, Bailleau, farmer at Brunelles, Noël of La Messesselle, Ducoeurjoly and Le Marié of Nogent. Similar councils were also established at Chartres and Chateaudun. Some idea of the magnitude of the horsebreeding operations in the Perche during this period may be gleaned from the fact that an old publication sets forth that "the district of Eure-et-Loir" 
delivered anmually for the trade about 10,000 fiveyear-old stallions, selling at from $\$ 200$ to $\$ 300$ each."

On March 22, 1841, the Duke of Montmorency, speaking at a meeting of the municipal council of Chateaudun, said: "For many years stock-breeding societies of Switzerland and of different parts of Germany and of upper Normandy have been coming into the Perche to buy Percheron stallions and mares." This confirms once again the claim that the Perche has been for generations recognized as the home of a distinct and valuable type.

In 1844 the general council of Eure-et-Loir voted the sum of $\$ 900$ to be given by the different committees to the best brood mares, in addition to the sum that previously had been awarded. The many privately-owned stallions serving in the district were inspected, authorized and pensioned by the government officials according to their merits in accordance with an edict of Oct. 27, 1847 .

More Pre-Stud Book Records.-Resuming now our examination of the official documents in the possession of the Government of France, at the point where the study was temporarily suspended in a preceding chapter (page 101), let us summarize briefly certain facts of historical interest relating to the pre-stud book period.

The records, from which we quote, supply the names of the leading stallioners of the Perche during the period when the breed was "modifying itself" in the direction of greater weight. Such men as Launay of Mauvaisinière, Langis (Orne), Pelle- 


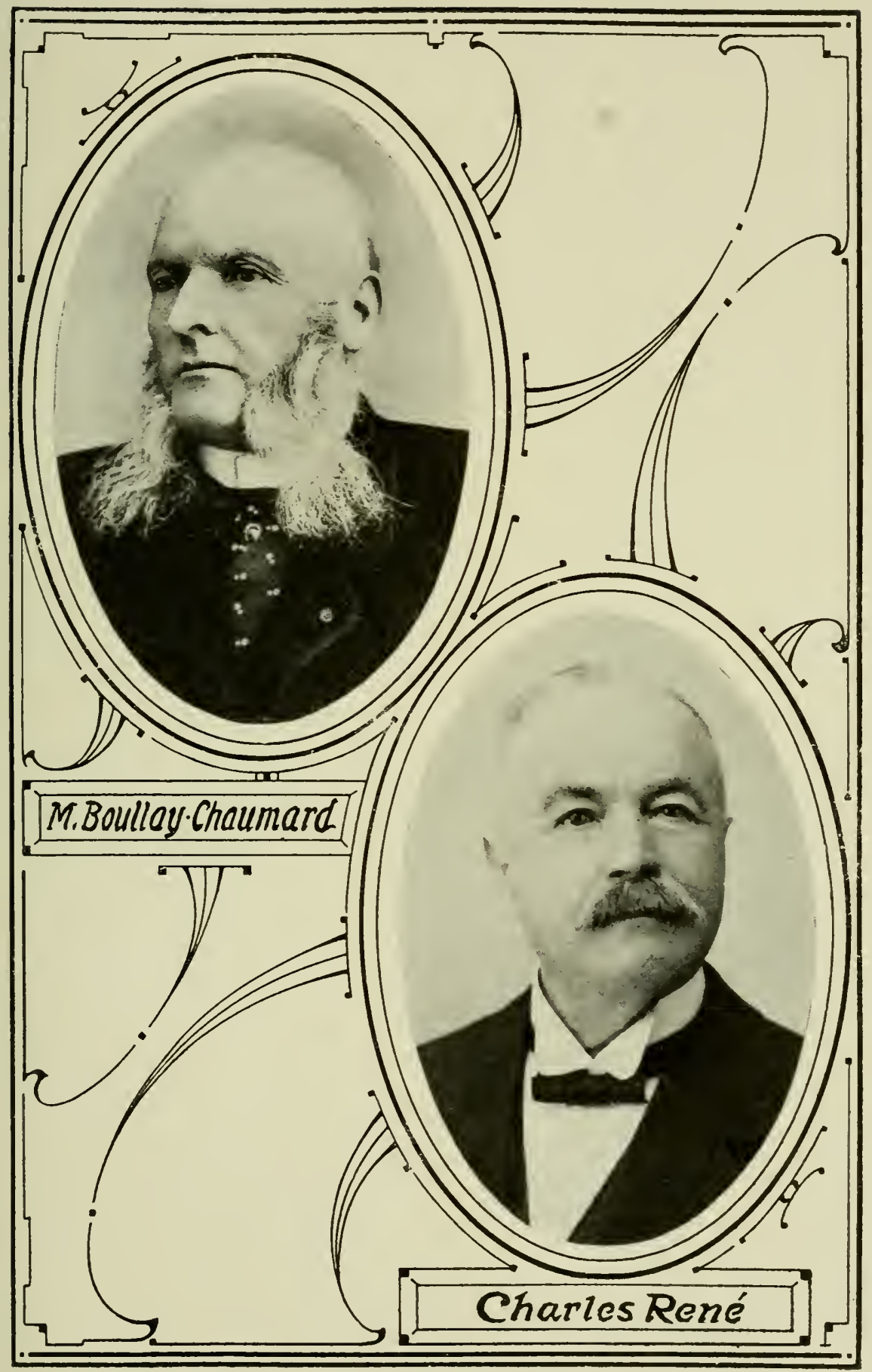

THE FIIST SECRETARY OF THE PERCHERON SOCIETY OF FRANCE (AT TOP) AND THE LONG-TERAI HONORARY TREASURER. 

tier, Corbon (Orne), Benoit, Tontay, Cottereau, Guillaumain, Dieu, Monnier, de Vasconcelles Pigeard, Marechal, Gaubert and their contemporaries contributed largely to progress in the direction of a draft type. Several of these were located in the Nogent district of Eure-et-Loir. Due credit should also be given to men among these earlier stallioners residing in that part of the Perche lying within the Department of Loir-et-Cher, such as the two Tardineaus, Ferrand and their enterprising colleagues. Some of these continued their work in this direction throughout a long series of years. However, a new school gradually succeeded them, carrying on the development of the race along similar lines, so that by the time the great American demand for still heavier horses set in the Perche was in a position through a very simple course of selection in mating to gradually evolve the ton horse of modern commerce, and this too without undue sacrifice of that vigor, soundness and quality which for generations had been characteristic of the lighter types.

Bailleau of Brunelles, near Nogent, according to the government records, appeared about 1836 with a draft horse, name not given. This stallion is described as "gris pommelé, crins blanches"-a dappled gray with white mane and four white markings, and with "flesh" or pink spots "between the nostrils." He was a good horse, first approved in 1836. It is recorded that he served as late as $\mathbf{1 8 4 5}$.

In 1837 we find record of the approved horse Grand Pierre, owned by M. Geru of Echaffour, Orne. 
This stallion was described as light gray, foaled in the year above mentioned, and approved by the government inspection of Nov. 23, 1846. There is record at the haras of his having served during the seasons of 1847 and 1848. He seems to have been displaced in 1849. Another stallion of this same period, also owned by M. Geru, was called Bijou; he was a dappled gray of diaft type, foaled in 1839 and approved in 1846. A third stallion of M. Geru was Jupiter, described as "white gray, dappled on thighs',; he was foaled in 1840, approved in 1846 , began to serve under official sanction in 1847, and on Feb. 1, 1851 was sold and taken out of the Department of Orne. Government records also tell us of a dappled iron-gray stallion Sultan, the property of M. Bailleau of Brunelles, that was approved and in service from 1847 to 1850 .

In 1844 we find the names of the two Percheron stallions Benvenuto and Democrate, both gray, in service at Nogent from the government stud at Le Pin. In 1847 there is record of 5 stallions serving in the Nogent district under a government subsidy, including a six-year-old dapple-gray owned by Count de Chamoy of Charbonnières, a five-year-old irongray and a six-year-old gray, both owned by $\mathrm{M}$. Ducoeurjoly, a five-year-old gray owned by M. Chouanard of Champeau, and a five-year-old gray which was the property of M. Baillean of Brunelles.

In 1849 a commission for the examination of stallions outside of the agricultural comice of Nogent was composed as follows: M. De Tarragon, presi- 


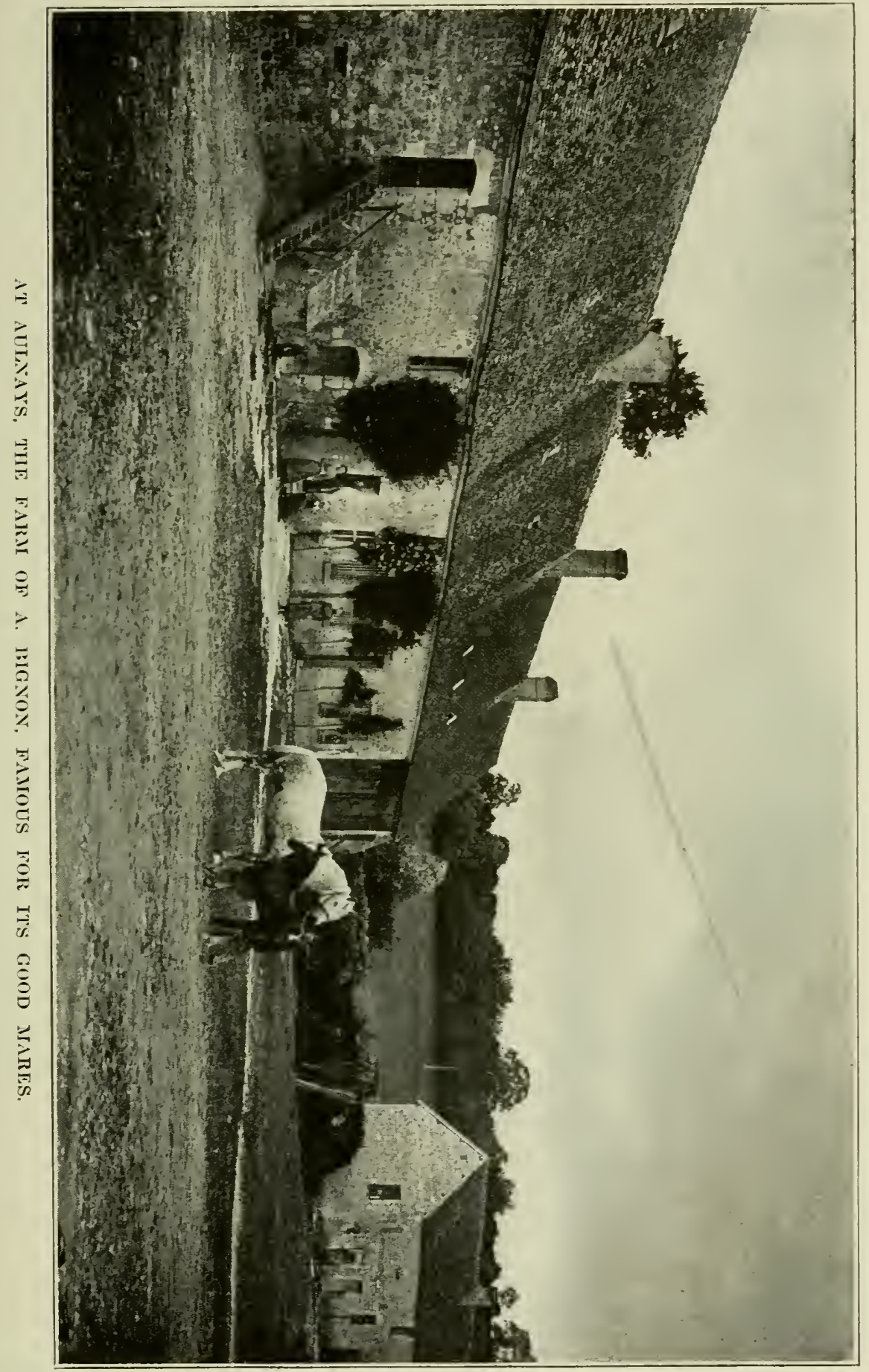



dent, M. Brissonet of Courville, M. De Poutoi, M. Etienne de Tausonville, M. Benoit, and M. Joseph Chouanard of La Touche. The statement was made by a contemporary writer that at this date "the predominant color of the Percheron breed is gray."

During this same year the local committee for the improvement of the Percheron breed awarded the following prizes: First, with 700 franes, to the stallion Collin, dapple-gray, owned by M. Ducoeurjoly; second, with 600 franes, awarded to the light-gray Brilliant, belonging to M. Viron, Chateaudun; third, with 600 franes, to Vigoureux, a light-gray horse belonging to M. Coeuret of Yèvres. In 1850 the same awarding committee gave prizes to the following stallions: Papillon, a five-year-old gray belonging to M. Sureau of St. Germain; L'Ami, a threeyear-old dapple-gray belonging to M. Chevallier of Dangeau; and LaFleur, a six-year-old gray belonging to M. Coueret of Yèvres.

M. Cheradame.-During an extended period beginning with 1845 there was no greater stallioner and breeder in the Perche than M. Cheradame of Ecouché (Orne). For more than 40 years he labored unceasingly and successfully to promote Percheron prestige and progress. According to M. Desiré Ducoeurjoly, to whom we are indebted for valuable information touching old-time breeding operations in the Perche, M. Cheradame bred chiefly the light-type Percherons-great trotters in their day. This interesting statement we have been able to confirm by examination of the government records. He also main- 
tained a few blooded horses and demi-sangs. His greatest work, however, was with his favorite Percherons. Notwithstanding the celebrity of these as fast travelers, it is important to note that while some of his approved stallions are described as "trait leger" (light draft), many others were distinctly designated as of "draft" type.

It is particularly fortunate that we have been able to gather some authenticated facts concerning Cheradame's work. While his name and fame have long been the subject of comment among later French breeders, there has been until now nothing available as to the actual material with which he worked, aside from one mere incidental reference by M. Du Haÿs, who in eulogizing Jean-le-Blanc, of which more anon, says: "He was a Percheron, a real Percheron, like the famous Toulouse of $\mathrm{M}$. Cheradame, for example."

This successful breeder of the olden days first appears in the government archives as owner of Destampes, a dappled gray, described as "de carosse"-coach horse, probably of the post or diligence stamp. This stallion was foaled in 1839 and was approved for service during the seasons of 1845,1846 and 1847.

Toulouse, "The Magnificent."'-As will presently appear, the founders of the Percheron Stud Book of France, following the lead of M. Du Haÿs, singled out for special mention alone among all the great stallions of the district that gave rise to the modern Pereheron a horse called Jean-le-Blanc, claimed to 


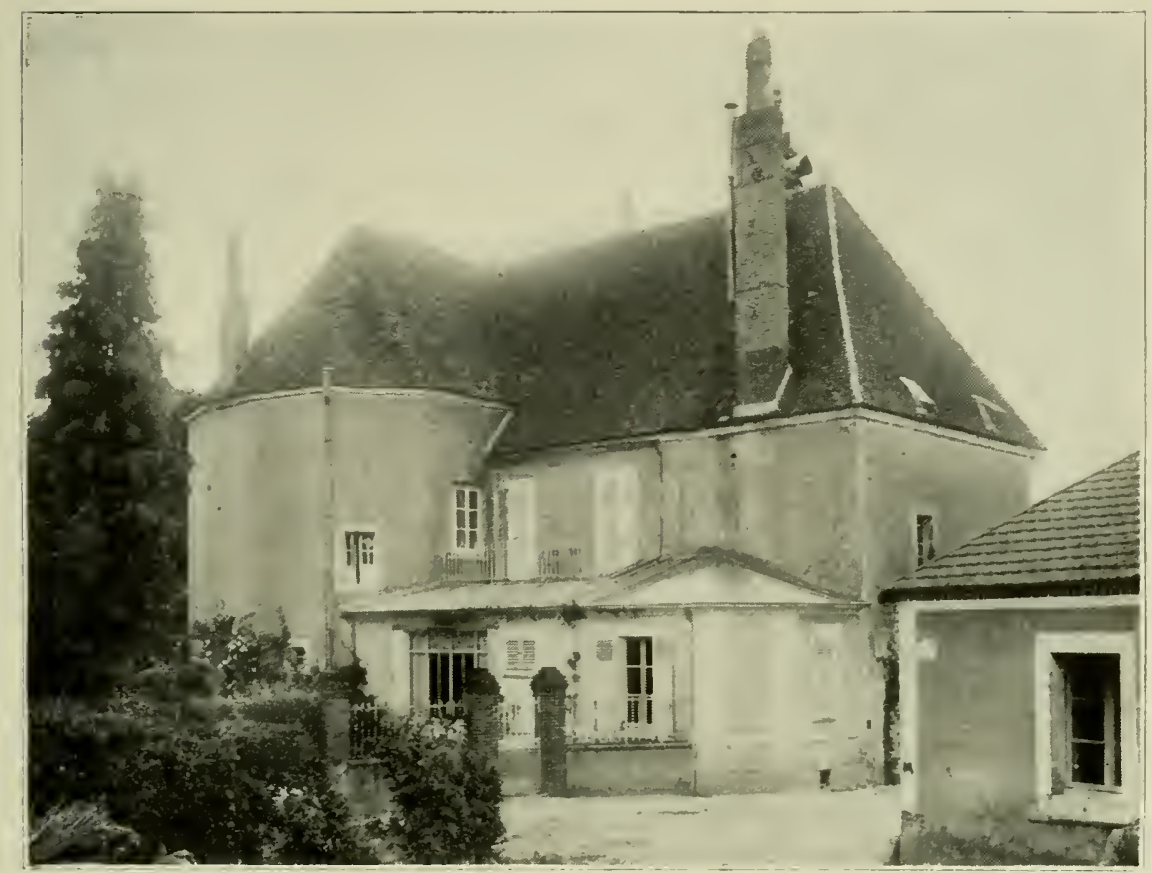

LA ROUSTIÈRE-RESIDENCE OF MIAURICE CHOUANARD, AND IN POSSESSION OH THE CHOUANARD FAMILY FOR UPWARDS OF TWO CENTURIES. THE FAMOUS STALLION KNOWN AS OLD COCO WAS BRED ON THIS FARM.

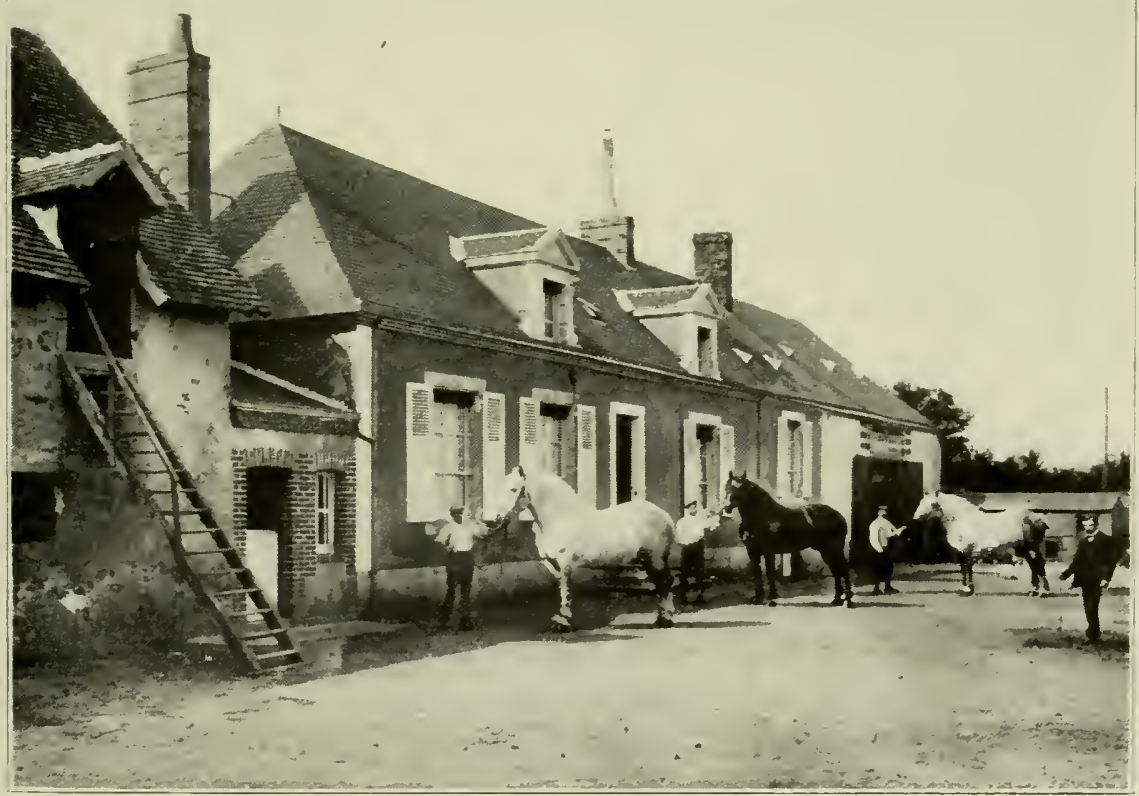

L'ARCHE-FARM AND RESIDENCE OF ERNEST PERRIOT, JR., NEAR LA FERTÉ BERNARD. 

be a direct descendant of the erstwhile "Arab" Gallipoly. As has just been stated, in placing Jean-leBlanc upon this pedestal Du Haÿs took cognizance of the existence of another "true" Percheron, "le fameux Toulouse de M. Cheradame, par example," Except for this laconic reference nothing, so far as we have been able to ascertain, has been published concerning this horse. No attempt was made to register him in the initial volume of the Stud Book of France, for the very good reason, we suppose, that no facts concerning him, not even legends, as in the case of Jean-le-Blanc, were at hand. And yet at that very time the truth was lying all untouched in the archives of the French Govermment. The facts now to be presented, therefore, will prove of absorbing interest to all students of Percheron history.

Toulouse is first mentioned (No. 162 in the Haras register at Le Pin) in an entry dated Nov. 30, 1847, at which time he was officially approved. This entry states that he was foaled in 1839 , so that it is reasonably certain that he had already seen service before being pensioned or subsidized by the government. He is described as "de trait" (draft), color "gris blanc" (light gray), with "flesh spots at the end of the nose." He began his service as a government-approved stallion in the spring of 1848 . He served during this season 60 mares, siring 42 living foals and receiving a bonus of 200 francs. In 1849 he served 58 mares with 36 foals resulting. In 1850 he had 40 mares that produced 30 foals, and in 1851 he served 44 mares. 
In the space reserved for "observations" in this original entry no particulars as to the breeding of Toulouse are given, but in 1853 we find him mentioned as a son of Sandy, whose breeding is not given, out of "an unknown Percheron mare." His height is here given as a little over 16 .hands. Farther along we find that in 1859-although he was then, it will be observed, 20 years old-he was still receiving his subsidy. Not only that, but it is particularly to be impressed at this point that whereas the custom of entering" "remarks" concerning these approved stallions had been for some years discontinued we find this extraordinary special tribute to this veteran of two decades:

"April 2, 1859-Toulouse est arrivé à la decrépitude. C'etait un magnifique étalon de trait. Bien difficile à remplacer. Je demande qu'il ne soit plus apprové en 1860."

That is to say: "Toulouse is getting worn out. He was a magnificent draft stallion. Very difficult to replace him. I recommend that he should not be approved for 1860."

Toulouse, "the magnificent," was now going the way of all flesh as no longer useful in the stud at the ripe old age of twenty years. Although apparently the greatest horse of his era in the Perche, so far as authentic records go, his very existence was scarcely a tradition as late as $\mathbf{1 8 8 3}$, the date of the founding of the stud book! Truly, once again let us reiterate, French breeders were at all times more concerned in making history than in writing it. 


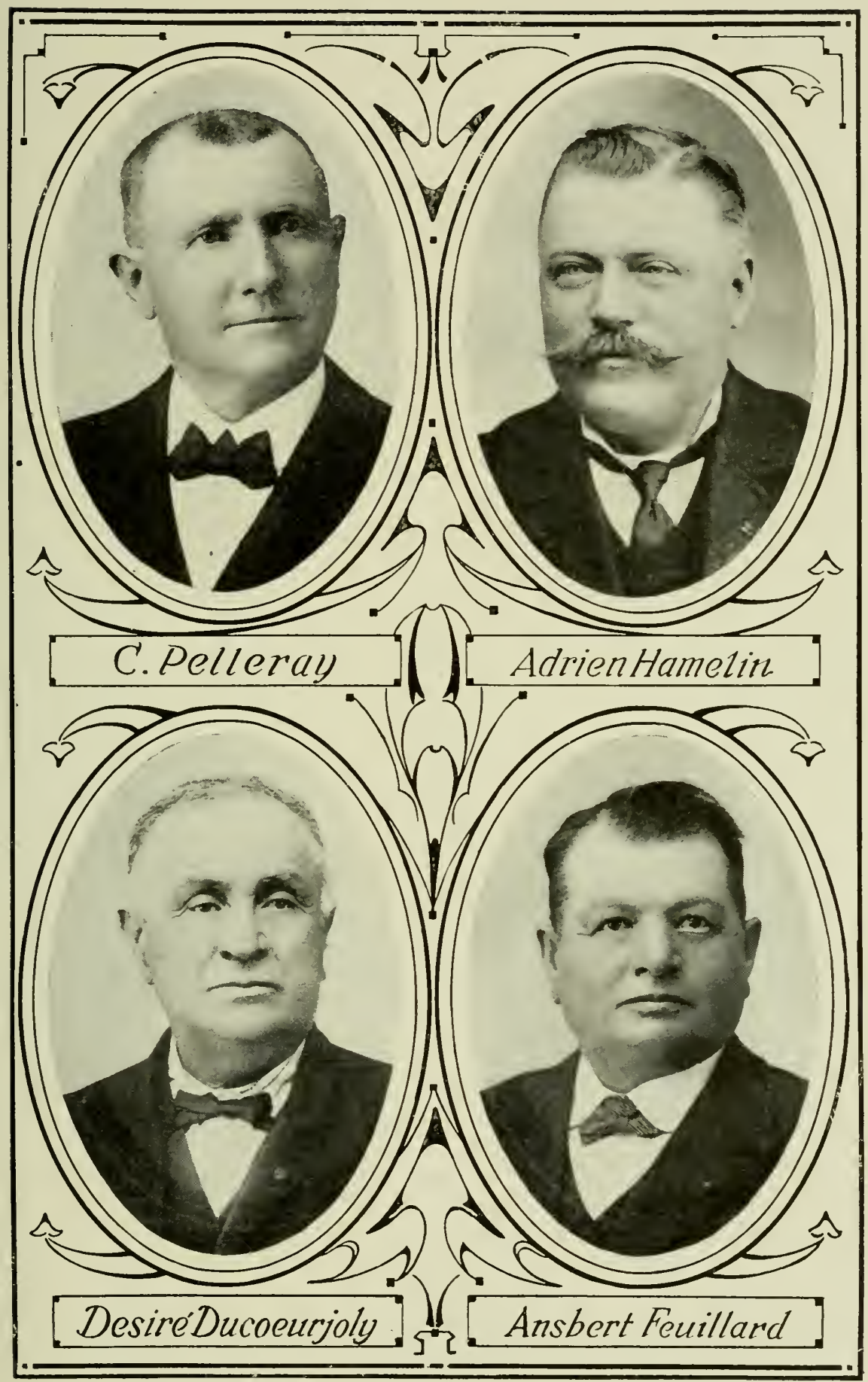



Immediately underneath the splendid isolated testimonial upon the government record is this additional entry: "1860-he has not gone yet; approved for 1860."

In spite of the inspector's reluctant recommendation of the year before the great stallion is given another year at stud! With this the record ends. To have been singled out for this almost extravagant commendation at a time when "remarks" were no longer the rule in the records is of course proof positive of the altogether exceptional character of this horse. He was 9 years old when first pensioned, and was used 13 years as an approved sire. It is probable, therefore, that this stallion served in his time as many as a thousand mares. Light-gray at an early age, old Toulouse in his later years would have been white as snow. Let us be glad of this opportunity to do tardy justice to a horse that was so honored officially in his own day and generation. It is to be regretted that we cannot do as much for Jean-le-Blanc. Indeed were it not for the apparent discrepancy in their ages, one might even suggest the possibility that in Toulouse we have the real Jean-le-Blanc. But as to this one may only speculate. It is indeed to be regretted that owing to the tardy establishment of registration facilities we cannot at this date supply the links in the chain that would undoubtedly connect up many a present day Percheron horse with Toulouse, "the magnificent."

Chocolat.-Another great horse owned by M. 
Cheradame at a later date was called Chocolat. It appears from the records that he was "de trait" (of the draft type), gray, and stood about 16 hands $1 \frac{1}{2}$ inches high. He was foaled in 1864, was approved at 6 year's old, and like Toulouse was kept in service until his twentieth year, in 1884. This long period of approval in the stud is convineing evidence of Chocolat's superior character and value as a sire. His pension from 1880 to 1884 inclusive seems to have been 300 franes.

Another draft stallion owned by M. Cheradame, and in use about 1860, was named Carnaval. There is also record of a Cheradame horse called Bon Espoir, a gray foaled in 1855, and another named Double, the latter" described as "trait leger" (light drafter), a gray standing 16 hands that served as an approved sire from 1880 to 1884 inclusive. Still another under the same ownership was Lilas, also a. light drafter, gray and 15.3 hands in stature. Lilas served from 1880 to 1883 inclusive.

The Ducoeurjolys.-Contemporaneons with Bailleau and the early work of Cheradame we find Ducoeurjoly (Jacques Francois) of Condreau, district of Nogent, begimning as an owner of approved stallions .with Collin, a celebrated horse already mentioned. Collin was a little over 16 hands high and was described as "an iron gray (gris de fer pommelé) draft horse with two white feet, born in. 1842 and approved Nov. 23, 1846." This horse served as an approved stallion for 4 years from 1847 to 1850 inclusive. Another horse, unnamed, 


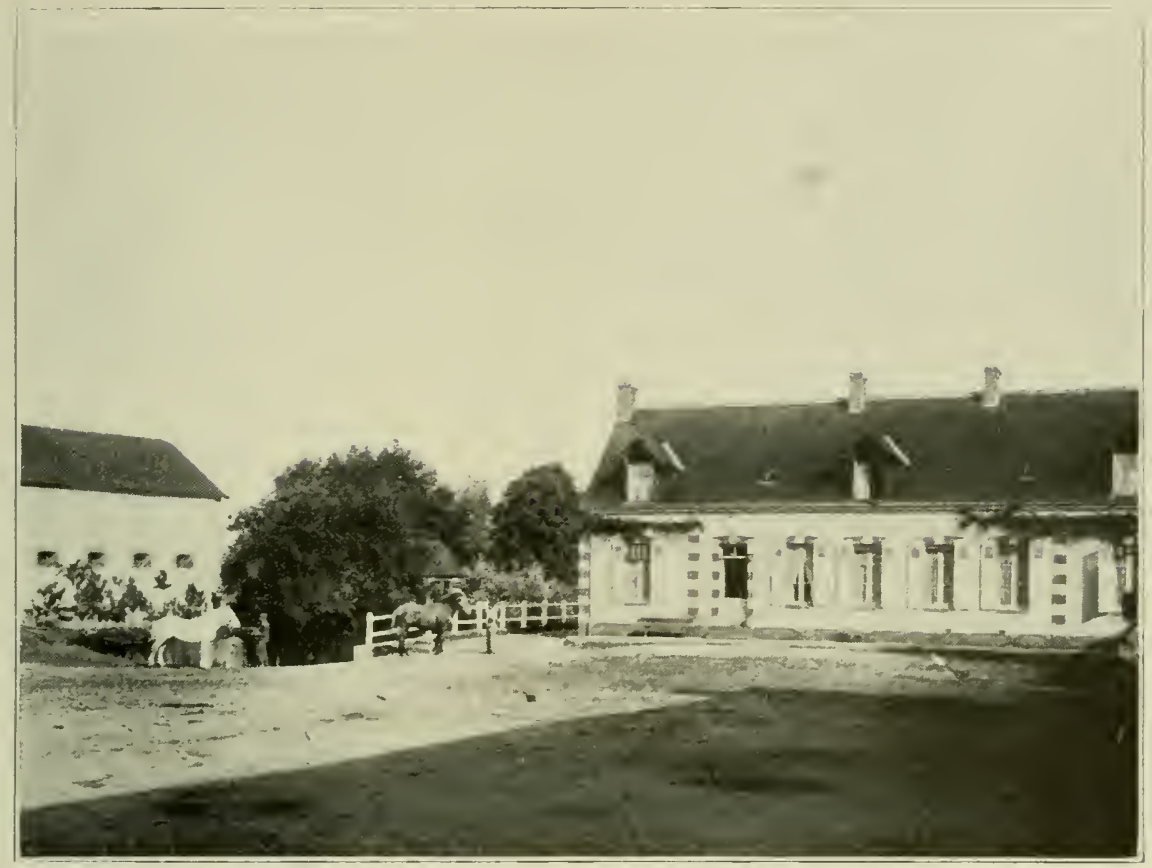

LA PELLOIS- BREEDING FARMI OF A. TACHEAU, NEAR LA FERTÉ BERNARD.

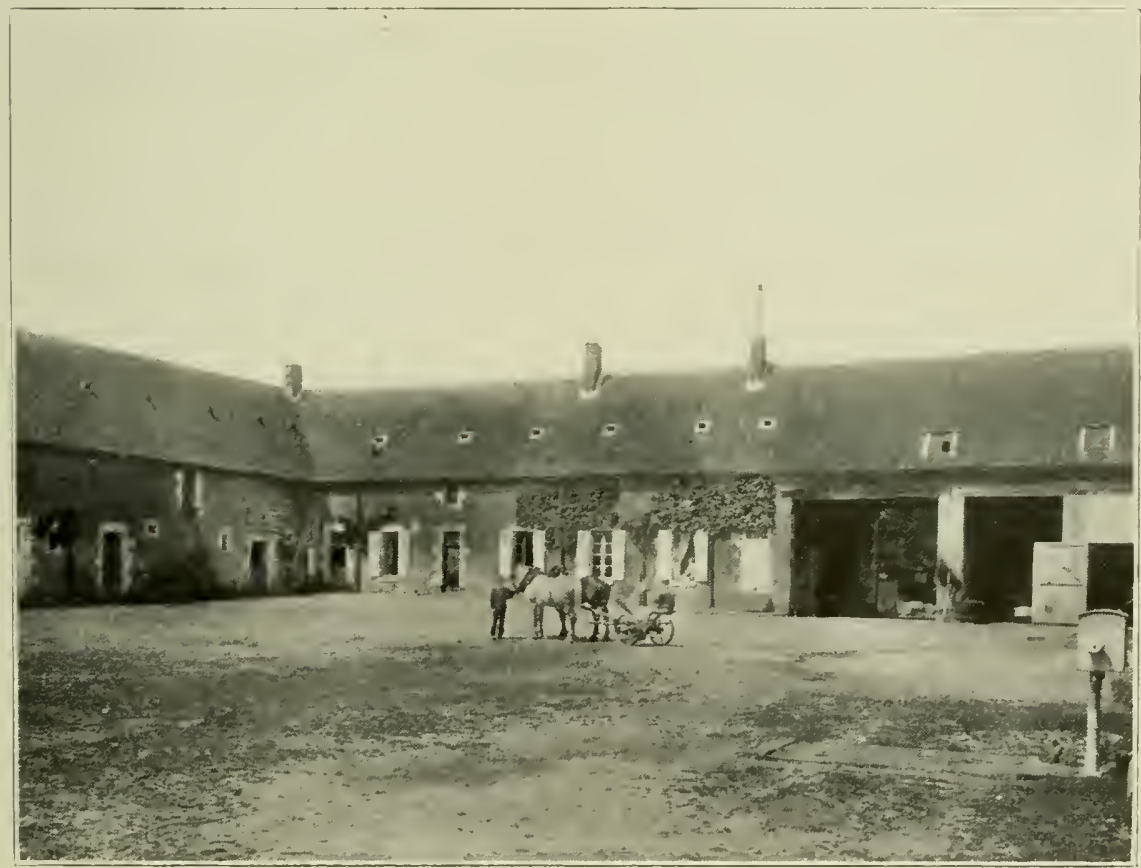

FARII OF M. JOS. AVELINE, DORCEAU. 

belonging to M. Ducoeurjoly, foaled in 1841 and approved Nov. 23, 1846, served 2 years.

The Ducoeurjolys always have been highly esteemed as good breeders and keen judges of animal form. However, they have never gone into the business so extensively as their aptitudes and knowledge of Percheron breeding would warrant, simply because they always have adhered to their vocation as "cultivators"-farmers as well as breeder's. Speculative dealing in colts has never attracted them. They have preferred to breed some of the very best, till their land and sell simply their own surplus animals. This is one of the few farms in the Perche where a good-sized flock of sheep has been profitably kept. We find several of the Ducoeurjoly horses mentioned as approved stallions in the early days and the celebrated old prize-winning mare Pauline (279) was their property. She was foaled in 1869 and won 12 prizes at the leading shows at different periods. The present Desiré Ducoeurjoly has attained high reputation both with mares and stallions.

Pelletier.-Another stallioner of importance in the ante-stud book days was Theodore Pelletier, probably related to the other Pelletier mentioned in our earlier chapters. He lived at St. Julien-sur-Sarthe, Orne. This locality is a great mare country at the present date.

Credited to Pelletier we find Colin, "son of Colin and out of an unnamed Percheron mare." The sire Colin was probably the Collin or Colin of Ducoeur- 
joly. 'This horse was describer as a "draft stallion of very good model; a good breeder, an impressive sire that begets excellent post horses; many of his male colts have been exported." He served from 1859 to $1862-4$ years. The first 2 years his pension was 300 francs, and the 2 latter years it was 400 franes. Pelletier owned another horse named Vulcain about the same period. He also had Nogent, a 16.1-hand gray that served during 1863 and 1864 . After the death of M. Theodore Pelletier we find a "light draft stallion, gray, 16 hands," entered as the property of "Widow Pelletier," St. Julien-surSarthe. This horse began serving in 1880.

Moisand.-About this time also we hear of Moisand, "Director of the Societé Hippique Percheronne," Chateaudun, Eure-et-Loire. From his town and district, a great grain-growing region, formerly came many Percheron horses, but since the inauguration of the French stud book foals born in the district are not eligible for entry. Judging from the pensions awarded to M. Moisand he owned many good stallions. Mina, a black-gray, nearly 17 hands high, foaled in 1858, served from 1862 to 1868; his pension, beginning at 500 franes, was raised to 650 francs. Moisand also had Coco, 16 hands high, a black-gray that served from 1862 to 1864. Another stallion of Moisand called Priape, served during the same period and was also a dark-gray. Moisand also had a horse called Pamphile, dappled gray, that served from 1863 to 1869 , and another named Sandy, foaled 1856, that served during 1866 and 


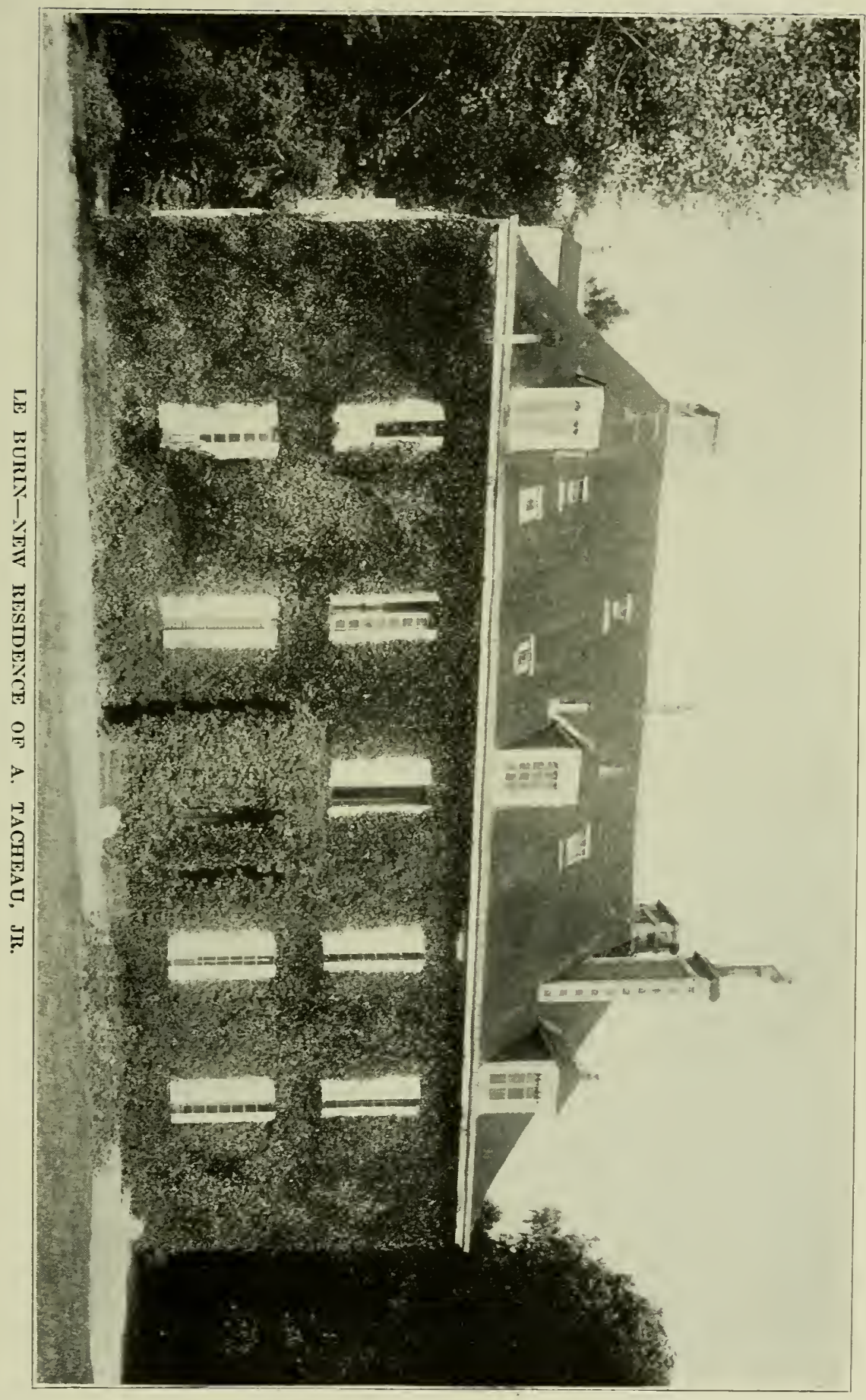



1867. Still another of his approved stallions was named Porthos.

Jousset and Mitau.-Beginning about 1870 we find that a certain Jousset, commune of Colimer, district of Mortagne, had several approved horses. M. Mitau of Essay, district of Alençon, had 2 approved stallions during the same period. Jousset had Briliant, described as "light draft" and 16 hands high, that served from 1880 to 1883. Mitau was still active in the business as late as 1890, at which date he owned the approved stallion Volta.

Old Records Brought to Light.-In 1851 we find trace of a six-year-old dapple-gray stallion named Henri, which was in stud around Mortagne, and others as follows: Decembis, 7 years old, in sorvice at Illiers; Bayard, "red-gray," 4 years old, at Mortagne; Chappelain, light-gray, 7 years old, at Courtalain; Mi Careme, dapple-gray, 6 years old, at Montdoubleau; Collin, dapple-gray, 8 years old at Nogent. At this same time there were also in stud at Nogent the following: Bienvenu, dapplegray, 6 years old; Nell, dark-gray, 6 years old; Courville, iron-gray, 4 years old; Laigle, dapple-gray, 4 years old; Collin, dapple-gray, 4 years old; Illiers, dapple-gray, 5 years old.

In 1852 we find the names of two more government stallions in service in the district of Nogent; Chartres, dapple-gray, 7 years old, and Voniche, dapple-gray, 7 years old. In 1854 the stallions depot of Nogent was dependent upon the stallion depot of Blois (Loir et Cher) instead of Le Pin (Orne). On 
the 17th of November, 1854, the council general of Eure-et-Loir voted a sum of $\$ 2,000$ to be given for more shows to be held and offered premiums for best stallions and mares. The prizes for mares ranged from $\$ 80$ up to $\$ 160$, and a stallion could attain up to $\$ 400$. The stallion show was to be held at Illiers, and the mare shows at Illiers, Courtalain and Nogent-le-Rotrou. The stallion show was held at Illier's on the 18th of November, 1855, and premiums were awarded as follows: First to Colin, belonging to M. Dorchêne of Nogent; second to Charbonnières, belonging to Count of Chamoy ; third to Laigle, belonging to Duke de Montmorency; fourth to General, belonging to Madame Chevallier of Dangeau. Three other stallions were given prizes: Papillon, dapple-gray, 6 years old, belonging to M. Pangoné of Cloyes; LaBelle, dapple-gray, 9 years old, belonging to M. Loride of Bonneval, and Colin, white, 15 years old, belonging to M. Penelle of Courtalain.

In 1856 the stallion depot of Blois sent to the Nogent station of stallions a horse named Bayard. In 1857 there was sent from the same depot the stallions Nelle and Ramon.

A mare show was held at Courtalain on the Sth of June, 1857, in which 2,200 franes were given to the best brood mares. The first preminm with 800 francs cash was given to Cocotte, a dapple-gray 7 years old owned by M. Roger of St. Pellerin. On the 12th of July, 1857, a big mare show was held at Nogent-le-Rotrou. It is interesting to note the names 


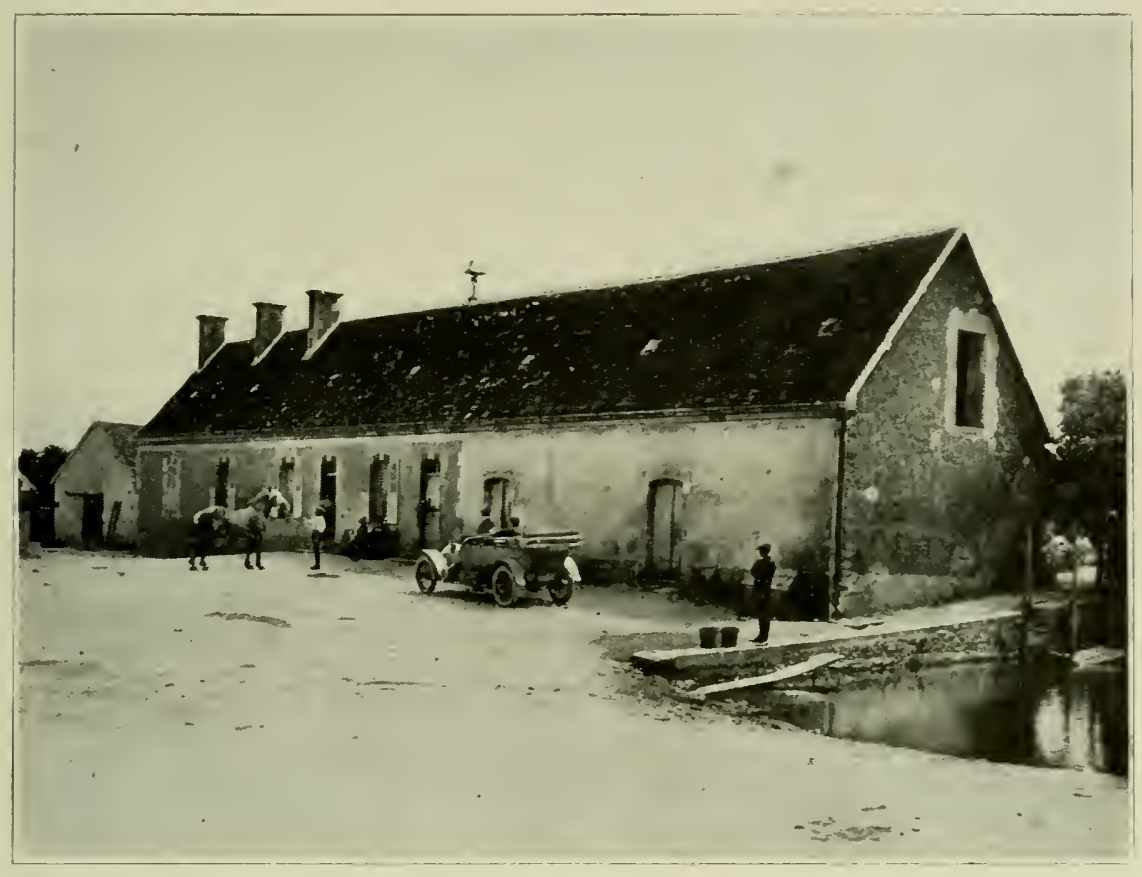

LA PLESSIS-FARII OF A. CHAPPELS.

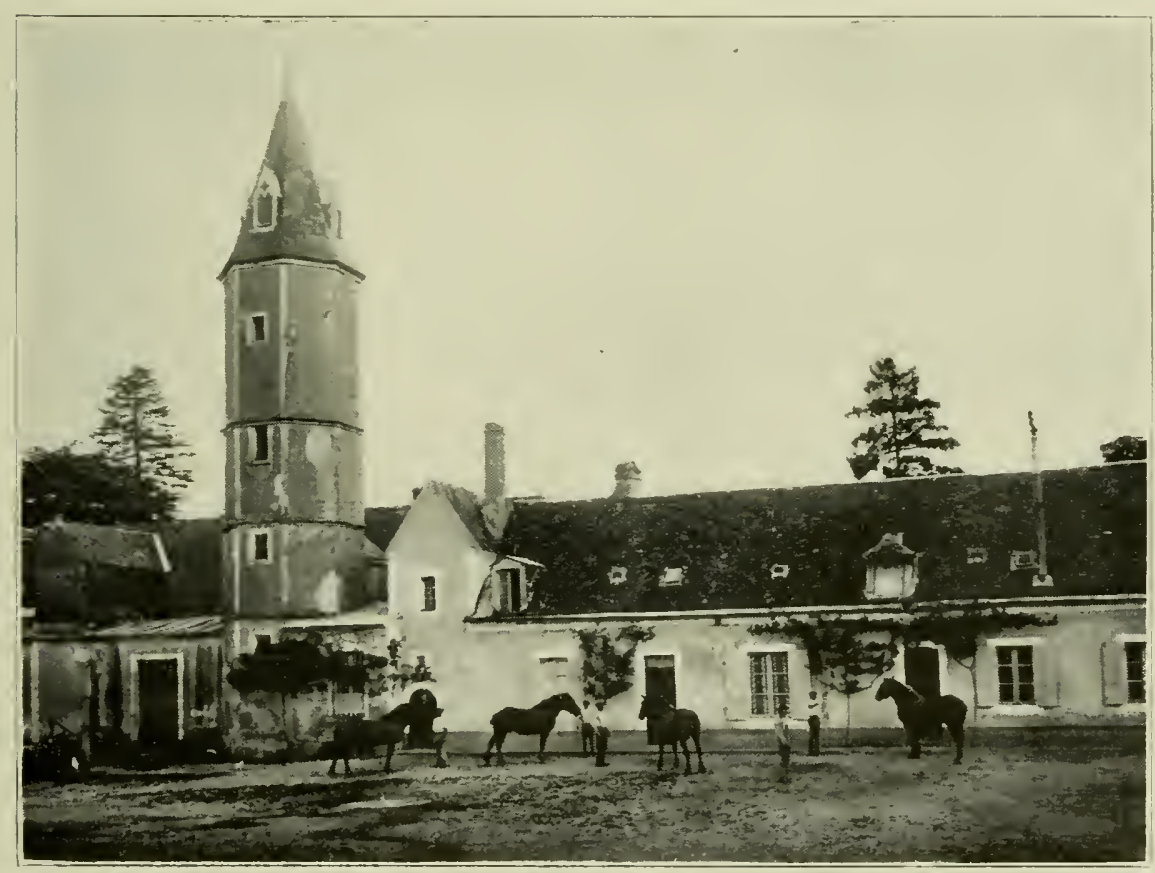

LA BOURDONNIÈRE, FARM OF M. THIBAULT. 

of the farmers who then kept the best brood mares in that district. The premiums were awarded as follows: First to Cocotte, belonging to M. Ducoeurjoly of Brunelles; second to Pelotte, belonging to Nicolas Glon of Souancé; third to L'Hermine, belonging to Durand of Souancé; fourth to Margot, belonging to Jean Glon near Nogent; fifth to Vigoureux, belonging to Bailleau of Illiers; sixth to Rosalie, belonging to Guillot, La Gaudaine; seventh to Rustique, belonging to Bouillon of Nogent.

A worthy gentleman, the Count de Chamoy, was keeping at this time a big stud at his farm of Charbonnières near Authon, about 15 miles from Nogent. He did great good in his neighborhood; he kept highclass stallions, among the most celebrated being Charbonnières, Eure-et-Loir and Decidé. Charbonnières was foaled at Charbonnières in 1851 and was out of Neel, by Dagobert, dam La Meuniére.

A stallion show was held at Illiers on the 16th of November, 1857 . Of 30 stallions shown 5 were given premiums and 8 were approved as follows: First premium with 1,400 francs to Sandy, belonging to M. Lahaye of Chateaudun; second to Pierrot, belonging to Count de Chamoy; third to Colin, belonging to M. Dorchêne of Nogent; fourth to Cliarbonnières, belonging to Count de Chamor; fifth to Bibi, belonging to M. Lahaye. The stallions approved were: Decidé, belonging to Count de Chamoy; Lamy, belonging to M. Maillard; Fbéne, belonging to H. de Chabot; Pierrot, belonging to Mme. Sauton; General, belonging to Mme. Chevallier; Lamy, be- 
longing to M. Baret; La Poule, belonging to M. Sédillot, and La Biehe, belonging to M. Gatineau of Beaufrancois.

In 1858 the imperial depot of stallions of Le Pin, to which the district of Nogent had now been joined, again sent to the station of Nogent for the 1858 stud the stallions Mortagne, Pionnier and Pausanias. On the 18th of July, 1858, a big mare show was held at Nogent-le-Rotrou, and we find the following awards:

First premium with 600 francs to Robine, belonging to M. Ducoeurjoly of Condreceau; second premium with 500 franes to Georgette, belonging to M. Ducoeurjoly of Brunelles; third premium with 500 franes to Belly, belonging to Count de Chamoy; fourth premium with 400 franes to Sophie, belonging to Guibert de Souancé; fifth premium with 400 francs to La Grise, belonging to Glon de Etillenx; sixth premium to Pelotte belonging to Richardeau de Souancé; seventh premium to Belotte, belonging to Lesieur of Sonancé; eighth premium to Chaton, belonging to Dordoigne of Brunelles; ninth premium to Sophie, belonging to Count de Chamoy.

In the same year we find in the old records the names of these celebrated stallions: Collin, belonging to M. Dorchêne; Agricole, belonging to M. Enault; Sandy, belonging to M. Pelletier; Vaillant, belong to M. Lenfant, and Voltaire, belonging to M. Perpere.

In May, 1858, there was a show at Alençon (Orne). In the awards we find the names of the following 
stallions: Ebene, 7 years old, property of Count de Chamoy; Charbomières, $\tau$ years old, property of Count de Chamoy; Couronne, 5 years old, property of Louis Chouanard of Margon; Lafleur, 3 years old, property of Desvaux of Courville; Colin, 6 years old, property of M. Dorchêne of La Gaudaine; Beaufrancois, 6 years old, property of M. Gatineau, and Sandie, 4 years old, property of M. Lahaye of Chateaudun.

In the mare class at same show were: Albertine, 4 years old, Seduisante, 6 years old, Brillante, 6 years old, and Grisette, 4 years old, all belonging to M. Joseph Chouanard of La Touche; Cocotte, 6 years old, and L'Amie, 7 years old, belonging to M. Ducoeurjoly of Brunelles; and Mina, 3 years old, owned by M. Gannier of Beaumont les Autels.

Another big show was held at Alençon in 1865. M. Cheradame of Ecouché had an extra 30-monthold gray colt named Lacour by Bon Espoir. He had also Picador, a splendid gray, and Carnaval. M. Guillemin of Coudray, near Nogent, won first prize in the brood mare class. Second prize was awarded to M. Vaux of St. Quentin de Blavon (Orne). M. Miteau of Aunay les Bois was third. M. Guillemin's mare also won the colors at the Universal Exhibition of Paris (1867).

In 1865 we find in old records the names of many of the breeders living at that time. In the district of Mortagne were Messrs. Guimond, Caget, Bignon, Provot, Pelletier, Chantepie, Desclos, Vallee, Olivier, Dujarrier, Vadé, Vaux, Perpere and Fromentin. Tn 
the district of Bellême were Messrs. Jamois, Chapelle, Segouin and Morin. In the district of Le Theil were Messr's. Bajon, Therin and Count de St. Pol. In the district of Regmalard were Messrs. Fardouet, Debray, Charpentier and Aveline. M. Simon had his stud station at:St. ,Lambert near Trun (Orne), and had owned the celebrated stallions Dagobert and Farmer.

In 1865 also we find the following names of breeders in the Nogent district: Messrs. Adolphe Chouanard of La Touche, Le Marié, Louis Chouanard of Champeau, Gasselin, Dorchêne, Glon, Neveu, Ducoeurjoly, Dordoigne, Vadé, Guillemin, Gaulard, Count de Bezenvah, Gannier.

To finish with the old records let us mention a show which was held at Chartres from the 1st to the 9 th of May, 1869. In the three-year-old class we find the names of the following stallions: Introuvable, belonging to M. Lallonet; Beaufrançois, belonging to M. Gatineau; Cheri, belonging to M. Fardouet; Mylord, belonging to M. Moisant; Monarque, belonging to M. Caget; Roland, belonging to M. Moisant; Cheri, belonging to M. Caget; Coco, belonging to M. Vinault; Chouanard, belonging to M. Desclos; Coquet, belonging to M. Maillard; Paul, belonging to M. Fardouet; Jean Bart, belonging to M. Perpere; Vulcain, belonging; to M. Pelletier, and Lacour, belonging to M. Cheradame.

Fardouet and Caget.-While these records could be multiplied, it scarcely seems necessary to prolong details of this character indefinitely. The point 


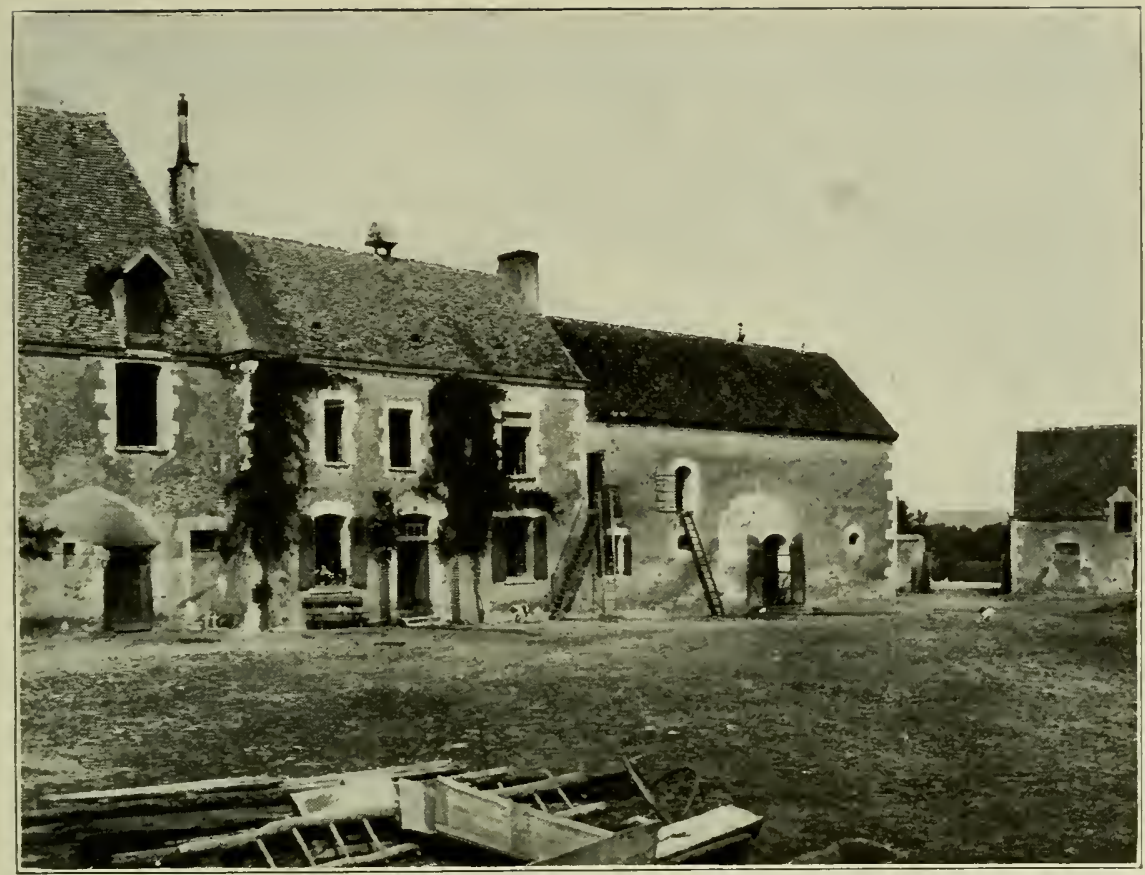

LE BOIS JOLY, FARII OF THE LATE II. FARDOUET, FIRST PRESIDENT OF THE PERCHERON SOCIETY OF FRANCE.

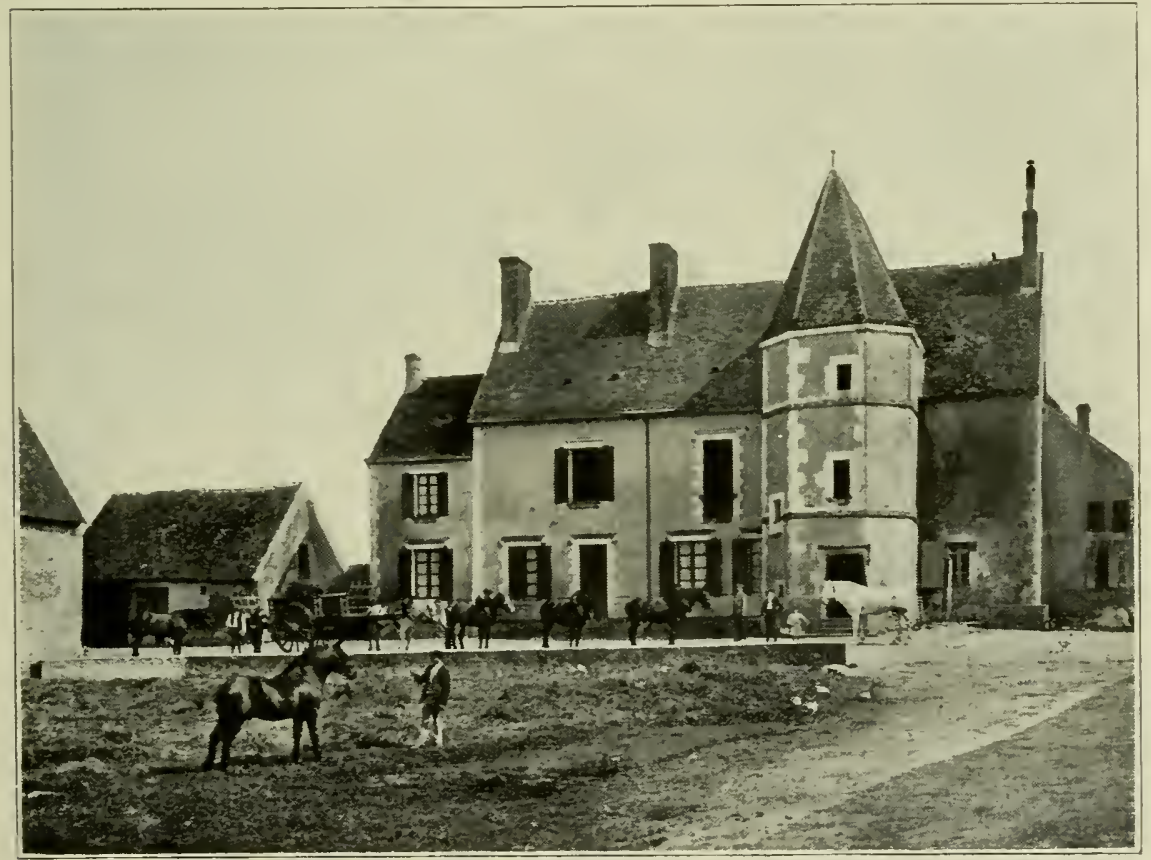

LA GRAND CHAMIPROND, FARM OF L. MOULIN. 

to be established is that prior to the founding of the stud book the same persistent government-supervised work in the interest of preserving Percheron integrity, as related in preceding chapters, was continuous, even though no published pedigree record was maintained. At this point, therefore, we shall only record further the fact that two of Cheradame's greatest contemporaries and successors in developing Percheron character were MM. Fardonet and Caget, both of whom left a legacy of inestimable value to France and America as a result of their labors. Here again we are able to supply government data until now not appearing in published records.

Michel Fardouet.-M. Fardonet's farm of La Benvrière was situated in the commune of Verrières in the department of Orne. His first approved stallion was Madere, foaled in 186.2. This horse served as a pensioned stallion, and had notable place in the Percheron annals of his time for several reasons. In the first place, he was a big horse standing 17 hands. In the second place, he was black. And most important of all, he served as a subsidized stallion in the Perche for a period of 14 years, from 1867 to 1879 inclusive. Here, therefore, is one prolific source of size and of the color that subsequently became for a time so popular in America.

Another good Fardouet stallion of this era was the gray Bon Espoir, foaled in 1862. He had government endorsement, as did also Bayard, a stallion that rendered good service during 1873 and 1874 . 
In 1879 M. Fardouet had Vermouth 2d, a big, good gray that served during that season 98 mares. M. Fardonet's later breeding operations may be studied from the French and American stud books. He became the first president of the Percheron Society of France, and it should be borne in mind, as illustrating the high quality of his stock, that the celebrated stallion Vidocq 483 (732), imported by M. W. Dunham in 1874, was for several years at the head of the stud at La Beuvrière. As to the type of the Fardonet stock it may be said that the horses were perhaps not so heavy-boned as those to be found elsewhere, but they were usually distinguished for their fine finish and good action.

During his long and honorable career no man had more approved or pensioned stallions than Michel Fardonet, who was succeeded by his son Alphonse of Le Bois' Joly, near Nogent.

Celestin Caget.-Clearly one of the ranking breeders of his time in the Perche was M. Celestin Caget. He had two properties, one at Medavy in the Mortagne district of Orne and another at St. Scolasse in the district of Alencon.

In 1870 Caget had 3 approved stallions, at least one of which, the famous old Selim (749), bred in Orne and foaled in 1866, was one of the best horses of his day. The official record reads: "Selim, fine draft horse, great depth of chest, good in shoulders, good loins, fine action." Again in 1872 Selim is referred to as "a good Percheron, well built, near' the ground." This horse was in service for 8 years 


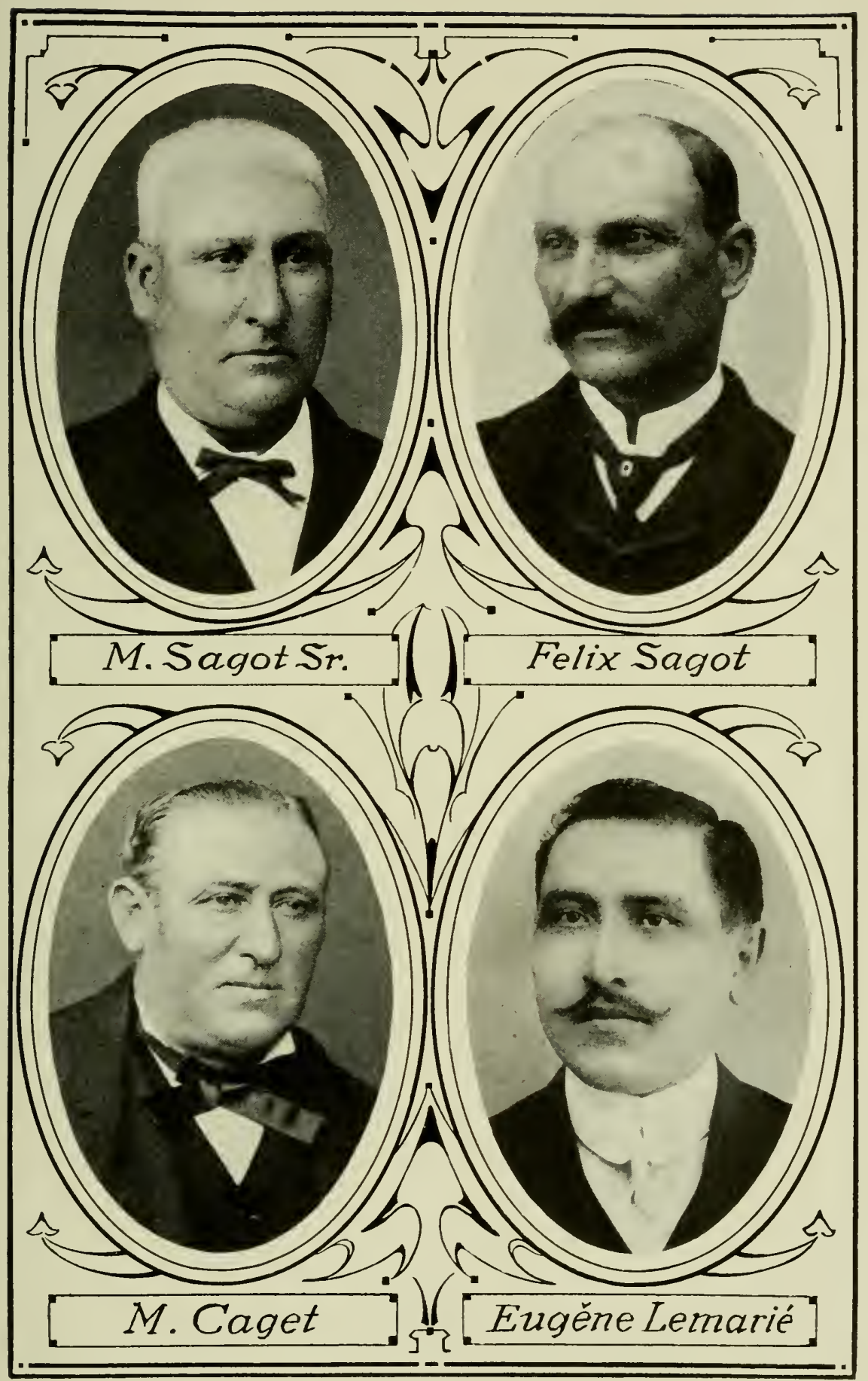



as a pensioned stock-getter. In $1885 \mathrm{M}$. Caget had 6 approved stallions, including the noted Romulus, dappled gray, about 16 hands high, afterwards sold to Mr. Dunham; Vautour, light gray, 16 hands high; Cheri, dappled gray, 16 hands high; and Madere, Voltaire and Picador, all grays. In 1887 Caget had 4 stallions pensioned-Porthos, Eveillè, Cheri and Madere.

Contemporaneously, in part, with the work of Caget pere is that of his son, Modeste Caget. The records show that pensioned stallions were owned by father and son throughout a period of full 30 years. M. DeLange of Alménèches, Orme, a son-inlaw of the elder Caget, was also a stallioner of good repute.

The Chouanards and La Touche.-The beautiful farm belonging to the late and much-regretted Charles Aveline, the farm of LaTouche near Nogent, has been for nearly a century the residence of the Chouanard family. M. Charles Aveline leased the farm in 1894, and bought it some years later. From the year 1820 to the year 1894 the Chouanards, at least one branch of the family, lived there. The family was numerous, and its members hold a prominent place in Percheron history. In fact, the name is still in evidence today, Emile Chouanard, Jules Chouanard, Charles Chouanard and Paul Chouanard still maintaining the reputation of their ancestors. To M. Paul Chouanard we acknowledge our indebtedness for some of the interesting facts herein chronicled. 
The Chouanard family originally came from the west of France, from Cholet, in the department of Maine-et-Loire. The first of the name of which we have record were cattle dealers and used to sell at the Paris cattle market, then at Poissy. This was long before the railways, and they sent their cattle by the road on foot to market. Their way was through the Perche, from Cholet to Paris, and during their numerous trips through the district they were attracted by the surrounding's, and decided to settle there. We find trace of a Chounanard (Joseph René), born in 1767, who died in the Perche in 1815, at Bretoncelles, about 12 miles from Nogent, where he had a farm. He left many children, and his first two sons were the ancestors of the Chouanards of today. One of his sons, Louis Chouanard, resided at the farm of Champeau near Nogent, and was the owner of some celebrated stallions. His brother, Joseph Chouanard, was the first Chouanard to live at La Touche. He leased the farm in the year 1820, and was known as Chouanard de la Touche, as his brother Louis was known as Chouanard of Champeau.

Joseph Chouanard was a man of strong character and good judgment. He was miversally esteemed, and was considered one of the highest authorities of his day on horse breeding. In fact, he was often called to judge at shows or to act as referee. He probably was the greatest mare man of his time in the Perche. He had a long career, quitting the farm in 1863 and retiring to Nogent, where 


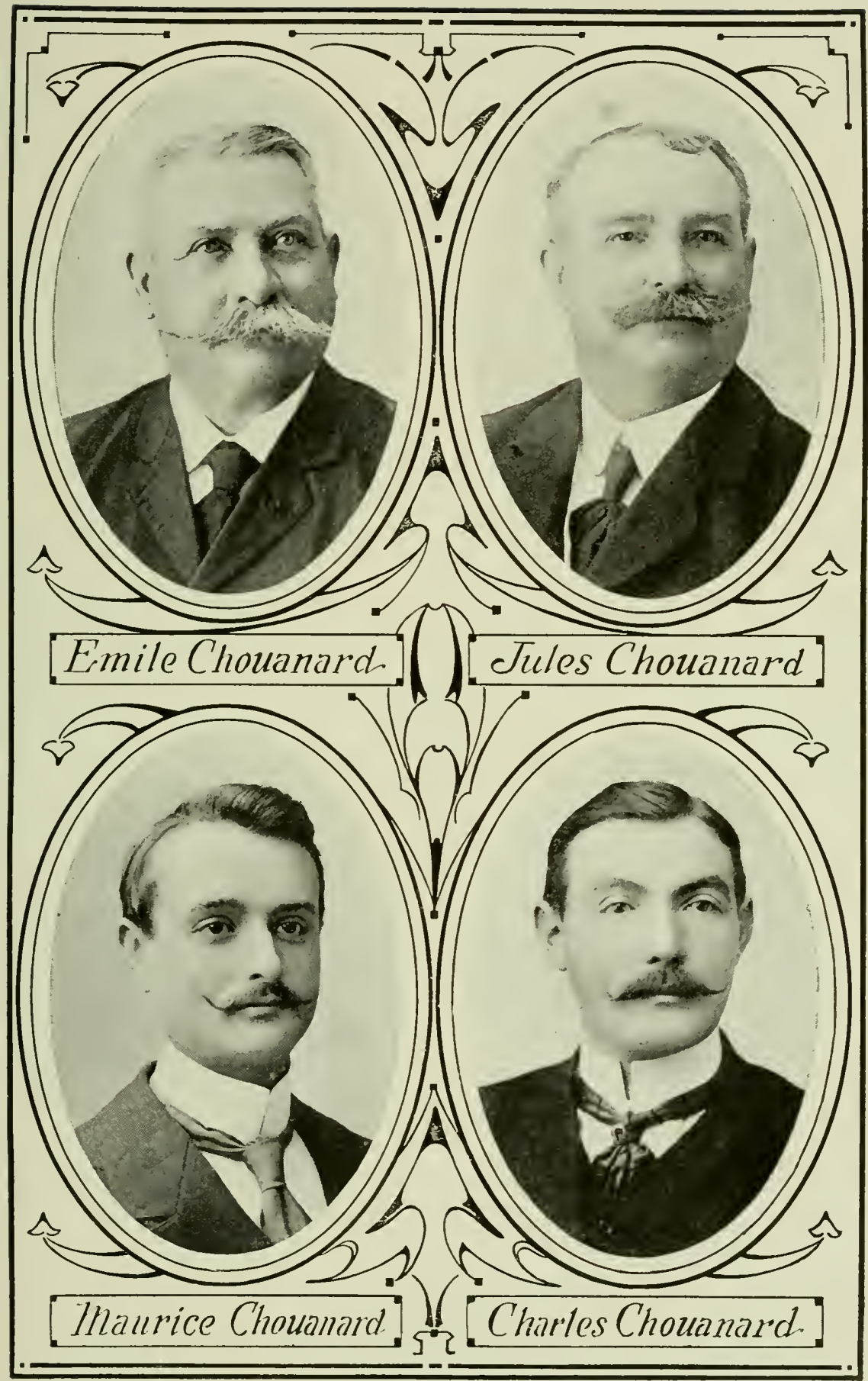



he died in 1876. His son, Adolphe Chouanard, succeeded him at La Touche in 1863.

Adolphe Chouanard was a mare man also and did an extensive business, especially with the Paris trade. When the first American buyers came, Adolphe Chouanard adapted his trade to the demands of the importers and La Touche was supplied with stock of all ages to suit the demand. Adolphe Chouanard did a large business with the first American importers. At the first show held by the Percheron society at Nogent in May, 1884, he won first prize with the famous mare Degourdie (2346) and sold her for $\$ 2,300$ to George E. Case of Minnesota. This was a great mare, quite white at 5 years old, with a wonderful body, great bone, and a very long arched neck. In the years 1886 and 1887 Adolphe Chouanard had more than 130 Percherons of all ages on hand, so that La Touche was one of the headquarters for the American trade, ranking in this respect with the great farms of Angust Tacheau, Sr., and of Colas of Beaulieu, other leaders of their time.

After the panic of the early '90's Adolphe Chouanard left La Touche, and in 1894 the farm changed hands, soon afterwards becoming the property of Charles Aveline.

The Perriots.-The records of Percheron progress in modern days in France hold no name wholly comparable with that of Perriot. Although this fact is largely due to the extraordinary achievements of the brothers Louis, Ernest and Albert, and Louis' 
son Edmond, their forbears were recognized as among the foremost breeders of the Perche. Perriot pére was born in 1810, and died in 1874 .

At the time when the great American demand first set in prior to 1880 the three brothers, known as Perriot d'Amilly, Perriot de Chênelière and Perriot de Champeau, were comparatively young men, and while all were recognized as close judges of a good horse, Mark W. Dunham was wont to credit the younger brother Albert with being the shrewdest of the three. He often put it like this: "Whenever they went out together picking up colts it would inevitably be found when they were divided up that Albert had the best ones." Be this as it may, they were a most remarkable trio, and in the great days that followed sold more high-priced horses for export than all of their contemporaries combined. Unfortunately Albert died at an early age in 1879, his decease being universally regarded as a real calamity to the district. It was from Albert that Mr. Dunham bought Africus (862), Bayard (717), Margot d'Amilly (795), Duke of Perche (740), Favora (725) and Superior (730).

The elder brother Louis was born in February, 1835, on his father's farm of Amilly, in the commune of Condeau, Orne, where he remained until as a young man he went to live with his grandmother, the grandfather having died. In 1859, as a young married man, he began his long and successful career as a breeder of horses of the best Percheron type on the farm known as Champeaux, 


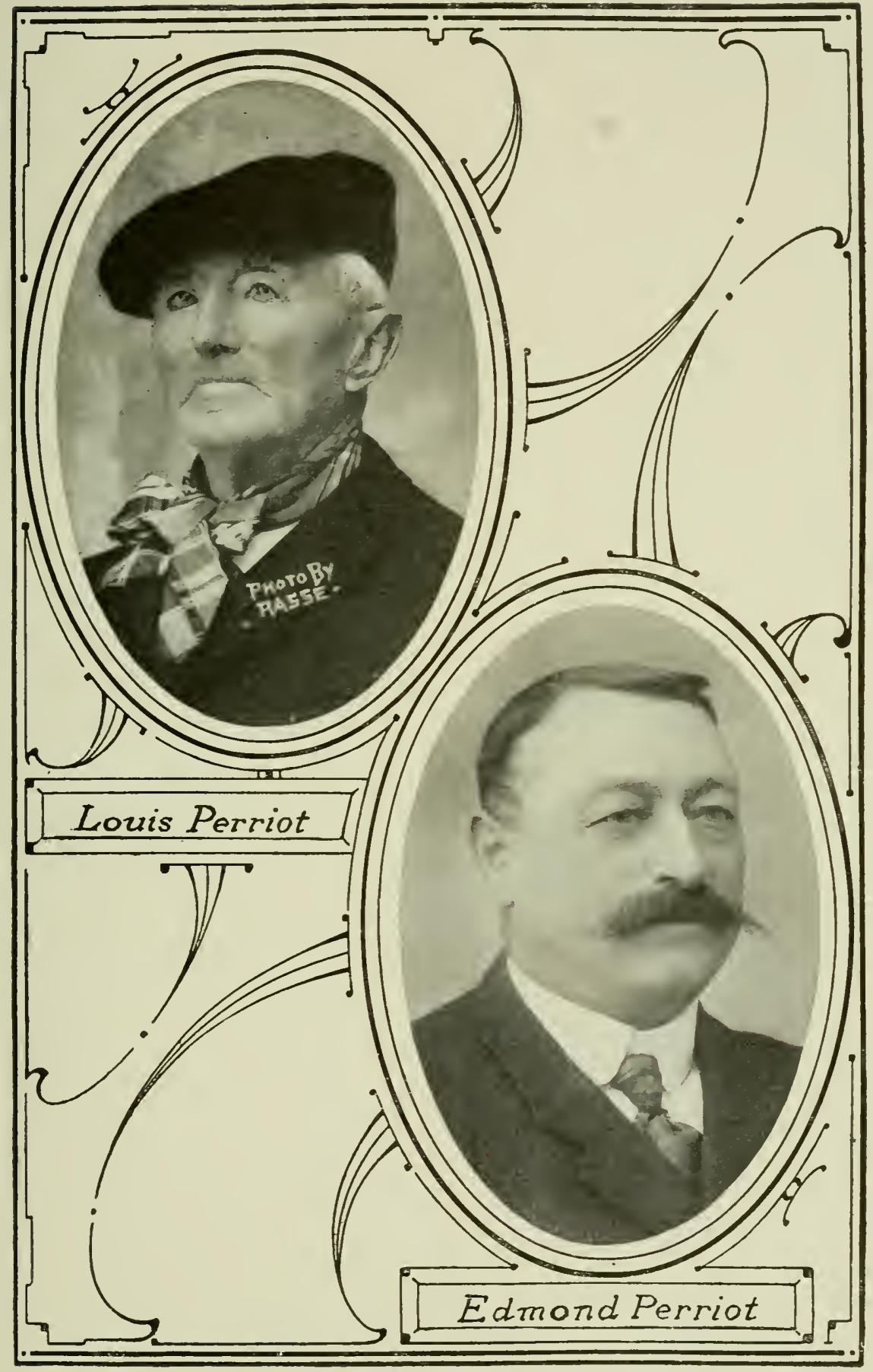



where Edmond, so well known in connection with latter-day breeding operations in the Perche, was born. In his later years Champeaux was ceded to the son Edmond, the father removing to the adjacent property known as La Borde, where he at an adanced age has continued to conduct farming and breeding operations.

Louis Perriot remembers well the famous stallion Vieux Chaslin, that figures so prominently in the pedigrees of many of the best horses of the foundation period of our modern records, and describes him as extraordinarily good in the chest, neck and head. He testifies that Vieux Chaslin's progeny was distinguished always for quality and vigor, being in great demand from all discriminating buyers. His father bought one of his best sons, Favori 1st, a gray, foaled in 1862. Vieux Chaslin was dropped in 1847 and served for a long series of years with remarkable success in the La Ferté district. He was owned by M. Vinault, one of the leading stallioners of his day in the Perche.

Favori 1st, the stallion that brought the elder Perriot his greatest fame, was the sire of Bayard (717), that got the celebrated stallion French Monarch (824), bought by Mr. Dunham for America in 1880 at 5 years of age and subsequently sold to Mr. Wheelock of Moline, Ill. This horse should not be confused with one of the same name, a black bred by Tacheau and sold into Iowa about 1874. Another noted son of Favori 1st was Favora (725), out of the mare Marie by the great Coco. Favora 
was imported by Mr. Dunham. He was not only a great horse individually, but a sire of uncommon merit. He was sold at $\$ 5,000$ to go to Oregon. Another Favora, foaled in 1868 and got by French Monarch, was imported by the Dillons in 1880 .

Louis Perriot was a frequent exhibitor at the shows about the time the Percheron Stud Book of France was established, although he never entered into the competitions with the zest subsequently displayed by his enterprising son Edmond. Both were famous for their skill in fitting horses for the showyard. At the Percheron society's show in 1887 Louis won first among two-year-old stallions with Marmont, and in 1888 he was second in the threeyear-old class with Kleber, and second in two-yearolds with Dompteur. At a subsequent show he was second in three-year-olds with Bacarat. He sold largely at one time to the Dillons, and from him Mr. Dunham obtained the great Baptiste (737) and Introuvable (24146). His work must be judged not from his showyard triumphs, but rather from his exceptionally long career as a shrewd, sound, conservative breeder. Endowed with a splendid physique, great courage and determination, and unbounded industry he is at this writing (1916) still conducting his own farm and breeding stud, although over 80 years of age. It should be observed that his son Edmond has been assisted and encouraged in his breeding operations by the judgment and experience of the father. Louis Perriot is the last of the old school. It will be necessary to con- 


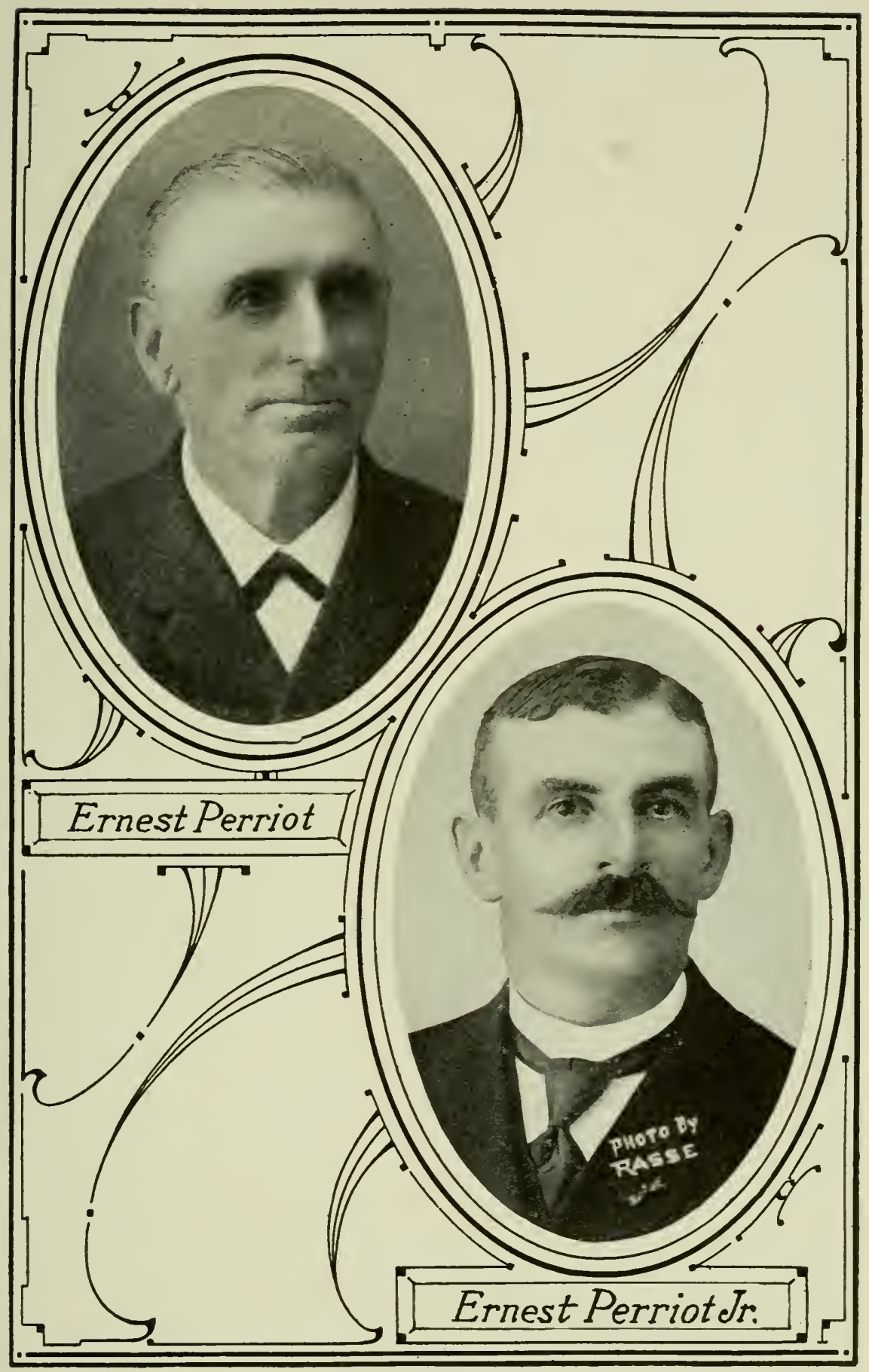



sult the stud book to get a list of the better-known horses and mares that he bred and raised.

Ernest Perriot stands out conspicuously as the greatest constructive Percheron breeder of modern times. He was born on his father's farm of Amilly, and began operations on his own account about the y ear 1870 at the farm of La Chênellière near Nogent, where he remained until shortly before his death in 1912 at l'Orme, also near Nogent. It is the consensus of opinion of all those who have been most familiar with Percheron breeding for the last half century that Ernest Perriot did more to develop the most desirable modern type of the Percheron than any of his contemporaries. This he did by selecting and retaining the individuals which measured up in the very best fashion to the standard sought. He wanted size with quality, and like most of those who have left the greatest impress on all of the leading improved varieties of domestic animals, did not hesitate to resort to the powerful influence of blood concentration. One has but to recall the names of a few of the great horses bred or raised by Ernest Perriot to realize the outstanding position he has occupied since the inception of stud book records. The list would begin with the celebrated Brilliant 1899 (756), and includes such celebrities as Brilliant 1271 (755), Gilbert, Bon Espoir, Fenelon, Childebert, Voltaire, Briard, Marathon, Iago (768), La Ferté, Jules, Mouille, Villers, Aiglon and Brilliant $3 \mathrm{~d}$. Most of these famous stallions are referred to at some length in our record of American importations. 
Ernest Perriot was one of the founders of the Percheron Stud Book of France, and occupied at different times the chief offices of that society. He was also the recipient of honorary decorations at the hands of the French Government. From 1880 to 1892 he was confessedly the leading stallioner of the Perche. His strains of blood were in keenest demand, and he sold at higher prices than anyone else was able to obtain. For a long series of years Mr. Dunham had first option on all his best. He sold to others, but loyally held back for Mr. Dunham's examination all his choicest specimens. Until Oaklawn was done others had no chance at the tops. Between these two great leaders of the trade during that period there existed a close friendship, based on mutual respect and characterized by perfect lovalty on both sides, and it is computed that during his lifetime Mr. Dunham paid Frnest Perriot fully $\$ 350,000$ for Percherons. Mr. Perriot did not make a practice of exhibiting his horses in the public competitions. He was a man of strong personality, a fine intellect, and an unswerving, inflexible strength of character-persistent always in pursuance of his ideals, which were attained in striking degree.

Edmond Perriot, son of Louis, born in 1863 at the farm of Champeaux, has been one of the great figures of the Perche in recent years. He married the daughter of M. Rigot, one of the ruling Percheron powers at that date, and this alliance proved the foundation of a most successful business career. It 


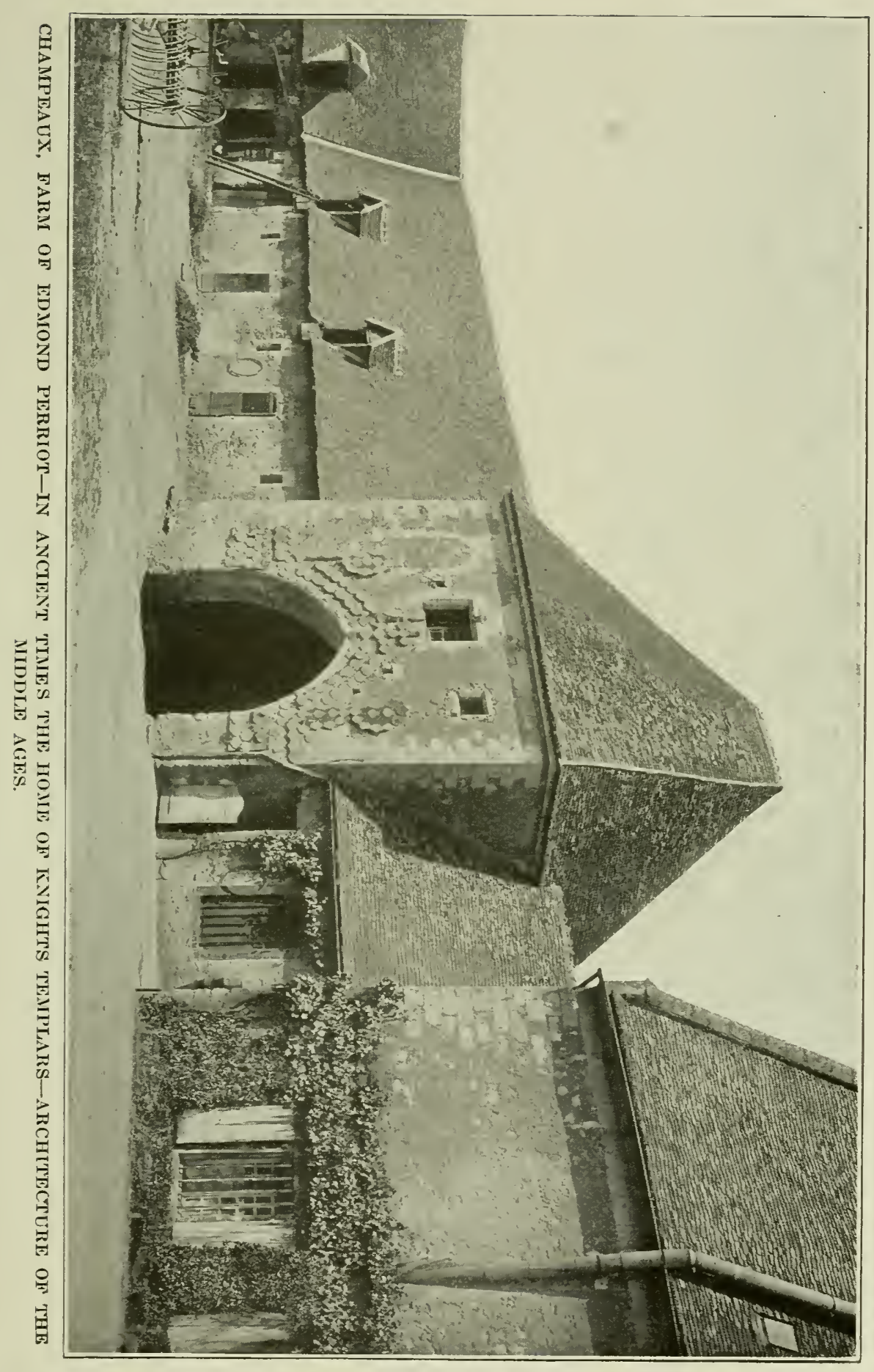


is said that M. Rigot owned or controlled more good Percheron mares in his day than any other dozen men in the district. Many of the best horses Mr. Dunham had from Ernest Perriot in the earlier days were from these Rigot mares. Edmond Perriot attained the top-most round of success, and during the Paris Exposition year, 1900, sold $\$ 100,000$ worth of horses to America for cash. His reminiscences of the American trade will therefore be of interest in this connection:

"One of my earliest recollections is that of seeing Mark W. Dumham, the father of the present W. S. Dunham, who comes over here to buy every year. That was long before the stud book was known here, when horses could be shipped to America without pedigree. Mr. Dunham came here for 20 years, buying from 100 to 150 head annually. He was a keen judge and only wanted the best, for which he was willing to pay a good price. His earliest competitor in buying that I recollect was Mr. Dillon, who was also an excellent judge of a horse, but who was getting on in years before he came out to the Perche and did not continue very long. The Ellwoods took his place and for long years the buying of mares and stallions in the Perche was practically monopolized by them and Mr. Dunham. From the very beginning prices have been relatively high for good breeding stock, and Mr. Dunham did not hesitate, even in the early days, to go as high as $\$ 3,000$ and even $\$ 5,000$ for the horse he wanted.

"Gradually other importers came to swell the field, and I remember when I was about 18 or 20 years old that my father and all his neighbors in the Perche were selling all the good horses they 
could raise for America. It was at this time, 1881 to 1883, that exportations to America reached to more than 2,500 head. The trade had then reached such vast proportions and become of such material importance to Percheron breeders that the Société Hippique Percheronne, or French Percheron Society, was organized on June 23, 1883, by a few breeders in Nogent and the district. Of course my father and uncle were included in the number. It had been projected since 1878. There was also a rival society, le Percheron Francais, backed by the Société des Agriculteur de France. There were many bitter quarrels between the two associations, but eventually they became fused into one.

"In the early '80's Mr. Dunham ceased to make his purchases personally, entrusting that work first to Leonard Johnson and subsequently to James M. Fletcher. The type selected by the Americans at the beginning was about the same size as the Paris omnibus horse. We used to ship about 7,000 head a year to the omnibus companies in Paris, composed of males unsuitable for breeding stallions; also many barren mares went to Paris, but the majority were shipped to Bordeaux, Montbeliard, Havre and other large cities. The proportions of dappled gray horses in the Perche at that time was about 75 per cent, and the weight of a mature stallion ran around 1,700 to 1,750 pounds.

"If I remember rightly it was the Ellwoods, about 1881, who first evinced a desire to buy larger horses, and they acquired the celebrated stallion Cesar, the precursor of the elephantine Percheron, as the French breeders say. Cesar weighed close on 2,200 pounds at 2 years old. Unfortunately he died in crossing the ocean. Nevertheless the fiat had gone forth for larger horses, consequent on the improved 


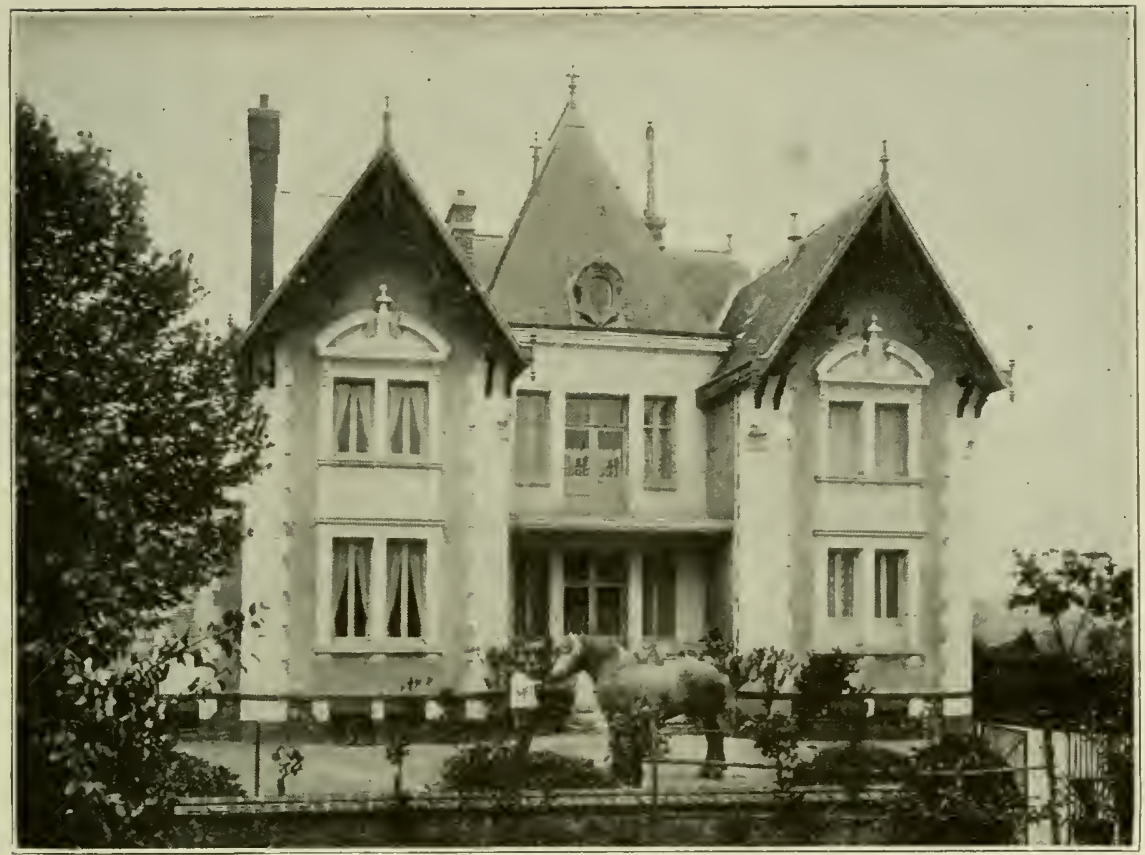

L' ORIE-RESIDENCE OF THE LATE ERNEST PERRIOT, PRINCE OF PERCHERON BREEDERS.

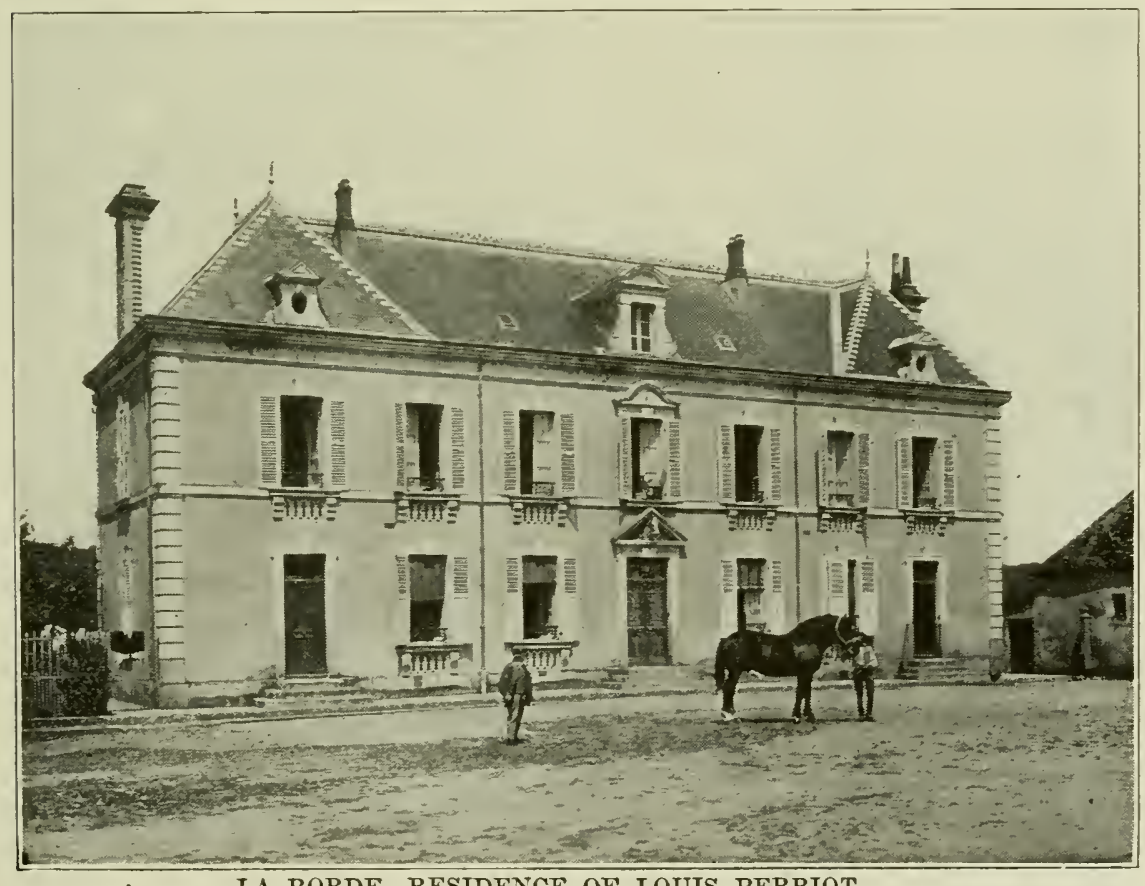

LA BORDE-RESIDENCE OF LOUIS PERRIOT. 

and heavier farm implements manufactured at that period in the United States. This gave to our breeders the opportunity to prove to the world the remarkable versatility of the Percheron horse, and friends and foes alike found that we could produce the real heavy, drafty type without sacrificing that high quality for which our product has always been famous. It was a crucial test in the history of our breed, but the breeders of the Perche rose successfully to the occasion.

"This new demand for a larger horse was taken up also by James B. McLaughlin, who came into prominence in the Perche after the Ellwoods had ceased to buy. Mr. McLaughlin was for years one of the most active of the American importers and at one time probably purchased as many horses as any other one importer. Indeed, a Paris or Nogent show without the presence of Mr. McLaughlin would be like Hamlet without the title character.

"From 1880 to 1891 trade was very brisk with Americans in the Perche, but in 1892 it fell off and from 1894 to 1898 there were practically no exportations to the United States on account of the financial depression in that country. From the latter date up to 1905 the average annual exportations of Percheron stallions was about 700 head, but in 1906 the enormous number of 1,300 stalilions and 200 mares were purchased by American importers. One of the prominent buyers during these busy years along with J. B. McLaughlin was James M. Fletcher, who followed Leonard Johnson and bought for the firm of Dunham, Fletcher \& Coleman. Afterwards quite a small army of American importers and breeders came to scour the Perche every year, and such men as W. S. Dunham, George Crouch, J. Omer Singmaster, Bell Bros., Robert 
Burgess, Chas. R. Coleman, Chas. Taylor of Taylor \& Jones, Judson Hayden, A. B. Holbert and others have made important purchases in the Perche.

"In 1889 I commenced showing on my own account at the Paris show, and obtained 3 prizes with 4 horses, being awarded a second prize on Margon, a three-year-old which I sold to Mr. Dillon. My greatest triumph perhaps was at Paris at the great exposition of 1900 , where I got 4 first prizes, the championships and the grand championship. I have been awarded 11 championships at the provincial shows in France since 1894, 6 championships at Paris since 1905, and 15 championships at the Percheron society's show since 1891.

"I have known some celebrated stallions that have done much for the breed. In 1899 I sold a very fine stallion Phenix to J. M. Fletcher. In 1900, Suffren, winner of first in the two-year-old class at Paris, was bought by J. B. McLanghlin, who also acquired a splendid three-year-old Raynal, first-prize winner at the same show. He got the famous stallion Orangiste the same year. This horse obtained first prize at Nantes and Nogent as a two-year-old. That year J. M. Fletcher bought 2 fine stallions, Chambellon and Scipion, aged and three-year-old champions respectively. Champeaux, a stallion sold to Mr. Dillon as a five-year-old, was a remarkable breeder, and his progeny must be all over America. One of the finest three-year-olds I ever saw was Fusain, first at Paris and Rouen. He was bought by J. B. McLaughlin. Of course nearly all our best stock traces back to Brilliant (756), the son of Coco 2d, born in 1867 on the farm of my uncle Ernest Perriot."

The Perriot Percherons were distinguished usually for their size, good bone, fine heads and well- 


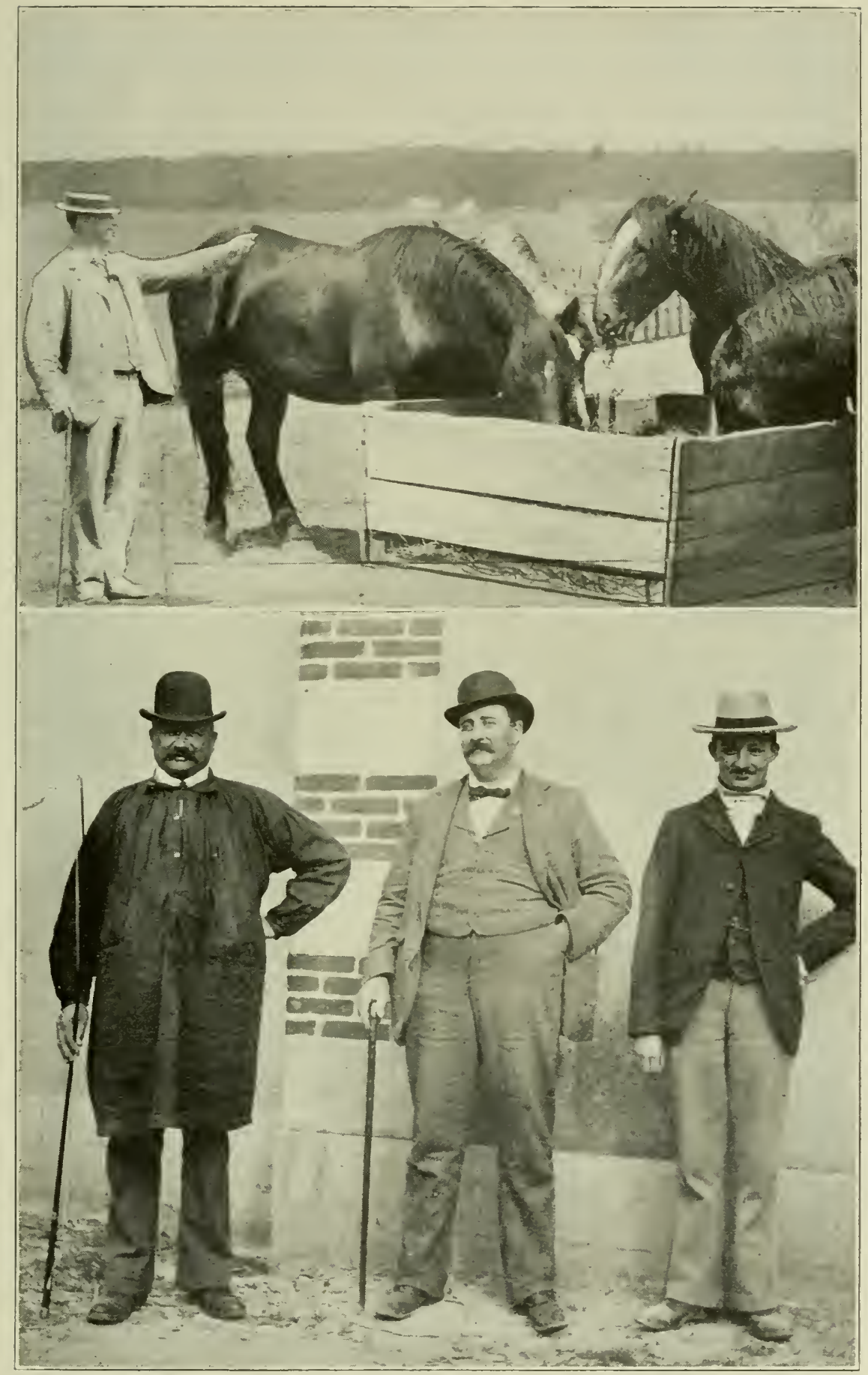

AT TOP, EDMOND PERRIOT; AT BOTTOM, A. TACHEAU, SR., J. O. SINGMASTER AND M. TACHEAU'S YOUNGEST SON, WHO DIED IN 1902. 

set necks-a heavy drafty sort standing on short legs. Towards the end of Ernest Perriot's career it was commonly allowed that some little lack of size and constitution had begun to appear. There was apparently some falling away from the oldtime outstanding excellence, and yet to this day among the strongly-bred Perriot stallions where the individual quality scarcely measures up to the older standards the blood continues to breed on with extraordinary success, producing horses of a character illustrating once more the operation of well known laws of heredity-reversion to ancestral types.

The Tacheaus.-Forever famous in the annals of the Perche will stand the names of Auguste Tacheau, père et fils. After M. Vinault the senior Tacheau was the greatest stallioner and breeder of the La Ferté Bernard region. Like Charles Aveline and other contemporaries, he was ever active in catering to the great American demand, and in this service acquired a fortune. When Charles Aveline was still a young man the two leaders in the development of Percheron interests were Tacheau grand-père and the father of Louis and Ernest Perriot. It was Tacheau père that acquired French Monarch (734) in 1868, and used him as a stud horse in the La Ferté district, during which time-1868 to 1874 - that great horse served a large number of mares and acquired a reputation as a sire of highclass stock, being then sold to America to S. S. Waterbury and A. W. Cook of Iowa. Dur- 
ing his active period of service in France it has been recorded that "during the 6 years that he served mares for M. Tacheau he acquired in the district as a stallion a reputation almost without equal, his progeny always being remarkable for their quality and their size."

M. Tacheau also bought from M. Sagot Coco 2d, a stallion that won many prizes, and, according to M. Pelleray and others, was the greatest sire of his day in all Perche. The name of Tacheau also will be associated with the celebrated stallion Besigue, sold to go to Dr. Hartman of Columbus, O.; the great horse died unfortunately on ship board on the Atlantic Ocean.

Probably the most noted stallion America ever obtained from the Tacheau stables was Seducteur, imported in 1888 by W. L. Ellwood and afterwards the property of H. G. McMillan. It was from M. Tacheau also that $\mathrm{Mr}$. Ellwood bought Baccarat, a prizewinner in France, which sold as a three-year-old to Rufus B. Kellogg of Green Bay, Wis., for $\$ 6,000$. In 1883 M. W. Dunham bought 20 two-year-old colts from M. Tacheau at $\$ 20,000$ for the lot. Other prepotent sires from Tacheau's were Bibi and Jupiter.

Auguste Tacheau's interest in Percherons was transmitted to his son, thus carrying on the traditional attachment of the family to the draft horse stock that has made the Perche famous on both sides the Atlantic. Tacheau pére was always popular with the American buyers of his time. He operated in a country of rich pastures, handled a 


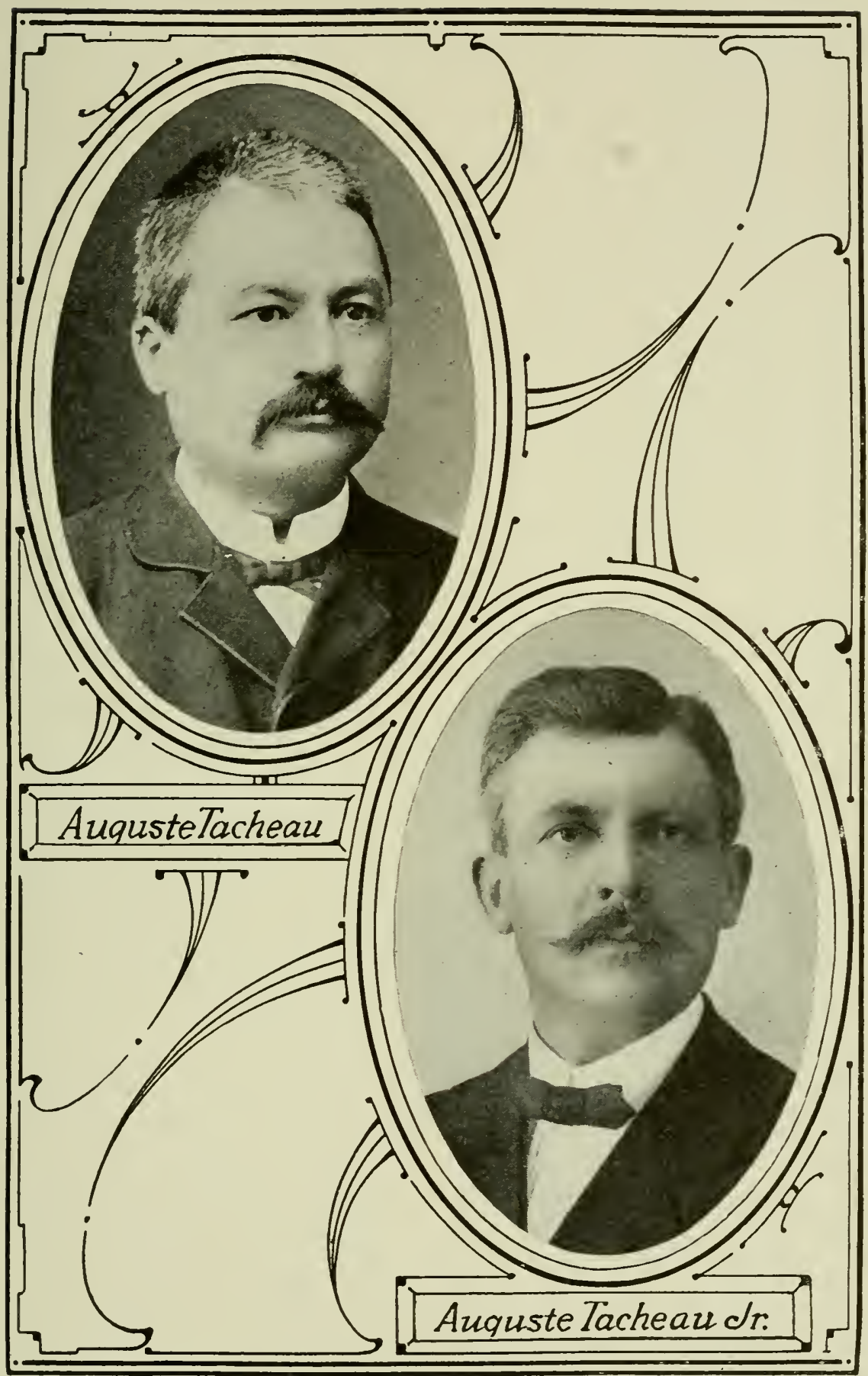



very large number of colts, and was a frequent and successful exhibitor at Nogent, Paris and other leading shows, not only with stallions but with mares as well. In 1886 he won first at Nogent in yeld mares with Queen of Perche, and first, second and third in the two-year-old stallion class on Seducteur (7057), Phenix (6983) and Fils de Voltaire (6832), also taking first for best lot of stallions. M. Tacheau was one of the members of the executive committee of the Société Hippique Percheronne after its organization in 1883. He died at Cannes in March, 1906.

Auguste Tacheau, Jr., has more than sustained his father's reputation and it is not too much to say that he is one of the foremost French breeders of this day and generation.

Charles Paul Aveline.- Another tower of strength in the Percheron trade at the time of the establishment of the stud book in France was the late M. Aveline, whose death in January, 1916, was mourned on both sides the Atlantic by all familiar with latter-day Percheron history. Born in 1853, the son of a breeder and farmer of high local repute, he early made his mark as a farmer, stallioner and breeder at La Crochetière, Verrières, Orne, a district which from time immemorial has been celebrated for rich pastures and good horses.

The first reference made to M. Aveline in the government haras records is in 1883, as the owner of a 17-hand, iron-gray stallion known as Brilliant. He was given a bonus of 300 francs by the government authorities in that year. Another stallion named 
Chéri, foaled in 1880, an iron-gray standing 18 hands high, is in the haras registry as approved for 1883, receiving the same stipend as Brilliant. It will be noted from this that three-year-old horses now began to receive official recognition. M. Aveline also had Margot, a dark-gray horse, foaled in 1878, 16.2 hands high, that was approved and served in 1883 with a pension similar to that accorded Chéri and Brilliant. During the succeeding years we find the names of the bay horse Décidé, Paul, a mouse-gray (gris souris), Monarque, a light-gray 17 hands high, Hercules, a black standing a little over 17 hands high, and Bon Coeur, a black 16-hand horse foaled in 1881, Sultan (362), Vulcain, Bon Courage, Dragon, Hautbois, Fronton, Chichi, Etradegant, Etudiant and Orangiste.

In his mature years M. Aveline removed to the fine estate of La Touche, near Nogent- his wife being a Chouanard-and here he maintained for a long series of years an establishment which was visited regularly, and always with keen enjoyment, by all American buyers. He was one of the founders of the Percheron Stud Book of France, and for 15 years prior to his death was the society's president, a fact which illustrates well his standing in the Perche. M. Aveline visited the Trans-Mississippi Exposition at St. Louis, Mo., in 1904, and was decorated by the French government with the cross of Commandeur of the Merite Agricole and Chevalier of the Legion of Honor. He was a man of rare intelligence, sound business judgment, courage, tact 


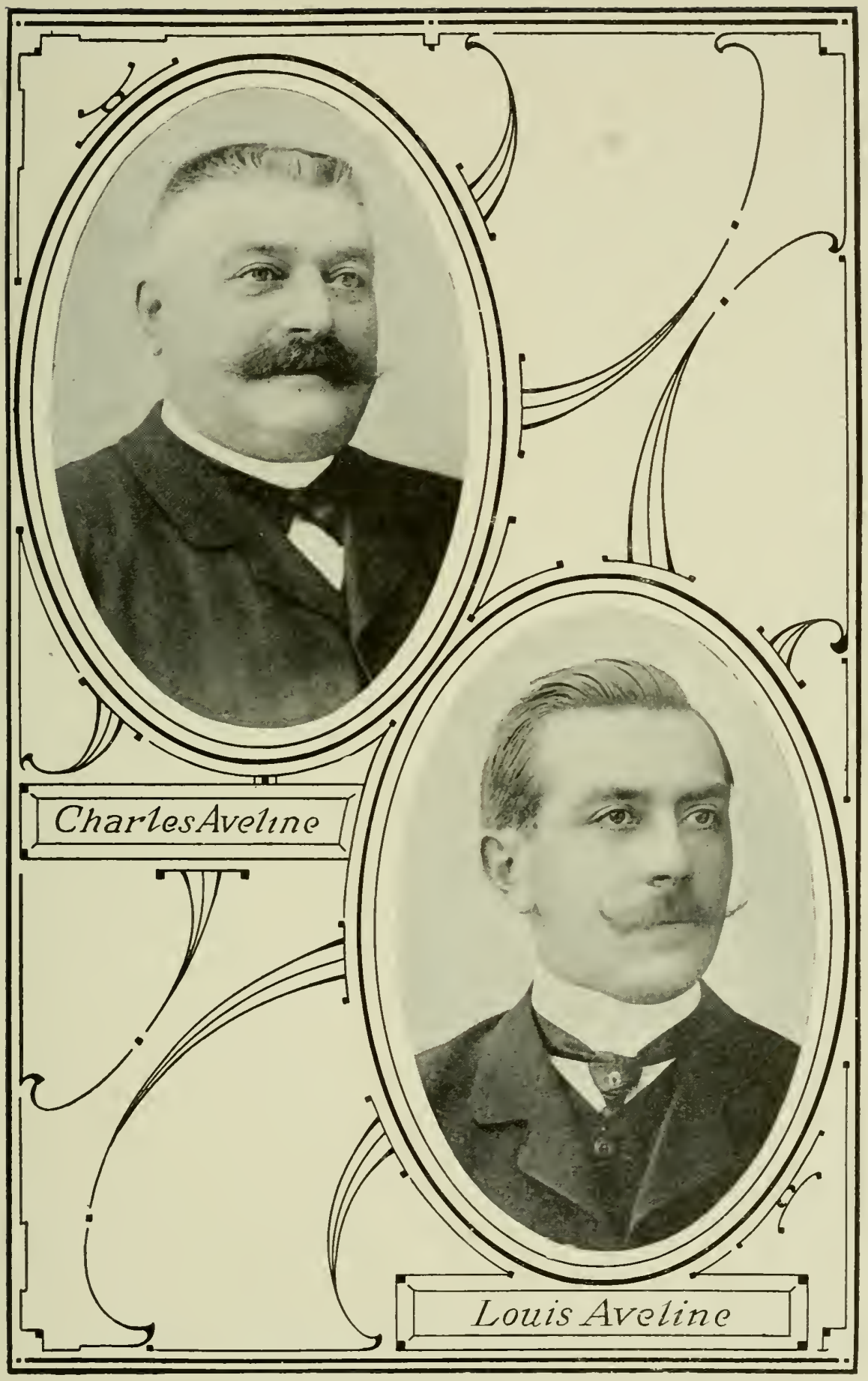



and honesty, and in his recent death contemporary Percheron breeding in France lost its leading light. He leaves a son Louis, who for some years has been active as successor to his father in the Percheron trade and who during the great war has been stationed in the United States as an officer of the French military service buying horses for the armies of France.

Credit Due These Pioneers.-From the foregoing it will appear that before the era of the foundation of the stud book there were men of good judgment, staunch admires of the Percheron breed, who united their efforts and created departmental and local committees for the purpose of improving the breed. To these men must be paid a special tribute of gratitude, whether they were in the government service, rich landowners of the district or only small farmers or tenants. They were not stimulated in the old days by big prices paid by importers. Some Percherons had been exported to different countries of Europe between 1820 and 1870, notably to Italy, Prussia, Saxony and Russia. And speaking of this period M. Paul Chouanard says:

"Before the Crimean war M. Joseph Chouanard, then residing at La Touche 1854-1855, sold during some years a number of Percheron stallions and mares to a Russian general named Schweider, who used to remain for a week at La Touche at each voyage. At the Hamburg Show (Germany) in 1863 3 Percheron stallions owned by a gentleman from Saxony took prizes."

The American people were the first, however, to 
recognize in a broad way the real merit of the breed for draft purposes in other lands. They pushed Percheron breeding on a large scale, and then it was that great prosperity began in the Perche.

Founding of the Stud Book.-The first volume of the "Stud Book Percheron, publié par la Société Hippique Percheronne, autorisée par le Gouvernment"' was issued at Nogent-le-Rotrou in 1883 under the Honorary Presidency of M. le Préfet d'Eure-etLoir, the Honorary Vice-President of M. le SousPréfet de Nogent-le-Rotrou, and the ex-officio patronage of M. le Maire de Nogent-le-Rotrou. This was the beginning of official registration of Percheron horses in the home of the breed. The charter membership included all the leading breeders of the Perche, about 125 in number, one of the most eminent of whom, M. Michel Fardouet, was elected to the active presidency of the association. Louis Perriot and M. Moulin were chosen vice-presidents, and M. Boullay-Chaumard was made secretary-treasurer. A board of directors, including 17 of the best-known supporters of Percheron interests, was created, prominent among those serving in such capacity being MM. Vinault, Sagot, Miard, Launay, Auguste Tacheau, Caget, Gautier, Desiré Ducoeurjoly, Rigot, Goupil and Aveline fils. This movement had the active support of leading patrons of the breed in America, including Messrs. M. W. Dunham, J. H. Sanders, founder of the American stud book, and others.

From the introduction to this initial volume of 


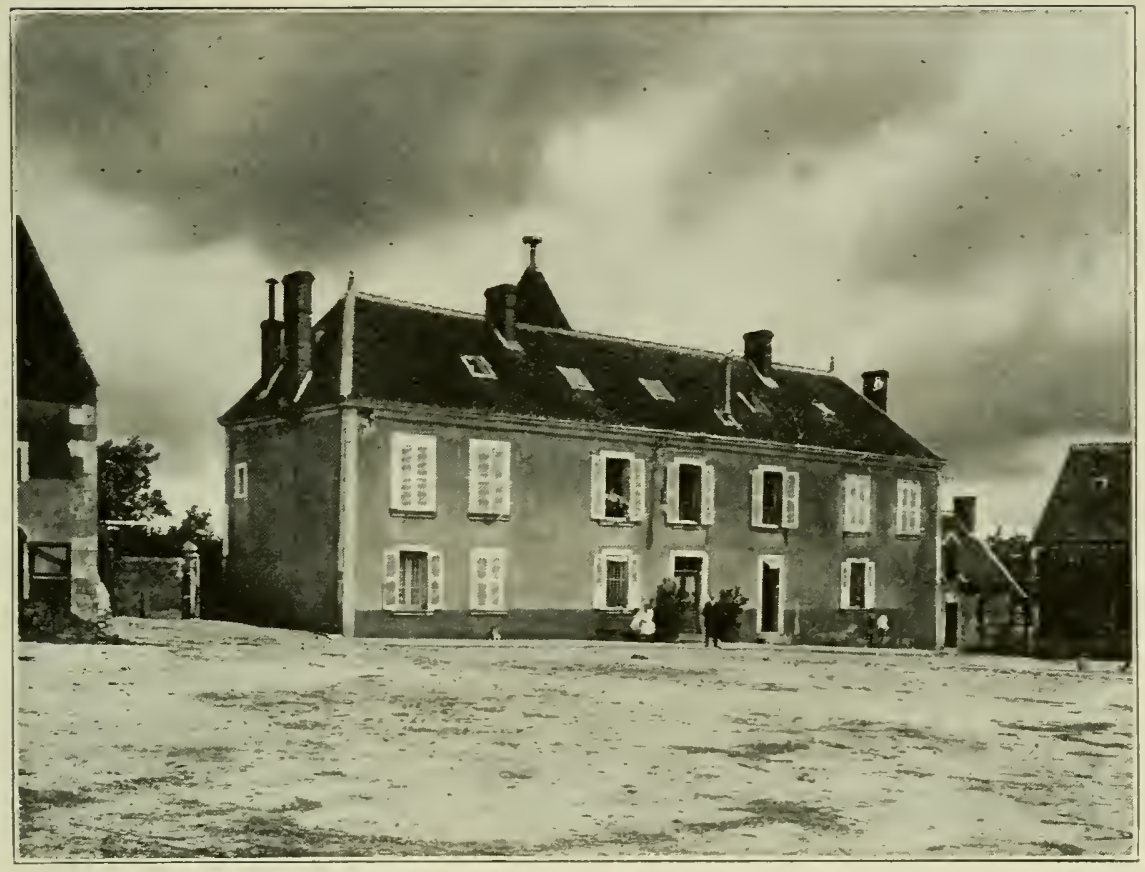

LA CROCHETIÈRE, FARII OF LOUIS AVELINE.

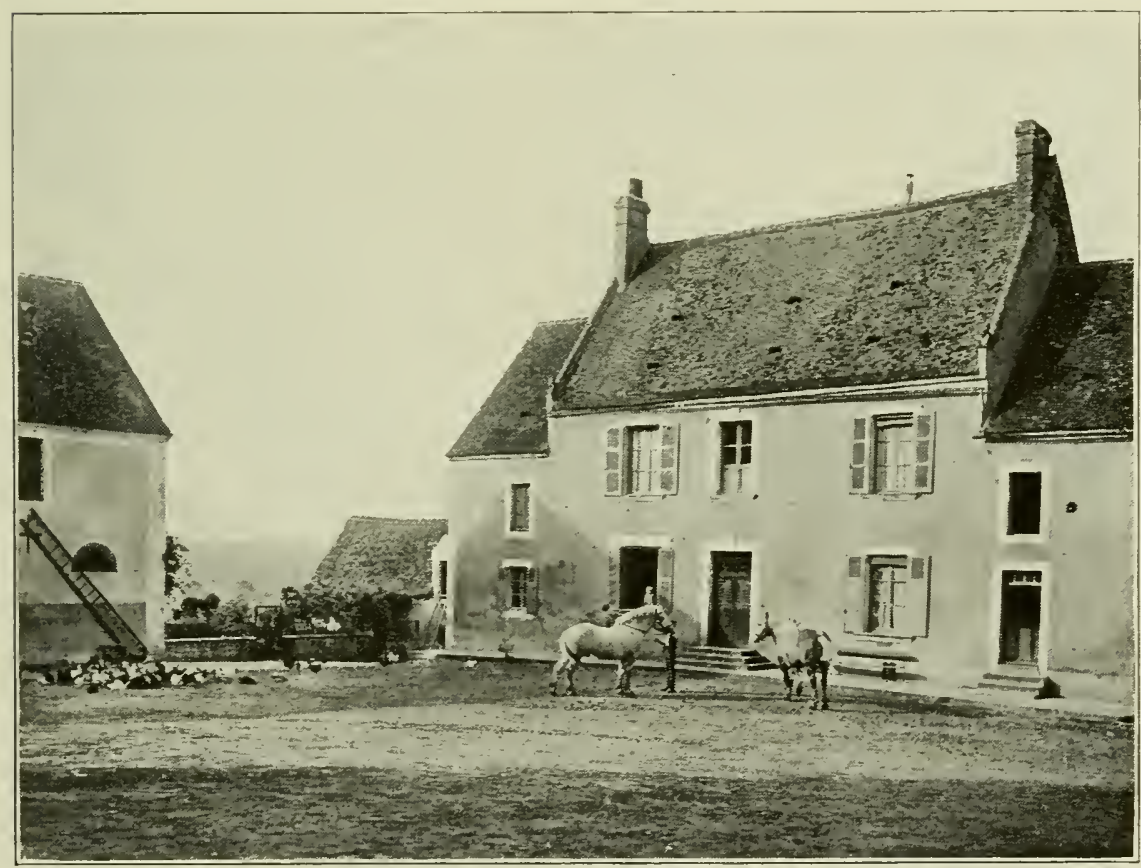

LA BRETONNERIE, FARM OF CHARLES CHOUANARD. 
the Stud Book of France, prepared by President Fardouet, we extract the following:

"In presenting the first volume of the Percheron stud book to the public, the Société Hippique Percheronne is sensible of the keenest pleasure in having accomplished a work that will be of untold value to the future as well as the present breeders and owners of the Percheron race. The organization embraces in its membership nearly all of the prominent breeders and stallioners of the Perche, many, very many of whom have grown old themselves in the commendable work, and whose ancestors for generations have, like them, devoted their lives to developing and fostering this matchless breed, whose antiquity of origin stands first among those of the equine races of civilized nations-a breed that has been moulded to the necessities of the different periods of its existence for hundreds of years under the vivifying influences and climatic effects of the Perche, as well as by the inimitable processes of educating both males and females from the earliest age and with the most judicious care possible by the actual performance of the work they will be called upon to do during their lives, thus slowly and surely developing their physical capabilities and instinctive aptitudes into hereditary and transmissible forces, which have been exerted with such potent power in the amelioration of all races with which it has come in contact.

"In feudal ages the country required a class of horses suited to an equestrian race, and the Perche supplied them. Under the empire of a higher civilization the peaceful pursuits of agriculture and commerce demanded horses for the post, the diligence, and for agricultural and draft purposes. The Perche was called upon, and she met the demand. 
The introduction of steam as a power marked a new era; the building of railroads and steamships, and its adoption as a power in all the useful arts, in manufacturing, has changed all. The post and diligence are gone; the agricultural and great commercial marts remain to be supplied. Labor and food have become more costly, and the people, by force of necessity and the demands of economy, call for larger, stronger, but equally active horses to fill the requirements of the time. How has the Perche sustained herself under the pressure of this last and most difficult demand? The answer fills us with pride and gratification.

"The government and all the departments of France are eager purchasers of Percheron stallions to improve and ameliorate their native breeds. Russia, Austria, Germany and Italy buy largely, both by direct government purchase and by private enterprise; even Great Britain, bound up as she is in her own egotism, is a customer of no small magnitude. With such magnificent acknowledgments of the value and superiority of the Percheron race we ought to be content; but this is not the half. The plains of South America are being supplied with stock of our breeding; and lastly, that beautiful country, that great republic across the sea, whose progress is the marvel of the world, is our most enamored admirer and liberal purchaser-so liberal, indeed, that grave apprenhensions are being expressed as to our future ability to supply the rapidly increasing demand upon us for our best males and females of all ages, without materially deteriorating our stock. This question is one that needs the most earnest thought and energetic action of all interested in the preservation to the Perche of her pristine glory. 


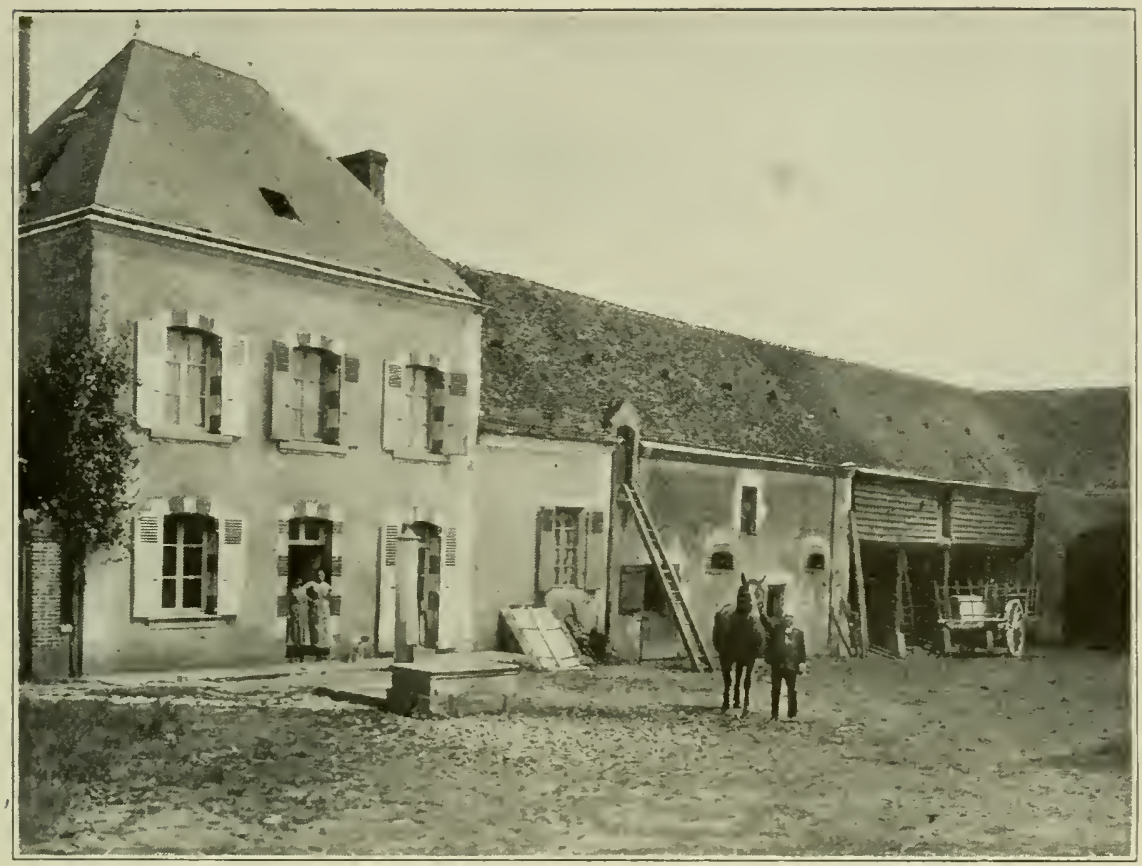

FARMI OF D. DUCOEURJOLY.

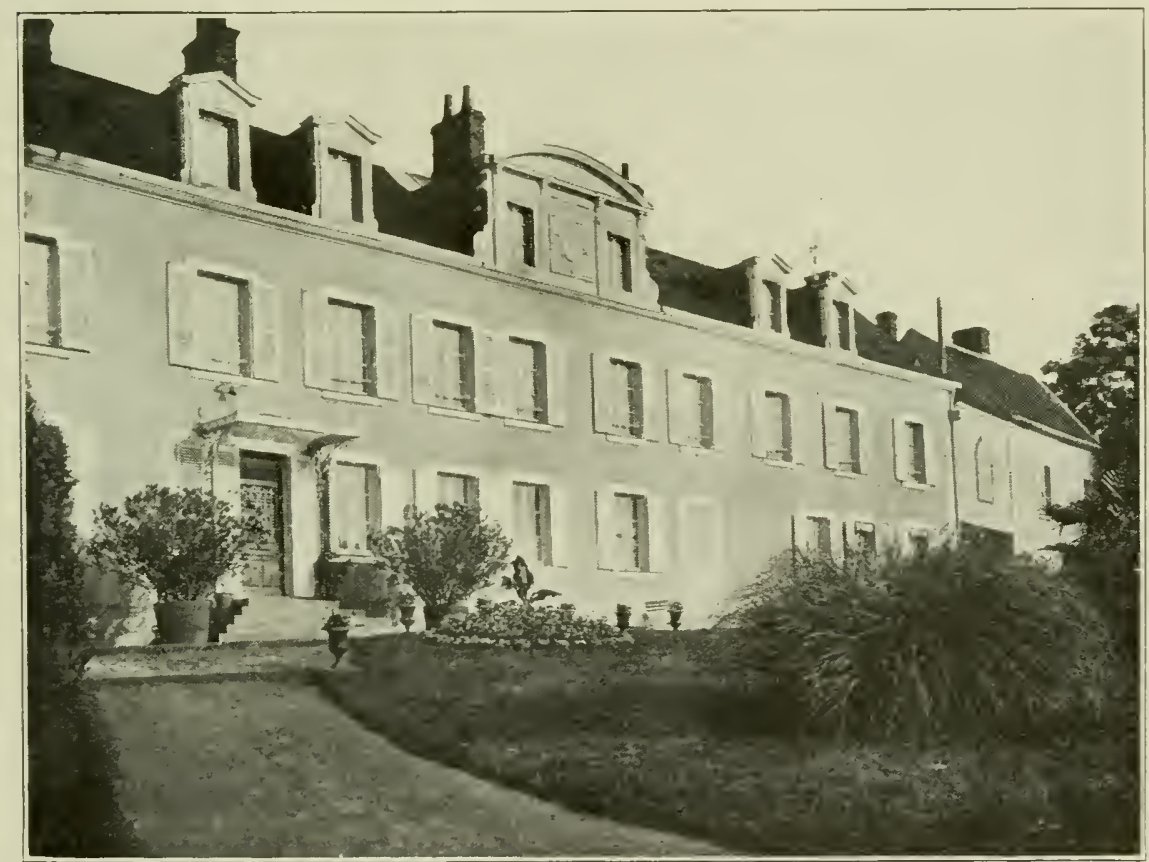

LA TOUCHE, RESIDENCE OF THE LATE CHARLES AVEIINE, LONG PRESIDENT OF THE PERCHERON SOCIETY OF FRANCE. 

"To preserve and perpetuate the valuable qualities of the Percheron race against invasion from all sources is one of the missions of this society. In order to accomplish this purpose, it becomes necessary thoroughly to investigate all elements of breeding that have contributed to the grand results we now enjoy, and by carefully classifying all animals with their pedigrees, that we may see what strains of blood, which families and what orders of union have been prolific of the greatest benefits in the past, thus establishing invaluable precedents from which more intelligently to shape our future course, and with greater degrees of certainty arrive at the desired ends. These investigations have shown us that the improvements of the past necessary to meet the changing demands have been accomplished by selecting animals best suited to the new requirements, and, by a judicious system of in-and-in breeding perpetuate the valuable qualities sought for, at the same time intensifying their hereditary powers of transmitting those qualities."

Meager Data at First Available.-In common with all other pioneer undertakings of this character, the effort to collect for the first time reliable information concerning the foundation stock was attended by many difficulties. In respect to the remote origin of the race, and indeed in respect to the work done by the preceding generation in the Perche, there was only of record M. Du Haÿs' treatise, already alluded to in preceding chapters. Valuable and interesting as was this cleverly written work, its author apparently had not the time nor the patience to search the archives of the government touching the Percherons of pre-stud book 
days, but contented himself rather with eulogizing the breed, and accepting, apparently without question, such traditions as had been handed down by writers who made no pretense of basing their statements upon anything more reliable than mere hearsay. True to their ancient habit of being more interested in the work of the moment than delving amidst dusty documents dealing with a long forgotten past, these stud book organizers builded, as best they could, upon Du Haÿs and the memories of the older inhabitants of the district at the time they took up pedigree registration.

Obviously little success was met with in attempting to obtain actual pedigrees of the remote ancestor's of the horses found in the Perche at the date this basic volume was undertaken. Clearly, in the absence of any known written records, the practical thing to do was to make a beginning with the stock in the hands of the leading breeders of the district at the time, with such particulars as were to be had concerning the ancestry in the first and second generations. This was the course in the main pursued and in this respect the beginnings of Percheron registration on both sides the Atlantic differed in no wise from the circumstances surrounding the first attempts at establishing public records for all our other best-known breeds of improved domestic animals.

The Case of Jean-le-Blanc.-The great majority of stallions and mares entered in the first volume were animals foaled between 1878 and the date of 


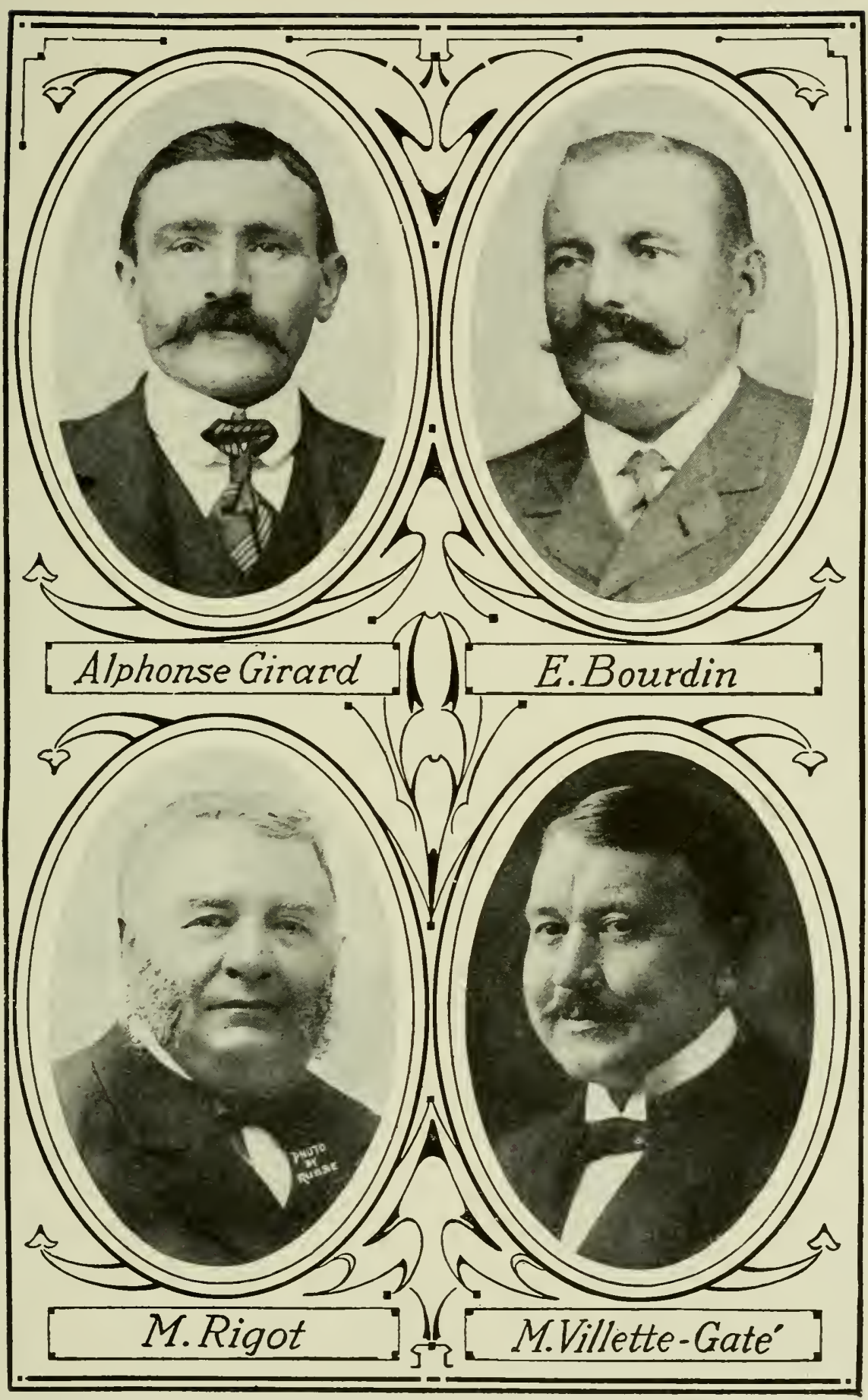



issue, 1883. In a few notable instances, such as the case of the stallion recorded as Jean-le-Blanc (739), an attempt was made to ground some of the contemporary pedigrees in the blood of stallions of good repute known to have lived in a distant past, but the record ascribed to such horses has in some cases yet to be substantiated by authentic data. Jean-le-Blanc's existence can scarcely be a subject of doubt, but in the matter of his alleged descent from Gallipoly, in the light of our investigations at Paris covering the period in which he is said to have been foaled, we can only enter up the old Scotch verdict-"not proven." There probably was such a stallion as Jean-le-Blanc, else the name could never have been handed down with so much veneration, but no man lives today who can verify any part of his history.

We have been at some pains to run down the story of this erstwhile celebrated progenitor of latter-day Percherons, but the most we can get in the Perche is from a few of the oldest breeders, who say that in their youth they remember hearing their fathers speak of such a horse. $\mathrm{He}$ is said to have been foaled in 1823 or 1824 , but while the official records of that period, which we have already presented, seem complete and circumspect in their listing of govermment-owned and government-approved horses, they contain no mention of Jean-le-Blanc. He is said to have lived to be 25 years of age and to have left a numerous progeny. Fortunately, however, at this late date the matter 
is one of merely academic interest. Those who made the entry of course acted in the utmost good faith. They had the tradition, and published it for what it was worth. They had no occasion for doubting its accuracy at the time. They had not the government archives before them. Criticism upon this head must therefore stop with the statement that those who were doing this pioneer work might have gone to Paris and searched, as we have now done, the manuscripts and records in the possession of the French Government. It is safe to say that had the Percheron breeders of France and America, who cooperated in launching this difficult enterprise in 1883, known of the mine of information then existing in Paris concerning the origin of the modern heavy draft type of Percheron horses, developed for the first time in this volume, they would have been quick to utilize it. The breed had a foundation history behind it which was not properly reflected by the earlier stud books. In other words, the Percheron of the ante-stud book days was a stronger-bred horse than is indicated by the existing foundation records. $\mathrm{He}$ is not the creation of the past 30 years. The pedigrees really run back at least to the era of the first Napoleon, but the missing links cannot now be gathered up. 


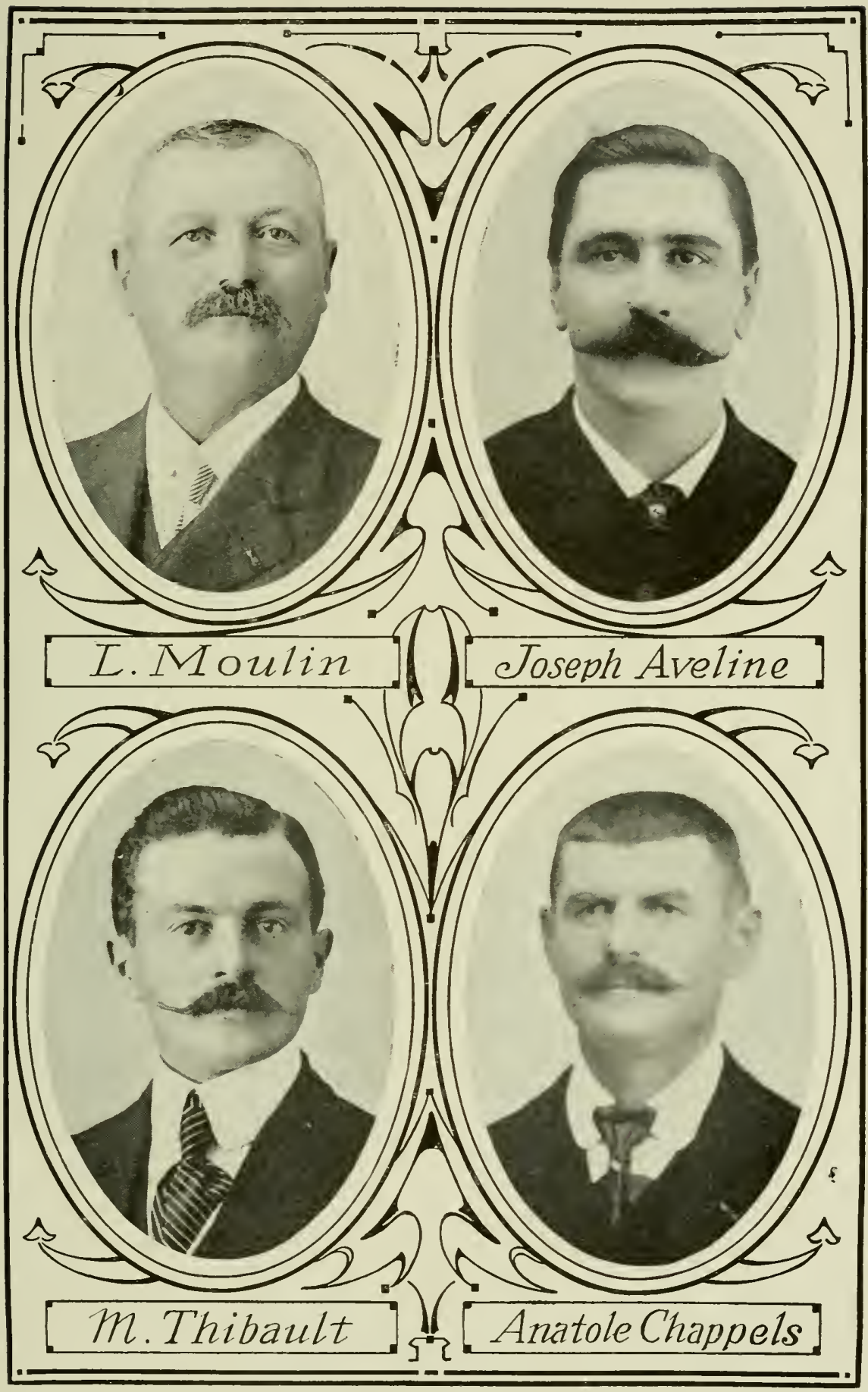





\section{GHAPTER IX.}

\section{THE GREAT EXPANSION OF THE '80'S.}

An extraordinary period of expansion in Percheron importing and breeding in America was inaugurated in 1881. It continued until about 1890, reaching its climax in 1887 and 1888. The country had recovered from the depression of the '70's, land was advancing fast in value, and the states west of the Missouri River were being settled rapidly. Horsepower was urgently needed for the development of these prairies and horse-breeding on large western. ranches was undertaken on a commercial basis. Business conditions were favorable. The result was a rapid growth of draft horse breeding in America.

Only 20 men made importations in 1880 , but the number of importers increased as follows: 1881, 29; 1882, 39; 1883, 42; 1884, 42; 1885, 50. Still more were engaged in 1886, 1887 and 1888. The number of breeders increased more than tenfold. In 1880 only 45 breeders were producing Percherons in America; by 1890 the number had increased to 593 . During this period of expansion 4,988 stallions and 2,566 mares were imported, and 1,920 stallions and 2,089 mares were bred in America.

Distribution by States.-Illinois was the leading state in the breeding of Percherons at this time, with 
a total of 203 breeders. The other prominent states, with the number of breeders in order, were: Iowa 66 , Ohio 55, New York 31, Minnesota 30, Michigan 28, Pennsylvania 23, Wisconsin 23, Indiana 21, Kansas 20, Missouri 18, and Nebraska 12: Breeding had been begun in 20 other states but was limited in extent.

This epoch was made notable by the coming of some new men whose means and ambitions enabled them to take high rank in Percheron operations. Foremost among these was W. L. Ellwood, DeKalb, Ill., who proved the strongest competitor which M. W. Dunham encountered in his lifetime. Mark Coad of Nebraska, Hon. T. W. Palner of Michigan, John W. Akin of New York, Fred Pabst and R. B. Kellogg of Wisconsin, Leonard Johnson, George E. Case and the Minnesota Percheron Horse Co., all of Minnesota, also acquired prominence during this period.

Oaklawn Breeding Operations.-Mark W. Dunham's breeding operations reached their climax during this period, as he reared 182 stallions and 173 mares of his own production, almost as many as his four leading contemporaries combined. His rank, however, depends less on mere numbers than on the character of colts produced. The influence of the Oaklawn Farm operations of this period has been so far-reaching that it must receive detailed consideration.

It was Mr. Dunham's idea from the outset to develop as rapidly as possible the breeding of Percherons in America, and he imported mares freely: in 
188136 , in 188243 , and in 1883 108. His total importations of mares from 1881 to 1890 amounted to 319 head. An examination of the Oaklawn Farm inventory shows that he had on hand on Jan. 1, 1887, 150 mares; on July 1, 1887, 148 mares and 37 more which were out on lease; on Jan. 1, 1888, 156 mares and 39 more out on lease; on July 1, 1888, 133 mares and 66 more out on lease; on Jan. 1, 1890, 179 mares and 13 out on lease. More details could be given, but enough has been cited to show the large number of mares kept in the Oaklawn stud. In individuality and breeding these mares were of the highest character, as they were imported by Mr. Dunham for his own use; he sought and secured the choicest mares obtainable in France, buying freely from all of the leading breeders and mare owners of the Perche. Breeders still living who were intimately acquainted with the mares assembled at Oaklawn in this period are agreed that no stud in America, and probably none in the world, ever numbered in its ranks so many mares of the best Percheron type and breeding. The 738 Percherons bred at Oaklawn between 1872 and 1900 were produced by 287 different dams. This fact, considered with the numbers owned at different dates, is evidence that the rate of increase was slow.

The Brilliant Blood.-In 1881 Mr. Dunham imported Brilliant 1271 (755) and in the same year Leonard Johnson, who was acting as a buyer in France for Mr. Dunham, imported his sire, Brilliant 1899 (756). Brilliant 1899 was used but one year on 
purebred mares; he then was sold into a community where he was bred only to grade mares until his death. Brilliant 1271 was placed at the head of the Oaklawn stud in 1882 and became the most famous sire ever used in America. However, his greatest descendants are the result of line-breeding his sons and grandsons on daughters and granddaughters of Brilliant 1899, so that the two together must be given the credit for the dominance of Brilliant blood in the Percheron breed.

The leading showring winner's of the '80's and early '90's were dominated by the Brilliant blood, but the most remarkable feature is the prepotency of the leading horses of this strain. Out of the 56 animals that won first prizes in the stallion and mare classes at the shows held by the Sociéte Hippique Percheronne de France during the years from 1901 to 1908 all but 9 traced directly in the sire's line to Brilliant 1271 or Brilliant 1899, or both, the chief lines of descent being through Brilliant 3d 11116 (2919), Villers 13169 (8081) and Marathon 11410 (10386).

In addition to this record, which includes only firstprize animals at the most important show in France, the record of the International Live Stock Exposition at Chicago offers cumulative evidence of the prepotency and value of Brilliant blood. Of the 11 different stallions that have won grand championship honors in the 14 shows that have been held, all but 2 trace directly in the sire's line to this strain, and the champions that have since become famous 
as sires are line-bred in Brilliant blood to a considerable degree. Such overwhelming evidence of the high merit of the descendants of Brilliant 1899 and Brilliant 1271 in the showring and the stud warrants detailed consideration of these horses and of the methods used in combining their blood.

The Story of Old Brilliant.-Foaled in 1867, Brilliant 1899 was extensively used in the stud of Ernest Perriot, Sr., until 1881. His greatest son, Brilliant 1271, was foaled in 1877. Old Brilliant begot other good sires, but his greatest honors come through his daughters. Four mares sired by Brilliant 1899 were the dams of Seducteur 8850 (7057), Tripoli 11110 (20034), Marathon 11410 (10386) and Brilliant 3d 11116-four of the greatest show horses and sires of the breed. Imported to America in 1881 by Leonard Johnson the old horse was taken directly to East Castle Rock, Minn. Here he remained part of a year and sired 3 purebred colts. He was sold in 1882 to P. C. Fockler, Independence, Ia. The horse was 15 years old when Mr. Fockler bought him for $\$ 2,000$, but his vigor and vitality were such that he lived to be nearly 30 years old, proving to be a sure sire until near the time of his death. During the last few months of his life he became partially paralyzed in his hindquarters and it was necessary to call in the neighbors to help him to his feet, after which he could walk around. Rather than see the game old sire suffer Mr. Fockler had him killed.

During his service in the stud at Independence Brilliant 1899 was bred only to grade mares. In- 
formation obtained by the Percheron Society of America in 1915 from Mrs. P. C. Fockler and Messrs. C. R. Kirkner, R. F. French, Becker, Myers, Leming and Stevenson, all of whom knew the horse and owned colts by him, indicates conclusively that the Percheron breed has suffered a great loss through failure to put this grand old sire at the head of a stud of purebred mares in this country.

All of the parties interviewed remembered the horse well and knew him as Old Brilliant. They knew nothing of the history-making character of his blood on the Percheron breed, but they were unanimous in considering him the greatest horse ever brought to their community. Colts sired by him were sold at remarkable prices, considering the depression which prevailed in values in the early ' 90 's. John Myers, a brother-in-law of Mr. Fockler, testified that he sold a three-year-old grade filly by Brilliant 1899 for $\$ 300$ when an ordinary work horse could be bought for $\$ 60$. Mr. Becker stated that he sold a three-year-old filly for $\$ 250$ when values wore correspondingly low. C. R. Kirkner knew of a Colorado man who came to Independence and bought 40 fillies sired by Brilliant; in fact, this man bought every filly he could find by the old sire, regardless of price. Mr. Myers spoke of an Idaho ranchman who came in and bought carloads of his colts, and added, "It did not make any difference what kind of a mare was bred to Old Brilliant, the offspring was always a typical Brilliant colt.' John Stevenson, an aged horseman who patronized the old sire 
extensively said: "Almost everyone was disappointed in the Brilliant colts when foaled, as they were too small. They never quit growing, however, and they always retained that smoothness of form which made them real beauties.' Mr. Ferrell, in commenting on the estimate in which the horse and his descendants were held in the community, remarked that it was quite a common thing to hear people remark at farm auctions whenever an extra good draft horse was put up for sale, "I'll bet that horse has some of Old Brilliant's blood in him.',

This testimony is enough to show that the horse was a remarkable sire, both in France and in America, and it is a calamity that so great a sire was not found by a breeder of Percherons who could have put him at the head of a purebred stud. The testimony of men who knew him at Independence was that he weighed a ton "in pretty good condition," and such supplementary information as has been obrained indicates that he was about 16.3 to 17 hands in height and weighed about 1,900 pounds when in breeding flesh. He was a deep-chested, wide-breasted horse of unusual style, symmetry, finish and quality, and with a head whose contour and character would delight any Percheron breeder living.

Brilliant 1271.-Generally considered as the greatest sire ever used in improving the Percheron breed in this country and held by the majority to be the 
greatest sire the breed has ever known, this Brilliant 1271 owes no small portion of his success to the fact that he was for 15 years at the head of the Oaklawn stud with access to probably the greatest group of draft mares ever assembled by one breeder. He was imported in 1881 as a four-year-old, but sired his four greatest sons before he left France. Fenelon, 2682 (38) and Voltaire 3540 (443) were foaled in 1880, and Gilbert 5154 (461) and Briard 5317 (1630) in 1882, before he left France. It is well to note in passing that the arguments of those who contend that young stallions do not beget as excellent progeny as mature horses find here a record in direct conflict with their theory. Fenelon and Voltaire, two remarkable show horses and sires, were begotten when Brilliant was but a two-year-old. Seducteur 8850 and Brilliant 3d 11116 were sired by Fenelon when he was but a three-year-old. There are no other horses with as great show and stud records as these in all of Brilliant's progeny.

Brilliant 1271 came to Oaklawn without any special flourish of trumpets, but was so good in allaround Percheron type and character that Mr. Dunham immediately put him into service with Success 452 and Vidocq 483 (732), then stud sires of proved worth.

In this connection it is of interest to give the first detailed description recorded of Brilliant 1271; it appears in the Oaklawn catalog of 1882 as follows:

'Black; foaled 1877; imported 1881; weight 1,850; 16 hands high. Long and very round body; extra- 


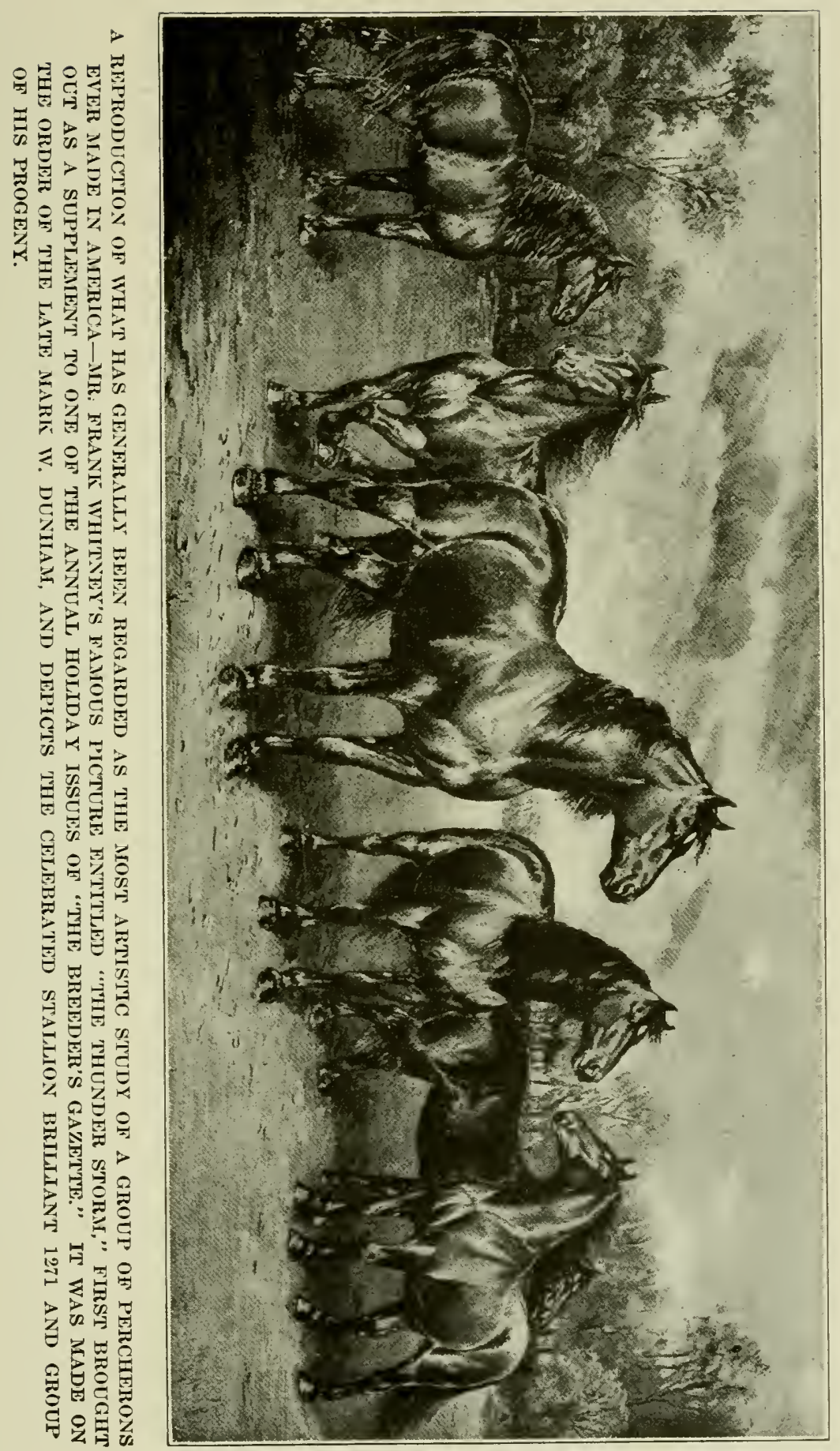



ordinary length of quarters, which are broad and level; very sloping shoulders of unusual depth; neck rather short; medium throttle; fine ear; wide between the eyes; slightly Roman nose; very broad breast; short legs and bone of uncommon width; good feet; immense stifle power. A horse with a combination of excellencies throughout."

Later descriptions give his weight as a little over a ton, but the testimony of men who knew him well is that he was in show shape at such weight and that he tipped the scales when in stud condition at about 1,900 pounds. A better idea of the horse can be obtained by a study of his picture, reproduced herewith. One thing is deserving of special emphasis: Brilliant 1271 was a most impressive horse in his general bearing, and masculine character was emphasized in every line. He was a dominant, vigorous, supermasculine stallion and no one could possible mistake his power. His colts from the first were of outstanding character, and Leonard Johnson, who was at that time purchaser for Mr. Dunham in France, was quick to appreciate their value. As a result 30 of his get were imported to Oaklawn Farm in 1882. Brilliant 1271 had already been put into stüd service at Oaklawn, but these colts sired in France and those which began to come at Oaklawn Farm in 1883 quickly convinced Mr. Dunham that he had secured a sire of incalculable value. He immediately extended his use in the stud and from that time until his death he was made the premier stallion of the Oaklawn stud.

Prepotency of Brilliant Blood.-The popularity of 
the Brilliant blood and its dominance in the ' 80 's, '90's and to the present day in the Percheron breed cannot be held to have been accidental. Percherons were measured then as now by their excellence in conformation, underpinning, quality, style and action. That the vast majority of the prize-winners in all leading shows, abroad and in America, were strongly bred in this blood, is proof that such horses had the highest individual excellence. Besides, it was found that they bred on with a high degree of certainty. It was this that soon led men to value the Brilliant blood very highly, and it is because of the two essentials of sheer individual merit and great prepotency that Brilliant dominates the Percheron breed as much as Baron's Pride does the Clydesdale, or Champion of England the Shorthorn. The most remarkable show horses of the '80's, which have since demonstrated the tremendous carrying power that spells prepotency, were Brilliant 3d 11116, Seducteur 8850 and Marathon 11410. All three were sired by sons of Brilliant 1271 out of daughters of Brilliant 1899. The blending of the blood of Brilliant 1899 and his son, Brilliant 1271, both splendid individuals, resulted in these three which were all greater as individuals than either Brilliant, and extraordinarily prepotent. Tripoli 11110 (20034), almost as great, was bred in exactly the same way, but was by still another son of Brilliant 1271 and out of another daughter of Brilliant 1899. Villers 13169 (8081), a fifth grandson of Brilliant 1271 through still another son, Briard 5317, is 


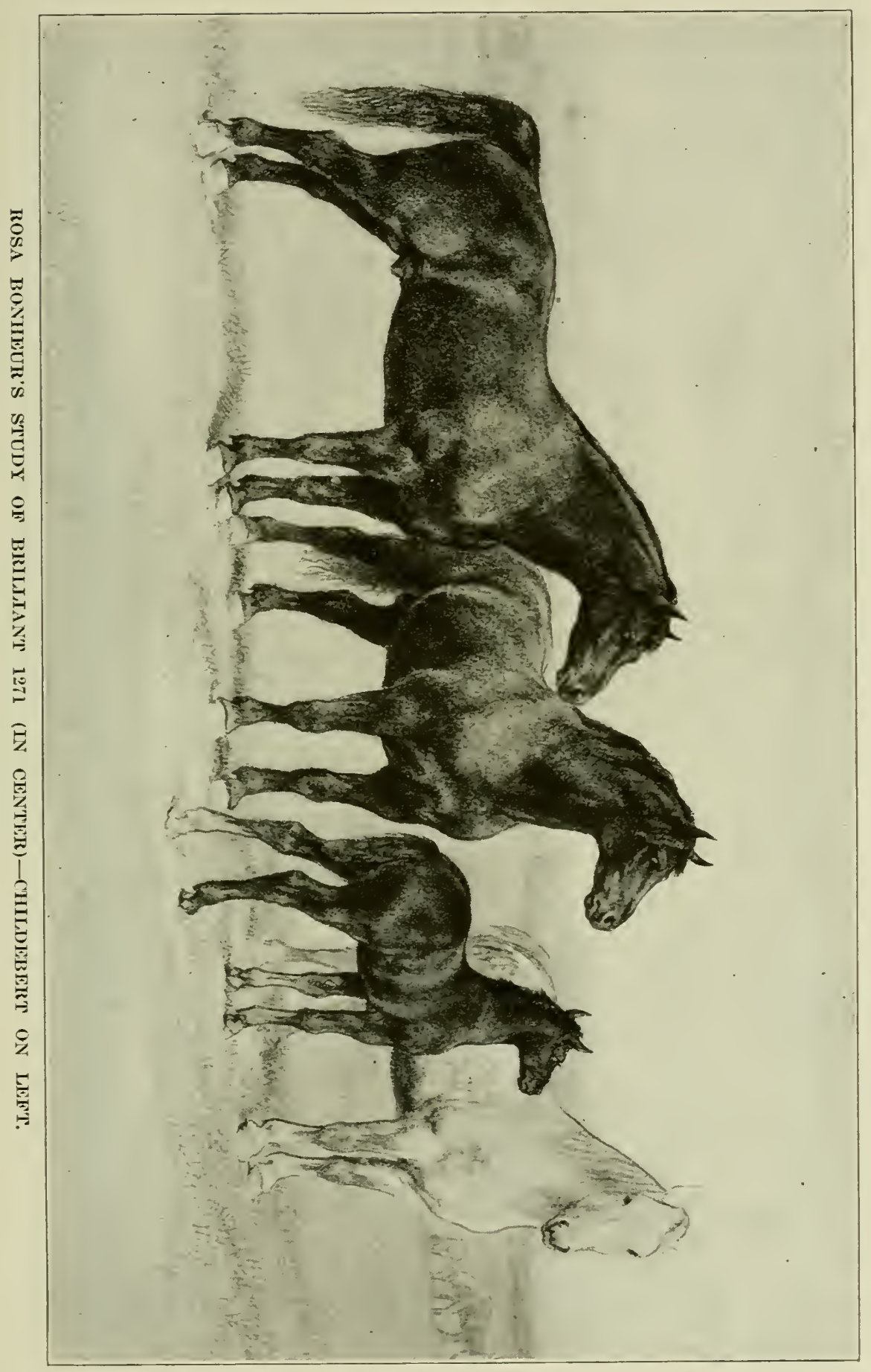



the only one of this remarkable galaxy of grandsons through which the blood of the two Brilliants has largely dominated the breed that is not out of a daughter of Brilliant 1899. He is closely allied in breeding, however, as his dam, Robine (5697), was a sister to the dam of Brilliant 1899.

Three other noted prize-winners of the same period -Producteur 4280 (68), winner of first prizes both abroad and in America, La Ferté 5144 (452), a show horse of extraordinary merit, and Cheri 5079 (2423), a noted winner on both sides of the ocean-have not been nearly so noted as sires and seldom appear now in the blood of winning horses. None was line-bred to any such degree as the five previously named, and only one, La Ferté, was of Brilliant blood, he being out of a daughter of Brilliant 1899.

The conclusion which must be drawn is that the accumulation of the characters which made both Brilliant 1899 and Brilliant 1271 valuable as individuals and as sires, by the expedient of combining their blood through line-breeding made their descendants extraordinarily valuable, not only because of unusual excellence as draft horses, but because of the power to transmit that excellence which we call prepotency. Ernest Perriot, Sr., has the honor of having brought about the breeding of all five of these line-bred sires of great note, and there is no question but that he has exerted a greater influence on the Percheron breed since 1880 than any other breeder in France or America.

Developments at Oaklawn.-With three of the 
greatest sires of the time and a goodly band of mares in his possession Mr. Dunham had optimistic dreams of breeding and raising annually a splendid group of colts. The troubles which forever beset breeders of draft horses who try to do things in a wholesale way soon made their appearance, however. Mr. Dunham raised 31 colts foaled in 1883, but the following spring when he had approximately 150 mares, a large proportion of them of breeding age, he raised but 13 colts. Abortion tells the story. In 1885 he reared 32 colts from 150 eligible mares, and in 1886 got but 20. Probably the mares were in too high condition. Anyhow they did not as a rule conceive for the first two or three years after importation and the foals produced by those that did breed were inclined to be so lacking in vitality that the mortality was extremely high. He also learned that abortion spread rapidly among mares kept in large bands; that navel ill was an ever-present source of trouble; and that idle mares after becoming acclimated were inclined to become so fat on rich bluegrass pasture that too high a proportion proved to be irregular breeders. Profiting, however, by these early experiences the present Oaklawn management is meeting with better success along this line. However, at the time of which we write Mr. Dunham, Sr., reluctantly came to the decision that Percheron breeding would have to be done by carrying the mares in smaller groups and on a basis where their work on the farm would serve the double purpose of keeping them in better breeding 
condition and reducing the cost of their keep. By 1887 he had sold many mares to men whom he had interested in Percheron breeding, and he also undertook the experiment of putting some out on lease.

Results Despite Difficulties.-Despite these reverses, which eliminated all hope of profit from his Percheron breeding operations, Mr. Dunham persevered and made some headway from 1887 on. In 1887 he raised 57 colts, in 1888 69, in 188951 and in 1890 44. A disastrous experiment in feeding silage in 1890 cost him several mares and a large number of colts, leading to the conclusion that silage was dangerous, as the presence of a little mold, harmless to cattle, was sure death to unborn foals and very dangerous to the mares. In none of these years lid he succeed in rearing more than one colt for every three mares; in 1890 he had 192 mares, most of them of breeding age, yet raised only 44 colts.

Not many of the colts bred at Oaklawn were exhibited, and consequently it has been difficult to obtain accurate information regarding them. Many of the best colts were sold as yearlings, and Mr. Dunham had unusual facilities for the selection of other show horses because of his heavy annual importations of the best obtainable in the Perche. The most satisfactory information regarding the estimate placed on the American-bred horses raised at Oaklawn is furnished by the prices paid for them. It must be remembered that purchasers going there had the opportunity of making selections from a large number of high-class imported horses or from the colts 
bred at Oaklawn; the fact that so many bought colts bred and raised there, at good prices, is evidence of the high character of the progeny.

Through the courtesy of W. S. Dunham we have been given access to the records which include all of the original Oaklawn Farm entries in regard to sales. Many animals were sold in pairs or in groups containing three or more, and it has been necessary to eliminate these on account of inability to determine the value of each. All horses sold individually for cash (no trades involved) have been listed, so far as important sires are concerned, and the cold figures give conclusive proof of the esteem in which American breeders held the colts bred and reared at Oaklawn. Prices and sires, given in order of their use, are as follows:

Vidocq 483: 2 stallions sold for $\$ 1,770$, an average of $\$ 885 ; 8$ mares sold for $\$ 6,170$, an average of $\$ 771$; 10 head sold for $\$ 7,940$, an average of $\$ 794$.

Brilliant 1271: 64 stallions sold for $\$ 60,275$, an average of $\$ 941 ; 44$ mares sold for $\$ 31,975$, an average of $\$ 726 ; 108$ head sold for $\$ 92,250$, an average of $\$ 854$.

Brilliant 3d 11116: 2 stallions sold for $\$ 2,100$, an average of $\$ 1,050 ; 2$ mares sold for $\$ 1,150$, an average of $\$ 575 ; 4$ head sold for $\$ 3,250$, an average of $\$ 812$.

Aiglon 13145: 14 stallions sold for $\$ 15,100$, an average of $\$ 1,078 ; 9$ mares sold for $\$ 3,850$, an average of $\$ 427 ; 23$ head sold for $\$ 18,950$, an average of $\$ 824$. 


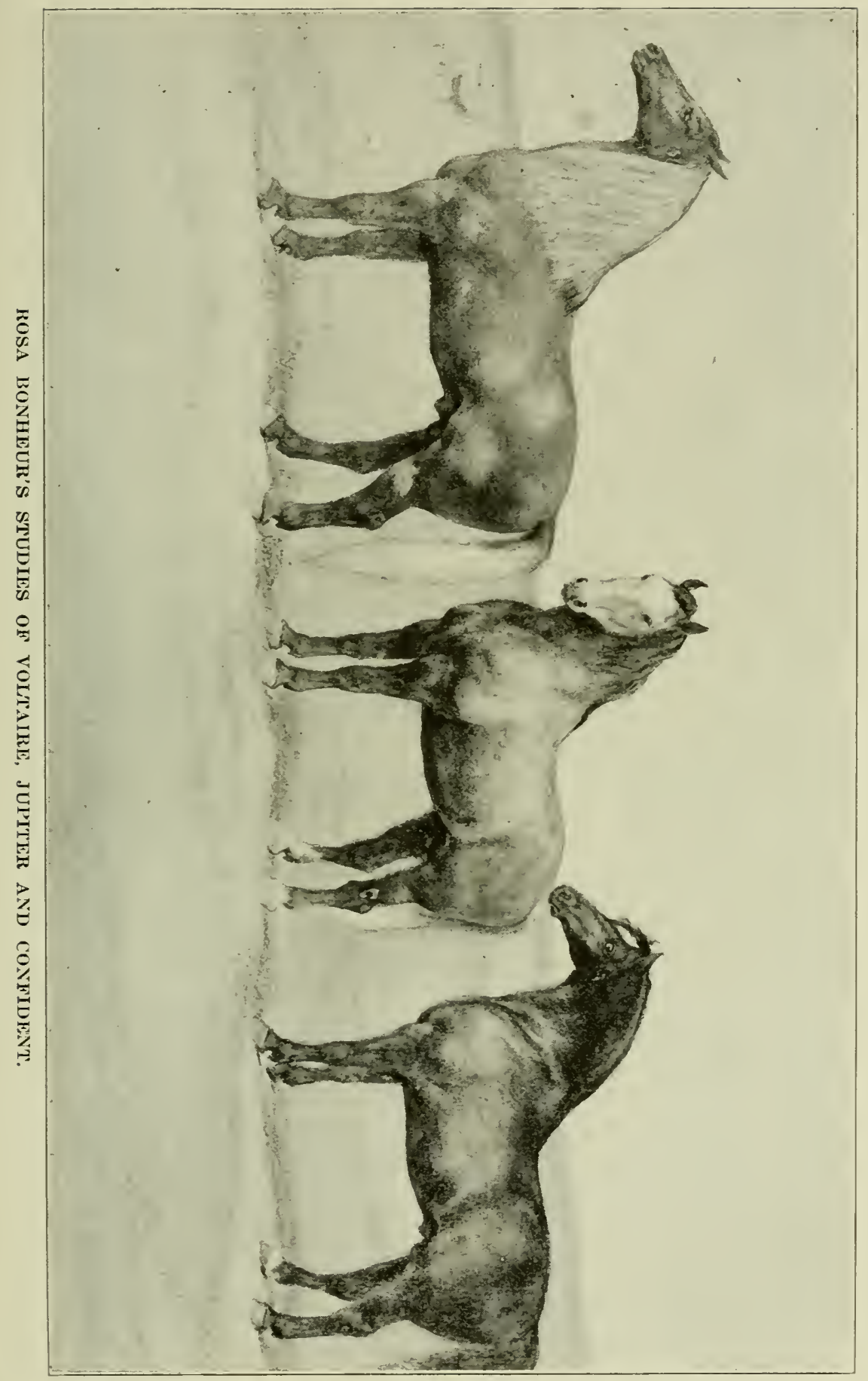



Introuvable 16875: 19 stallions sold for $\$ 18,000$, an average of $\$ 947 ; 7$ mares sold for $\$ 2,700$, an average of $\$ 385 ; 26$ head sold for $\$ 20,700$, an average of $\$ 796$.

Villers 13169: 9 stallions sold for $\$ 9,400$, an average of $\$ 1,044 ; 5$ mares sold for $\$ 1,925$, an average of $\$ 385 ; 14$ head sold for $\$ 11,325$, an average of $\$ 808$.

Remembering that a large proportion of these animals were sold during the ' 90 's, - when values were greatly depressed, and that by far the greater proportion were sold as one-, two- and three-year-olds it will be realized at once that Mr. Dunham's American-bred colts were highly valued by breeders. Of the 64 stallions by Brilliant 4 were sold as weanlings, 23 as yearlings, 18 as two-year-olds, 8 as three-yearolds, and only 11 as four-year-olds or over. Of the 44 mares listed 5 went as weanlings, 16 as yearlings, 15 as two-year-olds, 1 as a three-year-old and 7 at greater ages.

Great Mares of Oaklawn Stud.-It is difficult to particularize as to the mares used in the Oaklawn stud at this time. Among those of unusual excellence we may name Janecia 2768 (1368). Her colt foaled in 1886, Brannock 5688, was sold for $\$ 1,200$ as a two-year-old, and her next colt, Belidor 9520, foaled in 1888 , brought $\$ 2,500$ as a yearling. Both were by Brilliant 1271. She was a fairly regular breeder, producing 7 colts in 10 years, all but one of which were stallions. Individual prices on the others could not be ascertained, but her colts were all of extra good character. Constance 1478 (1425), 
imported in 1881, was another extra good mare that did well for Mr. Dunham. One of her colts, Wolford 2274, foaled in 1883, was sold as a three-year-old for $\$ 1,700$; another, Bancroft 3367, foaled in 1884, was sold as a four-year-old for $\$ 2,000$. She too was a regular producer, raising 9 foals in 12 years, 5 of which were fillies; all her foals except the last one were by Brilliant 1271 and all were of more than average value. One of Constance's daughters, Rivonia 2213, was in a group of 15 mares sold in 1885 to E. A. Hitchcock \& TV. B. Collier of St. Louis for $\$ 14,400$. Linda 2751 (1521), imported in 1883, was another profitable mare. Her first colt, Bassanio 4339, sired by Brilliant 1271 and foaled in 1885, was sold as a two-year-old for $\$ 1,400$. She continued to breed with regularity till 1898, producing 10 colts in 14 years, all above the average. Six were stallions and 4 were mares. Faustine 1314 (1431) was another excellent show mare and her colts though few were good. She was about 16 hands high, weighed 1,700 pounds, and although a failure at first because she did not raise a colt from 1881 to 1884, she later produced exceptionally good ones: Barcino 4341, foaled 1885, was sold as a yearling for $\$ 1,000$, and her next, Brastin 5689, foaled in 1886, brought $\$ 1,200$ as a two-year-old. Both were by Brilliant 1271. She raised but 6 colts in 16 years, however, and so cannot be considered a profitable matron.

Peerless 744, a medium-sized, symmetrical brood mare, raised 3 colts for Mr. Dunham and was then 
sold to Ballachey Bros., Brantford, Ontario, and raised 8 in 10 years. Rachel 1461 (1460) was the dam of Bartholdi 3666, sired by Brilliant 1271 and sold as a two-year-old for $\$ 1,500$; she was a regular producer of good ones, raising 5 by Brilliant 1271 . Delora 2756 (1530) was the dam of 8 good ones, the last of which, Ali 20012, was placed at the head of Grant Caldwell's stud at Dana, Ill., where he sired Ali 2d 30783, champion American-bred stallion at the International Live Stock Exposition in 1903. Brillantine 5675 (6948) was a great mare individually and raised good colts, but not many of them. Zither 2283 (Lisette 36 ) was another valuable brood mare. Not the least was Absala 5651 (6718), the dam of Linda 12986, foaled in 1889. Linda was the dam of 9 colts, foaled in 11 years, 1892 to 1902 inclusive, yet won championship honors at the International in 1901. One of Linda's colts, Allegro 20046, sold as a three-year-old in 1899 , when values were submerged almost to the point of extinction, for $\$ 1,150$, and she left many others as good. Comment on other mares might be added, but as we shall come back to Oaklawn mares from time to time in considering other studs.

Oaklawn Influence.-Mr. Dunham's aggressive work as a breeder, exhibitor and advertiser of Percherons did more to hasten the development of Percheron breeding than any other factor of this period. He exhibited at the Chicago shows, sent a strong exhibit to the New Orleans Exposition in 1885, and was one of the organizers of the first show held by 
the Percheron Society of America in 1886.* His horses were well toward the top in all shows, his advertising was pushed in every legitimate manner, and his farm and personality appealed to men of wealth who were interested in farming. From the very nature of his operations it is hard to distinguish between his work as an importer and as a breeder. Sales frequently carried animals of his own breeding as well as imported horses.

Vidocq 483 was champion at the Chicago show in 1881; Brilliant 1271 was first as aged stal!ion and champion at the New Orleans Exposition in 1885, where he was champion over all breeds; Producteur 4280 (68) (aged heavy-weight class), Gilbert 5154 (461) (four-year-old heavy-weight class), Tuduc 5156 (474) (three-year-old light-weight class), and Conde 5163 (two-year-old), were all first-prize winners in the great Percheron Society show in 1886 at Chicago; Ercilla 2211 (1429) (five-year-old heavy class), Bellora 2237 (1415) (four-year-old heavy class), Giara 2755 (1531) (four-year-old light class), Rose 4344 (4899) (three-year-old heavy class), and Belle 4352 (4852) (two-year-old) were all first-prize

* At the Percheron Society show at Chicago in 1986 the five-, four- and three-year-old stallion classes were divided into heavyand light-weight groups as follows: five-year-olds, 1, S00 pounds or over, and under 1,500 pounds; four-year-olds, 1,750 pounds or over, and under 1,750 pounds; three-year-olds 1,700 pounds or over, and under 1,700 pounds. Mares of same ages were also divided as follows: five-year-olds, 1,750 pounds or over, and under 1,750 pounds; four-year-olds, 1,700 pounds or over, and under 1,700 pounds; three-year-olds, 1,600 pounds or over, and under 1,600 pounds. The result was to double the number of prizes given, and to classify the animals more exactly into the large- and medium-sized types. For convenience we refer to these merely as the heavy- and light-weight classes. 
mares in their respective classes at the same show. Brilliant 1271 was awarded first in the class for the sweepstakes stallion with five of his get at this show.

In 1887 at the horse show held in connection with the Fat Stock Show at Chicago Oaklawn won first on Pacha 6977 (4358), a three-year-old, first on Gastronome 7058 (8952), a two-year-old, and first on Julia 5676 (7015), a two-year-old mare, besides numerous prizes below first. Brilliant 1271 was again first in class for stallion and four of his get. In 1888 at the same show Oaklawn won first in aged stallion class on La Ferté 5144, subsequently made senior champion over all breeds, first in the threeyear-old class on Dompteur 9201 (9886), and lesser prizes in various classes. In 1889 Fenelon 2682, then a seasoned sire 9 years of age, won first in the aged class, and Oaklawn also won first in the yearling class, with seconds in the three- and two-year-old stallion classes. Oaklawn also won firsts in the two mare classes on Vanity 2275, bred at Oaklawn, and Bertha 5340 (7008), the latter winning first in the class for mare with colt at side. In 1890 Oaklawn did not exhibit at the American Horse Show, but two grandsons of Brilliant 1271, Seducteur 8850 and Tripoli 11110, won the first places in the aged and three-year-old stallion classes, and another grandson, Baccarat, 11326, was second in the threeyear-old class. Each was shown by a different exhibitor. Albatros 13062, a son of Seducteur 8850, was the first-prize two-year-old and Kirsch 2d 11837, 
by Kirsch 7196 by Confident 3647 by Brilliant 1271, was first in the yearling class, so that the firsts in the yearling and two-year-old classes were both won by great-grandsons of Brilliant 1271. Every first was won by a grandson or great-grandson of Brilliant 1271, a record which was duly advertised by Mr. Dunham, as Brilliant 1271 was then in active service at the head of Oaklawn stud.

Oaklawn Sales of '80's.-Mr. Dunham's sales extended over a wide area, and he was very influential in developing breeding interests in other states. He had invested nearly a quarter of a million dollars in Percheron mares by 1890, and while the returns were not at all commensurate he had confidence in the ultimate development of Percheron breeding in America. While his chief attention was centerea on sales of stallions, he did all he could to encourage breeders in founding studs of Percherons in this country. To illustrate how widely the mares were distributed it may be noted that the 287 mares out of which Mr. Dunham bred colts between 1870 and 1900 , except those retained or which died, were sold to 88 different buyers. Prominent purchasers of mares in this epoch were: Speedwell Farms, Lyndon, Vt., whose operations are still continued; E. A. Hitcheock \& W. B. Collier, St. Louis, Mo., whose studs were soon dispersed; G. W. Wilcoxen, Canton, Ill., whose good Percherons have been of inestimable value in developing draft horse interests in Fulton Co., Ill.; H. A. Babcock, Neenah, Wis., who made his money in market horse operations and bought 
his Percherons with seasoned judgment; Willard \& Fuller, Mapleton, Minn.; The Minnesota Percheron Horse Co., Cazenovia, Minn.; T. \& J. Harper, Paw Paw, Ill.; W. J. Jordan \& Son, Newbern, Va.; Parsons \& Baldwin, Watervliet, Mich.; W. H. Penny, Stronghurst, Ill., and many others.

Oaklawn sold more history-making sires than any other establishment during this period. Among those which have exerted a far-reaching influence on the breed in this country were the following:

Confident 3647 (397), sold to R. Nagle \& Sons, Grand Ridge, Ill., as a four-year-old for $\$ 3,500$.

Fenelon 2682 (38), sold to R. Kellogg, Green Bay, Wis., as a four-year-old for $\$ 3,500$. He was subsequently sold to W. R. Allen of St. Louis for $\$ 6,000$, and later headed the stud of Thomas W. Palmer, then President of the American Percheron Breeders' Association.

Gilbert 5154 (461), sold to Leonard Johnson as a four-year-old for $\$ 3,200$.

Briard 5317 (1630), sold to Leonard Johnson as a four-year-old for $\$ 5,000$. (All of these were imported sons of Brilliant 1271).

Producteur 4280 (68), sold to Brickman \& Baker, Rednerville, Ontario.

Other sires sold at this time that were of great value were:

Bavardo 7236, sold to J. H. Smith, Milo, Ia., in 1888 as a yearling for $\$ 1,200$ and used chiefly on grade mares; Bendago 11807, sold to G. S. Hanna, Bloomington, Ill., in 1890 as a yearling for $\$ 1,200$, 
heading this stud for a time and leaving 36 purebred colts; Belidor 9520, sold to F. H. Redfield, Batavia, N. Y., in 1889 as a yearling for $\$ 2,500$ and being used on some purebred mares, though not many; Breme 7229, sold to the Little Missouri Horse Co. in February, 1888, when about 10 months old, for $\$ 700$, leaving some purebred colts, but being used chiefly on grade mares. The last four were bred at Oaklawn, and were sired by Brilliant 1271. There were numerous others of almost, if not quite, equal rank.

Mr. Dunham's Influence.-One of the leading features of Mr. Dunham's work at this time was its effect on others. He demonstrated conclusively that Percherons paid. He proved that Percherons could be bred in America, and sold at early ages and high prices. He tested out to his own satisfaction and for the benefit of others the impracticability of undertaking to keep Percheron mares in large bands, idle, for the sole purpose of rearing colts. He came to the conclusion that Percheron breeding must be carried out on farms where the mares could do work enough to pay their way and where their prolificacy would be increased by reason of healthier breeding condition induced by moderate work. He advertised early and late, more freely and with better results than any horseman of his own or earlier times, and he popularized Percherons on the soundest of all platforms-"their utility value on the farm, and their ability to raise the value of common horses from one-fourth to one-third by the first cross, and 
to continue raising the market value by each subsequent cross."

Ellwood Green.-It is doubtful whether the history of any breed furnishes a parallel to the spectacular career of W. L. Ellwood in Percherons. Backed by his father, I. L. Ellwood, a wealthy manufacturer of barbed wire, W. L. Ellwood began his operations in 1881 by importing a few Percherons. A few more were brought over in 1882, 1883, 1884 and 1885, but in 1886 he began in earnest by importing 164 stal. lions and 100 mares. His heavy importations continued during the next four years. He never hesitated at price in his efforts to obtain the best horses the Perche possessed. The firm, consisting of W. L. Ellwood and his father, who gave little attention to the horse business, acquired about 4,000 acres of land near DeKalb, Ill. This was divided into six large, well-equipped farms, which were first operated with grade Percheron mares. These were later replaced by purebreds. Excellent sale barns and offices were built in DeKalb, and a thoroughgoing business organization was developed to handle the farm operations, and the breeding, importation and sale of Percherons.

Mr. Ellwood decided at an early date that Percherons were the most desirable for American conditions. In one of his early catalogs he said: "I am sincere in my belief that it has been fully demonstrated that for individual merit, and powers of transmitting same to his progeny, the Percheron shows a purity of breeding that is unapproachable, 
justifying my use of the quotation that 'to compare him with other draft breeds is like comparing water with other elements, or gold with other metals.' ",

With this idea uppermost in his mind, Mr. Ellwood bought the best horses he could find, and he had the advantage of the assistance of Thomas Sloan, an experienced and discriminating judge. Practically unlimited means made it possible for him to outbid the other buyers who were then competing with him in the Perche, and even Mr. Dunham was hard pressed to hold his own in the showring during the Ellwood days. All told, the Ellwoods imported about 800 Percherons, and bred during the first 10 years 65 stallions and 67 mares, or a total of 132 head by 1890. This brought them into second place in the Percheron operations of this epoch, both as importers and as breeders.

Sires Used by Mr. Ellwood.-Some of the greatest show horses of the breed were imported and exhibited by Mr. Ellwood, who was quick to realize the advantage of this form of advertising. In 1886 at the first great show held by the American Percheron Horse Breeders' Association he won second in the aged stallion heavy-weight class on Cheri 5079 (2423), champion at the government show at Chartres, France, in 1885; second on Phebi 5048 (329) in the four-year-old heavy-weight class; first on King of Perche 4975 (6738) in the four-year-old light-weight class; first on Extrador 4979 (6890) in the three-year-old heavy-weight class; second on Paolo 5025 (4914) in the two-year-old class. He also 


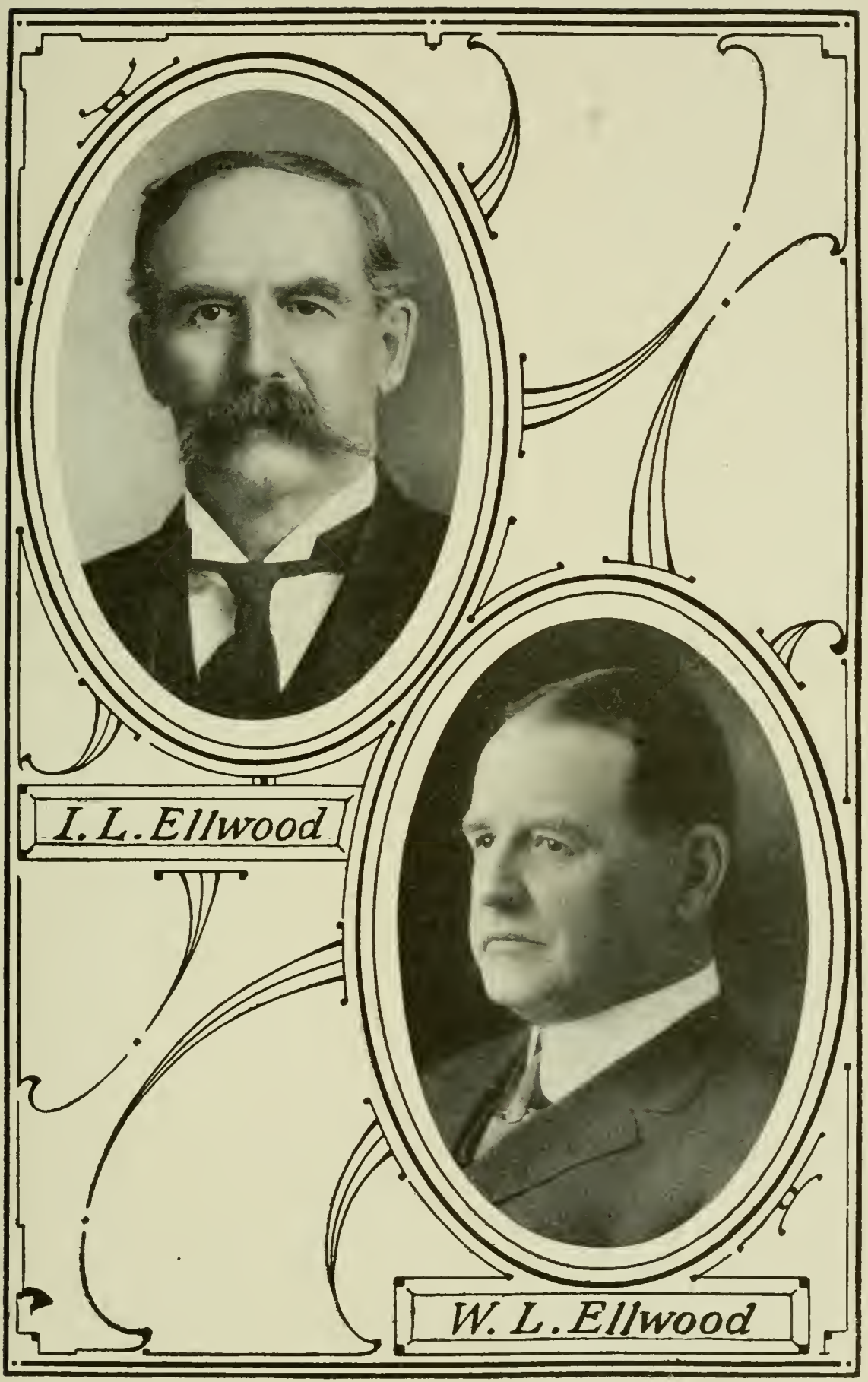



won second on Queen of Perche 5056 (6740) in the aged mare class for heavy-weights, this mare having won championship at the Percheron Society of France show at Nogent in June of that year. These winnings and others were enough to make Ellwood Green widely advertised, for cases are few and far between where new exhibitors break into the top ranks at the very outset to so great an extent.

Cheri and Seducteur.-Cheri was the first noted horse used at Ellwood Green, and it was most unfortunate that high condition inhibited his career in the stud. He sired but 17 stallions and 22 mares during his service in 1885, 1886, 1887 and 1888. He died in 1888. King of Perche 4975 (6738) was still more unfortunate; he also died in 1888 with but 9 stallions and 4 mares to his credit. The loss of these horses, probably largely due to too high condition maintained for too long a period, was a distinct injury to Percheron interests in America. Cheri was a most remarkable horse. Foaled in 1881 and imported in 1885, he was about 17 hands in height, weighed over a ton, and was a compact, well-proportioned stallion with good style, finish and action. He was gray in color, heavy-boned, but with excellent quality, and such colts as he did get were good ones. He too was line-bred, being sired by a grandson of Coco $2 d$ (714) out of a daughter of Coco $2 d$, and had his career in the stud been longer continued much benefit to the breed would have accrued. King of Perche was a marvelously finished show horse, but lacked in size. 
Urbain 6805 (5680), foaled in 1883 and imported in 1887, was also used at the head of the stud, and sired 11 stallions and 13 mares. He was a rugged, big horse, very good throughout. He won first at the national show at Remnes, France, in 1887 and third in the aged stallion class at the American Horse Show, Chicago, in 1890. Rigilo 4980 (2103) was another very good horse, foaled in 1883 and imported in 1886, that proved to be a very good breeder. He was. first at the Illinois State Fair in 1889 in the class for stallion and five of his get.

Seducteur 8850 was probably the greatest stock horse ever used at Ellwood Green. He was first in the two-year-old class at the show of the Societe Hippique Percheronne in 1886, and was second at the same show in 1888, being beaten only by his halfbrother Brilliant 3d 11116. In 1890 Seducteur won first at the American Horse Show at Chicago, and one of his colts, Albatross 13062 (30051), won first in the two-year-old class. Seducteur also won in the class for stallion and three of his get. The excessively high condition in which he was kept from 1886 to 1890 later affected his breeding powers, and he was a poor getter throughout his life. His colts, however, were so extraordinarily good that he was valued very highly and was subsequently at the head of two other purebred studs. No sire used in the west in the past 25 years stands higher than Seducteur in the estimation of American breeders. Individually he was large, standing about 17 hands high and weighing considerably over 2,100 pounds 


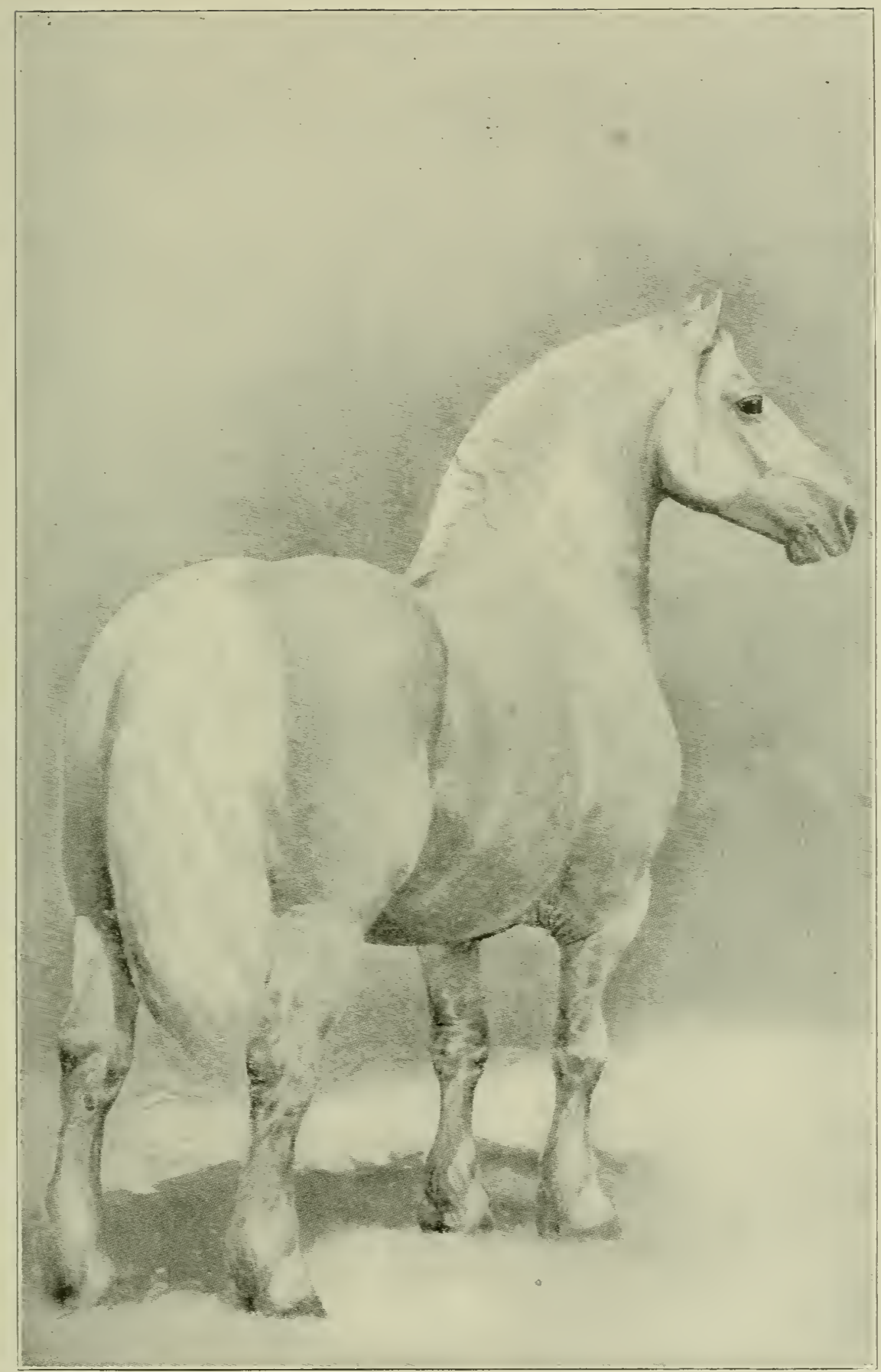

SEDUCTEUR 8850 (70\$7) FIRST-PRIZE TWO-YEAR-OLD, PERCHERON SOCIETY OF FRANCE SHOW IN 1886; FIRST-PRIZE AGED STAILION AND WINNER OF GET-OF-SIRE PRIZE AT CHICAGO IN 1890. 

in show condition. He was of the strong, sturdy type with extra heavy bone, and was a very massive, deep-middled, strong-backed horse, with extra good loin and a long, level croup. He stood well on his underpinning and was an up-headed, stylish horse, lacking a trifle in finish about the head and neck, but very masculine. He was used by Mr. Ellwood till about 1893, when he was sold to William Goodwin \& Son of Benson, Minn. Here he was used chiefly on grade mares. The Goodwins in turn sold him to parties near Malvern, Ia., about 1896 or '97, and here again he was used chiefly on grade mares, though he did sire three purebred colts during the two or three years he stood there. He was subsequently found and purchased by H. G. McMillan of Lakewood Farm, Rock Rapids, Ia., and his later history will be considered in connection with that stud.

Mares in Stud.-Mr. Ellwood's operations in Percherons ceased about 1898, and it is impossible to obtain exact inventory figures on the number of mares owned at different periods. An analysis of the catalogs issued gives the number of mares owned at different times, and the records in the offices of the Percheron society show the number of colts raised: In 1887 he had 144 mares and recorded 16 stallion colts and 10 filly foals as bred by himself; in 1888 he had 126 mares and recorded 9 colts and 12 fillies; in 1889 he had 129 mares and recorded 18 colts and 16 fillies; in 1890 he had 94 mares and recorded 13 colts and 10 fillies. It will be noted that 
the percentage of foals to mares owned was approximately 25 per cent. It must be remembered of course that in 1887 and 1888 many of the mares were too young to foal. In 1890 most of the mares were old enough to raise colts, but even then the percentage was very small. Part of the trouble was in the mares, for while Mr. Ellwood as a whole had a highclass lot of mares in size and in draft type, a good many of them lacked feminine character, being very massive with more draft type than brood mare pattern. Another trouble was in the stallions. Seducteur, relied upon in 1889 and later, was not sure. The acclimation troubles which often beset imported animals undoubtedly hindered many of the imported mares from raising colts for the first few years after importation. Queen of Perche 5056 (6740), Mr. Ellwood's greatest mare, a winner in France and America, raised but 4 foals in 12 years3 fillies and 1 stallion. Part of her trouble was probably due to fitting for the showring; she raised a colt imported in dam and one the next year, then quit for a time.

Influence on Other Studs.-Sales were made to many of the leading breeders, and some studs were founded directly on purchases made at Elwood Green. T. L. \& J. L. De Lancey, Northfield, Minn., made their start in Percheron breeding by purchasing a carload of mares in 1885 . The Minnesota Percheron Horse Co., Cazenovia, Minn., also made heavy purchases from the Ellwoods. T. W. Palmer, Detroit, Mich., R. B. Kellogg of Wisconsin, The River- 


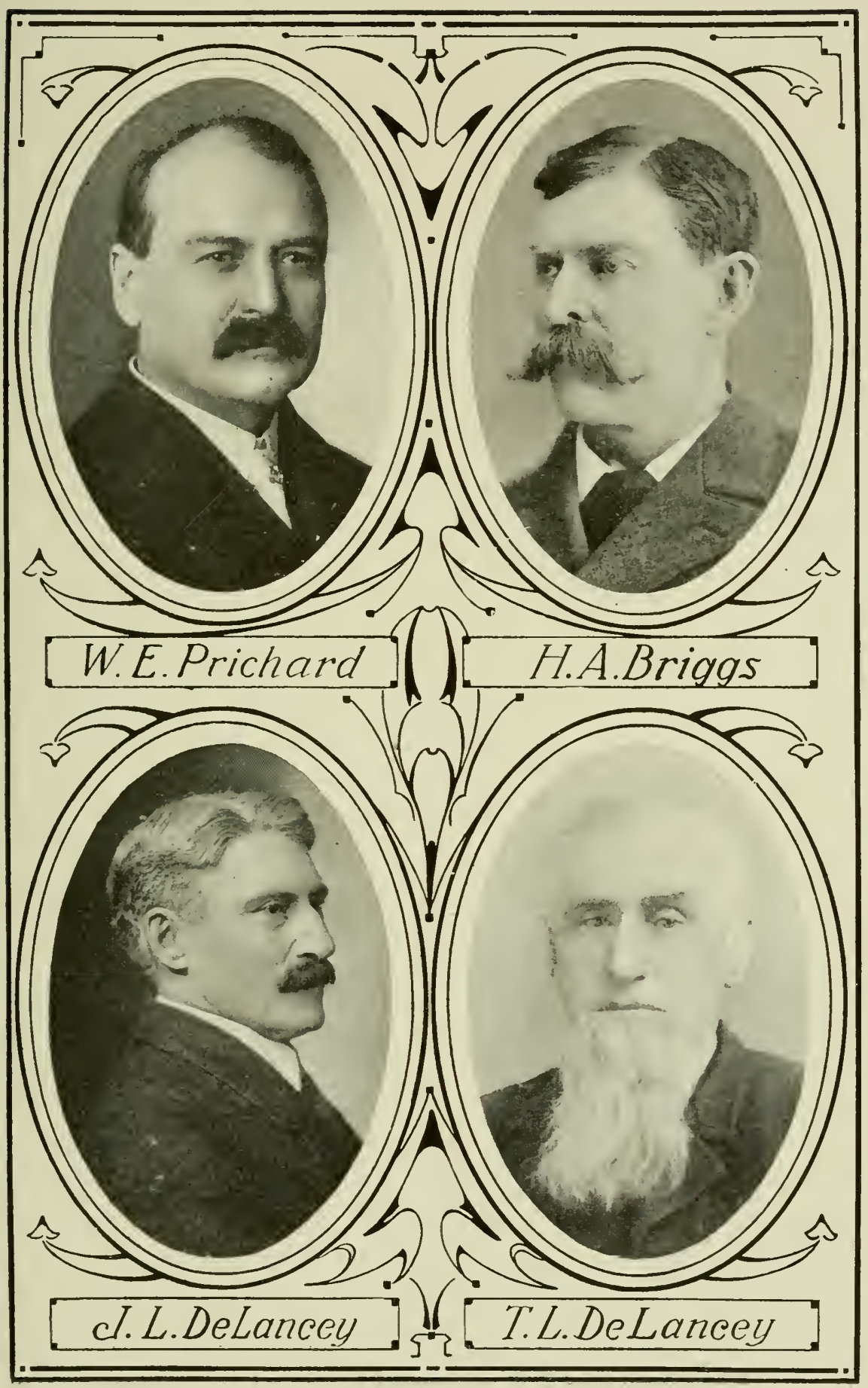



side Ranch of North Dakota, the Risser Horse Co., Onarga, Ill., the Colverdale Stock Farm and H. P. Malone, New Vienna, O., O. L. Thisler, Chapman, Kans., Walter Green, Mapleton, N. D., Thomas Cross, Bangor, Mich., C. E. Davis, Davis Junction, Ill., C. E. Sutton, Russell, Kans., Cross Bros., Durand, Ill., R. Nagle \& Sons, Grand Ridge, Ill., D. H. \& J.W. Snyder, Georgetown, Tex., and W. Sprole, Traer, Ia., were among the many who bought mares of the Ellwoods, and in some instances stallions as well. An analysis of the produce records of the imported mares sold shows that they were not as a whole very regular breeders, even in the hands of subsequent owners, and their influence on the breed has been much less than it should have been.

Noted Sires Sold.-Seducteur was the greatest sire sold. Superieur 5752 (2188), a very good horse and good breeder, went to head the De Lancey stud. Niger 4986 (2951) and Picador 3d 5078 (4815) were good horses sold in 1887 and 1888 to head the Minnesota Percheron Horse Company stud at Cazenovia, and the company bought a carload of the best mares Ellwood had about this time. Mark M. Coad, Fremont, Neb., who also had ranches in Wyoming, bought three sires about 1887, one of which, Turc 6539 (10052), proved to be a very prepotent stallion, probably one of the best, if not the best, ever used west of the Missouri River. There were numerous others that had less opportunity, but that have done much good in local spheres.

Summary of Ellwood Operations.-Great credit 
must be given to the Ellwoods for the benefits accruing from their work in this epoch of expansion. They were wealthy, very influential in Illinois and elsewhere, and exerted a tremendous influence in swinging popular favor more strongly toward Percherons. They had the means and the disposition to obtain the best horses that could be bought, and transferred to American shores a large percentage of the prizewinners of the French shows between 1885 and 1890 . They advertised in the showring, covering not only Illinois, but all nearby states, and were liberal users of newspaper advertising. They also resorted to colored posters of attractive character which were widely distributed. In addition to all these factors they sold their horses on a fair margin of profit and were at all times willing to take reasonable paper. They also had confidence in the ultimate development of Percheron breeding in America, and manifested this by liberal importations of mares for their own use and sale. The result was greatly to encourage the small breeder. Everything considered, the firm deserves a very high rank in the Percheron history of this period and the work has been of incalculable benefit to Percheron interests in America.

Daniel Dunham's Work.-Daniel Dunham of Wayne, Ill., stands third in rank among the breeders of this epoch, as he raised 50 stallions and 41 mares of his own breeding. His stud was founded on imported stock, some purchased from Oaklawn and some imported by himself. The majority of the mares were imported in 1880, but many others were 
bred by Mr. Dunham and reserved for his own use. He had 43 mares in 1889, only 28 of which were old enough to produce colts, and a comparison of the records made by his mares shows that he had more regular-producing brood mares in proportion to total number owned than either Oaklawn or Ellwood Green farms. Probably this was due in part to the fact that he kept his best breeding females, and in part to their being maintained under farm conditions, where some work was required.

Marquis 868 (774), a son of Superior 454 (730) out of a daughter of Coco $2 d$, was the leading sire used at this time. He was a gray of good type and left some very good colts. Prosper 2501 (1155), a gray imported in 1883 by Oaklawn Farm, was the next sire of consequence. He was sired by Vaillant (404) out of a daughter of Prosper (893). He was a large, massive, heavy-boned horse of very rugged type and crossed well on the daughters of Marquis 868 (774). Don Brilliant 2029 (2482), a black son of Brilliant 1899 out of a daughter of Favori 1st (711), was used a little later. He stood 16 hands high, weighed about 1,900 pounds and was imported by Daniel Dunham in 1882, with others, and sold to J. WV. Morgan \& Co., Tower Hill, Ill. The colts he sired were of such excellent character and so uniform that Mr. Dunham bought him back in 1890 at a long: price. He left the choicest colts of any sire used, but had a select band of mares to work on.

Mares were sold by Daniel Dunham to William Holegate, Wyoming, Ill., C. P. Dewey, Toulon, Ill., 
J. H. Cowlishaw, Blakeville, Ia., W. P. Buswell, Neponset, Ill., F. M. Buhr, Knittle, Ia., Tim Payne, Dunbar, Neb., D. E. Branham, Litchfield, Minn., and numerous others. Those sold near Toulon, Ill., and Wyoming, Ill., were most numerous and have favorably influenced Percheron breeding in those sections. Stallions were sold over a wide range of territory, but few had any opportunity on purebred mares. As a consequence they have achieved no special renown, although they undoubtedly did much good in improving the common horses of their time. Daniel Dunham's career, which was distinctly that of a breeder, was cut short by financial difficulties which made it necessary to sell the Percherons in 1893 at a great sacrifice. The dispersion of such a stud, which had been carefully built up by a man whose instincts were those of a creative breeder, was most unfortunate and its sale at a time when all business throughout the United States was depressed scattered and dissipated the stock, as other breeders were not in a position to purchase.

The Dillons.-The Dillons, operating as Ellis Dillon \& Company and later as Dillon Bros., took fourth place in number of animals bred during this period, but in point of influence they ranked close to Mark W. Dunham and W. L. Ellwood. They were aggressive importers, exhibitors and breeders, and but for their adherence in part to a rival stud book organization might have exerted more influence on Percheron affairs than they did. They bred and raised 39 stallions and 43 mares-Percherons-during this time 
and were also active breeders of other draft horses. They exerted a greater direct influence on draft horse operations in central Illinois than any other breeders of this period, and many of the leading: studs in McLean, Tazewell, Livingston and La Salle counties are founded wholly or in part on stock from the Dillon stud.

Sires Used.-The chief sires which the Dillons used at this time were Extrador 4525 (386), imported by them in 1883, and Papillon 3559 (379), imported by Mr. Dunham. Both horses were of the rugged, massive type and bred very drafty colts. Powerful 6670 (Bayard 7519) was one of the best sires ever imported by the Dillons, but he was sold by them in 1882 to William Hurt, Arrowsmith, Ill., and was not used in their own stud, though they subsequently bought and used one of his sons, Dave P. 14366, bred by William Hurt. Favora 1542 (765), foaled in 1868 and imported in 1880 by the Dillons, was another horse of great note in Percheron breeding. He was about 17 hands high, weighed over a ton even after 12 years old, and was an extremely well proportioned, rugged, heavy-boned horse whose stock was noted for size and draftiness. He was among the winners at the World's Exposition at Paris in 1878, and although a very aged horse for showring work took first at St. Louis in 1880 . He sired but 5 colts in this country, probably because he had been used to the limit in France and then fitted to a very high condition in his ten- and twelve-year-old form for show. It is evident also that he had but slight 
opportunity. The Dillons sold him to Rush Co., Ind., where he sired two purebred colts for J. T. McMillin, the president of the company that owned the horse.* These colts were foaled in 1888 and 1889. R. B. Kellogg shipped some mares to be bred to Favora in May, 1888, and secured two colts. Favora died on April 15, 1889, aged 21 years.

Dillons in the Showring.-The Dillons were good advertisers and were appreciative of the value of showring exhibitions. They exhibited more generally at the county and district fairs in Illinois than any other breeder's of this period, and also made strong displays at the state fairs and Chicago horse shows. The extremely hot pace set by Mark W. Dunham, W. L. Ellwood, Leonard Johnson and H. A. Briggs shut the Dillons out of the prize-lists at the most important shows so far as stallions were concerned, but their mares won high honors in the strongest competition. Modesty G. 586 was their most noted show mare. She was first in the aged mare class at the Chicago show in 1887, and was also first for mare and two of her produce. She was not a regular breeder, and raised only 5 colts in 17

*W. H. McMillin, Rushville, Ind., writing under date of May 12, 1915 , says:

"Favora 1546 was owned by a company of men at Gings, Ind., of which my father, J. T. McMillin, was the president.

He got about 70 per cent of his mares in foal, but there were only 2 purebred mares in the county during the time he was used here. Favora was the greatest breeding horse ever used in Rush county. The mares at that time were small, ranging from ponies up, but the colts at four years weighed from 1,500 to 2,000 pounds, and the shippers would buy every one they could get, even as three-year-olds. I think he was brought here in the spring of 1882. He died April 15, 1889, at 21 years. He weighed over 2,200 pounds while owned in Rush county and was the best draft horse I ever saw." 
years. Her daughters were prize-winners, however, and one, Lorilee G. 1532, was also a winner at the leading shows and proved to be a better breeder than her dam. Christiana 1586 was another splendid mare owned by the Dillons, a show and brood mare combined, and many of the best horses now in central Illinois trace to her. Allegra 4454 by Extrador 4525 (386) was her greatest daughter; bred to Powerful 6670 (7519) she produced Loretta P. 10285, an extraordinary brood mare. Christina P. 16608 was almost as great, and Capsheaf 16986 was one of the very good sires used in Illinois. Any one of these three would have been enough to blazon a mare's name in history, and it is not surprising that Allegra 4454 is generally considered the greatest mare Dillons ever bred, although her record was made in the hands of William Hurt.

Mark M. Coad.-Mr. Coad, a wealthy ranchman with extensive interests in Nebraska, Wyoming, and other western states, stands fifth among the leading breeders of this period. He began in 1885 by importing 59 mares and 18 stallions, thereby inaugurating operations on an extended scale. He subsequently made a few other purchases from other leading importers and became very active in Percheron affairs in the west. The extent of his operations is shown by the fact that he bred between 1885 and 189040 stallions and 32 mares, and still more in the next decade.

Ranch and range conditions prevailed so far as the mares and growing colts were concerned, although 
he did halter-break and grain-feed the stallions intended for sale and the horses meant for the showring. The proportion of colts raised to mares owned was at this time about 25 per cent, the low increase evidently being due to acclimation troubles and losses among the foals.

Mr. Coad was fortunate in importing a very good sire, Henri Le Blanc 4542 (2433), at the time he secured his mares. This horse did much good, but his owner obtained a much greater one in 1888 in Turc 6539, a stallion imported by W. L. Ellwood. This sire, a black with both hind pasterns and one front one white, was a son of Confident 3647 (397), he by Brilliant 1271 out of a daughter of Coco $2 \mathrm{~d}$. He was a large, massive horse, standing a fraction over 17 hands high and weighing over a ton. He was well-proportioned, stood well on his feet and legs, and was a clean-cut horse of excellent style and quality. As a sire, he proved to be extremely prepotent and got big, rugged colts that weighed from 1,700 to 1,900 pounds in ordinary field condition at three years of age. His colts were symmetrical, stood well on their underpinning and were almost invariably sound and clean. He remained in service at the head of Mr. Coad's stud for a number of years. His colts were so extremely good that James M. Fletcher bought two carloads of the stallions in 1897 and considered them extra good, both as individuals and as breeders. They finished out as big, drafty horses, most of them weighing over a ton, and sired draft colts rugged and sound. 
Appoline 4778 (4003) was one of Mr. Coad's best mares. She was of showyard merit and he won second on her and her two colts at the Columbian Exposition in 1893. She was not an especially regular breeder, producing only 7 colts in 14 years, but they were good. One, Starlight 17891, foaled in 1895 and sired by Turc, was second in a strong class of twoyear-old stallions at the Chicago Horse Show in November, 1897. Mirza 4759 (4050) was a good brood mare. One of her daughters, Vanity Fair 16568, won third in the two-year-old filly class at the Columbian. Mirza was quite prolific, raising 7 colts in 13 years, and they were above the average. Vaillante 4787 (Loret 2453) was another mare of splendid individuality. She was champion in 1888 and 1889 at the Nebraska State Fair and was third at the Columbian in the sweepstakes class. She was a shy breeder, however, raising but 2 colts of record, one Diana 7537, foaled in 1887, and the other, Monarch 16670, foaled in 1892. Bijou 4780 (307) was another clinking good mare in Mr. Coad's stud. She was champion at the Nebraska State Fair in 1890, and was also a brood mare of more than average merit. She raised 8 colts in 10 years, 6 of them sired by Turc 6539 (10052), and they were good ones.

Mr. Coad was keenly interested in his Percherons, and was a ready exhibitor at leading shows, although his home fair, Nebraska State, received chief attention. He was a heavy winner there in 1887, 1888, 1889, 1890, 1891 and 1892 in both mare and stallion classes on meritorious stock. He did much 
to popularize Percherons in his territory and while most of the stallions he raised were sold direct to ranchmen for the improvement of range horses, he unquestionably did much good for draft horse and Percheron interests. His appreciation of a good sire led him to send some of his mares to the farm of C. S. Dole, Crystal Lake, Ill., in 1890 where they were bred to the noted Fenelon 2682, a horse that was even then receiving recognition as a sire from constructive breeders. One of the colts which resulted, Malmaluke 16574, out of Lucette 4774 (3031), was later used to some extent in $\mathrm{Mr}$. Coad's stud.

A. Wickstrom, Wilcox, Neb., was one of the early purchasers of mares from Mr. Coad, obtaining some in 1888. William Ernst, Graf, Neb., was another who obtained some foundation females from $\mathrm{Mr}$. Coad in 1886. William Hahn, Graf, Neb., also made a slight start from this stud. Mr. Coad sold mares to Mrs. J. E. Wilson, Minneapolis, Minn., in 1887, some of which were shipped by her to Oaklawn and bred to Brilliant 1271 with good results. Everything considered, however, the chief influence of $\mathrm{Mr}$. Coad's work at this time was to popularize Percherons in his country, for he did not care to sell many of his mares and the vast majority of the stallions went to head bands of grade mares. The good thus accomplished is beyond calculation, for it raised the value of common stock fully 25 per cent by the first cross. 


\section{GHAPTER X.}

\section{OTHER PROMINENT FIGURES OF THE PERIOD.}

Hon. Thomas W. Palmer of Detroit, United States Senator from Michigan from 1883 to 1889, was another of the leading breeders of this period. He was very wealthy, having been prominently identified as a stockholder or director in numerous banks, factories, and lake navigation companies. He had been a leader in politics, also, and was influential in state and national affairs. An able debater and a forceful speaker, his public utterances were commended widely for their clearness and the soundness of judgment which they expressed. Mr. Palmer engaged in Percheron breeding in 1883. He gradually increased his stud until by 1890 he had bred 28 stallions and 38 mares. His foundation stock was purchased at Oaklawn Farm, but he imported 2 stallions and 7 mares on his own account in 1883 . He made another importation of mares in 1886.

Log Cabin Farm.-Mr. Palmer had two farms, but his Percherons were kept on the Log Cabin Farm near Detroit-land that is now in parks and golf links. The place comprised about 500 acres of good land, well adapted to farming and pasturage. The 
log cabin, one of Mr. Palmer's fancies from which the farm took its name, still stands in Palmer Park." $\mathrm{Mr}$. Palmer's duties in the business and political world made it impossible for him to give much personal attention to his Percherons, and most of the details fell to his partner, E. W. Cottrell, and to George T. Van Norman, manager of Log Cabin Farm. An examination of the original inventory of Log Cabin Farm, furnished through the courtesy of George N. Brady, executor of the estate, reveals the fact that approximately 90 mares of all ages were owned in the spring of 1892. Mr. Palmer had from 40 to 50 mares in the stud during the latter part of the '80's. The imported mares were shy breeders during the first few years and he did not raise over 10 colts per year until 1889, when there were 12 . In 189027 were raised, and the mares bred more regularly from then on.

Anchorite 1370 (863) was the first stallion used, being Mr. Palmer's chief stud sire until he acquired

*The following comment is from The Breeder's Gazette of June 11, 1913:

"Senator Palmer was famed as the owner of the Log Cabin Farm on the outskirts of Detroit, a property which had been owned by his ancestors and which he purchased and improved with lavish hand. The log cabin home on the place cost more than $\$ 20,000$. It is surrounded by a large wooded tract, and near it is an artificial lake. The interior decorations and furnishings of the cabin are in keeping with its pioneer aspect, and include relics and heirlooms of early days collected for many years. It has been made to look as much as possible like the primitive homes of the pioneers, although it includes all modern conveniences.

"Near this cabin the senator had a stock farm of 500 acres, with a fine herd of Jerseys and a stud of Percherons. In this rustic home the senator entertained many distinguished guests with unique hospitality. There was no formality, and dinner was announced with an old tin dinner horn. Senator Palmer was said to have refused an offer of a million dollars for the property." 


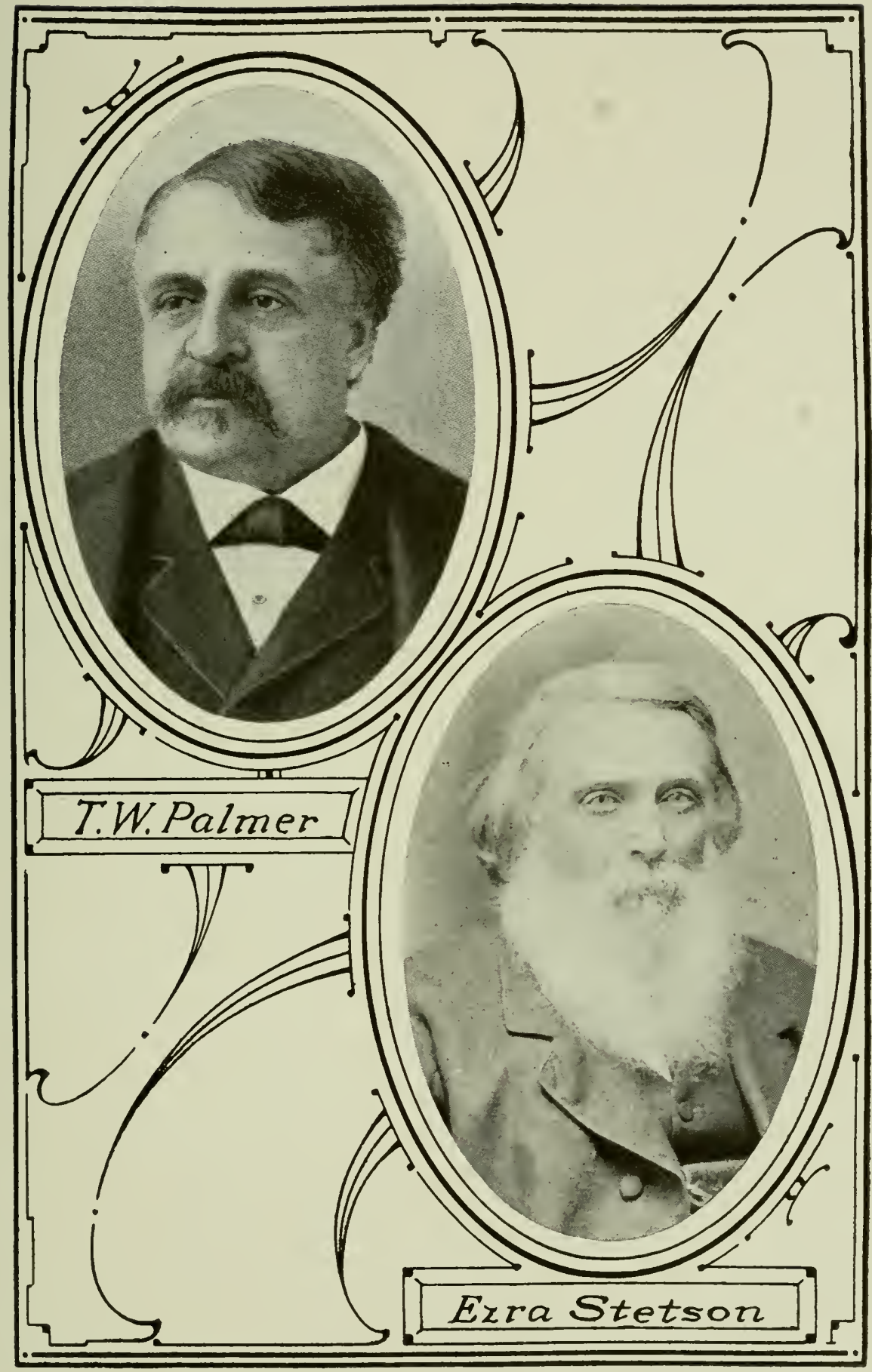



Fenelon. Anchorite was a medium-sized horse weighing around 1,750 pounds; he was very symmetrical, stylish, and of unusual quality. Sired by Romulus 873 (785), winner of first prize in the aged stallion class at the Universal Exhibition of Paris in 1878, Anchorite himself was a show horse and won first in the aged class for stallions under 1,800 pounds at the Percheron society show at Chicago in 1886. He was also a sire of merit. One of his daughters, Marie Antoinette 4882, out of a granddaughter of Vidocq 483 (732), won the gold medal offered by the Percheron Society of France at this same Chicago show for the best mare of any age bred in America. He sired medium-sized, symmetrical, sound stock of great quality and style. In fact, Anchorite's get proved just the kind of horses that were wanted in Michigan, where farmers did not take well to the large and massive type of drafters.

Mr. Palmer exhibited quite extensively at the leading shows. Anchorite was a consistent winner for him. Marie Antoinette, Loetitia 5198 (6495), and Rosa Bonheur 5100, imported in dam and sired by Bon Espoir (213), one of the best sons of Brilliant 1899, were his leading mares. Marie Antoinette was quite a producer and bred until she was over 20 years of age.

Mr. Palmer's influence was much greater than is indicated by the number and character of the colts he raised. His business ability, his sagacity, and his political standing all gave weight to his activities in behalf of the Percheron. He was elected first presi- 
dent of the American Percheron Horse Breeders' Association, which was incorporated on Nov. 10, 1885, succeeding the voluntary association known as the Percheron Horse Breeder's' Association of America, crganized in 1876 with Daniel Dunham as president. $\mathrm{Mr}$. Palmer served the association in the capacity of president with great ability for more than a decade. He was an enthusiastic supporter of the breed and encouraged the American breeder in every possible way.

Edgewood Farm. - Dr. Winter's operations, already referred to, were steadily continued during this period. While the number of horses which he bred and raised was not large, they were of good type and quality, although some were not of popular colors. He had from 20 to 25 mares of all ages. He raised only 3 colts in 1882, but the number gradually increased until in 1890 he recorded 11 of his own breeding. In all he produced 39 stallions and 27 mares during this decade.

Malbranche 293 was continued in the stud, but was not much used. La Force 249, imported in 1874 by the Princeton Horse Company, and Bernadotte 36, foaled in 1875, the first Percheron ever bred by Dr. Winter, were the chief sires in the stud. Valiant 473, a good horse imported by N. C. Buswell, and Salvator 4293 (701), imported in 1883 by Mark W. Dunham, were also used to some extent. Messidor 3753 (685), imported in 1885 by Mr. Dunham, later was bought by Dr. Winter and sired a few purebred colts in his stud. In 1886 Dr. Winter sent Agnes 4727 
to Oaklawn and had her bred to Brilliant 1271. To this mating she produced in 1887 a very good colt recorded as Brilliant A. 9998 and extensively used at a later date.

La Force apparently did as much good as any horse used at this time. About 16.2 hands high, he weighed around 1,800 pounds and was extremely handsome, round-bodied, and smoothly turned. He was solid black in color. Bernadotte was a compact horse, but hardly as blocky and massve as La Force. He left some excellent colts, but on account of his close relationship to most of Dr. Winter's mares he was not available for general use.

Aimee 520 was one of the best brood mares, and an unusually prolific one. She raised 14 colts in 17 years, beginning when she was 3 years of age. Two of her daughters, Olga 21851 and Prudance 21853, were also regular producers, one raising 7 and the other 8 colts in 9 years, showing that the tendency to regular reproduction is inherited in some instances at least. Aimee made her record while in Dr. Winter's ownership, and her daughters made theirs while owned by John C. Baker. Florence 2403 was another good brood mare, long-lived and a regular breeder. Jeanne 560 was another of the same kind; her colts were exceptionally good, the first being Bernadotte. Julie 568, Jeanne's second colt, was one of the doctor's best brood mares, raising 11 colts in 13 years.

While Edgewood Farm exhibited to some extent at local shows, not much showing was done and the larger fairs do not reveal a record of winnings by 
this farm. Dr. Winter was not an aggressive advertiser-and confined himself strictly to farming and breeding. He bred some very good stock, but in all fairness it must be said that he was not an especially good care-taker. Much of his stock would have been better off had it seen more feed.

I. L. Hoover, of Clinton, Wis., bought a number of Percherons from Edgewood Farm in the '80's. J. F. Campbell bought Charlotte 5320, and she proved a regular producer, raising 9 colts in the 12 years from 1889 to 1900, beginning in her three-year-old form. Jeannette 4730 went to the stud of Alexander Miller, De Voe, S. D. These were the chief purchasers during this period.

John W. Akin.-John W. Akin, Scipio, N. Y., was the only prominent Percheron importer and breeder in the Empire State. At the start he bought a few at Oaklawn Farm. In 1883 he made an importation of 25 stallions and 14 mares. In 1884 he brought over 28 stallions and 23 mares, and he made some other importations in 1887 and later. Most of the mares he retained and engaged in Percheron breeding. The results at the outset were none too encouraging. In $1884 \mathrm{Mr}$. Akin raised 1 colt, in 1885 3, in 1886 7, in 1887 8, in 1888 8, in 1889 16, in 189021. From 1888 to 1890 he had about 40 mares of producing age. A review of their produce records reveals few that would classify as brood mares. They were shy breeders, especially for the first few years after importation.

Men familiar with the stock in the Akin stud 
consider it as rather too small and too lacking in real draft character to have exerted any material influence on the breed. Mr. Akin is to be considered as a responsible breeder who did much to popularize Percherons in New York in an early day by distributing horses that worked some improvement on the light native stock of the state. So far as influence on Percheron breeding in America is concerned, the operations in this stud are practically valueless. A few animals were bred during the '90's, but the beginning and end of this farm's influence has already been considered, and the stud will not come up for further discussion.

Minnesota Breeders.-Illinois contributed 8 of the 20 leading breeders of this epoch, but Minnesota stands second with 3 among the first 20. It is safe to say that there were more high-class Percheron breeding establishments in Minnesota in the '80's than in any other state except Illinois. The breeders who brought the state to the front were Leonard Johnson, The Minnesota Percheron Horse Company, and George E. Case. They stood eleventh, fifteenth, and nineteenth respectively in number of Percherons bred in America during the period under discussion and the dispersion of their studs in the '90's was deeply regretted.

Leonard Johnson.-No finer-tempered or more honorable breeder of Percheron horses than Leonard Johnson ever lived, and there have been few who were his equals in judgment. He began about 1877 or 1878 as a buyer for Mark W. Dunham in France. 
He was as honest as the day is long, modest, and courteous in his speech and manner. His personality soon acquired for him the confidence and close friendship of the leading breeders in France-M. Fardouet, Père Caget, Ernest Perriot, Sr., the Tacheaus, and the Avelines. He was an idealist in judgment-ever looking for the perfect horse-and he never asked to see any but the best. His estimate of the real stock horses, the sires, is amply shown by the fact that he bought for Mr. Dunham many of the great sires which made Oaklawn famous. His first purchases were made in company with Mr. Dunham; his later operations were on his own responsibility. It is no reflection on Mark W. Dunham to say here that Leonard Johnson was a far better judge of breeding horses than was the master of Oaklawn. It has ever been characteristic of great leaders to surround themselves with men who are skilled beyond themselves in certain lines, and in no one thing did Mr. Dunham show keener judgment than in his selection of trusted lieutenants, of whom Leonard Johnson was one of the first.

Founding Maple Point Stud.-Mr. Johnson really began in 1874 by purchasing imp. Magnus 290, a rather massive horse for that time, weighing about 2,000 pounds. In 1875 he bought Superior 454 (730) and Vidocq 483 (732). Vidocq was subsequently resold to Mr. Dunham and was used at the head of the Oaklawn stud for several years. He has already been described. Superior stood about 16.2 hands high and weighed between 1,800 and 1,900 pounds in 
breeding condition. He was foaled in 1868 and imported in 1874. He was white at the time of his importation, and a symmetrical, stylish horse of great quality and finish, with extraordinary action. As a sire he was one of the best and undoubtedly ranks as one of the greatest sons of Favori 1st (711), the foundation sire of the Favori strain.

It was Mr. Johnson's keen judgment and integrity that led to his employment by Mr. Dunham as his buyer in France. While thus engaged he from time to time selected some of the horses that especially suited his ideas, and by arrangement with Mr. Dunham he shipped these to Maple Point Farm. Owing to his limited means Mr. Johnson's first selections were stallions, which were soon sold; but he also selected a few mares, which he retained. The first Percheron of his own breeding was foaled in 1881, and the number gradually increased until by 1890 he had raised 26 stallions and an equal number of mares.

Leading Sires Used.-It is doubtful whether any stud in America ever had such a group of really great sires as was owned at Maple Point in the ' 80 's. Unfortunately, Mr. Johnson did not have a large band of mares, nor did he have the means to retain his great stock horses. These stallions were sold after he had used them for a short time and many, like Brilliant 1899, went into communities in which they were lost to the breed, though they did do wonders in improving the grade stock.

Brilliant 1899, whose history has already been 
sketched, and Cheer 2017 (1404) were the two good sires obtained by Mr. Johnson in 1881. Cheer was a nice-turned, medium-sized horse weighing about 1,750, but a very good sire. Each of these sired 3 Percheron colts before being sold from Maple Point. In 1883 Mr. Johnson obtained La Grange 3065 (1334) and Baptiste $3064^{\circ}$ (41), both clinking good horses as individuals and as sires. La Grange was foaled in 1880 and imported in 1883 . He was a winner at the leading shows in France and was the best horse which Tacheau had in ' 83 . He was sired by Brilliant 1271 out of a daughter of Coco 2 d (714). A gray of excellent conformation, style, and quality, he was a show horse of the top kind. He left but one colt at Maple Point before he was sold to F. J. Shoe, of Shoe, Minn., after which he was used on grade mares.

Baptiste was a horse of much the same type as La Grange, and a winner abroad. He was a gray two-year-old when imported. He was sired by a son of Vidocq 483 out of a granddaughter of Superior 454 , both of which sires had been used at Maple Point. Baptiste was a compact, massive horse, standing about 16.3 hands high and weighing about a ton. He was a horse of wonderful finish. He was sold by Mr. Johnson to William Mies \& Sons, of Hampton, Minn., at an early date. He left only one colt at Maple Point, but he sired 28 purebreds for Mies \& Sons, 5 for Thomas Irvine, and 7 for G. S. Horton. He was used extensively on grade mares also and has contributed materially to Percheron improvement in Minnesota. He won first in the four- 
year-old class at the Minnesota State Fair in 1885 for Mr. Johnson, and was first in the aged stallion class in 1886 for William Mies \& Sons.

Jupiter 4301 (2243), foaled in 1882 and imported in 1885, was the next high-class sire obtained. A dark gray, about 16.3 hands high, and weighing from 1,900 to 2,000 pounds, he was massive, drafty sort with a great deal of symmetry and finish. He was distinctly in-bred, as he was begot by a son of Brilliant 1899 out of a daughter of Brilliant 1899. He sired 4 colts for Mr. Johnson before he was sold to William \& James Warden, of Frankfort, S. D. In the hands of the Wardens he was used on some Percheron mares, leaving 12 purebred colts, but his chief service was on grade mares.

Not content with anything less than the closest possible approach to ideal Percheron type, Mr. Jolnnson bought in 1886 two of the greatest sons of Brilliant 1271-Briard 5317 (1630) and Gilbert 5154 (461). Briard was a rugged, big horse, which stood about 17 hands high and weighed a little over a ton. Nicely balanced, with two good ends and a middle, he was a heavy-boned and heavy-muscled horse, but lacked a little in finish. He sired some excellent stock, built after his own pattern. Mr. Johnson paid M. IV. Dunham $\$ 5,000$ for Briard and after a season's use sold him to Hon. R. W. Daniels, of Buffalo, N. Y., for $\$ 4,500$. He was used on the ranch at Kelso, N. D., owned by Daniels \& Winsor. He sired only 3 colts at Maple Point, but left 11 other purebreds in North Dakota. Colts sired by him in 
France were prominent winners, and he is rated as one of the three best sons of Brilliant 1271, individuality and the prepotency of his descendants considered.

Gilbert was also sired by Brilliant 1271, and everything considered was probably the greatest. show horse the old sire ever begot. He was a winner in France and took first in the four-year-old class for stallions over 1,750 pounds at the great Percheron Society show at Chicago in 1886. He was first again in 1887 at the horse show at Chicago, and second at the same show in 1888, being beaten by La Ferté 5144 (452). Again in 1889 he was second, this time to Fenelon 2682 (38), and in 1890 he was second at the same show to Seducteur 8850 (7057). Gilbert was not shown in 1891 or 1892 , but came out in 1893, when 11 years old and after 7 years of stud service, and won third at the Columbian Exposition in the face of strong competition. No other horse of the breed has a showyard record excelling this, and it is doubtful whether any can equal it.

Gilbert was about 16.2 hands high and weighed around a ton in show condition. He was a remarkably well-balanced horse, symmetrical throughout, with great style and finish and the best of underpinning. He was a whirlwind in action, and remained sound and clean to the end of his days.

As a sire it must be admitted frankly that he was not the best of the sons of Brilliant 1271. He got some very good animals, but his colts lacked uniformity in type and in color and some were very disap- 
pointing. His best descendants come from the cross of Gilbert or his sons on daughters or granddaughters of Briard; he furnished the quality and finish to sweeten up the Briard stock. He sired 89 colts in America, most of which were bred by Leonard Johnson and the subsequent owner of the stallion, Alexander Miller.

Leopold 7011 (6221), foaled in 1885 and imported as a two-year-old, was another good colt, a large, heavy-boned, rugged draft horse of good lines and a fetching way of going. He was sired by Voltaire 3540 (443), one of the three best sons of Brilliant 1271, out of a granddaughter of Favori 1st. He came from Ernest Perriot and sired 7 colts of record while at Maple Point.

Tripoli 11110 (20034) was the last of the great group of sires used by Mr. Johnson during this period. He was individually the best colt Gilbert ever sired, being out of a daughter of Brilliant 1899. A black standing about 16.2 hands high and weighing around a ton in show condition, he was a winner in France and took first as a three-year-old at the Chicago show in 1890. He was much like Gilbert in type, but far excelled him as a sire, his colts being uniformly good in type and color. He subsequently headed the Upson Farm stud in North Dakota.

A review of the sires used at Maple Point shows that Mr. Johnson's judgment was of the best. It is doubtful whether any stud in this country ever owned so many high-class sires in so short a time. Certainly no establishment in America has ever 
owned so many good ones in proportion to the total number in the stud.

The Johnson Mares.-In his selection of mares Mr. Johnson was no less an idealist than in choosing his stallions. His means were limited so that he could not own many, but those he did have were the best he could find. All the colts which he raised during this period were out of about 18 or 20 matrons. Many were show mares, and brood mares as well.

Honest Lady 2015 (2779) was one of the best. She was first at the Minnesota State Fair in 1885 and again took the honors in 1887 on mare and her produce. She was a regular breeder, raising 6 colts in 7 years in the Maple Point stud, and good ones at that. Mouvette 6176 (636) was second in the twoyear-old class at the Minnesota fair. She later went to the stud of R. B. Kellogg where she produced 2 colts, and then was sold to D. Wittenberg, Cedarburg, Wis., for whom she raised two more.

Sada 3060, bred by Mr. Johnson, was first in the four-year-old class at Minnesota in 1887. She did not raise many colts. Messagere 5129 (6762) was first in the three-year-old class at the same state fair show. She was an irregular breeder, but raised some good colts. Clodie 5140 (7253) was second in the two-yearold class at the same show and proved a brood mare of worth. She was the most regular breeder in the stud, except Honest Lady. Coquette 6710 (581) was first among the aged mares in 1889. She raised only 2 colts-Atlantic 11858, sired by Seducteur, and Bertine 11337, a gray mare, sired by Gilbert. Atlan- 
tic left no purebred progeny and Bertine had only 2 colts. Elise 9675 (12262) stood first for Maple Point at the Minnesota fair of 1889 and Gretchen 4649 , bred by Rufus B. Kellogg, won second for the Johnson stable. Gretchen was a regular producer of good colts but Elise raised only 3.

As a whole Mr. Johnson's females were exceptional brood mares, producing high-class progeny, though the percentage of colts raised was disheartening.

Showyard Record.-Mr. Johnson was an enthusiastic exhibitor from the outset. He was the heaviest winner at the Minnesota State Fair at the beginning and he continued his lead despite strong competition, although T. L. \& J. L. DeLancey bested him in the later ' 80 's. He captured a fair share of the prizes at the leading shows of that period which were annually held at Chicago. It is probable that no prize ever gave him keener pleasure than winning the gold medal offered by the Société Hippique de Percheronne in 1886 at the Percheron Society show in Chicago for the best stallion bred in America. At this show, the greatest held in the ' 80 's, with more than 300 Percherons in the competition, Mr. Johnson won the coveted medal on Eclipse 3066, a colt of his own breeding, sired by Leman 1954 (1055) out of Selia 2012. This was a gray of good type and size, afterward used in the stud of J. L. LaValley, McCauleyville, Minn., where he sired some 18 purebred colts. Mr. Johnson showed many colts of his own breeding and with good results. 
Leonard Johnson's was the most potent influence of the '80's in the development of Percheron interests in the northwestern states. His high character and agreeable personality made him liked by all who knew him, and his remarkable judgment of Percherons made his fair winnings of the utmost value as object lessons to less well-informed breeders and farmers. He would not handle inferior stock, and was always willing to pay a long price for horses which he considered "true gold."

Minnesota Percheron Horse Company.-Controlled by the Payne Lumber Company of the Twin Cities, the Minnesota Percheron Horse Company became one of the important Percheron establishments of the state. The stud was founded in 1886 by the purchase of a carload of W. L. Ellwood's best mares. Later purchases were made from the Ellwood stud in 1888 and '89. The firm had extensive land interests at Cazenovia and was wealthy. The best were none too good, and its purchases were high-class as to individuality.

Exact data as to the number of mares owned are not obtainable, but the firm owned at least 30 mares by 1888 and about 50 mares by 1890 . Twenty-five stallions and 21 mares of the company's breeding, foaled from 1887 to 1890, are on record, and none of the dams was to be classed as a regular breeder.

Niger 4986 (2951) was the chief sire. He was imported in 1886 by Mr. Ellwood and was in the first lot bought by the Paynes. Picador $3 d 5078$ (4815), imported in 1886, was also taken to Cazen- 
ovia at the same time. Niger was a black son of Picador $2 \mathrm{~d}$ (5606) and was much like his illustrious grandsire, Picador 1st (7330), the foundation sire of the strain bearing his name. A massive, drafty horse weighing around a ton, Niger had a great deal of quality and finish. His colts were excellent and he was long at the head of the stud. The stud continued throughout the next decade in spite of hard times, but inasmuch as it was only well started by 1890 a more exhaustive consideration of its work will be taken up in another chapter.

George E. Case.-At St. Peter, Minn., George E. Case, a merchant, established a Percheron stud by direct importations from France. His ranked among the first 20 breeding establishments of America by 1890. He imported 28 mares in 1883, '84, and '85, and some 35 stallions. Most of the mares were retained for his own use and by 1890 he had raised some 16 stallions and 19 mares of his own breeding. At the same time he continued his importations and was actively engaged in the sale of stallions. As a director of the American Percheron Horse Breeders' Association he was very influential in spreading the gospel of better blood for draft horse improvement in the northwest.

Margot 3033 (1341) and Sandi 3803 (444) were the first two sires used by Mr. Case, but they left very few colts. Sandi was a good type, a thick and massive gray with a deal of quality. He was sired by Brilliant 1271 out of a daughter of Coco 2d. Not being imported until past four years of age, he left a 
number of good colts in France, some of which were brought over during' the ' 80 's by the leading importers of that period. Sandi was sold shortly after importation and then had access to grades only, until 1889, when he did sire one more purebred colt.

Senegal 8456 (8092) was the most important sire used in the Case stud. He was a gray sired by Voltaire 3540 (443) out of a daughter of Favori 1st and proved a horse of great merit, both individually and as a sire. He was not imported until 1887 and was not used long, but his colts were good.

Mr. Case won a number of prizes in 1885 at the Minnesota State Fair, but did not exhibit very extensively afterward. He was not as keen a judge as Leonard Johnson or 'T. L. \& J. L. DeLancey, and consequently was less well equipped with the material necessary for strong campaigns. His Percherons were a good useful sort, however, and being above the average in.merit did much good.

The gathering financial storm which wrecked so many good establishments drove Mr. Case to disperse his stud about 1892. The mares were scattered widely into the hands of small farmer's. There are descendants of this stock around St. Peter and St. Cloud in Mimnesota, but for the most part they were lost to the purebred industry.

Wisconsin's Leaders.-Capt. Fred Pabst and Rufus B. Kellogg were Wisconsin's representatives among the first 20 breeders of this epoch; they occupied tenth and twelfth places respectively in the number of Percherons bred and raised in their own 


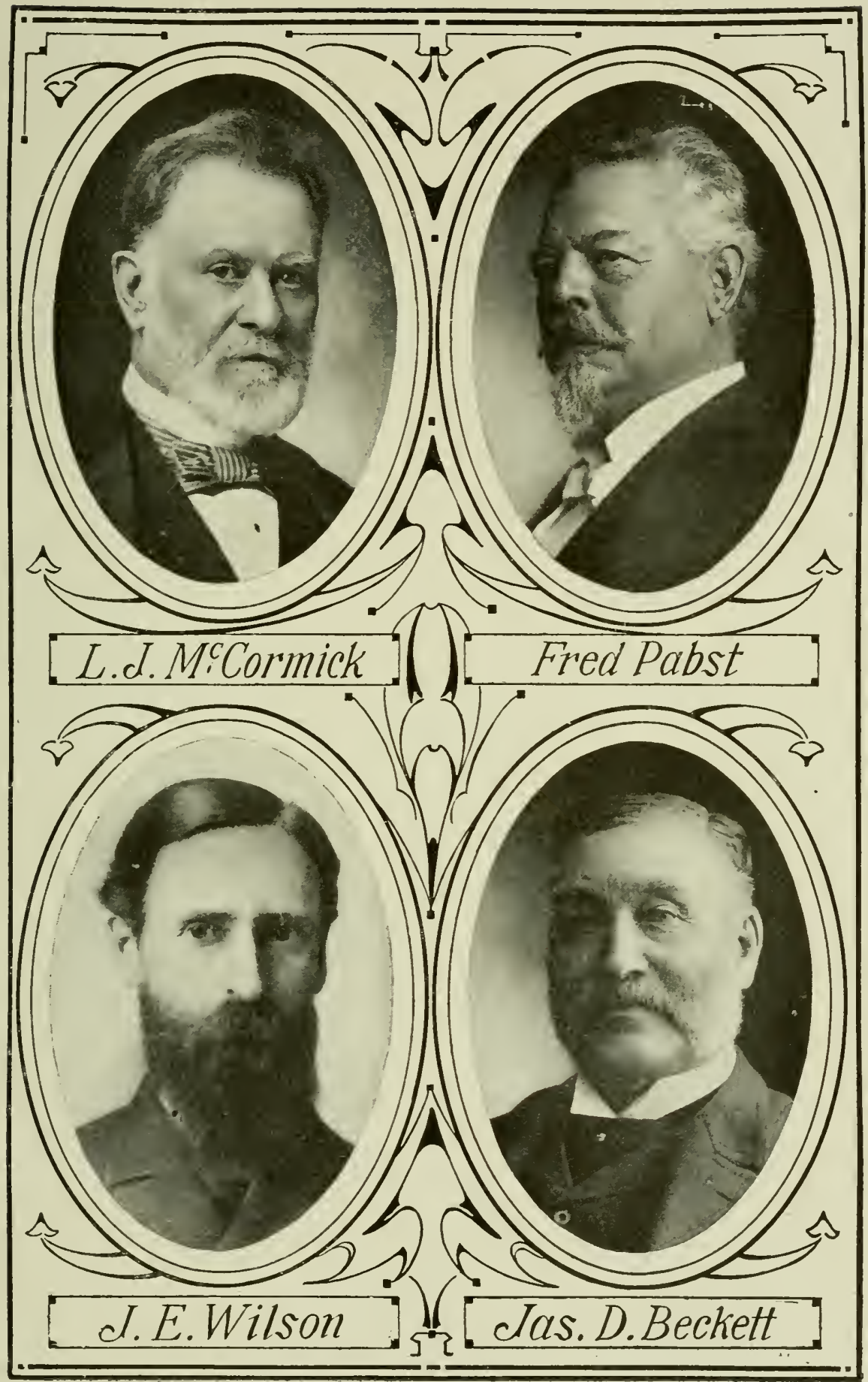



studs. Both were men of wealth and business ability, well educated and widely travelled, and their influence was unquestionably large in favorably shaping Wisconsin's sentiment toward Percherons.

Wauwatosa Farm.--The Wauwatosa stud, established by Fred Pabst in 1885, was started with the stallion Burg 4444 (2241) and 29 mares imported direct from France. In $1886 \mathrm{Mr}$. Pabst imported 26 more mares. Other stallions were imported each year, but Burg remained at the head of the stud and his leadership was never threatened.

Mr. Pabst in his first catalog, issued in 1890, gives his reasons for establishing a Percheron stud as follows:

"It is a well-known fact that I did not go into the business of raising horses as a mere money speculation. I did it because I thought I could advance a great interest in our state. It is universally admitted that the majority of the best Clydesdales imported to this country have for years been brought direct to the state of Wisconsin, but many of our people preferred the Percherons, and were going into neighboring states to procure them, because they there found better ones than could be found at home.

"I take a pride in the state in which I live and in which all my interests lie, and I determined that I would breed right here in our own state as good, or better, Percherons than could be found elsewhere, and to this purpose, I, in 1885, sent a man of experience to France with instructions to buy a herd of mares, the best to be found in that country, irrespective of prices. These mares were bought at prices that ordinary importers, who buy to sell again, could not afford to pay. They were brood mares, 
whose owners were not looking for buyers and who could only be persuaded to part with them for long prices."

These importations gave Mr. Pabst more than 50 mares of producing age from 1886 on. He raised 17 colts in 1887, 20 in 1888, 13 in 1889, and 10 in 1890a total of 27 stallions and 23 mares. Some trouble must have been encountered, as a review of $\mathrm{Mr}$. Pabst's records shows that he had 51 mares of producing age in 1890 and yet raised only 10 colts. In the absence of specific data it must be concluded that abortion entered the stud; a large number of his most reliable brood mares missed foaling in 1889 and 1890 , as is definitely shown by the records.

Burg, Vigoreux 9218 (5615), Voltaire 5316 (2221), and Prince Jerome 4445 (480) were the chief sires in service, although some 16 or 18 other horses were used to a slight extent at various times. Burg was the leading sire and remained at the head of the stud from 1885, when it was founded, until 1890. In that year he was sold to J. B. Johnson of Montford, Wis.

As an individual Burg was of showyard caliber. He was a rather blocky, massive type, with exceptionally heavy bone and a good deal of quality. He was quite well proportioned, stylish, of all-around draft qualities, and weighed over a ton. He won first as a two-year-old at the annual show held by the Société Hippique de Percheronne in France in 1884. He was not shown to any great extent in America, but was first in the class for stallion and five of his 
get at the Wisconsin State Fair in 1888, and won in the same class at the International Exposition at Buffalo in 1889. In many respects he was much on the type of Brilliant 1271. He was sired by Rochambeau (1382), a half-brother to Brilliant 1271, by Brilliant 1899. The colts sired by Burg were uniform in type, chiefly blacks and grays, and were of the massive draft pattern, although a bit more blocky and low-set than some breeders liked.

Vigoreux, a massive black sired by Picador 2d, by Picador 1st, was the next sire in rank. Imported by Mr. Dunham, from whom Capt. Pabst obtained him, he was a very good sort, of the rugged, massire pattern. Voltaire, a good gray of the Favori stock, and Prince Jerome, tracing to the same horse through his sire, and out of a daughter of Coco 2d, were also good stock-getters and left some good colts at Wauwatosa Stock Farm.

Couronne 4440 (1908) was sufficiently good as a brood mare to cause Mr. Pabst to use 3 of her sons to some degree in the stud. They were by Burg. She produced 4 colts in 5 years, every one a stallion of merit. Farorite 4436 (4296), Coquette 4433 (4295) and Julie 4423 (4257) were other good brood mares, producer's of colts that were winner's at the Wisconsin State Fair and that sold at excellent prices. None of them was noted for the number of colts produced, however, the mares being mostly shy breeders. Rustique 5403 (2217) was the only really prolific mare in the lot. Relatively few mares were sold from this farm in the period under discussion. 
The distribution of these Percherons will be considered later.

Kellogg Stock Farm.-Rufus B. Kellogg, Green Bay, Wis., was a wealthy banker and land-owner, a man of education and character. He, like Mr. Pabst, recognized the need of more and better breeding. stock for Wisconsin farmers. He had a real interest in his horses and studied bloodlines and the results of various matings with a keen and analytical mind. His success would probably have been greater had he been a more competent judge, though his career was cut short by death at so early a date-September, 1891,- that it is unfair to draw general conclusions. He was taken away at just about the time when the results of his work were becoming sufficiently apparent to permit of the elimination of the unreliable breeding stock. His farm consisted of 600 acres located near Green Bay. On part of it the town of DePere now stands. The land in this section is rather rolling but affords excellent pasturage.

Mr. Kellogg's stud was founded in 1881 by the purchase of Chevalier Bayard 1279 and Zoe 840 from M. W. Dunham. He subsequently made some importations of his own. In 1882 he brought over 3 stallions and 12 mares, and in 18856 stallions and 9 mares. Still other importations were made at later dates.

Mr. Kellogg's inventories show that he owned in 188647 Percherons valued at $\$ 27,850$, an average of $\$ 592$ each; in 188768 Percherons valued at $\$ 39,150$, an average of $\$ 575$, and in 189076 Percherons valued 
at $\$ 32,700$, an average of $\$ 430$. The lowering of the average value was due to the fact that more young horses were included in the later inventories and to the depreciation of all classes of live stock. The low spot was reached in 1893 and '94, but the depression was evident in 1890 .

The records in the Percheron Society of America offices show that Mr. Kellogg had between 30 and 40 mares by 1890, and that he raised 24 stallions and 28 mares of his own breeding between 1883 and 1890. Many of his mares were not imported until 1887, but the mares brought over in 1882 and 1884 were his chief reliance.

The Kellogg Stallions.-Chevalier Bayard was the first sire used. He left 3 fillies, but no stallions. Waterloo 2199 (733), foaled in 1870, was imported in 1882 by Mr. Kellogg. He was a noted stock horse in France and had left excellent progeny. He had been used too heavily before Mr. Kellog obtained him, however, and so did little after importation, though he begot 2 stallions and 5 mares at the Kellogg Farm stud.

In 1883 Mr. Kellogg bought Fenelon 2682, a horse that history has stamped as one of the three greatest sons of Brilliant 1271. He had been imported that same year and because of acclimation troubles proved a non-breeder during the season, failing to settle a single mare. Mr. Kellogg already had been subjected to loss because Waterloo was not a sure breeder, and consequently he returned Fenelon to Mr. Dunham without further trial. From the first 
he had given much attention to the breeding of the best horses in France and America and he was of the opinion that a sire with a known record as a getter was decidedly better than a young one. His purchase of Waterloo had been guided by this consideration. The age of the horse and the fact that he proved after importation to be a shy breeder troubled Mr. Kellogg. Fenelon's failure set him back again and he was forced to look further for a sire. Brilliant's success in Oaklawn stud caused him to look for a horse of somewhat similar breeding, and he finally purchased Narbonne 1334 (777) in 1885. This horse was foaled in 1876 and had been imported in 1881 by M. W. Dunham, who sold him to J. Barnes \& Co., Shannon, Ill. Mr. Kellogg had learned that Narbonne had sired many good things in France and that many of the animals imported in 1882 and 1883 were by him. He also ascertained that Narbonne was sired by Brilliant 1899 out of a daughter of Favori 1st, and he liked the colts sired at Shannon. Accordingly Narbonne was purchased as an eight-yearold in 1884. He sired 5 stallions and 3 mares for Mr. Kellogg. No information is obtainable as to his final disposition, but from the fact that he sired colts at the Kellogg' Stock Farm in 1884, '85, and '86 it must be concluded that Narbonne, like Waterloo, had seen too much service before Mr. Kellogg secured him.

Non Pareil 7248 (sans Pareil 6870) was imported by Mr. Kellogg in 1887. He was a gray grandson of Romulus 873 (785), the first-prize aged horse at 
the Universal Exposition at Paris in 1878, and out of a granddaughter of M. Dupont's Favori. He was used to some extent in 1887 and 1888, but did not leave many colts. Two or three other sires that do not appear to have been of any importance were used about 1888 and 1889, but in 1890 Mr. Kellogg secured the horse which practically made the reputation of his stud-Baccarat 11326 (18639).

Baccarat was foaled in 1887. He won in France in 1889 and was imported in that year by W. L. Ellwood. He won second in the three-year-old class at the Chicago Horse Show in 1890 for Mr. Kellogg, who bought him at a price reported to have been the highest ever paid for a Percheron stallion up to that time. He proved good from the outset. He was used in 1890 and '91 and sired 16 stallions and 8 mares of record. Mr. Kellogg's death on Sept. 24, 1891, was exceedingly unfortunate; he was only 53 years old and was just developing his Percheron breeding operations to a point where real progress could be made. He raised 19 colts of his own breeding in 1891 and 15 more in 1892.

Noted Mares.-Mr. Kellogg had no inclination to act as a dealer in hor'ses and his selections were made for his own stud. He sought mares of size, draft type and quality, and was insistent upon uniformity. Among the mares he imported were some which he had selected because of their records as brood mares in France. Bijou 4668 (4644) was one of these. She was the dam of Childebert 4283 (451), by Brilliant 1271 , one of the very good horses imported in 1885, 
as well as of other good ones. She produced only 2 colts for Mr. Kellogg, but they were winners. Ben Boalt 4746, her first colt for Mr. Kellogg, took honors in the leading shows in America and Fenelon 2d 7007, her second, was also of showyard character. Glorieuse 5226 (5970) was another good mare. She won second in the class for four-year-olds under 1,750 pounds at the Percheron Society show in 1886, and was a consistent brood mare, raising 5 good colts in 7 years. Mr. Kellogg also bought Lorilee G. 1532, one of the most noted show and brook mares of the Dillons. Mignonette 7264 (5729) was another good mare, and a regular producer. The mare Tontine 13129 (Bijou 21677) was valued very highly by Mr. Kellogg, although she had produced nothing prior to his death. She subsequently became a valuable brood mare.

Mr. Kellogg was a progressive breeder and appreciated the value of showyard exhibitions from educational and advertising points of view. Most of his wimnings were made at the Minnesota and Wisconsin state fairs, although he showed a few at Chicago. One of his leading contemporaries says of him:

"He exhibited mares of uniform kind and his animals were generally commendable for draft type, symmetry, quality, and soundness. Personally Mr. Kellogg was a gentleman, thoroughly reliable in word and act, and at all times courteous and honorable. He was a breeder of the highest type and exerted a profound influence on Percheron affairs in his time."

Influence on Other Studs.-At Mr. Kellogg's death 
most of his horses went to H. F. Hagemeister, of Green Bay, who bought them from the estate about 1895 or '96. Nicholas Schmidt, Wrightstown, Wis., bought some from Mr. Kellogg in 1890. William H. Shaw, Belvidere, Ill., was another buyer. Newton Rector, Circleville, O., made purchases from Mr. Kellogg in 1891, and Jesse M. Stetson bought some from the estate. Fearnaught 16302, bred by Mr. Kellogg, sired by Baccarat out of Fashion 7263 (9179), went to head Mr. Stetson's stable and sired some extra good mares, though his stallion colts were not of such a high average. This tendency on the part of sires to get better animals of one sex than of the other has often been noticed by breeders of all classes of stock. Fearnaught was distinctly a sire of mares.

D. G. McKay, Chippewa Falls, Wis., was another purchaser of horses from Mr. Kellog' in 1891, and B. F. Clark, Eureka, Wis., also bought some in the same year. Thomas Wishart, DePere, Wis., and E. C. Clark, Cadott, Wis., were other buyers. Mr. Hagemeister obtained most of the animals, however, purchasing 68 head of stallions, mares and colts. He also secured Baccarat and retained him until 1906, when he was sold, still vigorous at 19 years of age.

Mr. Kellog'g's work as a Percheron breeder has been far-reaching. He sought good animals, placing special emphasis on underpinning and soundness. He was one of the earliest American breeders to appreciate the value of tried sires and dams, and emphasized at all times the importance of accurate and careful breeding. His integrity, courtesy and 
broad spirit in reviewing his own or his contemporaries' work made him one of the most constructive breeders of his time. Percheron interests in America suffered a very great loss in his death just when he was on the threshold of achievement.

Reserve Forces in Illinois.-Illinois had a total of 203 breeders in the epoch under consideration and 8 out of the first 20 breeders in the United States resided there. The work of the leaders has already been discussed, but there were others of almost equal prominence who must be considered.

E. Stetson \& Sons, of Neponset, Ill., with 63 head, Degen Bros., of Ottawa, Ill., with 50 head, George S. Hanna of Bloomington, Ill., with 48 head, and E. Hodgson, of Ottawa, Ill., with 40 head, all recorded as bred by the parties named, stood ninth, thirteenth, and eighteenth respectively among the first 20 breeders of this epoch.

Stetson \& Sons.-Ezra Stetson, Neponset, Ill., became interested in Percherons at a very early date. He owned a good farm, had considerable means, and was of the opinion that farming operations could be much more efficiently accomplished if farmers had better horses. He was a physician of high character and integrity and his education was above the average. He recognized the futility of trying to improve the common horses of the district without purebred sires of desirable type as seed stock, and with this in mind he made an importation of 3 Percherons in 1874. Two were stallions--Richard Coeur de Lion 406 and Duke de Morny 152. The mare was Em- 
press Eugenie 545, a very valuable brood matron.

The nucleus formed by this importation was added to in 1882 by the purchase of 2 stallions and 6 mares at the W. T. Walters sale. The original sale sheet made out in Mr. Walters' own handwriting is here presented:

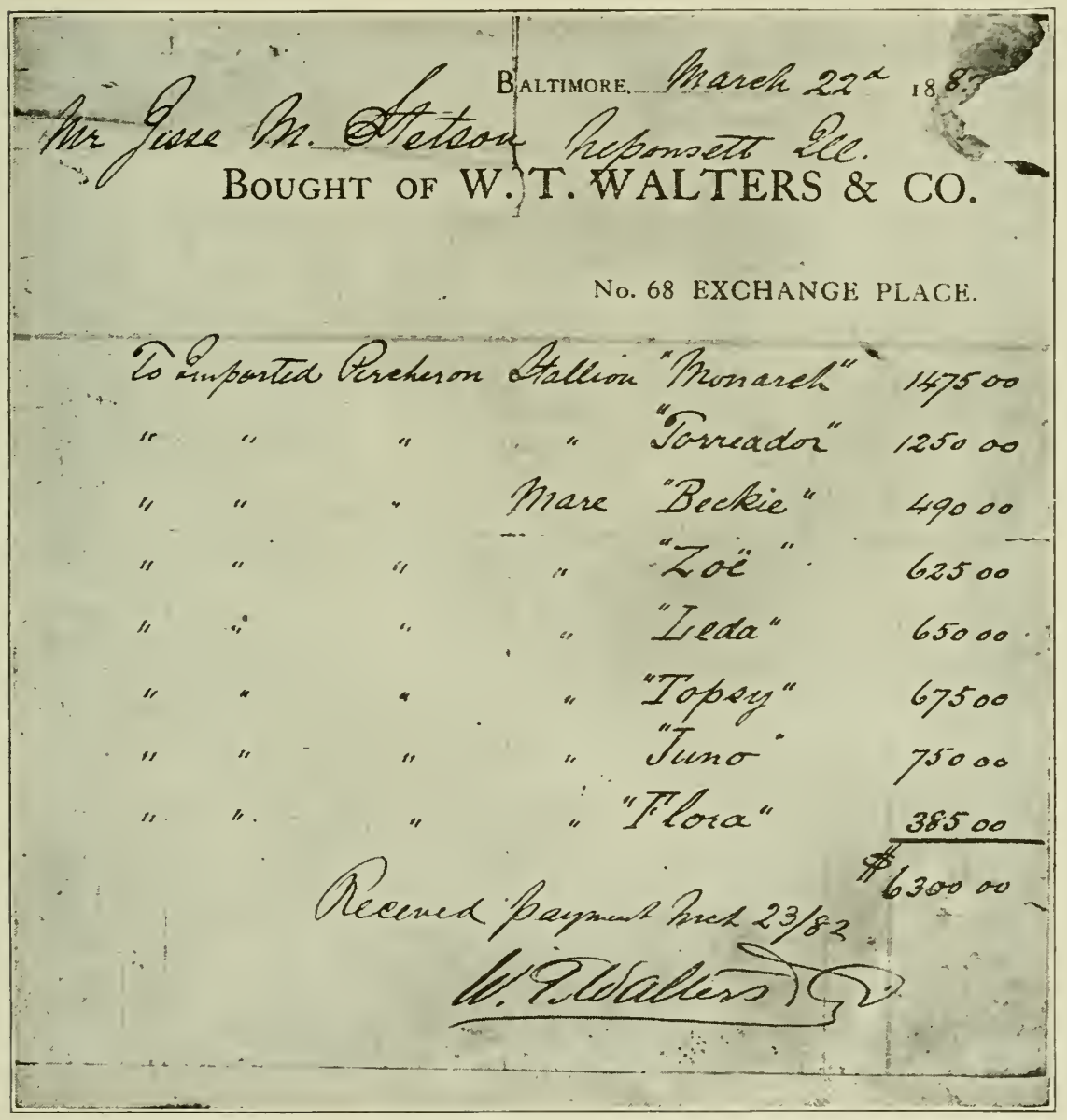

An importation of 4 stallions and 5 mares was made from France in 1883. Very few mares were 
purchased after this, but nearly all the females produced were kept and the stud soon grew to large proportions.

Mares Owned and Colts Raised.-An examination of the old stud records kept by Ezra Stetson shows that 14 Percheron mares were bred in 1883. Eight of these foaled, but the Percheron Society records show that he recorded only 5 colts of his own breeding, so it is evident that some of the colts died or were altered before time for registration.

The number of colts raised gradually increased. In 18855 were foaled to be recorded subsequently, in 1886 6, in 1887 6, in 1888 10, in 1889 8, and in 1890 15. Altogether Stetson \& Sons raised 33 stallions and 30 mares of their own breeding between 1881 and 1890.

Dr. Stetson bred and raised 4 Percherons prior to 1880, all out of Empress Eugenie. She raised 7 foals altogether, most of which were very good. Three of the mares were retained in the stud and proved valuable producers.

The Stetson Sires.-Richard Coeur de Lion was the first sire used and one of the best. He was a rather large, rugged gray, a bit upstanding, but fairly well balanced. On the whole his colts were larger than most of those begot by later sires used by Dr. Stetson; the older breeders, still living, who knew him, consider that he was probably the best sire used in the first 20 years. He sired only 5 purebred colts for Dr. Stetson but his get out of grade mares in the country did much good. He stood in 
Michigan in 1877, but afterwards returned to the Stetson stud.

Duke de Morny 152, imported with the others in 1874, sired only 3 purebreds for the doctor, but he also proved a valuable getter of grade stock out of the mares in that section and his descendants are valued to this day. Torreador 1140 (1607) was the next sire used to any extent. He was in the Walters purchase of 1882 and sired 12 stallions and 7 mares in Dr. Stetson's stud. Monarch 1128 (1606), the other stallion bought at the same time, was also used slightly. Victor 1141 (1600), imported by Mr. Walters, was sold to S. W. Ficklin in 1882, but was purchased by Dr. Stetson about 1886 . He was used more liberally than any other sire at that time. A gray, foaled in 1874, he was a horse of great style and quality, but upstanding and lacking in depth of rib and size of middle. Mr. Walters gives his height as 17.1 hands, but this is probably a bit too much. He was close to 17 hands, however, but too light in the barrel for modern standards. The best that can be said is that he imparted much style and quality to the Stetson stock at the expense of some of the draft attributes which were more needed.

Valuable Brood Mares._Empress Eugenie was a brood mare of more than average value. Two of her daughters were retained and one of them, Maria Louisa 835, proved to be a fairly good breeder. The best-known son of Empress Eugenie was Leroi 1743, sired by Richard Coeur de Lion. He was sold into Ohio, near Cardington, and is rated as one of the best 
of the sires used in that section in the '80's. Flora 1119, foaled in 1880, and Zoe 1142, imported in 1881, were among the mares bought from Mr. Walters in 1882. Zoe raised a colt in 1882 but did not have another of record until 1889, after which she settled down and foaled 9. Flora did somewhat better. She produced her first colt when three years of age and foaled 4 in succession, missed 2 years, raised 8 in 8 successive years, missed a year, and then foaled 3 more in 3 years-a total of 15 between 1883 and 1900, a record that has been equaled by very few mares. The first 8 were stallions, followed by 2 fillies, 3 stallions, and 2 more fillies, a total of 11 stallions and 4 fillies. Her colts on the whole were good, though the later ones by Fearnaught excelled the earlier by other sires.

Not much showyard work was done by the Stetsons, but quiet, steady advertising was resorted to and a great many Percheron stallions were sold and distributed over a wide range of territory. No effort was made to sell the mares as it was desired to increase the stud as rapidly as possible.

Dr. Stetson's influence was not as far-reaching as that of some of his contemporaries, but it was nevertheless of value. He was a man of lofty character and high ideals, and engaged in the business because he felt the necessity of making better draft blood available to American farmers. His words and acts were such as to assist in putting the business on an honorable basis.

Degen Bros.--The firm of Degen Bros., Ottawa, 
Ill., was quite active during the period under consideration. The Degens were dealers, but handled some mares and bred some good colts. They exhibited many horses at the leading fairs and were quite successful, but their stock appears to have been so scattered as to have been almost lost to sight. They bred 24 stallions and 19 mares during the time we are considering. These were sired by 10 different stallions, so it is evident that their breeding operations were incidental. The stallion L'Ami 6239 (1649) was imported by this firm and left a few colts in their stud. He subsequently won first at the Ohio State Fair in 1885 and is now considered to have been one of the best stock horses used in Ohio.

George S. Hanna.-George S. Hanna, a lawyer of Bloomington, Ill., had a stud of Percherons which achieved more than a local reputation. His early stock was imported by George W. Stubblefield, who also imported several of the sires used in this stud. Mr. Hanna's operations were on farms near Bloomington. He himself gave little attention to the business, and his Percheron breeding seems to have been carried on as an incident to farming. George W. Stubblefield was one of his chief advisers and helped sell some of the surplus produced.

The Hanna stud was established in 1882. The number of colts produced gradually increased until in 188710 colts of Mr. Hanna's own breeding were raised. By 189024 stallions and a like number of mares had been raised. No records are available as 
to the number of mares owned during this time, but they evidently totalled a fair number.

The chief sires used were Vigoreux 3177 (403), a black, imported by Mr. Stubblefield in 1881, and Bendago 11807, bred by M. W. Dunham. Bendago was sired by Brilliant 1271 out of Julia 5676 (7015). He was not used until 1891, and was in active service for three years. King's Europe 8258, bred by S. N. King and sired by Extrador 4525 (386) out of Jessie 6096 (1660), was another which has left a good reputation in central Illinois, though used but slightly in this stud.

Beauty 6480 was a mare of Mr. Hanna's breeding so well thought of that he bred her to Fenelon 2682 (38) in 1889. To this service she produced Fenelo 14118, a mare which later proved a good breeder under the ownership of F. E. Waters and Cyrus Orr. Mattie 18116 later passed into the ownership of Hanna \& Co., Howard, Kans., and proved a good producer. Rosalie 18843 , bred by Mr. Hanna, proved to be a good producer under the ownership of F. T. Fowler, F. H. Schrepel and Murrie Bros. None of the mares owned by Mr. Hanna was especially prolific, but a number of them produced more colts than were raised, the losses being considerable, as they are on every farm where the owner can give but slight attention to the work.

Mr. Hanna closed out his Percheron interests in 1894 by sale and trade. Among the purchasers were F. T. Fowler of Illinois, F. E. Waters of Iowa, Hanna \& Co., F. H. Schrepel and J. W. \& J. C. Robison of 
Kansas, and J. H. Mosby of Missouri. Other animals of Mr. Hanna's breeding were scattered here and there throughout central Illinois in the hands of farmers, and much of the stock has undoubtedly been lost because of neglecting the registration. Much good has accrued through the existence of this stud, however; it aided materially in the dissemination of good Percherons, helped greatly in improving the common stock of the country and contributed towards the fast gaining popularity of the breed.

E. Hodgson \& Son.-Eli Hodgson, whose earlier operations have already been reviewed, took his son, M. C. Hodgson, into partnership in 1868, so that the firm was in reality Hodgson \& Son from the outset. The second and last importation made by this firm was in 1881. This consisted of 5 stallions and 11 mares. Only one mare had been imported in 1874, so that the purchases in 1881 really formed the foundation of the stud. More than usual interest attaches to the Hodgson collection because of the fact that it is one of the few Percheron studs in America that has been held intact and continued by three generations in one family. Its chronology is as follows: Eli Hodgson from 1859 to 1868; Eli Hodgson \& Son, M. C., from 1868 until Eli Hodgson's death in 1890; M. C. Hodgson from 1890 until 1908, when it became what it now is, M. C. Hodgson \& Sons, E. E. and E. W.

The original Hodgson farm contained 480 acres in one tract, which has since been reduced to 320 . It was located about 3 miles from Ottawa in one of 
the richest farming sections in Illinois. General live stock farming was followed from the outset and the Percheron mares always had to earn their way in harness. The firm owned more than 40 mares in 1885 , but only 14 or 15 of these were Percherons. Few Percheron colts were foaled at first, but 3 were raised in 1885, and the number gradually increased each year, until by 189021 stallions and 19 mares of their own breeding had been produced.

French Victor 6088 (6125), a gray, was the greatest of the early sires used by the Hodgsons and one of the best they ever owned. He was bought as a suckling colt in France by E. Hodgson, who, with other American buyers, considered the dam Rapide (6124), by Brilliant 1899, one of the greatest Percheron mares in France. French Victor was by Plilibert (760) and was consequently close akin in breeding to La Ferte 5144 (452), one of the most noted show horses and sires ever brought to this country. They were sired by the same stallion and both were out of daughters of Brilliant 1899. Hodgson exhibited French Victor at the Illinois State Fair in 1885 and won first in the four-year-old class. French Victor was not shown to any extent subsequently, but was freely used in the stud and was just coming into general notice as a sire when his death occurred in 1889 from colic. His daughters were considered to be among the best ever bred by the firm.

Bernard 10570 and Loran B. 10567, foaled in 1886 and 1887 respectively, both sired by French Victor 
out of Margot 4563 (2826), were used to some extent, but the next sire of consequence was Parfait $3 \mathrm{~d}$ 10727 (12939). This stallion, a black, was imported by W. L. Ellwood in 1889 . He was a massive draft horse and got some very good colts, but did not nick nearly so well on the daughters of French Victor as did Confident 3647 (397), owned by Nagle \& Son at Grand Ridge, Ill., near Ottawa. In the judgment of good horsemen, including M. C. Hodgson himself, one of the worst errors the firm ever made was in not purchasing Confident to follow French Victor; he was a tried sire of the same line of breeding and his colts were distinctly better than those of any other sire used on the daughters of French Victor.

Georgiana 10578 (6123), Lady Tacheau 10520 (6119) and Margot 4563 (2826) were some of the best brood mares in the Hodgson stud during the '80's. Georgiana produced to the service of French Victor the mare Georgiana 2d 15099, considered by the Hodgrsons to have been the greatest mare they ever raised; she also produced other good colts. Lady Tacheau was a regular producer of good ones, the best being Lady Tacheau 2d 15100. Two of Margot's colts were considered good enough to use in the stud. The most interesting thing about these mares, to a breeder, is the way they have bred on. Two of the greatest mares ever owned in the stud, and still living, are Hattie 2d 23757 and Lisette $2 d$ 21574. They were foaled in 1899 and 1898 and are granddaughters of Georgiana 2d and Lady Tacheau $2 \mathrm{~d}$ respectively; they are both by Confident; both 
have been unusual brood mares. Details concerning their records will be given later.

Ohio Breeders.-Although none of the breeders in Ohio bred enough colts to be included among the first 20 breeders of the United States during this period, there were a number of small breeders who bred some excellent Percherons. Jones Bros. were the leaders, and Samuel Kendeigh, M. V. Bates, E. J. Condit, C. DeLano and J. M. Carr also bred a goodly number.

Jones Bros.-The firm of Jones Bros., Plain City, O., consisted of Albert and C. M. Jones, sons of Thomas Jones, whose early operations have already been discussed. The active direction of affairs rested with C. M. Jones. He had been associated in the business with his father since 1864, but bred and recorded a few animals of his own from 1878 on. In 1883 Thomas Jones discontinued operations and the horses passed to the sons. Thomas Jones bred 3, C. M. Jones 6, and Jones Bros. 31 during this period - a total of 40 Percherons from the one farm.

The Jones farm, on which Percherons have been bred since 1864, in the hands of two generations, is located at the edge of Plain City. It is not large and there never were more than 10 mares of producing age kept at one time. The development of this stud and its maintenance on the one farm in an unbroken line for 42 years (1864 to 1916) is particularly interesting and significant to other farmers who desire to breed a few good Percherons in the course of their ordinary farming operations. Much 
of the time the number of producing mares was less than 10. The number of colts raised and recorded annually varied from 1 to 7 .

A good foundation for the stud had been laid by Thomas Jones. Rose 604 and 3 of her daughters, all by Normandy 351, had been bred to Ajax 5, and from this foundation some excellent females were produced. Between the time when Ajax dropped out and the purchase of Greluchet 11333 (21165) in 1889 the firm had no stallion of consequence; the best mares were bred to horses owned by other parties. Napoleon 328, Valor 951, Mignon 6090 (2894), Lion 273, and L'Ami 6239 (1649) were among the sires so used.

Lion was one of the best of these stallions. He was owned by W. H. Case \& Co. at Delaware. This horse was a gray, about 16.2 hands high and weighed between 1,800 and 1,900 pounds in breeding condition. He was a well-balanced horse of drafty pattern, good in the underpinning and with proper action. His best son, Martell 2491, bred by the Joneses, was out of Norma 1779, a daughter of Ajax. Martell was sold as a yearling in 1883 for $\$ 500$. His purchaser, J. P. Thompson, kept and used him till 1888, when he won the silver cup at the Ohio State Fair for the best Percheron stallion bred in Ohio. He was sold immediately afterward to a man near Cleveland for $\$ 2,000$, but sired no purebred colts after leaving Thompson's ownership.

Mignon, commonly known as "Mingo Chief," was another good sire used in Delaware county and pat- 
ronized by Jones Bros. They raised 4 good colts sired by him. This sire appears to have left an unusually good lot of colts. He was a black, foaled in 1880, and imported in 1884 by J. G. Kemp. He was sold in 1888 to Charles McCurdy, who apparently managed to acquire several of the best sires used in Ohio at this period. Mignon was a big, thick horse of excellent proportions and good quality. He was a grandson of Brilliant 1899 through Bon Espoir 1270 (753), and adds more luster to the fame of the Brilliant strain.

L'Ami was owned by parties at Cardington, $\mathrm{O}$. $\mathrm{Mr}$. Jones sent some mares to be bred to him and among the colts obtained Austerlitz 9145. This horse was a gray, out of the mare Clio 2496. He was a highclass individual and stood for years in the vicinity of Delaware, O., where Mr. Jones sold him. He proved an extremely valuable stud horse, a getter of excellent geldings that were real market-toppers, and he got a few good purebred colts as well. The mare that is now considered the most valuable brood mare in Delaware county, Delia 65193, was sired by Austerlitz and her dam was by Martell 2491.

Greluchet was the first sire of note bought by the Jones firm after the death of Ajax. He was imported by Mark W. Dunham as a yearling in 1889 and was selected by C. M. Jones immediately after his importation as the best colt out of 19 yearling sons of Brilliant $3 \mathrm{~d}$. He was about 16.3 hands high and weighed about 1,900 pounds in fair breeding condition. In color he was black with a small star. Greluchet was 
well-balanced, with extra good feet and legs; he had a typical Percheron head, good neck and sloping shoulder's he was deep-bodied and massive, strong in back and loin, with a fairly level croup and heavilymuscled hindquarters. He had quality and much style and action. He was used in the Jones stud from 1890 till 1898. A discussion of his get will be taken up later.

In the 20 years from 1880 to 1900 no mares save those of their own breeding were used in the Jones stud, with one exception. One mare, and only one was bought. The mares used were all of one foundation family and what outsicle blood was infused came through the sires. The foundation matrons were good and as a result some extra good brood mares were developed in the stud. Rose 604 was the real foundation mare. She had three daughters, Maggie 578, Belle 522 and Dido 539, foaled in 1869, 1870 and 1871 respectively. All were by Normandy 351. Belle proved decidedly the best of the three, individually and as a brood mare. She was a well-proportioned mare of good quality and was noted for her fiery temperament. Norma 1779 and Alice 1781 were her two best daughters; both were by Ajax. She produced 10 colts of record in 14 years.

Belle, Norma, Alice, Clio 2496, Grisette 1778, Helena 1786 and Littie 1785 were the real producers in this stud during the ' 80 's, and most of the good things bred on this stock farm have descended through some of these dams. Norma, Alice and Grisette were the most valuable brood mares. They 
were regular producers, raising 9,9 and 7 colts of record respectively, besides some that were castrated or that died before being recorded. Besides this, their colts were good in type, size and quality and sold for good prices, especially Norma's colts. Martell 2491 was the best colt she raised during the time mentioned. Alice produced Clio, the dam of the good stock horse Austerlitz, already considered.

No showing of any consequence was practiced by the Joneses during this period, although the firm did win second at the Ohio State Fair in 1888 on Druid in the yearling stallion class. A few sales were made, but they were scattered.

Samuel Kendeigh.-Samuel Kendeigh began in a small way in 1884, and continued breeding Percherons till 1900. Buckeye Mark 4666 was the only animal of note bred by him during the earlier period of his work. This horse was out of Veranda 2747 (1571) and sired by Brilliant 1271. Buckeye Mark developed into a very good individual and was used for some time at the head of the stud. He was shown at the Ohio State Fair in 1888, where he won second in the regular class for three-year-old stallions.

$\mathrm{Mr}$. Kendeigh's operations were enlarged after this, and there are 18 colts of record bred and raised by him up to 1890 . His foundation stock was practically all drawn from Mark W. Dunham of Oaklawn Farm.

M. V. Bates.-Capt. M. V. Bates, a giant in stature, who at one time turned his size to cash account with the Barnum shows, established a Percheron stud on 
his farm near Seville, O., a short distance from Mr. Kendeigh's. Capt. Bates also secured his foundation stock, a stallion and 3 mares, from M. W. Dunham. Bates' operations began in 1884 and continued till 1900. He achieved no special success, and the horses he had were smaller than modern-type Percherons, but he did aid in distributing and popularizing Percherons in Ohio. Twelve colts of record were raised by 1890 . His sales were chiefly local.

E. J. Condit.-Located at Condit, Delaware Co., O., E. J. Condit was one of the earliest of the Ohio breeders. His operations were on a small scale. Although he began in 1882, he had raised by 1890 only 11 colts of his own breeding. Thirty-nine colts were bred and raised during the next decade.

Iowa's Percheron Breeders.-A. W. Cook, Charles City, Ia., has the honor of having been the first man to take an imported Percheron to Iowa. This was the stallion Duke of Normandy (John Sheridan) 168. The horse was bought by Cook in 1869 from Peter Bland, Milford Center, O., where he had been in service one year. Cook kept him till 1874, when he sold him in March to Jacob Erb \& Co., Ames, Ia., where he died the following August. Mr. Cook also has the honor of breeding the first Percheron of record in Iowa. Three mares were bought by him from B. H. Campbell of Illinois early in 1875. These mares raised fillies foaled in 1876, and it is from this date that Percheron breeding in Iowa starts.

Only 6 American-bred Percherons were raised in Iowa up to 1880 , but operations expanded rapidly. 
Before 1890951 stallions and 123 mares were imported directly to Iowa, and Iowa farmers proved to be liberal buyers of the best horses brought over by importers located in other states. As a consequence, Percheron breeding was so increased that 132 stallions and 160 mares, bred in Iowa, were raised by 1890, and the distribution of both mares and stallions was more general in this state than in any other except Illinois.

Mr. Cook's purchases were made in France and from Degen Bros. and B. H. Campbell of Illinois. W. W. \& Al Power of Pulaski, Ia., who were, next to Cook, the earliest Percheron breeders in the state, obtained their foundation stock from the Dillons of Normal, Ill.

Iowa Breeders of the '80's.-Altogether there were 66 breeders of Percherons in Iowa during this time, but nearly all owned only a few head. The leading breeders in the state, so far as number of animals bred is concerned, were Singmaster \& Sons, J. H. Barnett, John Lenhart, D. M. Baughman, D. Brownson \& Sons, P. P. \& L. H. Humbert and M. L. Ayres, but there were men of real metal among the smaller breeders whose stock has since come into prominence.

Maplehurst Stock Farm.-On the fertile prairies near Keota, Ia., Samuel Singmaster had located in 1843. His sons, William and Charles F., grew into the business with him and by 1874 the family was possessed of extensive holdings of good Iowa land. William, a bachelor, was the most keenly interested in horses and prevailed upon his father to finance 



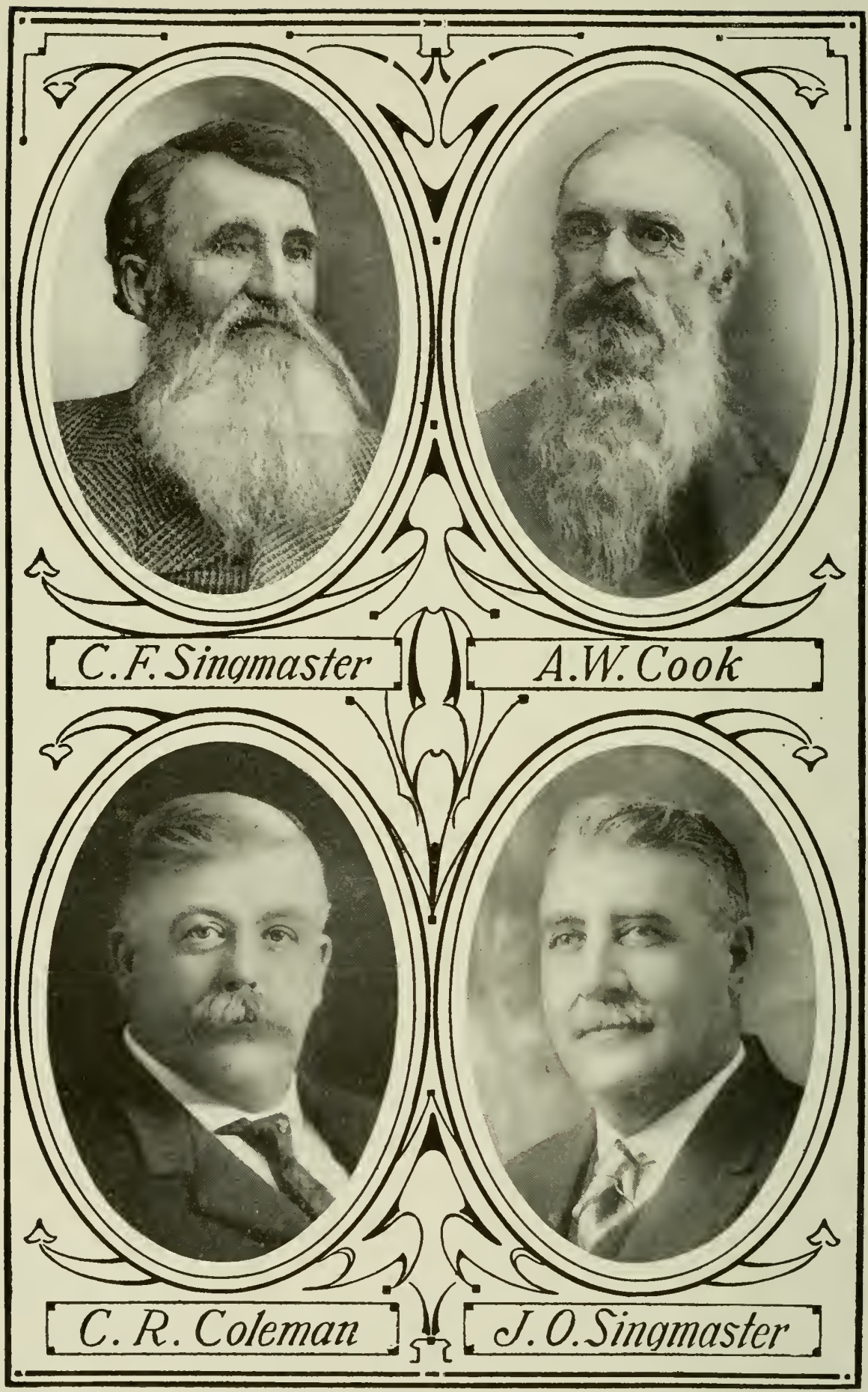


an importation in 1875 . The horses were selected by William Singmaster, but the business was handled under the name of Singmaster \& Sons. Four Percheron stallions constituted the first importation. No more were brought over until 1883 and 1884, when other importations, including both mares and stallions, were made. Percheron breeding by this firm really started in 1885 . Two colts of their own breeding were raised in 1886, 2 more in 1887, 12 in 1888, and by 189014 stallions and 27 mares of their own breeding had been produced.

Romer 7596 (7471) and Francillon 9842 (10428) were the most important sires used and were imported in 1887 and 1888 respectively. Both were horses of showyard caliber, and both won first honors in class at the Iowa State Fair. Duc Doudaville 2d 11695 (12685), imported in 1889, was another good horse, champion at the Iowa State Fair in 1890, and extensively used in the stud during the next decade.

J. H. Barnett.-J. H. Barnett, of Indianola, Ia., was one of the earliest of Iowa's Percheron breeders, beginning in 1883 . He did not own many Percherons and raised only 15 of his own breeding by 1890 , but his horses were good in type, and he won a number of prizes in the open classes at the Iowa State Fair in 1885, '86, '87, '88, '89 and '90. He contributed materially to the popularity of Percherons in the central part of Iowa, and encouraged many other breeders to make a start with Percherons.

Other Breeders.-D. M. Baughman, Pulaski, Ia., 
John Lenhart, Clarksville, Ia., the Humberts of Corning, Ia., and M. L. Ayres, Shenandoah, Ia., all made a beginning in Percheron breeding in the late '80's, but had no more than made a fair start by the end of the epoch we are considering.

Further Consideration of Illinois.-Lest it be thought that Illinois is receiving undue attention, it must again be noted that more than one-third of all of the breeders in the United States up to 1890 were located in that state. We have now to deal with the operations of men who although not among the leaders in the state were nevertheless men of influence in Percheron affairs.

Leander J. McCormick, for many years in active charge of the McCormick reaper interests, retired from active business about 1885 . He shortly afterward purchased 250 acres near Lake Forest, Ill., a short distance north of Chicago. He soon added 200 acres more and set out to develop a stock-farm. Jersey and Brown Swiss cattle were imported. Percherons were selected as the breed of horses best suited to Mr. McCormick's ideas of American needs, and the stud was founded by direct importations.

Accompanied by his son, R. Hall McCormick, who had inherited a love for good horses, L. J. McCormick went to France in 1887. Eighteen animals were selected. Martignac (10437) was chosen as the best two-year-old obtainable in the Perche, and was bought from M. Tacheau at a very long price. He was upon importation renamed Reaper 8076 (Martignac 10437) and so appears in the Percheron rec- 
ords in America. Fourteen head more were imported in 1888. Twenty-eight of the 32 head were mares. Twelve stallions and an equal number of mares were bred and raised by the Messrs. McCormick by 1890 inclusive.

Reaper was by Confident 3647 (397), one of Brilliant 1271's greatest sons, and was one of the best of his time. He stood about 17.1 hands high, weighed more than 2,100 pounds, and was a big, massive black, with great draft character. He had a very good head, a well-set neck and excellent underpinning. The mares were a fairly good lot, but not so outstanding as the sire. No sales were made at this time. The influence of this stud on others will be dealt with later.

Pre-eminence of McLean Co., Ill.-By 1890 Illinois had 203 American breeders of Percherons. Fortyfour of these were in McLean, 20 in La Salle, 10 in Dupage, 8 in Tazewell, 8 in Woodford and 8 in DeKalb counties. McLean county alone had more breeders than any state except the three leaders.

The leadership of the counties in the north-central part of Illinois in Percheron breeding, which has continued down to the present day, warrants a consideration of the underlying factors. The counties nearer to Chicago have from early days borne the orand of the dairy interests. Farmers within 50 miles were influenced in numerous ways to engage in dairying. Farms were given up largely, or wholly, to this industry and there was no room for horses, other than those actually required. The 
dairyman, accustomed to a pay check every month, was not favorable to an investment which might not return dividends for 3 or 4 years. For these reasons the spread of Percheron breeding in counties near Chicago was slow.

In McLean, La Salle, Woodford and Tazewell counties other conditions prevailed. Farms were large and the land well adapted to heavy machinery and draft horses. Beef cattle and hog-raising were the main lines of live stock production. Farmers were accustomed to making good-sized investments and waiting a year or two for returns. They were, on the average, wealthier than the dairy farmers around Chicago.

Besides these general factors, the human equation had some bearing. The leading importers in northern Illinois, Mark W. Dunham and W. L. Ellwood, had by unusual advertising built up a nationwide business. Buyers came from all states. These importers were therefore largely independent of local trade. In central Illinois there were a large number of small importers, who lacked the nationwide advertising and showring prestige requisite to making sales far from home. Their trade was therefore largely local. The result was that more farmers were induced to make purchases than would have been the case had the local field been less thoroughly worked. The advantages of using Percherons became so evident that more farmers invested and McLean, La Salle, Livingston, Tazewell, Iroquois, Woodford, and McDonough counties rapidly 
developed the leading Percheron breeding district of the United States.

William Hurt, whose operations as a Percheron breeder began in 1882, probably bred more highclass Percherons than any other breeder in McLean county. His foundation stock was obtained from the Dillons, and he secured in Powerful 6670 (Bayard 7519) one of the best sires ever used in central Illinois. Powerful was foaled in 1878 and imported in 1882 by Dillon Bros. He was a gray, about 17 hands high and weighed more than a ton-a massive, well-proportioned draft horse. He was a grandson of Favori 1st (711), one of the best and largest horses of his time. Powerful was purchased almost immediately after importation by Hurt and was owned by him till February, 1898, when he was sold conditionally to A. L. Robison, Sr., who used him till his death in 1905 at the ripe age of 27 years.

The colts sired by Powerful had size and good underpinning. Loiret 8181, one of his sons bred by Hurt, won first at the Illinois State Fair in 1888. Capsheaf 16986 was another of Powerful's sons of showyard character, and he was valued most highly as a sire of market horses. Levetta P. 10285 and Christina P. 16608 were two of his daughters that proved to be show mares and remarkable producers. These were all bred by William Hurt, and his sound judgment of what constituted merit in a draft horse made him one of the most influential breeders of his time. He exhibited freely, but chiefly at local 
shows in central Illinois. The winnings of Percherons bred by Mr. Hurt influenced general Percheron operations most favorably, because the animals he won on were the right kind-drafty, well-balanced and far better than the average in feet and legs. They were the durable, long-lived Percherons that continued sound to death and their descendants have done well wherever owned.

Mr. Hurt took his sons into business with him after 1890. The sale of stock to other studs will be dealt with in considering the later work of the firm.

Ed. Hodgson of El Paso, Zimri Hodgson of Healey, S. N. King of Bloomington, five different members of the Stubblefield family of Bloomington, F. F. Elder and W. M. Bright of Normal, and D. H. Vandolah were other prominent breeders before 1890 . Vandolah imported a great many Percherons as weanlings and carried them for a year or two on his farms. He is commonly accredited with having made more money in the importing business than any other man in the county. S. N. King bred King's Europe 8258, foaled in 1885. This horse was a good one, a prize-winner and a sire of merit, but his colts, like many of those of the Extrador 4525 (386) breeding, were rather hard feeders. Mr. King also used Bendago 11807, owned by Mr. Hanna, and Dave P. 14366, a son of Powerful bred by Mr. Hurt, in his stud. He bred some excellent horses.

A well-informed horseman has declared that Zimri Hodgson bred better horses than any other member 


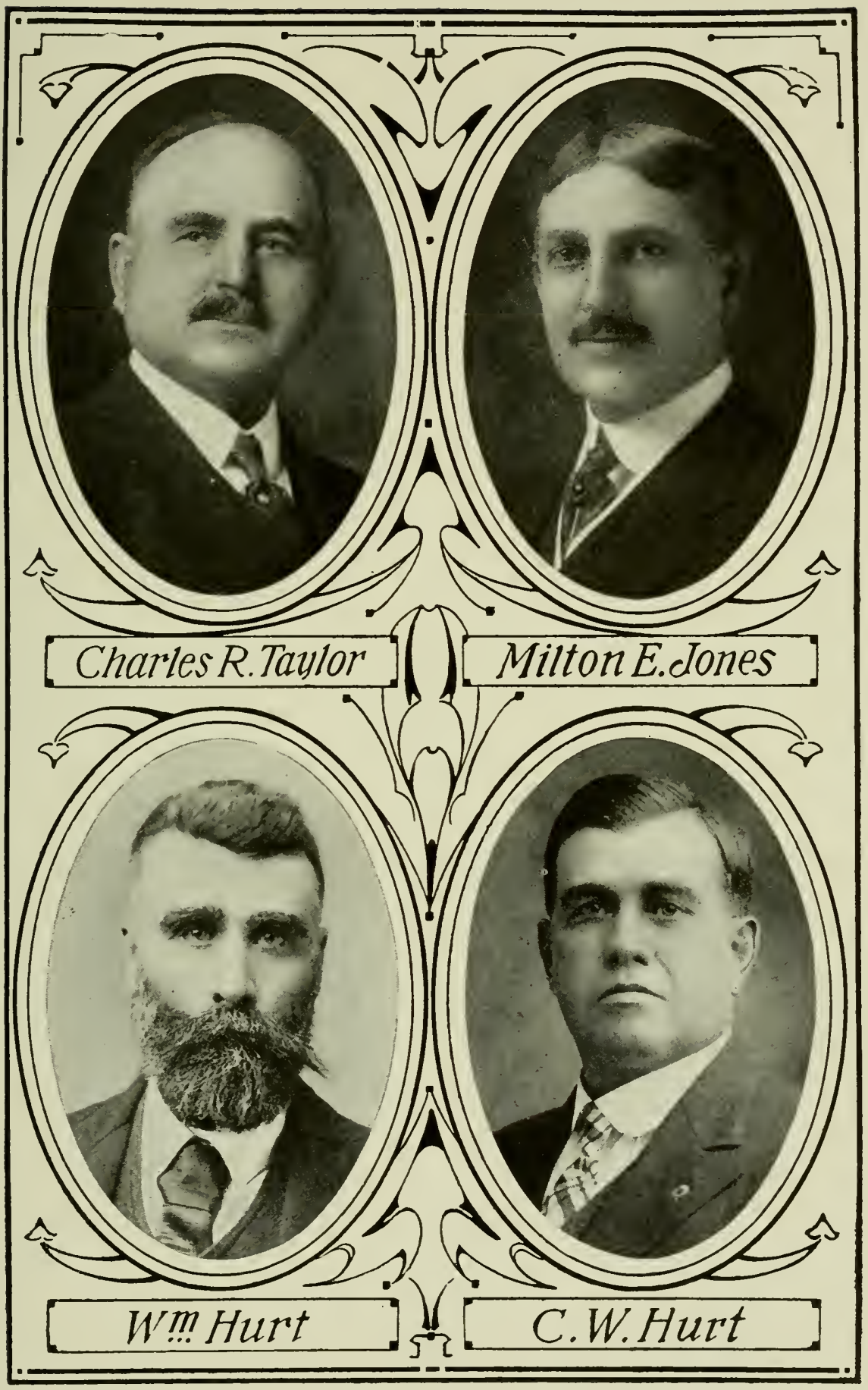



of that family. He influenced Percheron breeding very favorably, for his horses were of real merit.

G. W. Stubblefield was the leading importer among the men of that name in McLean county, and many of the studs in central Illinois were founded on purchases made from him. His early operations as an importer have already been discussed. His breeding. operations were incidental, for he was primarily an importer and dealer. Eight stallions and 10 mares are on record as bred by him from 1881 to 1890 . He had but 5 or 6 mares, of which Queen of the West 598 proved the most valuable. Henry Abrahams 224 was one of his best sires-an extremely prepotent horse that influenced the grade stock of McLean county quite strongly. St. Hilaire 3911 (2965), another good stock horse, left more purebred descendants; he was a well-balanced, massive horse weighing about a ton, and left some very good stock.

In Tazewell.-In Tazewell Co., Ill., Percheron breeding was started by the importations made by J. W. Richmond. These horses went to William R. Baldwin and others about Delavan, Ill. Baldwin also bought some horses from Mr. Ellwood, among them Jambe d'Argent 5796 (8233), a black horse of Favori 1st (711) breeding. This horse proved to be extra good and did much good in Tazewell county. Romeo 12725, later used at the head of Wm. Hurt \& Sons' stud, was bred by Baldwin and was by this sire.

D. H. \& F. S. Allen started in 1888 and have never been out of Percheron breeding. R. A. Brawner, an uncle of the Allens, was in on their first importa- 
tion, and bred a few during the following 20 years.

In La Salle.-In La Salle Co., Ill., M. C. Hodgson and W. E. Prichard, the leaders, have already been discussed. Richard Wolf began in 1882 and bred some good Percherons, though his operations were limited. R. Nagle \& Sons, Grand Ridge, Ill., in 1883 bought some of the best mares Mark W. Dunham imported and secured Confident 3647 (397), the son of Brilliant 1271. Mr. Nagle later bought some of Mr. Ellwood's best mares. Confident was a show horse in every sense of the word and a sire of the top rank. Had the members of this firm developed the colts and advertised the stock they would have been among the leading American breeders; they were poor feeders and bad caretakers, however, and the colts were stunted in growth and the stock was never in fit shape for show or sale. The real worth of the blood manifested itself whenever animals bred by Nagle \& Sons were given a fair chance, and every man who has been interviewed who bought stock of this breeding declared that the animals grew out and developed into marvelously good draft horses; but the profit went to the purchaser instead of to the breeder, as the animals were so rough and stunted while in the hands of the breeders that no one could be persuaded to pay a decent price for them. It is most unfortunate that conditions developed as they did; but R. Nagle was old and within a few years after starting could not give the horses the attention they deserved. The sons could not be made to realize the need of developing the colts. 
The net consequence was that a stud founded on good horses of good breeding exerted less than one-tenth the influence it should have had in upbuilding draft horse breeding, and all for the lack of proper feed and care.

Other Minnesota Breeders._-Besides the leading breeders in Minnesota, whose work has already been discussed, there were a number of less prominent men who bred and distributed much valuable stock. The most important of these were J. E. Wilson, James M. Dunn, William Mies \& Sons, and T. L. \& J. L. DeLancey.

J. E. Wilson was the founder of Wilson Bros., wellknown clothing manufacturers of Chicago. He had about 16,000 acres of land around Lake Wilson, Minn. He was engaged in general farming and stock-raising and became interested in Percherons about 1886. His foundation stock consisted of mares bought from Dunham and Ellwood. Kleber 7063 (10270), a son of the noted Gerome 3655 (436), was the most important early sire used. A little later $\mathrm{Mr}$. Wilson obtained some mares from Mark M. Coad, either directly or through $\mathrm{Mr}$. Ellwood. His real interest in the breed and his appreciation of the value of good sires are shown by the fact that he shipped a number of mares to Oaklawn to be bred to Brilliant 1271 at a time when the service fee for that sire was $\$ 200$. Five colts were obtained, all foaled in 1888.

Mr. Wilson's plans were broken by his death early in the ' 90 's. The widow carried the stock 
along for a time until prices improved, but disposed of it all by 1900 . Some of the animals were sold in Montana.

William Mies \& Sons began by purchasing Baptiste 3064 (41) from Leonard Johnson in 1886. This was an extraordinarily good horse, fully described in our discussion of Leonard Johnson's work. The Mieses had no Percheron mares at this time, but imported some in 1887 and 1888, and bred very good ones. The firm later became Mies Bros. Their Percheron breeding ceased about 1900 . The stock was scattered, but did substantial service in a general way.

James M. Dunn was a small breeder who began about 1886. Most of his stock was secured from Leonard Johnson. He bred but few animals.

T. L. \& J. L. DeLancey made their start in 1874 by buying 2 grade Percheron stallions and several mares in Kane Co., Ill. These were all sired by Success 452, Mark W. Dunham's first sire, and had the smooth finish and symmetry which marked all his colts. The stallions were sold at good prices. The mares were kept and bred to Leonard Johnson's imported stallions. The stallions resulting were sold profitably as grade Percherons, and the mares were kept for breeding purposes. In 1878 the firm purchased an imported stallion from Leonard Johnson, and subsequently began dealing in stallions to some extent. When Mr. Ellwood started the DeLanceys began making some purchases from him and continued purchasing sale stock from both Ellwood and 
Johnson until importations were made direct by the firm in 1888. Their Percheron breeding began with the purchase of a carload of mares from Ellwood in 1885. Superieur 5752 (2188) was the first sire used and the first Percheron bred by this firm was foaled in 1887. Six colts were bred by 1890; while many mares were purchased or imported, most of them were soon sold. The DeLanceys exhibited freely at the Minnesota State Fair in the ' 80 's with marked success, but as their chief work came after 1890 details will be given later.

Other Breeders in Wisconsin.-While Messr's. Pabst and Kellogg, whose work has already been dealt with, were the chief Badger State breeders, there were others whose Percheron breeding was important. Among these were H. A. Babcock of Neenah, H. A. Briggs of Delavan and Elkhorn, N. W. Morley of Baraboo, Peter Truax of Eau Claire and J. M. White of Rolling Prairie.

H. A. Babcock was a wealthy lumberman with extensive land interests near Neenah, Wis. He was a man of more than average ability, and before engaging in Percheron breeding had an extensive experience in purchasing horses for use in lumber camps. His keen observation of the essential points of a draft horse, gained through years of purchase and ownership of heavy draft teams engaged in such heavy hauling, made him an unusually discriminating judge. His first Percheron purchases from M. W. Dunham were marked by the men connected with Oaklawn because of the excellence of the animals 
bought. He began in 1880, but did not breed many until after 1884. All told 13 stallions and 15 mares were bred and raised by him in 1890. One of the best early sires used by Mr. Babcock was Canadien 7033 (6653), a gray son of the noted Voltaire 3540 (443). He was a medium-sized horse, standing about 16.2 hands high and weighing about 1,900 pounds when in good flesh. He was compact and well-proportioned and a very good sire. Sansonnet was used still earlier and sired the phenomenal show and brood mare Linda 12986. This mare, bred by Mr. Babcock, made most of her record in the hands of Oaklawn Farm, and her history has already been given. The greatest sire ever used was Villers 13169 (8081), of which more anon. Relatively few animals were sold by Mr. Babcock before 1890 . Further discussion of his work will come later.

H. A. Briggs, who bred and raised 17 Percherons on Prairie View Farm by 1890, began breeding about 1886. He bought some mares from R. B. Kellogg, and made an importation himself in 1887. His farm consisted of 420 acres between Elkhorn and Delavan-a very good farm of dark prairie loam. Mr. Briggs worked his mares as much as the amount of work to be done would permit, and states that the mares which had a moderate amount of work gave him better results than the idle mares did. The largest number of producing mares kept at any one time was 25. A smaller number was usually owned. The first and best sire used was Louis 6337 (2430), a black with a star. He was 
about 17 hands high and weighed 2,150 pounds in show condition. He was fairly well-proportioned and very good in action. He won first as an aged stallion at the Wisconsin State Fair in 1892, and was also first in the class for get-of-sire. He won second in the same classes at the Minnesota State Fair the same year. His colts were large and of rugged draft type.

N. W. Morley, Baraboo, Wis., began in 1886 by purchasing some Percherons from M. W. Dunham. By 1890 he had bred and raised 5 stallions and 8 mares, and his operations, while not extensive, were with good stock. Ravenstein 1301, sired by Brilliant 1899 out of a half-sister to his own (Brilliant's) dam, was the first sire used. He left some good colts and the best one Morley ever raised, Sadi 8233, a stallion, was sired by Ravenstein out of Florentine 969 (875). Bon Coeur 3479 (367) was another good sire used to some extent at an early date. He was a line-bred Brilliant, sired by Brilliant 1271 out of a daughter of Brilliant 1899. His colts were uniform and a good kind.

Other Michigan Breeders.-Mr. Palmer's work, already reviewed, was supplemented by the work of 27 other Michigan breeders. Among the most prominent were Savage \& Farnum of Grosse Isle, Jacob P. Sleight of Bath, and E. Woodman of Paw Paw. Savage \& Farnum were advertising agents, engaged in placing advertising in leading papers throughout the country. They had a farm on an island in the river below Detroit and here they 
established Grosse Isle Stock Farm. Their foundation stock was obtained from M. W. Dunham and John W. Akin, and they subsequently made some scattering purchases and still later bought a number from Thomas W. Palmer. The Percheron breeding operations of this firm began in 1884. By 1890 they bred and raised 23 stallions and 19 mares. The most noted stallion they owned at this time was Romulus 873, imported in 1879 by Mark W. Dunham and sold that year to H. Walker \& Son of Detroit. Romulus was a gray, foaled in 1873, and had the distinction of having won first in the aged stallion class at the Universal Exposition at Paris in 1878. He was about 16.1 hands high and weighed about 1,700 pounds in breeding condition, but was an extraordinary show horse in every way-beautifully balanced, with superb style, finish and action. He was an extremely prepotent sire and some of the best horses imported in the early '80's were by him. He sired but ten purebred colts in America, which were bred by Dunham (1) and Hiram Walker \& Son (9). Too much showyard fitting apparently interfered with his usefulness, for he got no purebred colts for Savage \& Farnum.

An item of interest in connection with the operations of Savage \& Farnum is the fact that among their importations was the stallion Sebastopol 5272 (7043), later famous as the sire of Armour's Big Jim, four times champion gelding over all breeds at the International Live Stock Exposition. J. H. S. Johnstone, whose persistent efforts traced Big Jim 
to his source, found that he was bred by D. C. Graham, Cameron, Ill. Sebastopol was an aged horse when he sired the world-renowned champion, but this performance was no fluke, as he sired many high-class geldings that sold at good prices. It seems unfortunate that a horse with such a record as a gelding-getter should not have been used on purebred mares, but so far as can be ascertained he left but one purebred colt, the Percheron mare Sebastin 17105, foaled in 1892, and she left but few colts. The old horse was owned by B. F. Tinkham, Cameron, Ill., at the time he sired Big Jim.

Savage \& Farnum exhibited quite freely at the Michigan and Ohio State Fairs and with fair success. This combined with the general advertising done by the firm, assisted materially in popularizing the breed in their territory.

Jacob P. Sleight, Bath, Mich., began Percheron breeding in 1882. His first purchases were made from M. W. Dunham, T. Hall and H. Walker \& Sons. He bred a few good colts. Abydos 960 (869), bought from Oaklawn Farm, was his best producer.

Parsons \& Baldwin, Watervliet, Mich., began in 1884, and bred 9 Percherons by 1890. They began with the purchase of Floreda 1490 (1433) and her daughter Flora 2964, sired by Brilliant 1271. These were secured from M. W. Dunham. Flora was bred to Confident, owned by Nagle \& Sons, in 1886, and to this service she foaled Nancy 10089, one of the three best mares owned by the firm during this epoch. Floreda was undoubtedly the greatest brood 
mare the firm ever owned; all of her colts, even from different sires, were good. Further discussion of the work of this firm will come later.

E. Woodman, Paw Paw, Mich., did not begin until 1888 and was but fairly started at the end of this epoch. He raised 9 of his own breeding in 1889 and 1890. His foundation stock was drawn from the Dunhams. Most of his work falls in the next epoch and will be taken up later.

Other Breeders in New York.-Considering later history it seems extraordinary that New York state stood fourth in number of breeders during this epoch, but such is the case. Of the 31 breeders in the state, the leader, John W. Akin, has already been considered. A. P. Wright of Buffalo, E. H. Geiger of Danville, Frank B. Redfield of Batavia and B. B. Lord \& Son of Sinclairville were others whose work helped greatly to popularize the breed in the Empire State and there were many others who aided materially in the work. Reference must be made also to B. T. Babbit, who was one of the first, if not the first, to breed purebred Percherons in the state of New York.

A. P. Wright began in 1884 with a few mares and the stallion Jucher 3512 (2142), all bought from M. W. Dunham. His horses were well bred, but his operations were limited and terminated before much had been accomplished. E. H. Geiger also obtained his foundation stock from Oaklawn Farm, but his operations were too limited to be of much consequence. F. B. Redfield was engaged in breeding 
purebred stock of several kinds, and made his start in Percherons about 1886, with some purchases from Mr. Dunham. His chief sire was the American-bred Belidor 9520, by Brilliant 1271, an extra good colt which we have already mentioned. Redfield bred some good colts, but did not survive the depression of the '90's, closing' out about 1892.

B. T. Babbitt, of New York City, millionaire soap and saleratus manufacturer, bought 7 mares and 9 stallions from Mark W. Dunham in 1874. He mas an enthusiastic horseman, but knew little about breeding Percherons and no special good came from his investment except in an advertising way, although some of the animals did some good in regions where they were subsequently sold.

For some reason few of the Percherons owned in New York state during this period have continued their impression down to the present day. Most of the animals were scattered and passed into the hands of men who permitted their registration to go by default, and their blood has gradually been swallowed up in the common stock of the state.

Percheron Breeding in Pennsylvania.-Pennsylvania had 23 breeders by 1890 , but Powell Bros. were the only ones whose operations were at all extensive. They began breeding in 1884 and by 1890 had bred and raised 16 stallions and 18 mares. They were importers of and dealers in many kinds of purebred live stock, including practically all breeds of draft horses. J. T. Vance of Washington, J. P. Scott of Remington, and F. M. Finley of Finleyville were 
others whose Percheron studs were but fairly started by the close of this epoch, and their operations will be dealt with later.

Shadeland, the Powell Bros.' stock-farm, made its start in Percherons when some stallions and mares were imported in 1884. Additional mares were brought over in following years, and a goodsized band of brood mares was owned from that time on. Cresus 5435 (2513) was the most important early sire used. He was a gray of good type, a son of Selim (749). Noireau 5463 (1675), a gray son of Narbonne 1334 (777) by Brilliant 1899, was the next most important sire used. He was imported at the same time Cresus was in 1884, but was not given any opportunity on the purebred mares until 1888 and later. He left some good stock. The broad basis of operations maintained by Powell Bros. made them distributors of a great many Percherons in the eastern states, but their influence on Percheron affairs was lessened by reason of the fact that they were dealers in all breeds and necessarily did not give Percherons as strong support as would otherwise have been the case. Their work was of far-reaching consequence, however, and many of the Percherons now in the eastern states trace to Shadeland Stock Farm.

The Little Missouri Horse Co., of Meadville, Pa., was another company whose operations were farreaching in popularizing Percheron sires for breeding up common grade stock. The stud was barely started at this time, however, and the story of this 



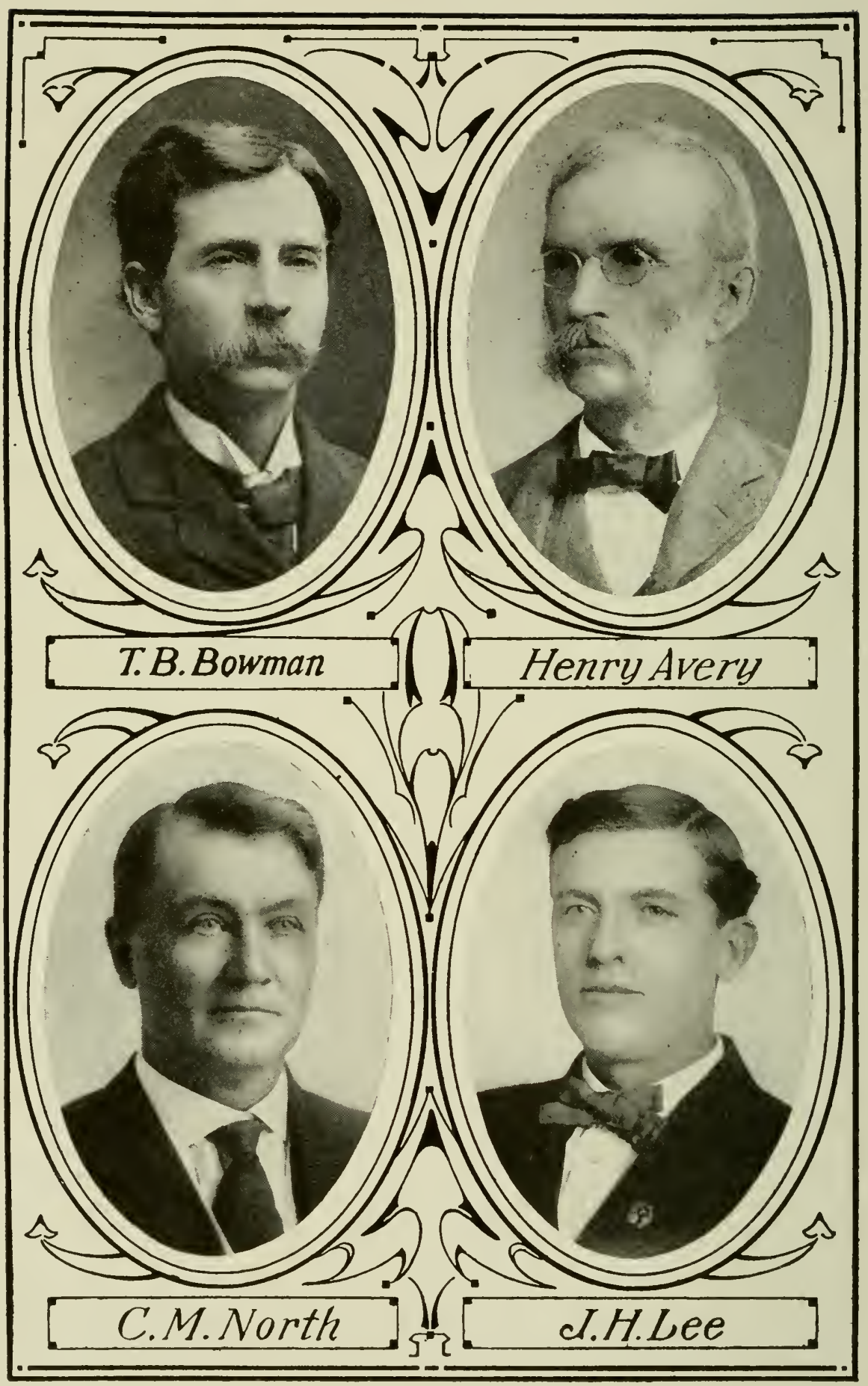


ranch is so fascinating in interest that it will be dealt with in full at a later period.

Progress in Indiana.-Indiana had no outstanding leaders and the development of Percheron affairs in that state was slow. S. Crumpacker and R. F. Small of Westville and H. Hulman of Terre Haute were the only ones who bred more than 10 Percherons each during the time considered. Mr. Crumpacker was engaged in importing and raised some Percherons as early as 1880. His operations were incidental to his work as an importer in the firm of Crumpacker \& Winters. Mr. Small obtained his foundation stock from this firm. Orphan Boy 1857, imported in 1882, was his first important sire, and he later used a good horse called Grandee 686 (743). Grandee was a black son of the great Farori 1st, and was a good, big horse, like most of those of this strain. He was 16 years old when he sired his first foals for Mr. Small, but continued in service until he was 21 years of age. Mr. Hulman did not begin until about 1886 or 1887. He purchased his foundation stock from M. W. Dunham.

In the Sunflower State.-To the Yankee pioneer, Henry Avery, Wakefield, Kans., goes the honor of having bred the first Percherons in Kansas. He had gone into the west when Indians were still plentiful and had secured extensive land holdings near the Republican River, some 12 or 15 miles northwest of Fort Riley and a short distance west of where the Kansas Agricultural College now stands. He liked good horses, had a genuine love for drafters, and 
made his start by purchasing some stock from the Dillons in 1877. In 1880 he bought Vidou 953 from M. W. Dunham. A year later he bought Nyanza 869, bred at Oaklawn, and also bought a mare. In subsequent years he made numerous purchases from Mr. Dunham. Mr. Avery's operations expanded rapidly and he found it advantageous to sell some of the stallions and mares he had taken to Kansas. As a result of increasing business he prevailed upon $\mathrm{C}$. $\mathrm{R}$. Coleman, who was at that time working for M. W. Dunham, to go to Kansas and buy one of his farms near Wakefield for the purpose of engaging with him in breeding and dealing in Percherons. The firm of Avery \& Coleman was accordingly formed about 1886. Mr. Avery kept some Percherons under his own management, however, so that from 1886 on he had two establishments, his own and that in which he held a partnership interest. He himself bred 14 Percherons between 1881 and 1890, and the firm of Avery \& Coleman bred 28, making a total of 42 head-two and a half times as many as any other person or firm in the state. Nyanza was the most important early sire used. Voltaire $3 \mathrm{~d} 4320$ (2963), a good horse sired by the noted show stallion Voltaire 3540 (443), was another used after 1885; he left some very good colts. Waterloo 16 th 9287 (14946), imported in 1888, was another extra good one used in the Avery stud.

The activities of Henry Avery did more for Percherons at this time than those of any other breeder in Kansas, and he is entitled to much credit for the 
courage which led him to buy some excellent stallions and mares and for his aggressive championship of the Percheron cause at a time when the breed was practically unknown to Kansas farmers. Some of his best work came later, and will be taken up in due course.

O. L. Thisler, Chapman, Kans., began in 1884 by purchasing some stock from W. L. Ellwood, with whom he continued to deal for a number of years. He was more of a dealer than a breeder, however, and bred but 16 head up to 1890 .

William A. Pierce came nearly being the first Percheron breeder in Kansas; he purchased in 1880 a stallion and mare which had been imported in 1878 by Chas. W. Pierce of Boston. The horses were taken to his farm at Maple Hill, where he continued the business in a modest way, without making any particular effort to expand his operations in this direction.

There were 16 Kansas breeders other than those already discussed, but most of them did not start until 1886 or 1887 and their work was only well started at the close of this epoch.

In Missouri.-Ethan Allen Hitchcock and William B. Collier of St. Louis, A. F. McKee of Browning and D. Braymer of Braymer were the leaders among the 18 breeders located in Missouri during this epoch.

Mr. Hitchcock was a wealthy manufacturer and business man of St. Louis. He was splendidly educated and one of the most cultured gentlemen ever engaged in Percheron breeding. He bought his 
foundation stock from Oaklawn Farm in 1883 and the following year he and Mr. Collier, who was closely allied with him in business interests, bought 15 mares from Mark W. Dunham for $\$ 14,500$. They were, needless to say, a select band. Mr. Hitchcock also purchased Cesar 3526 (601) from Mr. Dunham to head the stud, paying $\$ 6,000$ - a price that was probably the record at the time. Cesar was of large size and a remarkable show horse, but hardly as good a sire as he was an individual. Monarque 5149 (2428), a son of Brilliant 1271, was secured and used a little later; he was a good one, standing about 16.2 hands high, deep-bodied, thick and massive, and much on the type of his illustrious sire; he was an exceptionally valuable stud horse, both in France and America; one of his imported sons, Baccarat 11326 (18639), subsequently made the reputation of $R$. B. Kellogg's stud. Monarque left more and better colts than any other horse ever used in Mr. Hitchcock's stud, but Cesar was used to a greater extent in $\mathrm{Mr}$. Collier's stud. It is extremely unfortunate that the pedigrees of so few of the descendants of animals bred in these studs have been preserved to the present day. Most of the colts raised were stallions which went ont in districts where grade mares prevailed. Of the mares, the only ones which have done much good were those which were taken to Mr. Collier's western ranch at Lakeport, Cal., where a considerable number were bred from this stock by $\mathrm{Mr}$. Collier and by Mrs. Wm. B. Collier. Some of the descendants of Umi 2236, one of the foundation mares 
bought from Mr. Dunham in 1884, are now in the stud of William Bond, Newark, Cal.

A. F. McKee was at one time bookkeeper for Mark W. Dunham. When he left to engage in farming in Missouri he bought some of the Oaklawn mares and also took a few on lease. He was not especially successful however, and his Percherons lacked development.

D. Braymer was a stock-farmer who bought a few Percherons from Oaklawn Farm about 1883. He bred but few animals, but was a very good judge of horses and his selections were above the average. He obtained as one of his sires Luther 1272 (1384), an extraordinarily good stock horse, but unfortunately chestnut in color.

Other States.-Of progress elsewhere some details might be given, but for the most part operations had only fairly begun in the other states and territorities at the end of this epoch. They can more fittingly be dealt with later. 


\section{GHAPTER XI.}

\section{AN ERA OF PROFOUND DEPRESSION.}

Between 1891 and 1900 the United States passed through a period of hard times that is without parallel in extent and duration. All industries were affected, thousands made bankrupt, and hundreds of thousands driven to bitter extremes of poverty. Farmers and stockmen were compelled to sell their products for less than the cost of production.

Percheron breeding suffered in common with other industries. The gradual tightening of loans had curtailed importations as early as 1890 and few horses were imported after 1891. The value of work horses was so reduced that incentive to breed better horses was largely lost. Good work animals could be bought for $\$ 50$ to $\$ 60$; purebred mares of all draft breeds sometimes sold as low as $\$ 100$ apiece, and stallions proportionately low. Percheron breeders with well-selected studs representing an average cost of $\$ 500$ per animal or more saw their investments shrink to one-half or one-third of that value. Many breeders held on until forced to sell; others with independent incomes grew weary of the cost and sold out at the bottom. Some men weathered the storm by allowing the horses to shift for themselves on pasture or range till the tide turned. A 


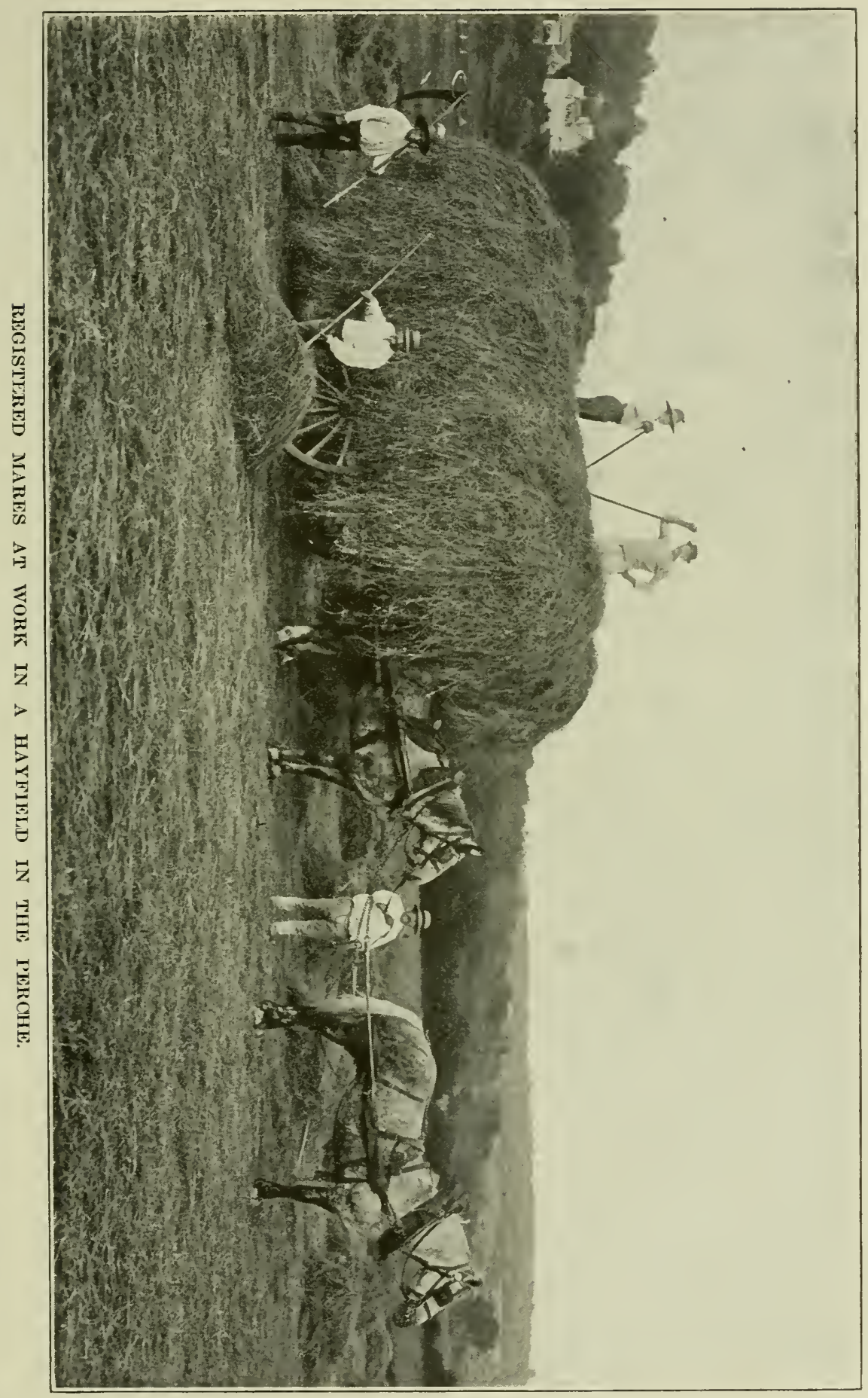



very few with means and courage bred persistently on, exercising the same careful selection of sires as in better days.

In this period the registration of the colts produced was neglected. The American Percheron Horse Breeders' Association recorded but 479 animals in 1894, 539 in 1895 and 392 in 1896. Only 8,807 American-bred Percherons and 1,490 imported animals were recorded in the entire decade, or about as many as were recorded in the single fiscal year of 1914. A large proportion of those which were recorded were foaled or imported before 1890. More than 1,000 American-bred animals foaled in this period were not placed on the records until many years later.

The depression in value of horses was due to the general tie-up in manufactures and in general business which began developing about 1890 . This culminated in the panic of 1893, when the loss of confidence among money holders was so great that it was virtually impossible to raise money on first farm mortgages or approved bonds. Building and manufacturing were stagnant and prices dropped to abnormally low levels.

The most noticeable direct effect of all this was a widespread distribution of Percheron mares. Wealthy owners, lacking knowledge of and confidence in the business, sold out for whatever price could be obtained. Others, forced to sell something to raise funds on which to live, sold all or part of their Percherons. Prices were so low that hundreds 
of farmers bought good, big mares at from $\$ 300$ to $\$ 400$ per pair, or less, considering the investment a good one when the work value alone was reckoned. Stallion owners and dealers were pressed into service to help sell mares on long-time notes to help relieve men whose bands of mares constituted a heavy expense for feed and care. J. L. DeLancey, J. M. F'letcher and other well-informed horsemen who went through the panic agree in declaring that the best of Percheron mares were actually bought by farmers as low as $\$ 300$ each-and this for the very best stock. Such expansion of breeding as did occur between 1892 and 1897 was due almost wholly to sacrifice of valuable Percherons by men who either had to sell or who became panic-stricken. From 1897 on there was some improvement in prices and a gradual awakening of interest. It was slight, however, as is abundantly attested by the lack of interest in the breeding classes at the first International Live Stock Exposition in 1900.

What the Figures Show.-In 1890 there were 593 breeders of Percherons in the United States; by 1900 the number had increased to 1,63t. Illinois came first with 547 breeders; Iowa second with 204; Ohio third with 146; Minnesota fourth with 124; Wisconsin fifth with 83; Kansas sixth with 72; Indiana seventh with 64 ; Michigan eighth with 53 ; Nebraska ninth with 48, and South Dakota tenth with 47 . The remaining 246 breeders were scattered through 24 states and territories, so that more than four-fifths of all the Percheron breeders in the United States 
were located in the territory of the Mississippi and Missouri valleys. Nearly half of them were in the states of Illinois and Iowa, which explains why these two states now contribute 42 percent of all Percherons bred in America.

One hundred and fifty-nine mares were imported and 114 bred in America between 1871 and 1880; 2,566 were imported and 2,089 bred in America between 1881 and 1890. Roughly speaking, there were approximately 5,000 Percheron mares available in 1891, yet in the decade we are considering only 4,897 stallions and 4,990 mares, eventually recorded, were foaled, and more than 1,000 of these were not recorded until long after the close of the decade. The total number of recorded American-bred Percherons produced in the 10 years was but 9,887 , or an average of less than two colts per mare in 10 years for the Percheron mares owned by breeders in 1891. In view of the fact that mares in farmers' hands will normally average two colts every three years it is evident that there was enormous waste of Percheron resources during this period. The mares averaged but one colt each five years. What actually occurred was refusal or neglect of farmers and breeders to breed their mares, and the castration of purebred stallion colts. Besides, hundreds of mares were sold without registration, for work purposes only, and all traces of them were subsequently lost.

Incalculable damage to constructive breeding of Percherons resulted from the stagnation. Carefully selected brood mares, which had been well cared for 
and mated to stallions whose individuality and breeding were such as to warrant confidence in good results, passed into the hands of men who were incompetent judges either of individual horses or of bloodlines. A large proportion of the new owners were poor caretakers and without knowledge regarding the feeding and development of purebred horses. Their ignorance damaged the breed. Good Percheron mares were mated to stallions that were unfit to be used. Bad breeding was followed by worse feeding. Feed was low in price, but money was hard to get, and the feed given to horses was looked upon as largely lost. The result was that most Percherons had to survive on pasture, straw, some hay and a very little grain. The best live stock in the world will be dwarfed and injured in conformation under such conditions.*

That Percherons did survive and steadily increase in popularity speaks volumes for the hardiness, adaptability and easy-keeping qualities of the breed. The injury done to intelligent breeding operations had some compensations: it placed Percherons in the hands of hundreds of farmers who bought them at low prices and became cognizant of their many sterling qualities by actual experience under adverse conditions.

Oaklawn Farm.-Under Mr. Dunham's capable management Oaklawn Farm continued its leadership

*For conclusive results regarding injury to conformation of animals through starvation or semi-starvation rations, see published reports of work done by Dr. H. J. Waters at the Missouri and Kansas Experiment Stations. 
in Percheron affairs throughout the hard times. Some importations were made each year up to 1893 , and while many mares were sold, the number kept at Oaklawn was considerable. Approximately 200 mares were owned and kept at Oaklawn or were out on lease during '91 and '92. A good many were sold in '92 and '93, so that the mares on hand on July 1, 1893, totaled but 115 head. On July 1, 1897, there were 133 and on May 21, 1901, 89 head. The number of colts bred, raised and subsequently recorded was as follows, by years: 1891, 30 stallions and 23 mares; 1892, 32 stallions and 29 mares; 1893, 21 stallions and 25 mares; 1894, 10 stallions and 16 miares; 1895, 13 stallions and 12 mares; 1896, 21 stallions and 15 mares; 1897, 23 stallions and 19 mares; 1898, 26 stallions and 35 mares; 1899, 15 stallions and 14 mares; 1900, 25 stallions and 7 mares-a total of 216 stallions and 204 mares for the decade. It is interesting to note that although in some particular years one sex greatly outnumbered the other, the total for the 10 years is nearly the same for each sex.

The chief sires used at Oaklawn in this period were as follows: Brilliant 1271 (755), in 1891 and 1892 (he died early in 1893); Marathon 11410 (10386), for the season of 1890 only; Brilliant 3d 11116 (2919), in 1891 and 1892; Aiglon 13145 (8187), in the years from 1892 to 1896 ; Introuvable 16875 (24146) from 1893 to 1896; and Villers 13169 (8081) from April 19, 1897, to March 15, 1900.

Brilliant 3d.-Next to Brilliant 1271, Brilliant 3d was the greatest of this group of great sires. He 
was foaled in 1884 and won the highest honors at the annual show held by the Société Hippique Percheromne de France in 1888. He was bought for Oaklawn early in 1889 by James M. Fletcher, who did all of Mr. Dunham's buying in France from 1887 on. At the time of his purchase, he was considered the greatest Percheron in France, individually and as a sire, and the showyard records of winnings during the past 20 years confirm the estimate which Mr. Fletcher and the leading French breeders placed on him. More prize-wimners trace to Brilliant 3d than to any other horse used in France or America since 1886. Tndividually Brilliant $3 \mathrm{~d}$ was medium-sized, standing about 16.3 hands and weighing a little over a ton in show condition. He was well-balanced, massive in build, with heavy bone of the best quality, and was excellent in action. In all-around individual excellence he stands among the greatest of the breed. He made three seasons in France, 1886, '87 and '88, and probably sired a few foals in 1889 before being imported. His colts were noted for their musually high-class type, and it is believed that no sire used in the Percheron breed ever begot so large a proportion of valuable colts and so few inferior ones.

Plans had been made at Oaklawn to show Brilliant 3d in 1889 at the Chicago Horse Show, and Mr. Dunham intended to drive home at this show the value of Brilliant blood by showing four generationsBrilliant 1271, Fenelon, Brilliant 3d and 19 yearling sons of Brilliant $3 \mathrm{~d}$ imported at the same time. An 


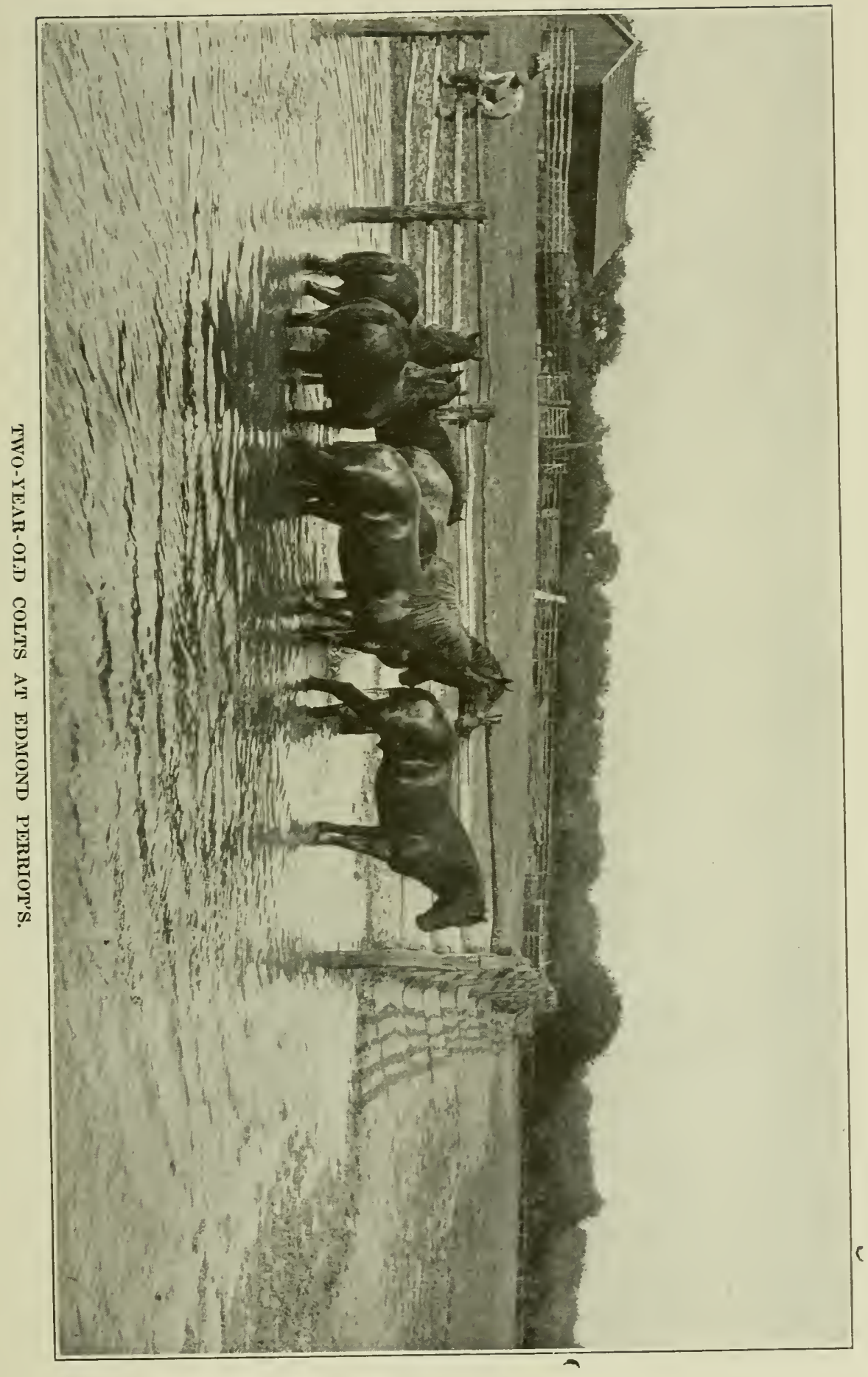



unfortunate experiment resulted in an extremely acute founder which nearly resulted in the death of Brilliant $3 d$ and he was ruined for use in the showyard.* He gradually recovered, although he was unfit for stud use for two years. Some colts were sired by him in 1891 and 1892, 15 in all, at Oaklawn, but he was so badly crippled that Mr. Dunham desired to be rid of him. He was accordingly sold on Dec. 20, 1892, to Avery \& Coleman, Wakefield, Kans., where he was used for three years and then dropped from sight.

In spite of his foundered condition, the colts sired by Brilliant 3d were good, both at Oaklawn and in Kansas. All of those sired at Oaklawn were blacks or grays, but more than half of those sired in Kansas were off-colors-bays, browns and sorrels. The offcolors were clearly due to the dams, however, as 10 out of the 11 off-colored colts were out of top-cross mares, bred up and recorded by Mr. Avery from some grade mares he bought of the Dillons in 1878. The sorrel and bay colors were so strongly fixed in these dams that not even Brilliant 3d's remarkable prepotency could entirely offset it, and he has been unjustly faulted for siring a good many colts not of popular colors.

The colts sired by Brilliant 3d at Oaklawn were developed and sold at high prices, those on which

* Anxiety to have Brilliant $3 \mathrm{~d}$ in the best possible condition led to the use of whole milk, recommended by another breeder. Too much was given, probably because of inexperience and the greediness of the horse. The result was the most acute case of founder ever known at Oaklawn. Heroic measures saved him, but he was hopelessly crippled for life. 
individual prices can be ascertained averaging $\$ 812$ each during the time when extremely low prices were the rule. The colts he begot in Kansas were not developed, were small because stunted, and consequently sold at very low prices. Despite this they grew out and made good breeding stock, quite profitable to their subsequent owners. As a whole, however, the chief good done to the breed by Brilliant 3d was in France, as the colts sired by him in America were too few to make his services here especially important. His imported descendants, however, have exerted a profound influence on Percheron breeding in America. He was unquestionably the greatest sire the breed has known in the last 30 years, when his work in both France and America is considered, and his injury just after importation was a great loss to Percheron breeding in this country.

Other Oaklawn Sires.-Brilliant 3d's injuries led Mr. Dunham to use Marathon freely in 1890. Marathon was foaled in 1885 . He was first in the threeyear-old class at the annual show held by the Société Hippique Percherome de France in 1888 and first in the aged stallion class at that show in 1889 . He stood 17 hands high, weighed more than 2,100 pounds in show condition, and was unusual in his muscular development and well-proportioned throughout. He was somewhat larger and more massive in type than Brilliant 3d, with hardly so much finish. Both were grandsons of Brilliant 1271 -Brilliant 3d through Fenelon and Marathon 



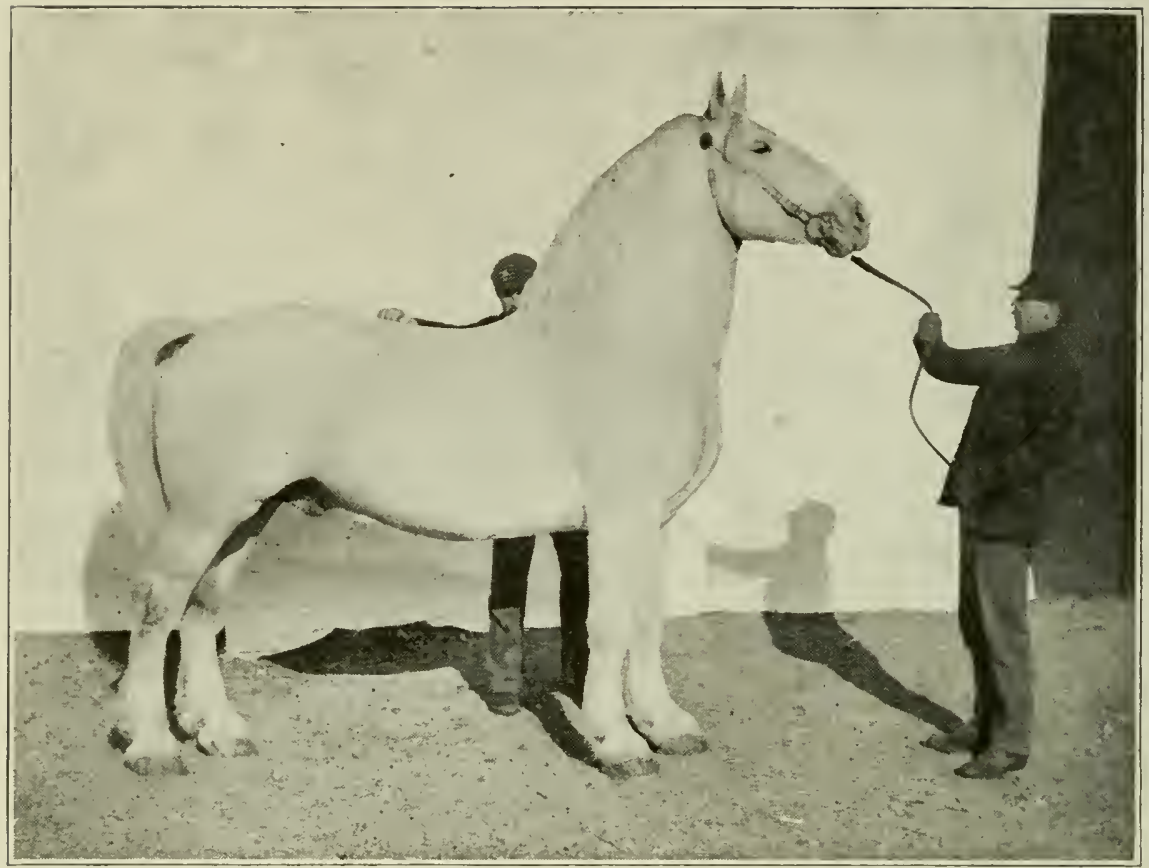

LA FEK'TÉ 5144. - FROM AN OLD PHOTOGRAPH AT OAKLAWN FARM.

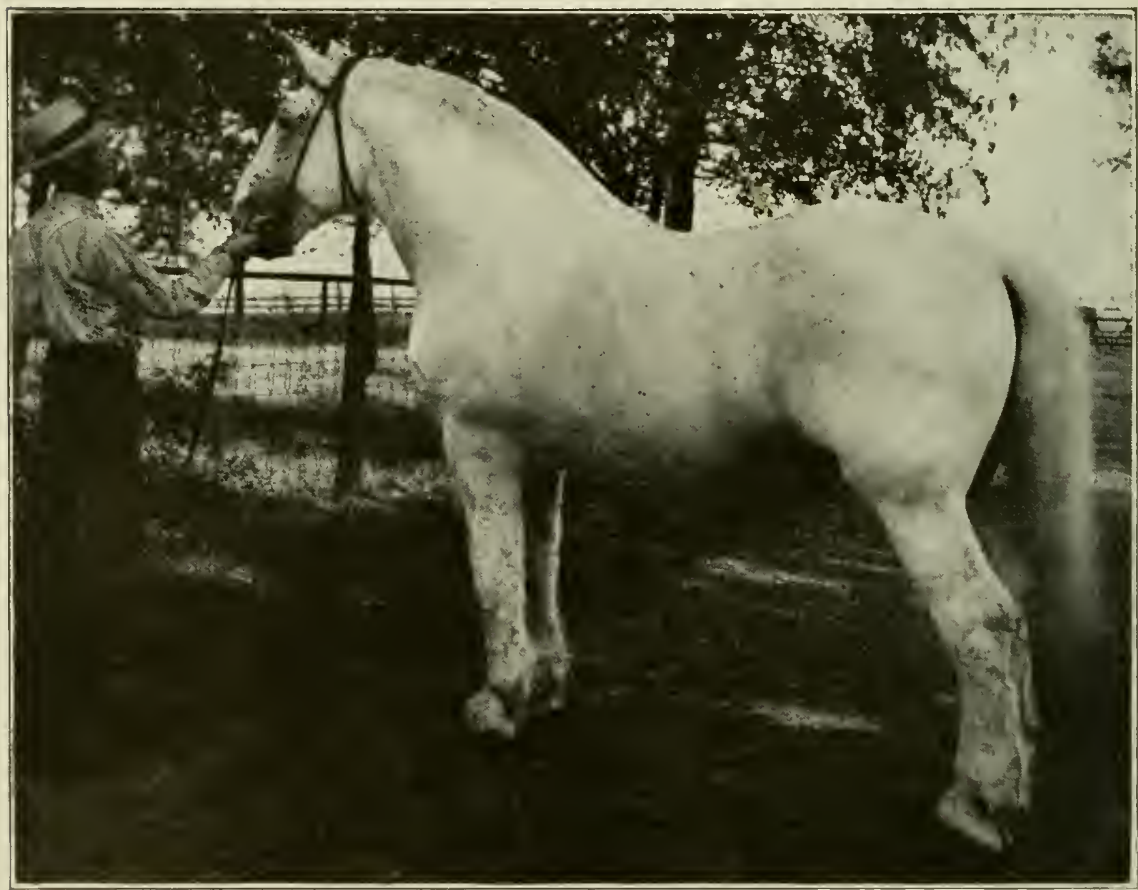

PUIVEKEUL 6670 (BAYARD 7519), UNE OF THE NUST NUTED SIKES LIER USED IN CENTRAL ILLINOIS. THIS PICTURE TAKEN WHEN HE WAS 26 YEARS OF AGE. 
through Voltaire-and both were out of daughters of Brilliant 1899. Marathon sired colts of great uniformity, much after his own type. He stands seventh among the sires in France in number of prize-winning descendants at the Société Hippique Percheronne de France shows from 1901 to 1910. His colts at Oaklawn proved to be extra good-large, heavyboned, well-proportioned. Before they were all foaled, in 1891, C. P. Jones of Minneapolis, Minn., came to Oaklawn and secured the assistance of James M. Fletcher in purchasing three or four carloads of grade draft mares in Kane and Du Page counties. After buying the mares he went to Oaklawn to buy a stallion and would not be put off with anything short of Marathon, then the best individual in stud service. He finally bought the horse for $\$ 3,000$ cash and shipped him to Minnesota with the grade mares. Marathon did not sire a purebred colt after leaving Oaklawn, and his sale was undoubtedly a serious loss to Percheron breeding interests there, as the sale of Brilliant $3 \mathrm{~d}$ and the death of Brilliant 1271 removed the only sires at all comparable with Marathon, and his absence was keenly felt from 1893 on. In this case, as in many others where a valuable sire is lost, the mistake was not fully realized until nearly a decade had elapsed.

Introuvable 16875 (24146), champion at the Columbian Exposition in 1893, was used from 1893 to 1897. He was black without markings and a horse of immense size, standing over 17.2 hands high and weighing more than 2,300 pounds in show condition. 
He was hardly as symmetrical as his predecessors, and was a bit coarse; but his colts were large and sold well, and they have bred on very satisfactorily. Introuvable died at Oaklawn Farm on June 22, 1897.

Aiglon 13145 (8187) was used in the stud from 1892 to 1896 and sired more colts at Oaklawn than any other horse used during this decade. He is generally considered the greatest son Gilbert 5154 ever sired. His dam, Bijou (4328), was a half-sister of La Ferté 5144. She was a very large mare, standing about 17 hands high and weighing about 2,100 pounds. With all her size she was a mare of unusual finish and was one of the best mares in France during her time. Individually Aiglon was about 16.1 hands high and weighed about 1,900 pounds. He was of a rather blocky type, deep-bodied, massive, very heavy in muscling, and symmetrical in build. His quality and finish were excellent, and his colts, while not the largest, were unusually good and sold at high prices.

La Ferté 5144, previously discussed, was used to some extent during this time, but was out on lease to M. C. Brownlee, Little York, Ill., in 1893. He died in 1895.

Viller's 13169 (8081) was sold to H. A. Babcock, Neenah, Wis., and was used by him from 1890 to 1897. Mr. Dunham was so impressed with the character of his colts that he bought him back on April 19, 1897, and he was used at Oaklawn for four seasons. He was about 17 hands in height and 
weighed over 2,100 pounds in show condition. He was an exceptional horse, fine in head with a cleancut neck, well set on, strong back, powerful luin, level croup, well-set tail, heavily muscled quarters, thighs and gaskins, deep-ribbed, round-barrelled, extra well-set legs and good feet. He was heavy in bone, with tendons well set back, and was extra good in quality and action. As a sire he is outranked only by Brilliant $3 \mathrm{~d}$ and Besigue (19602) in number of prize-winning descendants, and he undoubtedly did more for the breed in America than even Brilliant 3d, owing to longer and more liberal service. He had a touch of founder at one time, which made him a bit short in front. This was the only thing which dissuaded A. L. Robison, Sr., Pekin, Ill., from placing him at the head of the Leslie Farm stud in 1900, and Mr. Robison recently stated that he felt he had erred in judgment, Villers being one of the most perfect Percheron types he had ever seen. Villers was eventually sold to Perry \& Porterfield, Wayne, Neb., March 15, 1901, but had no chance on purebred mares.

The most noted son of Villers was Jules (37987), a horse that was rated as the leading sire in the Perche between 1900 and the time of his death.

Oaklawn Mares and Colts.-Mr. Dunham persistently held to his best mares, save in rare instances when it seemed necessary to let a great brood mare go to close the sale of a group. The most important dams have been considered with the exception of Bertha 5340 (7008). She was one of Oaklawn's 
greatest dams, a remarkable show mare and a producer of uniformly high-class colts. She raised 9 colts of record in 13 years, and James M. Fletcher states that to the best of his recollection she produced more dollars' worth of colts than any mare ever used at Oaklawn. Illustre 20489 was one of her good sons that later headed the Lakewood stud at Rock Rapids, Ia.; he was sold as a two-year-old in 1899 when prices were low for $\$ 1,350$.

Some other good colts bred at Oaklawn during this time and sold to head purebred studs were Aleutian 21977, foaled in 1898 and sold to the Denver Trust \& Warehouse Co., and Aurelian 21974, also foaled in 1898, and sold to head a stud in Minnesota.

Oaklawn Sales and Leases.-Among important sales or leases during this period were many to men who have since become prominent Percheron breeders in their respective communities. Some of the chief ones were as follows:

W. P. Reiser, Walla Walla, Wash., on Oct. 10, 1898, bought a stallion and 2 mares.

W. F. Mixer, Painesville, O., in 1890 and 1891, bought a pair of mares.

C. M. Jones, Plain City, O., bought the stud sire Moreri 16950 (40246).

John Yost \& Son, Thornville, O., in 1899, bought 6 mares and a stallion.

H. H. Lewis, Selma, Ind., in 1892 and 1893, bought a pair of mares and a stallion; he also leased 11 mares about 1893 .

Dilley Bros., Hebron, Ind., in 1890, '91 and '92, 
bought a stallion and 4 mares. They also had some mares on lease.

E. J. Wigle, Kingsville, Ontario, in 1899, bought a stallion and 3 mares.

H. G. McMillan, Rock Rapids, Ia., in 1899, bought a stud stallion.

Willard \& Fuller, Mapleton, Minn., in 1890, bought 3 stallions and 3 mares. This firm leased 2 stallions and 10 extra good mares in 1893, and also leased another stallion in 1894.

M. C. Brownlee, Little York, Ill., about 1893, leased the stallion La Ferte and 14 mares. This lease terminated July 25, 1896.

A. P. Nave, Attica, Ind., leased a stallion and 11 mares in August, 1897. He bought a stallion and 5 mares in 1899.

W. H. Penny, Raritan, Ill., bought a stallion in each of the years 1890, '91 and '95, and 3 mares in 1891 and 1899.

W. L. Houser, Mondovi, Wis., in 1900, bought a stallion and 2 mares.

G. H. \& F. A. Reed, Lilylake, Ill., in 1897 bought a pair of mares, and in 1898 bought another pair of mares and a stallion.

H. A. Babcock, Neenah, Wis., leased 8 mares early in the ' 90 's.

Elijah Walker, Macon, Ill., had 3 mares, and Rolley Patterson \& Bros., Hunrich, Ill., and Harry Dunbar, Galesburg, Ill., were others who had 4 mares each out on lease during this time.

This does not begin to be a complete review, but 
it does give a glimpse into operations during the depressed times.

The Great Leader.-Over and above all details, the most striking feature of Oaklawn's work at this time is to be found in the personality of Mark W. Dunham himself. His genius for organization and his extraordinary ability as a salesman enabled him to maintain the great Oaklawn stud intact in spite of the financial panic and the hard times.

When other men could not sell Percherons, or sold at ridiculously low prices, $\mathrm{Mr}$. Dunham inspired confidence in the final outcome, encouraged many men to hold on, and was successful in making sales at good prices. There was not a season, even in the worst years, when he was not well sold out by May, so far as stallions of serviceable age were concerned. It is true that he did not make importations for several years and that his operations were limited; but the stallions he raised or bought in America were sold at prices that left him a good profit, and he was instrumental in causing several wealthy men to enlarge their Percheron holdings at a time when the vast majority of breeders had given up all hope. He had faith, enthusiasm, foresight, and a knowledge of human nature which made him more than ever a commanding figure in the business when others had failed to weather the storm. His death in February, 1899 , aged 53 years, was as great a loss to Percheron interests as the death of a general of military genius at the critical point in a great battle, for Percheron breeding was just rounding into shape for a mar- 
velous recovery from years of depression. Mark W. Dunham's death removed the one leader in whom all interests had confidence, the one who could have brought order out of chaos in the breeding field and in record association affairs. The bitter strife which split Percheron breeders into three rival camps and did incalculable damage between 1900 and 1911 would undoubtedly have been averted had he survived. No more honorable breeder ever lived, and there were few indeed, in any land, who possessed his genius for constructive work and his ability to command support from all classes of men. Time, giving true perspective, reveals him as the great Percheron leader of his period, and the fleeting years only increase the estimate which thoughtful Percheron breeders place on his work.

At the time of Mark W. Dunham's death his son Wirth S. was but 21 years old, and the two daughters were young. Mrs. Dunham had died some years before. It was Mr. Dunham's request that the business should devolve on Wirth, but that he should take James M. Fletcher and C. R. Coleman into partnership in the selling organization, retaining control of the farm and brood mares under the name of the estate.

James M. Fletcher, a nephew of Mark W. Dunham, attained a high place in Percheron affairs. He was a horseman by birth and training, and was developed by frequent trips to France with Leonard Johnson and by association with Mr. Dunham's operations at Oaklawn. He spoke French fluently and from 1887 
to the time of Mr. Dunham's death bought far more horses in France than any other buyer. His judgment of horses was conceded to be second to none and he was a careful buyer. Oaklawn's importance as a purchaser gave the farm the first option on the colts held by the leading stallioner and breeder of France, Ernest Perriot, Sr., and on those held by many other leaders. Mr. Dunham had well-founded confidence in James Fletcher's judgment and integrity.

C. R. Coleman had been with Mr. Dunham in the early '80's, had subsequently been in partnership with Mr. Avery at Wakefield, Kans., for about a decade, and had again worked for the Oaklawn organization as a salesman. He had formed a partnership with James M. Fletcher about 1896 or 1897 and the firm had a good many horses in '97 and '98. Mr. Dunham realized Mr. Coleman's ability as a salesman, and feit that with Fletcher to handle the purcliasing and Coleman the selling the firm would be on a safe foundation, despite the fact that Wirth, on account of having been kept away at school, knew practically nothing of the business.

Mr. Dunham's judgment proved true in this as in other matters, and the firm of Dunham, Fletcher \& Coleman, organized in 1899, maintained the prestige of Oaklawn until the ripening experience of the son enabled him to succeed to sole control of the business.

Other Illinois Breeders.-Daniel Dunham's stud was sold in 1892 or '93. The Ellwoods sold and 
traded their horses for land so rapidly that they raised but few after 1893 and were virtually out of business by 1899 . The Winter \& Munger stud was scattered to the four-winds by private sales in 1894, '95 and '96, winding' up entirely in 1899. Geo. S. Hanna's stud was dispersed, larg'ely by trades for farm land, in 1892, '93 and '94, and the mares were widely scattered. Jesse M. Stetson succeeded to most of the Percherons owned by Dr. Ezra Stetson on his death about 1895, but Jesse M. himself died about 4 years later and most of the stock was scattered all over the United States by sales held by the estate in 1899, 1900 and 1901.

John and Mat Huston of Blandinsville, Ill., began breeding Percherons early in the '70's, but did not breed many until after making heavy importations late in the ' 80 's. They kept on during the depression and raised 20 stallions and 24 mares during this period. Their stock was unusually high-class in character, because of the selection of extra good sires and dams. Plein-D'Avenir 11287 (7361), Figaro 5961 (7708) and Forfait 16873 (28578) were a trio of exceptional sires. A large proportion of the colts bred by the Hustons went into use on purebred mares, which is significant of their high-class type and character. Joln Huston considered PleinD'Avenir the greatest Percheron he ever saw, individually and as a sire, and while his opinion may be considered somewhat biased, it is certain that he was an extremely massive, heavy-boned sire, weighing more than 2,200 pounds, and a getter of high- 
class colts. He was crippled while young, which debarred him from the showring, and undoubtedly limited his use to some extent. He was a grandson of Brilliant 1271, through Childebert 4283 (451). Forfait was somewhat smaller and a show horse of much finish, somewhat on the type of Gilbert. He was useful in imparting more style and finish. The stud was dispersed in November, 1901, and while the stock did much good in the hands of new owners, more would have been accomplished had it been held intact by John Huston, who was a most observant, constructive breeder.

E. Hodgson and TV. E. Prichard, both of Ottawa, Ill., held persistently on, and raised some extra good mares during this time, most of which were sired by Confident 3647 (397), at the head of the Nagle stud. $\mathrm{Mr}$. Prichard used Confident a little more freely than Mr. Hodgson did and got more high-class brood mares by him. The best animals owned in both studs at the present time are daughters or granddaughters of Confident, and both these veteran breeders, now in their ' 70 's, agree in declaring that they should have bought the old horse early in the '90's. As it was, his colts raised at Nagle's were stunted and the breed lost much good blood it should have received from a really great sire.*

*M. C. Hodgson \& Sons wrote the following interesting note in January, 1915:

"Hattie 2d 23757 , foaled in 1899 , by Confident, has raised 3 colts in 11 years, besides foaling 2 which died young. We still own 3 of these colts, which we value conservatively at $\$ 1,600$, and have sold 4 of her colts, foaled in $1905,{ }^{\prime} 07$, ' 09 and ' 10 , for $\$ 4,400$ -an average of $\$ 1,100$ each. Three were sold as two-year-olds and one as a three. We sold the first colt out of her oldest 



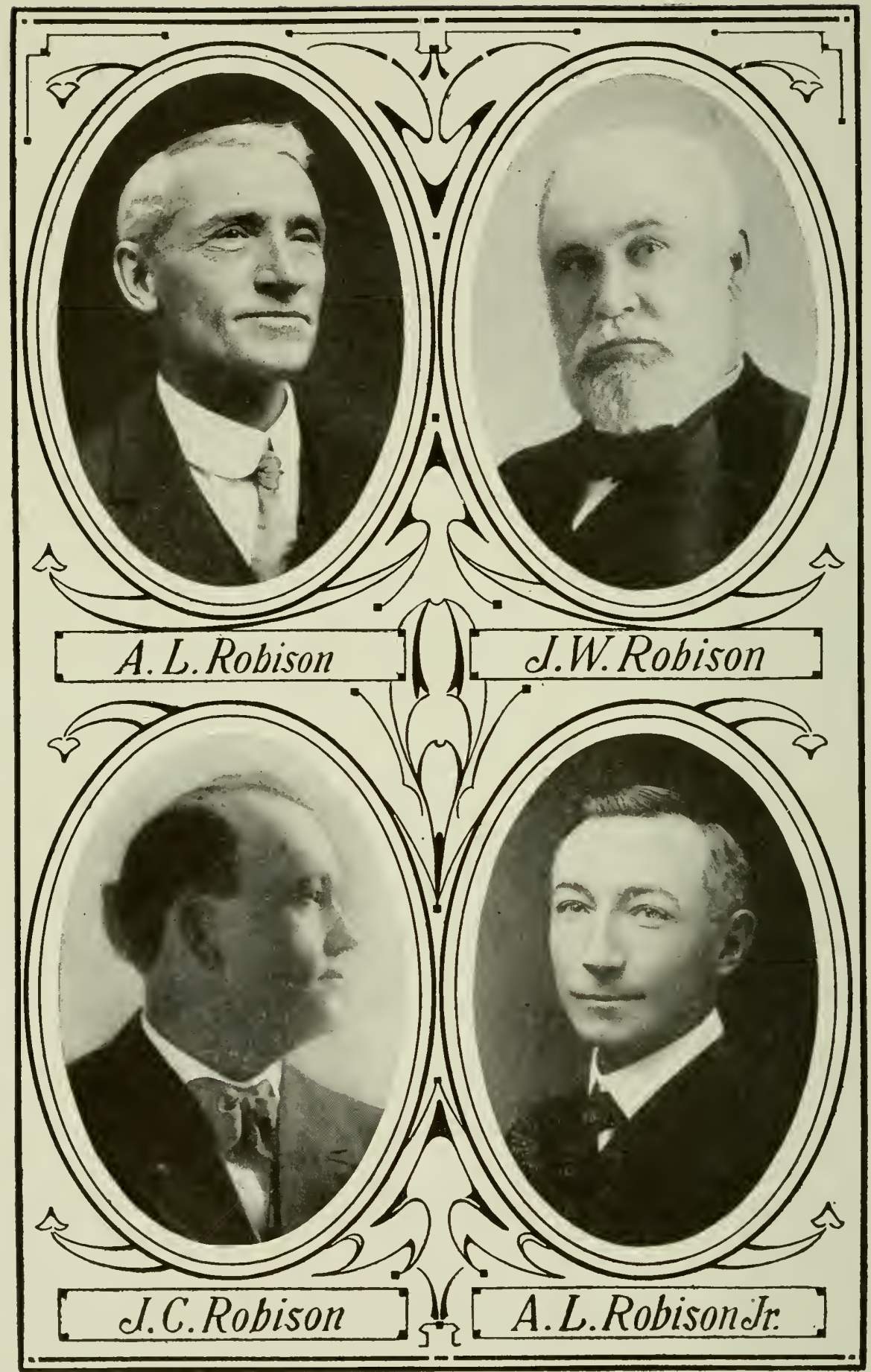


James Brown, Dwight, Ill., bred a few good colts from 1891 to 1897, but discontinued in 1899. William Hurt and W. R. Baldwin were among those who held on through the dark days, breeding a few good ones each year and encouraging farmers in their localities to stick to good horses and be ready for the tide to turn.

New Blood.-Much credit must be given to the men who had the courage and foresight to found purebred studs of consequence during the darkest days. Among those in Illinois entitled to special mention in this connection are A. L. Robison, Sr., of Pekin, Ill., and Dan Augstin of Carlock, Ill.

daughter, Hattie $3 \mathrm{~d} 41634$, for $\$ 900$, and have four other colts left out of Hattie $3 \mathrm{~d}$ which we value at $\$ 2,400$, conservatively figured. Modesty 70296, the second colt produced by Hattie $3 \mathrm{~d}$, was foaled in 1909, raised colts in 1912, ' 13 , and ' 14 and is due to foal again in 1915. Lisette $2 \mathrm{~d} 21574$, a half-sister to Hattie $2 \mathrm{~d}$, also by Confident, was foaled in 1898, and has dropped a colt every year from 1901 till 1914 except in 1913, a total of 13 colts in 14 years. Four of the colts died young, however, so that she has actually raised 9 colts in 14 years. We have sold 6 of her colts as yearlings and two-year-olds-none older-for $\$ 5,150$ and think those remaining are worth at least $\$ 1,000$. We still have the mare, now 17 years old and carrying her 14 th colt. She is worth at least $\$ 400$, considering that she is still good for several years in her breeding career."

W. E. Prichard says of his two aged mares by Confident in the 1914 Christmas issue of "The Breeder's Gazette":

"Beauty of Highland 18611 was foaled in 1893 , and is still living and breeding regularly at 21 years of age. I have sold of her direct produce colts to the value of $\$ 8,650$ and have the old mare and 7 of her produce conservatively valued at $\$ 6,500$. Litta 17192 was foaled in 1892 , and is still breeding at 22 years of age. I have sold colts produced by her to the value of $\$ 5,850$ and still have the mare and several of her produce valued conservatively at $\$ 3,300 . "$

Both breeders are agreed in declaring that they have done no more than hundreds of other good horsemen can do if they select good stock and give it proper care. It must be noted, however, that both men are dealers as well as breeders, and sold their horses direct to the firal user, thus eliminating or absorbing the middleman's usual profit. 
A. L. Robison, Sr., made his start in 1894, upon the urgent insistence of his father-in-law, Wilson Richmond. Of the latter Mr. Robison says:

"He was a born hor'seman, always bred and owned good horses and for 50 years was never without a good stallion available for his own use and for other breeders. I think he was the keenest judge and had the best eye for a sire of any man I have ever known. He was confident prices would soon swing back, and repeatedly urged me to buy all the good Percheron mares I could while prices were low. Some of my first mares were bought from him, and it was largely at his suggestion that I bought Porerful 6670 (Bayard 7519) in 1889, when he was 20 years old. He always insisted that a man breeding Percherons should, if possible, never place other than a tried sire at the head of his stud. His sound counsel and reliable judgment were of incalcuable value to me in founding Leslie Farm stud. Powerful made our stud at the outset, and I subsequently bought Seducteur 8850 (7057) and Rabelais 52564 (43442), both tried sires and horses with the best of breeding behind them. The veteran has left us, but his influence is still with us."

To this definite policy-the use of tried sires only - the remarkable progress of the Robison stud is justly due, and it is questionable whether many other breeders in America can point to a record so free from mistakes in stud sires used.

Dan Augstin had been breeding good draft horses from sometime in the ' 80 's, and stepped into the Percheron ranks in 1895. He, too, was influenced to make purchases while horses were low. John Baughman was his first counselor, and Ferdinand 



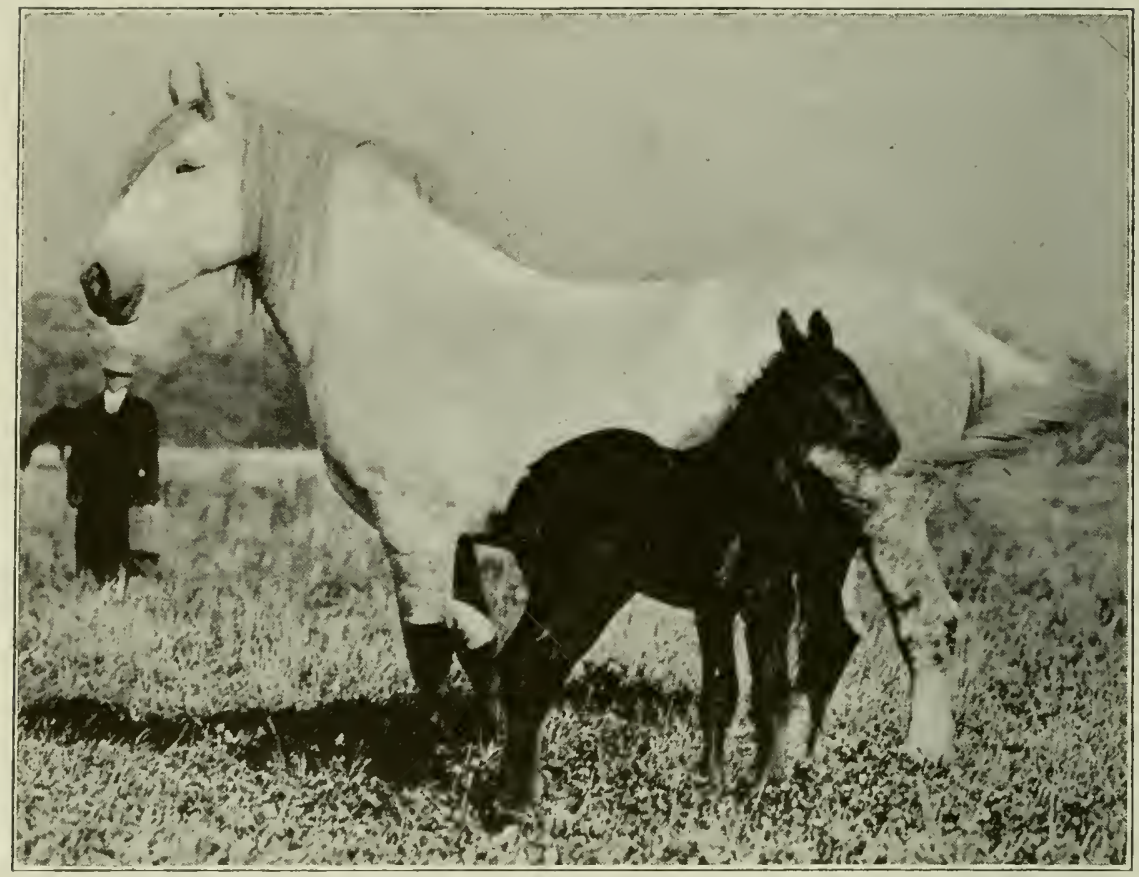

PERCHERON MARE AND FOAL IN AN ILIINOIS PASTURE.

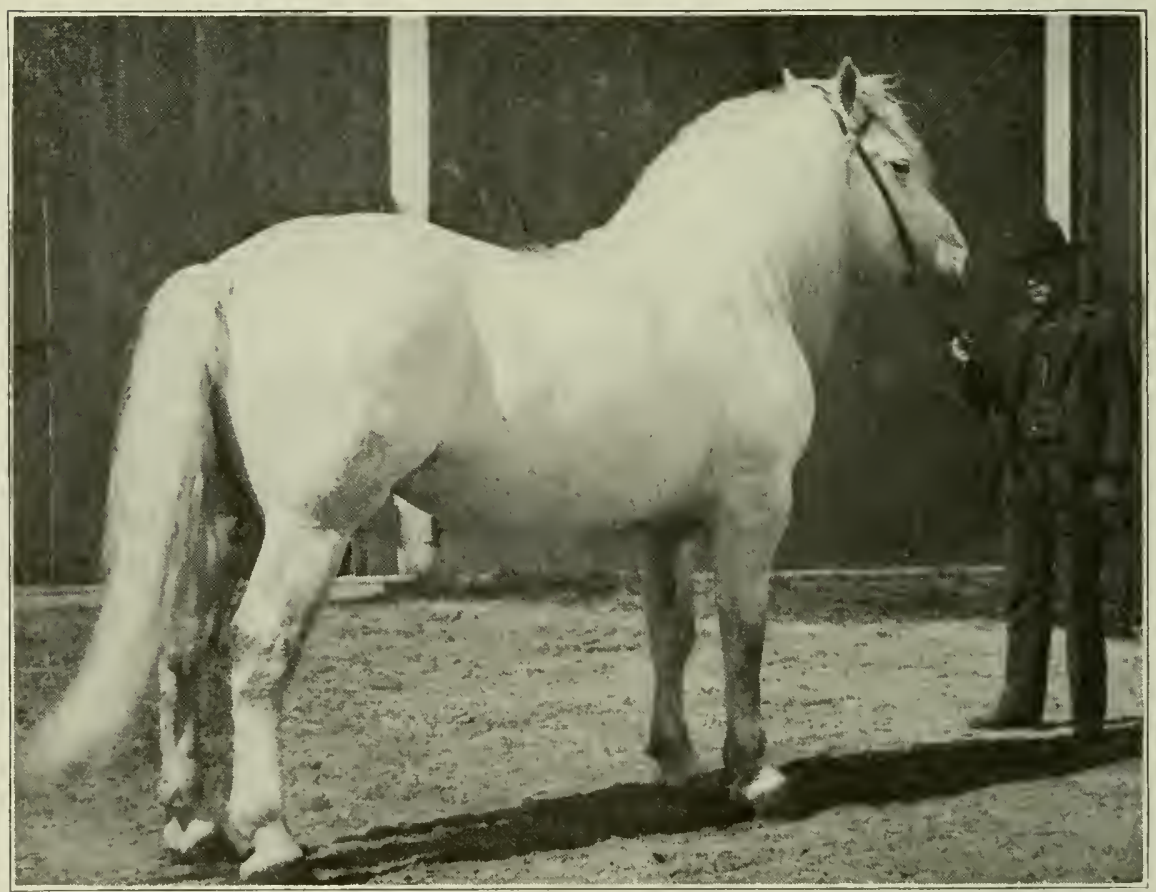

IMPORTED HORACE 7884, AN OLD-TIMEE WINNER AND POPULAR SIRE IN MIIHIGAN. 
Basting, Yuton, Ill., and William Hurt, Arrowsmith, Ill., were others whose excellent stock and enthusiastic support of Percherons did much to encourage him to make a start in dark days.

Augstin's foundation stock was drawn largely from Ed. Hodgson and William Hurt. He had some of Hodgrson's mares on lease for a time and also purchased some. In this case, as in the one previously cited, mistakes were avoided and good foundation stock secured by heeding the counsel of experienced breeders who had no ulterior motives. These cases and hundrds of others which could be given emphasize the value of experienced advisors when beginners are founding studs, and the extreme importance of starting right. Countless breeders of live stock have rushed in "where angels fear to tread" and have found to their sorrow that buying breeding animals is vastly different from purchasing sugar or salt.

There are other important breeders in Illinois who started during this period, but it is impossible to consider all. The number increased materially, especially in counties where much stock was already available. In McLean county Percheron breeders increased to 81; in La Salle to 39; in Tazewell to 24; in Woodford to 18; in Fulton to 21; in Iroquois to 19 ; in Livingston to 28; in Bureau to 29; and in DuPage to 19. North central Illinois had laid the foundation which makes it today the most centralized and most heavily stocked Percheron breeding district in the United States. 
Progress in Iowa.-The number of breeders in Iowa increased from 66 in 1890 to 204 in 1900, more than trebling during the hard times. Singmaster \& Sons, H. G. McMillan, L. H. Humbert, M. L. Ayres, William Sprole, J. H. Barnett, L. G. Parker and H. S. Hoyman were the leading breeders of this period.

The Singmasters continued operations along the same general lines as in the '80's, but leased a good many mares and sold some on a share basis, agreeing to take the first 3 colts at weaning time in full payment for the mare. The mares kept at the home farms ran out on pasture and received scant attention during the hard times, but breeding was kept up and many colts raised, although records were not kept as carefully as they should have been. The breeding was done largely in hit or miss fashion, without making special effort to mate certain mares to sires best suited to them in type and bloodlines. As a consequence the horses bred during this time lacked uniformity in type, color and prepotency. These faults were so apparent that they have of their own weight forced a revision of policy. Progress has been marked in later years, but nothing of consequence was done by the firm during the '90's, save in the production of a large number of Percherons.

J. H. Barnett, whose work has previously been touched on, bred 40 Percherons at Chestnut Farm during this period. He was one of the best farmers and stockmen of central Iowa and his personal 
standing and popularity were such that he was elected to the state senate as a Democrat, although the district was strongly Republican. He served in the state senate in 1888 and 1890, and his influence, admittedly great in Iowa, was thrown strongly in favor of Percheron horses. He counselled farmers to hold their good mares and to buy more while they were cheap. He practiced this himself and bought R. A. Noble's entire stud of 26 head in 1897. His best colts, on which he won many premiums at the Iowa State Fair in the '80's and '90's, were descended from his foundation mares bought of $\mathrm{M}$. IV. Dunham Oct. 23, 1882. Itala 1436 was the most profitable. She was struck by lightning when about 4 years old and blinded for life, but raised 10 colts of record between 1884 and 1897, and proved to be the most profitable mare he ever owned. The best sire ever owned by Mr. Barnett was Champagne 2312 (1117), a bay grandson of Coco 2d (714), bought from M. W. Dunham in 1883 by the Warren County Breeders' Association, in which Mr. Barnett was a leader. This horse continued in use well into the '90's and left some very good stock. Mr. Barnett's influence was at all times for careful, constructive breeding, and he gave much needed support to Percheron interests during depressed times.

William Sprole was one of the most substantial farmers and cattle breeders near Traer, Ia. He began Percheron-breeding in 1886 by selecting a pair of the best mares obtainable at Oaklawn. He gave $\$ 3,000$ for the pair. One was a daughter of Brilliant 
1899. In the next few years he bought some of the best mares W. L. Ellwood imported and also bought the stallion Superior 14042, bred by. Ellwood, to use in his stud. He held on throughout the '90's, despite discouragements, and as might be expected from the high character of his foundation purchases, bred some exceptional colts. He was not a dealer, however, and sold most of the colts at modest prices to a local trade. James M. Fletcher thought so well of the colts that he bought a number of them about 1897 or 1898 and paid $\$ 1,000$ for one which Mr. Sprole had sold to a neighbor. The good done by Mr. Sprole's operations was far-reaching; he was a man of strict integrity, careful in his breeding operations, and very influential in his district. The Traer district was noted for extra good draft horses during the late ' 90 's and the early part of this century. No small share in this is directly attributable to Mr. Sprole's work.

L. G. Parker was another Iowa breeder who bred some good horses, near Mason City. Although the number he raised was not large-33 in this decadethe animals were good and bred on well. He bought Cagliostro 11115 (18849), one of the best sons of Brilliant $3 \mathrm{~d}$, imported with that sire, and used him to good advantage from 1890 till about 1898. Some of the best things subsequently owned by G. N. Haugen and Martin Tagesen were sired by or descended from him. The Parker stud was dispersed shortly after 1900 , but the stock has done much for Percheron breeders in northern Iowa and adjacent states. 


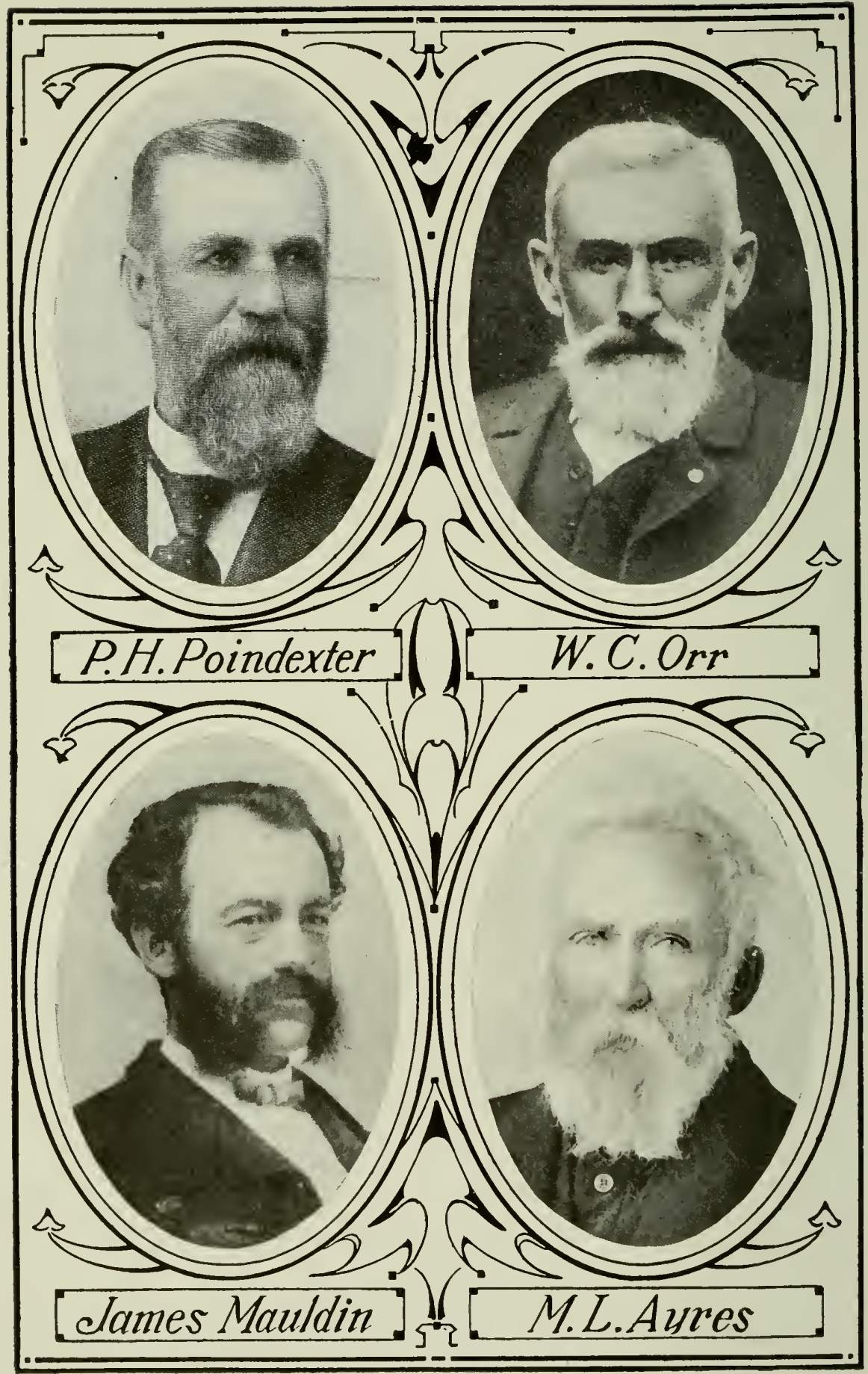


L. H. Humbert was one of the leading breeders in southern Iowa. French himself, he selected some very good breeding stock in the Perche. He had started before the depression, had faith in the final outcome, and held to his good stock through the worst years. He ranked fourth in Iowa in number of animals bred during this decade, sold most of his surplus locally, and did much to encourage others to keep on.

M. L. Ayres, like Mr. Humbert, had started before the hard times. He was a ruggecl farmer, with decided ideas regarding the values of good horses; he hung tenaciously to his best stock, although the panic crippled him to a considerable extent financially. Many of the stallions produced by him during the '90's were castrated, and a great many of the mares sold without registration. He kept the best, however, and was in a sound position to go on when times changed for the better. He handled good horses and was one of the best feeders Iowa has ever had engaged in the development of Percherons. The best sire he used during this period was Said 4825 (674). Massena 26143 (40251) and Blande 29259 (36577) were valuable sires used a little later. Blande was a son of Brilliant $3 d$ and had been used some time in Ernest Perriot's stud. Mr. Ayres has undoubtedly exerted a greater influence on Percheron breeding than any other man in southwestern Jowa. He bought and developed a good many American-bred colts and always insisted that the colts he bought in the district near Blandinsville, 
Ill., were heavier-boned, more rugged, draftier horses than any he could buy elsewhere.

H. S. Hoyman, Stanwood, Ia., bred only 19 Percherons during this decade, but helped give stability and encouragement to Percheron interests in east central Iowa, and started a great many others in Percheron breeding when times changed for the better.

A factor which cannot be overlooked in considering Percheron breeding in Iowa is the influence of Percheron sires in communities where there were no Percheron mares. Iowa farmers believed in draft horses, purchased more Percherons than the farmers in any other state except Illinois, and even in districts where only grade mares were available were liberal buyers and patrons of the best Percheron sires obtainable. Some noted Percheron horses were used in the state on grade mares only, and while the breed as a whole suffered a loss, farmers in general made an immediate gain by having available sires good enough in individuality and breeding to have been at the head of some of the best purebred studs. The record of Brilliant 1899 was an illustration of this, and there were numerous others almost as important. The ultimate effect, however, was to strengthen the esteem of Iowa farmers for Percherons, and the breed is more widely distributed now in that state than in any other.

Lakewood Farm.-A number of studs that subsequently became widely known were founded in Iowa during the depression. The most important 
was that of H. G. McMillan, whose Lakewood stud at Rock Rapids, Ia., has furnished more Americanbred prize-winners than any other stud in America in the past 20 years.

Mr. MeMillan had grown up with good horses, as his father, located near Washington, Ia., had been a strong supporter of draft horses for farm work and a patron of the earliest Percheron sires taken to that part of Iowa. H. G. McMillan himself, after being admitted to the bar, located at Rock Rapids, Ia., and soon won prominence in law and politics. He was a heavy purchaser of farm land, and Lakewood Farm, located near Rock Rapids, comprised about 1,000 acres during the '80's and '90's.

To Lakewood Farm Mr. McMillan took some of the good mares of his father's breeding-mares which had 4 and 5 top crosses by purebred Percheron sires. The economic advantage which these heavy draft mares had in farm operations impressed him, and as he had faith in the ultimate outcome for horsebreeding he bought in 1896 the entire Percheron stud of J. H. Funk, consisting of about 30 head.

Mr. Funk had started in the '80's, while located near Dwight, Ill. His foundation stock was drawn from the Dillons, D. H. Vandolah, J. J. Kemp and Copeland \& Holder. He had selected some of the best stock obtainable from these importers and transferred his Percheron horses to a farm near Iowa Falls, Ia., about 1890. Here he bred Nubian 17467, foaled in 1892, the horse at the head of the stud when it was purchased by Lakewood Farm. 
Mr. Funk had other business interests and could not give personal attention to his Percherons. His men had not been good horsemen and he had grown so discouraged that he took Mr. McMillan to his farm in the winter, when the horses were thin, ill-conditioned and rough in the extreme, and practically forced their sale at a mere song. Despite the bad condition of the horses, they had real merit in blood and individuality and soon grew into highclass horses when put under proper conditions. Nubian developed into a very large, massive stallion, standing over 17 hands high and weighing over 2,200 pounds when in good condition. He was fairly well-proportioned, and heavy in bone, with flint-like quality in cannons and joints. His colts averaged well in size and type and were above the average in soundness. The mares bought from Mr. Funk proved good breeders and one, Myrtha 8133 (12601), was one of the most valuable brood mares owned in the early history of the Lakewood stud. She was the dam of Nubian and of several other good ones.

The same year, and shortly after purchasing the J. H. Funk stud, Mr. McMillan bought about 25 Percherons from Winter \& Munger, Princeton, Ill. This stud was one of the good ones in Illinois, and has been fully discussed in earlier chapters. In this: bunch Lakewood Farm acquired some very valuable brood mares and some good young stock. The Winter \& Munger horses, like Funk's, had been allowed to fall into very bad condition, and they were bought cheaply, but as in the case of the others, the good 


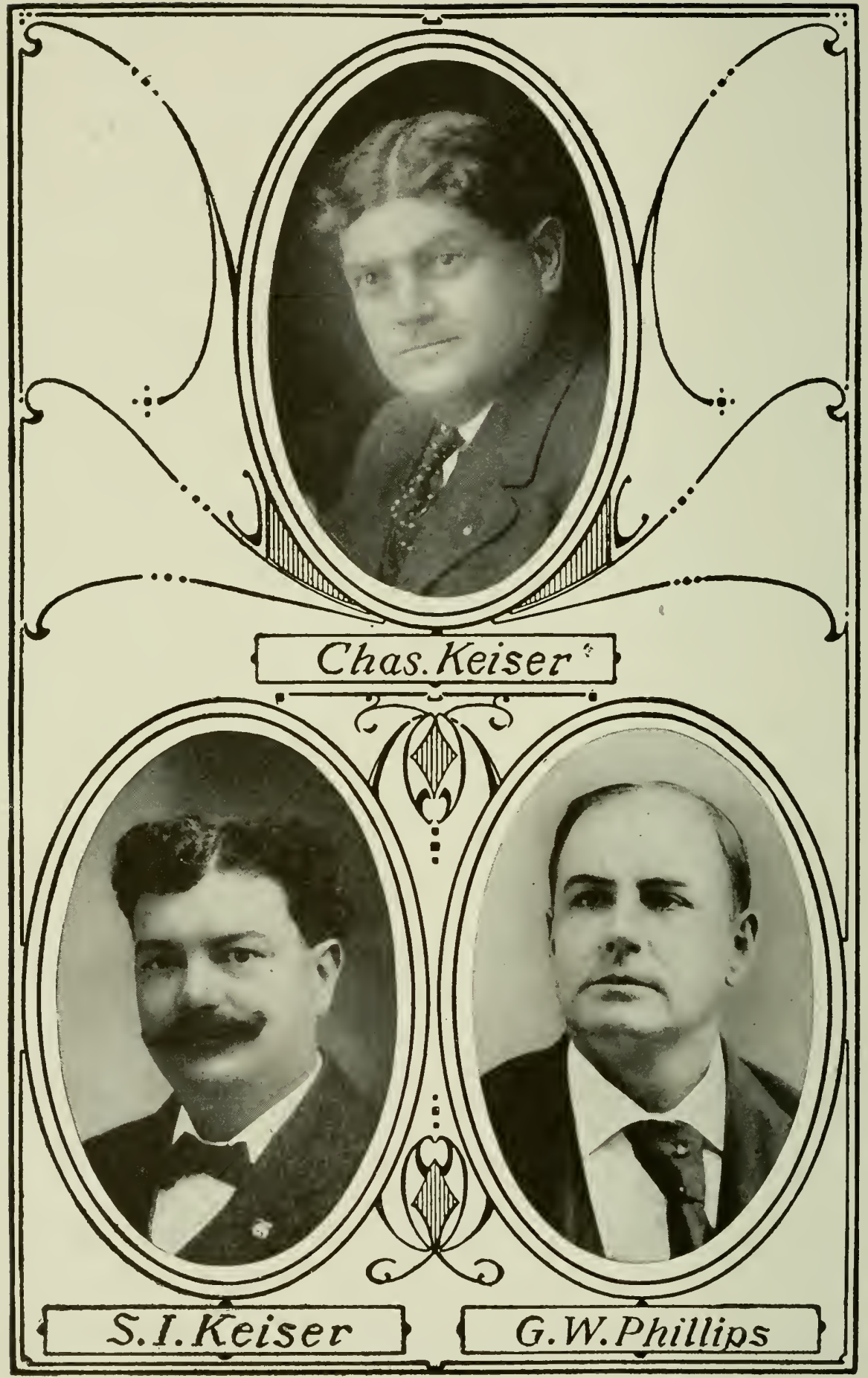


breeding soon showed itself when feed and care were properly given.

On Dec. 5, 1899, Illustre 20489, bred at Oaklawn, was bought to supplement Nubian in the Lakewood stud. He was by Introuvable 16875 and out of Bertha 5340, and was very good individually, but did not prove as effective as had been hoped. Through advertising Illustre, however, Mr. McMillan discovered Seducteur 8850 (7057) and bought him in the spring of 1900 . The old horse had been in the hands of Jacob Waltemeyer, Melbourne, Ia., for several years and had sired some extra good colts, but had not been very sure. He was taken to Lakewood Farm and made seasons there in 1900 and 1901, but was sold in the spring of 1902 to A. L. Robison, Sr., to head the Leslie Farm stud at Pekin, Ill.

In the fall of 1900 , a deal was made for the mares and young stock owned by the Upson Farming Co., Cuming's, N. D. The horses owned by this firm had been bred from some of the best stock obtained from Leonard Johnson. In this lot were Norma 9672 (13394) (the mare that subsequently produced Iolanthe 40925, twice an International champion), Gondole 6696 (10862), a great brood mare, and a number of other females.

This rounded out the foundation purchases made for the Lakewood stud in this decade. Three complete studs, in which breeding operations had been carried on for from 12 to 22 years and in which the best breeding mares had been retained, were bought outright. This took some exceptional breeding ani- 
mals to Lakewood Farm, both as to individuality and bloodlines. From this foundation winners were bred and developed.

Developments in Ohio.-Despite all discouragements, and in part because of them, the number of breeders in Ohio increased from 55 in 1890 to 146 in 1900, almost trebling during the depression. Although third in number of breeders, the state stood fifth in the number of recorded Percherons produced during the decade, Illinois, Iowa, Minnesota and Wisconsin outranking Ohio in the order named in number produced. Jones Bros., whose actual work was directed by C. M. Jones, retained the leadership held since 1864 and bred 53 Percherons during the time considered. Several men who had been prominent during the ' 80 's dropped from front-rank positions, either dispersing their studs, or materially curtailing their operations, and a number of new men, most of whom made their start before 1890, took their places. Bell Bros., H. A. Rohrs, Garfield \& Rudolph C. Green, John Yost \& Son and G. C. Steiner were the most prominent new breeders. E. J. Condit and S. Kendeigh were the only old breeders to hold rank with Jones Bros. among the leaders.

Pleasant Valley Farm.-Small in numbers as Jones Bros.' Pleasant Valley stud was, never comprising more than 10 mares of producing age, it held the lead in the state in numbers and in class of horses produced. The stock, as previously shown, was all descended from one foundation mare of the right kind and the sires were good. Greluchet 11333 
(21165), already considered, remained in use till 1898, when he was sold to John Yost \& Son, Thornville, $\mathrm{O}$. He was a very prepotent sire and his colts possessed real draft qualities. Yost had bred mares to him for some time before purchasing, and his colts were so good that C. M. Jones later sent a number of mares to be bred to him.

The most valuable sire used in Ohio during this period, however, was Moreri 16950 (40246). He was the first-prize yearling at the Columbian Exposition in 1893 and was bought that fall by C. M. Jones. He was used in 1894, '95 and '96 at Pleasant Valley, and then was sold to a company at Marion, O., in which Wesley King was a leader. Here he remained in service until his death. Moreri was black with a star, stood about 17 hands high and in show condition weighed over 2,200 pounds, or about a ton in breeding condition. He had an excellent head, a clean-cut, well-poised neck, deep chest, and strong back and loin. His well-proportioned croup was a trifle high, and he showed heavily muscled hindquarters. He was a very massive, bold-appearing, stylish horse, with a perfect set of feet and legs and the best of quality. His colts were characterized by good Percheron type, and were sound and clean. His daughters stand second to none in the estimation of Ohio breeders, and there is no question but that he did the breed more good than any other horse used in Ohio during his time. Moreri's greatest son was Mark 20288, out of the mare Norma 1779, a daughter of Ajax 5. Mark was a massive, power- 
fully built gray, standing over 17 hands high, with the style and action typical of his sire. He was used for several years by Mr. Jones, and while but few purebred mares were available, he sired more market-topping geldings than any sire ever used in that vicinity. Four of the crack gray geldings that drew leather in the gray show teams of Packingtown were by Mark, and while none achieved championship honors, they gave a good account of themselves. One of these geldings was out of a daughter of Ajax 5, and one out of a daughter of Greluchet, so that Mark's pathway was made easier by the work of his predecessors.

Ruth 20284, later the dam of a ton horse of great character used for several years at the head of C. F. Camp's stud, was another of Moreri's daughters, and Estella 21479, later a showring winner for John Yost \& Son, was still another. Besides these, however, there were dozens of his daughters, both purebred and grade, that did splendid service in raising the draft horse standard in central Ohio.

It was not an easy matter for a small breeder to pull through the hard times. C. M. Jones in commenting on this says:

"I was often discouraged and almost ready to quit, but I always had faith that the tide would turn. Mark W. Dunham was to me, as to others, a steady support. He counselled me, even in the darkest days, to hold on to all my good mares and buy more if I could. I would not have sold Moreri had times been better, but $\$ 2,600$ for him in 1896 meant more to me 
than $\$ 10,000$ would now and I let him go in order to hold all my good brood mares. The tide did turn at last, and my Percherons have paid well, as they will pay any other man who sticks to the best."

Other Ohio Breeders.-Mention has already been made of E. J. Condit, of Delaware Co., O. He too hung on through the depression and raised from 3 to 5 colts per year, a total of 39 in the decade. His Percherons possessed the requisite weight, were of a good type, and were utilized by various successful breeders. Some subsequent owners, who frankly admit they have made good profit in Percherons descended from the Condit stud, state that the horses were not on the whole as sound and clean as they should have been. Despite this, considerable good was accomplished by this stud.

Bell Bros., Wooster, O., had been importing and breeding Shires up to 1890 . They engaged in the Percheron business in 1893 and have been in it ever since.

H. A. Rohrs of Napoleon, O., made his start in 1886 by importing a mare and a stallion. He had previously visited Oaklawn Farm, but could not agree on prices, so imported direct. The stallion Sapeur 6327 (4484) was of medium size, but wellproportioned and proved exceptionally prepotent as a sire. The mare, Charlotte 12321 (18182), was much of the same type, and proved a valuable producer. In $1889 \mathrm{Mr}$. Rohrs imported Monarque 12315 (12402), a son of La Ferte 5144 (452), and some mares, so that he was well established at the time 
of the depression. He held out, and had the nerve to ship some of his mares away to be bred to Fenelon 2682 (38) in 1893. The colts produced justified his judgment. He later shipped mares to Theudis 25015 (40871) and Carnot 66666 (66666) with satisfactory results. Such work stamps Mr. Rohrs as a constructive breeder. His operations were small, he did not show or advertise largely, and most of his horses were sold for use on grade mares, but his contribution to Percheron breeding in Ohio was material in its stabilizing effects during the panic and is worthy of emulation by other small breeders.

Ohio's breeders, other than those mentioned, were for the most part farmers who owned but a few Percheron mares. They were too frequently handicapped by not having access to a high-class sire, and few had the courage to ship their mares away during the period of low prices. The real advancement made during this time was therefore slight.

In Minnesota.-Minnesota dropped to fourth place in number of breeders by 1900 , but held her former place, third, in number of Percherons bred and raised. The number of breeders increased from 30 in 1890 to 124 in 1900. This was a greater proportional gain in numbers than was made in either Illinois or Iowa. A total of 691 Percherons are of record as bred in Minnesota during this period.

The Minnesota Percheron Horse Co., L. C. Hodgson, J. Koester and T. L. \& J. L. De Lancey were the leaders who survived the hard times. Leonard Jolinson and George E. Case, whose studs were 
among the best in the '80's, were forced to sell, and their stock was widely scattered. Many of the good animals from these studs went to men who knew nothing about Percherons and were virtually lost to the breed. Some of Leonard Johnson's best horses, however, went to the Upson Farming Co., and later did considerable good for the breed. The William Mies stud passed into the hands of his sons, under the name of William Mies \& Sons, about 1894, and they continued the business for a short time, but closed out before prices recovered. Willard \& Fuller was a strong firm and had the only prominent Percheron stud established in Minnesota during the depression.

The Minnesota Percheron Horse Co. had by far the most important stud in the state during this period. One hundred and five Percherons are of record as raised by this firm during the time considered and the stud ranked first in Minnesota and eleventh in the United States at this time. Niger 4986 (2951), already described, continued at the head of the stud up to and including the season of 1895 . His colts, like those of his illustrious grandsire Picador 1st (7330), were large, stylish and good in the underpinning. They were sound and clean for the most part, and demonstrated the value of the Picador blood, noted for these characteristics. Fier-a-Bras 15746 (13555) was put into service in 1894 and proved valuable, especially on the daughters of Niger. Fier-a-Bras was a black son of Briard 5317 (1630), and was a large, massive stallion of good pro- 
portions. He was first in aged class at the Columbian Exposition in 1893 for Oaklawn Farm, from which he was purchased. He continued in service throughout this period and eventually succeeded Niger as the head of the stud. The use of these good sires, with others almost as good, but less important, gave the Minnesota Percheron Horse Co. some very good Percherons, and it is much to be regretted that the stud was dispersed about the beginning of the century. The Paynes, who controlled this great stud, had other business interests which finally led them to close out their Percherons, but the Percheron breeders of the northwest owe them a substantial debt for their steadiness and constructive work during a most discouraging period.

L. C. Hodgson was another who began in the '80's and held on throughout all the lean years. He was originally from Ottawa, Ill., a cousin of the Dillons, and bought his foundation stock of 3 mares from Adolphus Dillon in 1884. He removed to Minnesota in 1886, taking his Percherons and adding more from time to time. The business subsequently passed to the sons, now Hodgron Bros., of St. Cloud, Minn., so that this stud has been carried on through two generations. Sonora 1636 and Marie Keet 1608, two of Mr. Hodgson's foundation mares, were probably the most profitable he ever owned. Both were regular producers of good stock. Marie Keet produced Norman Chief 12516, foaled in 1884, to the service of French Victor 6088 (6125), then at the head of E. Hodgson's stud at Ottawa. Norman Chief was a 
high-class horse, both individually and as a sire. He won first in the aged stallion class at the Minnesota State Fair and was made champion over some imported horses that had won blue ribbons in many a hard-fought showring. His only defeat came when he encountered Gilbert and 3 of his get in the class for get-of-sire. Norman Chief was a black, standing: about 17 hands high and weighing 1,950 pounds in good condition. He was a well-balanced, active horse, and proved very prepotent as a sire. He was sold about 1894 for $\$ 2,000$ to South Dakota. The price speaks volumes for his merit, when his age and the low price of horses is considered. Tictor $2 \mathrm{~d}$ 12780, sired by Norman Chief out of Sonora 1636, was another good sire used, and Richelien 21567, bred by M. C. Hodgson and used a little later, left a notable impress on the horses of Rock county. While Mr. Hodg'son did not breed many Percherons, they were above the average in merit and the stud has been a raluable one in the northwest.

J. \& D. Koester, Northfield Minn., was another of the smaller firms which held on to Percherons through dark days. They did not breed many, but their success in the showring attests the fact that they had some good ones. The Koesters made substantial winning's at the Minnesota State Fair in 1896, '97 and '98, defeating' such exhibitors as the De Lanceys and Willard \& Fuller in some classes. The influence of this stud was valuable because of the good quality of the horses owned.

Belleview Farm.-T. L. \& J. L. De Lancey; whose 
earlier operations have been discussed, kept on through the depression and were persistent exhibitors at their state fair during the '90's. They did not breed many Percherons, but unlike most men who were active dealers, did give careful attention to constructive breeding. They held their best mares and selected their stud stallions with care. Their result was colts that made good in the showring and the stud.

The most valuable brood mare was probably Charmante 10931 (20451). She was imported in 1889 by the De Lanceys, and raised 9 colts in the 11 years 1891 to 1901 inclusive. Seven of these were produced in consecutive years. Her colts were uniformly good, though she was bred to 4 different stallions. All 5 of her stallion colts went to head purebred studs and 3 of them left numerous purebred colts. Klondike 21633 was sold to H. N. Lightley in 1899 and remained at the head of that stud for about 10 years; Titus 2d 21634 was sold to H. A. Briggs in 1898, who sold him to head the purebred stud of W. H. Miller at Alpena, S. D. Spuller 2d 23607 sired some purebred colts in the Uehling \& Golder stud at Oakland, Neb. All these sons of Charmante were show horses and all weighed more than a ton. Charmante herself was a show mare, having won second at the Société Hippique Percheronne de France show in 1889, and was repeatedly a winner at leading shows in America, even when laboring under the disadvantage of nursing foals. She was champion mare at the Minnesota 
State Fair in 1890 and was again made champion in 1898 after raising 7 colts in the intervening time. Her daughters were good also, and one, Charlotte 21635, won second as a two-year-old at the state fair. Charlotte went to the Jean DuLuth Co., and did much toward building up that stud. Milena 21636, another daughter of Charmante, was also a showyard winner and was sold by the De Lanceys to Charles B. Crandall, Randolph, Minn., in 1898. Milena was really owned for a time by Crandall Bros. They bred her to Spuller 17123 (20848) and to this service she foaled in 1900 the stallion Titian 25925, used for a number of years at the head of the Crandall \& Danforth stud at Randolph, Minn.

The chief sires used by the De Lanceys during this time were Pluton 10921 (15387), Sophocle 13575 (20845), Titus 17122 (36778) and Lyceen 21630 (42509). Lyceen is considered to have done them the most good, and his stock, sired in France and America, has been on the average of superior type and quality. Lyceen was sold to G. W. Patterson and later went to Jean DuLuth Farm. Lyceen was bought by the DeLanceys from Ernest Perriot, Sr., and was of Brilliant breeding. Titus was one of the best sires used and was a big, rugged, heavy-boned horse, weighing more than 2,200 pounds. He did not remain long in the Belleview Farm stud however; James M. Fletcher bought him about 1896 or '97 and sold him to Wyatt Stanley, Stronghurst, Ill. Here he sired some very good colts, including a number of purebreds. 
Although the number of horses bred by the De Lanceys was small, their influence in Minnesota was considerable; they were active in the showring and good advertisers, even in the hard times. Their horses were of superior merit, especially good in the underpinning. Sales were made from this stud to Geo. W. Patterson, Crandall \& Danforth, H. N. Lightley, and the Jean Du Luth stud, as well as to numerous smaller breeders, so that a considerable proportion of Minnesota studs of the present day are founded wholly or in part on purchases made at Belleview Farm.

Willard \& Fuller.-As has already been stated, the number of breeders in Minnesota increased more than four fold between 1890 and 1900. Most of the new men did not start till about 1897 or 1898 and many did not purchase until later. The only new Minnesota stud of any consequence established during the depression was that of Willard \& Fuller at Mapleton. This stud was really started in 1890 , when the old show horse and sire Dagobert 5151 (2431) was purchased, together with a few mares. Two more stallions were bought in 1893 , and 10 mares were leased the same year. All foundation animals were obtained from Mark IV. Dumbam. Dagobert was the best sire ever used, but Noir Coco 13163 (20768) also got some drafty colts. Willard \& Fuller placed great emphasis on size and massiveness and their horses were all of this stamp.

Mr. R. E. Fuller, a member of the old firm, is now located at Redwood Falls Minn., and still breeds 
Percherons, but on a less extensive scale. He reports that Coquette 4366 (5310) was the most valuable mare Willard \& Fuller ever owned, as she was very typical, weighing over a ton, and her descendants, even to the fifth generation, have all developed, or give promise of developing, into ton horses or better of the right type. Some of the best mares ever owned at Oaklawn were held by this firm on lease and some of them were later purchased. As a whole this firm contributed materially to the development of Percheron interests in the northwest. Willard \& Fuller bred big, rugged drafters of good type and soundness, and through the distribution of such stock made it possible for farmers to improve the general average of their horses.

In Wisconsin.-Wisconsin made substantial gains during the hard times, the number of Percheron breeders increasing from 23 in 1890 to 83 in 1900 . In number of colts raised and recorded the state stood fourth, with 602 Percherons for this period. The chief breeders were substantially the same as in the '80's. Fred Pabst, H. A. Briggs, H. A. Babcock, G. N. Milinlls and Peter Truax all held on to their good stock despite discouragements. R. B. Kellogg's death broke the well-laid plans for his stud, and while the business was carried on for some years by the estate, constructive work could not be looked for. Some of the animals were sold to E. Stetson and others, but H. F. Hagemeister obtained most of the Percherons and the great sire Baccarat about 1896 or ' 97 , so that the stud was continued without 
material changes. All these breeders had faith in the ultimate outcome and possessed the means to carry their studs through the hard times. Considerable advertising and showing was done, even in the worst years, especially by Briggs and Pabst. The horse-breeding interests of Wisconsin were materially conserved by the stability and confidence of her leading breeders. Progress in building up a better average class of horses in the state was greatly facilitated by the distribution of good stock horses, which persisted, though at low prices, throughout this entire period from all her Percheron studs. As a consequence Wisconsin farmers were in a sound position when prices did turn for the better and had a keen appreciation of the value of Percheron sires. So marked was this, that in 1914 more than 74 percent of all the purebred draft stallions in the state were Percherons-eloquent testimony to the sound foundation laid by the early breeders of the state.

In Kansas.-Kansas advanced from 20 breeders in 1890 to 72 breeders in 1900, and stood sixth in number of Percherons raised and recorded during this period, with a total of 383 head. Henry Avery and his partnership firm of Avery \& Coleman and O. L. Thisler were again the leaders. M. D. Covell, J. Fuhrman, Thomas McGee, C. Spohr and S. C. Bartlett were others whose studs were founded in the '80's and who had the confidence and courage to hold to their Percherons through hard times. Hanna \& Co., with stock from the long-established stud of George Hanna in Illinois, began making Kansas Per- 



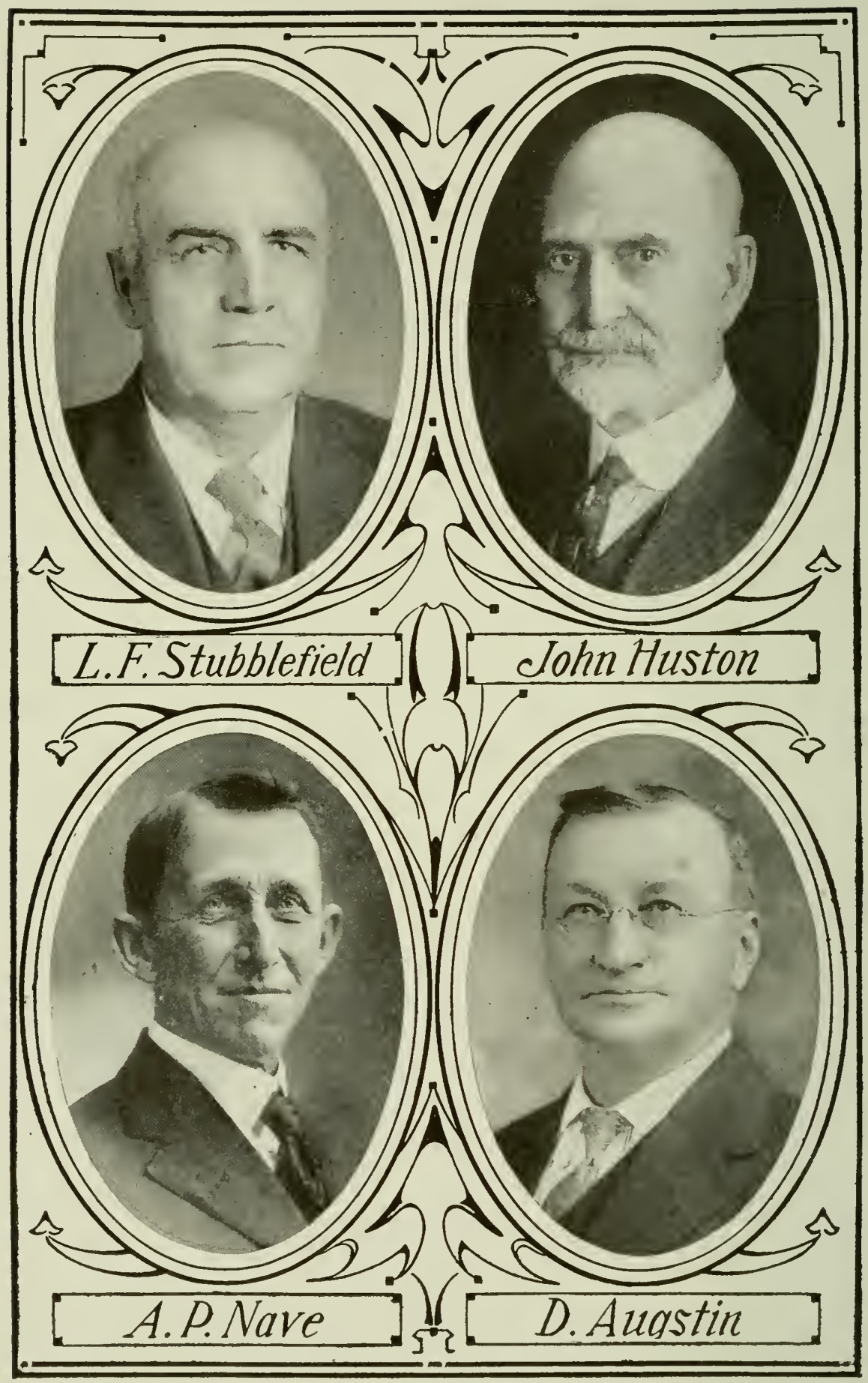


cheron history in 1895. Wyatt Stanley, one of the best Percheron breeders from Stronghurst, Ill., was another addition about the same time. Both these studs had good stock and were controlled by men of experience, so that the state was a material gainer by their operations.

The great handicap to draft horse breeding in Kansas during this period was lack of feed. Dry years predominated. Pastures, never too abundant, were burned brown, and were in far too many instances overstocked. Crops were short, grain cheap, and money hard to raise. What grain was produced had to be sold to enable the farmer to live, and the horses were forced to rely almost wholly on the none too abundant pasturage. As a result the Percherons produced during this period were almost all lacking in size, as must inevitably be the case under such conditions. Lack of interest in horse-breeding in the state and in states still farther west, which were the natural outlets for the Kansas Percheron breeders, made it difficult to sell good horses and prices were exceedingly low. Even the veteran Henry Arery told J. C. Robison, who went to him in 1897 to buy the first Percheron mares for Whiterater Falls Stock Farm, that he could take one or all of the Percheron mares he owned at $\$ 100$ a head. In this bunch were mares of splendid individuality and breeding, though all were lacking in size. Among the mares were half a dozen or more daughters of Brilliant 3d, now recognized as the leading sire of the breed; and yet they were for sale at $\$ 100$ apiece. 
$\mathrm{Mr}$. Robison bought one, and one only, and has often since deeply regretted his own lack of foresight.

M. D. Covell was in reality the oldest Percheron breeder in Kansas; he made his first importation of Percherons in 1871, while located in Ohio. His first Kansas-bred Percherons were not foaled until 1884, and from that time on the stud was very influential in southern Kansas. C. L. Covell took control when M. D. dropped out in 1893, and the stud was carried on by him until after the close of the century. The horses in this stud were good, and they formed the foundation, wholly or in part, of many of the good studs now in Kansas.

J. W. \& J. C. Robison were the most prominent new breeders who established Percheron studs in Kansas during the years of depression. J. W., the father, moved from Illinois to Kansas in 1874, and took good grade Percheron mares with him. His first sire, Norval 1369 (794), was bought of G. L. Cushman in 1883, and he used Percheron sires continually from that time on. His grade mares by successive crosses were bred up to splendid type and size, and many of them were subsequently recorded as French Draft under the top-cross rules. J. W. Robison was a horseman reared in the heart of the Percheron district in Illinois, and he foresaw the inevitable recovery in horse values at a time when prices were lowest. Percheron mares were accordingly bought in 1897, '98 and '99, and from that time on until they were numerous enough to justify reliance upon mares of his own breeding. The son, 
J. C., was taken in at the outset and has continued the business since the death of the father.

There were numerous other breeders in the Sunflower State who began about the same time and who have bred good stock. Many quit just a little too soon to reap the harvest of their labors, but their work has benefitted the breed in the hands of later breeders. A notable instance is that of S. W. McMillan, Topeka, Kans., who had a few very select mares bought from the Ellwood stud. He lost heart and sold 6 of them to J. W. \& J. C. Robison in 1900 for a small sum. In this group was the mare Fine 13085 (26998), considered to have been the best brood mare ever owned at Whitewater Falls, and her foal Zaza. Zaza was afterwards first at the St. Louis exposition in 1904 and sold to $\mathrm{E}$. B. White for $\$ 1,000$, who considers her the greatest brood mare he has ever owned; in $1914 \mathrm{Mr}$. White had sold nearly $\$ 10,000$ worth of her descendants and had all but 2 of her female descendants left. Yet this mare Zaza. now one of the greatest living brood mares, was bred by an obscure Kansas breeder who knew and loved good Percherons, but who lost courage when victory was within his grasp.

There were many other instances of like character in Kansas, and in other states. Such cases were unusually frequent in the Sunflower State, however, for the reason that good horses of good breeding had been taken there and widely distributed, but so decreased in size by unfavorable environment that their real value was lost to sight for a time. The 
breeders of the state have eome back, however, in a remarkable manner, and the work done by the men who held on during trying times has aided beyond calculation in raising the general average merit of horses bred in the state. 



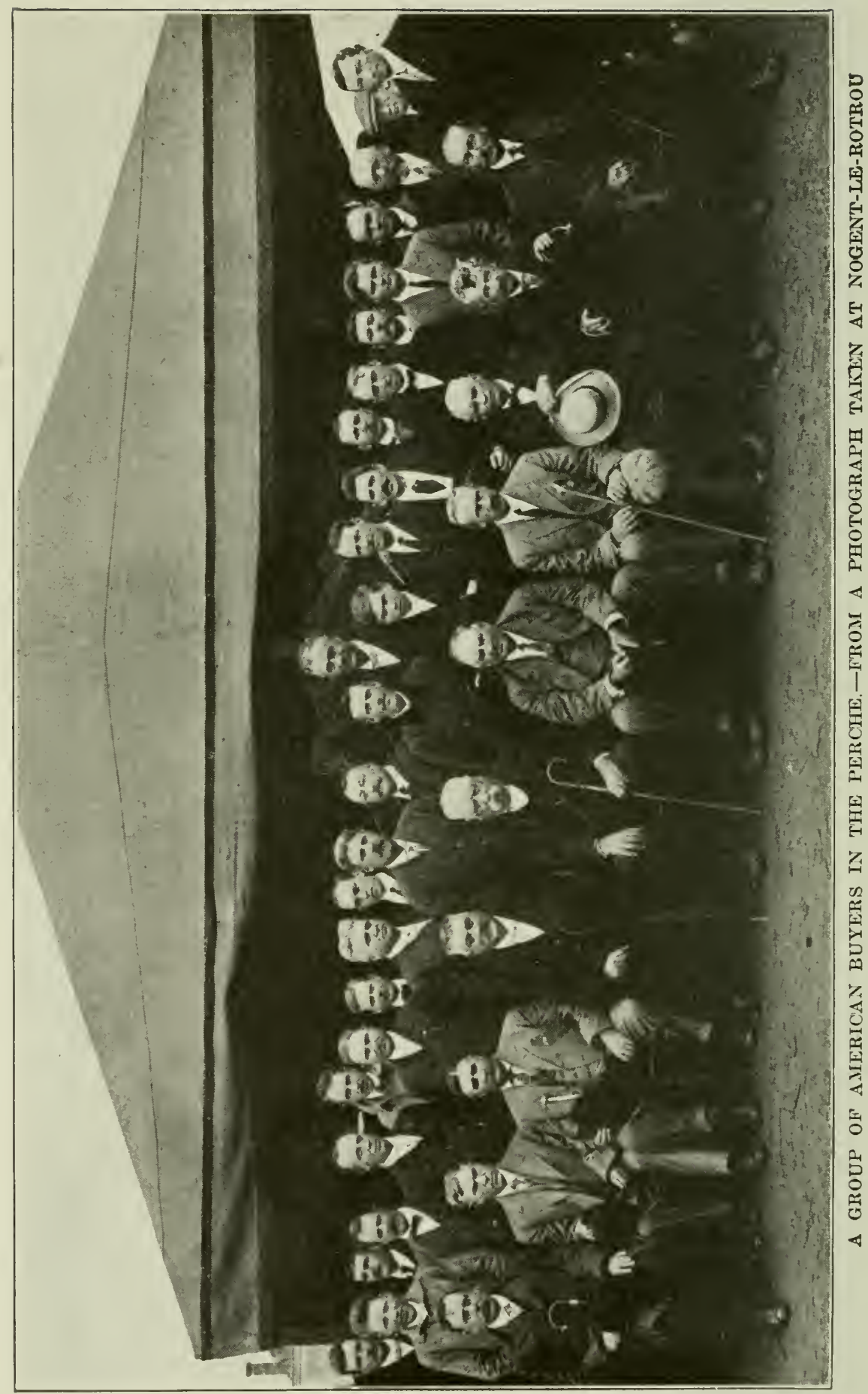




\section{GHAPTER XII.}

THE NEW CENTURY DAWNS AUSPICIOUSLY.

The extreme depression in business which had prevailed during the '90's had shown considerable amelioration prior to 1901 . Business conditions in general showed much improvement during the first few years of the twentieth century.

The period from 1901 to 1910 inclusive was fraught with momentous changes for Percheron interests. The commercial demand for horses of all kinds, particularly draft horses, steadily grew. With the exception of the year 1908, when some depression in values occurred as the aftermath of the panic in the fall of 1907, prices advanced year by year until 1910. Values were at pre-panic levels in 1909 and made further advance in 1910.

The purchase of horses for export contributed to some extent to the rise in prices, particularly in 1901, 1902 and 1903. The British were heavy buyers on account of the Boer War, and after the war had closed made extensive purchases of horses and mules in the United States to restock the farms of South Africa. The exports amounted to 82,250 head in 1901, valued at $\$ 8,873,845$, and in 1902 103,020 head, valued at $\$ 10,048,046$ were taken. The purchase of these horses on foreign account had an effect upon 
horse-breeding in the United States that was much more far-reaching than the figures would seem to indicate. The wide publicity attending the inspections focused attention on the fact that there was a shortage of horses abroad and that the United States was the best place in which to make purchases. Confidence in horse-breeding was gradually regained, and the steadily increasing demand for commercial horses and the increased prices which users of draft horses were willing to pay served to strengthen it. Wyoming bronchos that had sold for $\$ 5$ or $\$ 10$ a head during the '90's brought $\$ 55$ in 1902 for shipment to South Africa.

The opening decade of the new century saw an advance in prices paid for farm products of all kinds. Farmers began to bestir themselves to an appreciation of the increased yields resulting from more thorough tillage of their lands. Improvements in agricultural machinery made it possible for one man to do more work on the farm; to operate his improved machines additional horsepower was required. The increase in the number of draft horses used in farm work and the increase in the weight and strength of these horses, were among the more marked developments of this period. The International Live Stock Exposition, founded in 1900, had fairly struck its stride by 1902 ; its nnequaled displays of draft horses of all breeds, both in the purebred and market classes, aroused interest and inspired the leading farmers and horsemen of the United States to redoubled efforts in improving the 
common stock. The waves set in motion by the International extended to the state fairs, which broadened their classifications and increased greatly their exhibits of horses.

All of these factors combined to focus public attention upon horse breeding, particularly upon the sort of breeding stock which would increase the size and weight of the common class of horses. The draft breeds all reaped increasing benefit, the Percheron, already the most widely distributed, best known and most popular draft horse in the United States, to the largest degree.

The Actual Increase.-In 1900 there were 1,634 breeders of Percherons in the United States; by 1910 the number had increased to 5,338. Between 1890 and 1900 only 8,807 American-bred Percherons and 1,490 imported Percherons were recorded. Between 1901 and 1910 inclusive 31,900 American-bred and 10,048 imported Percherons were recorded. In round numbers there were approximately 9,000 Percheron mares available for breeding in 1901. These mares, their filly foals and such females as were imported during the decade were responsible for the 31,900 American-bred animals recorded during this period-only about 3 American-bred colts during the 10 years for each Percheron mare. As this is below the normal production it shows that many mares were not bred and that many of the colts which were foaled were never recorded. Many were the men, particularly the smaller breeders, who had so lost faith in horse breeding by reason of the long- 
continued depression of the '90's that they were timid even when prices began to rise and they did not immediately grasp the opportunities which lay before them.

The actual experience of one well-known Percheron breeder is a case in point. He attended a sale of well-bred Percherons in 1900. The stud was one of the oldest in the United States, the management had been good, and the mares sold were excellent. Yet this breeder, fearing the outcome, bought only a few. For those he did buy he paid from $\$ 95$ to $\$ 175$ each, and within 5 years mares of the same breeding and quality brought 5 times that price. Large as was the increase in the number of Percherons between 1901 and 1910, it was by no means so great as it would have been had breeders had a clear conception of the extent and far-reaching character of the commercial demand for draft horses.

Pedigree Publication Suspended.-The decade beginning with the panic of 1893 was characterized, as has already been indicated, by a depression in the Percheron importing and breeding industry so profound and so widespread in its operation that the association which, up to that period had control of pedigree registration in the United States, was unable to maintain itself. Meetings were poorly attended. Funds ran low. The salary of the Secretary, Mr. S. D. Thompson, was in arrears, and finally through a forced sale of the assets of the bankrupt organization he acquired legal title to the 



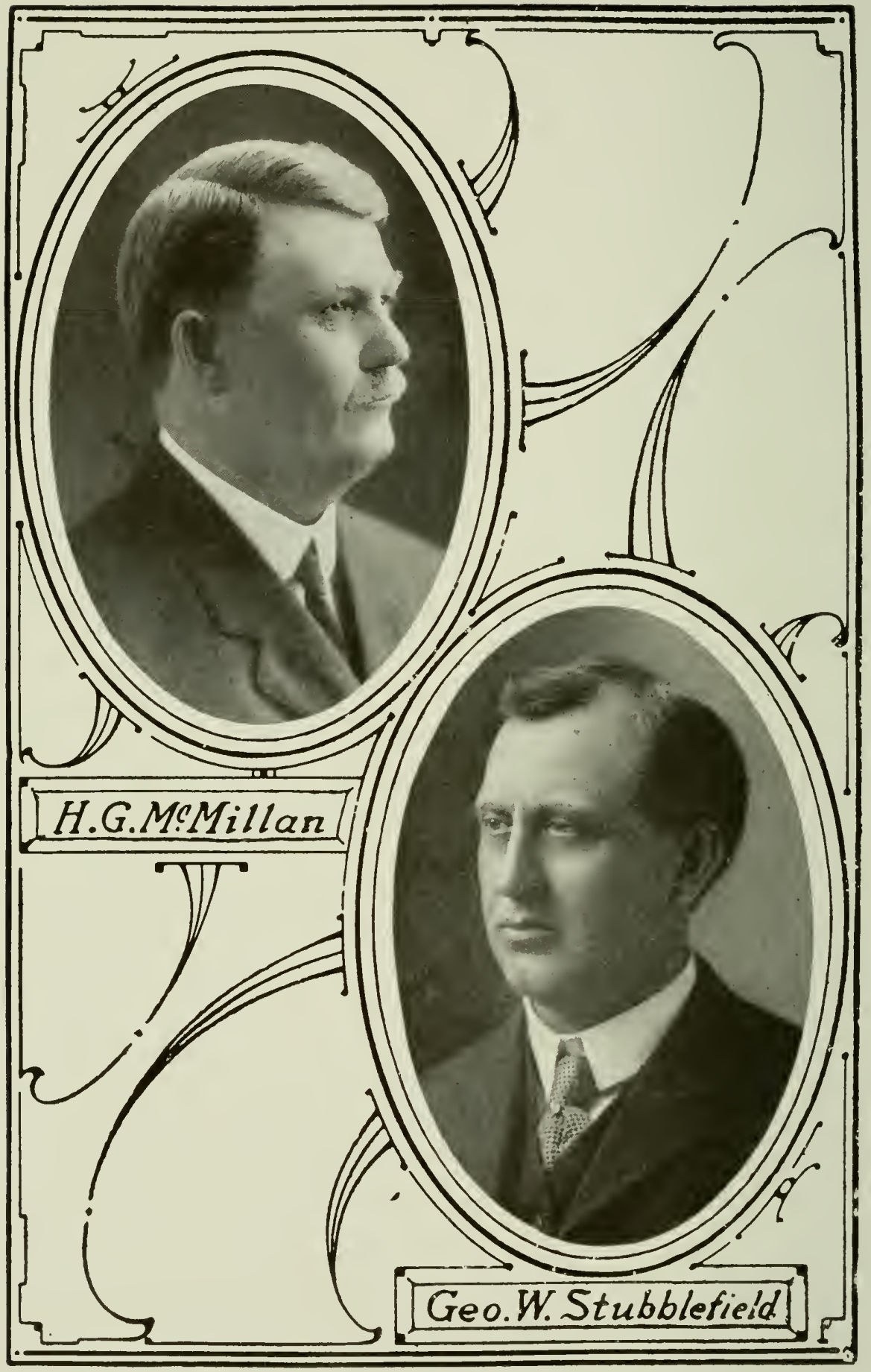


books and records. Mr. Thompson maintained an office where pedigrees of imported and home-bred horses could be filed and certificates issued, but between 1898 and 1905 no stud book was actually printed.

New Association Formed.-Interest in the production of Percherons, which had during the dull years of the middle and later '90's receded almost to the vanishing point, in the meantime began to revive, and on Dec. 23, 1902, at a meeting held in Chicago a new organization was formed for the purpose of establishing upon a substantial footing and under the direct control of owners of Percheron horses, an association which should become responsible for the further registration of pedigrees, and to promote the general interest of the breed. Mr. H. A. Briggs of Elkhorn, Wis., presided, and Mr. George W. Stubblefield of Bloomington, Ill., was chosen Secretary. The following were named as Directors for a term of one year each: Messrs. H. G. McMillan, then of Cedar Rapids, Ia.; W. S. Dumham, Wayne, Ill.; J. L. DeLancey, Northfield, Minn.; C. R. Taylor, Williamsville, Ill.; A. P. Nave, Attica, Ind.; C. O. Keiser, Keota, Ia., and H. A. Briggs. The Directors met and elected H. G. McMillan President, H. A. Briggs Vice-President, J. L. DeLancey Treasurer and Geo. W. Stubblefield Secretary. At a meeting held at the Great Northern Hotel, Chicago, on Aug. 8, 1903, the number of Directors was increased from seven to eleven, and Messrs. H. F. Hagemeister, H. W. Avery, G. W. Patterson and C. M. Jones were 
duly chosen to fill the new directorships thus created.

Old Records Acquired.-At a meeting of this organization held in Chicago, Dec. 6, 1904, President McMillan said in the course of his address:

"We are now in possession of all of the original books and records heretofore controlled by $\mathrm{Mr}$. Thompson. We are the only association having such records. We have all records and original data in the United States pertaining to the pedigrees of Percheron horses, including the original applications, affidavits and correspondence connected therewith. We are the only society in a position to issue accurate and complete pedigrees and that can publish a stud book that is full and authentic in all respects. We now own all the records. The certificates of pedigrees issued by us will be carefully verified and can be relied upon as truthfully stating the pedigree of the horse to which it relates. We propose to issue stud books within the coming year that will be a reliable and trustworthy record of pedigrees issued up to date. Breeders and buyers of Percheron horses everywhere can then verify their pedigrees and know when they are being imposed upon.

"That the work of our association is appreciated, there can be no doubt. A year ago we had less than one hundred members; today we have 315. By our next annual meeting I firmly believe we will have over 500 stockholders. It should not be forgotten that our membership represents live members who are actually engaged in importing and breeding Percheron horses and who have pedigrees to record. With our present large list of active breeders and importers and being in possession of all the original 
records and data pertaining to Percheron horses our future growth and success is assured and I prophesy that it will not be long before we will be in possession of the field without serious opposition or rivalry.'

A new era of prosperity and pogress began with the organization of this powerful association. With the exception of some little opposition growing out of the refusal of certain interests, headed by the Messr's. McLaughlin, to co-operate in the work undertaken by the new association, there was a general feeling of relief that the further conduct of Percheron registration in America had now been settled in responsible hands. The McLaughlin faction organized the Percheron Registry Association in 1904, and issued five volumes of what was called the Percheron Register, in which some 4,800 pedigrees were recorded, but the inclination of breeders and importers generally had been to discourage division of energy and effort, and by 1911 the general association, now known as the Percheron Society of America, so dominated the field that the Messrs. McLaughlin, in the interest of harmony, gave up their enterprise and became affiliated with what was now really a national organization, approved by the United States Department of Agriculture, and commanding the respect and support of an overwhelming majority of all interested in Percheron progress in the United States.

Influence of Dealers and Importers.-The dealers and importers exerted a paramount influence in de- 
veloping the interest in Percherons during this period. The existing stock in the United States was badly scattered, much of it unrecorded and a great deal of it in the hands of men who were giving their Percherons no particular attention. Leading dealers gathered this stock together and distributed it through private sales and public auctions into the hands of a large number of new admirers of the breed; they also sold Percheron mares to many small breeder's who lacked the means and acquaintanceship necessary to seek out and assemble them. In many instances dealers bought fillies or young mares, bred them to their own stallions and sold them as bred mares, thereby receiving credit for breeding a vastly larger number of animals than they would otherwise have had.

Importers reaped an unprecedented harvest. Good imported stallions were syndicated all over the United States and Canada on the company plan at prices ranging from $\$ 2,000$ to $\$ 5,000$ each. These prices were abnormal, but importers justified them on the ground of the heary expense involved in placing horses by this method and on the additional plea that most of the horses were sold on long-time payments. This plan of selling horses did result in distributing thousands of high-class stallions throughout the United States. The larger portion of these went into communities where they were bred exclusively to grade mares, so that the Percheron breed lost the services of many of the best breeding stallions brought over during this time. 



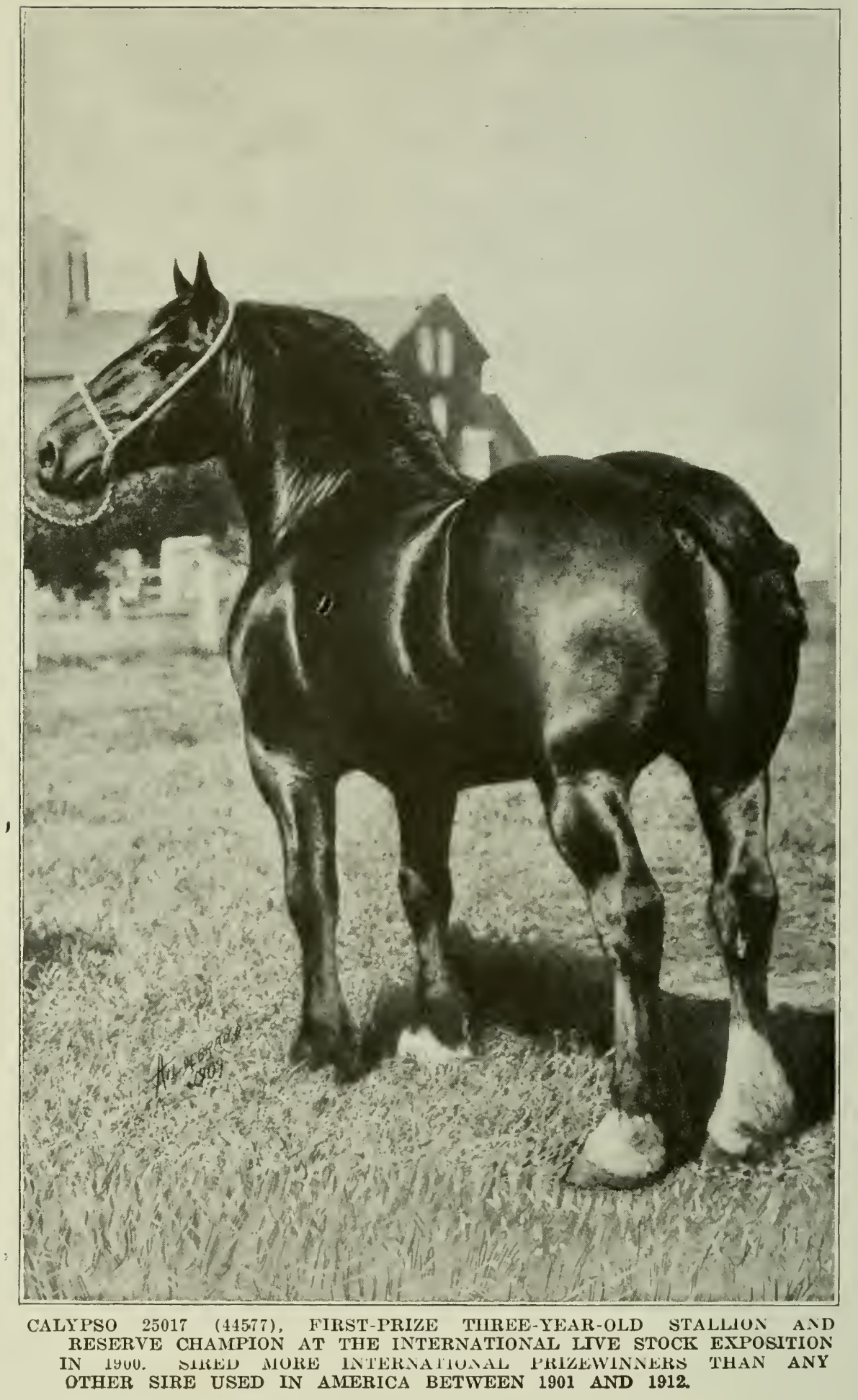


This loss was compensated in large degree by the general improvement wrought upon the grade horses of the country. The progeny of these sires proved so much more valuable in farm work and sold for so much higher prices that farmers were awakened to the worth of Percheron sires. This increased the demand for Percheron stallions, whether bred in America or imported from France, and led many other men to establish small studs of Percheron mares. The work of the importers, therefore, resulted in a widespread and marked improvement in the character and value of the common horses bred in the United States, and also caused a general expansion in Percheron breeding on this side of the water.

The large exhibits of Percherons made at the leading fairs by importers and dealers also proved a potent factor in educating farmers in Percheron type and aided materially in popularizing the breed.

\section{The Development by States.-Illinois, as was to} be expected, showed the greatest increase in the number of breeders during this period, there being 1,476 by 1910 . Iowa was second with 860 , Ohio third with 471 , Kansas fourth with 319 , Indiana fifth with 284, Minnesota sixth with 279, Wisconsin seventh with 269, Nebraska eighth with 229, South Dakota ninth with 171, and North Dakota tenth with 160 breeders.

Illinois, Iowa and Ohio, the pioneer states in Percheron breeding, had more than half of the Percherons in the United States by 1910. Percheron breeding naturally increased most rapidly where the 
horses were already in most general use and where their value was best known. It is significant, however, of the widespread interest in Percherons to note that the breeders were scattered over 41 states and Canada by 1910.

In Illinois.-Oaklawn maintained its position as the leading Percheron breeding establishment in Illinois during this period. Selling horses proved so much more profitable than breeding them that a large number of the Oaklawn mares were sold and the breeding operations were materially curtailed. Nevertheless, 162 Percherons bred at Oaklawn were recorded during this period. Every effort was made to keep the best sires available in service. Theudis 25015 (40871), one of the best-known sires in France, was imported in 1900 and placed at the head of the stud. He had been for some time the stud sire of M. Tacheau, the younger, at whose establishment he had divided honors with his, sire Besigue (19602). Thendis' get had won high honors in France and many of the best stallions imported in the late ' 90 's and the early years of the new century were sired by him. His get won first and third at the International Live Stock Exposition in 1901, beating the get of Jules (37.987), another of the well-known contemporary sires of the breed. Theudis was an eight-year-old when imported. He was one of the largest of the sons of Besigue, a stallion of great substance, standing about 17 hands high, and weighing approximately 2,200 pounds in show condition; he was very deep-bodied, massive and well propor- 



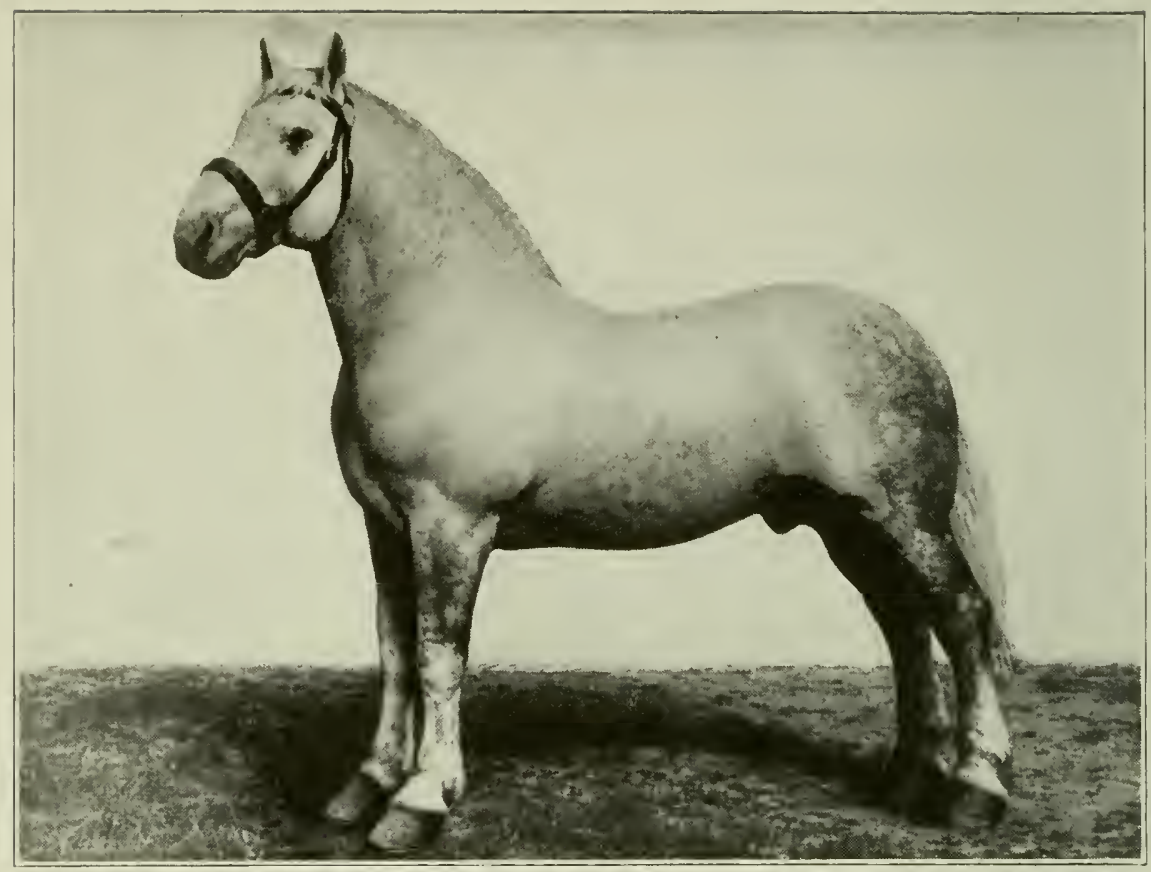

BESIGUE (19602), ONE UF THE GREAT SIRES USED IN FRANCE BETIVEEN 1893 AND HIS DEATH IN 1904; VERY PREPOTENT. PICTURE TALEN WHEN IIE WAS 14 YEARS OID. HE DIED ON WATER EN RUUTE TO AMERICA IN 1904.

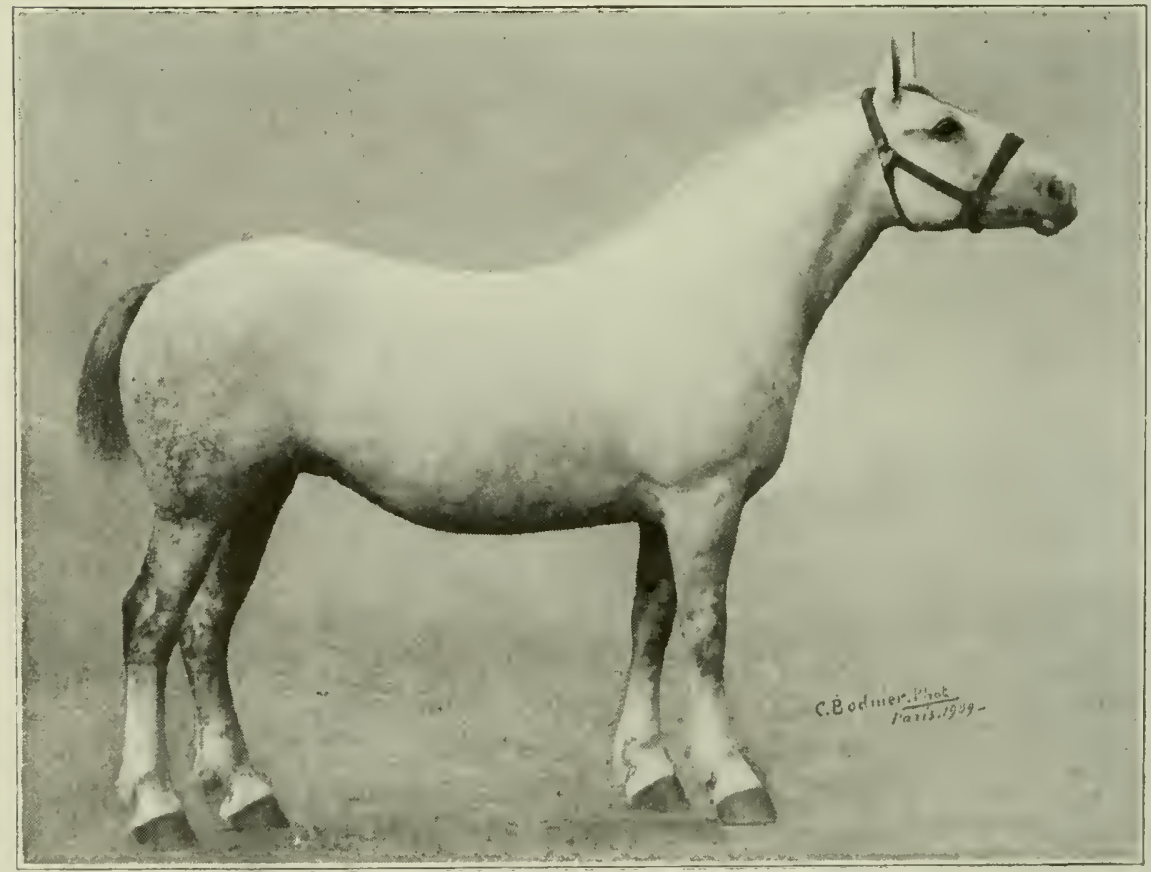

MARE SUZANNE (81567)-WINNER AT LEADLNG FRHNCH SHUIIS. 
tioned, with excellent quality, symmetry, style and action. Three of Theudis' sons, Calypso, Rabelais and Casino, subsequently headed the Lakewood, Leslie Farm, and the Whitewater Falls Farm studs, and practically made the reputations of those breeding establishments. Unfortunately Theudis had seen very heavy service in France and was not a sure getter after being imported. He made but two seasons at Oaklawn and died Oct. 1, 1902, at 10 years of age. His failure to round into breeding form after importation was undoubtedly a distinct loss to the breed, as his colts were high-class in character and had more size than most of the grandsons of Besigue.

Invincible 22715 (38109), a black stallion of unusual size and scale, was also used at Oaklawn for a time. He was bred from the M. Lefeurre stock and weighed in breeding condition 2,200 pounds. He left a number of colts of excellent type at Oaklawn.

Picador 27370 (48373), a wimner of second prize in the aged class at the International Live Stock Exposition in 1901 and 1902, was also used to some extent. He was black, of the Picador strain and was an extremely deep-bodied, massive, powerfully muscled sire. He was so wide and thick as to give the impression of being lowset; he stood almost 17 hands high, however, and weighed 2,250 pounds in show condition. With all his size, Picador possessed symmetry and style, but was somewhat deficient in straightness of action. Among his progeny at Oak- 
lawn was the mare Britomart 40427, which subsequently won the championship at the International Live Stock Exposition in 1905.

Picador was succeeded by Pink 24765 (47513), a grandson of Besigue. Pink was the most noted show horse that ever headed the Oaklawn stud; indeed he probably was the most noted Percheron to grace our showrings during the decade. He won first place as a three-year-old at the Iowa and Minnesota State Fairs and at the International Live Stock Exposition in 1903, and was the grand champion at Minnesota and the International. He was first as an aged stallion and champion at the International in 1904, and stood second in the aged classes at the International in 1905 and 1906 despite heavy seasons in the stud. He remained at the head of the Oaklawn stud and in active service from the spring of 1904 until 1911, when he was sold to R. W. Bradshaw of Canada. Individually Pink was considered by many good judges to be well-nigh perfect as a Percheron type. He stood 17 hands high and weighed 2,100 pounds in fair condition. He was very deep-bodied, strong-backed, well ribbed down in the hind flank, and a model in the set of his legs from front, side and rear. His symmetry was faulted by a slight droop in the croup, but this was not marked, and in general proportions, style and finish he was one of the most remarkable horses of the period. His quality was extraordinary, as his cannons and joints were clean-cut, his skin fine and the bones of his head as clearly outlined as in any Thoroughbred. 
Pink's colts, as a rule, were very uniform, early maturing and exceptionally good sellers. Mr. Dunham states that none of his stallion colts had to be kept past 2 years of age and that very few of them sold for less than $\$ 1,000$. They matured into large, massive horses. Many of the mares sired by Pink weighed more than 2,000 pounds in breeding condition. One of his sons, Pink Borodino 57905, out of the champion Britomart, a daughter of Picador, went to head the H. I. Messinger stud, where he rendered excellent account of himself. A daughter of Pink, the mare Pink Mirabella 57902, out of the champion mare Mouvette 30012 (43850), was second in the open classes and champion American-bred mare at the 1913 International. Another daughter, Pink Brillante 57897, foaled 1908, raised foals from 1911 to 1915 inclusive. Her 1916 foal, past 2 months old, was accidentally killed. The mare, though thin, won the championship at the Iowa State Fair and was later champion Percheron female at the 1916 International. Many of the sons of Pink have been used on purebred mares with excellent results, and the value of his blood is now adequately recognized.

It is difficult to particularize as to the females in any breeding stud, but some of the brood mares owned at Oaklawn during this period are worthy of special mention: Jeanne D'Arc 17894 (37422) was champion at the International in 1900 . Linda 12986 was champion in 1901. Mourette was champion in 1903. Britomart, the daughter of Picador, bred at 
Oaklawn, was champion in 1905. All of these mares were valuable breeding matrons, as were numerous others not selected for showyard fame.

Oaklawn Farm gave special prominence to exhibits of Percherons at the leading state fairs and at the International, being one of the most consistent and heaviest winners of prizes at the Internationals of 1901, 1902, 1903 and 1904 and bringing out the champion stallion for 4 successive years. A large number of the prizes and the reserve championship in stallions were won in 1905 and 1906, while the mare championships fell to this stud in 1901, 1903 and 1905. Showing was discontinued in 1907, 1908 and 1909, but the Oaklawn entries were back in the ring in 1910. The large and well fitted exhibits of Percherons from Oaklawn Farm spurred others to greater exertions and stimulated draft horse improvement generally. Extensive publicity in the agricultural journals supplemented the showyard advertising.

John C. Baker was one of the large Illinois breeders of this period. Hercules 19985 was his chief stud stallion. He was a gray, foaled in 1904, and was out of a daughter of Brilliant 1271. He was a very large, massive type; possibly he lacked a bit in symmetry and finish, but his colts were large, drafty and good sellers. So good was Hercules that he went to the stud of S. S. Russell \& Sons when 14 years of age. He was also used by Stetson Bros., Neponset, Ill. Mr. Baker bred a large number of Percherons, but buyers complained that he was not 



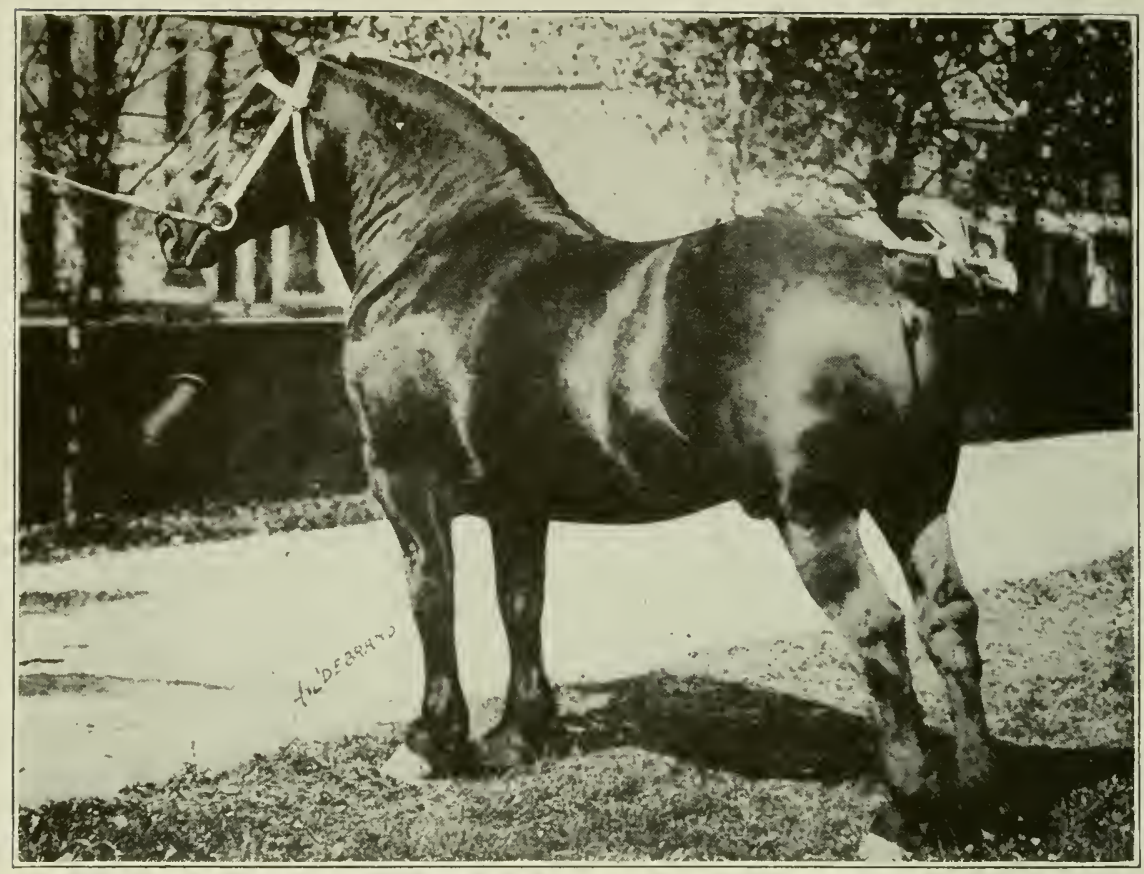

INTIME S7219 (83153), RESERVE CHAMPION, CHICAGO INTIERNATIONAL, 1910.

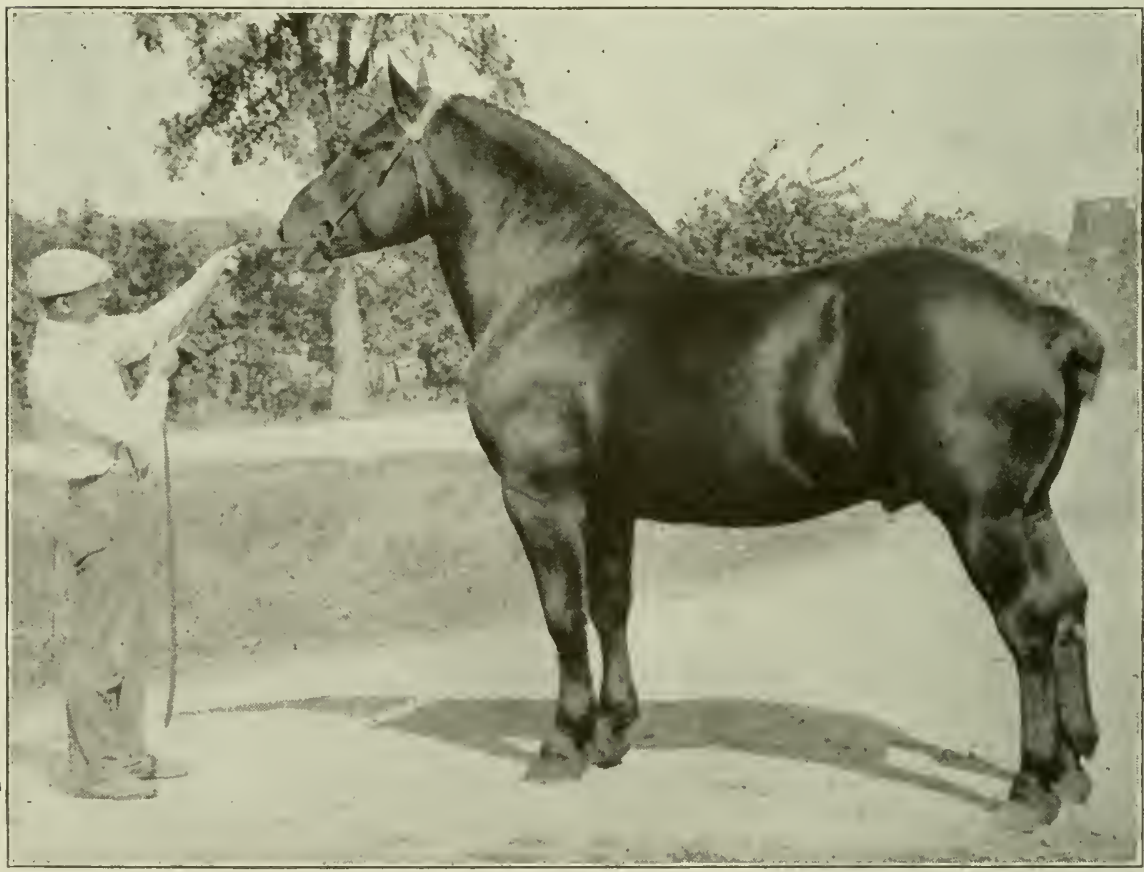

PINK 24765 (47513), CHAMPION STALLION, CHICAGO INTERNATIONAL, 1903-04. 
a good caretaker and that his colts were not so well developed as they should have been. This, coupled with the fact that Mr. Baker did not exhibit at the fairs to any extent, undoubtedly lessened the influence of his stud.

Dan Augstin bred a total of 150 Percherons during this period and raised most of them himself. They were by a number of different sires. $\mathrm{Mr}$. Augstin was located in a community where there were many stallions above the average in merit, and he mated his brood mares with many different horses besides those owned by himself in an attempt to obtain the best results.

Kellermann 10715 (20594) was one of the sires used to advantage on Mr. Augstin's mares, and his son Absolom 27014 was also of decided value. Kellerman was a black, imported in 1889 by W. L. Ellwood and purchased shortly after by L. F. Stubblefield. He was of Favori and Coco breeding, a horse of great scale and substance, a bit on the rugged type, weighing about 2,200 pounds in good condition. He sired 53 purebred colts in the McLean county district. A large number of purebred colts left by Kellermann were bred in the stud of $\mathrm{Mr}$. Augstin, although Wm. Hurt \& Sons, L. F. Stubblefield, several other members of the Stubblefield family, S. Noble King, and H. M. Rollins had colts by him-Hurt and King even more than Augstin.

Absolom by Kellermann was also used by Dan Augstin and some of the best mares which he retained were sired by this horse. Coquette 50404, 
the most noted show mare ever bred in the Augstin stud, was one of Absolom's daughters; her colts were always of showyard character. One of them, Roseland 87467, was second in the open class at the Illinois State Fair in 1914 and the champion mare bred by exhibitor.

Kimberly 25726 (44616), imported by Dunham, Fletcher \& Coleman in 1901, was for some time at the head of the Stubblefield stud. He was freely used by Mr. Augstin, and to good advantage. He represented a most unusual and desirable combination of bloodlines, as he was a son of Besigue and had for dam Biche 44501, a daughter of King of Perche 4975 (6738). King of Perche will be remembered as one of the most famous horses in the Ellwood stud in the ' 80 's, and Besigue was the ranking sire in France between 1893 and his death in 1904. Kimberly was a large, powerfully-built, rugged horse, standing over 17 hands high. He weighed 2,560 pounds at one time when in show condition and in breeding flesh scaled 2,200 pounds. He left 35 purebred colts, a number of which were in Mr. Augstin's stud.

Roland 42911, bred by C. W. Hurt but purchased in dam by Mr. Augstin, was the most valuable sire used after 1906. The horses produced in the Augstin stud were of the thick, massive, drafty kinds, inclined to be a little lowset, and of the "Dutchman's type," but a rugged sort and valuable for breeding purposes. The care and management which Dan Augstin gave his horses was decidedly above the 
average and the colts had an opportunity for full development.

L. F. Stubblefield, McLean, Ill., did not breed nearly so many horses as many of his contemporaries, but his work was constructive in a high degree. The sires Kellerman and Kimberly headed this stud for a time and left a number of excellent colts. Some of the best mares retained in this stud were by those sires, and the Kellerman blood has been particularly valuable in the production of Percherons of showyard caliber.

Forfait $\mathrm{Jr}$. 40974 was placed at the head of the Stubblefield stud in the spring of 1908 and was used to good advantage. He was not of the largest type, but stood 16\%/4 hands high, and weighed a ton in show condition. He was very deep-bodied, wellribbed, and powerfully-built throughout, with an unusually good set of legs, excellent feet, and rare quality. He was fortunate in having an unusual lot of mares in his harem, daughters of Kellermann and Kimberly, and his colts were uniform in style and of superior character. A number of them have won honors in the leading showrings. The mare Elsie 94834 was one of the good daughter's of Forfait $\mathrm{Jr}$. She was out of a daughter of Kellermann and was good enough to win fourth in the open class for two-year-old mares at the Illinois State Fair in 1914.

The three sires, Kellermann, Kimberly, and Forfait Jr., were responsible for the improvement in Mr. Stubblefield's Percherons during' the decade 
and marked progress was evidenced at each successive cross. The quiet, persistent accomplishments of this stud had a telling effect upon breeders conversant with L. F. Stubblefield's work, and the influence of this collection has undoubtedly been far greater than that of many contemporary establish-. ments of greater numbers.

H. I. Messenger, Lockport, Ill., bred 109 Percherons foaled during this decade, nearly all of which were raised by himself. Morse 22714 (40383), one of the good sons of Besigue was used with success and added materially to the size of the Messenger stock. Extrador Jr. 12569 and Rochefort 29886 (45787) were used to some extent, and the stallion Charlemagne 41259 (Hang 52519) also did good service in this stud.

Pink Borodino 57905, a son of Pink out of the champion mare Britomart, was bought by Mr. Messenger from Oaklawn as a foal, and from the time he became old enough was at the head of the stud. His colts possessed size, good conformation and soundness. In earlier year's Mr. Messenger did not feed his colts liberally enough to permit of the best possible development, but they have gone on well in the hands of new owners and have rendered excellent service. Mr. Messenger did relatively little exhibiting at fairs and no advertising until after 1910 , so that the stud really exerted less influence than the merits of the animals justified.

The Leslie Farm stud founded by A. L. Robison $\&$ Sons, Pekin, Ill., during the period of depressed 
values in the '90's, was another breeding establishment that exerted material influence upon Percheron development during this period. Powerful 6670 (Bayard 7519), purchased in 1897, was continued in service until his death. He was a tried sire with a wide reputation when he went to head the Leslie Farm stud, and his colts were large, well-proportioned and good breeders. When the Powerful fillies became old enough to breed $\mathrm{Mr}$. Robison cast about to obtain another sire and finally decided that Seducteur 8850 (7057) was the horse he wanted. Seducteur had made a great showyard record while in the hands of W. L. Ellwood, and after 8 years' service, chiefly on grade mares, had passed into the hands of H. G. McMillan at Lakewood Farm. Mr. Robison went to Iowa in the spring of 1902 determined to buy the horse, although he was then 18 years old and known to be an uncertain breeder. After laboring all day in an attempt to obtain a price on Seducteur Mr. Robison finally succeeded in inducing the owner of the Lakewood stud to place a figure on him. The price was purposely placed so high that it was thought to be prohibitive. Nothing daunted Mr. Robison bought the horse and shipped him to Leslie Farm, where he remained in service until his death in 1905 . While he sired but few colts, those he did beget were of superior character, possessing great size, symmetry and ruggedness.

On the death of both Powerful and Seducteur within a few months of each other in 1905 search 
had to be made for a new sire. The Robison policy of obtaining tried sires had proved so successful that it was continued. Every horse-buyer of note in Illinois was communicated with and attempts were made to locate stallions that already had proved of more than average merit in improving horses in the communities where they had been standing. After long search and the following of many blind trails Rabelais 52564 (43442), foaled in 1897 and imported in 1899, was located. He was a son of Theudis, of Oaklawn fame, and out of Biche (28196), a daughter of Seducteur. Mr. Robison and his son Archie rode for 3 days looking at the grade colts which this horse had sired; he had not been used on any purebred mares. At the conclusion of this careful investigation it was concluded that if Rabelais would prove as prepotent on purebred mares as he had already proved on grade mares, he was exactly what the Leslie Farm stud wanted, and as he was of exceptional breeding and closely akin in bloodlines to the horses already in the stud he was purchased and placed in service at Leslie Farm in 1906. Results were all that had been hoped. Rabelais' colts were uniform in type, possessed ample size, and were of the deep-bodied, well-ribbed, massive kind, heavy in bone and of very drafty type. He remained at the head of the stud until his death in 1914.

The use of these 3 tried sires resulted in steady improvement at Leslie Farm. Very few studs made more consistent progress in improving the weight, 
size, style, symmetry and quality of the Percherons produced. The care and management of the young animals was far above the average, with the result that a large proportion of the colts bred and raised at Leslie Farm were sold as weanlings and yearlings at prices far in advance of the usual figure. Little was done in exhibiting at leading shows during this period, but the influence of the breeding operations carried on at Leslie Farm was widespread. Special attention was given to the encouragement of small breeders in the immediate vicinity. The result was the development of a large number of small breeding establishments founded on purchases made at Leslie Farm and the general improvement of all horses within the Tazewell district.

Numerous other breeders have contributed materially to the upbuilding of Percheron interests in Tazewell county, but men best acquainted with the rise of Percheron breeding in that territory are free to concede that Leslie Farm has led in the development of the Tazewell country as a Percheron center until it now stands second in the United States in that regard.

M. C. Hodgson and W. E. Prichard, both of Ottawa, Ill., whose operations have been reviewed at length in preceding chapters, continued their Percheron-breeding operations during this period and made material progress. No sires of special prominence were in service in the Hodgson stud during this period; most of the stallions were of Hodgson breeding and used for a short time. This 
procedure was not calculated to develop sires of reputation, but the animals produced gained steadily in size and draft character.

"Billy" Pritchard also used stallions of his own breeding during most of this time. Sultan 41622, out of a daughter of Confident 3647 (397), was one of the best. The stallion Noirot 62489 (67573) was imported in 1909 to head the stud and gave good results, although criticized by many breeders on the score of coarseness.

Both Pritchard and Hodgson were persistent advertisers and exhibited at many shows. Both did considerable dealing in addition to their breeding operations, and were thereby enabled to place the horses of their own breeding at prices considerably higher than the majority of breeders obtained, as they sold direct to the ultimate user instead of to dealers.

The Stetson stud at Neponset, Ill., and that of Russell \& Sons, at the same place, both bred some good Percherons during this period, although the number was not particularly large.

The sires in the Stetson paddocks during this time did not nick so satisfactorily with the mares as was desired; few of the colts were as good as their dams. Most of the mares kept in the stud during this period were daughters of Fearnaught 16302, son of Baccarat 11326 (18639), the famous head of the Tel$\operatorname{logg}$ stud. The daughters of Fearnaught were roomy, well-proportioned mares, ranging from 1,700 to 2,000 pounds in weight, with unusual quality and 



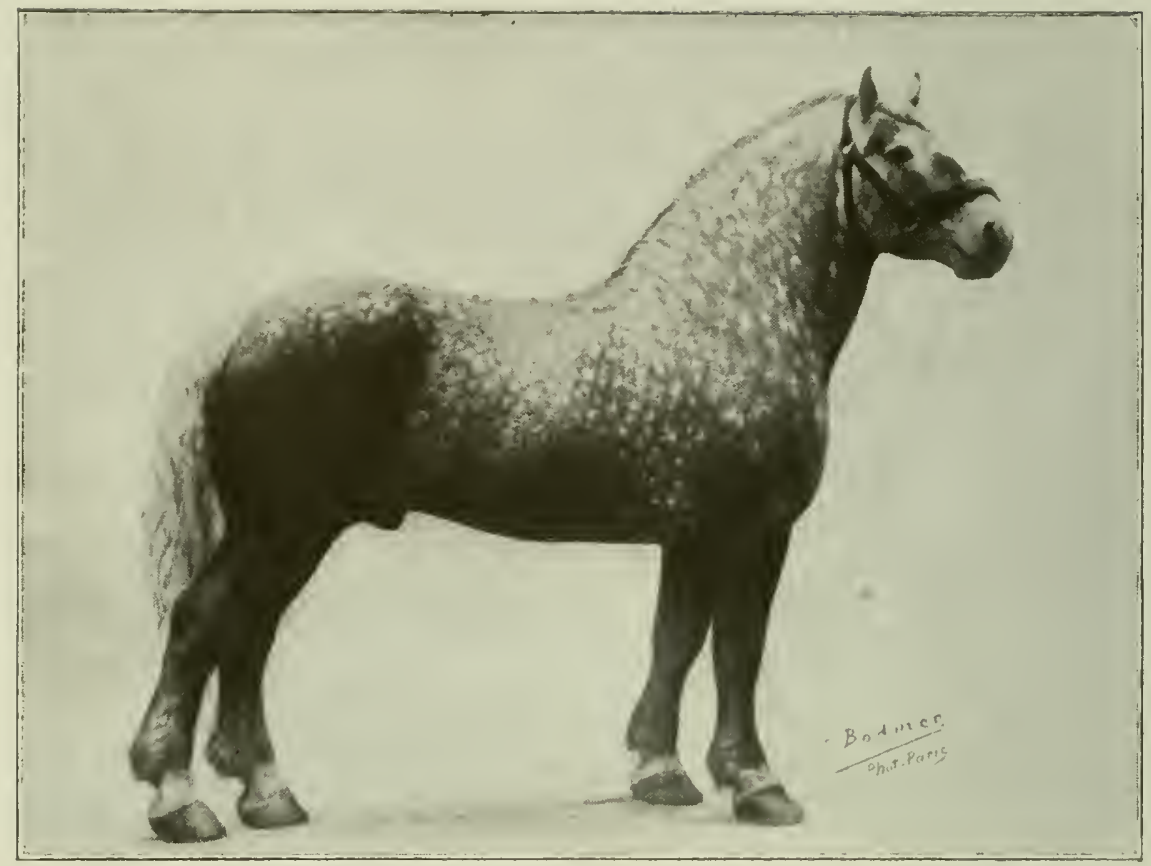

STALLION BAMBOCHEUR (62018)-PRIZEWINAER AT FRENCH SHOWS.

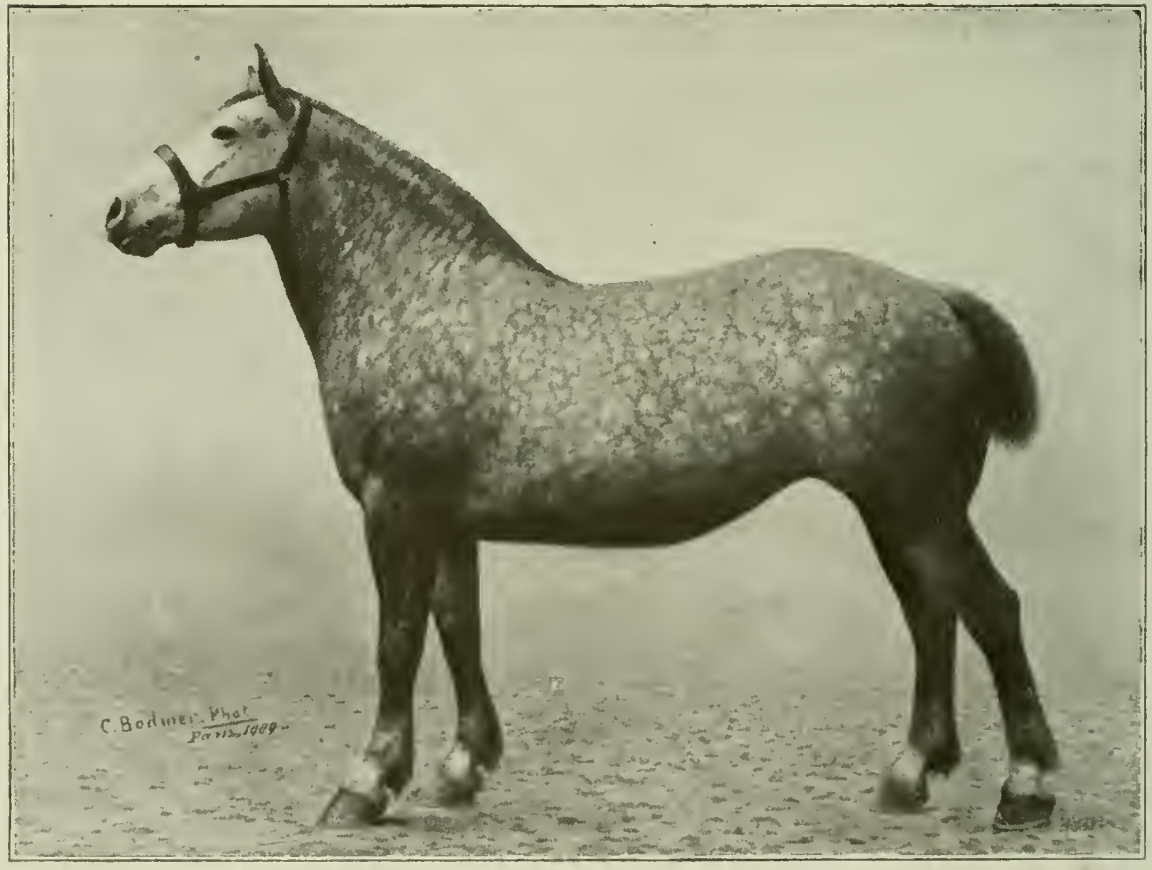

MARE ERICA (6S318)-PRIZEIVINNER IN FRANCE. 
finish. They were particularly good in the underpinning, and as the owner's themselves expressed it, were a better lot of mares than most of their daughters proved to be. This was undoubtedly due to failure to obtain the right sire to nick with the daughters of Fearnaught. Despite this, many excellent Percherons were sold from this stud and it contributed materially to the breed's improvement.

Russell \& Sons did not breed extensively, but the horses they produced were a good, useful sort, of very drafty pattern. The foundation laid during this period was so sound that at the first and only exhibit made by the firm at the International Live Stock Exposition in 1913 first and third prizes in the futurity stakes were won on stallions of their own breeding.

William Rumney, Somonauk, Ill., bred a number of Percherons during the decade, but did not give any special attention to their development. Buyers complained that his colts had not been well nurtured, and while later they grew into useful horses, lack of feed and care undoubtedly detracted from their influence on our horse stocks.

Important Illinois Dispersions.-The dispersion of the studs of Wyatt Stanley, Stronghurst, Ill., and of John Huston, Blandinsville, Ill., in November, 1901, were important events. The Stanley stud had been established in the '90's by the purchase of an excellent group of Brilliant-bred mares and the stallion Titus 17122 (36778). Titus was a big, rugged, heavy-boned, massive draft horse, 
weighing more than 2,200 pounds, and his colts were of the same pattern. Buyers of these animals came from a wide territory, and a number of breeders were among the leading purchasers. G. H. \& F. A. Reed, Lilylake, Ill., G. W. Patterson, Worthington, Minn., J. W. \& J. C. Robison, Towanda, Kans., and W. S. Dunham, Wayne, Ill. were prominent among the buyers, especially of mares. The entire lot of 34 head, including young, old and blemished animals, sold for $\$ 11,117$, an average of $\$ 327.50$ per head.

The John Huston sale was held on the following day. Mr. Huston's work as an importer and breeder during the '80's and '90's was well known and the attendance at this sale was more numerous and from more widely scattered territory than at the Stanley sale. The dispersion of this stud was the culmination of 25 years' work with Percherons, and Percherons only. Mr. Huston had bred persistently for the upstanding, drafty sort, with special emphasis on underpinning and quality. His horses were of the large pattern, the stallions standing about 17 hands high, and the mares $16 \frac{1}{2}$ hands high, or more, yet well proportioned. In the opinion of the horsemen present at the vendue it was doubtful whether halfa-dozen of the best mares could have been duplicated in America for size, weight, bone and quality, and the other matrons were not far behind the tops. A. P. Nave, Attica, Ind., was one of the heaviest buyers, and added some grand breeding matrons to the stud he had previously started. Isaac Agen- 
bright, G. W. Patterson, J. H. Barnes and Granville Kesling were active in the bidding and obtained a number of animals. Thirty-four head sold for $\$ 11,405$, an average of $\$ 356.55$.

These two sales distributed some of the best Percherons to be had among a number of new studs and encouraged Percheron breeders generally. The wide publicity given to these auctions and the crowd of buyers from all parts of the country which assembled to bid on good Percherons gave notice to breeders that conditions had changed, and that many men had confidence enough in the outcome of the horse business to pay good prices for Percherons.

New Studs Founded in Illinois.-Hundreds of new breeding establishments were started in Illinois during the period under discussion. It is impossible to mention all of these. One of the most important was at Gregory Farm, Whitehall, Ill., by W. S. Corsa, whose later operations in the Percheron field have made him one of the best-known breeders. Gregory Farm required a number of draft horses for general farm work and many heavy mares were in use on Mr. Corsa's farm in Nebraska. Cocardos 16949 (35219), the black son of Brilliant 3d, was bought by Mr. Corsa and placed at the head of his Nebraska bunch of grade mares. Mr. Corsa did not at that time know that Cocardos had won first prize in the three-year-old class at the World's Columbian Exposition in 1903, neither did he know that he was the sire of the noted stallion Lyceen 21630 (42509) and other good ones. Cocardos' get 
out of the grade mares in Nebraska were of super-

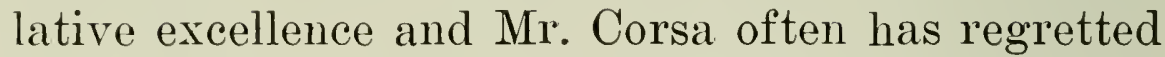
since that he did not know this stallion's true value in time to use him on purebred mares. Radziwill 27328 (44228) was purchased in the fall of 1901 or spring of 1902 to use on the mares at Gregory Farm. He had been imported by Dunham, Fletcher \& Coleman and shown at the International in 1901, where he attracted much attention. The use of these two sires on the grade mares at Gregory Farm and at the farm in Nebraska impressed Mr. Corsa most favorably, and having noticed a rapidly increasing demand for Percherons he determined to purchase a few purebred mares. The first purchase of mares was made from H. S. Hoyman \& Son in 1903, when Electress 31729 and Bona 31730 were purchased. Lucretia 19582 was bought about the same time. Some good mares were bought from Parsons \& Baldwin shortly afterward and a few purchases were made from Oaklawn. A little later some mares of Brilliant breeding were bought from Lee Bros. of Kansas. Among these was Folichonne 31518 (54111), one of the most valuable mares ever owned in the stud. She was an inbred Brilliant, having for sire Besigue and for her dam a daughter of the same Besigue. These mares and the others which had been added from time to time gave Gregory Farm quite a band of matrons by 1908 . Their produce, sired by Radziwill, was so satisfactory that Mr. Corsa determined to secure the best stallion obtainable to succeed Radziwill in the stud, and for 



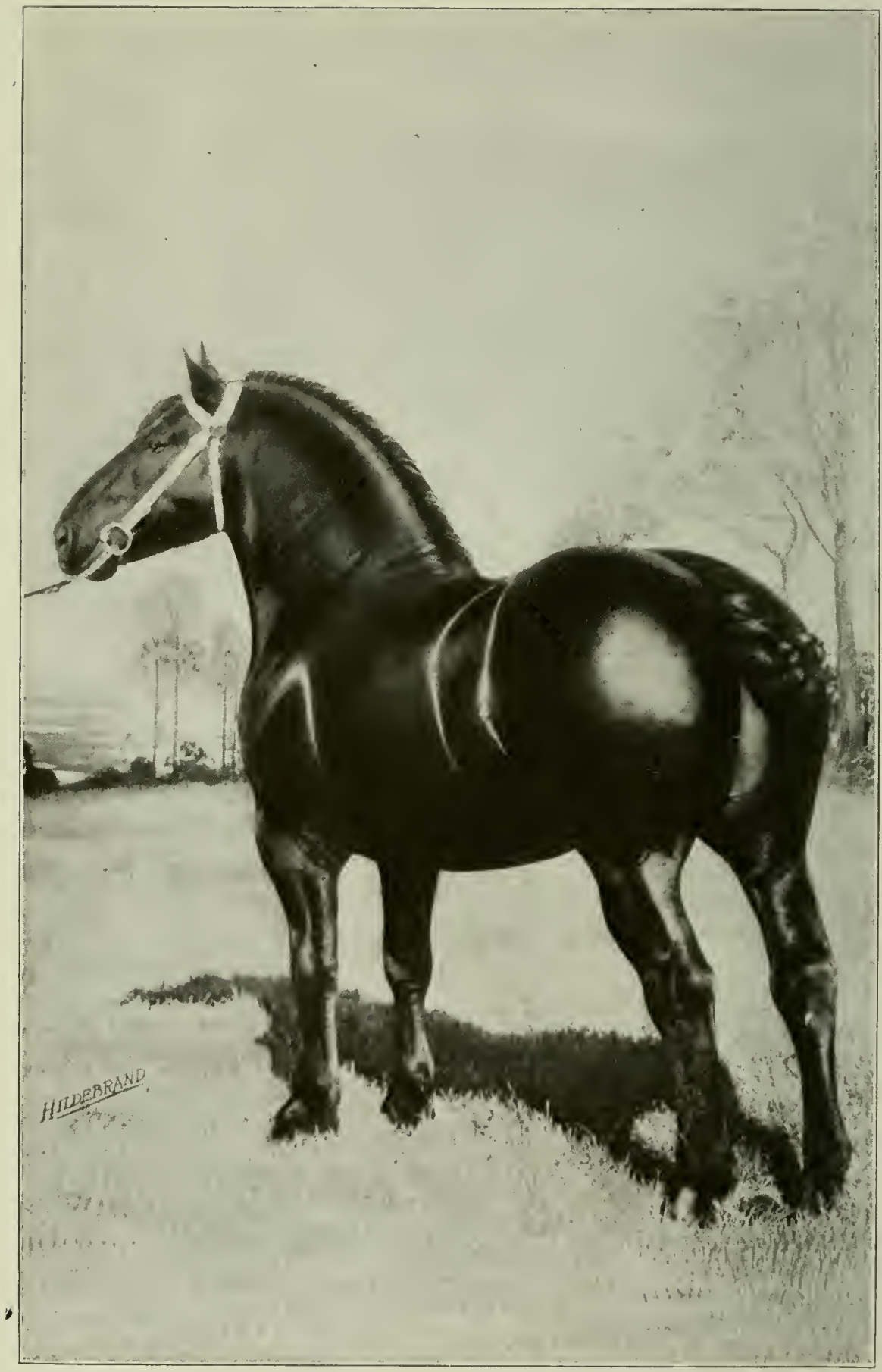

CARNOT 66666 (66666), CHAMPION AT INTERNATIONAL EXPOSITION, 1909. 
use on the fillies sired by him. Carnot 66666 (66666), a winner of first prize at Paris and with practically an unbroken string of victories in the United States to his credit, was champion stallion at the International in 1909. His purchase at the hitherto unheard of price of $\$ 10,000$ was consummated and he went to the head of the Gregory Farm stud in 1910. Actual breeding operations at Gregory Farm during the first decade of the century were carefully planned, but no showing or advertising of consequence was done until after the purchase of Carnot in 1909. The mares that had been purchased and those bred at White Hall, however, had given Mr. Corsa a strong foundation, worthy of the highpriced sire selected, and subsequent breeding operations, combined with unusually skillful advertising in the showring and agricultural press, have placed the Gregory Farm stud among the leading Percheron breeding establishments of the present period.

Progress in Iowa.-Iowa, second in Percheron breeding from an early period, maintained its rank during this decade. While there were fewer noted and extensive breeders of Percherons in Iowa than in Illinois, the operations were more widely scattered through all parts of the state than was the case in Illinois. A foundation was laid which has brought the state very close to Illinois in the number of Percherons produced.

The Lakewood Farm stud was the leading Percheron-breeding establishment in Iowa during this period, and bred more Percherons than any other 
in the United States during this time. To the purchases made prior to $1900 \mathrm{Mr}$. McMillan added some of the best mares from the E. L. Humbert stud, the Minnesota Percheron Horse Co., and the Wyatt Stanley stud, and also numerous other mares bought from scattered breeders. Seducteur was bought in the spring of 1900. Calypso 25017 (44577), firstprize winner in the three-year-old class at the International in 1900 and reserve champion at that show, was purchased in time to make his first season at Lakewood Farm in 1901. He was a line-bred Brilliant, a son of the noted Thendis and out of a daughter of Brilliant 3d. Individually he was not of the largest type, but stood about $16^{3 / 4}$ hands in height and weighed 1,900 pounds in breeding condition. He was a remarkably well-proportioned horse, beautifully balanced throughout, with two good ends and a good middle. His underpinning could not be surpassed and his style, quality and action have seldom been equalled. All in all, Calypso was one of the most perfect types of the breed used in America after 1900, and the only serious criticism ever lodged against him was on the point of size. He proved to be one of the most prepotent sires ever known to the breed. His get won more prizes for get-ofsire than that of any other stallion used in America during his time; his excellence as a sire made the reputation of Lakewood Farm. He worked under the disadvantage of being bred to large numbers of mares that were intended solely for sale purposes; they were not really good enough to be mated to a 
sire of such outstanding excellence. Despite this, time has demonstrated that no sire ever begot a more uniform and a more excellent lot of colts than Calypso, when the character of the mares used is taken into consideration.

It must not be inferred from this that there were no good mares in the Lakewood Farm stud. There was a large number of mares of the best type and breeding, whose progeny by Calypso carried the colors of the Lakewood stud to the front in the strongest of competition at the leading shows.

Olbert 42815 (53109), first-prize aged stallion and reserve champion at the 1905 International, was purchased and used in the Lakewood stud during the seasons of 1906 and 1907. He was an upstanding gray, over 17 hands high and weighing 2,100 pounds in fair condition. He was an upheaded, stylish stallion, rather more rangy in pattern than most of the horses of 1905 and 1906. He was a horse of surpassing quality, with flintlike bone, tendons well set back and joints clearly defined. Olbert was purchased for the particular purpose of being mated to the daughters of Calypso, with a view to increasing the scale and draftiness of the Lakewood Farm Percherons. He begot size, but his colts were so rough and rangy in appearance as yearlings and two-year-olds that he was disposed of before his real value as a sire became apparent. His get did not round into sale form until 3 and 4 years of age, but they were horses of tremendous scale and massiveness, with more than usual quality. His 
blood, at first unappreciated, was later highly valued by breeders who were seeking to increase the size of their Percherons without sacrificing quality. His subsequent development into a sire of high rank vindicated the judgment of John Huston, who insisted, as one juclge on the committee at the International in 1905, that Olbert showed every evidence of developing into a great stock horse. Had this stallion been given an opportunity to head a great band of brood mares, no one can estimate how farreaching his influence might have been. As it is, Olbert has a conspicuous place among Percheron sires.

Actual breeding operations at Lakewood Farm were subordinated to the work of purchasing and distributing Percherons. Mr. McMillan was one of the first to realize the opportunity open to men who were good judges of Percherons and who had the means and inclination to assemble the Percheron stock which had been so widely scattered throughout the years of depression. For years he made heavy purchases of both mares and stallions, particularly in Illinois and Iowa. After carrying these animals long enough to put them in shape for sale they were sold at public auction and were widely distributed throughout the northwest. A large number of the animals which were recorded as bred at Lakewood Farm were from mares purchased for sale purposes, bred to the Lakewood Farm sires and sold in foal, so that the number actually bred and raised at Lakewood Farm is but a part of the grand total. 



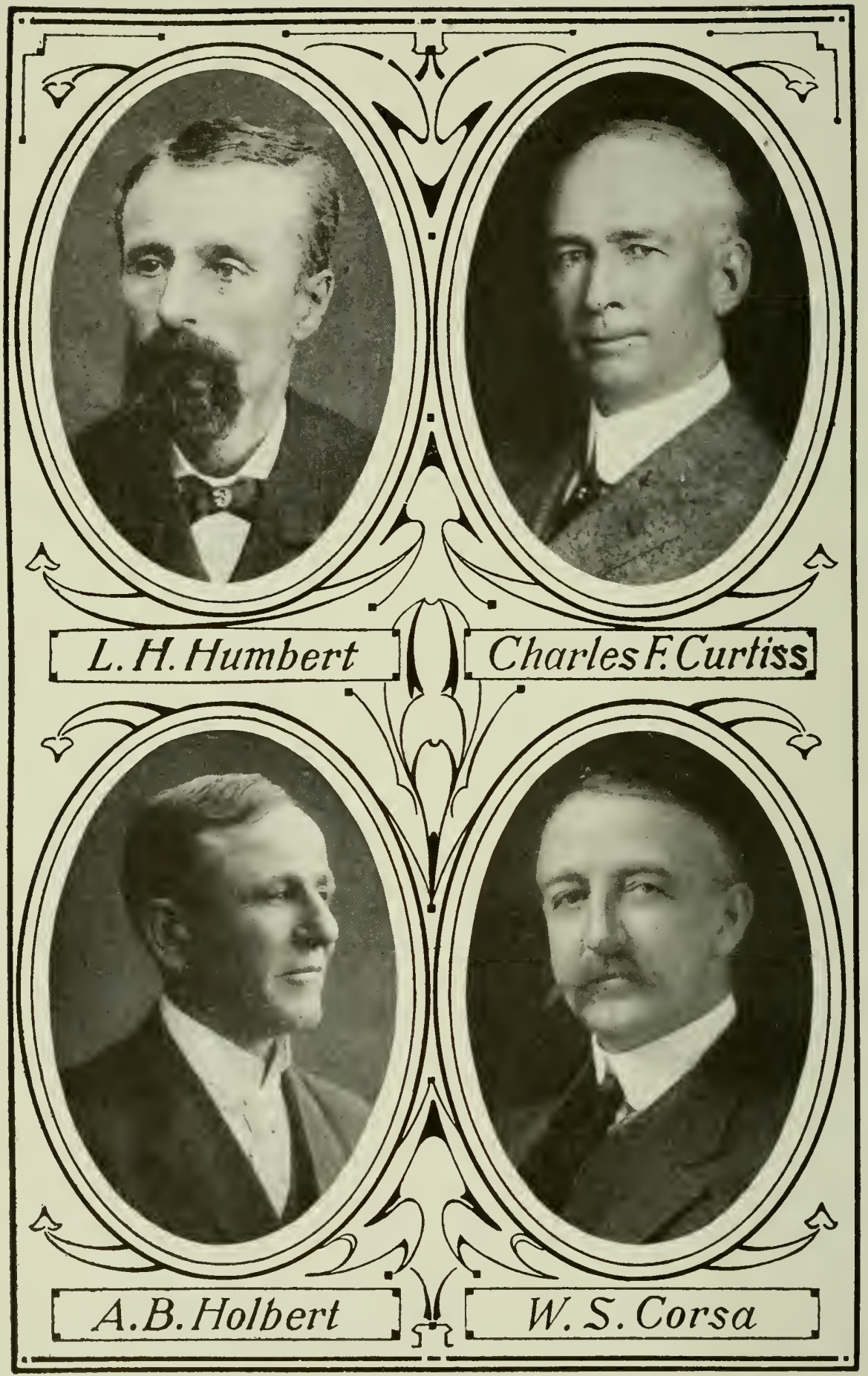


The showyard winnings of the Percherons from the Lakewood stud constitute an important contribution to the showyard history of this period, beginning at the International of 1906, where the purple ribbon for grand champion mare fell to Iolanthe 40925, and where the get of Calypso won first for get-of-sire. McMillan \& Son showed repeatedly at the Iowa and Minnesota State Fairs and at the International with marked success. The mare Iolanthe, bred at Lakewood Farm, was first-prize three-year-old at the Iowa and Minnesota State Fairs and won the championship at Minnesota, as well as at the International, in 1906. She came back as an aged mare and won the championship at the International in 1910, the only mare that ever accomplished this feat in the history of the show. The American-bred colts brought to the front from the I akewood stud were the first successfully to compete with imported horses in the leading showrings. This stud did more to overcome the erroneous inpression that American-bred horses were not so good as the imported ones than any other breeding establishment of the period.

Singmaster \& Sons, Keota, Ia., continued operations on an extensive scale, both as importers and as breeders. The other draft breeds which had received considerable attention from them prior to this time were relegated to the background and Percheron interests became paramount at Maple Grove Farms. C. F. Singmaster and his son, J. O., were the most active in the development of this stud, 
although Thomas Singmaster, brother of C. F., also carried on extensive breeding operations.

The heavy importations made by the Singmasters led them to test out a large number of different sires, and more than 25 were in service during this period. While this practice resulted in the production of a large number of high-class Percherons, it did not lead to the development of any sires of outstanding reputation. Bataclan 21264 (43368) was given more liberal opportunities in the stud than most of his contemporaries, and he subsequently sired a number of purebred colts in the studs of J. H. Letts and Brockway \& Sons. Niagara 32338 (48905) was also used rather extensively and left many good colts at Maple Grove in 1905 and 1906. He later saw service in the stud of O. L. Thisler of Kansas, and still later went to P. W. Cox \& Sons. A number of mares bred to him were sold to Glover \& Son of North Dakota, where they contributed to the success of their stud.

While no sires of nation-wide reputation were used in the Singmaster studs during this period, the type was materially improved by persistent selection of the best mares and by carefully mating them to such sires as seemed to be best fitted to overcome deficiencies. Relatively little was done in the way of showyard exhibitions until 1907, but from that time on the Singmaster stud was most strongly represented in the leading shows. The persistent, widespread advertising done by this firm and the extensive sales made affected most favorably draft horse development in all sections, and a large num- 


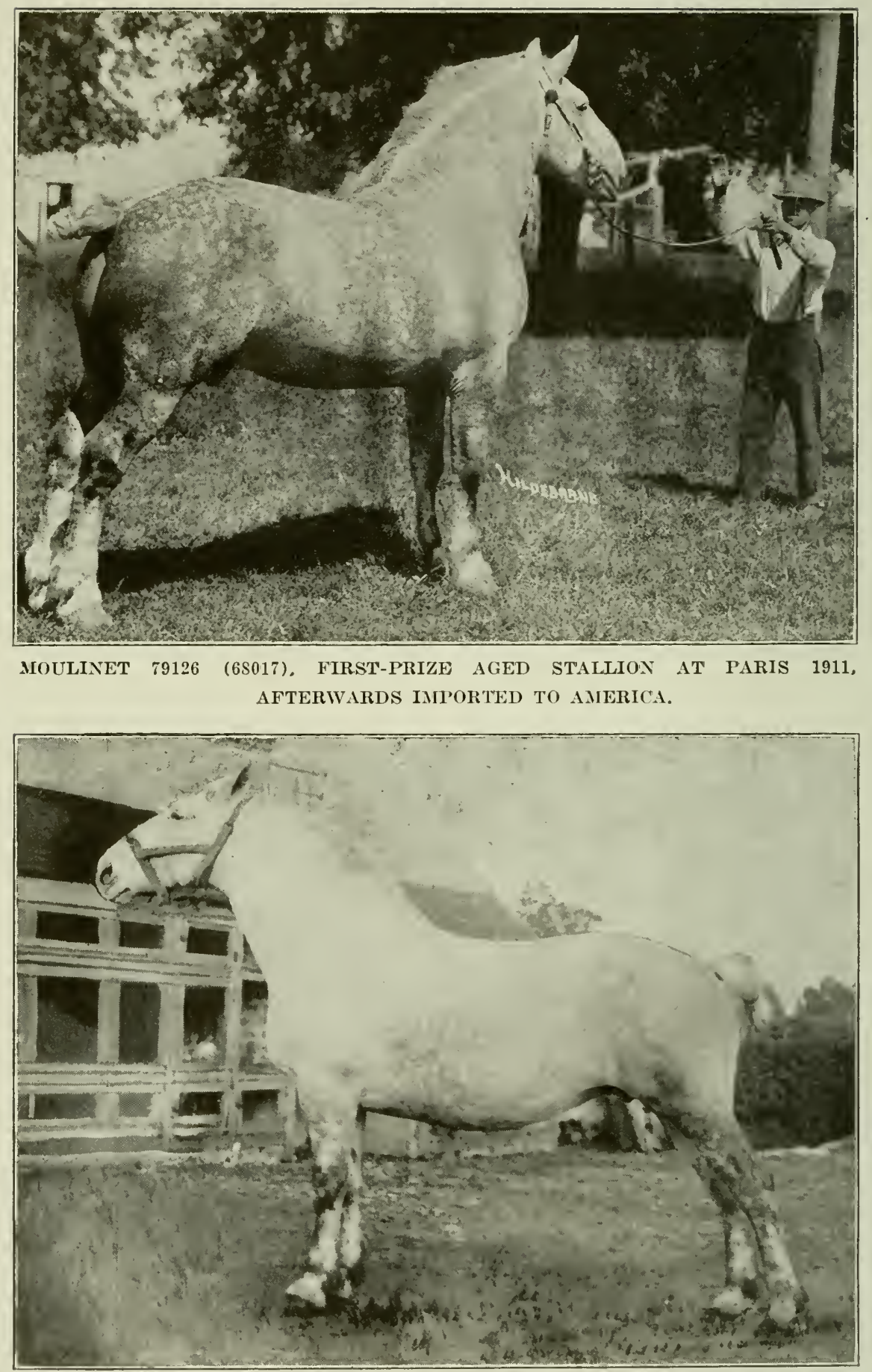

INDIVISE, A PRIZEWINNING MARE AT FRENCH SHOWS. 
ber of breeding establishments were founded on the purchases of mares and stallions from Maple Grove. The quality and character of the animals purchased has improved steadily, and the stud today ranks among the leading breeding establishments in the United States.

Maasdam \& Wheeler, Fairfield, Ia., were extensive dealers and importers from 1901 to 1910. Their breeding operations were subordinate to their other activities, but they were well to the front in the showrings. They exhibited the gray mare Amorita, champion at the International in 1909. They distributed a large number of animals of drafty type and their sales in the western states were most extensive.

L. M. Hartley, one of the early draft horse breeders in southeastern Iowa, was another breeder who produced a number of Percherons during this period and was also active as a dealer. His horses were characterized by heary bone and extreme ruggedness and massiveness. They were very powerful, well-proportioned draft horses, possessing more draftiness than finish. They proved extremely valuable in increasing the size and bone of the stock they were used upon and a number of the best sires of market horses trace to this stud. Samson 27328 and Tavernier 35719, whose dam was a daughter of Samson, were the leading stallions used. Both were prepotent. Samson was sired by Martigny 2528 (1271), a gray stallion imported in 1883 by Mr. Dunham and sold to Mr. Hartley in 1884. Martigny 
was of the Favori and Coco breeding, and the most valuable of the early sires used in the Hartley stud. Bred to Tontine 5756 (4240), a grand-daughter of Brilliant 1899, he begot Samson. Samson stamped his foals so indelibly with his own likeness that experienced horsemen who knew the old horse could pick his colts with almost unerring certainty out of bands containing numerous animals of other breeding. Little was done in the way of showing the horses bred in this stud, but persistent newspaper advertising was resorted to and the horses were sold over a wide range of territory.

E. D. Seaman, a neighbor of L. M. Hartley, had stock of much the same pattern and was also an extensive breeder during this period.

F. E. Waters, West Liberty, Ia., confined his work largely to actual breeding operations and produced some very drafty, useful stock, particularly after acquiring Morse 22714 (40383) and Brilliant D. 45336. These sires were both above the average in size and draftiness. Crossed on the thick mares already in the stud they begot some very useful stock which has been widely distributed throughout the northwest.

M. L. Ayres, whose work has already been discussed, was among the ten leading breeders in Iowa during this period. Blandé 29259 (36577) was the leading sire used; he was a son of Brilliant $3 \mathrm{~d}$ out of a daughter of the noted show horse La Ferté 5144 (452) and had been at the head of M. Perriott's stud in France for some time prior to his importation by 
Mr. Ayres. Blandé was a black with strip and snip in his face, and a horse of excellent pattern, standing about 16.3 hands high and weighing 2,000 pounds. He was deep-bodied, strong-backed, long and level in the croup, with excellent feet and set of legs, and possessed good quality and action. He was an extremely prepotent sire and many of the best stallions imported from France were sired by him. He was the sire of the Olbert referred to in the discussion of the Lakewood stud and of many other good horses. His colts sired in Mr. Ayres' stud were uniform and closely resembled their sire, even to color and markings. Mr. Ayres was an excellent feeder and gave his foals every opportunity for development. The colts sold from this breeding establishment were of the heary-boned, deep-bodied, thick, drafty kind, and rendered excellent service wherever used. Mr. Ayres' advanced age and lack of general education handicapped his operations, but the horses bred by him were undeniably of great value to Percheron interests.

James Loonan was another of the 10 leading breeders in Iowa during this period, and his operations were strictly along breeding lines. His horses were rather low-down, thick, wide and drafty, somewhat on the "Dutchman's type." Superior 40605, out of a daughter of Confident, one of the most noted sons of Brilliant, was the greatest sire used in this stud. He was about 17 hands high and a deep, thick, drafty horse, weighing 2,200 pounds in show condition. His colts were uniform in type and of high average ex- 
cellence; he rendered excellent service from the time he entered Mr. Loonan's stud as a three-year-old in 1906. Some showing was practiced, animals bred in this stud being exhibited at the International in 1910 and 1911, where for both years the second prize was won on the get of Superior. Mr. Loonan's general advertising was somewhat limited in character, but horses have been sold from this stud over a large part of Iowa and to some extent in the northwestern states and Canada.

Isadore Link was another Iowa breeder whose work already has been touched upon. While he did not breed a large number of Percherons, they were of good type and were much sought after by dealers who recognized their excellent conformation and quality.

There were numerous other breeders in Iowa whose operations are deserving of attention, but they were for the most part men who bred limited numbers of Percherons. They contributed materially to the improvement of draft horses in Iowa, however, by the use of high-class sires and by distributing animals of good type and breeding, thereby aidling materially in bringing Iowa to its present premier position among the states in number and total value of all horses.

Ohio's Contributions.-Ohio, third in Percheron breeding with a total of 471 breeders by 1910 , bred 2,286 Percherons during the decade. The Hartman Stock Farm, Columbus, O., was the ranking breeding establishment in the state, and a heavy importer 
as well. Its operations began in 1901 with the purchase of a number of American-bred mares. This was followed in 1902 by the importation of more than 50 mares and several stallions, and additional importations were made in 1903, 1904 and later. Ugolin 31488 (46131) was the first stallion used, but he sired only a few purebred colts.

Dr. Hartman was very wealthy and ambitious to build up the greatest Percheron breeding establishment in America. He bought a number of the best mares from the Dunham stud, several from A. P. Nave, and purchased the best he could obtain in France. He also secured at a long price the stallion Besigue, the most noted sire used in France between 1893 and the time of his purchase by Dr. Hartman in 1904. Unfortunately the horse died on shipboard, so that Dr. Hartman's plan of bringing over the greatest sire France possessed to head his breeding establishment failed of completion. He had more than 120 Percheron mares in his stud in 1904, but results were extremely unsatisfactory. A large number of the mares were worked in teams at heavy hauling by teamsters who were every thing but horsemen. Heary pulling and backing of the mares while in foal resulted in the loss of many foals. The plan of running the mares in large bands favored the spread of abortion, which cut down the number of foals produced. The supposed tendency of imported mares to be shy breeders on account of acclimation fever for the first 2 or 3 years after importation was another retarding factor, so that 
the number of foals produced was very small in proportion to the number of mares owned. Lack of success in producing and raising colts discouraged Dr. Hartman, and he sold most of his mares before 1910.

The steady importations of stallions and the tendency of the men in charge continually to try out new horses led to the use of more than 20 different stallions in the Hartman stud, with the result that none of them was given a thorough enough trial to achieve any particular reputation.

Dr. Hartman exhibited at the Ohio State Fair and at the International with fair success. Considerable newspaper advertising was instituted and the Percheron importing and breeding operations carried on by the Hartman Stock Farm did much to increase the popularity of Percherons, besides leading to the direct distribution of a large number of valuable mares and stallions.

The mare Folichomne, already referred to as one of the most valuable brood mares in the Gregory Farm stud, was one of those imported by the Hartman Stock Farm, and many other mares that have done much good in other breeding establishments were imported or bred by this stud. While the experiment was a failure from a financial standpoint so far as Dr. Hartman was concerned, it nevertheless benefited Percheron breeding interests in the United States in a material degree.

C. M. Jones, Plain City, O., the oldest living Percheron breeder in the United States, whose opera- 
tions have already been reviewed in some detail, was another of the most influential breeders in Ohio during this period. His work was continued along the same conservative lines, but the animals bred in this stud, while few in number, were of uniformly high character. Most of the stallions produced by Mr. Jones went to head purebred studs, and such mares as were sold proved valuable additions to other breeding establishments. Diamant 30018 (46611), first prize two-year-old at the 1902 International, was purchased by Mr. Jones at that show and was the head of his stud from that time on. He was almost black when shown, but subsequently developed into a typical gray. He stood 17 hands high, weighed more than a ton in breeding condition and was a stylish, deep-bodied, massive, heavyboned horse, with excellent underpinning and good quality; he could have been a little deeper in the back rib to advantage. Diamant proved to be an excellent breeder, siring drafty colts of excellent conformation, quality, style and action. Although he stood at a higher service fee than any other stallion in the community he always had all he could do. His colts, whether grade or purebred, commanded top prices. He was the sire of some very good mares which went into the C. F. Camp and John Yost \& Sons studs, and was also the sire of Dorus 51052, used for some years at the head of C. F. Camp's stud. Dorus sired Dora C. 81201, a prizewinner at the Ohio State Fair. Some of the daughters of Diamant bred to Aiglon 34397 (51598), 
a son of Besigue, by C. F. Camp produced colts that were good enough to win the Eastern Percheron Breeders' Futurity. The colt Algernon 112779, winner of these Futurity stakes at the Ohio State Fair in 1915, was bred on this identical line. Mr. Jones did not do much exhibiting, but the influence of his stud was marked, even during this period.

John Yost \& Sons, Thornville, O., whose horses have been discussed in some detail, were among the leading breeders in Ohio during this period. Some of the best mares in their stud have been drawn from the C. M. Jones establishment, and three of the Jones stallions, WVamba 22034, Moreri Jr. 26195, and Dunham 42077, were used in the Yost stud between 1901 and 1910 with excellent results.

Henry A. Rohrs, Napoleon, O., who founded his stud in 1886, and whose work has been briefly touched upon, was one of the five leading breeders in Ohio during this period. He shipped some mares to Oaklawn in 1902 and got a couple of fillies by Theudis. One of these died without prodnce but the other, Thendisanna 35420 proved to be a good breeder. Mr. Rohrs shipped her to White Hall, Ill., to be mated to Carnot in 1912, obtaining a filly Carnole 108892. These two instances indicate Mr. Rohr's willingness to go to considerable expense in his breeding, and his influence upon those breeders who came in contact with him was effective in leading them to exercise greater care in the selection of their stock, particnlarly the sires.

Lonzo McClain, E. D. Koli, D. L. Buchanan, B. L. 



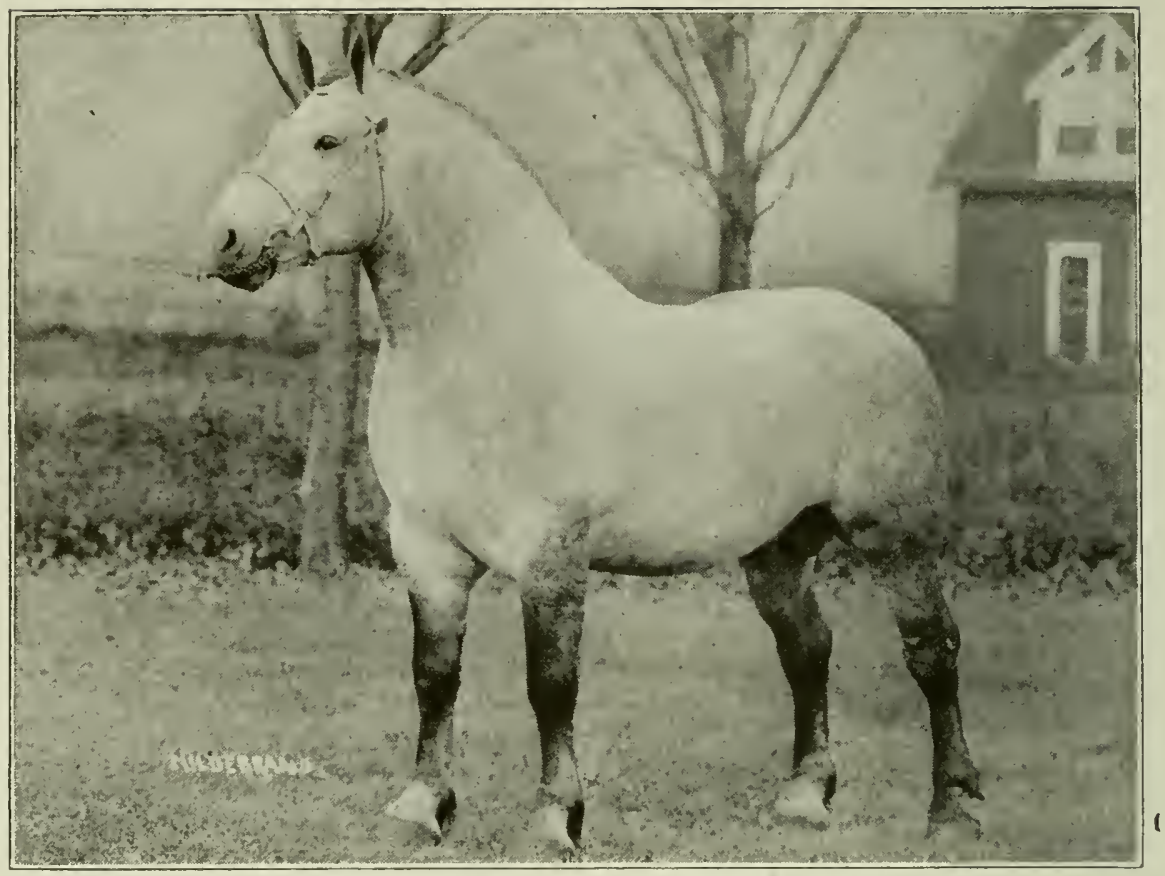

IMPRECATION 79304 (79214), CHAMPION AT CIICAGO INTERNATIONAL, 1911-12.

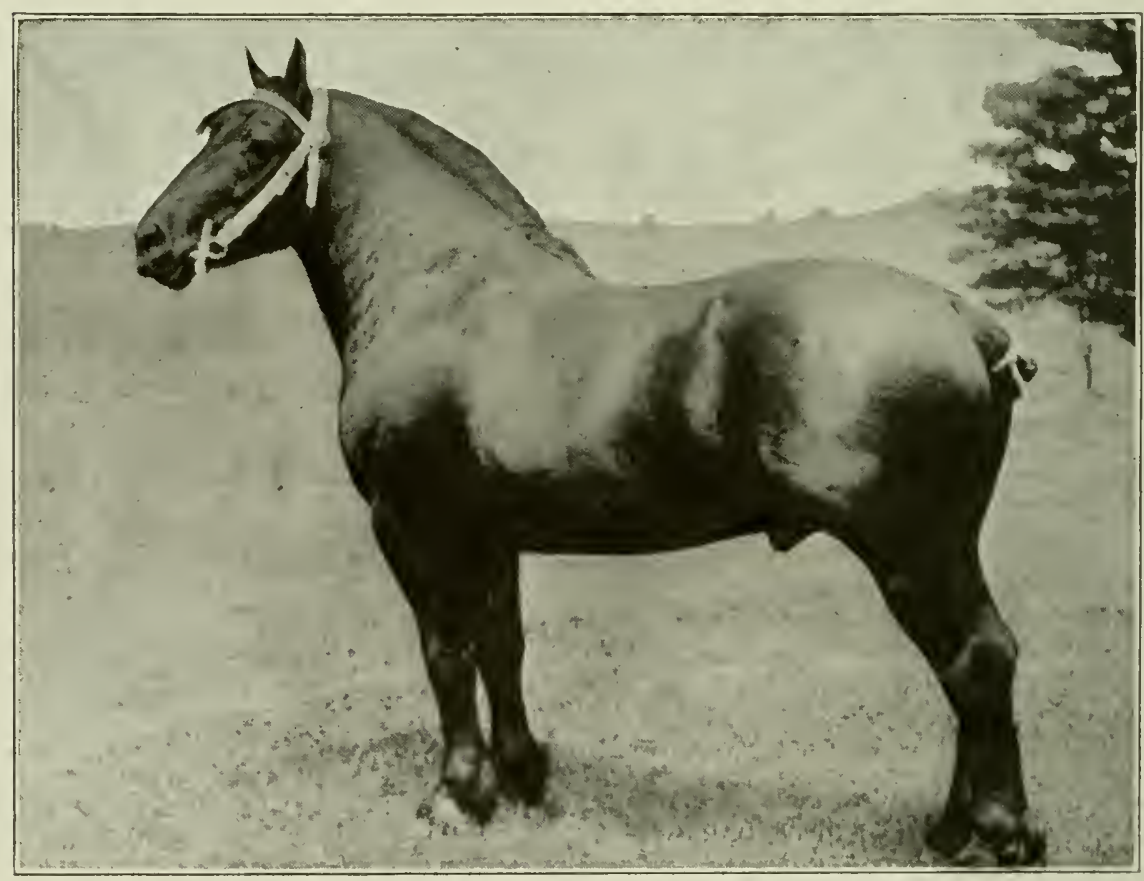

DRAGON 52155 (63516), CHAMPION AT CHICAGO INTERNATIONAL, 1907. 
Robinson, F. M. Camp, E. J. Condit and A. B. Newson were other breeders whose work was valuable to Percheron interests in Ohio during this period. And there were many others whose operations, while less extensive, were potent, particularly in the local field. Of those named Mr. Camp has bred more prizewinners than any other, and his success has been due largely to his insistence upon procuring the best possible foundation stock and to his unusually intelligent care in the management and feeding of the colts he has produced. His stock was characterized by size, good conformation, excellent underpinning, ample style and action. He has demonstrated that it is possible for a small breeder whose chief interests are in farming to produce horses capable of winning in the hottest competition.

The filly that won the first Eastern Percheron Futurity stake at the Ohio State Fair and the stallions that won the same futurity stakes in 1914 and 1915 were all bred by Camp. The stallion that won the futurity in 1914 won second in the twoyear-old stallion class at the Iowa State Fair, and third at the Panama-Pacific Exposition in San Francisco in 1915, proving that his early performance was no fluke. These winnings, convincing evidence of the soundness of Mr. Camp's methods, should serve to drive home to thousands of other farmerbreeders who have but a few Percherons the fact that large numbers are not required to produce prizewinners that sell for long prices. Sound judgment in the selection of foundation stock, the use of good 
sires, and intelligent management in the breeding. and development of the colts mean far more than the possession of a large band of mares.

McLaughlin Bros., whose headquarters were at Columbus, O., were among the most extensive importers operating in the United States during this period. They confined their operations exclusively to imported horses and rarely bought mares except on special orders. They imported a large number of very high-class stallions, excellent both in individuality and in bloodlines, between 1901 and 1908 . Nearly all their stallions were sold to syndicates on the company plan at high prices, and as a result comparatively few of the many stallions which they imported were ever used on purebred mares, as most of them went to neighborhoods where only grade mares were available. There were some notable exceptions to the rule, but the majority of the stallions imported by this firm have been lost to the breed. The firm was very active, however, in advertising and popularizing Percherons. The McLaughlins were extensive exhibitors at the leading shows, sending forward horses that were as a rule well brought out. They were aggressive and extensive advertisers in the agricultural press. The firm is no longer in existence, but $\mathrm{Mr}$. James $\mathbf{P}$. McLaughlin still retains his old-time interest in the breed, carrying on his operations at Annington Farm in the state of Maryland.

The Percherons bred in Ohio during this period were good, although they did not possess on an 
average so much scale as the Illinois and Iowa horses.

Progress in Kansas.-Kansas, fourth in Percheron breeding, with 319 breeders by 1910, bred a total of 2,039 Percherons during this period. Slower progress was made in this state than in Illinois, Iowa or Ohio. This was due in part to the fact that the farmers had been harder hit by years of depression, and also to the fact that they had severe drouths and short crops in 1902 and 1904. The steadily increasing demand for draft horses for farm use was a stimulant, and the sale of many imported stallions in the Sunflower State by strong importing firms hastened the liking of Percheron sires.

J. C. \& J. W. Robison, whose first Percheron mares were purchased in 1897, had the leading stud in Kansas during this period. The first mare purchased was Rosalie 4894, a daughter of Nyanza 869. J. C. Robison bought her from Henry Avery, Wakefield, Kans., and at the time he was there Mr. Avery offered to let him take one or all of the mares at $\$ 100$ each. This band of mares contained several daughters of Brilliant $3 \mathrm{~d}$ and many others of excellent breeding, but the horses were then lacking in size and $\mathrm{Mr}$. Robison was entirely unacquainted with Brilliant $3 \mathrm{~d}$ 's reputation as a sire. He finally purchased the one mare with considerable trepidation, but has regretted often since that he did not buy the entire band.

In the spring of $1900 \mathrm{~J}$. C. Robison bought for 
the firm 4 imported mares and 2 colts at the side of their dams, from S. W. McMillan, Topeka, Kans. These mares were of the Ellwood stock and excellent individuals, but $\mathrm{Mr}$. McMillan had become discouraged by reason of the long depression in values. He sold the entire bunch to $\mathrm{Mr}$. Robison for $\$ 610$. Among the band thus purchased for a song was the mare Fine 13085 (26998). She had a filly foal at side when purchased, which Mr. Robison recorded as Zaza 24618. Zaza subsequently won first in the aged mare classes at the St. Louis Exposition in 1904. Her half-sister Fauvette 27223, produced by Fine in 1901, won first in the threeyear-old class, and the two were sold immediately after the show to E. B. White of Leesburg, Va., for $\$ 1,000$ each. Fine produced another foal in 1902, but after that time quit breeding.

Three other valuable mares were added to the Robison stud in 1901 by purchases made at the Wyatt Stanley sale. One was Albertine 5119 (7587), a daughter of Confident. Another was the mare Azalia, sired by Brilliant 1271 and out of Albertine. The third mare was Idalia, another daughter of Brilliant 1271. These mares were excellent individuals and had been good producers in the hands of their previous owners, but transplanting them to Kansas apparently interfered with their breeding, for none of them proved to be satisfactory producers after passing into the ownership of the Whitewater Falls stud. Their failure to breed regularly was a sore disappointment to $\mathrm{Mr}$. Robison, as they were 
mares of the most desirable bloodlines and excellent individuals.

Endymion, another grand, big mare, a daughter of Brilliant 3d, also proved to be an unreliable producer. She was bought by the Robisons in 1903, and although bred regularly proved barren until 1907. She was subsequently sold to C. N. Miller, Lindsay, Ark., who got a foal out of her in 1909. He in turn sold her to W. S. Corsa in 1910, who did not succeed in getting a foal from her until 1914. She produced altogether only 5 foals in 17 years.

Some mares were purchased by Robison \& Son from Thodore Moore, Arkansas City, Kans. These were of the Dillon stock and Victorine 61629, later one of the best brood mares in Mr. Corsa's stud, was bred by Mr. Robison out of Victoria 41198, one of the mares included in this purchase. Rosa Bonheur 11324 (10382) would probably rank next to Fine as a valuable brood mare. She was a daughter of Confident and was imported by the Ellwoods. She passed into the hands of O. L. Thisler and later to T. K. Tomson \& Son, from whom Mr. Robison bought her. She produced 4 foals from 1902 to 1905 at the Whitewater Falls Farm, and they were all exceptionally high-class. The last one, Brilliant 42592, was used for some time in the home stud. Some other good mares were bought from S. C. Hanna, who had obtained some of the best matrons from his brother's stud at Bloomington, Ill. Some of the best things bred by the Robisons during this period came from this foundation. 
The chief stud sires used at Whitewater Falls during this period were Fantome 25972 (43683), Social 9311 (18468), and Casino 27830 (45462). Casino was the stallion that really made the reputation of the stud. He was imported in 1901 by Singmaster \& Sons, and was a line-bred Brilliant, a son of Theudis out of a granddaughter of Brilliant 1899. He went to the head of the Whitewater Falls stud in 1902 and is still in active service, although now 20 years of age. He was a winner of numerous prizes at state fairs in 1902 and 1903, won first in the aged stallion class in 1904 at St. Louis World's Fair, and has a long record of prizes to his credit, both individually and as a sire. He stood about 17 hands high and weighed from 1,900 to 1,950 pounds in breeding condition. He was a deep-bodied, strongbacked, well-ribbed horse, symmetrical throughout, and with the stylish carriage of head and neck and the freedom of action so much desired in Percherons. His colts were uniform in type, and while he, like Calypso, suffered the disadvantage of being bred to many mares that were intended purely for sale, his progeny has been considerably above the average and he is justly entitled to rank among the noted sires of the breed. He wrought decided improvement in the Whitewater Falls Farm Percherons, and had his best daughters been carefully retained this breeding establishment would have had a band of mares of very much more excellence than it did possess. High prices tempted Mr. Robison to sell many of Casino's daughters. however. This policy, 
while .successful from a financial standpoint, undoubtedly interfered with the development of the stud.

Mr. Robison's operations as a dealer were extensive. In the later years of this period he bought large numbers of mares in various sections, particularly in Illinois and Iowa, and distributed them through the southwest by public auctions held at Whitewater Falls Farm. This resulted in the establishment of a large number of new breeding places and aided in popularizing Percherons in Kansas and the states to the southwest, where the bulk of the sales were made.

Henry Avery, Wakefield, Kans., whose earlier operations, both individually and as a member of the firm of Avery \& Coleman, have already been fully reviewed, was one of the leading breeders in Kansas during this period. He exhibited at the St. Louis Exposition in 1904, where he won first and third on two-year-old mares. The stallion Bosquet 40105 (46612) was the last sire in use and left some very good colts, a number of which went to the stables of J. H. Tangeman when the Avery stud was dispersed in 1905. The prices realized were satisfactory, considering the fact that everything, old, young and blemished, was sold.

There is no doubt but that Henry Avery rendered a great service to Percheron breeding in Kansas. His stud was dispersed at a time when victory was practically within his grasp. The animals sold passed into the hands of many breeders in Kansas 
and wherever given a fair opportunity for full development have demonstrated the good breeding they possessed by maturing into large, well-proportioned, valuable Percherons.

J. H. Tangeman, one of the heavy purchasers of Avery stock, did not breed a large number of Percherons, but produced very good stock. Many of his animals were considerably above the average in breeding.

O. T. Thisler also bred a number of Percherons during this period. He was always more of a dealer than breeder and we have previously referred to his purchases from the Ellwood stud. He also made some purchases at a later date from Singmaster \& Sons. He came quite active in developing Percherons in Kansas and at points farther west.

C. H. Spohr, one of the five leading breeders in Kansas during this period started with stock from the Covell stud. The mare Mollie 19915, bred from this foundation, was a valuable brood mare, a regular producer of good colts. She raised colts of record in 1902, 1903, 1904, 1905, 1907, 1908, 1909, 1910, 1912 and 1914, an achievement that is surpassed by few brood mares. Three of her stallions, Castillon 1st, Castillon 2d and Castillon 3d, are reported to have sold for $\$ 800$ each, and the mare was a money-maker from the start of her career. Castillon 27318 (46308) was the most valuable sire used in this stud. He was a black with a star in his forehead, foaled in 1900 and imported in 1901 by H. A. Briggs. Sired by Paladin (Conat 34847) and a 
grandson of the noted sire Champeaux 6218 (2248), he was out of a line-bred Brilliant dam. He was a large, well-proportioned, rugged stallion, weighing 2,350 pounds in show condition, and his get has been distributed throughout the southwest. The management of the stud has since passed into the hands of John and John A. Spohr.

Other Kansas breeders who came into prominence during this period were F. H. Shrepel, G. E. Clark, S. S. Spangler, Snyder Bros., Lee Bros., Clark A. Smith, S. C. Hanna and Dr. J. T. Axtell. None of these had bred very many animals at the close of the decade, but they laid strong foundations for later work.

Dr. J. T. Axtell achieved some note by attempting to create a strain of bay Percherons. He bought a number of typical animals of that color and by breeding these together attempted to create a definite strain. Results proved embarrassing, for practically 50 percent of his Percherons were blacks and greys. It should be possible, by persistent effort to develop a strain of bays, and if the doctor's efforts are not interrupted something of this kind undoubtedly may be accomplished.

The chief work done by Percheron breeders in Kansas during this decade consisted in popularizing the breed and in improving the size, quality and type of the market horses and the Percherons in the state. Extensive sales were made into Oklahoma, Texas and other southwest states. The breeders of Kansas have exerted a greater influence upon Per- 
cheron development in the southwest than have those of any other commonwealth.

Progress in Minnesota.-Minnesota, fifth in Percheron breeding during the decade under consideration, had 279 breeders by 1910, and 1,583 Percherons bred in that state are of record as foaled during that period. G. W. Patterson, the Patterson-Erickson Co., T. L. \& J. L. DeLancey, the Jean DuLuth Co., H. W. Lightley, Crandall \& Danforth, L. C. Hodgson and L. W. Orr were the leading breeders.

T. L. \& J. L. DeLancey, whose operations have already been sketched, were the most aggressive of the Minnesota firms so far as exhibitions at the leading state fairs were concerned, and at this time probably were the most active in distributing Percherons. They did not breed a large number, but the horses they did produce were of superior character and successfully contended in the open classes at the Minnesota State Fair during 1900, 1901, 1902 and 1904. The mare Charmante 10931 (20451) was their most valuable breeding matron and held her showyard form to a late age. Her colts without exception were of high character and winners in the leading shows. The DeLanceys sold foundation animals to a number of other studs in Minnesota and wielded a decided influence in the development of Percheron interests during the early part of this period.

George W. Patterson, Worthington, Minn., founded his stud in 1901 by purchasing 6 mares 
and a stallion at the Wyatt Stanley and John Huston sales, held late in the fall of 1901. Forfait 16873 (28578), head of the John Huston stable for years, was purchased to head Mr. Patterson's stud, but died before being used. Mr. Patterson thereupon purchased Lyceen 21620 (42509) from T. L. \& J. L. DeLancey, and used him until the spring of 1908, when he sold him to the Jean DuLuth stud.

The first colts bred by Mr. Patterson were dropped in 1903, and Lyceen was the chief sire during the first 5 years, although Collegian 22744 (43609), a son of Lyceen and also imported by the DeLanceys, was used to some extent. In addition to his 6 foundation mares Mr. Patterson secured several from Nagle and Sons, Grand Ridge, Ill., and others from the Minnesota Percheron Horse Co.

The mare Frou Frou 22681 was bred by H. G. McMillan, passed into Mr. Patterson's stud and proved to be a most regular breeder for him and also in the hands of her later owners A. J. Lasby and G. J. Gilbertson. Some mares were also obtained by Mr. Patterson from T. L. \& J. L. DeLancey and M. C. Hodgson. Among the best ones were those purchased from Hodgson \& Nagle. They included Rose Bonheur 12962, a daughter of the famous Confident which proved a very satisfactory breeder.

In the spring of $1907 \mathrm{Mr}$. Patterson transferred his business to Patterson-Erickson Co. and extended his holding of Percherons. A disappointing number of colts was produced, which might have been due 
in part to the fact that he carried a large number of his mares in idleness. Many failed to get in foal and the loss of colts was heavy, but despite these difficulties this breeding establisment bred 106 Percherons during the 10 years. Numerous sales were made, and the mares produced were widely scattered throughout the northwest. Some of them went to A. A. Sandahl of Montana and were subsequently sold to Prof. Oliver Jenkins of the Leland Stanford University, in California. A. J. Lasby obtained some mares from this breeding establishment and others were sold to the Jean DuLuth Co. Lyceen was bought by the Jean DuLuth Co. in the spring of 1908 and stood at the head of that stud until 1913.

All in all, the breeding operations conducted by G. W. Patterson and the Patterson-Erickson Co., resulted in increasing the popularity of Percherons in Minnesota and in distributing a number of animals throught the state and the northwest. The state fair showrings saw some of the horses during the latter part of the decade. The stud was finally dispersed in the spring of 1914, U. L. Burdick of North Dakota taking all of the remainder.

H. W. Lightley, whose work has been touched upon previously, was another of the leading breeders in Minnesota. He added some mares by purchase, but for the most part extended his Percheron holdings by retaining mares of his own breeding in the stud. The stallion Klondike 21633, bred by T. L. \& J. L. DeLancey, was the chief sire used by Mr. 
Lightley in the early part of the period. This was a very rugged, big horse, his sire being the noted Titus 17122 (36778) and his dam the DeLancey mare Charmante. He proved an effective sire. Dewey 23968 was used a little later with good results; he was bred by Mr. Lightley and while not so massive in type as Klondike, left some excellent colts. This stud bred only 33 Percherons during the 10 years, but the business was carried on steadily and on the death of the father passed into the hands of the sons, who are still conducting it.

The Jean DuLuth Co., Duluth, Minn., began in 1904. The foundation mares were obtained from T. L. \& J. L. Delancey, G. W. Patterson, and a few others, but the breeding operations were limited in character until about 1908, when the business was expanded. Special attention never was given to producing Percherons however; the horses have been bred as a sideline to general farming. The purchase of Lyceen, placed a valuable sire at the head of the stud in 1908, and while he did not beget many colts, they were of superior character. In 1913 the entire stud was sold to U. L. Burdick of North Dakota.

Crandall Bros., Red Wing, Minn., reorganized as Crandall \& Danforth, Randolph, Minn., about 1905. The foundation mares used by Crandall Bros., were secured from Levy Bailey, G. W. Patterson and William Mies \& Co. These purchases, together with other scattered ones, formed the basis of their Percheron stud, and when Mr. Danforth became a member of the firm the business was carried on with the 
foundation stock already assembled. The first sire of consequence was Spuller 17123 (20848), purchased from T. L. \& J. L. DeLancey. He was a horse of rugged character and great size, and proved an extremely prepotent breeder. One of his best colts was the stallion Titian 25925, bred by Crandall Bros. out of Milena 21636, a daughter of the great sire Titus whose merits were discussed in our consideration of the DeLancey and Wyatt Stanley studs. Titian was a dark-gray, foaled in 1900. He was large, rugged and massive, and proved prepotent. He probably was the most valuable sire used by Crandall Bros. and Crandall \& Danforth during this period and really made the reputation of the stud. He was used freely by neighboring breeders, including A. J. Lasby, T. L. \& J. L. DeLancey, L. W. Orr and others, and begot 50 colts of record, whose descendants are scattered all over Minnesota. A number of prizes in the open classes at the Minnesota State Fair are to the credit of the Crandall firm, but the exhibitions were not long continued and did not extend beyond the limits of the state. The bulk of the sales were local. The main work of this stud was to popularize Percherons in Minnesota, and its influence is still marked.

L. C. Hodgson continued breeding Percherons in a small way during the early part of the century, and recorded 22 colts. Richelien 21567 and Sansonnet $2 \mathrm{~d} 24588$ were his most important sires during this time.

L. W. Orr, Afton, Minn., was one of the smaller 
breeders in the state and his work was unique. He began in 1900 with a single mare which he bought from Jacob Koester. This was Fany 20458; she raised colts of record every year from 1901 until 1910, inclusive, then missed until 1914, when she produced another foal. Mr. Orr kept two of her best daughters for some time and these were also regular breeders in his hands and in the hands of later owners.* His entire stud was originally developed from this one mare and her produce. The financial returns to $\mathrm{Mr}$. Orr were such as to seem almost fictitious, but they are well attested-an indication

\footnotetext{
*Regarding the produce of Fany 20458 MIr. L. W. Orr of Afton, Minn., writes:

"I bought the mare Fany in 1900 from J. Koester of Minnesota. She was foaled in 1895 and had produced some colts before I bought her. During the years 1901 to 1916, inclusive, a period of 16 years, she has never failed to get in foal, and I have saved and reared 12 colts produced by her in the 16 years (four were lost through abortion or shortly after birth). Of the colts foaled by her in my possession I sold the first, Rosalie 30609 as a mature mare for $\$ 500$; her second colt, Pickador 33150 , a stallion, I sold for $\$ 800$; her third colt, a mare, Gladdis 34797 , I sold at maturity for $\$ 500$; her fourth colt, a stallion, Canton 425411, I sold for $\$ 1,000$; her fifth colt, a mare, Blanche 43448 , and her sixth colt, a mare, Rosette 46841, I still own and consider the pair easily worth $\$ 1,000$; her seventh colt, a stallion, Donald 539\$2, I sold for $\$ 600$ as a yearling rising two; her eighth colt, also a stallion, Pluton 59395 , I sold for $\$ \$ 00$; her ninth colt, a mare, Hazel 72135 , I reared, but she died before she foaled a colt for me; her tenth colt, a stallion, Tripoli 82581, I sold for $\$ S 00$; and her eleventh colt, a stallion, Superior 115223, I still own, and consider him easily worth $\$ \$ 00$. Her last colt, foaled in 1916 , is one of the best stallion foals she has ever produced, and I think $\$ 350$ is a moderate estimate of his value.

"I have sold seven of her colts for" $\$ 5,000$ in cash, and still own four, valued conservatively at $\$ 2,150$. Fany has been a regular work mare, and has done as much work as any mare I have ever owned, taking her turn in the teams most of the time the year around. She has never been shod except when I have chosen to take her out to county and district fairs, but it is interesting to note that I have won more in prize money by exhibiting her than the mare herself cost. Her daughters have been prolific, have reared excellent colts, and I believe that two of them will in time make a better record than the old mare as money-makers.

"I have never made an investment that has paid me as well as the purchase of this mare."
} 
of what a small breeder can do if he has a good mare to start with.

Among the many other breeders whose operations were more extensive than the average were Manuel Cross, A. J. \& W. J. Lasby and D. N. Tollman.

Most of the Percheron breeding in Minnesota, however, was conducted by farmers who had from one to three mares. The large establishments which had made this state famous in an earlier period, notably those of Leonard Johnson and the Minnesota Percheron Horse Co., had for the most part been dispersed. The mares passed at moderate prices into the hands of farmers who have built up Percheron studs of importance from a beginning of one or two mares.

The Hoosier Horsemen.-Indiana, sixth in Percheron breeding, had a total of 184 Percheron breeders by 1910 and 1,582 Percherons bred in the state were foaled during this period. A. P. Nave, George D. Enyart, C. A. Randolph, William Day, L. A. Rickel and Granville Kesling were among the most active Percheron breeders in the state. J. Crouch \& Son and L. W. Cochran were heavy importers and very active as dealers, influencing Percheron progress in the state to a marked degree.

J. Crouch \& Son, although strictly importers and dealers, were especially influential in encouraging Percheron breeding in Indiana as they imported a large number during this time. The horses which they brought from France to Lafayette Stock Farm 



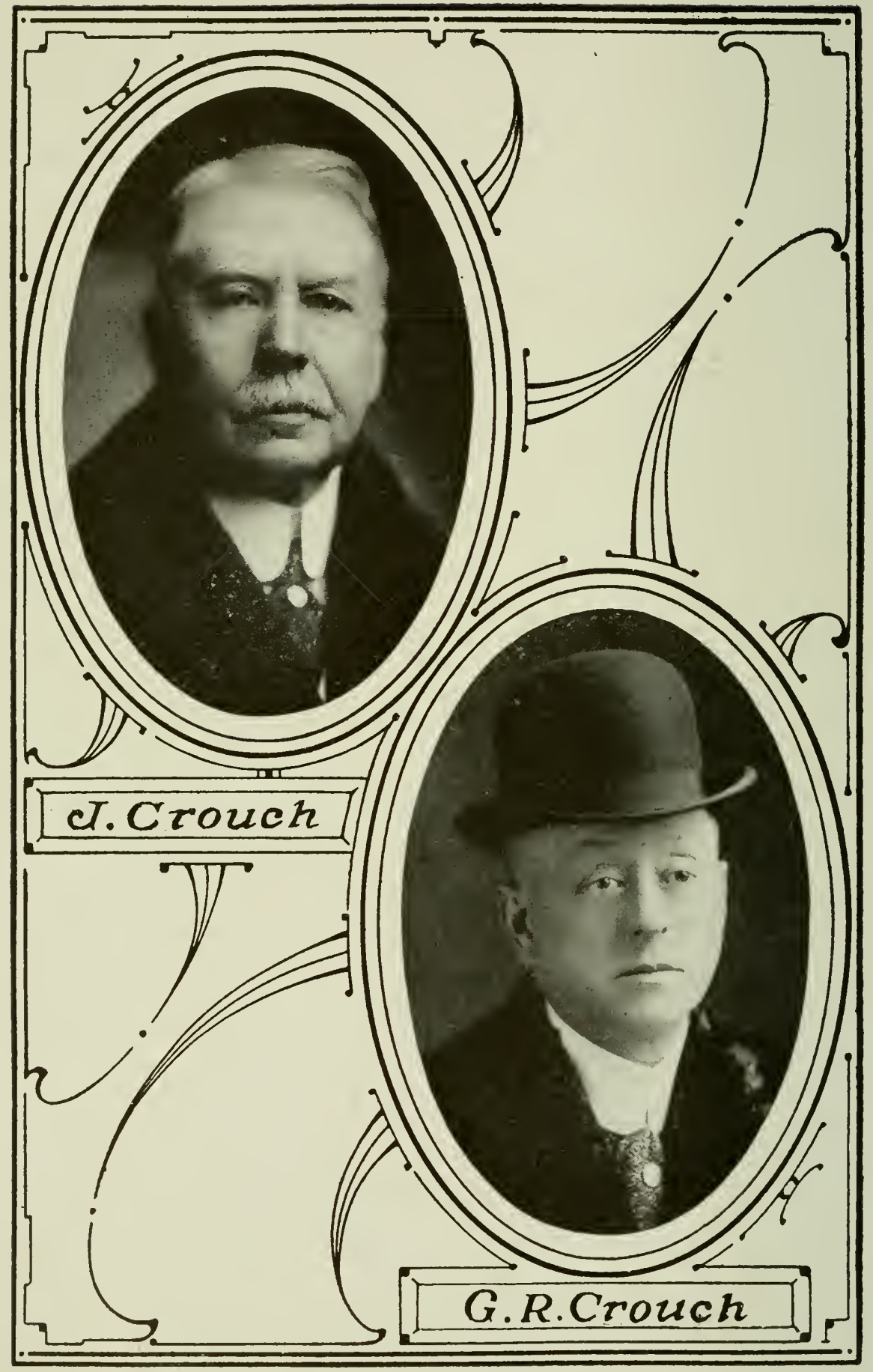


were high class, including many of the most noted prizewinners in France. Crouch \& Son were aggressive exhibitors in the showring, winning a large portion of the prizes at the Indiana and Ohio State Fairs, and at the International Live Stock Exposition. Through their widespread newspaper advertising they did a great deal towards popularizing Percherons in Indiana and adjoining states.

A. P. Nave was the most active and influential breeder in Indiana during the decade. The foundation of his Walnut Grove stud was laid in 1897 by leasing mares from M. W. Dunham, a number of which he subsequently purchased. He also made a number of purchases from William Rumney \& Sons, David Risser and the Stetson Estate in Tllinois, and was a heavy buyer of the best mares sold by John Huston, Blandinsville, Ill., in 1901.

The mares which A. P. Nave purchased for foundation purposes were among the best to be obtained in the United States at that time, and these were added to by importations from France. Mr. Nave has the distinction of being the first Percheron breeder in the United States to make importations of mares from France after the depression of the '90's. He also bought all the good mares he could find in various parts of Indiana and Illinois. One of the most important bunches of well-bred stock which he secured was purchased from Ben Miller, Mount Ayr, Ind. Mr. Nave also bought the entire stud of E. L. Packer, Toulon, Ill., as well as that of T. L. Newton, Beaverdam, Wis. Later Mr. Nave 
obtained the entire collection of John Hanchett, Big Rapids, Mich., which included the grand stallion Gauthier 57626 (70231). He also bought some very good mares from Robert Burnham, of Champaign, Ill., and from W. H. Parker, Maroa, Ill. These rumerous purchases of well-bred Percherons of good type gave Mr. Nave a most extensive band of more than average merit. He selected big, rugged mares standing around $16 \%$ to 17 hands in height, deepbodied, strong-backed, symmetrical, and of extreme draftiness. Those secured from the Huston stud were among the best; Minerva 31076 (43173), Rose 31068 (50734) and Lisa 31071 (46682) were well up in the prizelists at the 1902 International. Cora B. 22867, Castillonne 40389 (52602) and Julie 40388 (51192) were winners for Mr. Nave at the 1903 International, Castillone and Julie being first and second in the two-year-old filly class, while the best American-bred mare at the show was Cora B.

Brilliant 19648 was the first sire of importance used at Walnut Grove and proved a very effective breeder. He was followed by Abo 22626 (43517), a massive black horse standing 17 hands in height and weighing more than a ton. Abo was very potent, begetting a uniform lot of heavy-boned black colts.

Victoria 24449 (42905) was the most noted sire used in the Nave stud. He was one of the most famous sons of Besigue. Black, with a star and white hind feet, he was one of the largest sons of Besigue, standing over 17.1 hands high, and being 
deep-bodied, well-proportioned and of very massive type. He had been imported in 1900 by McLaughlin Bros., who sold him to Iowa. He came into prominence when his son Pink won the championship at the International in 1903. Two of Mr. Nave's imported show mares were sired by Victoria and he decided to make a trip to Iowa to locate the stallion. He found him in the hands of a farmer who had given him very poor care and who had no idea of his real worth as a sire. Mr. Nave had a favorable impression of his value, as he had seen many of his colts and knew that many of the best horses imported in 1900, 1901, 1902 and 1903 had been sired by him. He had imported some of these colts himself. He succeeded in purchasing Victoria at a moderate figure, but had an opportunity to sell him shortly afterwards to a breeder in Virginia, so that only a few colts sired by this stallion were bred at Walnut Grove.

Mr. Nave was among the first to hold public sales of Percheron horses, and his auctions in November, 1901, and in March, 1902, were important events in breed history. They were the first public sales of Percheron horses in eastern territory. Satisfactory prices were obtained, and the mares sold were distributed among many small breeders who now trace their success to this foundation stock.

All in all, Mr. Nave's work as a breeder, exhibitor and advertiser of Percheron horses was of greatest importance. He undoubtedly did more to encourage farmers to use Percheron mares on their farms than 
any other breeder in the state of Indiana during this decade.

H. B. Lyman, Lafayette, Ind., began breeding Percherons a little before the opening of the century. Among his foundation mares were Jessie 24942, bred by George Shawver, Lewiston, Ill., Celestine 12216 (22835), bought from Evan Jones, and Lafayette Fair 20783, bred by G. H. Van Dolah of Illinois. He also picked up a few good mares from other sources, and though his breeding operations were not extensive he produced some very good Percherons. Noble, bred by L. M. Yoder, was his first sire and left some excellent colts. Mr. Lyman's Percheron breeding was incidental to his other business and to his farming interests, but he bred and sold many Percherons in Indiana and contributed to the popularity of the breed.

C. A. Randolph, Fowler, Ind., established a Percheron stud in 1903 by the purchase of a few mares, most of which were bought in northern Indiana and central Illinois. These mares were not of the largest type, but had the quality, and the size was increased by mating to good sires. Protecteur 30043 (47573) was the first sire placed in service. He was an imported stallion, a dark-brown in color, but of good size and type; he left some excellent colts. He was followed by Trasbot 34694 (51036), and he in turn was succeeded by Glorieux 50743 (59261). Glorieux sired a few high-class colts, but was not so extensively used as Buck 44521, bred by Mr. Randolph and sired by Trasbot. Buck was used for several 
years and his colts were of very satisfactory type, with more quality than the average. Mr. Randolph was successful in the shomring with the sons and daughters of Buck, and this stallion undoubtedly contributed materially to the up-building of this breeding establishment. The horse was extensively used from 1908 until 1913. Mr. Randolph's dispersion sale on Jan. 30, 1914, was one of the most successful ever held in Indiana. Mr. Randolph's operations were not so extensive as those of some others in the state during this decade, but he was a man of high character and extremely popular in his community, so that his influence was much greater than the number of Percherons bred by him would indicate. He was unusually helpful in encouraging and assisting small breeders to get a start in Percherons.

William Day, Fowler, Ind., bred only 30 Percherons during this decade, but laid a strong foundation for later work. He, like numerous others among the smaller breeders in the state, was an aggressive champion of Percheron interests and assisted in popularizing the breed.

Wisconsin's Workers.-Wisconsin, serenth in Percheron breeding during the time under consideration, had a total of 269 breeders by 1910 and produced 1,388 Percherons of record during the decade. Fred Pabst and G. N. Mihills were the leading breeders in the Badger state. The Richland County Horse Co., the Hagemeister Stock Farm and C. D. Holt \& Son also produced a good many Percherons, and H. A. Babcock, Louis Lewellen, Jacob Burgy 
and James J. Boyd were influential in Percheron affairs during this time.

The Pabst Percheron business was greatly increased by the purchase of the entire stud of the Little Missouri Horse Co., of North Dakota, in 1906. This gave Fred Pabst a large band of high grade Percheron horses, including about 1,000 suckling colts that carried 3 or 4 crosses of Percheron blood. About 150 purebred Percherons were also included in this purchase, and while many of them lacked size on account of having been raised under range conditions, they were well bred and for the most part of good type and superior quality. More than 30 of these mares were retained in the stud and proved good breeders.

Mr. Pabst bought from the Hagemeister Stock Farm in the early part of the decade, and scattered purchases were made from H. D. \& F. A. Reed, the Hartman Stock Farm and various small breeders in Wisconsin. Duc 50740 (53786) and Mylord 54216 (64236) were the sires most in use, and both were effective in getting more size.

Mr. Pabst and his family controlled the Pabst Brewing Co., of Milwaukee, and employed there and in branch establishments nearly 800 draft geldings. Experience had satisfied Fred Pabst that grade Percheron geldings were the most satisfactory for heavy draft work in the cities, and his superintendent, James G. Boyd, has long been recognized as one of the shrewdest judges of durable draft geldings. Practically all of the horses pur- 
chased were high grade Percherons, and it was decided to exhibit a six-horse team. In 1904 a sixhorse team bearing the Pabst colors won the championship at the Louisiana Purchase Exposition and at the International. The exhibition of this great team at leading shows was another factor in popularizing Percheron breeding. Much credit is due t'ie Pabst establishment for showing the geldings at leading shows and for the exhibits of this firm at the Wisconsin State Fair. Erery effort was made to encourage and assist small breeders in obtaining a start in Percheron horses, and a large share of the credit for Percheron improvement in Wisconsin must go to the Pabsts, father and son.

G. N. Mihills, lumberman, had begun breeding Percherons in the '90's and continued throughout this period. He made a number of purchases from the Pabst Stock Farm and reserved many of the females which he himself had bred. In spite of his Percherons being a side issue, Mr. Mihills produced 100 of his own breeding during this period and made numerous sales throughout Wisconsin, assisting materially in the upbuilding the state's Percheron interests. Brentt 24062 and Ripon 22299 were the chief sires used in the early part of the decade. Both were valuable stock horses. Brentt was more freely used than Ripon.

The Richland County Horse Co. was composed of a number of farmers at Richland Center, Wis., who purchased a band of mares in 1905 . J. W. Martin and R. C. Lybrand were the leading spirits 
in the movement. Although the mares were purchased and the business was conducted in the name of the Richland County Horse Co. the mares were in reality owned by the individual farmers. The stallions were owned by the company. The mares were purchased from various sources, but mainly in southeastern Iowa. They were of the rugged, drafty sort, but some were lacking in finish. While the Richland County Horse Co. bred many Percherons during this period, very few of the farmers gave sufficient care and feed to their horses to obtain the best results. The criticism generally lodged against the colts bred in Richland county was that they lacked size, frankly admitted to be due to lack of feed. A number of browns, chestnuts and bays were produced from this stock, which did not add to its popularity. All in all, however, the efforts of the farmers in the Richland County Horse Co. resulted in popularizing Percherons in that part of the state and induced more farmers to make a start with better horses.

The Hagemeister Stock Farm, C. D. Holt \& Son and Lewis Lewellen bred some good Percherons and sold many to local buyers. None of these firms did much in exhibiting at the leading shows, though Lewellen has been more active in later years and has made many exhibits of highly creditable Percherons at the Wisconsin State Fair. Mr. Lewellen also sold the foundation mares which P. F. Wickham of South Dakota used in founding his stud. The Lewellen mares have proved profitable in the 
hands of later owners, as they have been regular producers of saleable colts.

H. A. Babcock's work was limited during this decade, but the horses he did breed were superior. Had his operations been larger Wisconsin's draft horse interests would be further advanced.

James G. Boyd, of Milwaukee, Wis., bred a few Percherons on his farm near that city. His preference always has been for the thick, drafty, easyfeeding lind, and while the horses which he had produced have not been so large as the Percherons bred in Illinois and Iowa, they have effected a decided improvement in the stud where they have been used. Most of Mr. Boyd's sales were made in Wisconsin, though he sold some Percherons to go to Canada. He has always been an aggressive champion of Percheron interests and because of his position as superintendent of the Pabst stables, for which he has purchased thousands of geldings, he has exerted a potent influence for draft horse improvement in the state.

Work in Nebraska.-Nebraska, eighth in Percheron breeding during this period, had a total of 229 breeders by 1910, and 1,518 Percherons bred in the state are recorded as foaled during this decade. North \& Robinson and M. M. Coad were the leading breeders, but Uehling \& Golder, Rhea Bro.. and James A. Barr were also active.

North \& Robinson had a large ranch near Cairo, Neb., and practically handled their mares under ranch conditions. During part of the time the stal- 
lions ran in pasture with the mares. The firm made heavy imporations, mainly of stallions. The mares were purchased from many different sources, but chiefly in Illinois and Iowa. The trade was largely with the ranchmen of the west and the colts were raised in the pasture, so that many of them did not develop so much size as was to be found in the Percherons of Illinois and Iowa, but they were rugged, hardy youngsters, thoroughly accustomed to the range and profitable to the men who purchased them. The firm conducted numerous public sales, advertised liberally especially in the west, and exhibited to some extent at the Nebraska State Fair. North \& Robinson contributed materially to the building up of draft horse interests in the northwest and to the popularization of Percherons in that territory.

Mark M. Coad's stud was continued on the lines already discussed, until his Percherons were dispersed about 1905. It was unfortunate that they received so little feed and attention, as they were of superior breeding. Despite the fact that Mr. Coad's horses were not well grown out, they were of such type and quality as to win high honors year after year at the Nebraska State Fair and their merits were recognized by shrewd Percheron breeders. The mares bred in this stud were widely distributed, and their descendants have been found in many good breeding establishments, notably those of J. E. Wilson and Thomas Trvine of Minnesota, C. H. Winship, William Thatch, Rhea Bros. 



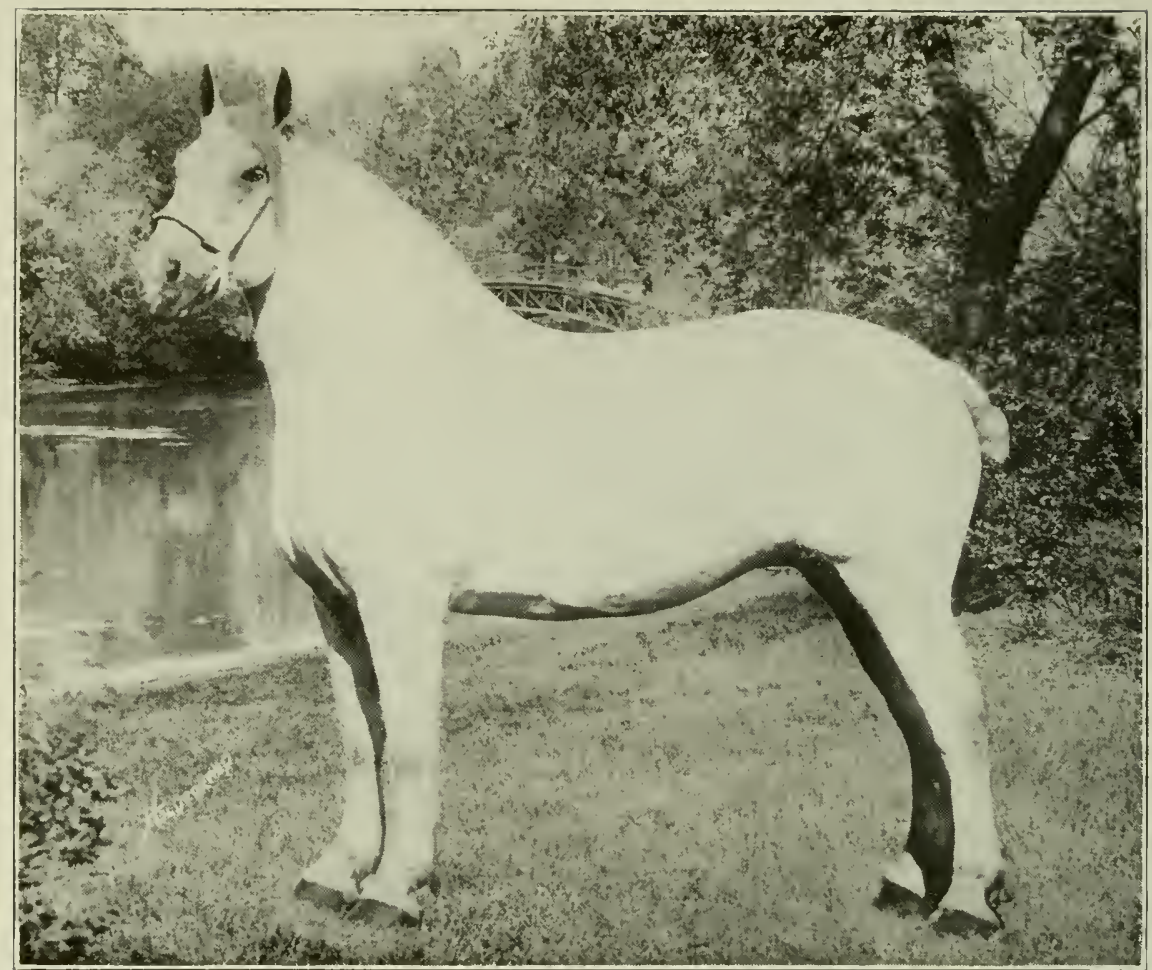

LE BELLE 34989, BRED IN \$OU'TH DAKOTA, DEVWLOPEi) IN IOWA, AND NOW OWNED IN VIREINIA. A GREAT BROOD MLARE. CHAMPION AMIERICAN-BRED HARE AT INTERNATIONAL LIVE STUCK EXPOSITION IN 1911.

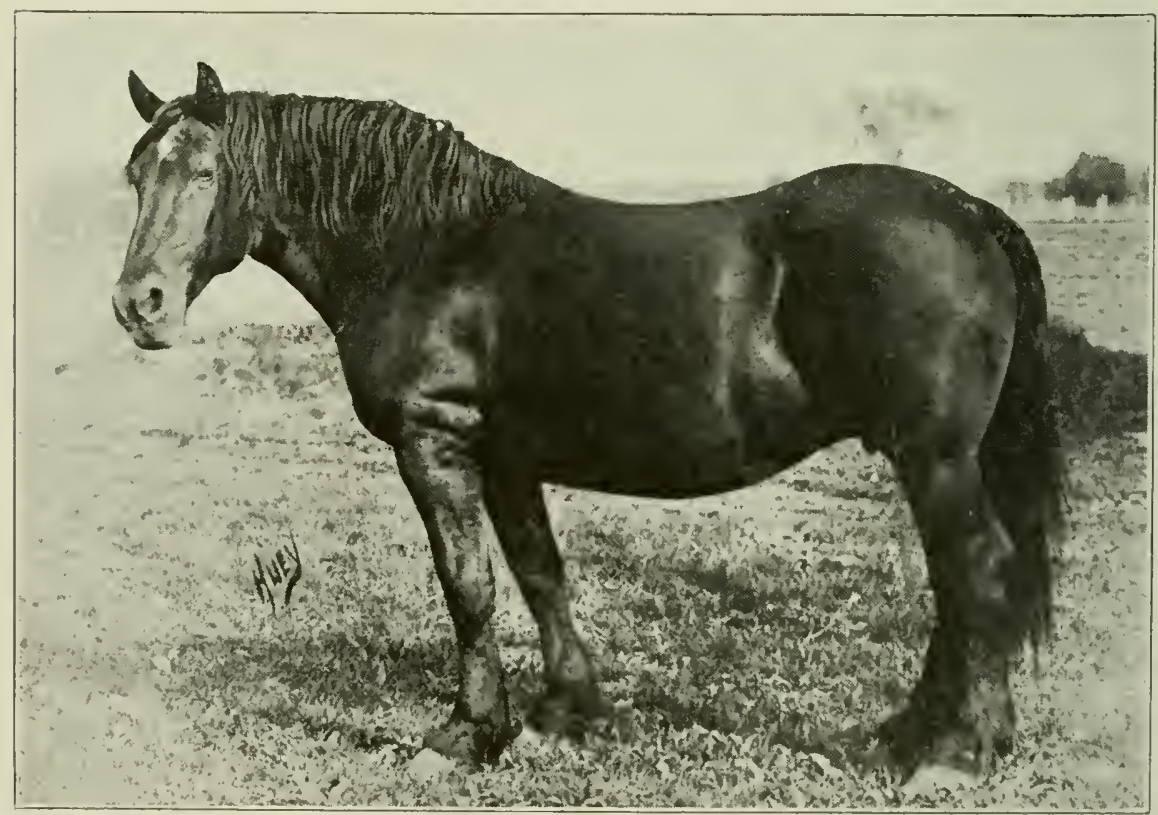

I'ERCILRUN MARE GEORGIANA 2S622. TAKEN AT 22 YEARS OF AGE AFTEK SHE HAD PRODUCED 19 LIVING FOALS. 
and E. T. Graham of Nebraska and James H. Letts of Iowa. One of the best brood mares ever used at the Missouri Agricultural College came from the Coad stock, and many of the good Percherons in southwestern Iowa now trace to this breeding. Mark M. Coad left a profound impression upon Percheron breeding west of the Missouri River, and did more to popularize the breed in that country than any other breeder of his time.

The work of Uehling \& Golder, Rhea Bros. and James A. Barr already has been discussed in earlier chapters. All continued breeding Percherons throughout the entire decade, and all made improvements in the size and quality of their stock. There were numerous smaller breeders in the state.

North Dakota's Great Range Project.-North Dakota, ninth in Percheron breeding during this decade, had a total of 160 breeders of Percherons by 1910 , and 765 Percherons of record were bred in the state during this period.

The Little Missouri Horse Co. had the most important breeding establishment. While the stud was dispersed in 1906, the work done by this breeding establishment was uniquely important and representative of the improvement of range horses.

The story of the Little Missouri Horse Co. is a romance of itself. A. C. Huidekoper, while hunt. ing buffaloes in North Dakota in 1880, was so impressed with the good grasses there that he started a cattle ranch. The heavy winter losses in '86 and '87 caused him to swing to horses, and in 1889 
he took 7 Percheron stallions and 26 mares to the ranch, about 30 miles south of Medora, S. D. With this seed stock he began the improvement of about 500 grade horses. Many of the mares were of the trotting type, weighing not over 900 pounds. The work of grading up this mixed band of mares until in 1906 the holdings numbered more than 4,000 head, with approximately 1,000 foals branded that season, all of true Percheron type, was an object lesson of incalculable value to western horsemen. Some size was lacking, due to the fact the colts were raised on the range without grain, but the grades matured at weights from 1,500 to 1,800 pounds and were so uniformly good that the type became famous among marketmen. Mr. Huidekoper, commenting on his reasons for preferriing Percherons for his work, says:

"I can not refrain from calling attention to the activity of the Percheron horse. My experience at the ranch taught me that a Percheron stallion turned into a large corral will take the exercise that he requires to keep him in good, serviceable condition. Furthermore, he does it intelligently. When first turned out he takes several minutes to play, to work off his surplus spirit, and then looks over the corral to see what is going on outside. He watches the men at the cookhouse, the men at the stable, the people around the ranch. If he sees a cowboy saddling up, he knows the rider is going out to get the harem. During the interval of waiting he trots around and around his enclosure, and takes his exercise like an athlete in training. This disposition of the Percheron to be active and to keep 
himself in serviceable condition we considered to be of decided economic importance on the ranch. Our Percherons, as the result of their activity proved surer than any other draft horses we used. Our Percheron stallions proved to be the most prepotent of any draft sires we ever used. So marked was their impress on the range mares that the Percheron foals could be picked out without difficulty or question."

Jericho 12609 (18827) was one of the first stallions used. Included in the importation made by Mr. Huidekoper in 1889, he was a high-class horse, heavy-boned, with great finish, and weighed over a ton. He was a horse of showyard caliber in use on a ranch, and while his merits seemed wasted in some degree, his type was so distinctive that he proved an extremely valuable sire on the purebred mares, as well as on the grades. One of the best stallions used later was Rival 22471, bred on the ranch and sired by Jericho. Although range-bred he weighed over a ton and was a beautifully balanced, deep-bodied, heavy-boned, symmetrical horse of real showyard character. Peer 14379 was another range-bred sire of much the same type, but smaller.

The Percheron sires used by the Little Missouri Horse Co. were so notably successful that the draft stallions of other breeds were soon discarded. The colts by the Percheron sires were uniform in type, whether from large or small mares, and were so like the sires in conformation, symmetry, quality and spirit that they proved to be durable, saleable 
horses. A large number of the geldings were shipped to the breaking and fitting stables at Conneaut Lake, Pa., from which they were sold to ice companies in Boston and New York. These horses averaged about 1,550 pounds each, although some of them weighed more than 1,800 pounds. The brand proved a handicap, but the true worth of the horses overcame this difficulty.

Here was a powerful influence at work in favor of the Percheron breed for range conditions. Horsemen from all over the northwest came to this ranch to study the results obtained and to purchase rangebred sires for use on their own grade stocks. The purebred Percherons proved as hardy as the rangebred grades. The Percheron mares lived on the range both summer and winter. The stallions were taken up late in the fall and fitted for spring service. The Percherons proved durable, adaptable, hardy, and preeminently suited to the improvement of the light-weight range-bred mares. No other breeding establishment in the northwest carried out such a persistent and extended campaign along well-defined lines in the improvement of the native horses. The fact that the Huidekoper family possessed an eastern establishment where the horses could be broken and fitted for sale was another factor of importance, as it provided for the placing of these range horses on the leading eastern city markets on the basis of their true value as draft horses. The brand became so well known in the eastern markets that horses of this type and breeding 
speedily came into general demand in spite of the prejudice against branded western horses.

Work effected in North Dakota by the Little Missouri Horse Co. was far-reaching, resulting to a greater extent than that of any other breeding establishment in the northwestern states in popularizing Percherons for use on the range. Great credit must be given to A. C. Huidekoper, who founded this enterprise and to Earle C. Huidekoper, who as general manager after 1896 directed the systematic improvement of the horses bred on this ranch. Percheron breeders generally have known little of the work of this breeding establishment, and it has been belittled by some on account of the fact that some of the Percherons raised there, which subsequently passed into the cornbelt states through Fred Pabst's stud, were lacking in size. This was due to the fact they were raised under range conditions and was not traceable to any weakness in the foundation stock. The story of the work of the Little Missouri Horse Co. is an epic of the northwest. It is fitting that due credit should be given in the history of the Percheron to the mighty influence wielded by this stud in the development of Percheron interests on the ranges of the west.

The Riverside Ranch Co., controlled by Cosgrove Bros. of St. Paul, carried out on a somewhat smaller scale the same kind of work that had been done by the Little Missouri Horse Co. This stud was closed out just before the beginning of the century, and reference is made to it here on account of the fact 
that the horses bred on Riverside Ranch were distributed into some of the leading studs in Canada and their descendants are to be found today among the Percherons owned by George Lane, D. J. Wylie and Upper Bros.

White Bros., C. F. White, O. O. Ellison, P. A. Manseau and the Coal Harbor Stock Farm were other North Dakota Percheron breeders of importance during this time. None of them bred a large number of Percherons, but they did produce good horses and by their work in distributing Percheron sires aided in popularizing the breed for range horse improvement. P. A. Manseau, in particular, although a small breeder, was instrumental in encouraging many other farmers and ranchmen to engage in Percheron breeding in a small way, and many of the studs now in North Dakota owe their existence to the encouragement which he gave.

Progress in South Dakota.-South Dakota, tenth in Percheron breeding, had a total of 171 breeders by 1910, and 701 Percherons bred in the state were foaled during this period. Alex. Miller was the leading South Dakota breeder of this period, but his work practically ceased in 1905. During this halfdecade, however, he bred 54 Percherons of record, and his mares which passed into other studs have since made history. Miller-bred mares have won the highest honors at the International. La Belle 34982, one of the daughters of Brunelles 11415 (12162), was the champion American-bred mare at the International in 1911, and is today one of the 
greatest brood mares of the breed. Mr. Miller was one of the really constructive breeders of Percherons and South Dakota suffered a loss beyond calculation when he found it necessary to curtail his Percheron breeding operations.

J. J. Fry, James R. Warden, W. H. Miller, A. D. McClelland \& Son, Hugh MeGlinchy and M. A. Hommersand were other leading breeders in the state. None of them bred a large number of Percherons, but they produced horses much above the average in the state, and by their work and their exhibitions at local shows did much to raise the standard of the draft horses in the state.

Marked improvement in the common horses produced in South Dakota was effected during this time, and the average selling price of Dakota-bred geldings advanced decidedly because of the widespread distribution of Percheron sires, due largely to the work of the small breeders.

In Other States.-Michigan, Missouri, Pennsylvania, Virginia and California were the eleventh, twelfth, thirteenth, fourteenth and fifteenth states respectively in Percheron breeding. Colorado, Montana, Washington, New York, Oklahoma and Oregon followed in the order named. Michigan bred 686 Percherons of record during this decade, and Oregon, the last named, is credited with 107 for the same period.

Michigan.-In Michigan Henry C. Waldron, A. A. Palmer, C. Kern and John Hanchett were the leading breeders. Mr. Hanchett in particular had some very 
good mares and a sire of unusual excellence, but he found it necessary to close out his holdings and his entire bunch was sold to A. P. Nave of Indiana. Progress in Michigan was relatively slow on account of the fact that the farmers were not accustomed to using heavy horses and did not realize their advantages over lightweights. The persistent work of the breeders named and a number of others was effective, however, in gradually educating them to the advantages accruing from the use of draft horses, and large numbers of grade drafters and many purebred Percherons have been shipped into the state in the last 5 years.

Missouri.-In Missouri A. M. Walker, J. W. Barnhart, J. F. Roelofson, N. S. Cox and J. M. West were the leading breeders. Mr. Walker bred almost as many as his three leading contemporaries. Progress in Missouri was slow because Missouri farmers were more familiar with mules than with draft horses. The belief that draft horses would not stand the hot weather was another retarding factor. Besides, scalpers and speculators did a great deal of harm by purchasing coarselegged horses which were at a discount in draft horse breeding sections and disposing of them to men in Missouri, who on account of their unfamiliarity with good draft horses did not know that they were being supplied with inferior stock. The certain failure of these stallions created a prejudice against all draft horses which the Percheron breeders in Missouri found difficult to overcome. However, their persistent work in 
selecting Percherons of good type and quality, well adapted to stand hot weather, and the success which they themselves achieved in using Percherons in Missouri, even during the hot weather, gradually had its influence upon farmers. Within the last 8 year's a large number of draft horses, both grade and purebred, has been taken into Missouri, particularly into the northern part. While no studs of national reputation have been developed within the state, some very good horses have been bred there and the number of breeders has been very greatly increased.

Pennsylvania.-In Pennsylvania William Paden, Bond Bros., George A. Hogg and Powell Bros. were the leading breeders, and the Little Missouri Horse Co., which continued in a small way after closing out its holdings in North Dakota, also bred quite a number of Percherons in Pennsylvania. Sales within the state were limited, however, as Pennsylvania farmers in general have been slow to use heavy horses. A disposition prevailed for many years to buy young western horses in thin condition for farm work, disposing of them when they reached maturity. This policy retarded Percheron breeding and the state has never produced as many horses as actually are needed for its own use. The work of the few breeders located in Pennsylvania did, however, favorably influence draft horse breeding in the state and the number of draft mares kept on Pennsylvania farms is being slowly but surely increased. 
Virginia.-In Virginia John F. Lewis, E. B. White, D. M. Cloyd and Charles Edgar were the leading breeders during this period and there were many other smaller breeders scattered throughout the state. Charles Edgar's stud was dispersed about the close of the decade and most of the Percherons owned by him were shipped west. The John F. Lewis stud was dispersed a little later, but most of these horses were distributed in Virginia and adjoining states.

O. E. Jordan.-Located in the extreme southwestern part of Virginia, Mr. Jordan did a great good for Percheron interests. The Jordan family has been breeding Percherons persistently since early in the eighties, having used some very excellent sires, including the stallion Victoria 24449 (42905), sire of the champion Pink. While none of the breeders in this particular district has bred many Percherons they have had horses of very superior type and with perhaps more size and real draft character than most of those produced in Virginia. Mr. Jordan's operations have been more far-reaching and have exerted a more favorable influence on draft horse breeding than the number of Percherons he has bred would indicate.

Selma Farm.--E. B. White began breeding Percherons in 1903, and today his stud is recognized as one of the high-class breeding establishments of the United States. The Selma Farm stud was started in 1903 by the purchase of 2 mares from the Hartman Stock Farm. In 1904 the two first-prize 



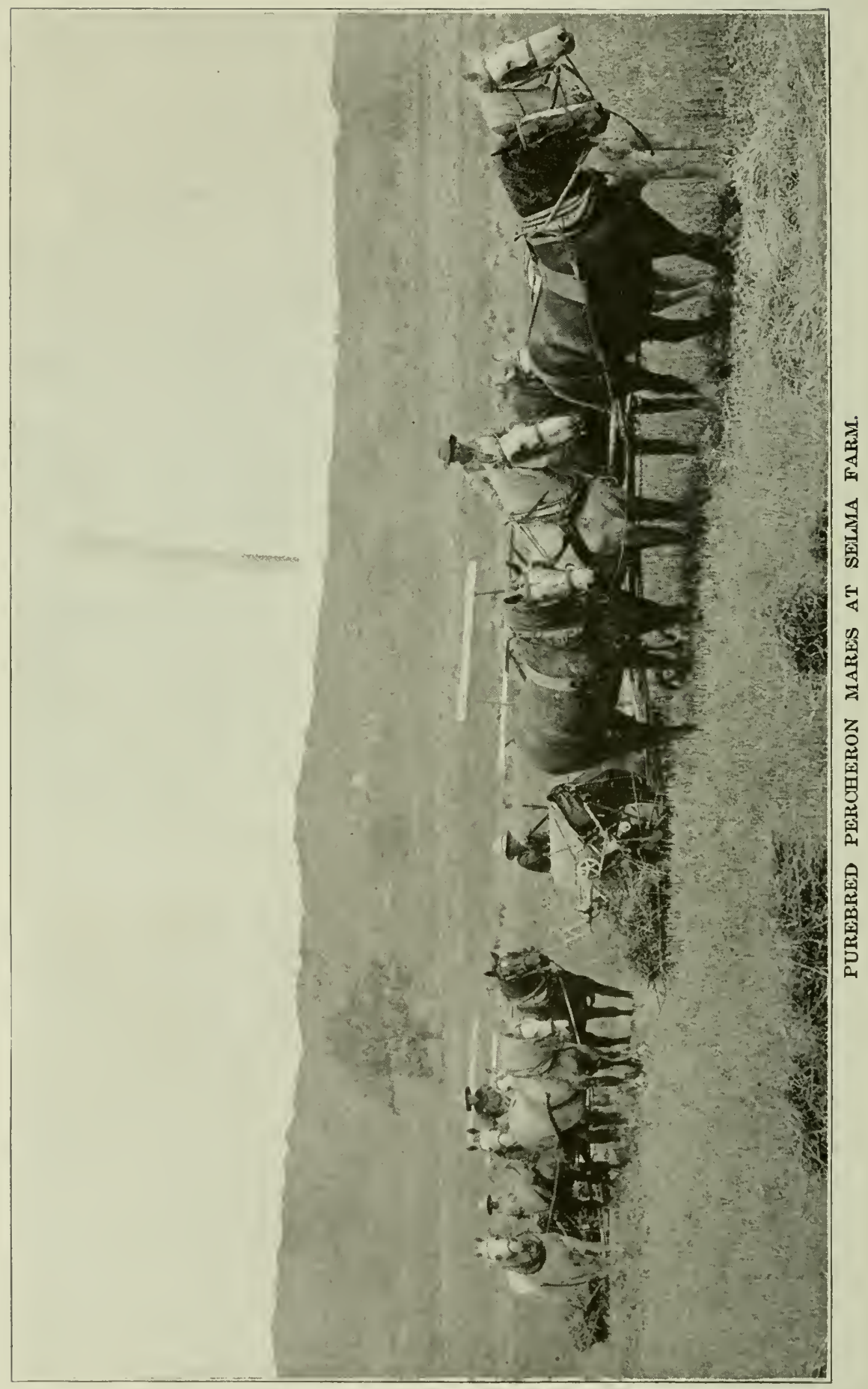


mares at the St. Louis Exposition, Zaza 24618 and Fauvette 27223, were purchased from J. C. Robison of Kansas. Both of these mares were daughters of the famous brood mare Fine 13085 (26998), imported by TV. L. Ellwood. Mr. White made additional purchases from time to time, seeking to obtain the best mares possible. He imported 23 mares from France, a number of which were noted in the showring. Besides these Mr. White purchased some noted American-bred show mares. The Americanbred mares and their produce proved more satisfactory in the stud than the imported mares. Practically all the best horses produced at Selma Farm have been bred from the mares secured in this country.

One of the first stallions used by $\mathrm{Mr}$. White was Sam 52055 (54508), third-prize winner at the International in 1906; he left some good colts, which have been successful sires. Cassius 35839, which Mr. White purchased as a stallion foal at the side of Zaza in 1904, was also used to some extent. Mr. White's determination to have the best Percherons possible to obtain lead him to purchase Etudiant 70802 (59291), which he imported in 1909. Etudiant was at that time considered one of the best individuals in France and had quite a reputation as a sire. He stood about 17.1 high and was deep-bodied, massive, well-proportioned, and of drafty type, with extraordinarily heavy muscling in the quarters and haunches. He was open to some criticism for being somewhat too straight in his hind pasterns, but he 
was a horse of excellent type and quality and weighed 2,100 pounds. Etudiant had beaten Carnot 66666 (66666) at the Percheron society show at Nogent in 1909 and was being fitted for exhibition at the 1909 International Live Stock Exposition when he contracted influenza which settled in his testicles and made it impossible to show him. This practically ruined him for breeding purposes for some years following. He begot only 7 purebred colts while in use at Selma Farm and for this reason did not materially influence the development of the stud.

Dragon 52155 (63516), champion at the International in 1907, was obtained by $\mathrm{Mr}$. White to succeed Etudiant and results from his services have been so satisfactory that he is now properly ranked among the leading sires of the breed.

Selma Farm is one of the few breeding establishments in this country where particular emphasis has been placed on quality and uniformity in type and conformation. The foundation mares selected were the best that could be obtained in France or America, and while numerous disappointments were encountered in securing a sire of the first rank, some excellent colts were got. The policy of retaining the best animals in the stud and eliminating all that did not come up to the desired standard in type and quality has given Selma Farm one of the most uniform bands of Percherons now existing in the United States. During the period considered this stud has been the most important factor in 
Percheron breeding in the eastern part of the United States. The work done at Selma Farm influenced others to establish studs in the eastern states and many small breeding establishments there now have animals tracing to this stud.

California.-In California no studs of outstanding importance were developed during the decade, but J. F. Spaulding, J. W. Johnston, Mrs. Eschleman Sherman, H. T. Liliencrantz and the California Polytechnic School all had establishments of some consequence, which aided in the improvement of draft horses in the state. Conditions in California, however, have not been favorable to the development of draft horse interests. There are but two seasons, one wet and one dry, and the long dry season has been particularly favorable to the use of tractors. Besides this, the tendency to operate California farms in large areas devoted to small grain lead to the employment of large numbers of men whose knowledge of horsemanship was so rudimentary as to make it unsafe to trust them with good draft mares. Mule teams and tractors were mostly used, so that horse-breeding interests in California have been greatly retarded and it is doubtful whether the state will ever come to the general use of draft horses in any such degree as prevails in the Mississippi Valley. Great progress has been made in recent years, however, and more Percherons are being purchased than ever before.

Colorado.-In Colorado A. J. Zang, the Yampa Live Stock Co. and Nels Shuland were the only breeders 
with any considerable number of Percherons, but there were many small breeders who bred a few. A. J. Zang bought some good mares and an unusually high-class stallion in founding his stud and the horses he has bred have been very favorably commented upon by some of the best judges in the United States. The stallion Champagne. 51743 (65402), used in the stud practically from its inception, proved extremely prepotent and his colts are characterized by uniformity in type and by excellent quality. The persistent work done in this stud has aided in large measure all Percheron-breeding interests in Colorado. The greatest progress in this state, however, has been made in grading up the native range horses, in which Percherons have had the leading part. The free use of Percheron stallions on the native horses in Colorado has increased the size, improved the symmetry and conformation, and brought about such improvement in the general type and quality of the horses that they are worth from two to three times as much as the native stock from which they sprang. A large proportion of the range horses in Colorado, Wyoming, Montana and other western states, carrying from two to three crosses of Percheron blood, have weighed from 1,350 to 1,500 pounds at maturity, even when raised under range conditions without grain feed, and have made admirable heavy artillery horses for use in the European war. Hundreds of thousands of these good western-bred horses have been purchased and shipped abroad for artillery and cavalry uses. The 
horses produced in Colorado, Wyoming, Montana and adjacent states by the use of Percheron blood have been much alike in type and conformation and have yielded a handsome profit to the ranchmen who bred them.

Montana.-In Montana A. A. Sandahl, the Ball Ranch Co. and John F. Forbis were the leading breeders. A. A. Sandahl's entire stud was dispersed about the close of this decade, the majority of the horses going to Oliver Jenkins of California. No stallions of outstanding importance were used in the purebred studs in this state during the decade and the chief work done by the Percheron breeders in Montana was along the same general lines as in Colorado.

Washington.-In Washington the conditions were intermediate between those existing in California and those prevailing in Colorado and Montana. Progress was slow and was retarded in some degree by the fact that some inferior horses were sold at long prices by speculators and scalpers to inexperienced men. The work of the Percheron breeders in Washington has aided in overcoming this and in recent years better horses have been distributed throughout the state. P. W. Cox \& Sons, The Stooke \& Amery Ranch Co. and Fryer Bros. were among the leading breeders in the state and there were a number of small breeding establishments which have since grown to some importance.

New York.-No developments of importance took place in New York during the decade, except the 
establishment of the Heart's Delight stud at Chazy, N. Y. This stud, founded by the purchase of some very high-class mares, has gradually increased its Percheron holdings and bids fair to become one of the most important breeding establishments in the United States, when the quality and size of the animals produced are taken into consideration. The earlier stallions used were not particularly successful as sires, but Idlefonse 79307 (83004), champion at the 1913 International, was purchased at that show and is getting more satisfactory colts than the sires which preceded him.

New York has been slow in increasing its investments in draft horses; the tendency has been to purchase work horses rather than produce them. Percheron breeders scattered throughout the state are gradually overcoming this and it is probable that New York will in the future produce a much larger number of the horses needed than it has done in the past.

About all that occurred in most of the other states during this decade were the establishment and gradual development of small Percheron studs, many of which may prove to be of importance in the future.

Growth of the Percheron Society of America.The new association, organized Dec. 23, 1902, was known at that time as the American Percheron Horse Breeders and Importers Association. The capital stock was originally $\$ 10,000$. In August, 1905 , legal action was taken to change the name to The Percheron Society of America. The capital 



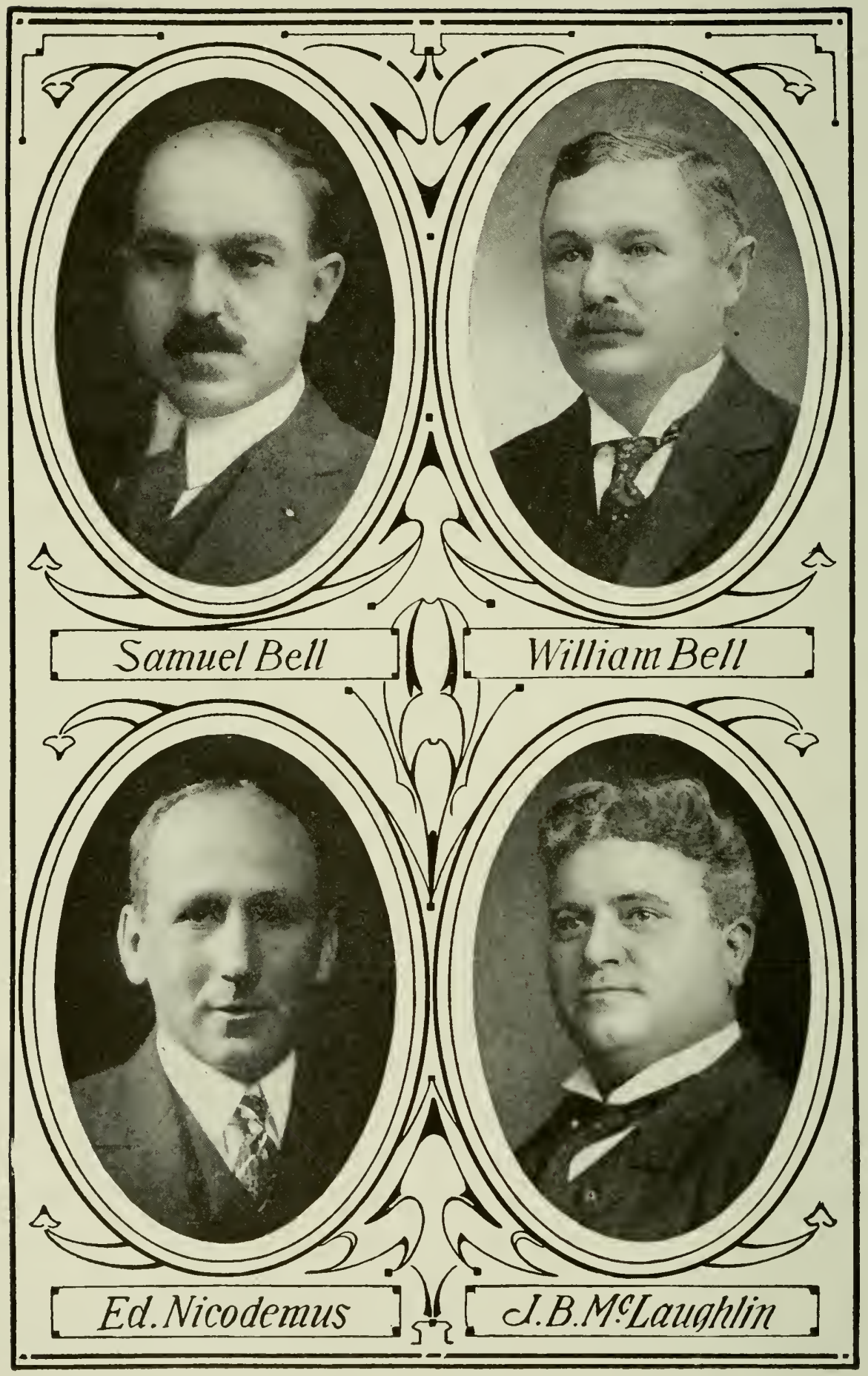


stock was increased to $\$ 20,000$ in February, 1907, and in July, 1908, was increased to $\$ 30,000$. By the time of the annual meeting in November, 1910, all capital stock had been sold, and there were many other breeders desirous of becoming members. The capital stock was, therefore, increased to $\$ 100,000$, consisting of 10,000 shares of $\$ 10$ each.

The growth of the association was extremely rapid, the membership having increased to almost 2,900 separate breeders, between December, 1902, and Nov. 28, 1910. In February, 1911, the McLaughlin interests, previously referred to, were absorbed by the Percheron Society of America, and this brought about an increase of approximately 100 members. The rapid expansion of Percheron interests, and the very considerable increase in number of breeders actually owning Percheron mares and engaged in the production of Percheron horses, led to an extraordinary increase in membership, excelled by but one association in America.

On Nov. 28, 1910, there were 3,000 shares of stock outstanding in the hands of approximately 2,900 members. At the close of the fiscal year, Oct. 31, 1916 , less than six years later, there were 8,330 shares of outstanding stock of the Percheron Society of America in the hands of more than 8,000 members. This membership was scattered over the entire United States and Canada, although Illinois, Iowa, Ohio and Kansas, pioneers in Percheron breeding, still held more than one-third of the total membership. 
Of registrations made, certificates of pedigree numbered from 1 to 35,912 were issued under the regime of S. D. Thompson, Secretary. The numbers from 35,912 to 40,000 are vacant. Some certificates above 35,912 bearing S. D. Thompson's signature were issued during a short period of conflict, but these have been declared null and void. Certificates numbered from 40,00 to 70,335 were issued under the administration of George W. Stubblefield, as Secretary. There are some vacant numbers in this 30,335 , due to the system of numbering in vogue at that time. Registrations from 70,335 on have no vacant numbers. All certificates of pedigree numbered above 70,335 to date have been issued under the administration of Secretary Dinsmore, beginning Aug. 1, 1910. Between Aug. 1, 1910, and the close of the fiscal year, Oct. 31, 1916, approximately 58,000 pedigrees were issued. The fact that almost 58,000 pedigrees were issued in the past six years, while the total number issued in the preceding 34 years amounted to approximately 65,000 , illustrates the tremendous expansion in Percheron breeding that has occurred in recent years. It also illustrates the fact that progress in breeding purebred live stock becomes cumulative as the years roll by.

A Canadian Association.-The Canadian Percheron Horse Breeders' Association completes the trio of great organizations engaged in promoting the Percheron horse. It was incorporated under the act respecting live stock record associations in Canada, Dec. 3, 1907, accepted all registrations 
made by the Société Hippique Percheronne de France, and the Percheron Society of America, the parent organizations, as valid, and has been actively engaged in the promotion of Percheron interests since that time. The actual registrations are made by the National Live Stock Records at Ottawa, as the Canadian registrations are made under a department of the Canadian government. The inauguration of this system was due largely to the fact that breeders were few and widely scattered, and lacked the financial organization necessary to properly care for the interests of many breeds which were represented in Canada by small numbers of breeders. This, combined with the paternal tendency of the Canadian Government, led to the establishment of the National Live Stock Records, which controls the registration of all animals in the Dominion of Canada. Associations of breeders exist, however, for each breed, and said associations receive a certain percentage of the fees paid in to the National Live Stock Records for promotion work.

W. B. Thorne, of Aldersyde, Alberta, was elected as first President of the Canadian Percheron Horse Breeder's' Association, and served from 1907 to 1911. F. R. Pike, of High River, Alberta, was SecretaryTreasurer from 1907 to 1915 inclusive. R. C. Upper was President during 1912, Geo. Lane in 1913, J. C. Drewry in 1914 and Geo. Lane during the years 1915 and 1916.

The work of the association has been to act in an advisory capacity on matters relating to the regis- 
tration of Percheron horses with the National Live Stock Records, decide upon the form in which the stud books shall be published, and to promote, by advertising, grants of special prizes, and in all other proper ways, the breeding of Percheron horses in the Dominion of Canada. The association has been handicapped by lack of funds, and the breeders generally consider that the plan of organization followed in the United States, where the breeder's of each kind of live stock control their own associations and attend to the registration and promotion work, is much more effective in promoting breed interests.

Percheron Breeding in Canada.-While some Percheron breeding had been done in the Dominion of Canada during the ' 80 's, as noted in previous chapters, relatively little progress was made by Percherons until after 1900. The population of Canada was, prior to that time, largely in the eastern part of the Dominion, and was made up in large part of settlers from Great Britain and Scotland, who, naturally, brought their own breeds of horses with them, had well settled preferences for the same, and were further encouraged to handle the British breeds rather than breeds drawn from the United States or the continent by the aggressive action of English and Scotch live stock men who employed many of the Canadian stockmen as agents in fact, if not in name, by furnishing numbers of animals on easy terms, to be sold in Canada. This naturally tied the Canadians by close business connections 
with the breeders in Great Britain and Scotland so that it was extremely difficult for other breeds to obtain any foothold in the eastern part of the Dominion.

With the development of the great Northwest, Percherons came into more general demand. Many of the settlers had come from the United States and were well acquainted with the advantages which Percherons possessed. Aside from this, extensive traffic in live stock and in many other lines of business sprung up between the provinces of western Canada and the western part of the United States.

The first extensive breeder of Percherons in western Canada was George Lane, of the Bar U Ranch. This great cattle outfit handled large numbers of horses, and $\mathrm{Mr}$. Lane, the managing partner, says as follows:

"When I first came to Canada from Montana, in 1883 , to take charge of the cattle on what was then the newly started Bar U Ranch, I was particularly impressed by the absence of horses such as we had been accustomed to in Montana, and some of the other western states. By this I mean horses that were able to do ordinary hauling and farm work, and that also had the endurance and the speed necessary for making long trips to the railroad, to the democrat or buckboard.

"After considering the matter carefully, and noting conditions in different localities, I came to the conclusion that it was Percheron blood that was lacking in the horses of western Canada. There were some excellent horses, particularly those sired by Thoroughbred stallions, but the majority of the 
horses were not equal in type or utility to the Montana Percheron grades I had been accustomed to. Having fully made up my mind that the Percheron horse was what was required in western Canada, I set to work as soon as I was able, to try and obtain some of the right kind. I secured and used some Percheron stallions on our grade mares, and in 1898 we purchased, from James Mauldin of Dillon, Mont., his entire herd of Percherons, known as the Diamond $\mathrm{O}$ bunch. This comprised about 35 head of Percherons of excellent type, conformation and quality. They were heavy boned, matronly mares, with the best of underpinning, and these mares proved to be producers of the kind of horses which breeders are always looking for. We also obtained about 1200 head of grade Percherons from Mauldin at the same time, and added these to our holdings of grade horses.

"The same year that we bought the Mauldin Percherons, we purchased the tops from the River Side Ranch Company's Percheron stud. These were known as the H. F. mares. These, added to the Diamond $\mathrm{O}$ mares obtained from Mauldin, gave us the foundation of our present Percheron stud.

"Among the earliest and best sires we used were Paris 12016 and Presbourg 29982 (48649). Both gave us good results, and Presbourg particularly proved to be an extremely prepotent sire of highclass brood mares. Experienced judges, in going over the band of mares in 1914 with a view to selecting the brood mares of the best type, picked on more Presbourg mares than mares of any other breeding, and these matrons have been noted as among the best producers in our stud.'

In $1906 \mathrm{Mr}$. Lane went to France and selected a few mares. He subsequently made importations in 



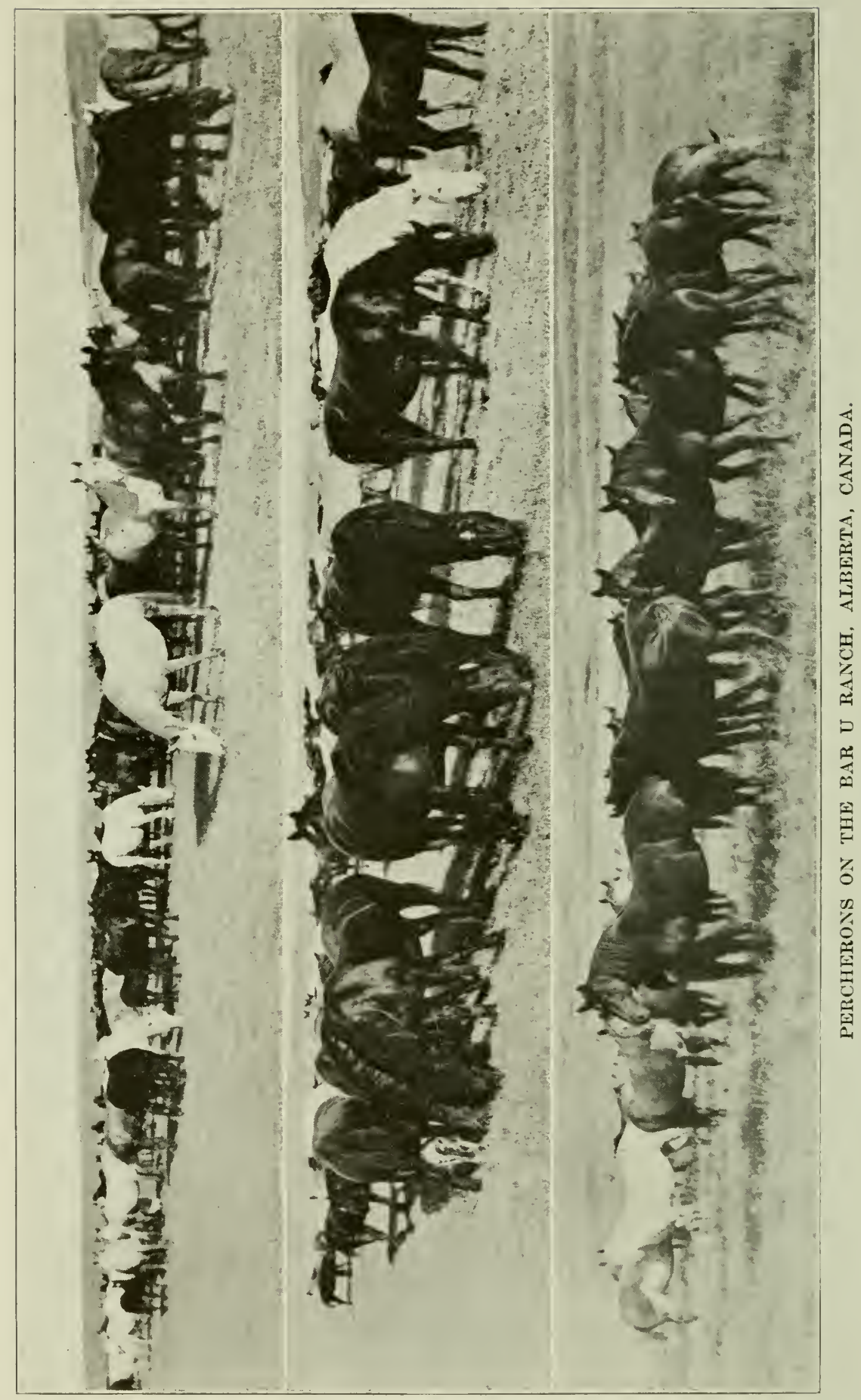


1908, 1909 and 1910, importing more than 100 head of the best mares he could find in France, and selected the best stock sires he could possibly obtain. The policy has been to keep practically all of the mares produced, and the stud now numbers considerably over 400 head of purebred Percherons, the largest single band of Percheron horses owned in the world. Halifax 60328 (75867), Pinson 57211 (63122) and Americain 61316 (63422) are the chief sires now in service.

The Percherons produced at the Bar U and Namaka ranches under the direction of $\mathrm{Mr}$. Lane are of superior type and quality. So good a judge as James Fletcher frankly stated that he did not believe any other breeder had 20 mares that were equal to the 20 best mares in this stud. Louis Aveline, who visited the stud in 1915, also stated that the Percherons being produced on these ranches were equal to any produced in France, and added that he did not believe it would be possible to select from any one establishment in France, at the present time, three stallions equal to the three stallions then in service.

Careful management and intelligent feeding have enabled Mr. Lane to produce Percherons of as much size as any produced in the cornbelt states. Over 90 foals were raised in 1915, and 117 foals were raised in 1916. Men who have watched the development of this stud for years are outspoken in their admiration of the Percherons produced. Present indications are that this breeding establishment will 
make a success, financially and otherwise, of the productions of Percherons on a large scale, as the demand for the horses produced is already in excess of the supply, and profitable prices are being paid for the horses in cash right at the ranches. Relatively little advertising has been done, and no mares have been sold except in small bands to Canadian breeders who desired to make a start in Percherons, but in spite of this, it has not been possible, to date, to produce nearly as many stallions as the trade called for.

W. B. Thorne of Aldersyde, Alberta, and S. A. Davenport of Acme, Alberta, are very aggressive breeders who have produced Percherons of showyard caliber, and who have been particularly aggressive in promoting Percheron interests in the Dominion.

J. C. Drewry established one of the larger Percheron studs about 1907 or 1908, purchased some of the best to be found in the United States, and had bred colts of very high-class character, achieving notable success in the showring, but his career was cut short by his untimely death in 1914. While the stud is still being carried on under the direction of the estate, the loss of Mr. Drewry, who was a good advertiser and particularly skillful in promoting Percheron interests through the public press, has been seriously felt by his fellow breeders.

There are numerous other smaller breeders in northwestern Canada, but it is impossible to discuss all. Great credit must go to the Percheron breed- 
ers of western Canada for their aggressive campaign in behalf of Percheron interests, confronted with hostile sentiment. They have made notable progress, and the breed is today the most popular one in Alberta, and is making very rapid headway in Saskatchewan and Manitoba. 


\section{GHAPTER XIII.}

\section{DISTRIBUTION AND STATISTICS OF PRODUC- TION IN THE UNITED STATES.}

The most accurate guide to the distribution of Percherons in the United States, so far as purebred breeding stock is concerned, is believed to be found in an analysis of the registrations made in the Percheron Society of America year by year. While this gives only the number of horses recorded from each state during the year under consideration, it affords accurate knowledge as to the distribution of purebred mares throughout the United States, and it is a matter of record in the reports of the stallion enrollment boards that the Percheron stallions are distributed in practically the same proportion.

The Percheron Society of America recorded 9,044 Percherons during the fiscal year ending Oct. 31, 1916; all but 140 of these were American-bred. Illinois, which has occupied front rank in Percheron breeding since the beginning, stood first with 2,014 head, or 22.27 percent of the total. Iowa, which from earliest days has followed closely after Illinois, ranked second with 1,772 registrations, or 19.59 percent of the total. Olio, the state to which the first Percherons were imported, was third with 747 registrations, or 8.26 percent of the total. Kansas, 


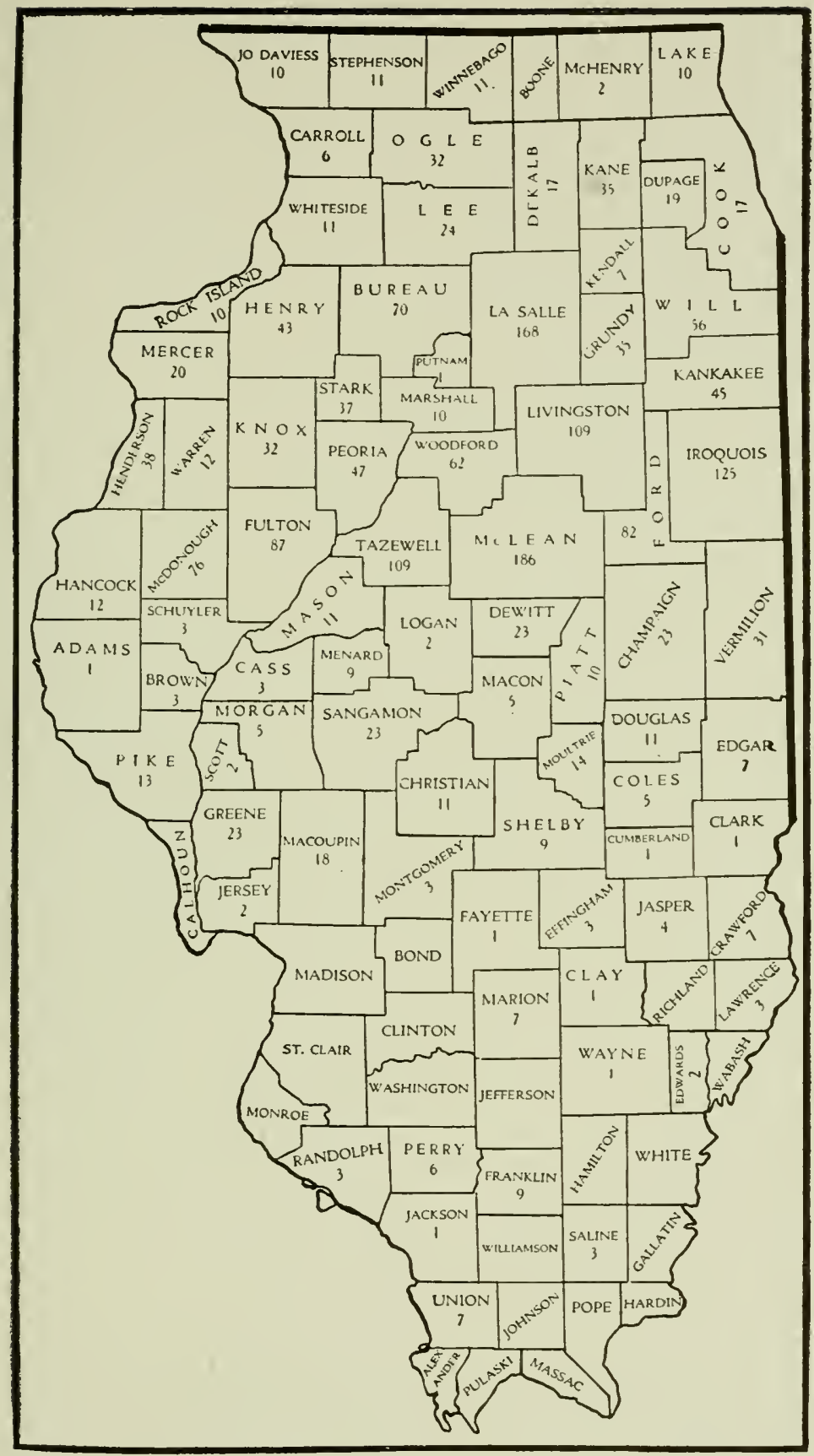

Illinois had in 19161,709 members of the Percheron Society of America. The total number of Percheron horses recorded from Illinois between Nov. 1, 1915, and Oct. 31, 1916, was 2,014. The number appearing in each County is the number of Percheron horses recorded from that County between Nov, 1, 1915, and Oct. 31, 1916, inclusive. 

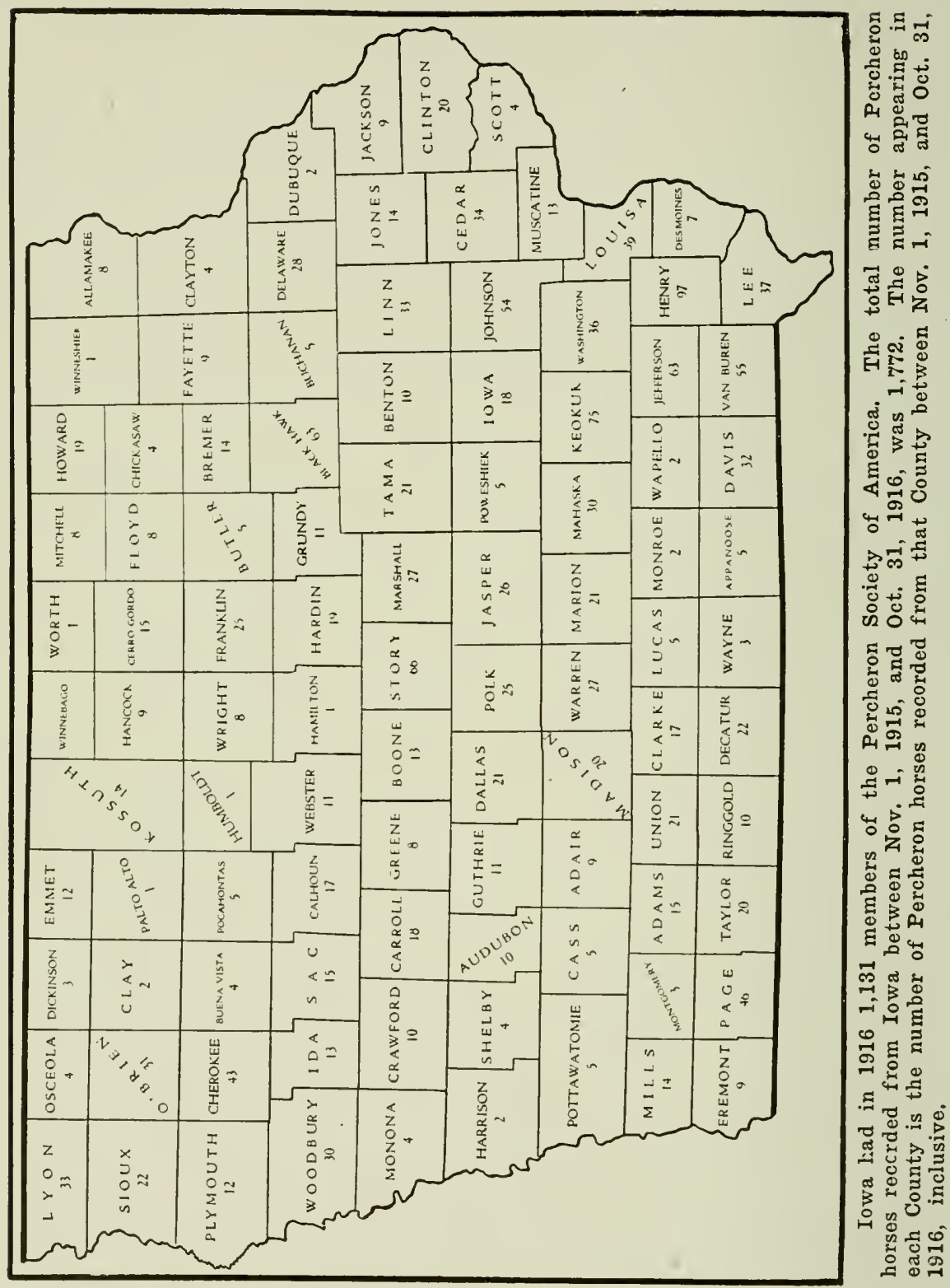

the leading Percheron-breeding center west of the Missouri River, stood fourth, with 653 head recorded during the year, 7.22 percent of the total. Nebraska came fifth, with 466 heqad, or 5.15 percent; Wiscon- 
sin, sixth, with 414, or 4.58 percent; Indiana, seventh, with 367 , or 4.06 percent, and Minnesota, eighth, with 347 , or 3.84 percent.

The rank of the other states was as follows:

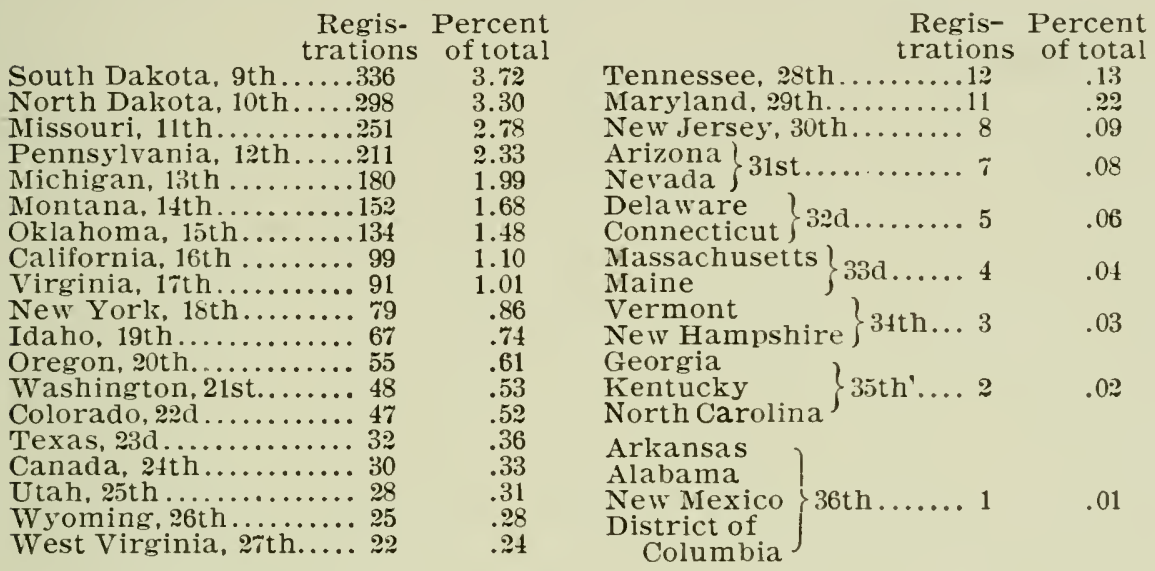

The tendency for the breeding of any class of live stock to become concentrated in districts where it was first introduced and where its merits are most widely known is indicated in this data. Illinois and Iowa contributed 41.86 percent of the total registrations recorded during the year, while more than half of the Percherons recorded were raised in the first three states-Illinois, Iowa and Ohio.

The first eight states contributed 74.97 percent of the total number of Percherons registered during the year, while all the other states combined contributed only 25 percent. Nevertheless, the wide distribution of Percherons in the United States is shown by the fact that they were recorded during the year from 45 states, counting the District of Columbia and Canada. The number recorded 
from Canada, however, was but a mere fraction of the total. Most of the Percherons in Canada are recorded in the Canadian Percheron Stud Book; the

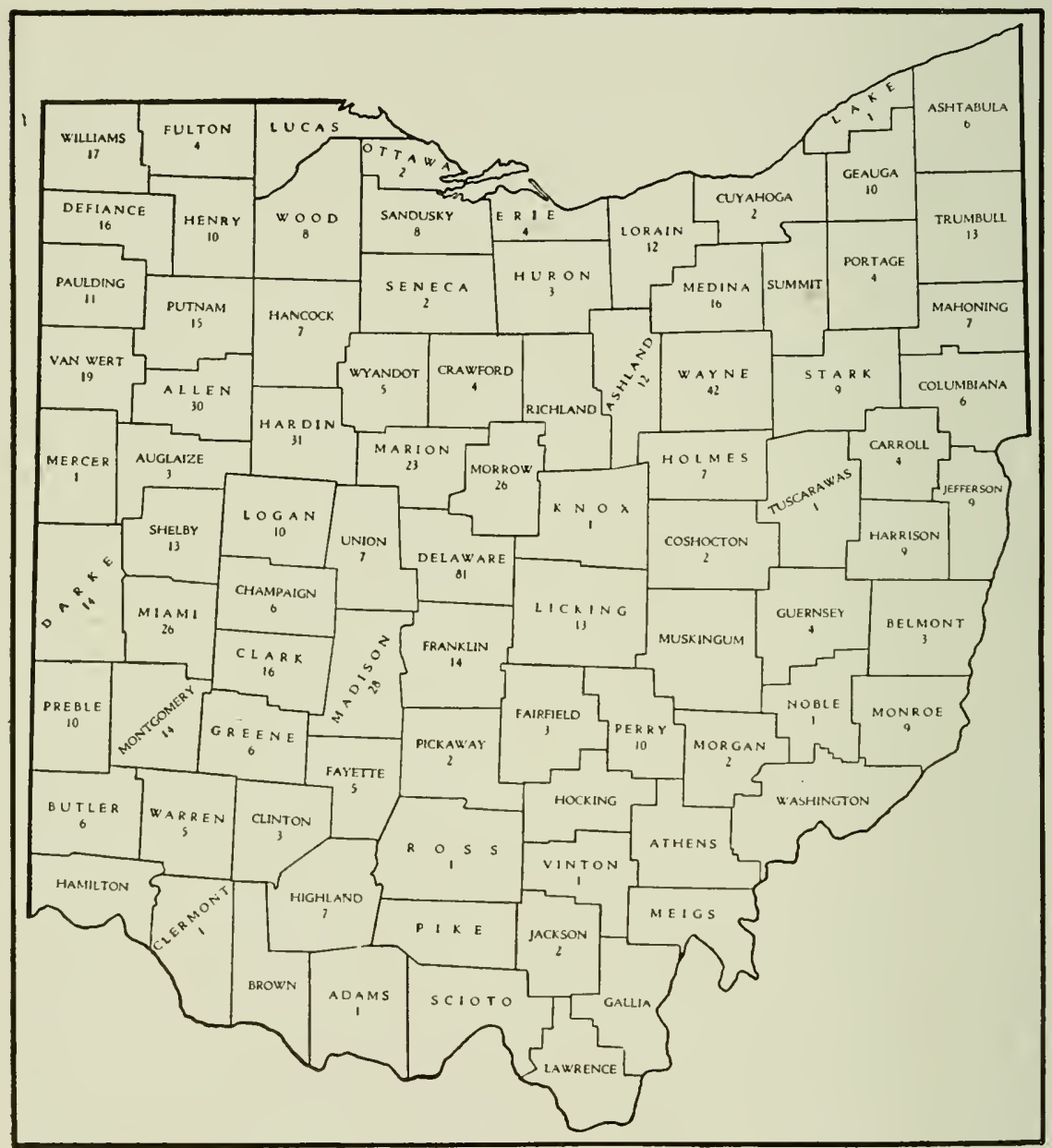

Ohio had in 1916779 members of the Percheron Society of America. The total number of Percheron horses recorded from Ohio between Novi. 1, 1915, and Oet. 31, 1916, was 747. The number appearing in each County is the number of Percheron horses recorded from that county between Nov, 1, 1915, and Oct. 31, 1916, inclusive.

ones registered in the Percheron Society of America are those selected to compete for special prizes offered by the Percheron Society of America in Ca- 


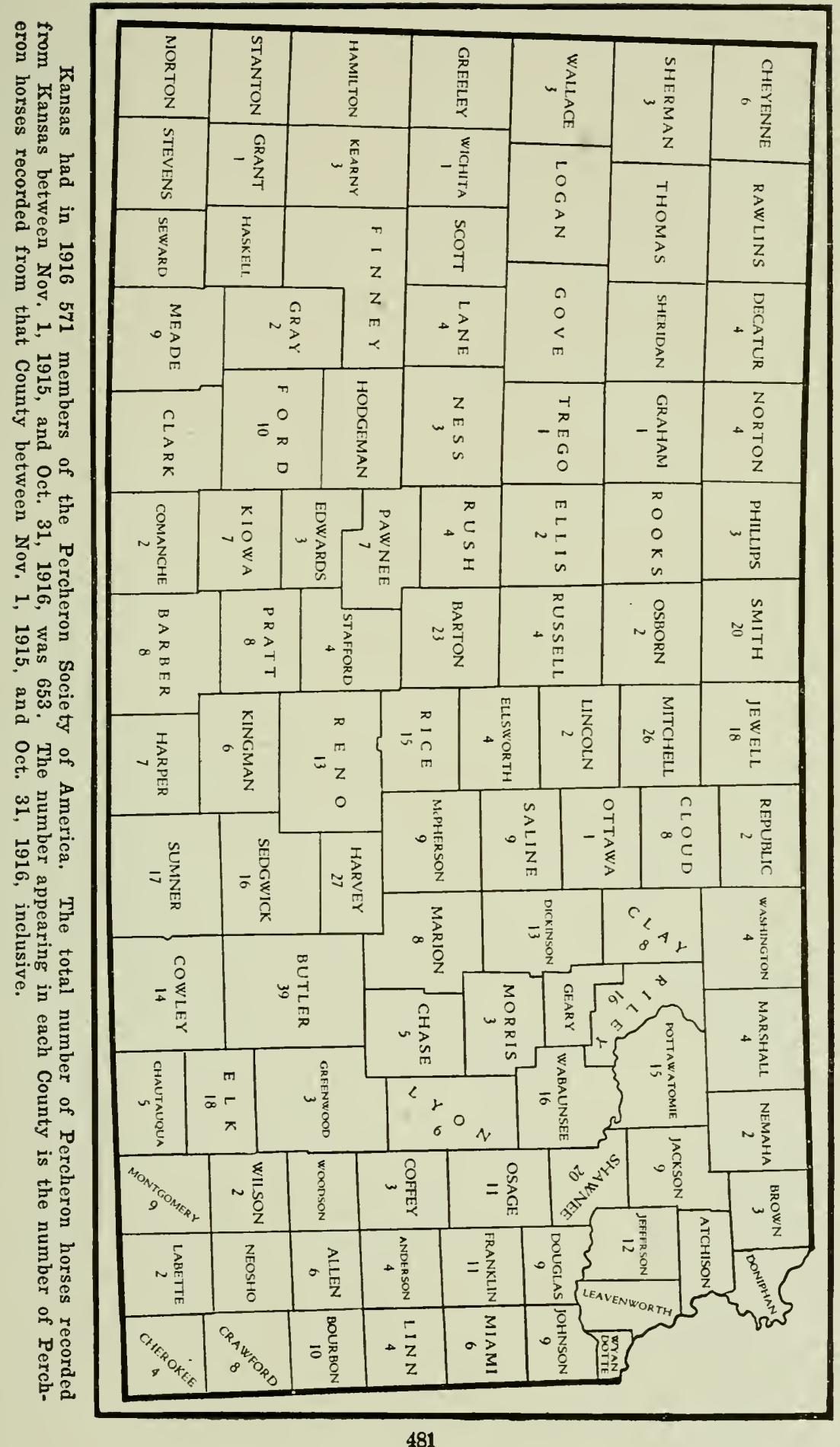




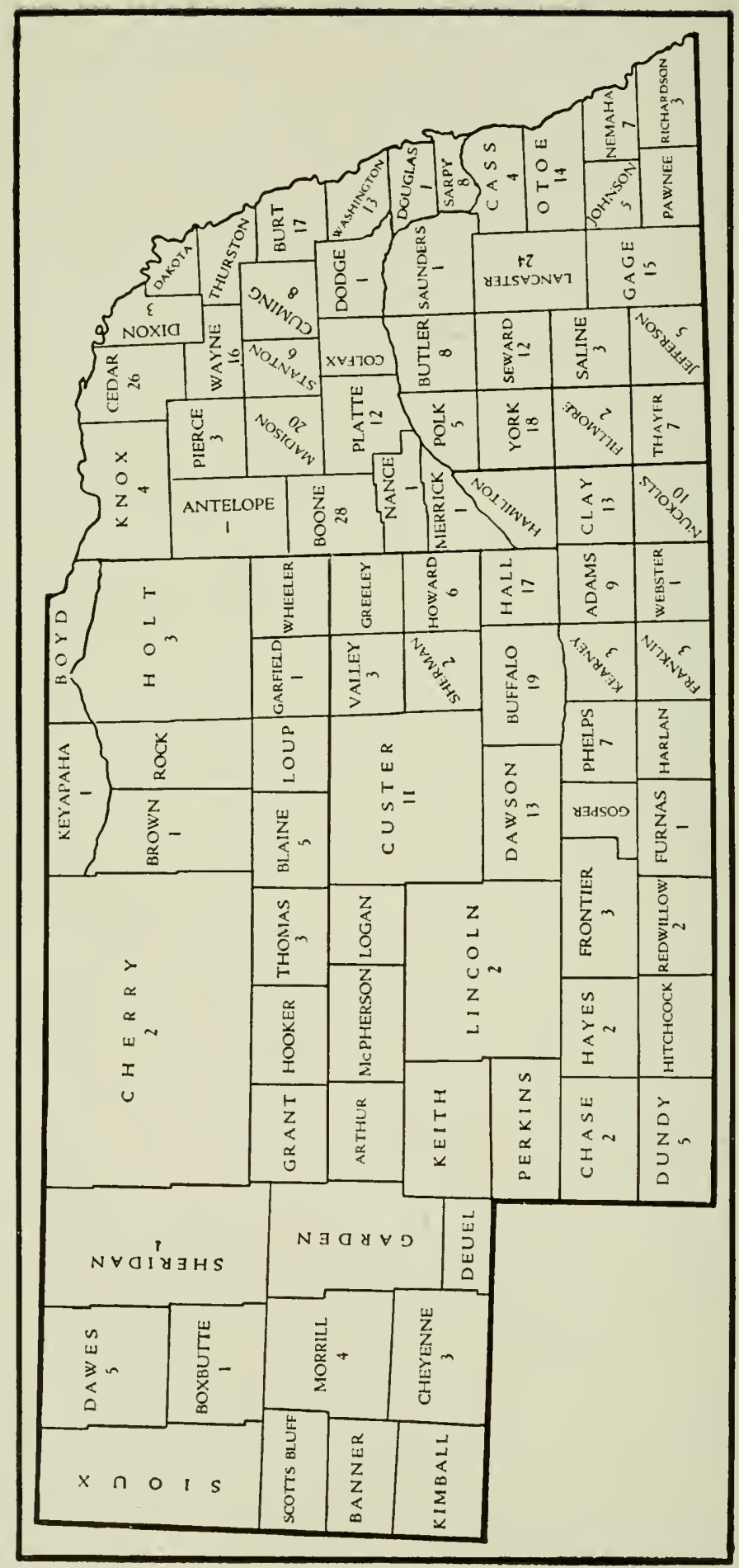

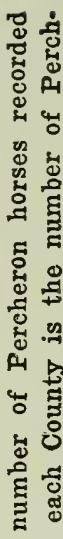

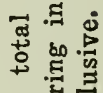

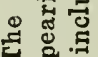
क्ष ฮீ है ह 풀 ○ خे -0 भ त (1) हू 25 두 3 어 乐 क्षै क्षे

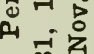
व 廿 吃 के हี घ 유 代 क क्ष 명 동 $\Xi \$$

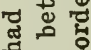
. जै 范 行。 薏 
nadian shows, or those which have been recorded here to permit of their exportation to the United States, if opportunity arises.

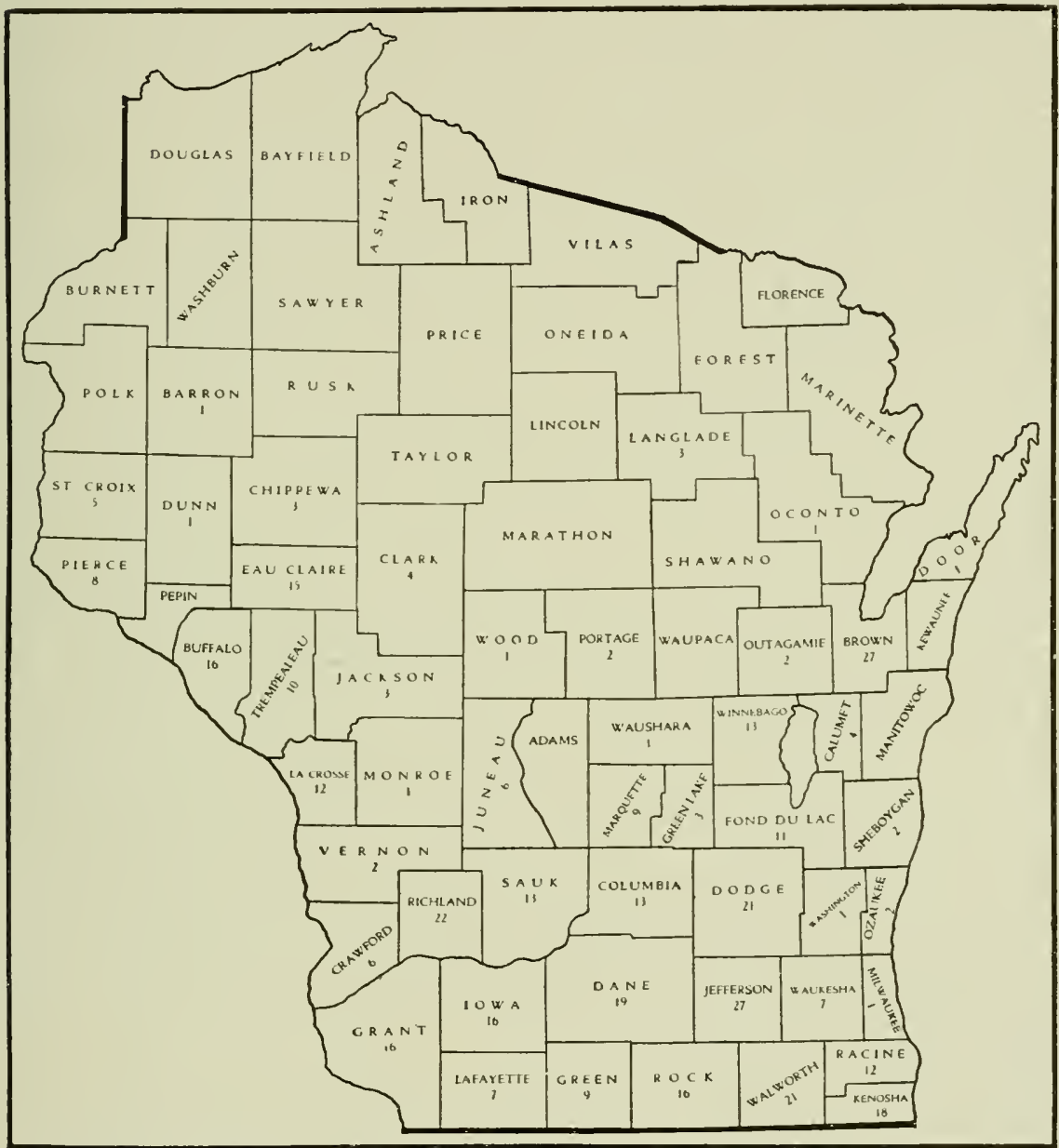

Wisconsin had in 1916366 members of the Percheron Srciety of America, The total number of Percheron hirses recorded from Wisconsin between Nov, 1 , 1915, and Oct. 31, 1916, was 414. The number appearing in each County is the number of Percheron horses recorded from that County between Nov. 1, 1915, and Oct. 31, 1916, inclusive.

Another indication of the widespread distribution of Percheron breeding is the fact that the 9,044 reg- 


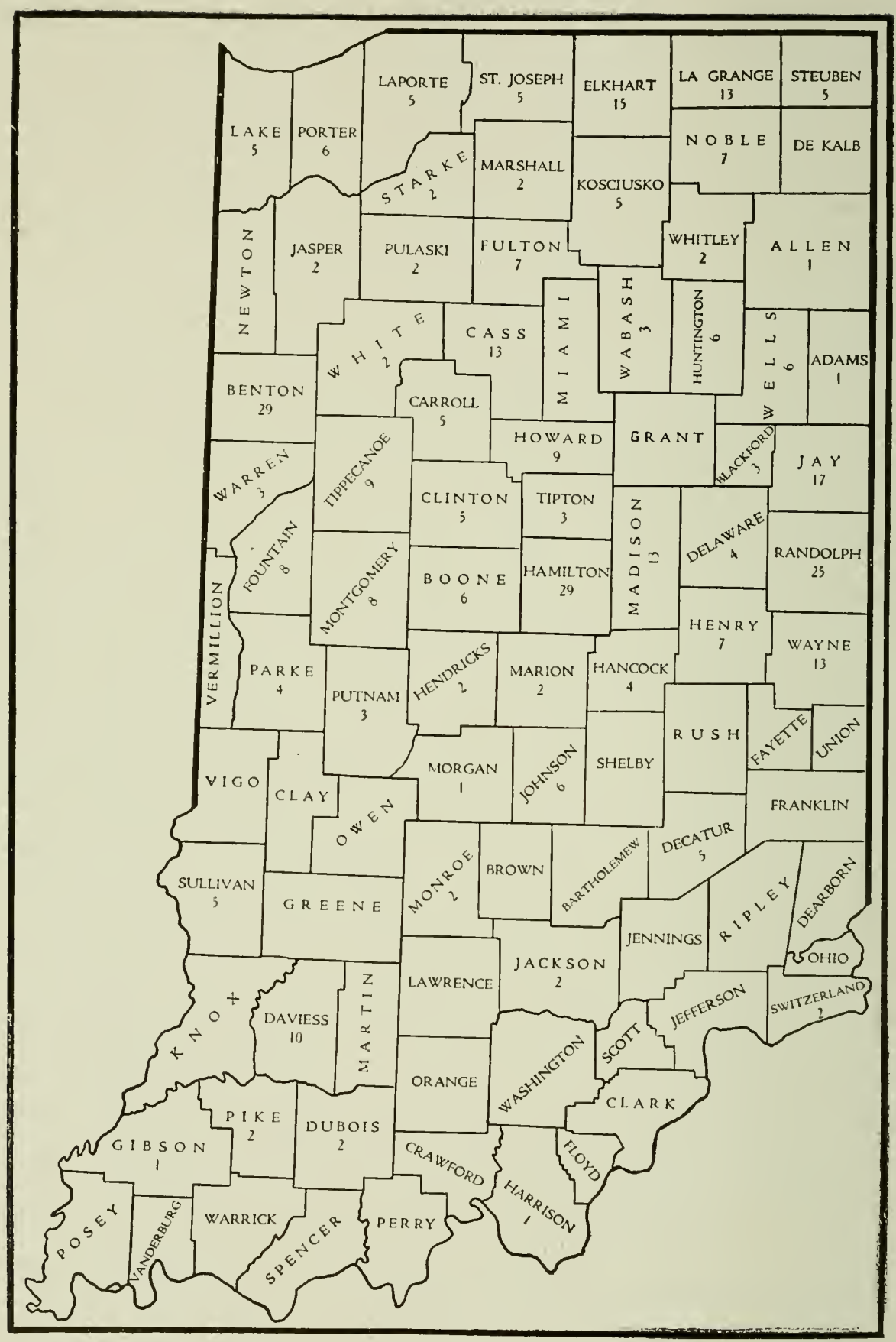

Indiana had in 1916412 members of the Percheron Society of America. The total number of Percheron horses recorded from Indiana between Nov. 1, 1915, and Oct. 31, 1916, was 367 . The number appearing in each County is the number of Percheron horses recorded from that County between Nov. 1, 1915, and Oct. 31, 1916, inclusive. 
istrations were made by 4,347 breeders, an average of only about 2 per breeder. This means that a

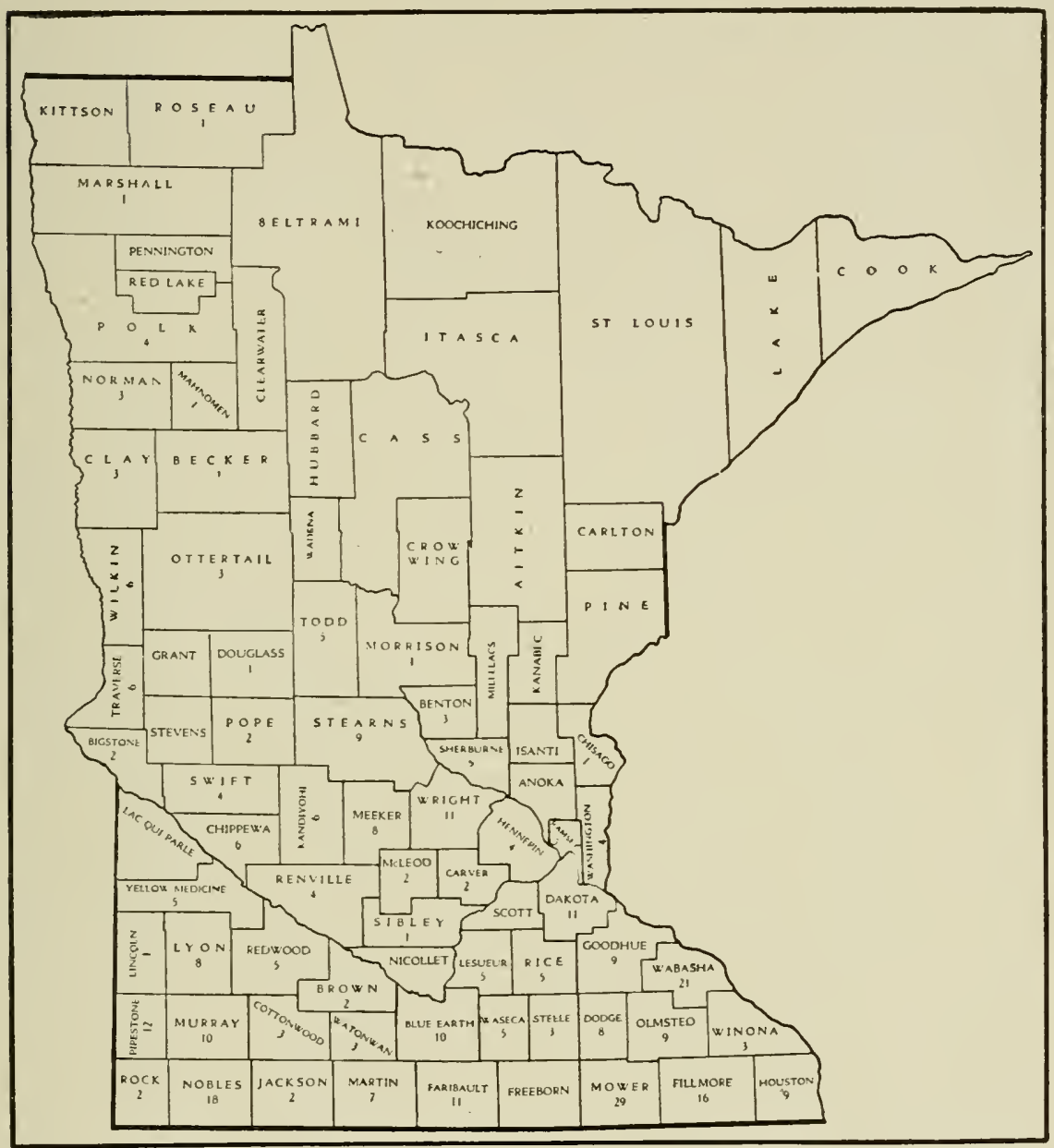

Minnesota had in 1916397 members of the Percheron Society of America. The total number of Percheron horses recorded from Minnesota between Nor. 1 , 1915, and Oct, 31, 1916, was 347. The number appearing in each County is the number of Percheron horses recorded from that County between Nor. 1, 1915, and Cct. 31, 1916, inclusive.

great many breeders recorded but one animal, as many others recorded from 5 to 10 head each.

In Illinois the breeding of Percherons is concen- 
trated very largely in 10 counties in the north-central part of the state, contiguous to each other. These 10 counties contributed more than 53 percent of the Percherons recorded by Illinois breeders during the year. The counties, in order of rank and with the number of horses recorded, are as follows: McLean, 186 ; LaSalle, 168; Iroquois, 125 ; Livingston, 109 ; Tazewell, 109 ; Fulton, 87 ; Ford, 82 ; McDonough, 76; Burean, 70, and Woodford County, 62. This represents a total of 1,074 registrations from the 10 counties, out of 2,014 for the entire state.

In Iowa the leading counties are more widely scattered. The first, second, fourth, sixth, seventh and tenth counties are all located in the southeastern part of the state, practically contiguous to each other, while the third county is in the central part of the state, the fifth is in the northeast-central portion, and the ninth is in the northwest corner. The first 10 counties in Iowa contributed only 33.8 percent of the registrations from the state. Another fact which shows how much more widely Percherons are scattered in Iowa than in Illinois is that they were recorded from 98 out of the 99 counties in Iowa during the year, but from only 81 out of the 102 counties in Illinois. The 10 leading Iowa coun ties, with the number of registrations, are as follows: Henry, 97; Keokuk, 75; Story, 66; Jefferson, 63; Black Hawk, 63; Van Buren, 55; Johnson, 54 ; Page, 46 ; Cherokee, 43 , and Lee, 37.

In Ohio the 10 leading Percheron-producing counties, with the number of registrations from each dur- 


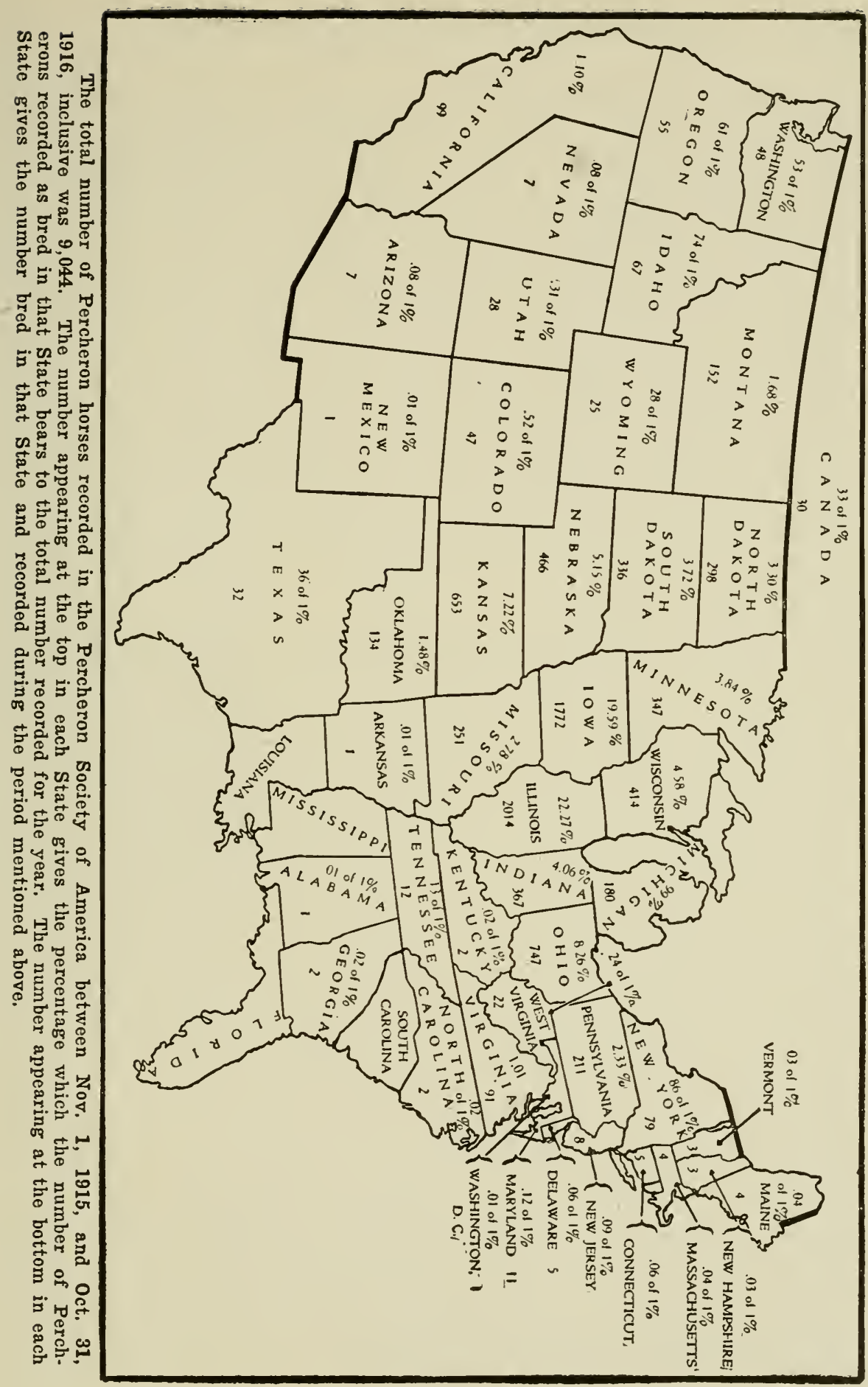


ing the year are as follows: Delaware, 81 ; Wayne, 42; Hardin, 31; Allen, 30 ; Madison, 28; Miami, 26; Morrow, 26; Marion, 23; Van Wert, 19, and Williams County, 17. The first, fifth, seventh and eighth counties are practically in one body in the central part of the state, but the others are scattered from the northeastern to the western part, without any particular concentration of breeding in any one district. Delaware is far in the lead of all other counties in Ohio in the number of Percherons raised, but Percheron breeding is by no means so general as in Towa, as registrations were made from only 75 of the 88 counties in the state.

The Percheron-breeding districts in the other leading states are clearly shown by the maps accompanying this analysis. The significant fact is that Percheron breeding has expanded most rapidly in those communities where the breed has been longest known - eloquent testimony to the wearing qualities of the breed. The endurance, adaptability and moneymaking qualities of the Percheron have won it lifelong friends wherever farmers have had an opportunity to become acquainted with the sterling worth of the world's most popular draft breed.

Percherons in the South.-Touching the matter of the adaptibility of the Percheron to the conditions prevailing in the Southern States we have asked for expressions of opinion, based on observation and experience, from two well-known animal husbandmen connected respectively with the Texas and Georgia agricultural colleges. 
The evidence of Prof. John C. Burns of College Station, Tex., is as follows:

"The Percheron is decidedly the most popular draft breed in the south, though it still lacks much of being so popular as horses of the light type. A large majority of southern farmers have long practiced a system of farming, cotton raising, which permits of the use of light-weight teams, both horses and mules, to good advantage. This accounts largely for the preference that is given to horses of the light type. Of course, prejudice also has played an important part in keeping down the popularity of draft horses, the general belief being that they can not withstand the hot climate.

"I have had an opportunity to observe the Percheron under many different conditions in Texas. I have seen registered stallions at the head of bands of range mares; stallions restricted to the stall and paddock, that were being offered for public service; registered mares with foals at side; weanling, yearlings, and two-year-olds in the process of development on the farm; and mares and geldings at work in the field and on the road. Wherever these animals were being given the care and attention to be expected from any good horseman, they were thriving and proving satisfactory. The fact that the period of hot weather in the south is long and the heat often severe makes it even more important here than in the north that Percheron mares and geldings be worked by intelligent teamsters who are good caretakers. From the middle of September until the middle of May, as a rule, no better teams could be desired, and during this period they easily excel teams of light horses and light mules in much of the work of the farm. But during the remaining four months of hot weather extreme care must be 
exercised to prevent them from becoming overheated. Nevertheless, one finds the general health of Percherons in the south equally as good as that of light horses.

"More Percheron horses are needed in the south, and there are two important reasons why they are needed:

"First, diversified farming is rapidly gaining' headway. More feed crops are being raised. Such a system of farming calls into use heavier farm implements and machinery, the handling of which rerequires heavier teams.

"Second, the south has long given much attention to the raising of mules, animals that have proved so well adapted to the work on southern farms. The great majority of the mules, however, are the products of light mares and are therefore themselves generally small and of the class known as cotton mules. Even in the past there has rarely been a time when large, smooth-turned mules were not in demand at good prices. while light mules have often been a drug on the market. The changing to diversified farming is making the heavy mule more necessary and more in demand than ever and in the production of such mules Percheron blood must play an important part. By the use of good Percheron stallions excellent mule foundations can be obtained by grading up from native or Spanish mares and from mares of Saddle, Thoroughbred and Standardbred breeding. More mares that possess size and draft conformation must be used, if large, highpriced mules, capable of doing the heavy work of the farm, are to be produced.

"Feeding Percheron horses in the south does not differ greatly from feeding them in other sections of the country. Oats here, as elsewhere, is one of the 
best feeds that can be used. Combined with a little wheat bran oats is especially desirable for feeding during hot weather. During the winter corn may be used extensively, especialy for mature work animals. Kafir, milo, and feterita make excellent feeds, but, like corn, they serve best in the ration during the cold months. Almost any of the good, clean, well-cured grass hays, such as Bermuda, Johnson grass, Sudan grass, sorghum, or prairie hay serves well as roughage. Legume hay, especially alfalfa, is also often fed as a part of the roughage with good results.

"The South needs more Percheron horses. But here let it be said that a kind vastly different from the majority that has been sold here is needed. The southern states have been a dumping ground for inferior, unsound stallions that have been driven from the northern states as a result of the operation in those states of stallion license laws. The farmers of the southern states must awake to this fact, exercise better judgment in purchasing stallions, and, if necessary, have laws enacted for their protection. A few inferior, unsound stallions can do more damage in a short time to the progress of the breed than several good stallions can overcome in many years. Percheron horses that are typical of the breed are sound and of good conformation, quality, style, and action. Such horses will pave the way for the breed's more rapid progress and greater popularity in the south as nothing else will.',

Prof. Milton P. Jarnagin of the Georgia State College of Agriculture says:

"In 1906 we began shipping grade Percheron mares from the middle west to Tennessee. Up to that time there had been strenuous objection in the south to any of the draft breeds, and the first mares which 
we shipped carried but a small infusion of draft blood. It was soon observed that these mares of more weight gave a better account of themselves as farm workers than the lighter mares had done. Even after the first shipment it was evident that farmers were willing to pay more money for the heavier ones than for medium-weight mares. In 1910 we shipped in a carload of high grade Percheron mares. These sold well and developed into valuable breeding and work mares. In 1911 I purchased 6 registered mares in central Illinois. They have been regular breeders and good farm worker's in Tennessee. Since 1911 we have been carrying grade and purebred Percheron mares on the farm of the Georgia State College of Agriculture. These mares have also done satisfactory work and have proved regular breeders. We have demonstrated conclusively that with reasonable supervision the negro will make a satisfactory teamster with grade or purebred mares.

"During six weeks of the hottest summer months the mules are able to do but little more work than the mares. We work our mares regularly through the entire season, but during the hottest weather they are given the lightest work and the mules the heaviest work. For the other ten and a half months of the year our mares do more work than the mules do.

"I feel positive that we will work mules in the cottonbelt permanently. However, there is a strong, growing demand for homeraised mules, and even the most skeptical farmer is willing to admit that the Percheron stallion is the best 'grand-daddy' a mule ever had. In other words, there is a broadening demand for Percheron stallions to sire mule mares. The user of mules knows that the massive, full-made, strong-boned mule is more durable and more salable 
than the over-refined mule with a Thoroughbred or trottingbred dam. Regardless of whether the dam ultimately is used to produce horses or mule mares, he is clamoring for brood mares showing a strong infusion of draft blood.

"The complaints that have been raised against the Percheron from the southern territory have been made as a result of inferior counterfeits being dumped into the southern states. Quality, finish and courage should be dominant features in all Percheron horses sent to the south. Wherever animals filling these requirements have gone they have made friends for this great breed of horses."

Horse Stock of the United States.-The estimates of the Department of Agriculture for Jan. 1, 1917, show 21,126,000 horses on farms in the United States, with an arerage valuation of $\$ 102.94$, or a total valuation of $\$ 2,174,629,000$, and $4,639,000$ mules with an average valuation of $\$ 118.32$, or a total valuation of $\$ 548,864,000$.

The 1910 census, taken June 1, 1910, gives a total of 1,731,982 colts foaled in 1909, or, as we would class them, yearlings. While the estimates of the Department of Agriculture indicate that there has been some falling off in the production of horses within the past 6 years, it seems safe to assume that we are producing at least $1,500,000$ foals annually which come to at least one year of age. The 1910 census also shows that of the total number of farms in the United States only 16.1 percent reported yearlings, from which we may safely conclude that only 16 percent of the farmers in the United States are producing horses. 
Of the yearlings on farms in $1910,21.5$ percent were in the east-north-central section, 38.4 percent in the west-north-central and 11.1 percent in the west-south-central. That is to say, a fraction more than 70 percent of the yearlings reported by the census of 1910, which is unquestionably the most accurate source of data we have, were in these three sections. The states comprising the eastnorth-central section are Ohio, Indiana, Illinois, Michigan and Wisconsin. Those in the west-northcentral are Minnesota, Iowa, Missouri, North Dakota, South Dakota, Nebraska and Kansas, and in the west-south-central Arkansas, Louisiana, Oklahoma and Texas.

\section{Percherons the Leading Draft Type.-The most} reliable estimates which we have been able to obtain indicate that there are probably about 150,000 purebred drafters in this country at this date. This figure includes all ages. Of this total it is estimated that approximately 90,000 are Percherons. In other words, our most reliable sources of information indicate that nearly two-thirds of the purebred draft horses in America are Percherons.

The last analysis made of the stallion enrollment boards' reports in the 10 leading horse producing states shows that 64 percent of the total number of purebred draft stallions are Percherons. The figures from other states which have since made reports on stallions in service, particularly Kansas and Indiana, increase the total percentage of Percheron sires, so that it is safe to say that at least 66 


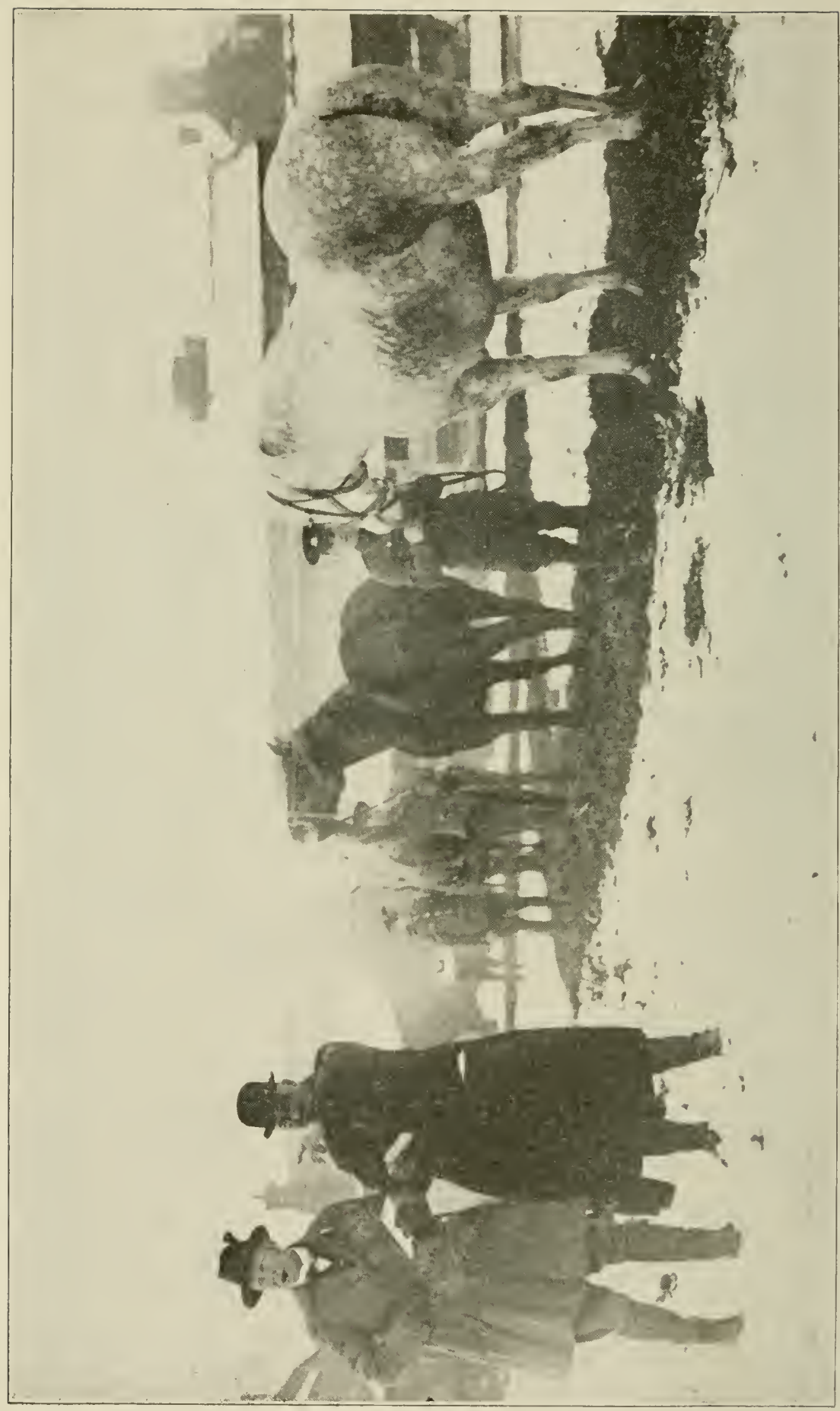

它

量穿

点

है

至

7

骂

空

0

녹

,

贾

究

佥。

员

点皆

目园

$T$

ํㅗㄴ

द

些会

咨光

5

.

,

온

고

느를

要

is

?

要

조

동

4.

0

3

5

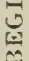


percent of all purebred draft stallions in use in the United States are Percherons.

War Exports.-Our exports since the great European war began aggregated for the 27 months ending Dec. 1st, 1916, 774,947 horses and 255,014 mules, totalling in value $\$ 216,941,912$. The strongest demand has been for artillery and transport horses, which have brought from $\$ 35$ to $\$ 60$ per head more than cavalry horses. Men who have been in particularly close touch with the work of the inspectors declare that at least 75 percent of the artillery and transport horses have been grade Percherons. How well these horses have met the foreign demand is attested in the leading editorial of the London "Live Stock Journal" for Nov. 17, 1916, from which we quote:

"In the meantime the Percheron type has made many friends in England. The breed, mostly represented, it is true, by 'grade' hor'ses as yet, is firmly established in the hearts and minds of the responsible officers of the British army. Go where one will in army circles, he hears nothing but praise for a horse that has proved his sterling worth in artillery. East and west, north and sonth the story is the same; the half-bred Percheron has filled many wants and has proved himself a gentleman of a horse, as well as a willing and never failing worker. TVe shall have a further opportunity of stating how pleased army men are with the type, but for the moment our chief concern lies in stating the facts of the case in connection with the recent importation of two purebred Percheron stallions and some brood mares. 
"It is the intention of their owners to use these horses in producing reliable artillery horses from Shire and Clydesdale mares, but they will also breed true to type, using the several Percheron mares accompanying the stallions, and so lay the foundation for an English Percheron Stud Book. Let it be added that this desire to try out the Percheron in England is not an idle whim or passing fancy. It is a thorough determination, brought about as the result of sincere conviction on the part of army anthorities that the half-bred Percheron fills the bill best of the many types bought for us the world over since the outbreak of the war."

One point clearly brought out by the developments of the trade in the past 2 years is that the United States is the only nation with a surplus of horses ranging from 1,200 to 1,500 pounds or over in weight. Attempts to purchase such horses in Canada have been made at different times since the war began, but the proportion of horses obtained was so slight in comparison with the total number examined and the cost of inspecting and purchasing them was so great that practically all purchases have been made in the United States, so far as North America is concerned. In South America the Argentine appears to have been the only country which has exported any considerable number of horses. About 150,000 head in all have probably been exported from Buenos Aires since the war began. The cavalry horses bought there have brought about $\$ 90$ in our money, and the best artillery horses from $\$ 125$ to $\$ 130$. Inasmuch as the cavalry horses bought in this country have brought from $\$ 125$ to $\$ 150$ and 


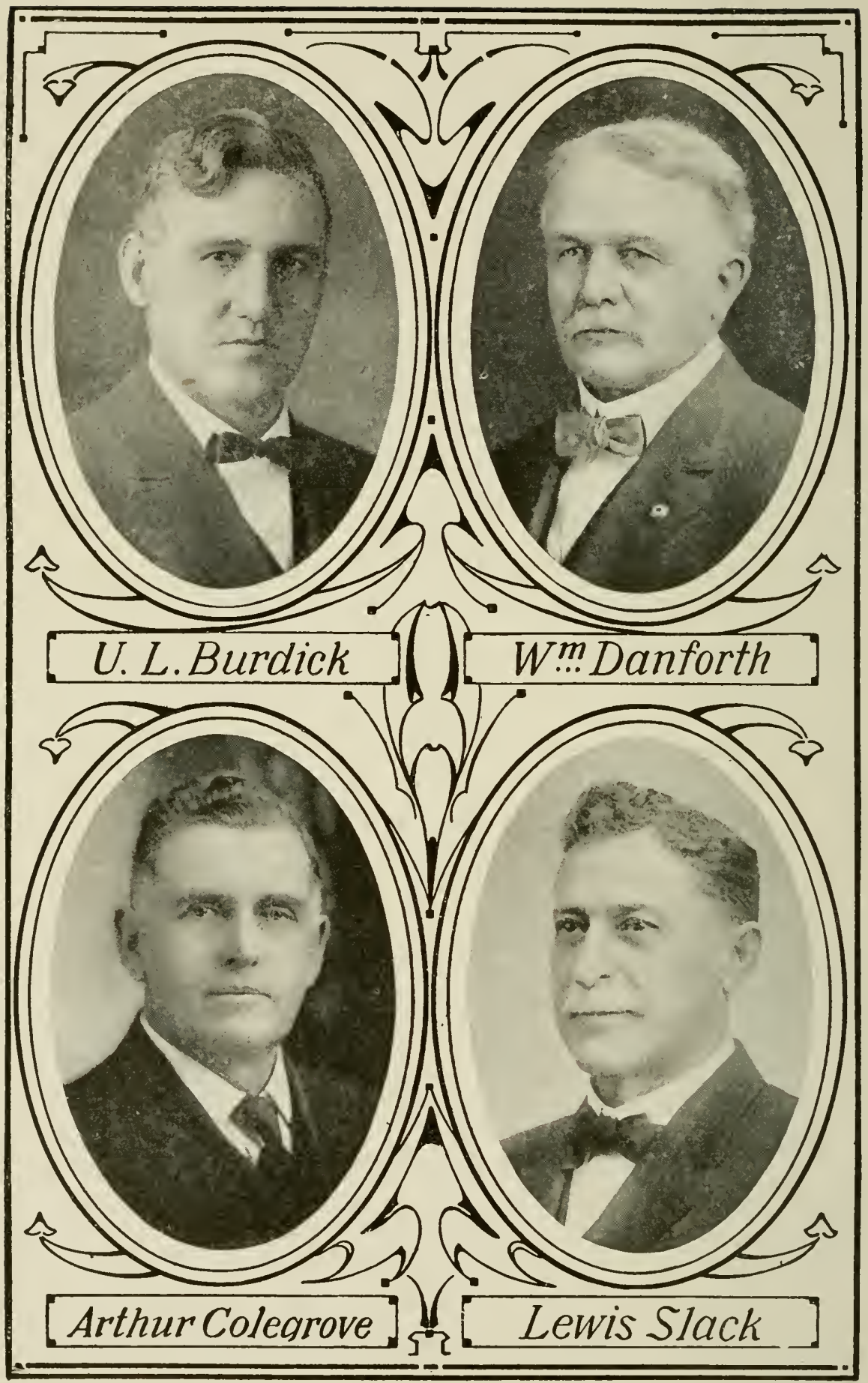


the artillery horses from $\$ 165$ to $\$ 210$, it is manifest that the Argentine has not been favorably considered as a source of horses for foreign use. One reason is found in the long shipment and another in the fact that they have but a very small proportion. of horses large enough for artillery work.

French Embargo on Exports.-Practically no importations of Percherons have been made since the European war began. A few horses bought before the war broke out were brought over in the autumn of 1914, but these were not Percherons. From that time until Jan. 1, 1917, no more Percherons were imported, except 59 brought over in the spring of 1916. Almost immediately after the war began the French Government placed an absolute embargo on the exportation of horses to foreign countries. This embargo was not lifted until Jan. 1, 1916, when through the strenuous efforts of Charles Aveline, then President of the Percheron Society of France, the government did agree to release for export 200 Percheron stallions rising four year's old or over. This suspension of the embargo lasted from Jan. 1 to March 1, 1916, and but 59 horses were brought out under this release order. Another order of similar character released 200 more stallions for export during December, 1916, and January and February, 1917, but these horses were required to be coming four years old or over.

American Breeding Stimulated.-The elimination of imports has greatly stimulated Percheron breeding in this country. Importers and dealers have 
been forced to purchase their stock here. They have scoured the country for good colts of both sexes and have paid higher prices than ever before. This has encouraged our breeder's to spend more time and money in breeding good mares to better sires. This demand has also caused growers to feed their colts more liberally, with results which were exlibited in most convincing form at the 1916 International Live Stock Exposition.

During the twelvemonth ended Oct. 30, 1915, registrations were made by the Percheron Society of America as follows:

American-bred stallions, 3,795; American-bred mares, 4,542; total American-breds, 8,337.

Imported stallions, 107 ; imported mares, 48 ; total imported Percherons, 155. Grand total, 8,492.

During the fiscal year ended Oct. 30, 1916, registrations were as follows:

American-bred stallions, 4,043; American-bred mares, 4,861; total American-breds, 8,904.

Imported stallions, 123; imported mares, 17 ; total imported Percherons, 140.

Almost all of the registrations under the head of "imported" for 1915 were of animals imported prior to the beginning of the war, and of the 140 imported animals recorded during the fiscal year of 1916 all but 59 were imported prior to the war.

The most decisive testimony regarding the effect of the war in stimulating Percheron breeding comes from the small farmer-breeders scattered throughout this country. They testify without exception that 



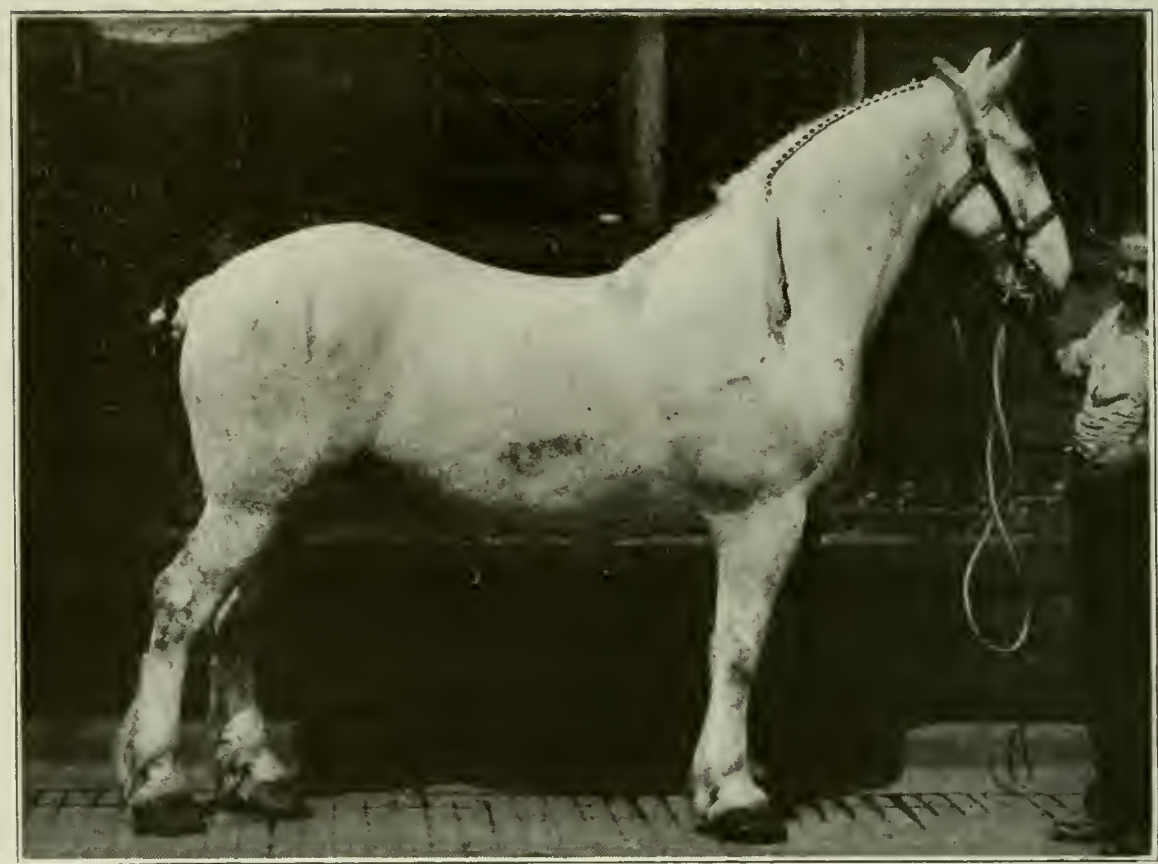

ARMOUR'S PERCHERON GELDING MACL-TAKEN AFTER NINE YEARS OF STEADY SLKVIL

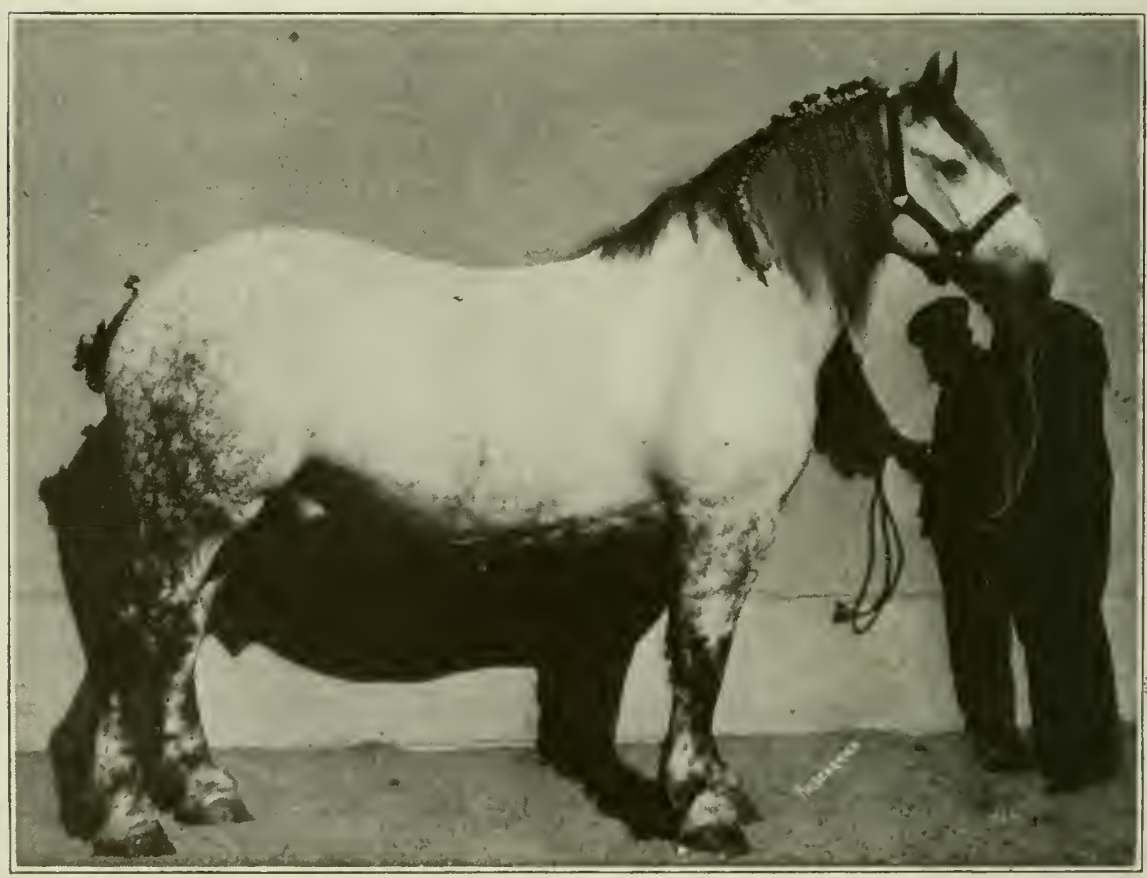

THL: FAMUUS PERCHERUN GELDING BIG JIM, 
they have had a better demand for their surplus stallions and that they have sold them at earlier ages and at better prices than at any time in the last 20 years.

Commercial Market for Draft Horses.-Ellsworth \& McNair are known throughout the United States and abroad as extensive handlers of horses of all kinds, including many draft horses. Harry McNair, of this firm, is probably as well versed in the commercial demand for draft horses as any man in the world. What he has to say on this subject is of particular interest. His statement follows:

"The point of orgin of most of the draft horses used in the United States is in the west, particularly in the states of Iowa and Illinois. The best market for the surplus draft horses is very largely in our eastern states, particularly Pennsylvania, New York and New England. It is true that many horses are used in the cities, towns and villages of the middle west and that large numbers of draft horses are sold into the northern woods for logging purposes, but the chief market for high-class draft horses is, and always has been, in the eastern part of the United States. The reason for this is not difficult to find when we consider that more than 23,000,000 people live in Pennsylvania, New York and New England and that the total valuation of the horses used in the cities, towns and villages of that section amounts to more than $\$ 135,000,000$.

The eastern section is densely populated and given up largely to manufacturing and commerce, necessitating unusual requirements in the way of transportation. The number of horses produced on the farms of the east is very small. The census of 1910 shows that in that year yearlings were found 
on farms in the east to but a limited extent. The percentages of the total number of eastern farms on which yearling colts were found follows: Connecticut, 2 percent; Maine, 5.4; New Hampshire, 3.4; Rhode Island, 1.3; Vermont, 9; Massachusetts, 1.9; New York, 9.5, and Pennsylvania, 11.1. It is true that horses may have been produced on some farms that did not report yearlings in 1910, but the percentage of yearlings available in any year is a fairly accurate index to horse production in any particular district. The farms in the east are not producing as many horses as they need in their actual farm work, to say nothing of surplus fit and available for city use. The thousands upon thousands of draft horses annually shipped from western farms to the eastern states are used for all kinds of transportation purposes where strength and weight is needed. Ice companies, coal companies, transfer companies, manufacturing establishments, department stores, wholesale houses, warehouses and mills are all extensive users of draft horses, and the farms of New England also take large numbers of draft horses every spring for use in agricultural work. The lumber interests in this territory are also extensive and require large numbers of horses to go into the woods each fall. There are more than 100 dealers or firms located in the states mentioned which make a business of handling heavy draft horses for the eastern trade.

"From all that I have been able to learn, the demand for heavy draft horses between July 1, 1916, and Nov. 15, 1916 was probably as good as it has been at any time within the past 20 years. I feel satisfied that the prices which the dealers in the east obtained from the ultimate consumers were as high as at any time since 1900, if not higher. 
"One thing which farmer's generally do not fully understand and which they should at all times keep in mind is that the trade for draft horses is a seasonable one. Heavy draft horses are in demand mainly during the spring and fall months. During: the winter there is little call for them and there is not much trading during June. The reasons underlying this seasonable condition in the trade are related to the demands of commerce. During: April and May ice companies are buying heavily for their summer requirements and a great many commercial concerns which do a much heavier business in the summer than they do in the winter, such as city lumber companies, building concerns, contractors for excavations, and the like, are all in the market for draft horses during the latter part of March and April and the early part of May. The demand naturally falls off during June as parties needing these drafters have obtained them and the only horses bought are occasional animals to fill unforeseen emergencies. In the latter part of July, August and during September the large coal companies are on the market purchasing horses for delivery of coal during the fall and winter months; the logging companies are also in the market for heavy draft horses and some additional purchases are always made in the fall on account of an extra call for horses on contract work. These basic factors underlie the trade for draft horses, which is naturally strongest during the spring months and next best during the early fall months. There is no particular demand for the heavy draft horses during January and February; the men who need them have already obtained them, and such purchases as are made are emergency ones to fill out teams or take care of unforeseen work. I am satisfied that if 
farmers generally would bear in mind the fact that the trade in draft geldings is a seasonable one, they could obtain much more for their horses than they have generally secured, by having the horses fit for sale at these particular times.

"Another feature which is worthy of mention is that the eastern buyers have been willing to pay higher prices and for this reason have obtained the better class of draft geldings. The majority of Chicago and other western buyers, when they do want big horses, are willing to take second-class ones which can be obtained somewhat cheaper, but the eastern buyers are inclined to take the best horses they can get even at higher prices. I know of many teams that have been sold in New York, Brooklyn and Boston at prices ranging from $\$ 800$ to $\$ 900$ per team.

"The number of draft horses passing through our large commercial markets during the past 2 years has not been at all representative of the actual demand or sales. The reason for this is that the commercial markets have been given up largely to the export trade, which has been almost exclusively for cavalry, artillery and transport horses. It is likely that the draft horses would have continued to move freely through the large markets had it not been for the very extensive movement in war horses.

"By reason of this the eastern buyers of heavy draft horses have within the last 18 months been avoiding the large market and going directly to the country, making their purchases from farmers or small dealers who have assembled and fed their horses for the eastern markets.

"I am no prophet and will not undertake to make any predictions as to what will occur in the commercial horse market when the war ends. I believe, 
however, that exports will continue for a considerable period, although probably not on the same extensive scale. I am of the opinion, however, that we probably shall ship a somewhat better class of horses to foreign nations after the war; it is likely that they will seek the draftier type of mares weighing from 1,400 to 1,700 pounds and with evidence of draft breeding. Whether exports continue or not, however, the demand for draft horses in the United States will continue. In spite of the extensive use of auto-trucks, which has unquestionably curtailed the demand for heavy draft horses very materially, especially in Chicago, the need for horses in our city transportation will continue. The experience of thousands of users has satisfied them that on short hauls and in construction work as it is generally conducted horses are more economical than auto trucks.

"I am satisfied that the only type of horse which it will really pay the farmer to raise in the future is the draft horse, and the better the horse the more profit will accrue to the farmer. Draft horses are more efficient in farm work than any others; they do more work, and do it more thoroughly and more cheaply. Where draft mares are kept for the farm work, as they can be wherever the farmer is a good manager and an intelligent horseman, the revenue accruing from the sale of the colts constitutes an annual income of no slight importance. If all the mares now in the United States which range in weight from 1,100 to 1,500 pounds could be bred to first-class draft stallions, and their daughters in turn bred to the best draft stallions, and the grand-daughters likewise, the value of the progeny in the United States would be increased at least $\$ 50$ per head, whether we consider that value 
in draft horses from the standpoint of efficiency in farm work or from the standpoint of their actual worth to user's in our large cities or in foreign countries. There is every encouragement to produce the big horses of approved draft type, conformation and quality, which will weigh 1,650 pounds and up in good working condition. I can see no encouragement for the man who is producing the cheap or undersized horses. I fully believe that the prices on these smaller horses will drop materially after the war.

"So far as I can judge, the average price which farmers in the United States have received for cavalry horses has been in the neighborhood of $\$ 115$ per head. The average price for the French artillery horse has been around $\$ 140$, and for the British artillery horse around $\$ 165$ to the farmers who sold such horses. There is here a difference of from $\$ 25$ to $\$ 50$ per head in favor of the heavier horse and this increase in weight has in all instances been due to the use of draft blood. During this very time, however, when the heavy artillery horses were selling from our farms at an average of $\$ 165$ per head, horses with one more cross of draft blood, which would weigh from 1,600 to 1,800 pounds in working condition have been bringing from $\$ 225$ to $\$ 250$ on the farms, and the horses with still more size and draft character have brought from $\$ 250$ to $\$ 275$ on the farms. I cannot see how there can be any clearer evidence of the advantage of producing draft horses on the farm, or of using purebred draft stallions in increasing the value of the common horses of our country.",

Geldings at the Show.-Tremendous impetus has been given the breeding of better geldings by the exhibits made at the International Live Stock Ex- 



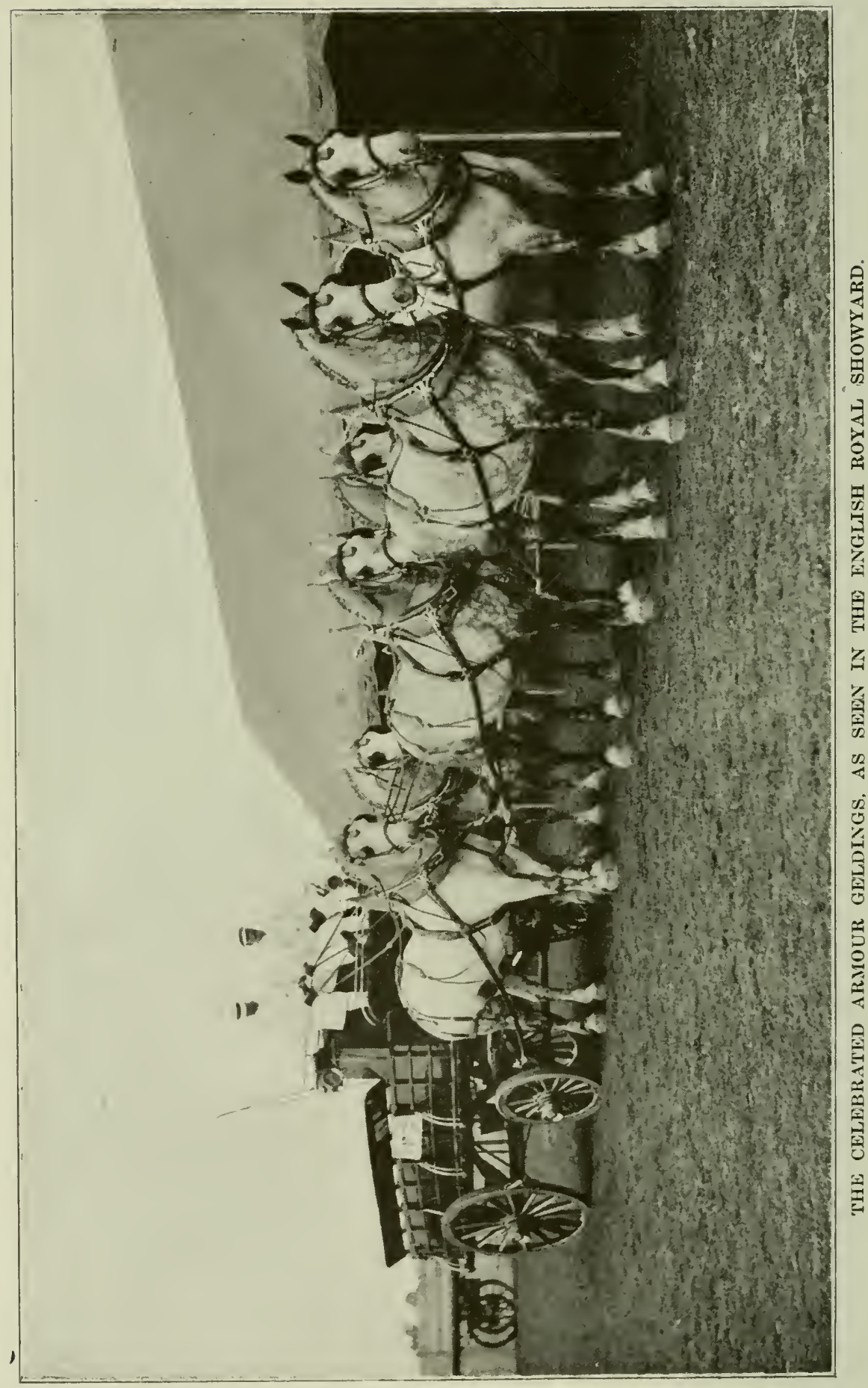


positions by the great packing companies, breweries and other exhibitors. Without attempting to give a detailed list of the winnings, it is worth while to call attention to the fact that the Armour gelding Jim, admitted by experienced judges to have been the greatest gelding ever exhibited in America, won first and championship in the heavy gelding classes in 1903, 1905, 1906 and 1907. He has been the only gelding to achieve such an extraordinary record in the history of the entire show.

All the geldings exhibited by Armour \& Co. have been grade Percherons. They won the heavy fourin-hand class in 1904, 1905 and 1906, the class for heavy geldings in the treys abreast in 1904, 1905 and 1906, and the class for the sixes in 1905 and 1906. The high estimate placed on the Armour gelding's is abundantly attested by the frank admission of Thomas B. Freshney, a breeder of Shires in England, who freely acknowledged in 1905 that they could turn out no such six-horse team in England, taking size, draftiness, weight and dashing action into consideration. At the International in 1907 Mr. Sparks of London, who at that time owned the best pair of Shires in England, stated that all prejudices aside he had never seen a gelding quite so good as Armour's Jim. In 1906 Big Jim defeated Tom, a brown gelding sent over by King Edward VII of England to uphold the honor of the Shires at the International, and in 1907 he defeated Drew, a horse that under the name of King Harry was the champion gelding of Scotland in his day 
and was imported by Clydesdale enthusiasts to uphold their colors at the International.

The Percheron standard also has been ably upheld during the various shows by the exhibits sent forward by Swift \& Co., Schwarzschild \& Sulzberger, and the Pabst Brewing Co. Exhibits by all these companies were well to the front in the various shows, and the Pabst six-horse team won the highest honors in 1904. In more recent years J. Crouch \& Son have been well represented in all classes for geldings, winning the championship for single gelding in 1910 on Prince, the trey hitch in 1910 and 1911, and the blue ribbon on the six-horse team in 1912. It is worthy of note that while other breeds have put forward the best purebred geldings that they could find in this country or abroad, the Percheron honors have in all cases been won on grade Percheron gelding's bred in the United States and bought on the open market as work geldings:

The Armour six-liorse team, champion at the International in 1906, was sent to Great Britain and exhibited at the Olympic Horse Show in 1907. The team subsequently toured Great Britain and created a sensation that has probably never been equalled in the tight little isle.

The wonderful enduring qualities of the Percheron also are attested by the fact that a large proportion of the geldings which won the highest honors in these shows continued in steady service until well up in years. An especially notable instance of this is found in the gelding Mack, pur- 
chased as a six-year-old in the spring of 1905 , by Tom Donnellan, superintendant of stables for Armour \& Co. He was the off horse in the lead team in the famous Armour six, and was a member of the trey team that won first for Armour in 1906 and 1907; in 1914, when fifteen years of age and after 9 years of hard service on the city streets, he was selected as a high-class representative of what is desired in good Percheron geldings and used for demonstration purposes on an extension train in Wisconsin during that year and the following one. In spite of his age and long service and the fact that he had not missed a single day's work during the preceding 9 years, Mack weighed more than 1,800 pounds in ordinary working condition and was absolutely sound and right. This horse and others shown in the famous Percheron teams exemplified in their conformation, set of legs, well-shaped, durable feet, clean joints, clean-cut quality and their long years of service the characteristics which have made Percheron geldings popular with great Packingtown firms and with the cartage companies of the large cities, where endurance is estimated at its true value.

Percheron geldings won first and championship in the single gelding class 7 times out of a possible 14; won the blue ribbon on pairs under 3,500 pounds 9 times out of a possible 13; won on heavy geldings three abreast 7 times out of a possible 14; won on the light four-in-hand 7 times out of a possible 9 , and won the heavy gelding six-in-hand 6 times out 
of a possible 14, to say nothing of the innumerable seconds and thirds. Of this record the breed has reason to be proud, in view of the fact that it has in all instances been represented by grade Percheron geldings bought on the open market as work horses, while adherents of other breeds have scoured two continents and selected the best purebred geldings that could be obtained to uphold their colors. 


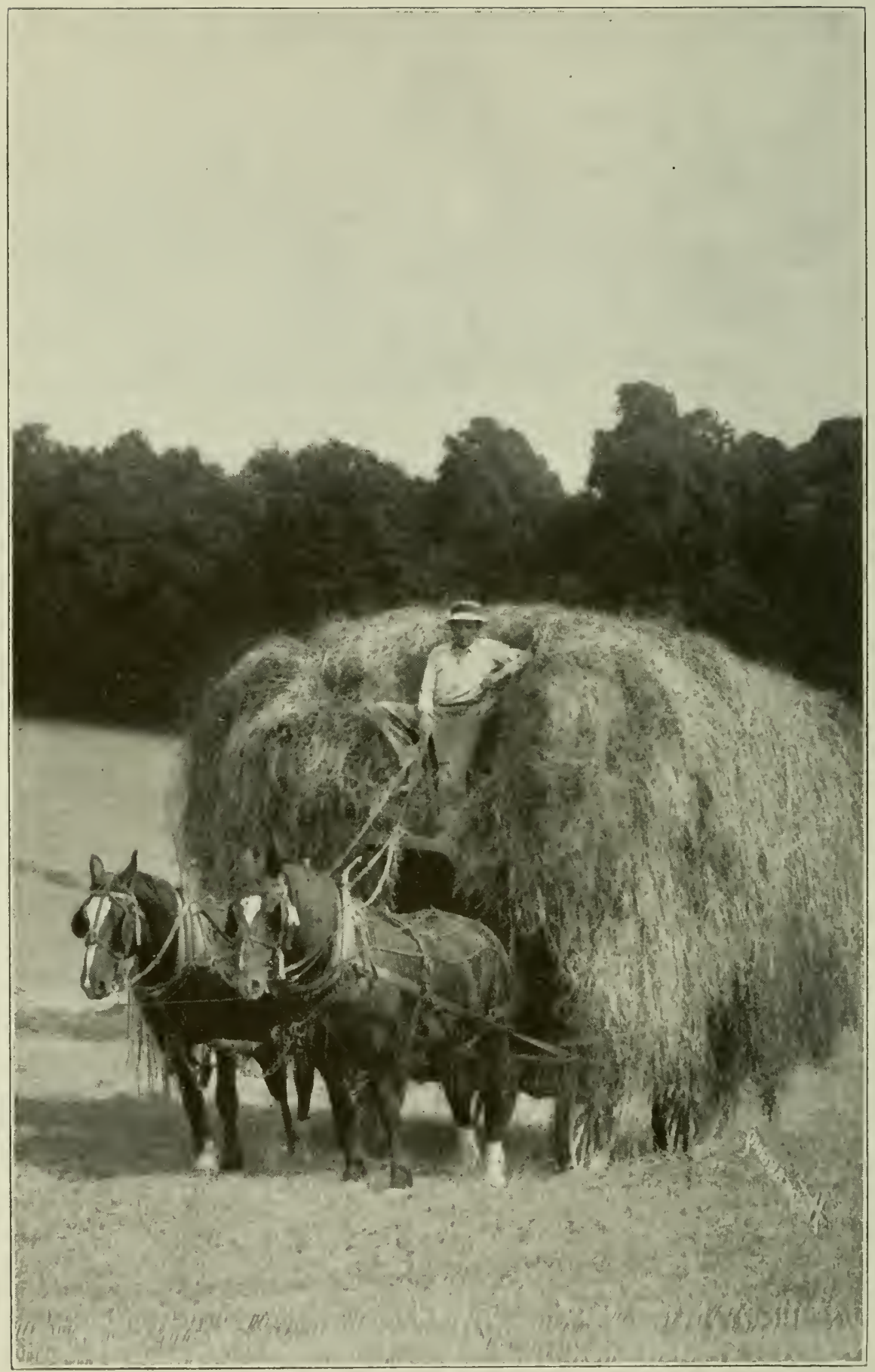

PERCHERON MARES AT DELCHESTER FARAS. 


\section{GHAPTER XIV.}

\section{SELECTION, CARE AND MANAGEMENT.}

Under this head we have the pleasure of submitting the views of a number of recognized authorities in the trade. The authors believe that these statements will prove interesting and instructive, more especially to those who may be engaging in the business of breeding Percherons for the first time.

Edmond Perriot.-Speaking of types of Percherons as regarded in France and by American buyers, this veteran "stallioner" of the Perche says:

"The Percheron trpes that we as breeders are interested in today may be divided into three classes-the type sought by Americans, the one bought by the government haras, and the type which the breeders in the Perche love to see. Regarding the last type, what we look for is a great deal of character and reproductive ability as shown in the head and neck and eye. We forgive some thing's that the American buyer would never overlook, but we demand that a good breeding stallion should have an expressive physiognomy. We like to see in a stallion a well-crested, swan-curred neck, a clean throatlatch, a well-poised head with small, fine ears -an intelligent head above all, with a large prominent eye, full of brilliance and fire. The eye we regard as of very great importance. I have never yet seen a good reproductive sire that had a common eye. 
"The type that the government wants is a snuglybuilt, compact stallion, with a rather short, level back and moderately high withers, and showing a pleasing symmetry of form, with a good length of neck, sloping shoulder's and rather small, neat and clean head. But perhaps the most important point for them is the action. The legs must be clean and not show too much bone, while a general lightness of foot is desired, with moderately high knee and hock action. To put it plainly, the government haras are always looking towards the problem of supplying the army with good cavalry and artillery horses, and the most of the stallions bought by them are used on French Coach mares of different types.

"The American likes a big-framed, heavy, drafty type, even if the head and neck are not quite ideal. He is looking above all for strong underpinning, and will not forgive a hock that is not perfectly straight and clean. He also likes a good length of pastern and pays considerable attention to action."

James M. Fletcher.-The views of one so long associated with Oaklawn's breeding and importing operations are surely worth printing:

"In my opinion, a typical Percheron stallion should weigh between 1,900 and 2,100 pounds in good condition. His height will range from $16 \frac{1}{2}$ to $171 / 4$ hands. In selecting a stallion I look for an intelligent head broad between the eyes and carrying well-set ears, a well-cut neck set on sloping shoulders, and a short back, with the tail set neither too high nor too low. He should have a broad breast with a muscular forearm, broad quarters, a deep body with well-sprung rib, legs squarely set with clean bone, sloping pastern not too long, and a wide, deep foot. Avoid a stallion narrow between the eyes, ugly-headed, with ears set too wide, narrow in front 
or behind, short-ribbed, or with a crooked or puffy hind leg, a straight pastern, or a flat foot.

"A stallion should be housed in a large, roomy, well-ventilated borstall, and given plenty of exercise, either in a well-enclosed yard or under saddle on the road every day. Plenty of fresh water, clean, fresh hay and sweet, clean oats and bran in sufficient quantities during breeding season to keep the horse in good condition are essential in my plan of feeding. stallions. I aroid corn in any form as a feed, as well as dirty or musty hay or oats. A moderate amount of green feed is beneficial. A good stallioner will not permit his charge to become too fat or too thin, and will be sure that he does not lack exercise. A clean, well-cared-for stable with good ventilation is necessary, and there should be sufficient grooming to keep his coat in a clean, healthy condition.

"In selecting a brood mare I should choose one from a producing family, weighing 1,700 to 2,100 pounds and standing 16 to $171 / 4$ hands high. She should be sound and of feminine type. The mare should have a fine head with eyes well apart and well-set ears not too heavy, a slim, graceful neck well set on sloping shoulders, a large, roomy barrel, a well-sprung rib, a tail not too low, clean, sound. well-placed leg's not inclined to be meaty or to carrv too much hair, sloping pasterns and deep, tough hoof. The mare to be aroided is the one of masculine type or from a family of shy producers. They are rarely successful. A coarse, Roman head, heavy, poorly-set ears, a masculine neck, a tail set too low, a short rib, a crooked, puffy hind leg, a straight pastern and a foot that is too narrow or too flat are also very undesirable features.

"Brood mares not in the harness should be kept in pasture as much as possible at all seasons of the 
year. The expectant mother should be given a wellventilated, roomy boxstall and permitted to run out as much as possible. Feed clean, fresh hay, ground oats and bran, and such green feed as the season affords. Mares should be kept in healthy condition, neither too fat nor too thin. As foaling time approaches a night watch should be kept. During the period of suckling the mare must be fed well on milk-producing feeds, such as dampened ground oats or bran. Keep in the pasture as much as possible.

"The stallion colts should be thoroughly halterbroken at or before weaning time. After taking the colt from its mother, he should be placed in roomy, well-ventilated pens or boxstalls that adjoin clean, well-drained yards or pastures, where he may have plenty of exercise. These yards or pastures should be fenced, either with boards or closely-woven heavy wire of such weight as to discourage any disposition to get out. They should be located also on dry, well-drained ground. The stable should be kept clean. The colt must have sufficient feed to keep him in a healthy and growing condition, but not too fat. It is a mistake to permit colts to go back after weaning time through lack of feed. A colt stunted at this time will never recover his lost ground.

"I believe a ration of ground oats and bran with plenty of sweet hay the best for colts. After the first winter place them in well-fenced pastures with ample shed protection from bad weather. Do not locate this pasture adjacent to one in which mares are kept. Have plenty of fresh water always accessible and feed enough grain to keep the youngsters in a healthy growing sondition.

"I should handle my colts in this manner, with proper winter protection, until they are $2 \frac{1}{2}$ years 


$$
3
$$




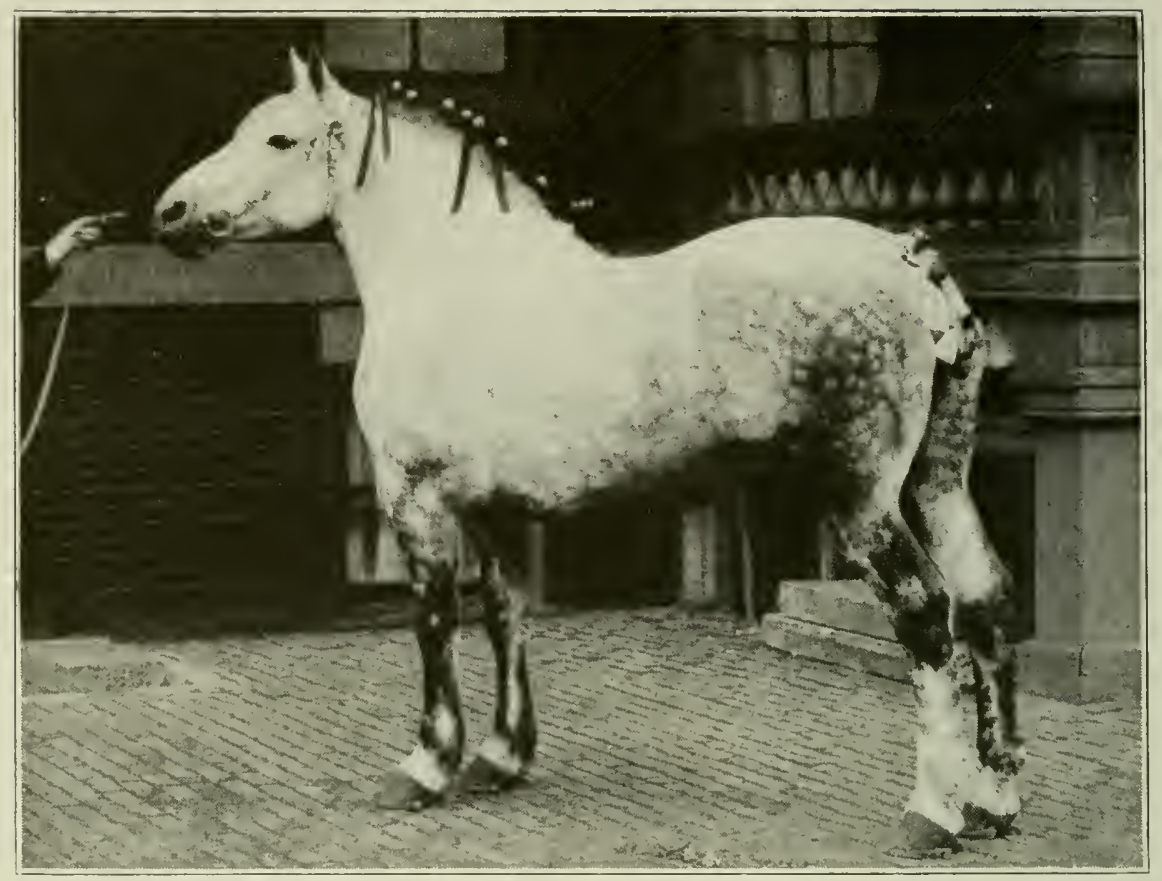

OASTILIE 78956 (64553)-CHAMIPION CHICAGO INTERNATIONAL, 1911.

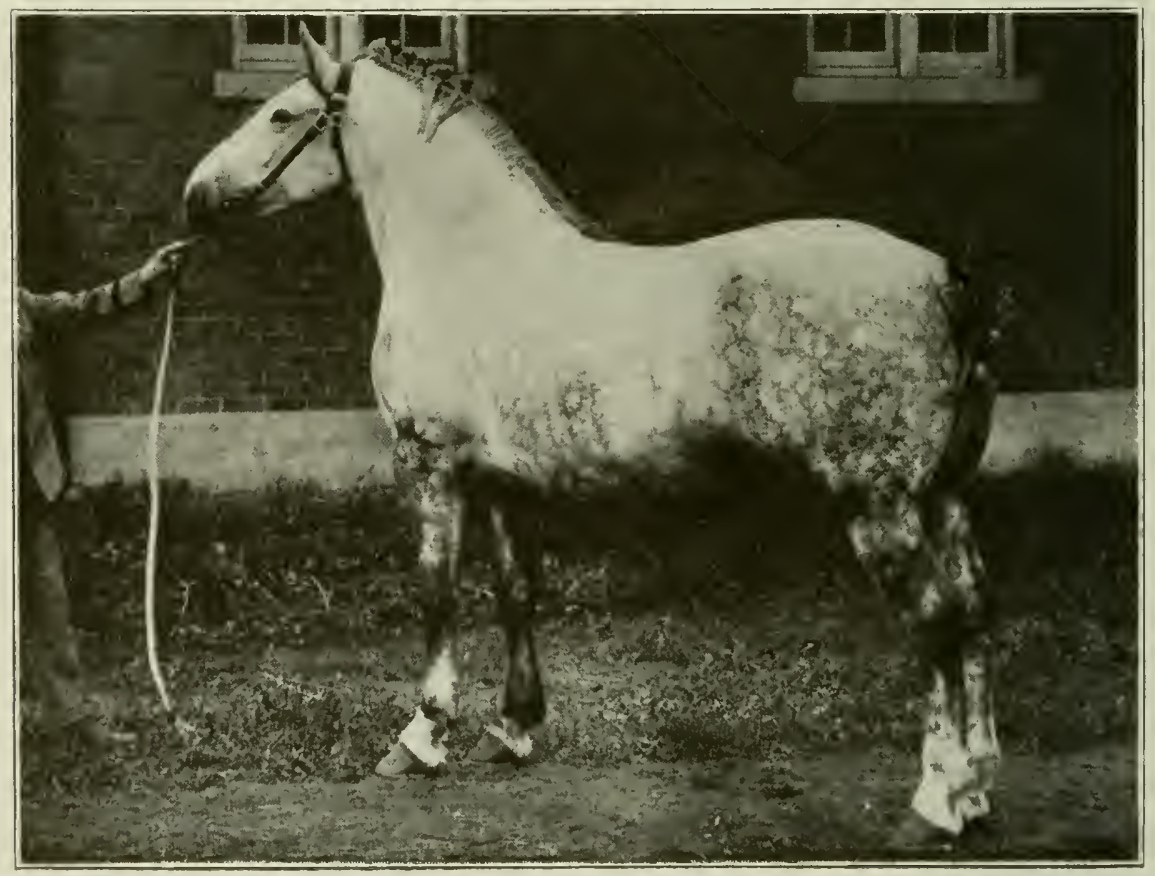

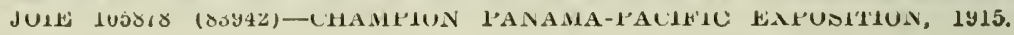


old, and then place them in roomy boxstalls and feed them for market. Stallion colts kept in confinement and highly fed easily become blemished. Through lack of exercise they do not develop proper bone and muscle, and rarely reach their full size. They also are inclined to bad dispositions."

W. E. Prichard.-This from one of the veterans of the trade in the middle west:

"Forty-seven years of experience and observation have convinced me that the most serviceable Percheron stallion should stand from 16.2 to 17.1 hands high and weigh from 1,800 to 2,000 pounds in thrifty breeding condition. Some 200 pounds or more fat could be added to this weight, but it is to the injury of the stallion; it is usually not real horse, it is worthless blubber.

"In looking over a stallion have him stand in the shade of a stable door. Take him by the bit with the left hand, look in his mouth, look in his eyes, look over his face; then drop your eyes down to his breast and shoulders, then down to his knees, pasterns and feet. See that he stands squarely on his feet. Then step to his left shoulder; chin him. Then step back about 10 feet and take in the topline and depth of body, specially the flank. Step behind and observe the width of quarters, the fullness and depth of the stifles. Step around to the right side and look him over just as on the left. Examine his coronets; observe how he stands on his pasterns, which should be fair in length and sloping. See that he has plenty of bone of good quality below the knee and hock, and is sound. Then let him walk. out and return on the walk. Have him move at the trot out and back and see that his action is straight.

"The stallion should be rugged and masculine, not feminine in appearance. He should have a 
strong head well poised on a good neck. His breast should be full, wide and deep. The body should measure well at the heart and be full and deep at the flank. The back should be strong and short, well-coupled with long hips of good width. He should stand on good, big feet and be of kind disposition.

"Before settling for the stallion see his certificate of registration and try his wind. Buy of a responsible breeder or dealer-one who can and will treat you right if anything goes wrong.

"If it is possible to give a stallion work, break him to harness and give him constant work about the farm out of season. When the breeding season comes he will be in condition and it will be easy to give him daily exercise of from 5 to 6 miles. If you cannot work the stallion, make a paddock, enclosing an acre of ground with good grass and plenty of water always at hand. Build a stall for shelter from sun and storm so that he can go in and out at will. Feed oats and a little dry bran in every feed. If he does not eat oats readily, feed a little corn and good timothy hay. Handled in this manner the stallion should live long and be useful as a sire.

"Our experience has been that the full-made, wide, deep-bodied mare of medium height, standing on rather short legs, is the most successful in the hands of the average breeder. Her weight in ordinary working condition should be from 1,600 to 1,900 pounds. She should have plenty of bone both fore and aft, specially below the knee and hock. We like as much refinement about the head and neck as is consistent with the conformation. The mare should have a strong back well coupled to broad hips. Of course she should stand on sound feet and limbs. Be sure that she has a sweet disposition and 
is not nervous or fretful. The frothy-dispositioned mare is a nuisance and should be avoided. Look your mare over and find a stallion that can correct her faults. Keep her in harness, if you can, working her up nearly to foaling time.

"We prefer to keep our mares in harness almost up to foaling time, working them carefully, slowly, and in moderation. The feed before foaling is on the laxative order-oats and bran, not too much hay. We have fed our mares some silage for some time before foaling and like it very much; about 12 pounds twice a day make a reasonable feed. The silage must be absolutely free from mold.

"When the mare foals, if we are present and the afterbirth is separated from the navel, we disinfect the navel at once with a good disinfecting powder and repeat the treatment until the cord is dried up. We give the mare tepid water to drink, a little at a time for three or four hours until her thirst is quenched. One should be sure that the foal sucks within a reasonable time. Give it a chance to nurse without assistance if possible. Do not be deceived by its nosing around the mare's udder; be sure that it is nursing. TVe always give a foal about an ounce of castor oil before it sucks, if we see it in time. This assists in regulating the bowels. The foal should be watched for the first three days quite closely to see that the bowels are working properly. Make sure that the mare cleans in a couple of hours after foaling. One can usually remove the afterbirth by taking a round stick and wrapping the point of the afterbirth around it and winding it up and out of the mare slowly. Examine the afterbirth carefully to see that it is whole and complete. If fragments are left, infection will follow and the mare may be lost. Feed her moderately for a couple 
of weeks, until the foal is old enough to take the milk freely.

"It goes without saying that a stallion foal should get a good start in life while by the side of his mother: He should know how to eat grain before weaning time, so that when weaned he will hardly miss his mother's milk. After weaning he should have a grass lot with feed and water always before him and should be halter-broken and stabled at night. Have oats, corn, bran and good hay, clover or some alfalfa, always available. We aim to have grain before our weanlings so that they can get it as they want it.

"When spring comes our yearling stallions are placed in a pasture by themselves. They are fed grain three times a day and have good water always available. If the grass is not plentiful enough, we give hay or silage to supplement it. In other words, we give them plenty to eat and the freedom of the pasture for exercise. When winter comes again the yearlings are run in a 20 -acre bluegrass pasture and fed sorghum, silage, hay and grain in a roomy barn where they go in and out at will. The next spring they are coming two-year-olds. In March and April they are kept off the pasture and yarded about the barn. When grass is good in May they are turned on the pasture and grained three times daily. TVe had twelve two-year-olds rumning together last season. They get exercise, sunshine and shade as they want it, and they grow and grow. They grow bone and muscle and develop as colts should, and only as colts can that are raised in the open. Last summer was dry and hot and the late pastures were bare, but we planted some sweet-corn which ripened early enough to cut. With that and our silage the colts managed to squeeze through and those who see 



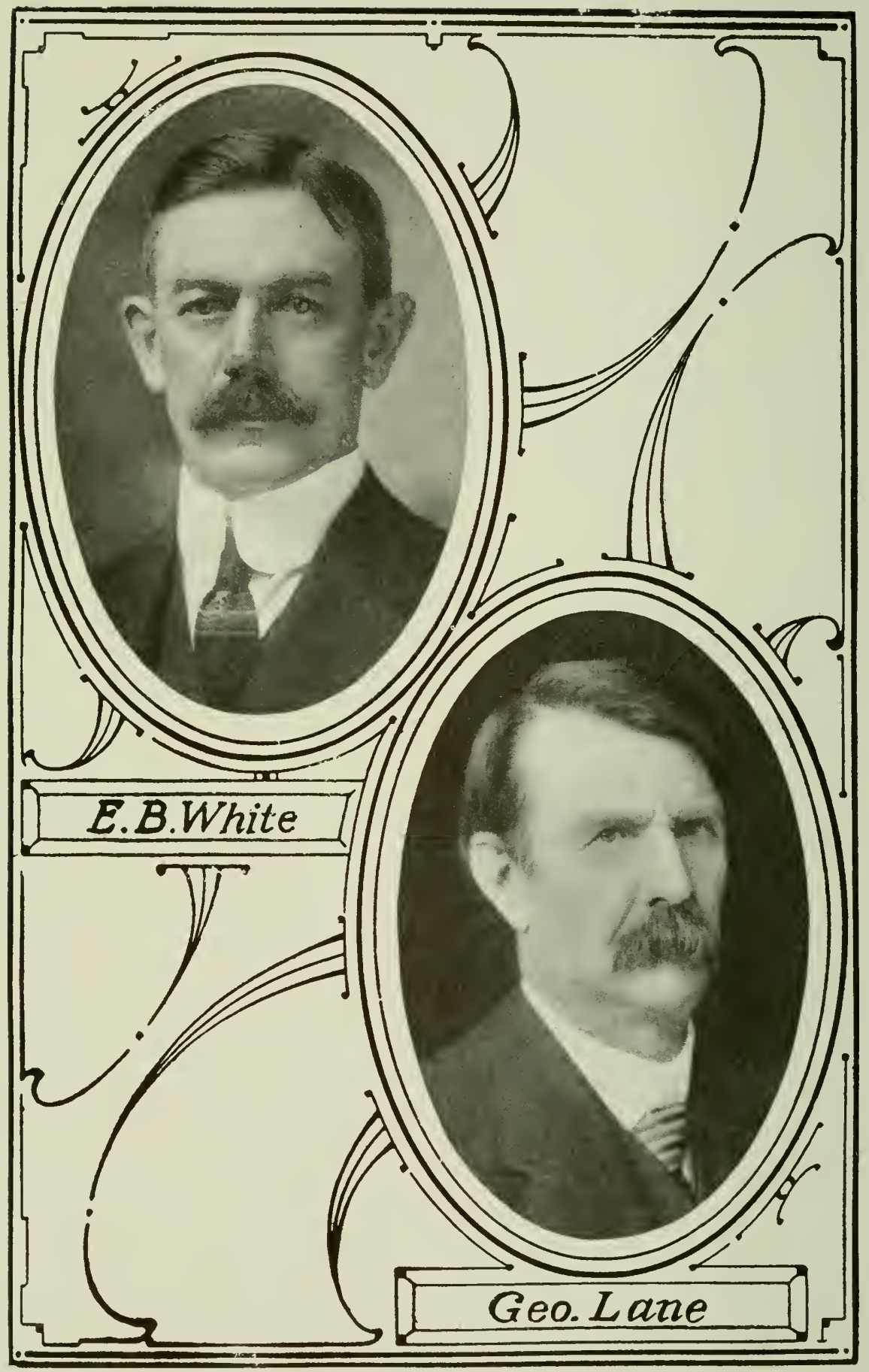


them seem to think they look very well. At one time our two-year-olds and yearlings were rumning on sweet clover up to their knees, and liked it immensely. We sowed sweet clover in oats last spring and it looks like a success.

"Our two-year-olds have not been housed in a closed barm since the first winter, and then only at night. A variety of feeds is essential-oats, corn, bran, silage, timothy hay, sorghum, sweet clover, bluegrass, and alfalfa. We can raise Percherons in America as good and as big and as rugged, and yet as refined and as full of quality, as they can in France. To accomplish this end we must breed good mares to good stallions, give abundant exercise in the open, and feed, feed, feed.'

E. B. White.-The present President of the Percheron Society of America expresses his judgment as follows:

6'The main things to seek in the Percheron stallion are bone of good quality and quantity, good feet and correctly-set legs, specially the pasterns, a good back, plenty of depth in hoof, a good middle, and straight and free action at both walk and trot. Of course the horse should be sound and clean. He should show quality, but not be coachy. The size of a draft horse's head should be in proportion to his body and show quality. The eyes should be prominent and the horse should appear always alert. I believe that alertness strongly indicates prepotency. I never have seen a prepotent sire that nearly always appeared dull and sleepy. He should be of medium size, and I would suggest that he weigh not more than 2,100 pounds in show condition. I believe that the very large ones are seldom, if ever, satisfactory in the stud. The things to be avoided are unsoundness, especially the kind that is generally considered 
hereditary, any faulty conformation that is frequently found in the breed, such as a droopy rump, crooked hocks, and the like. I prefer not to have an off-colored horse, not that the color makes the horse, but it indicates the possibility of the presence of some other blood than that of the breed and to that extent makes uncertain the type of colts which the stallion will sire.

"I do not believe that one can afford to work a high-class stallion; the risk is too great. He should have a large boxstall opening into a paddock containing about an acre, and the door should be kept open day and night so that the stallion can go in and out at will. The fence must be secure, but at the same time constructed so that the horse can see through and ascertain what is going on. If possible, I like to have a knoll in the paddock, from which the horse can get a good look over a large part of the farm. He should be made happy and contented. The stallion should be kept in the stall a month before the breeding season begins, fed more heavily and given plenty of exercise, so that when the season begins he will weigh about 150 pounds less than in show condition and be hard. I use only oats, bran and timothy hay for my stallions. Other feeds may be as good, and they may be better, but I know from experience that these are both good and safe.

"I believe that the size desired in the colt should be mainly derived from the mare. Therefore, I like a large, open, roomy mare, but she must be feminine. While I do not want a long back, at the same time I prefer it to a short, pony-built mare. She, like the stallion, must be sound and have good true action. Mares while pregnant can and should be worked when it is possible for the owner or his sons to handle them or when a reliable man is to be 
secured. When this is not possible it is best that the mare remain idle, but in this case she should be out every day unless the weather is very bad and she should be allowed the run of large pastures and not be confined to paddocks. A fair number of mares can be allowed to run together, but I regard it desirable not to have more than eight in one pasture.

"About one week before foaling the mare's feed should be oats and bran, largely bran, so that her bowels may be in good condition. If one is sure that the foal will receive proper attention, especially the navel, the mare may be put to work within two weeks after foaling; otherwise I prefer to have her remain idle until the navel has healed. On my farm the mares carrying foals are not worked, but this is because of my inability to secure reliable labor. When they are suckling I feed my mares oats and bran and mixed hay, half timothy and half clover or alfalfa. When flies are bad the mare and foal have a boxstall during the day and are turned out at night.

"The stallions and fillies should be separated when not more than seven months old. This is before there is a possibility of any of the fillies coming in heat and causing the stallions to fret and worry. If a stallion is never allowed to get near enough to a mare in heat to smell her, he will run in a pasture with a number of others nearly as contented as the same number of geldings. These stallions should have abundance of range. I prefer a field about twice as large as would be necessary to furnish them sufficient pasture, and I put in the pasture a like number of cattle. When running in large pastures the colts are able to take abundant exercise and will consume large amounts of oats 
and bran, of which they should be given all they will clean up nicely.

"For pasture I prefer bluegrass on limestone land, with ruming water at hand. My colts run together in such a pasture until they are about twenty-seven months old. The flies then compel me to stable them during the day. I find that when they are separated during the day they get more rough when turned together at night than when allowed to remain together all the time.

"When it is not practicable for small breeders to make ample arrangements for raising their colts, I would advise selling the stallion foals at weaning time. I should like to see some man in every breeding community engaged solely in the purchase and development of these youngsters."

J. L. DeLancey.-This from one who has helped to make Percheron history in the Northwest:

"The problems for the beginner in the breeding of Percherons are many, nearly all of which can be solved easily by putting to proper use the information which one can obtain from experienced, constructive breeders. It is, however, to be regretted that we do not have more constructive breeders, both in this country and in France, but those we have had and have now have done a wonderful work. And there is much to do in the future. It is unfortunate for the breed that until very recently the cheaper class of Percheron was more profitable to the importer and dealer than the better ones. But the time has now come when the breeder of the good ones meets with a just reward, not only in pecuniary profits, but in personal satisfaction and public appreciation.

"The person who is establishing a stud of Percherons today, either on a large or small scale, should 



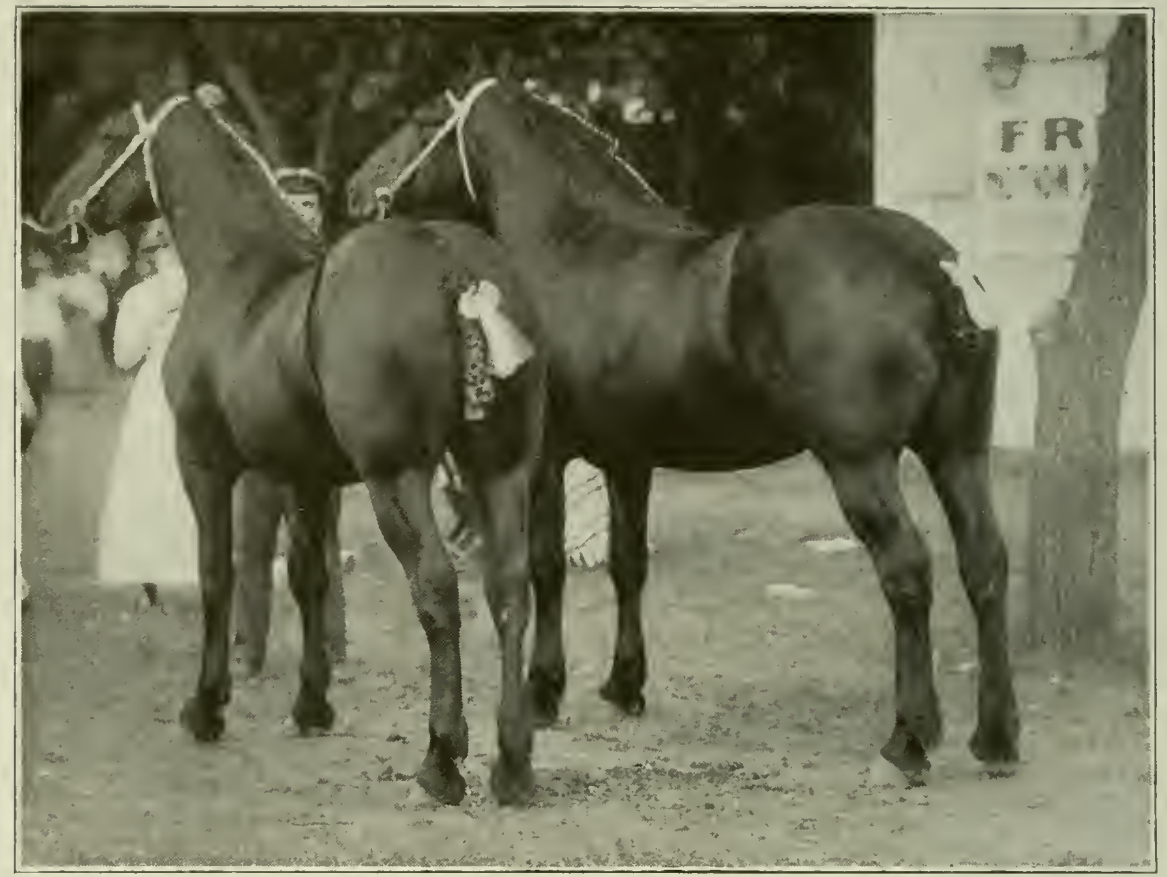

ON RIGHT, MARE HELEN HELIX 97206, CHAMPION NEBRASKA STATE FAIR 1916; ON LEFT, MARE DOROTHY B. 122455, RESERVE CIIAIIPION NEBRASIA STATE FAIR, 1916.

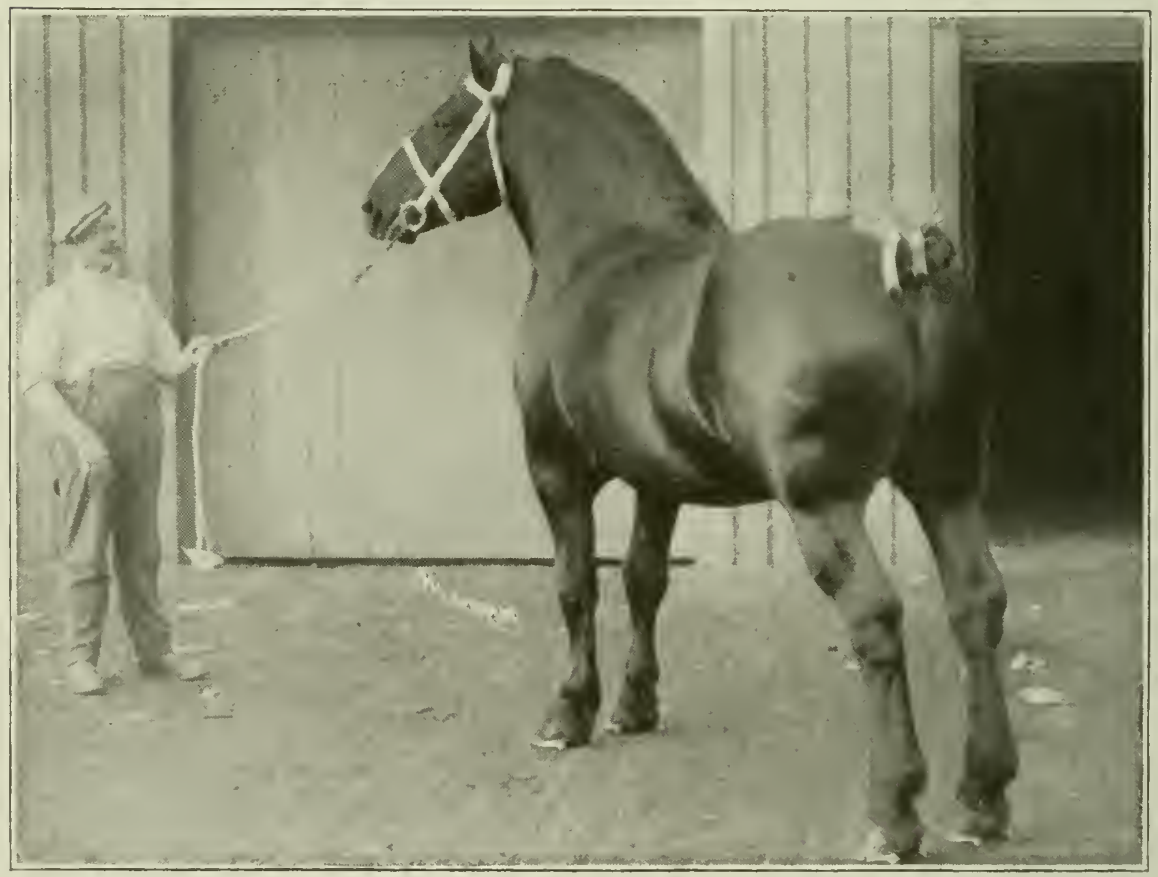


use greater care in the selection of his foundation stock, both as to their breeding and conformation, than ever before. The mares should be of good. size, standing squarely on large, wide-heeled feet with round hoofheads, above which are pasterns of proper slope, strong, flat bone, flat, wide hocks and large, flat knees. Also they should have good ends, long, well-sprung ribs and level toplines. Avoid all undersized and very blocky mares.

"In choosing" a stallion one must remember that the sire is half the stud, and that his selection is most important. There are many experienced breeders who can tell at the first glance a stallion that will be more than an average breeder. The same stallion, on close inspection, may have faults, either in breeding or conformation, which would make him undesirable as a stud-header. But if one can get the strong' 'personality' in a stallion which so attracts the man of experience, and without the other faults, one is almost sure to be piloting in safe waters for a sire.

"The general points to seck in the selection of a sire are much the same as for mares. In addition he should be stronger and more masculine in appearance, especially in head and neck, as well as more upstanding. The day of the blocky Percheron stallion is past. A stallion to head a stud of registered mares should stand not less than 17 hands high, and weigh no less than 2,100 pounds in sale condition.

"In the selection of both stallion and mares the breeding is very important and should be carefully considered. The families of Percherons which have made the greatest successes as sires and dams are well known, and one should get as much of the blood of these strains as possible in the foundation stock. 
"Brood mares should have plenty of exercise. Much the best plan is to work them, feeding clean, nourishing feed, so that when the foals come they may be strong and well. With proper cleanliness and disinfection the loss should be very small.

"The feeding' and care of the foals after weaning is almost as important as the selection of the sire and dams. The foals should be weaned at five months old, having had oats for four months prior to weaning time. After weaning they should have the run of a grass paddock, when flies are not bad, and be fed liberally on grain. We have never been in favor of over-feeding either stallions or colts, but there is little danger in giving. too much grain the first year. After that feed them liberally, but not all that they will eat. Many good colts have been ruined by over-feeding. It is advisable to let from two to six stallions run together until two and one-half years old; then separate them.

"It is next to impossible to over-feed a colt running" on grass. The feed given them then will give the best results, but when they are taken up greater care should be used in the selection of feeds. And always give plenty of exercise. The word exercise should be strong in the mind of every breeder of Percherons. Without it one grows a small-boned, soft-muscled, blemished colt. And if the mature stallions do not get exercise and plenty of it, they soon become non-breeders and the colts they do sire will be weaklings.

"The beginner in Percheron breeding, who begins right and then follows it with judicious care and feeding, will find his undertaking both interesting and profitable. Besides that, he is conferring a lasting benefit to the community in which he lives."

J. O. Singmaster._Out of his long experience as 
a breeder and importer Mr. Singmaster submits these views:

"In my opinion, the chief characteristics of a Percheron stallion are these: a head of good length and breadth, broad between the eyes, wide-open nostrils; eyes full and rather outstanding, rather than deep-set or in any way out of normal; a gracefully curved and massive neck; broad and heary shoulders; a deep-ribbed body; a back well dereloped from the point of the shoulder and of graceful symmetry; medium-closely ribbed at the point of the hip; the hindquarters slightly narrower than the shoulders; a gently sloping and rather long hip; the legs to match this body - a good, straight limb, a flat bone of rather heary type; long, springy pastern joints; good, dark-colored hoofs of above medium size, and clean leg's both front and rear. He should also have a heavy tail, docked at 9 inches for beauty of carriage, and still long enough to brush away the flies. There are other points, but these should assist the inexperienced purchaser in guarding his own interests. The stallion's weight in selling' condition should be 2,100 pounds and in breeding condition 1,950 pounds. I prefer the dark or steel gray or black colors, without markings other than a star in the face. Plenty of bone to support the body is essential, but abnormal bone is rather a weakness that foretells an early breakdown or roughness of limb.

"The breeding season in our latitude should not be earlier than April 1. The stallion should be put on the road for exercise a month earlier, so as to harden him for producing fertile semen. We would not increase his feed of bright timothy hay and oats until he is put to breeding; then increase the amount fed and add small quantities of clover hay or alfalfa 
and use bran mash as a bowel corrective. He should have 4 to 6 miles of exercise daily, except Sunday, when he should rest and not be used. If the stallion does not settle his mares by May 1, put him to work, either to a wagon or at farm work, from 2 to 4 hours per day. The stallioner should be a kind man and yet have his stallion under complete control. Never strike your horse, but guide him, control him. It is sometimes necessary to reduce your stallion to subjection, but never when you are in a passion.

"Select the type of mare that suits you best. We prefer the rather lengthy mare of good-reaching neck, with a sweet, feminine head, a good pair of shoulders, a deep body closely ribbed to the point of the hip, a gently sloping hip, and flat-boned legs with springy pastern joints. At the throatlatch she should be much lighter and cleaner than the male. The prominent eye and the medium-sized hoof, darkcolored and sloping but not steep, should be sought. Get your mares of similar conformation, so that when mated with a stallion of opposite good points they will produce foals of distinctive conformation or type that will build your reputation as a studious breeder of all that is best in Percherons. Color in the mare is not so essential as in the male. The mare should weigh from 1,750 to 1,900 pounds and be a square walker, with no wobbly joints. Percherons are of good disposition, and it stands us in hand to have it so remain, but it requires care in mating and care in handling the colts.

"Thirty days before the foaling date the mare should be fed on bran mash and clean, sweet hay, with a light ration of oats. Two days before foaling she should be placed in a thoroughly cleansed and disinfected boxstall, not less than 12 by 12 feet. A 
thick bedding of clean, bright straw is to be placed for her. If this is looked after one need use only a drying powder on the navel. It is the filthy condition that is usually responsible for the deaths that annually occur from navel disease.

"Young foals should be allowed to eat bran and oats with the dam, besides the mother's milk for the first month. Then a smaller box should be placed beside the dam's feedbox, and the foal will soon take care of its allowance, which may be changed in amount according to its needs. At four months it should have a good ration in addition to the pasturage. Keep the foal growing if you want the best results.

"One can expect only ordinary results unless he starts right, with both the sire and dam of good weights and breeding. To this add feeding and care and be repaid in the value of a well-bred and wellcared-for colt."

W. S. Dunham.-The son of the founder of Oaklawn, who has won for himself high place in the esteem of all latter-day breeder's of Percherons, supplies the following summary of his views on several important matters:

"In setting forth my opinions as to those things which are requisite in the selection of a stallion for breeding purposes, perhaps the best thing to do is to tell how I look at them when I buy them.

"When a horse is brought out for my inspection I first note his general conformation and size. A stallion to be successful in the stud should have good feet and legs and stand well on them. Nothing is so sure to be transmitted to the offspring as faults of conformation in the bony structure, such as curby formation of the hind leg, lack of bone, or crooked 
or badly placed hind legs. In order to suit me a stallion must have some quality and must be a true mover. If he has a powerful forearm and shoulder, he is almost sure to transmit these qualities to his offspring and to beget colts of large size. For a sire do not buy too small a horse, and do not buy one that is lacking in substance or that does not stand well on his legs, feet and pasterns.

"The matured stallion when in use during the breeding season should have plenty of exercise and good feed. He should, if possible, be kept gaining in weight during the season. I find that the best way to take care of such a horse is to give him a yard to run in, with plenty of oats, bran and good hay. I do not believe that he needs artificial feeds or stimulants. It keeps him more tractable and surer if he has plenty of exercise, or even work when not in stud service. The stallion which one purchases for stud purposes of course should be sound.

"Brood mares should be selected with due reference to size and soundness. They should be of feminine type and of the largest size to be found, short in the back but long below, and of good substance. Lightness of bone is apt to reappear in the colts. It does not hurt the mares any, in fact it does them good, if they are worked, except for a short time preceding foaling. They should not be kept in too high condition. Our own mares are kept at work except when they are producing foals, but after they have their foals they are kept on first-class pasture and fed some grain. The foals have access to grain and are accustomed to eat before they are weaned, so that at weaning time they lose very little in condition.

"For proper development it is necessary that the 
young stallions have pasture and space to run in. They should be well fed and kept in growing condition. The great fault of our American breeders is that they keep their stallion foals too much in the barn, where they cannot possibly develop the bone and substance which is necessary to make them first-class horses. Colts should run at large as much as possible; the exercise, the grass and the extra feed they get make them grow into desirable horses. The importance of exercise and grass cannot be dwelt upon too much. It is lack of these which prevents so many of our American-bred colts from developing into the kind of horse which they should be.',

J. B. McLaughlin.-Few Americans know the Perche and its horses better than Mr. McLaughlin. He says:

"Proper draft horse size is of course the prime requisite for the Percheron stallion. Correct conformation and alignment of the legs, big, broad joints, heavy bone with quality, pasterns sloping at an angle of about 45 degrees, a short back and a long hip with the tail set high, great depth through the chest, or heart as we usually call it, great width of chest, with the front legs not set too far out, plenty of middle, with great width to hips and stifles - these points, together with a big, broad foot with a high heel and plenty of straight, clean, vigorous action at both the walk and trot, are the most essential characteristics of a Percheron stallion. The things most to be avoided are improper conformation and alignment of the legs. A perpendicular line projected from the middle of the front toe should bisect equally the pastern joint and the knee joint. A line passed through the point of the stifle, the point of the hock and the point of the hind toe 
should bisect equally the hock joint and the pastern joint.

"A stallion should have at least 5 miles of exercise each day. Out of the breeding season the best thing is to work him moderately. He should have oats and corn enough to keep him always in good condition. He should be given enough bran or clover or alfalfa hay to keep his bowels in good shape. I think it is a great mistake to try to get a horse thin through starvation or lack of nourishing food. The old adage, 'Put your trust in God, and keep your bowels open,' works equally well with men and horses.

"Good brood mares should be feminine in appearance. They should be longer in the backs and broader in the hips and have more quality than stallions. They should be worked and always should be well fed.

"Cleanliness and antiseptic conditions are essential at foaling time. If the mare's bowels are not sufficiently loose from the feed and grass, epsom salts should be given to make them so. The mare should have a thoroughly clean box in which to foal. If the season and conditions are right, the pasture is just as good or better. The navel cord should be immediately treated with iodine or something. similar in order to prevent infection. Just so soon as the colt can eat it should be fed all that it can handle in addition to his mother's milk. The dam should be fed grain, in addition to the pasture, in order to increase the flow of milk.

"In developing the colts I would advise feed, more feed, and still more feed, with oats if possible; oats are the great developer of hard, clean, flinty bone. If oats are not available, feed corn, and plenty of it. For the first two years of its life a colt cannot be 



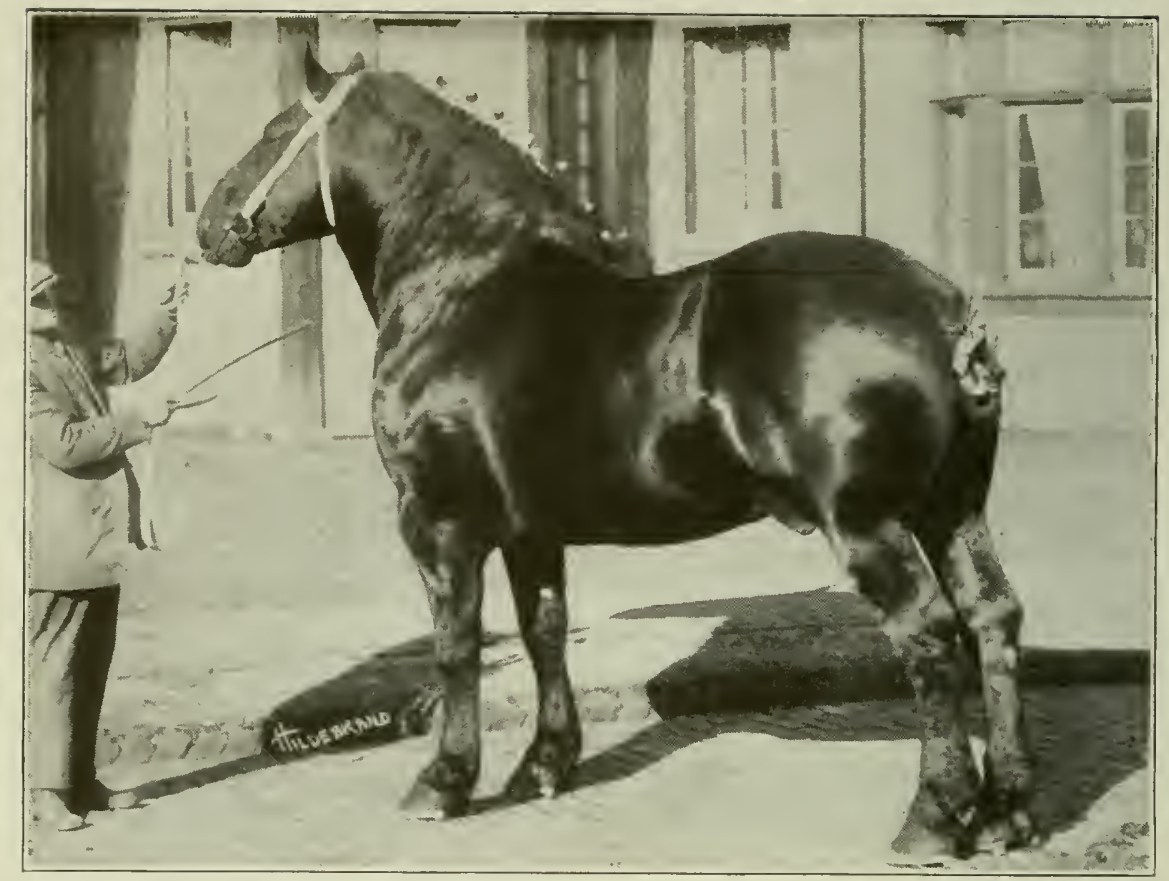

KONTACT 87277 (95804), FOURTH-PRIZE AGED STALLION, INTERNATIONAL LIVE STOCK EXPOSITION, 1916.

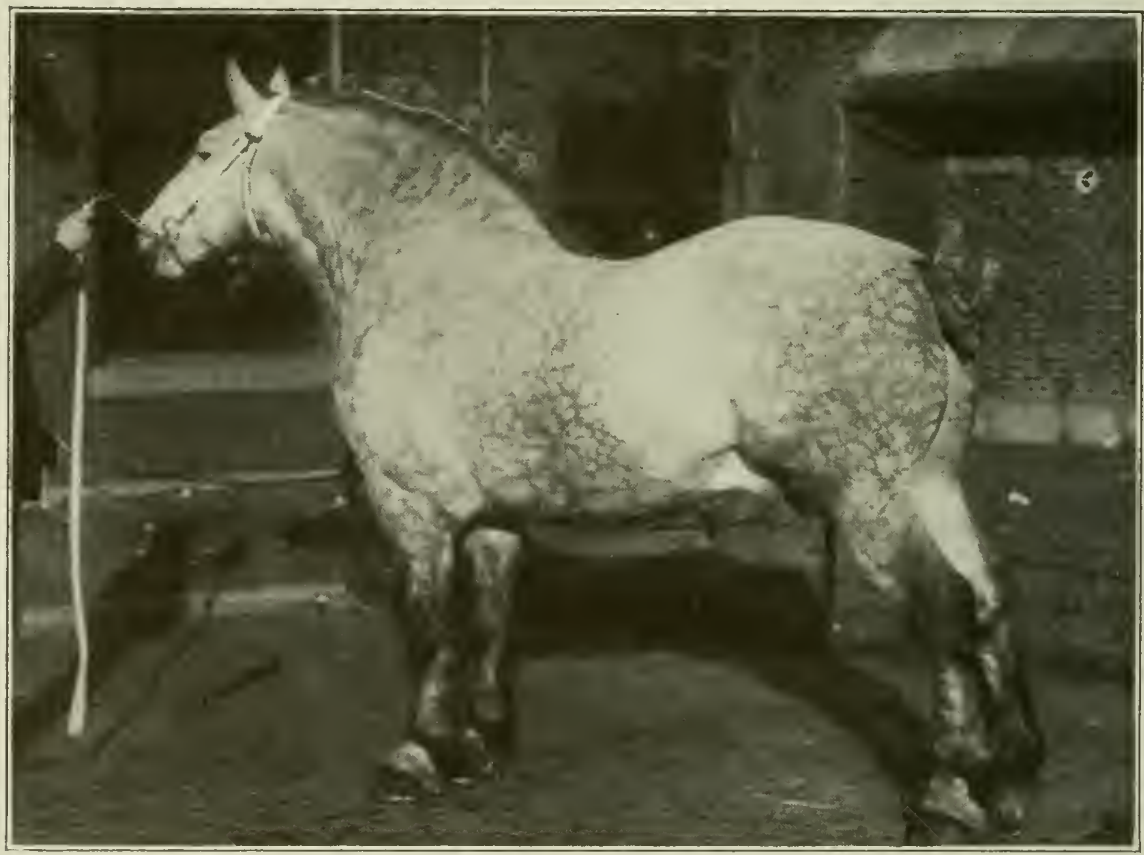

GLURGE P. 82495, RESERVE CHAMPION AMERICAN-BRED STALIION, ILLINOIS STATE FAIR, 1916. 
fed too much grain, as this induces early maturity, great size and heavy bone.

"During' the fall and winter after weaning the colt should be fed all the grain he will eat, with enough succulent feed, such as bran and clover or alfalfa hay, to keep his bowels in good condition. When the colt is turned out to pasture in the spring he should still be fed grain in order to make him grow properly. I always prefer a hill pasture for yearlings, as it induces great muscular derelopment. The winter that the colts are rising twos they should run in a paddock or field together, and should be fed all the grain they will eat. The spring and summer when they are two-year-olds they should still run together in pasture, with plenty of grain; the exercise that they take playing with each other adds greatly to their development.

"The fall that they are two-year-olds, when it becomes necessary to separate them, they should be placed in boxes, with paddocks if possible, and fed all they will eat. A few carrots do them a great deal of good at this time.

"In a sentence: in order to develop a Percheron stallion to his best estate, it requires from the time he is foaled plenty of exercise, either voluntary or forced, and all the feed that one can induce him to consume, and of such a nature that his bowels are always kept open."

W. S. Corsa.-The buyer of Carnot is a close student of animal form and his observations have weight:

"Fortunately for the horse-breeding interests, owning a stallion is largely a matter of convenience. Some one man or set of men usually will provide the stallion, but no one gets anywhere in raising horses unless he owns mares. While every one of us is 
vitally concerned as to the stallion he is to use, the fact remains that more men own mares than own stallions. The wide, general interest is in the mares; the deep, personal pleasure for us and our families is in the produce of the mares, while attached to them and surrounding them are perpetually perplexing problems periling the profits.

"If the mare delivers a good foal annually, she does her part. If the foal is raised and properly developed, the owner does his part. If both mare and owner do their part, then there is pleasure and profit in the business. With this end in view we must start with the right kind of mares. This would seem first to require soundness. Although the available stallion may be a breeder and an impressive sire, sound and of correct pattern and sufficient size, we cannot expect him to overcome a material unsoundness in the mare.

"The size of a brood mare is also of importance. We would not expect to raise real drafters from 1,400-pound mares; the offspring at maturity are seldom more than chunks. On the other hand, there is quite a temptation to use, and a very general demand for, the 'ton mare.' There are many such mares that are quick in their movements and handy at work on the farm; they make good mothers and regular breeders. They are the exception, however, among those of their size. In general, I believe the experience of breeders of purebred live stock will bear out the statement that the excessively large females are seldom the best breeders.

"A mare weighing from 1,700 to 1,800 pounds in ordinarily good condition is the draft mare that may be expected to give a good account of herself both at work and in the stud. Get size in the offspring through the selection of the sire and through 
the kind, quality and quantity of feed given the colts. Fortunately, it is among these under excessive weights that we find the greater number of mares of acceptable brood type-sweetly feminine sorts which usually have necks long enough so that one may put his arm around and love them.

"Avoid flat, shelly feet, straight pasterns, crooked hind legs, excessively sloping rumps, low backs and straight shoulders, both in the mares and in the stallion to which they are bred. The size of the bone may well be considered, though too much stress frequently has been placed upon mere size. It is the quality, however, which counts. We want a clean, flat, hard, flinty bone, and enough of it to hold up the mare and carry her on any work she may be called upon to do. It is desirable also that the front legs should not cut under too much just below and back of the knee.

"Having found a mare that is sound and acceptable in size, type and conformation, let us hope and pray that she has snap and courage to carry on the work that comes with the heat of the day and to pass them on as an heritage to her offspring. Such a mare not only moves more gaily, but is likely to move more correctly than the duil-headed, wabblylegged mare.

"It is idle to expect a soft, flabby, or poorly conditioned mare to stand up under the heart- and body-breaking stress of spring work, much less to conceive. It is to this weakened condition of the mare far more than to the condition of the stallion that the failure of most of the early spring mating. is due. Stallion owners commonly recognize that mares begin to settle when the let-np comes in the spring work, about the time that most mares have a little chance to begin to gain. Mares that are 
grained into gaining condition and are hardened by proper exercise or work are ready for spring labor; also they are in condition to be bred. The prevailing practice among breeders of live stock other than horses is to have all the young come at about the same time, so that they can all be carried along and finally sent to market together. For obvious reasons this does not work out well in the foal crop. Where several mares are on a farm for the dual purpose of farm work and raising foals, the farm work is less interrupted and the foals can be given better care and attention if the entire foal crop does not make its appearance at once. Practically every farmer can take care of one or two early foals, say of March or even late February foaling, if he wants to. The early foal, like the early calf or pig, has an advantage over the younger things when fall comes and it is time to show or sell. If, however, one is not equipped and lacks the energy to care for foals in the early days of the year, then by all means let him arrange to have the foals come at grass time. For the many this will be the more favorable time.

"If one wants to make some preparation for the early foals, it is all very simple and inexpensive. A small building containing two boxstalls, each 18 by 20 feet, separated by a space 6 feet wide, serves every purpose. The south half-end of the space may be inclosed to make a very comfortable place for a man to wait for the expected newcomer. The building should face south, and entirely across the front should run a strip of 4- or 6-pane window sash, so that every bright hour may bathe the stalls in sunshine. This simple structure should be placed a short distance from other buildings and away from other horses. Adjoining it should be provided 
a nice lot where the mother and her baby may enjoy themselves free from the danger and annoyance of other horses.

"But whenever and wherever the foal comes, when the mare lies down it must be somebody's business to be on the spot ready to help the mare and take care of the foal. Inexperienced men, either through excitement or through ignorance, too often unduly hasten the coming of the foal. This is bad for the mare and often fatal for the foal. The rope is fiequently called into use too soon, and more often is used too severely and without judgment. Give the mare a little time; nature will assist powerfully if left to herself.

"The navel cord of the foal should be left untied. Paint at once with iodine and completely cover with some drying powder. The powder should be applied repeatedly until the cord has entirely dried up and healed. In aggravated cases give the iodine treatment once or twice a day, spraying the interior of the cord if the trouble is extreme, and apply the powder three or four times a day. Beware the little pus pockets. As a further precaution against navelill, give the first bacterin treatment in 24 hours; repeat in 6 days and again when the foal is about a month old. Fortunately for men remote from a veterinarian, this treatment does not require professional services. Any one with ordinary horse experience can do the work.*

*Note-Touching the important matter of Pyemic and Septic Joint Diseases of Sucklings (Omphalophlebitis Septica) Dr. Theo. C. Tiedebohl supplies the following:

"This disease is both contagious and infectious, affecting a new born animal, occurring usually in the first few days of life, and seldom after 30 days, and in the greater majority of cases, it develops as the result of umbilical infections, due to the fact that the stump of the umbilical cord still being moist but yet no longer nourished, malsing it a favorable seat for infection, infective organism gains entrance into 
"As soon as the foal is able to stand, it should be given an injection of warm castor oil or warm soapy water, preferably castor oil. This should be repeated, if necessary, until the caretaker is satisfied that all the little hard lumps have been expelled. Many foals are lost because the caretaker is too quickly satisfied with the results of one injection.

"If all has gone well the mare should be rebred on the ninth day after her date of foaling. Do not neglect this. In our experience mares bred at that time are much more sure to settle in foal than when bred at a later date. Assuming that her foal is exceptionally good, then by all means, if possible, breed the mare back to the same stallion as before just as long as this excellence in the produce is evident. Do not change; rather count yourself fortunate that you have this happy 'nick.'

"Foals are inquisitive youngsters and when only a few days old will begin nibbling around the grain box. From the time they are two weeks old, they

the blood vessels and either causes a local pus formation or gains entrance into the circulatory system itself.

"From a bacteriological standpoint, no specific organism has been isolated that I know of at this time. The varieties which are usually found are as follows: Bacillus Coli Communis, Bacillus Bipolaris Septicus and Streptococcus.

"As for the treatment, many medicinal agents have been employed, but with varying results. The Bacterin treatment is now the most valuable adjunct. It consists of injections of killed bacterial cultures containing varying amounts of killed bacteria, the doses varying from one billion to ten billion. The bacterin is injected hypodermatically under the slin. The point of inoculation should be antisepticized with any good standard antiseptic, using about a $5 \%$ solution. If the infection is known to exist on the place, a second dose should be given about the 6 th day, followed if necessary when the colt is about 30 days old.

"No harm can result from the injection of bacterin if they are made by a reliable firm. There are many vaccincs on the market. Some of them are called Polyvalent, due to the fact that they contain killcd cultures of different types of bacteria. Others are Autogenous, etc. If the laymen are to employ bacterin treatment, it is well for them to state when ordering the bacterin, the use they want it for and the biological companies will send them bacterin made from cultures, suitable for navel infection. It is usually put up in small 1 CC ampules in solution ready for administration." 
should have their daily chance at the 'wee bite,' and as they get older do not make the bites too 'wee.' Crushed oats and bran make excellent feed. There may be a better, but we need not worry about that. About this time the foal on most farms is having its troubles. Often the mare and foal have to fight it out with too many other's of the same kind or with mixed lots of horses. The ideal arrangement is for the mare and her foal, with no other horses, to be placed in a grass lot that has not been pastured by horses for at least a year. The nearer this condition can be obtained, the better the foal thrives and the freer it is from infection and trouble.

"The next critical period for the foal is at weaning time. Then the ravages of distemper are most threatening, and an unchecked outbreak is always frightful and frequently fatal. However, with the colt long since a good feeder and carrying considerable immunity from previous bacterin or serum treatments, it only remains to reinforce the immunity against distemper by vaccinating a week before weaning and by following with the same treatment a week after weaning. The colt with his companions is now headed for winter quarters. Before going, however, there is another good foot trimming and leveling and, if it has not been done previously, he is neck-branded. The brand, usually a herd number, is made a part of the owner's records. This is for the convenience of the owner while he lives, and afterward, if necessary, for the convenience of his administrator.

"Just a last word about the little fellows as they are taken from their mothers and put in their winter home. This has been freshly prepared for them, thoroughly cleaned and disinfected. Throughout the winter it should be regularly cleaned and occasion- 
ally disinfected. Arrange the quarters, if possible, so that the colts may go in or out at will, except in stormy weather, when a gate may be used to keep them within shelter, where they will be out of drafts but supplied with an abundance of fresh air. If the gate to the shelter opens out on several acres of grassland where the colts may play tag and nibble a little lunch between their two regular daily feeds of grain, there will be some very happy and probably very profitable colts. And profitable colts are the controlling and compelling argument in favor of the use of draft mares on the farm."

A. L. Robison \& Son.-From this firm we have the subjoined remarks touching the management of mares and foals:

"At the outset it may be said that the man who would succeed in the management of Percheron mares and foals must have mares of correct pattern, and they must all be of that one pattern. The more nearly they are alike in bloodlines the better, and they must be mated with a sire of the same type that has likewise descended from an ancestral line of which he is a typical specimen. It is a thankless task wasting good feed and faithful care on mares and foals that do not resemble some one definite standard. The greatest mistake young breeders make is in picking mares here and there that strike the fancy. Years later they may awake to the fact that the diverse types or uncongenial bloodlines, or likely both, have foiled their attempts to produce such colts and fillies as the breed needs. With a foundation uniform both in pattern and ancestry one is assured that the offspring will be of the same sort. Then there is the foundation on which skillful feeding and care will build finished horses that are a monument to competent management. 



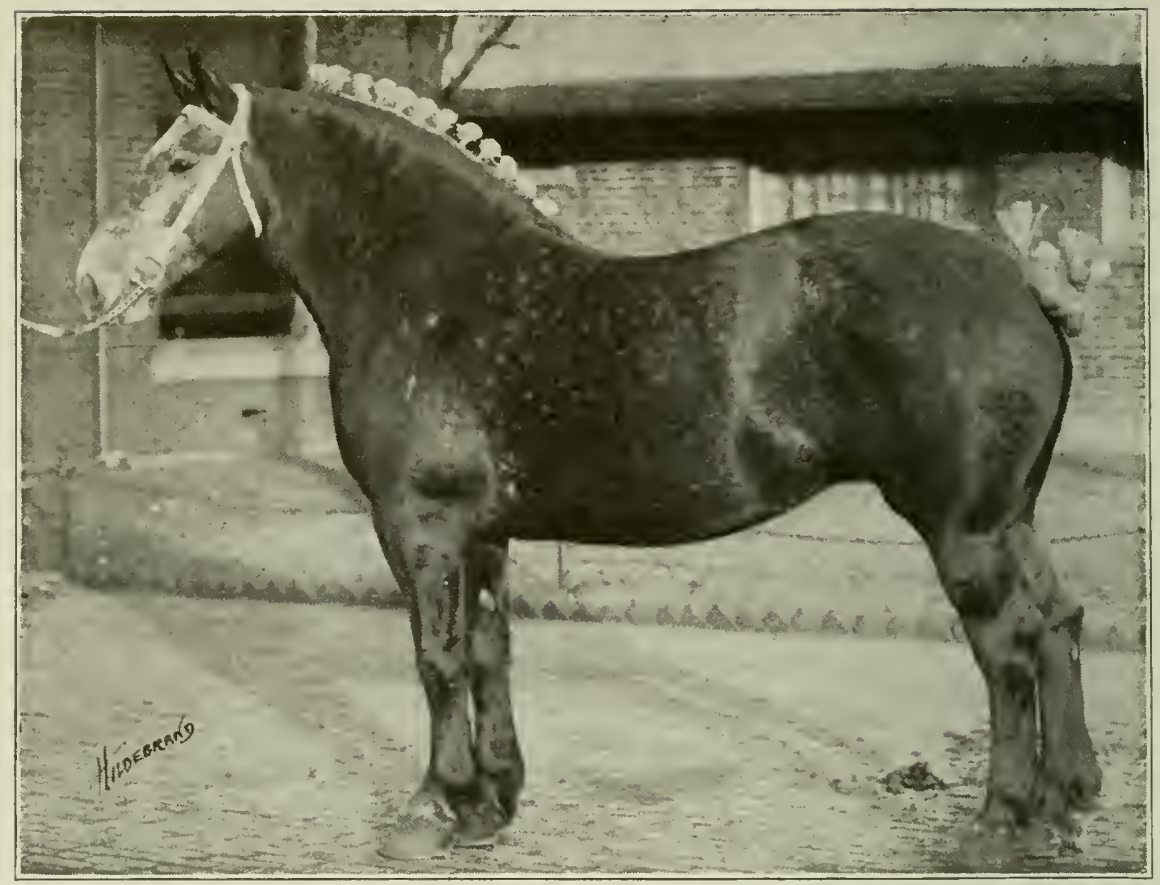

ROSELAND 87467, FIRST-PRIZE AGED MLARE AT ILLINOIS STATE FAIR IN 1916 AND RESERVE CHAMPION AT SAME SHOW.

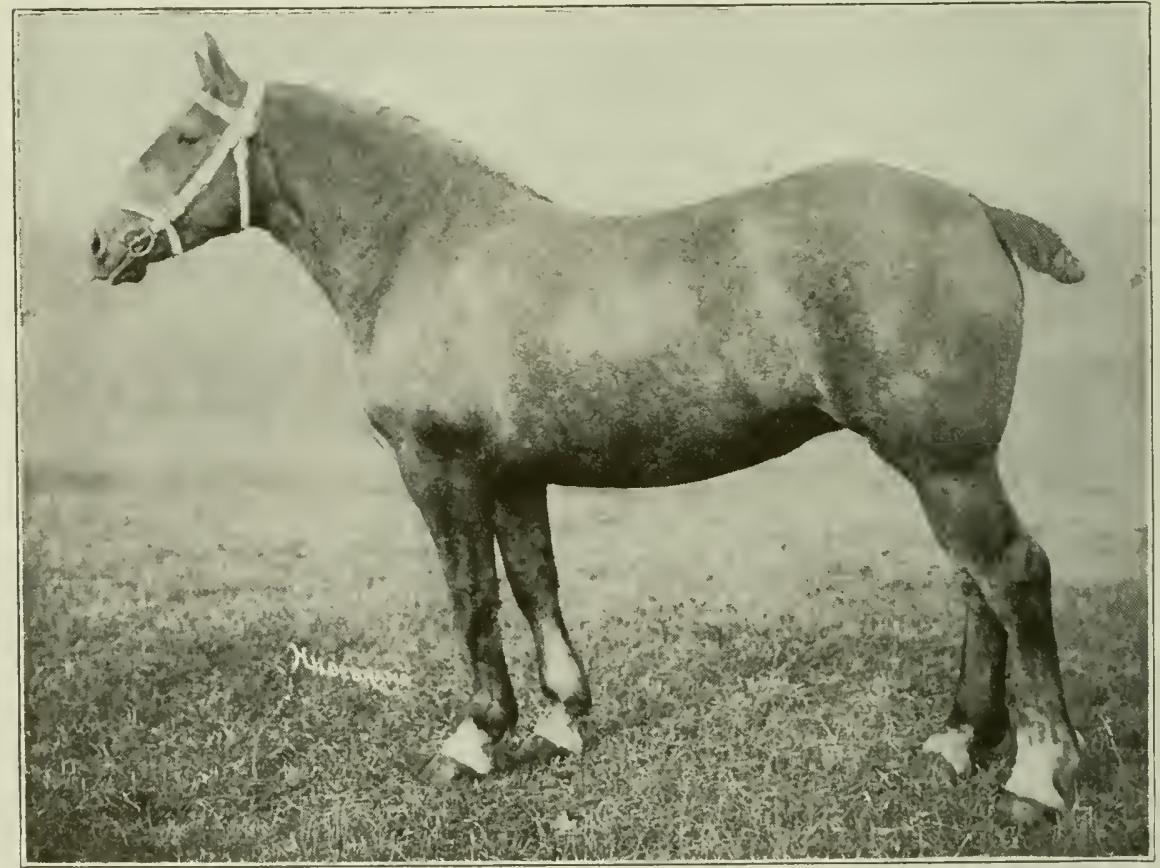

LEGITIME 98978 (99389), FIRST-PRIZE TWO-YEAR-OLD AND GRAND CHAMPION MARE, INTERNATIONAL LIVE STOCK EXPOSITION, 1913 
"Producing matrons must not be allowed to take on a load of fat. Thrifty, vigorous, muscular, bigboned mares are easy feeders, and a kind-hearted attendant may get them so fat that they will not breed regularly. It is best to have them come through the winter in moderate flesh. Then during the spring on bluegrass pasture they are fed corn generously, perhaps 10 ears twice a day, so as to be gaining in flesh at the time of breeding. By this plan they get in foal much more promptly and surely. We never pasture timothy and clover in the spring, for the mares do not breed so well on anything but bluegrass. Those that have foals are left on the pasture all summer, and fed sufficient corn to keep them in strong flesh but not fat. Oats are not so good for this purpose, as they are apt to cause colic in horses getting early summer grass. After Aug. 1 we feed some oats. Mares that are not suckling foals are given no grain when on pasture. They are, however, usually put in the harmess and worked through the season.*

"We do not breed two-year-old fillies. There are several reasons. Such early breeding probably checks their growth to some extent, and our records show that it develops irregular breeding and a shorter period of production. The filly bred so young is restless at foaling time, and is not a good mother. She is likely not to breed while suckling her first foal at three years old, and that starts her at the very beginning with the every-other-year habit of breeding. Tre sometimes put two-year-olds to light

*Note-Readers will observe that Robison \& Son recommend general use of corn with mares, and as the practice they follow is opposed to that pursued by a majority of breeders, it may be well to state that while Robison \& Son have obtained satisfactory results with their system of feeding, this may largely be due to the fact that they have extraordinarily good bluegrass pastures, mixed with white clover, and that such pastures are not overstocked. The high protein content of bluegrass has apparently served in their case to balance the surplus of corn. 
work. At three they are bred and put to work for the season. Early work develops a large feeding capacity, as well as powerful frame and muscle. It accustoms the fillies to being handled, and so they behave well when maternal duties come upon them. Some of our best old brood mares did not produce their first foals until five years old.

"After the foals are weaned in October, and the milkflow is dried up, the mares are turned on good pasture, and fed 5 or 6 ears of corn and 3 quarts of oats apiece twice a day for sixty days, to build up their flesh in good shape for the winter. After that they get no grain until spring. During the winter they run on bluegrass pasture and second-crop timothy in the meadows, but are not allowed in stalkfields. We are also careful to keep them out of oat stubblefields late in the fall, for frosted green oats cause abortion. The mares are not fed straw either. Special care is exercised to keep them away from rye straw, as a very little rye ergot is sufficient to cause abortion. Besides the grass from which they often paw the snow, the mares have free access to stacks of timothy hay, with just a sprinkling of clover in it. Sometimes they are fed a little cane, but never any corn-fodder. Fodder with the ears on is a dangerous feed for a band of mares, because at some time one of the mares is almost sure to get too much corn and lose her foal as a result.

"The brood mares have no shelter in winter, other than the haystacks for a windbreak. They will crowd in quite closely and quietly around the stacks during a storm. When we have tried turning them to the sheds they at once begin to fight for a monopoly of the shelter. In that case a big shed only protects the 'boss' mare anyway, and there is the danger besides of injury from kicking. The mares that run out 
all the time do not mind the cold. On some of the coldest nights they will be found far out in the field, and when the snow is deep they are out early pawing away the snow to get at the grass beneath. The water tank for the mares has a heater, which is kept burning all winter, so that they cannot become suddenly chilled by taking a big drink of icewater. We see to it that they come up to drink twice a day. Drinking cold water is more likely to cause a mare to lose her foal than exposure to a rain or snow storm, even with extreme cold weather immediately afterward.

"In the spring the mares that are soon to foal are kept in pastures near the barn. At night those that are soon to foal are put in a little pasture near the house, and some one goes to look at them about four times during the night or even every hour, in some cases. This attention is absolutely necessary, if one would avoid the frequent loss of foals and sometimes the loss of a valuable mare. Whenever help is needed it is needed at once. If the afterbirth does not all come away naturally, within a day, the uterus is flushed full of warm antiseptic water and the membrane removed carefully by hand. The mare is fed lightly at first after foaling. She is not given much grain for the first two weeks. If she is fed heavily there is too copious a flow of milk, and the foal is likely to develop digestive disorders, and maybe die. Mixed timothy and clover hay is about all that is needed at first.

"Mares are bred at the ninth day after" foaling" and are tried regularly thereafter for several periods. Breeding is more successful in the afternoon, as the mares are quieter then after returning to the pasture. Dry, shy-breeding mares are worked all day before they are bred. After the first two weeks from 
foaling, some corn is fed to the mare, and the amount is increased to a heavy feed a couple of weeks later. "The earliest foals are taught to eat at four weeks old by putting a little bran, whole oats, shelled corn and alfalfa-molasses meal in a litte feedbox just out of reach of the mares. In the pasture a feed trough is kept in a pen, with a creep provided, so that foals can go in but the mares cannot. After the first foals learn to eat, they are fed twice a day in this trough, and the later foals learn to eat by imitation. Sometimes they begin at two weeks old. They are given all the grain they will eat twice a day, and, after they get well accustomed to eating, the feed is mainly oats. There is no danger of overloading them with fat or injuring the joints when they are running out day and night and get plenty of exercise.

"All the foals that are as much as four months old are weaned about Oct. 1 . To do this each mare is tied at the feed trough in a long shed and her foal is haltered and tied alongside with a rope it cannot break. Of course, it pulls and tugs at it for a while, but no damage is done. The mare is right there and the youngster soon settles down to good behavior. As the foals are all thoroughly accustomed to dry feed, they do not miss the milk much, but go right on eating and growing. The mares are fed timothy hay alone and milked dry twice a day for a few days. It helps if one greases the udders with warm lard. After the milk is dried up the mares are turned out on pasture and fed grain in preparation for winter. The weanlings are given the open shed for shelter and run on pasture for sixty days, with grain. They are likely to get wormy at this time and rock salt is a useful preventive.

"Beginning in December the colts are put in boxstalls, two or three together, at night, and turned 
out to pasture in the daytime. They are fed oats, bran, shelled corn, chopped cane, oilmeal and alfalfa hay, all they will eat. The colts grow faster and develop a greater feeding capacity on alfalfa hay than they used to have when we fed mixed timothy and clover. Their grain is principally oats. The first winter is a critical time with a colt. If fed so as to grow well up to the age of 12 months, the colt may be kept going easily enough on good pasture in summer and rich hay in winter, supplemented with enough grain to maintain a good degree of flesh, so that there is no lack of nourishment at any time in the year."

Lee Brothers.-Selection and care of breeding stock is discussed by Mr. J. H. Lee of this rellknown Kansas firm:

"The selection of a stallion to use either on purebred or grade mares should be studied carefully. One should exercise his very best judgment, not only as to the animal's individuality and breeding, but as to what he will do in the stud. One horse may be a good individual but be lacking in bone, another in size, and so on.

"In all our experience we have found it easy to right a wrong early, not waiting until we have one or two crops of colts and then seeing where our stallion is lacking. Some localities want a heavy, low-down block; others want a tall, rangy, lightboned horse. My idea of a good Percheron stallion is one which at the age of three or four weighs about a ton, is black or gray in colors, neither the lowdown kind or the tall, rangy kind, but one well balanced all around. I want him wide between the eyes and with a good, clear eye. I prefer hazel eyes, as they seldom lose their sight. See that his ears are well set, not pointed or drooping, but stand- 
ing up well and about the same distance apart at top and bottom. He should show a clean-cut neck nicely set on his shoulders, with his head up to attract attention. I want always to see a wide breast and clean, flat bone, not a meaty, large bone (it will always give trouble, both in the stallion and his offspring). Well-set limbs are essential; see that he is not buck- or calf-kneed, and that he is clean around his pastern joints. Look for sidebones; they are considered by 75 per cent of the farmers as a buyer's trick to buy horses cheap, but they have worked more harm to the heavy horse for market than any other one thing in the past five years. See that the horse has a good hoof, not the pancake kind or the narrow, contracted kind, but a well-shaped, solid hoof. If one follows this he will find a good front end. Next have the stallion deep through the heart, close-coupled, good of withers, strong in topline, well-sprung of rib and with a place to carry some hay, not too sloping on the hips, with a well-set hind leg clean at the hock, no curbs, thoroughpins, bog or bone spavins, and clean about his pasterns. See that his legs are well set; no one wants a cow-hock or a crooked leg. Have the salesman move the horse from you, first at a walk, then at a trot; watch closely and see that he moves straight away, that he is not a paddler or a weaver.

"Often high-fed horses that have had the shipping fever or distemper are left weak in the back or a little thick in the wind. My advice would be not to buy either kind because he is cheap; in the long run he is high-priced. Our old stud sire, Scipion, now in his 18th year, is as clean as a ribbon all over and sound, except for being cut a little in the wind, due to his age. 
"The care of the stallion will show itself in more than one way. He should have a good boxstall, if possible 25 feet square, with a high ceiling and ample light. It should be in a place where he can see what is going on around him, see the other horses come and go and feel that he is not alone. A stallion likes company. Give him from 3 to 6 miles every day to a cart or at the side of another horse, and when the breeding season is over hitch him with a steady horse and put him to work. In the beginning start at light work, increasing it each time, from an empty wagon to a manure spreader and hay-hauling, and from that to any kind of work at which he can have plenty of time, so as not to become overheated or broken in constitution. During the breeding season twrn the stallion into a bluegrass or clover pasture of 2 or more acres, or at least give him a paddock 200 feet square, where he can have plenty of exercise and see everything that is going on. Give him plenty of good alfalfa hay, or perhaps prairie hay, and feed him equal parts by measure of bran and oats, together with a small amount of corn chop. Wet this feed well. Some horses require a greater amount of feed than others. In starting a new stallion in our barn he is tried out with a very small amount of feed. This is increased little by little, until we have him eating what we think he should have. Our foreman requires one thing of our feeders - the horse must be ready for every meal.

"In buying" the brood mare a man can use almost the same rules as in buying a stallion. Her care should be the care of any good horse. She may be worked hard in the field while carrying her foal, if at night she is given a good place to rest with good feed. After foaling let her rest for ten days 
or two weeks, rebreeding her on the 9 th day if possible. Then leave the baby in a boxstall, with other foals or alone. Bring the mother in from the field once between morning and noon for her baby to nurse. Never allow the mare to get too hot or the foal to nurse when the mare is hot.

"When the foal is thirty days old put some oats where it can nibble at them; increase the amount as it cleans them up, until oats may be left in the box for the foal to eat any time. As time goes on and the baby is left at the stable, try turning it out in a small pasture with a few calves or foals where it can eat grass and get plenty of exercise. When the foal is two months old it will not be necessary to let it nurse between regular meal times, but you will have a better colt if you do. After the foals are six months old and weaned turn them on alfalfa pasture, if possible, and feed them grain twice each day. When the pasture is killed by frost or is too closely cropped, take them to their winter quarters, preferably a place where they can have plenty of exercise all day and a shed to shelter them from storms at night. Do not start to put them in the closed barn or shed; let them run in and out at any time; have plenty of clean alfalfa where they can run to it, and feed grain twice each day.

"One reason that the colts in this country do not mature so quickly as imported stock is that we are too stingy with our feed. However, most of the imported stallions have their growth at two and one-half years, while our stallions will continue to grow until five years of age. We always feed plenty of oats and very little corm to growing colts. Oats make bone and keep them growing, while corn makes fat and in time will burn out their stomacl:s.

"We let our colts run together until the December" 



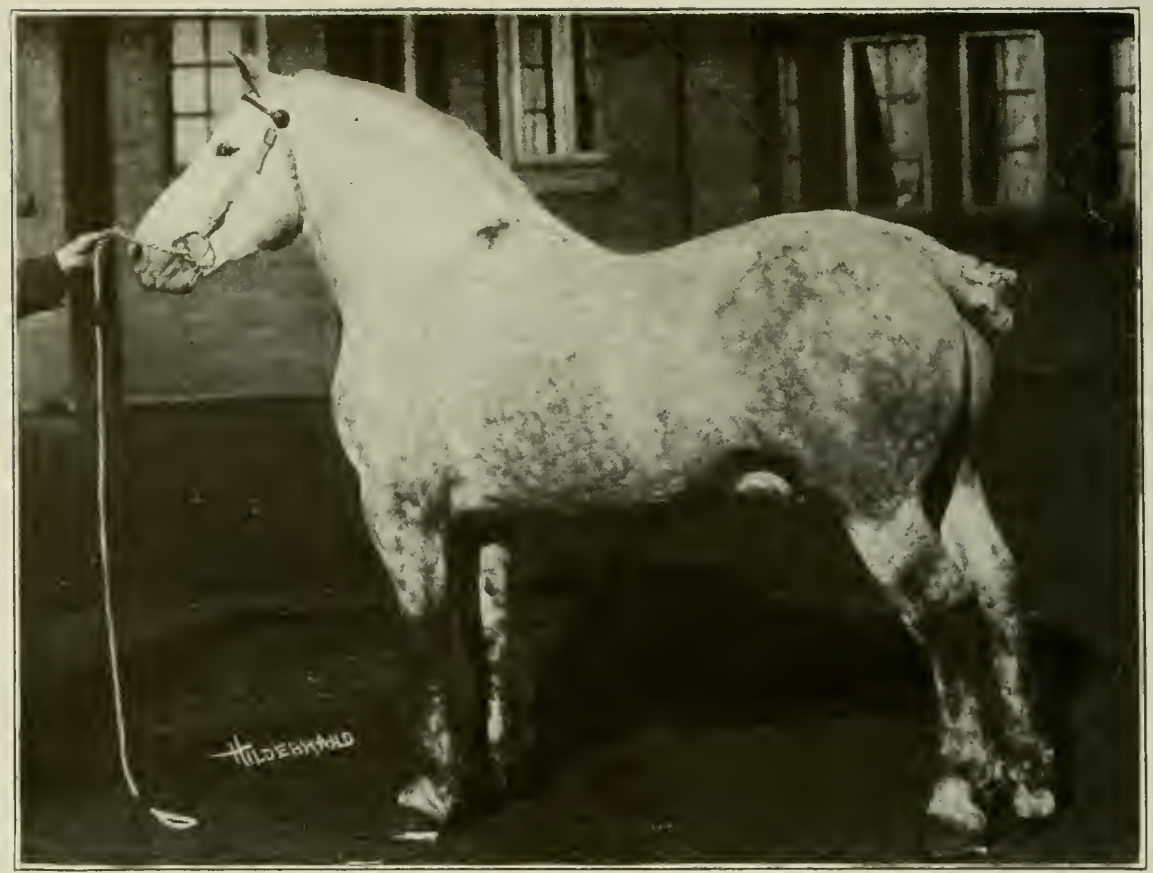

KEOTA JALAP 106186, SECOND-PRIZE TWO-YEAR-OLD STALLION, INTERNATIONAL LIVE STOCK EXPOSITION, 1916.

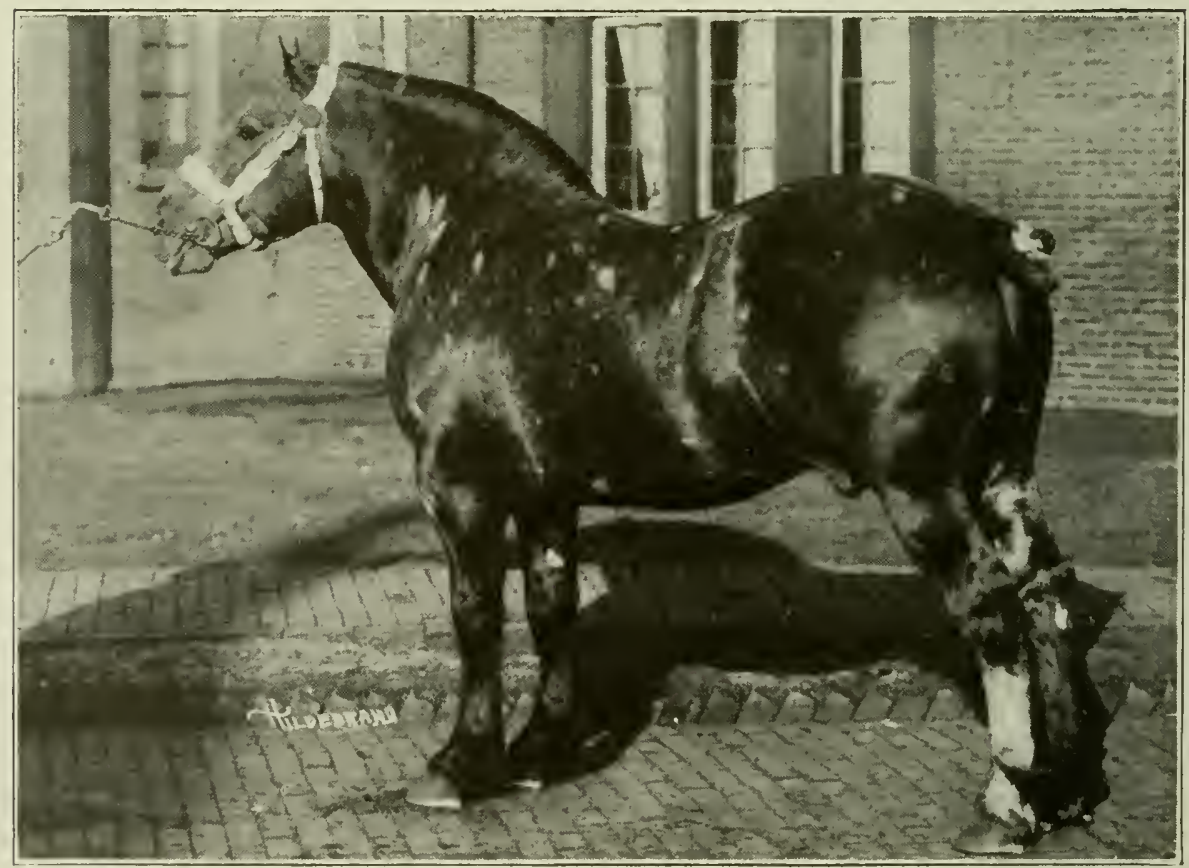

IVAN 108146, FIRST-PRIZE THREE-YEAR-OLD, OPEN CLASSES, AND CHAMIPION AMERICAN-BRED STALLION, INTERNATIONAL LIVE STOCK EXPOSITION, 1916. 
or January before they will be two years of age, then put them in boxstalls and give plenty of clean straw, alfalfa, oats, bran and some chop feed wet, three times each day. The barn man should take them out of their stalls every morning and clean them well, even their hoofs. Arrange so that they have a paddock to run in at least every other day. "Teach the colt to stand when out of the stall, and teach him to move. Let the barn man start with him, and follow, not with a whip, but with a cornshuck to make a shuffling noise, something new to the colt. After a few times he will be moving like a coacher when he hear's the shuffling of the shuck, and will never know low he learned it. Whips in the showring have lost more blue ribbons for horses than they ever won.'

Dan Augstin's Story.-Thirty years of Percheron breeding are thus recalled by Mr. Augstin:

"Ever since I can remember I have been interested in Percherons. When only a lad I used to go over to the old Dillon place to 'talk horse' every Sunday that mother would let me. That was a great treat to me, as fine draft horses were very scarce at that time. I learned a great deal in this way about the breeding and showyard records of these good horses. I made the vow then that if I ever got to be a man I too would own some Percherons.

"When I first started farming for myself I had only 80 acres of land and was not able to put my money in purebred Percherons. I did the next best thing and purchased high-class grade mares. These were bred to the best Percheron stallions in the community. My grade colts from such sires as old Powerful and Kellermann developed into massive, big horses of the right type. I made a strenuous effort each year to have every mare have a foal, and 
it was not long before I had plenty of horses to use and some to sell. These big, strong-made colts brought good prices, considering horse values at that time. Soon I was able to sell enough horses so as to buy more land. This policy I have continued to follow until my farm now comprises a total of 400 acres.

"I bought my first purebred Percheron mare in 1888. Seldom have I made a mistake in buying a mare, because I never allow myself to be persuaded into taking anything that is not of good breeding. If I buy a filly I make sure that she is out of a mare that produces the right kind and does it quite regularly. I have bought a few imported mares, whose parents and past records I could not trace satisfactorily, but in so doing I have always made it a practice to buy nothing except good individuals from reliable importers. Frequently, when times were hard, I have bought mares for which I thought I was paying twice as much as they were worth. However, I always satisfied myself before I made such a purchase that the mare was the kind I wanted. After 30 years of experience in the business I have found that the initial cost of an animal is of little concern, if it is the right kind. Some mares are just as highpriced at $\$ 500$ as others are at $\$ 1,500$.

"I beleve more in Percheron bloodlines than many breeders do. If Percheron breeders generally would pay more attention to selecting animals of the right kind of breeding, progress would be made more rapidly. Now that the war has cut off the importation of horses from Europe and we are trying to produce the good kind here at home, the cry has gone up from everywhere, 'I am in need of a good sire.' Breeders are just now coming to realize that constructive breeding of the highest degree cannot take 
place without the right kind of bloodlines to build upon. Why have purebreds and pedigrees, unless we give preference to those families that have been producing the desirable kind? When I first started in the business I bred my grade mares to the best sires available at a cost of $\$ 25$ or $\$ 30$ for the service fee. My neighbors thought I was crazy, but they soon saw the error of their ways.

"Frequently one hears it said, 'I want a stallion or a mare, but I will not buy anything but a prizewinner.' No greater mistake was ever made. Of course it is a fine advertisement to have a champion in the stud, but not all champions produce champions, by a long way. Many outstanding individuals come from the common ranks. Always select the very best breeding stock available; but that does not mean that one should purchase a prizewinner and turn down one that is not. Many show animals are ruined as producers and many equally good individuals never see the tanbark. I have made a great many mistakes since I first began, but believe that I have made fewer in selecting my breeding stock than in other ways, because I have given bloodlines and individuality first importance and price only second concern.

"In my early experiences at selling Percherons I never permitted a man to go away if he really wanted to buy and would offer me anything like a reasonable price. Here is where so many of our small breeders make a serious mistake. They ask such unreasonable prices that a dealer can not buy. The small breeder is not well enough known to sell at retail and often holds his stock long enough past the right selling time so that the feed bill eats up all the profit. Whenever an animal is looking at its best and one wants to sell it, then is the time to 
cash in, provided of course that he can get anything like a reasonable price. The small breeder almost always loses money if he passes up a dealer who is a good buyer, thinking that the price ought to be as much as the dealer would ask if the animal were in his own barn. That is not good business logic. Many breeders in this country still have this lesson to learn if they are going to produce breeding animals to sell profitably. The demand is now wide open for all the good Percherons we can produce, but the small breeder is likely to stand in his own light by misjudging his stuff and thinking he has an animal that would warrant a long price, when as a matter of fact he has only an ordinary individual. Effective selling goes a long way toward making the business profitable.

"Feed and care are as important as breeding' and individuality. The average breeder needs to be schooled along this line more than any other. I have proved to my own satisfaction that there is nothing else so essential as feed and care in producing purebred draft horses. Since we began treating our foals at birth with antitoxin streptococci and having them come when the mares can get on the grass, we have had practically no deaths. We give them an injection of this antitoxin when they are a few hours old and then again in about a week. Altogether too many breeder's make the mistake of having their foals come too early in the spring. They are inclined to be constipated because their mothers have been on dry feed so long. There is also much more danger of other complications setting in when dam and youngster must be kept in a stall for some time without exercise.

"I am sure from my own experience, that a far larger percentage of the foals born during the latter 
part of April and May live than of those that come in February and March. I find also that I am more successful in getting my mares in foal by breeding during the second heat period after foaling than on the 9th day. This gives them a chance to heal before being bred, as well as to rest somewhat before entering upon another year's work.

"Just so soon as the foal shows signs of wanting" to nibble grain I tie the mare up and give it a box to itself. It gets all the oats and bran it will eat from that time on. We sprinkle a little shelled corn on the oats and bran. Our foals seem to like a little corn particularly well. To this we add a little alfalfa meal in the winter, but not in the summer, as the molasses is likely to sour to some extent and sweet feeds draw flies around the feedbox. A foal always does better if fed in a clean box. Good alfalfa and clover hay are the best roughages. We use these feeds for all our animals, even our mature show horses. We never use black-strap molasses, as it always causes more or less digestive troubles. It is not any trouble to get a horse fat if it is healthy and has plenty of clean feeds, with good water to drink.

"For best results one should keep the idle mares that are nursing foals in the barn in the daytime during the hot weather and turn them out at night on good pasture. Generally speaking, we never let our foals go hungry from the time they will eat until they are well along toward maturity. We push our stallion colts harder than we do the fillies in order to make them salable sooner. One can not feed a colt too much of the right kind of feed, if he gives it plenty of exercise. We feed all our weanlings all they will eat, but keep them out of doors in large paddocks and pastures every day, unless it is storming badly. Open sheds or large boxstalls with doors 
opening into a large lot are most suitable for developing colts of this age. In fact we handle all our stallion colts in this way until the winter before they are three years old. Of course, if we have a colt which we wish to fit for the show, we keep him by himself. In the main we run our stallion colts together, even though we intend to show them. It is useless to expect that one can put on as much flesh that way, but he can unquestionably grow a more rugged and sturdy colt.

"Every man who raises colts in this way knows that he has more or less trouble with sore heels. The fact that such colts take an abundance of exercise, which gives them a strong appetite to consume more feed than they otherwise would, clearly overshadows such an annoyance as sore heels. We even run our two-year-olds, weighing 1,700 to 1,800 pounds together, but they do not look their best in the showring. I know, however, that they are worth more to the man who buys them than if they were kept up in boxstalls all the time. By raising my colts in this way I have very little difficulty with filled hocks. It is more economical to develop them by such a method because it requires less labor.

"Farmers are comparatively busy most of the year and have not the time and in many cases lack the help to give their stallion colts the exercise they need if they are kept shut up in a barn. Every farmer can provide his colts a good grass paddock, however, and let them do their own exercising while he does something else. Here is where the French breeders have the advantage of us. They have unusually fine pastures and furthermore every effort is made to improve them, because the French breeders fully realize the importance of developing draft colts out of doors. My long experience in developing stallion colts has 
taught me the importance of liberal feeding, but there must be an abundance of outdoor exercise, preferably in good pastures."

U. L. Burdick.-A deep interest in Percheron breeding has been manifested by $\mathrm{Mr}$. Burdick, one of the present directors of the Percheron Society, and we only regret that he has not favored us with a more extended statement:

"The essential features of a draft stallion are good feet, strong, flat bone, and size well balanced with quality. I would not select a horse with light bone, nor with poor feet, nor with large size unless he had quality to go with it. Nor would I select a horse with quality if he did not have size. I am speaking about ranch conditions only.

"Stallions should have plenty of good hay and oats, and plenty of exercise in a fenced lot.

"Brood mares must be selected with as much care as the stallions. The fine little Percheron mares rarely make successful breeders. Turn the mares out in a good pasture and let them foal as far away from the barn as possible.

"We try to get the foals to eat oats as early as possible, and they do not shrink a pound in weaning. Oats, water and hay left to colts to take at their own will mature them more quickly than any other method."

On the Northwestern Range-The following from N.r. J. P. Gammon of northern Wyoming will be found of special interest:

"Thirty-three years ago I began the breeding" of Percheron horses on the range in northern Wyoming. I realized at that time that in order to be successful in this far-western country the horses I raised must be of a good quality, excelling the pam- 
pered horses of the lower altitudes in breeding and size. My start in the business consisted of a number of high-grade and purebred mares, of good colors and size, picked to conform to my idea of what good dams should be. I chose for the head of the band an imported stallion that weighed 2,140 pounds, as good a horse as I could purchase at that time. With this start I have been able to build up by the purchase of new blood, always of the best, until I now have a band of Percherons that is the delight of all who see them.

"In the early days the country was new and there was plenty of good grass; the horses made excellent growth and kept fat the year around, rumning on the range. Later, as the country was stocked and the settlers came in large numbers, the range kept getting shorter, and my horses came in thin in the spring instead of fat as before. I saw that if I continued in the horse business I would have to change with the country. The day of the range was passing; it was necessary to provide some means of feeding through the winter, and about the only way to do this was to secure a ranch from which I could cut hay, and also have pasture for use as it became necessary. I finally purchased a ranch at the foot of the Big Horn Mountains, where I could cut plenty of hay and raise grain and also have plenty of pasture when necessary. Being close to the forest reserve of the Big Horn Mountains, I could also use that in summer, giving the horses an ideal summer pasture at the nominal cost of 35 cents per head for the season. I have been operating this ranch for several years, using the forest reserve in the summer. Late in the fall I bring the horses off the mountains and feed them on alfalfa hay until the grass starts in the spring. Under this system 



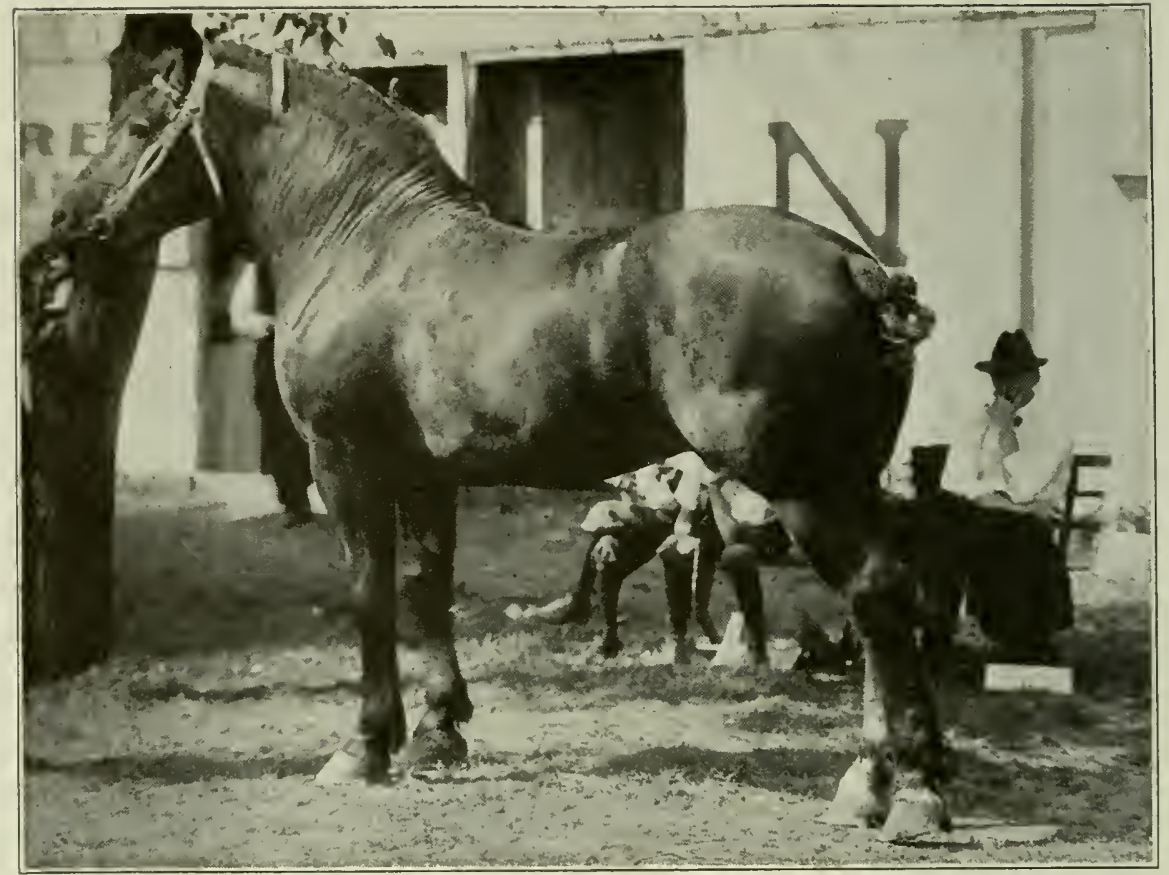

VANDOME 116151, CHAMPION STALLION, KANSAS STATE FAIR, 1916.

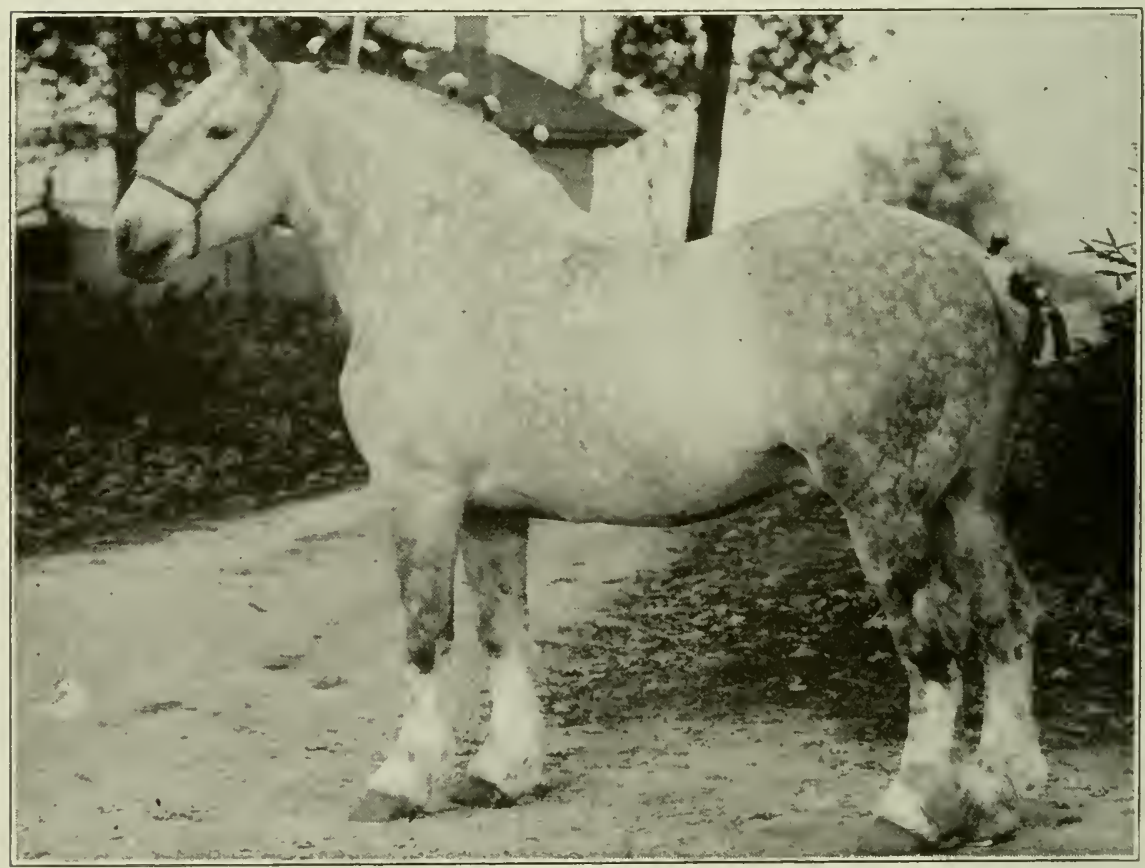

GRENAT S0714 (71632), CHAMPION STALLION, ILLINOIS STATE FAIR, 1912. 
I raise horses to maturity that would surprise the average easterner.

"About Jan. 1 I wean the foals, and during the first winter I feed them oats and alfalfa hay. I find that in this way I can raise horses that compare favorably with the eastern horses that are fed hay and grain throughout the year, and I think we get a much more hardy and tougher horse, of immense lung power and a constitution that cannot be excelled in the lower altitudes. One of the noticeable things about the horses raised in this country is that even many of the larger ones can be worked all winter without shoes. Actual tests show that the average range-bred and range-raised horse has a bone as solid as the Thoroughbred, and that the legs are usually free from puffs and enlargements. The horses which I have raised under western conditions are as large as or even larger than the eastern horse. I have mares in my band that have never tasted grain, except during the first winter after foaling, that weigh from a ton to 2,200 pounds, and I have also had two-year-old fillies weighing as much as 1,900 pounds.

"By buying' a young stallion in the east and maturing him here I get a larger horse with more and better bone than would have been the case had he remained in the east until maturity. I account for this by the fact that our feeds are so much stronger and of so much better quality than those grown in the eastern states. This is a broad assertion, but our oats seldom make less than 40 pounds to the bushel and have gone as high as 48, and I am threshing today oats that are yielding 80 bushels to the acre. The last three stallions that I bought in the east for my own use prove to my mind that my assertion is true. Two of them I bought as year- 
lings, and the other was 5 months old when purchased. The first two made horses that weighed 2,350 pounds, and the other weighed 2,225 pounds as a three-year-old.

"The big factor that has aided in the development of these big-boned, heavy horses under our conditions is the fact that even the stallions that necessarily have been brought into our herds have become acclimated with a marked degree of rapidity. They could, if the occasion demanded, be put under exactly the same range conditions as all the mares and young stuff endure. There seems to be something about the Percheron that is highly adaptable to range conditions. They can build bone and size with scarcely any grain. This is important and should not be overlooked by the western horseman when selecting horses for size, and horses that will have to rustle to no limited extent during many months of the year.

"Another pleasing feature of the horse business under range conditions and as we are handling them is the freedom from many of the more common diseases and unsoundnesses. Seldom are we confronted with problems in doctoring sick horses. Neither do we have animals discarded because of inferior bone or poor vitality. There is also a noticeable uniformity in the results of our breeding work. I can only account for it by the fact that our horses have the free use of a large domain of excellent range, plenty of good mountain water, hay of first grade throughout the winter, a great deal of work and exercise for the mares when kept in close pastures, and the continuous freedom for exercise of all our breeding stallions. We are giving to the lovers of draft horses a big, well-made horse, tipping the scales at more than a ton and doing a vast amount 
of work-all from grazing on the range and a nearly grainless ration. These horses are transmitting their draft characteristics to their purebred offspring and also are proving of unlimited value in crossing on smaller-typed horses.

"Four good legs constitute the foundation of any draft horse, and a square, compact, close-coupled body must follow a close second. From an experience covering a long term of years I have reached the conclusion that we can raise better horses here in the west, with its pure air and splendid water and range conditions, ideal for plenty of exercise, feeding them nothing but hay and grass, than can be raised under the ordinary eastern conditions where the horses are fed all kinds of feed during the entire year. Our horses are as large as the eastern horses, and more free from blemishes or imperfections. It has also been my observation that the Percheron is one of the best rustlers of any of the draft breeds, often going through the winter under the same conditions as the common range animal and many of them coming out in the spring in good shape and fit for work. The tendency in this country is toward the Percheron, with better sires and dams than were found a few years ago. In a large number of the horses of the Percheron breed that I see today on the farms of this county I can trace a resemblance to my first sire, brought into the country years ago. With the passing of the years this improvement will be more noticeable."

Management of Foals and Yearlings.-We are indebted to Messrs. M. C. Hodgson \& Sons for this statement of their experience in the feeding and development of young stock:

"At the very outset, credit must be given to Eli Hodgson, father of M. C. Hodg'son and grandfather 
of the younger members of our firm, for much of the success that has accrued to us in our Percheron. operations. His sound counsel in regard to the selection of foundation animals and the feeding and management of young ones has been of incalculable value. While we have gained some things from long experience, the fundamentals on which our success has been based have come largely from Eli Hodgson.

"For some years we had our foals come in February and March, because early-born colts have an advantage in the showring and in selling. But after many years of experience we have changed the time of foaling, and now have our foals coming during the latter part of April and in May. We would much rather have them foaled in June than in March. Our experience has shown us conclusively that the mares foal more easily, the foals have more vitality, and the percentage of loss is much lower with the later fosls. Under conditions prevailing in our latitude it is possible for our mares to foal out on pasture after Apil 15, and they do foal on pasture in the great majority of cases. A good bluegrass pasture, well exposed to the sun, is the safest place we have found in which to have a mare drop her offspring. We let the mare run out day and night, unless a bad storm comes up, in which case we put her in a boxstall if she is near foaling. In such case we take particular pains to see that the stall is thoroughly cleaned and disinfected with one of the coaltar dips. We then put in some clean straw and sprinkle more disinfectant over this. Our plan of having the mares foal on pasture when it is possible, and to put them in thoroughly cleaned, welldisinfected stalls in the few instances when it is necessary to have them foal inside, has enabled us 
to reduce the loss through navel-ill to a minimum.

"We keep careful records of the breeding dates of our mares. We know when they are about to foal, and from long experience we have learned to tell quite accurately about when they are to drop foals. We make it a rule to be with the mare when she foals, whether in the pasture or in the barn, either night or day, for if a mare does not foal safely within 30 minutes from the time she starts, intelligent help must be given.

"Besides having been able to save more foals by having the mares foal fairly late, we have found that mares are much more apt to become pregnant if bred after the grass is good and they have begun to make satisfactory gains on pasture. Any experienced stallion owner will testify that mares bred in March and April are hard to settle. This is of no slight importance when every effort is being made to get every mare safely in foal.

"After the foals are dropped, they run with their mothers in pasture night and day until hot weather and flies begin to cause trouble. They are started on grain feed when they are about four weeks of age. As soon as the mares begin to bunch up in the pasture and fight flies, we adopt the plan of housing the mares and foals in a cool, partially darkened barn during the daytime. They are put in about 7 o'clock in the morning and left in until 4 or 5 o'clock in the evening. Each mare is tied in a roomy double stall, which has two feed boxes and a manger for hay. The mares are fed grain twice a day, and as soon as the foals have learned to eat they are given some grain in a separate feedbox beside their dams. The youngsters are not tied up, but rum loose in the barn, which has a wide central alleyway where they are at liberty. 
"For roughage we place mixed clover and timothy hay in the mangers for the mares and foals. We also place some bright alfalfa hay in a separate place where the foals have access to it. Both mares and foals are allowed all the hay they will eat, but when they are on good pasture they do not utilize very large amounts. Our grain ration is the same for the mares and foals, and consists of bran and oats mixed in the proportion of 2 bushels of oats to 1 of bran. This is mixed and fed dry. The mares are allowed a moderate ration of this-about a half-pound per 100 pounds of live weight. A mare weighing 1,600 pounds will receive about 8 pounds of the grain ration per day. This is divided into two feeds, morning and evening. The foals are allowed all of this grain mixture that they will eat up at two feeds per day, although we take the precaution to see that they are not given enough to cause them to leave any grain in their feedboxes from one feed to the next.

"Poth the mares and foals are turned out about 4:30 or 5 o'clock in the evening, and run on bluegrass pasture all night, being taken in again in the morning. This general policy is continued throughout the entire summer. The barn doors are closed in the daytime, and the barn is partially darkened, so that the flies cause little trouble.

"We do not work mares that are nursing foals, as we usually have enough dry mares or young horses to do our farm work. We believe that we get better results with the foals by not requiring the mares that are nursing them to do anything while they are raising their offspring. Our policy of giving some grain to the mares while they are nursing foals may be objected to by some, but we have found that it increases the milk flow and contributes ma- 



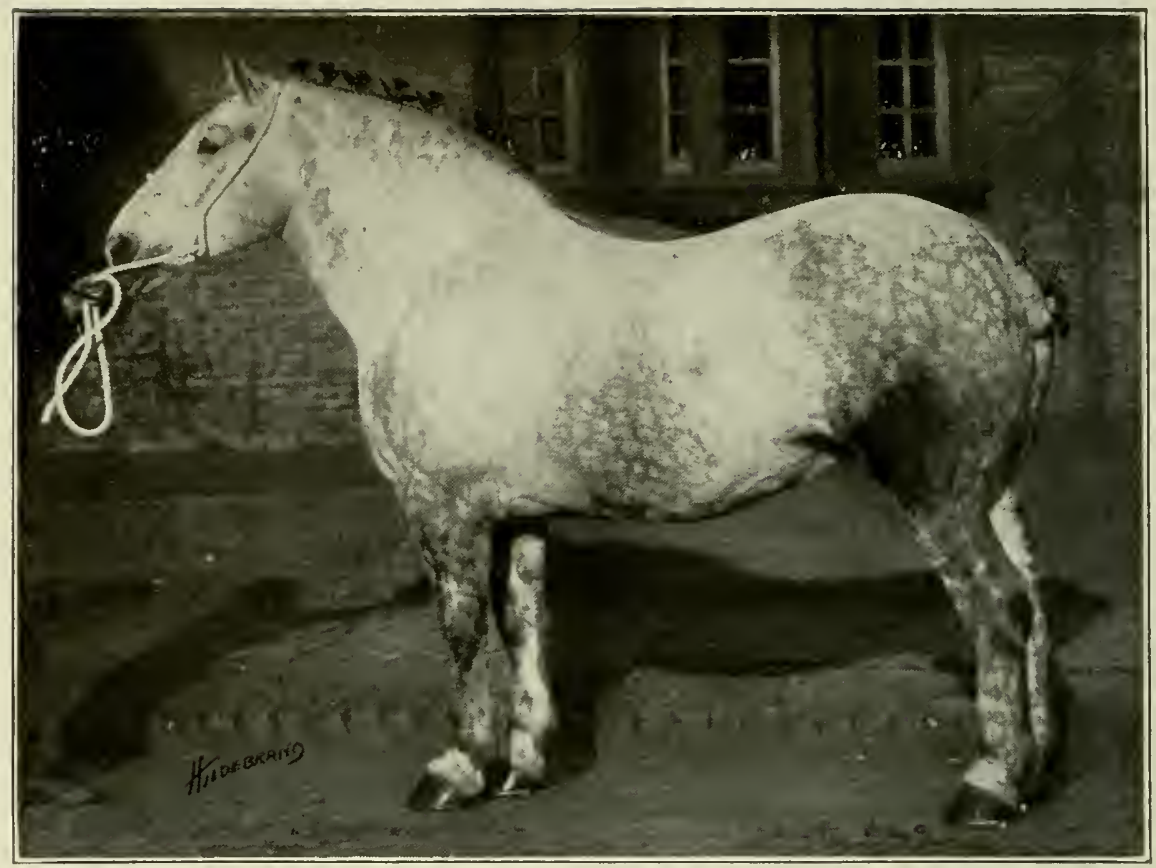

LACTINE 101472 (100912), RESERVE SENIOR CHAMPION MLARE, INTERNATIONAL LTVE STOCK EXPOSITION, 1916.

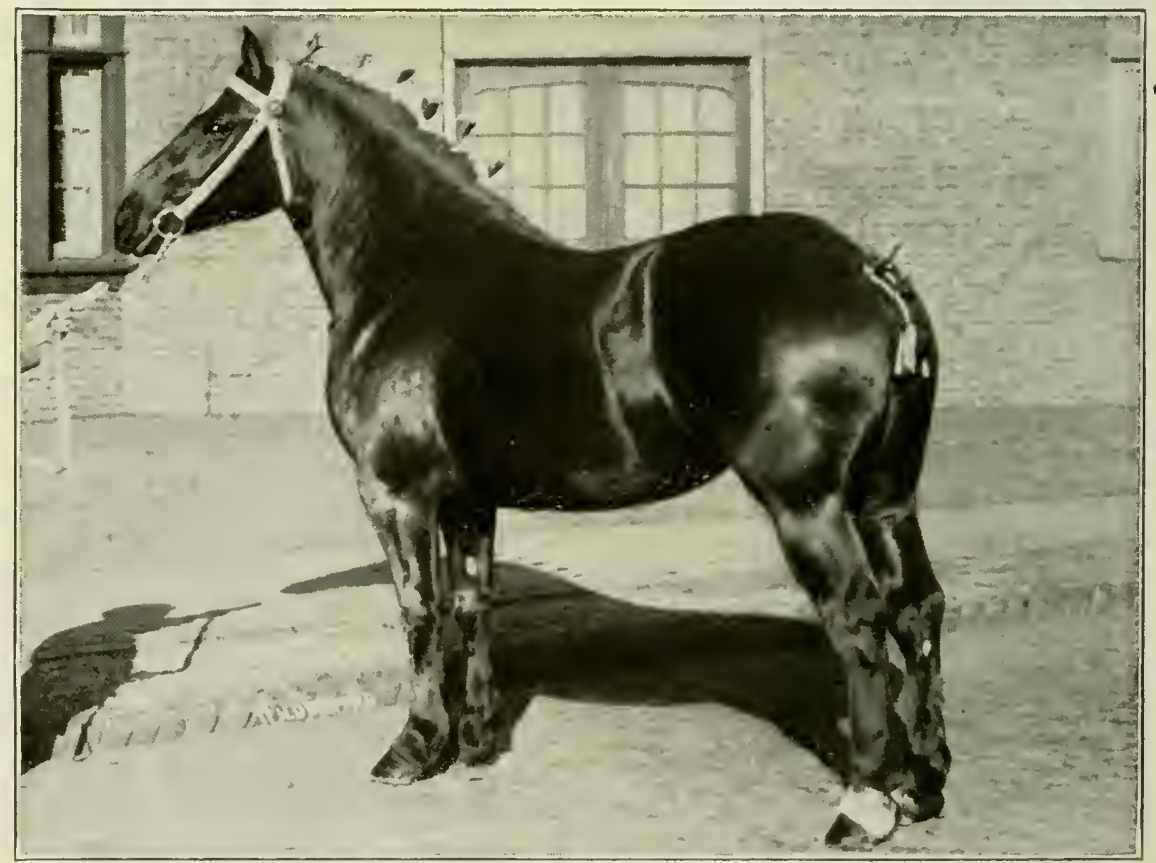

TURQUOISE 110346, FIRST-PRIZE TWO-YEAR-OLD AND RESERVE CHAMPION MLARE, INTERNATIONAI, LIVE STOCK EXPOSITION, 1916. 
terially to the rapid development of the youngsters.

"We make it a rule to wean the foals about Nov. 1. They have been haltered some time before this, but are not tied up until we are ready to wean them. We place a strong leather halter on each one, but also take the precaution to run a rope through the halter rings and tie it around the neck, fastening it to the manger, so that there is no possibility of a colt's breaking loose when first tied, thereby acquiring bad habits. The mares are turned out in pasture but are brought back the following day and the foals are allowed to strip them out once. After this the mares are turned back in a separate pasture and do not see their young again for some weeks. The foals are kept tied up for two or three days, until they have become accustomed to the haiters and have forgotten in some degree about their mothers. We then begin turning them out during the daytime, keeping them tied up at night. We take the time at this period in their growth to halter-break them thoroughly. From this time until the following May they are turned out regularly on bluegrass pasture every day and are kept in at night. The only exception to this is in case of a cold, wet storm during the winter. They are kept in out of the storm.

"From the time the foals are weaned until the following spring we give them alfalfa hay for roughage, and for grain allow each about 3 ears of corn per day, and in addition to this all of the oats and bran mixture they will eat. This system is followed until the pasture grass is very good the following spring, usually about the 10 th or 15 th of May. From this time until the hot weather and flies begin to bother the colts they are allowed to run out on pasture, both night and day. The stallions are sep- 
arated from the fillies about this time, and the yearling stallions are kept in the barn during the day. We have a half-basement barn which is fairly cool during the summer, and turn the yearling stallions into it during the day. This is partially darkened and some burlap strips hanging down protect the colts from the flies. Our yearling stallions receive the oats and bran mixture, fed three times a day throughout the entire summer and fall. They are given about all they will clean up. In addition to this, they have access to mixed clover and timothy hay, and alfalfa when we have it. This is given to them in the mangers during the day in the barn. At night they run out on bluegrass pasture.

"We usually have from 6 to 12 yearling stallions that are handled in this way. They are all allowed to run together. It occasionally happens that one will get his heels tramped on by some of the others, but by watching closely and by taking such a colt out immediately we have little trouble. It is of course necessary to use some carbolic salve, or something of the kind, on the injured part until it heals up, but as soon as this is done, the colt is turned out again with the rest of the bunch. We have not had much difficulty on this score.

"The yearling fillies are usually turned with the two-year-old fillies into a separate pasture, where they run ont both night and day throughout the entire summer. We do not feed any hay to the fillies, but give them a moderate ration of the oats and bran mixture. This is given twice a day. Their allowance probably amounts to half-a-pound per 100 pounds of live weight per day.

"'In November or' December' we begin tying up the yearling stallions at night, but allow them to run out during the day. From this time until the following 
spring, or until they are sold, these stallions coming two years old receive about 5 ear's of corn each per day, and in addition all of the oats and bran mixture that they will clean up. They are fed three times per day. For hay, we continue with the mixed clover and timothy, although we would feed alfalfa if we had enough of it to supply all of our horses. So far we have not had enough, and so have retained it for the younger colts.

"The fillies coming two years old are tied up, when we have room. If we do not have enough room, they are allowed to run loose in the shed, where they are protected from the cold storms and where they may take refuge during the night, but they are out every day during the winter on pasture.

"By following these general methods we have made excellent gains on our foals and yearlings. We have found it very advantageous to keep the mares and foals in and protected from the hot weather and the flies, as our own experience and our observation of operations on other farms have satisfied us that extreme heat and flies materially retard the development of foals. We have been able to secure quite satisfactory growth in bone and muscle. Our colts have matured into rugged, heavy-boned, massive draft horses, standing from $16 \frac{1}{4}$ to 17 hands in height by the time they are 24 months of age. The weight varies with individual colts, but they are deep-bodied, well-proportioned, and with size and weight enough to balance their height and general development. We believe our policies of feeding and management of yearlings and weanlings are justified by the results. We seldom have had any two-yearolds left unsold. If we do carry over a colt, it is usually one that we want to develop or use in our own stud. We have realized substantial prices for 
the colts of our own breeding and raising by the time they were from 20 to 24 months of age.

"It is quite likely that our policy of liberal feeding might not be justified if good breeding and Percheron type did not exist in the colts to which this system was applied. The colts which we have raised, however, have been bred by us from mares whose dams and grandams, and in some cases their great-grandams, were bred by the members of our own family.

"Eli and M. C. Hodgson made an importation of 12 weanling fillies in 1881 . All of the mares now in our stud trace back to three of the twelve, which is merely an indication of the careful attention that we have given to eliminating animals that did not satisfy us in type. On the other hand, we have held fast to the most desirable strains that have come into our possession, and never have permitted anyone to purchase our best mares. By persistently retaining our best mares and by the long-continued use of good sires, we have been able to produce a band of mares that are of good type, excellent in set of legs, good in the feet, and real producers of rugged, drafty colts which have found a ready sale before they were two years of age. We are satisfied that the tendency to breed regularly, the tendency to prolificacy, is just as certainly transmitted as color or type; we have held fast to our most prolific strains.

"Any breeder who will select good foundation stock, breed to good sires, and follow out intelligently the same general methods in feeding and management cannot fail to realize substantial profits from his Percherons, but emphasis must be placed on persistent, patient, never-ending watchfulness."

Feeding Alfalfa-Mr. J. C. Robison of Towanda, 
Kans., has this to say about the use of this great forage plant in connection with horse breeding:

"My father sowed the first piece of alfalfa in this county in the spring of 1895 . We have increased the acreage until now we have about 1,000 acres of it. We have pastured it a little, but find it does not pay to do that, as we get so much more feed from the same acreage by mowing it and feeding as hay.

"If the alfalfa is cut when about one-tenth in bloom, we experience no bad results from feeding it, either from heaves or in any other way. Our Percherons are allowed to run to the alfalfa stacks or to eat as much as they like in the barns, and I am sure we are able to put on more pounds of flesh and make more growth, both in bone and muscle, than on any other feed with a smaller amount of grain. We prefer to mix with it some kind of coarse, rough feed, such as sugar-cane hav, shock corn or straw, as the horses crave these feeds when given alfalfa.

"Alfalfa has been the salvation of Kansas and the west."

The experience of J. A. Gifford, Twin Falls Co., Idaho, in feeding alfalfa seems of particular value. He says:

"When living in Kansas in $1896 \mathrm{I}$ seeded 50 acres to alfalfa. The stand was good. I cut the weeds with a mowing machine, carrying the cutterbar high enough so as not to injure the alfalfa, and let them lie. The next year I cut the alfalfa and stacked it in the field. When I came to the tops and bottoms of the stacks, that hay was fed on the ground, the horses being allowed to eat as much of it as they would. They began to show signs of heaves. After 
I built barns, I no longer fed damaged hay to my horses, and I have seen no signs of heaves among them since.

"I have raised colts from birth to maturity on grain and alfalfa hay, and they have made before weaning time from 100 to 150 pounds of gain a month. I expect a colt from 5 to 6 months old to weigh from 700 to 800 pounds, and at 12 months about 1,200 pounds. I want more mature hay for horses than for cattle, and they should clean it all up each time it is fed. I consider one acre of alfalfa cat and fed judiciously worth more than two acres pastured. By judicious feeding I mean to give no more than will be cleaned up each time.

"I have had experience in both stacking and housing hay; I am strongly in favor of housing. I built a haybarn in the middle of an alfalfa field, intending to cure the hay in the windrow, with buck rakes take it to barn, drop it from the rake to a sling, and so get it into the barn. But I found that the dew, without any rain, bleached the hay, and I decided to shock it. I could not handle it satisfactorily with rakes, and so laid them aside. I made floats, 7 by 14 feet with a railing 2 feet high at each end. On each of these I laid a sling, with each end fastened to the top of the railing. These I put on a slingload, drove to the barn, hooked onto the sling, and put the hay into barn. No leaves were wasted. I am highly pleased with this method of handling hay.

"I regard alfalfa as the best hay for growing out any kind of stock that I ever fed. I am careful not to put it into barn in such a condition that it will mow-burn."

Importance of Soundness.-Mr. J. S. Golder, a Nebraska breeder of long experience, gives some useful 
hints to beginners, especially in reference to the matter of unsoundness in draft breeding stock. He says :

"To the young man setting out to own a team of high-class Percheron mares I would say, start right, however small the beginning may be. If he has only the one mare and she is a good one, he need not be ashamed to show her. If he can take that one mare to the fair and get first prize on her, he will have done something that many an older and larger breeder has never accomplished.

"Many people have an idea that purebred mares require more care than grades. This is entirely erroneous. They do not require it; but somehow they seem to get it, which goes with the spirit of success. In order to begin right, I would impress upon the prospective buyer to buy them sound. Do not squeeze the eagle too hard. Use good judgment and buy them sound. I would rather have one good one and have her sound than half-a-dozen good ones and have them unsound. When you go out to buy an animal and find it a little coarse in the pastern, turn it down, and hard at that. If you hesitate, the seller may try to cover it up with a lot of excuses. Then one asks himself whether it will breed on. Of course it will, not only for one generation, but through halfa-dozen. I know for sure that it will persist for three generations. It matters not whether it is a coarse pastern or a coarse hock, bad eyes or bad wind, they are all the same when it comes to breeding.

"I once bought a stallion. He was a good one, but developed a sidebone at the age of four. Most of his colts developed sidebones at the age of two. More than that, nearly every one of his fillies passed them on. We were forced to put them all on the auction block and sell them as coarse in the pasterns for what 
they would bring. While some thought they went cheaply, and they did, they were dear too.

"I believe that the horse business now has the brightest future that it has known in many, many years. With the importations cut off, American dealers find that they can get just about what they want at home, and perhaps somewhat cheaper. The American farmer and breeder can raise them just as good and big as they can in France if he will. We have just as good feeds and much more room to exercise them in. That is another place where the young breeder makes a mistake-not giving enough feed of the right kind, and not enough exercise. Feed liberally of the right sort of feeds, such as oats, bran, alfalfa, clover and such, and do not confine the horses to a boxstall.",

\section{Growing Purebred Percheron Fillies.-Prof. J. L.} Edmonds of the Illinois Agricultural Experiment Station summarizes the results of careful study of this subject at the University of Illinois farm in the following language:

"Well-bred young things deserve good feeding. They demand it, if profits are duly considered. Their growing-out should permit the fullest development of inherent possibilities.

"A record of the feed consumption and increase in weight and height of a lot of 10 purebred Percheron weanling fillies, foaled in 1914, was made at the Illinois Experiment Station. These fillies were carried through two winters and one summer-from late in the fall of the year in which they were foaled until they were ready to be turned on grass as two-yearolds.

"These fillies were fed home-grown rations. The grain feeds were oats and corn, one-half of each by 



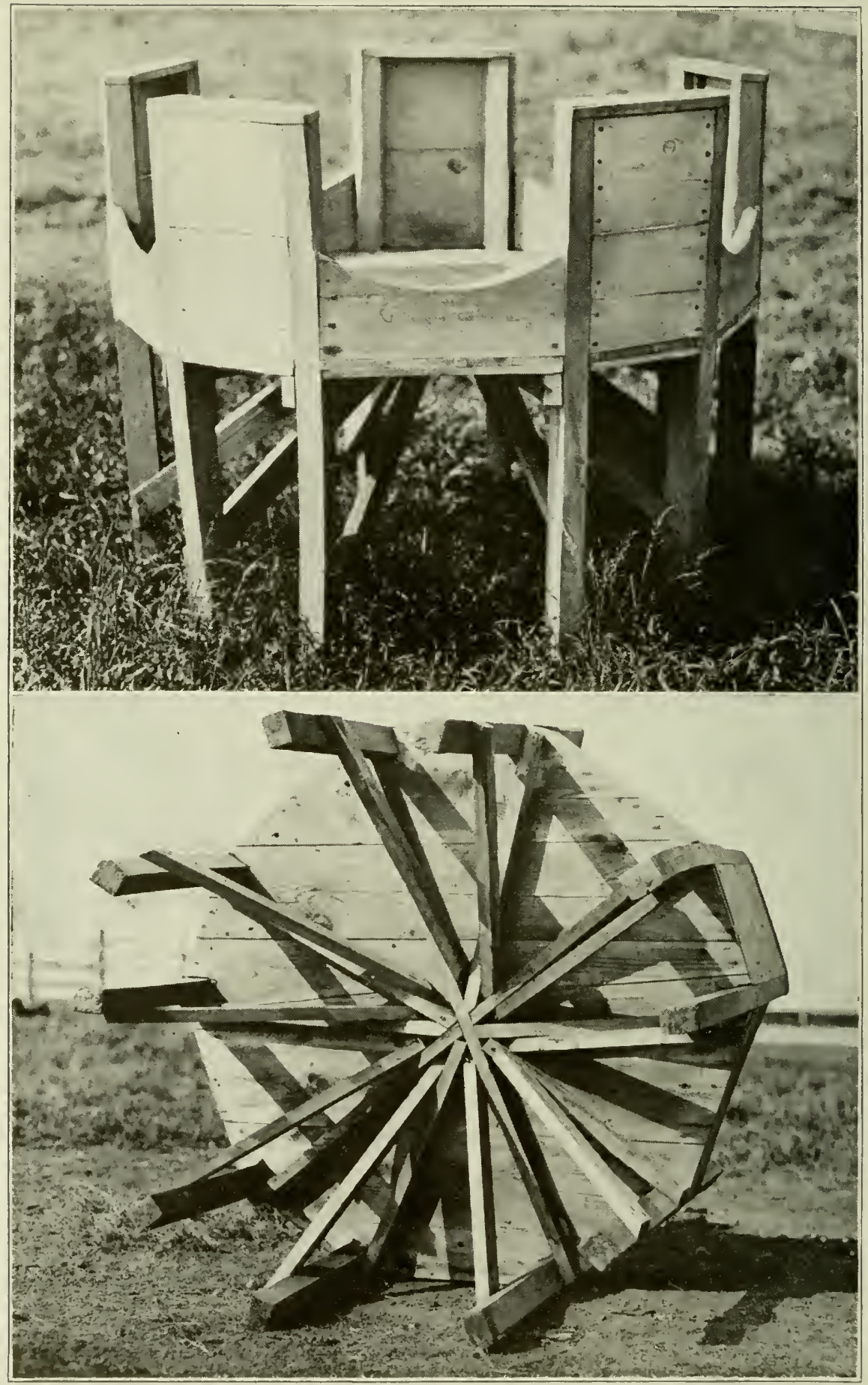

TUMBLER RACK FOR COLT-FEEDING IN PADDOCKS.-SEE ARTICLE

BY PROF. EDMONDS. 
weight. Grain was fed three times per day, except when the fillies were on grass; then it was fed twice per day. During the first winter the oats and corn were ground. Alfalfa hay was the sole roughage used; it was fed twice per day, except when the fillies were on pasture, during a part of which time no hay was fed; after the pasture became short hay was fed once per day. More grain would have been eaten than was fed. With the alfalfa hay, however, the aim throughout the trial was to feed as much of it as would be thoroughly cleaned up. Alfalfa, corn and oats were the feeds selected, because it was desired to obtain good results with farm feeds without recourse to purchased mill feeds. The pasture, 8 acres in area, was bluegrass, with a slight mixture of timothy, orchard grass and medium red and white clover.

"During' the first few weeks the fillies were allowed as much grain and hay as they would readily consume. This, although it resulted in good gains, did not seem to be a profitable or entirely safe procedure, because of the high grain consumption. Accordingly the grain ration was gradually restricted until it was reduced to an amount which insured the consumption of a pound or more of alfalfa hay per day to the hundredweight. Experience here would seem to indicate that a liberal portion of rell-cured legume hay should be the foundation for feeding young, growing horses. In addition to the legume roughage, enough grain should be fed to produce good growth. The feed sheets indicate that as the individual becomes older, it is possible and desirable to decrease the proportion of grain and increase the proportion of hay and still obtain excellent results. Alfalfa hay fed with corn and oats gave results of a character which indicate that there is little or no 
need of feeding bran or other purchased mill feeds when a good quality of alfalfa hay can be grown on the farm. Alfalfa hay, because of its high protein and mineral content, especially calcium, is suited to grow the heavy muscles and large, strong bones which are necessary for the real drafter. A greener, leafier quality of hay was fed to these fillies than usually gives the best results when fed to hardworked horses. In the case of these growing fillies it was not found necessary, as is the case with mature animals, to limit the amount of alfalfa hay which was fed. Furthermore, when alfalfa hay is the roughage used, a considerable proportion of the grain ration, in this trial one-half by weight, may be corn, the grain grown in greatest quantity in the middle west.

"From this and similar trials it seems quite clear that in addition to liberal grain-feeding to growing drafters, which is admittedly necessary and important, the development of size and quality of bone is also intimately associated with the grazing on pasture of nutritious grasses and clovers, and the feeding of good legume roughages during seasons when such pasture is not available. In this test desirable growth was made on pasture which was not fully indicated by the weights of the fillies. On most farms the use of more pasture than was available in this trial would be of advantage. A grain feed of approximately $1 / 2$ of a pound of grain per day to the hundredweight of filly seems to be enough to produce proper development on pasture.

"Since, as the experiment showed, 45.35 bushels of corn, 79.36 bushels of oats, 2.58 tons of alfalfa, and $4 / 5$ of an acre of good pasture kept an individual of the kind used in thrifty and salable condition from the fall of the year in which it was foaled 
up to the time when it was two years of age, it would seem worth while to grow out well-bred young drafters properly. Thus we may obtain the size and finish which experience has shown to be necessary for the greatest remuneration.

"The accompanying table is of interest, because it gives feed consumption and gains by seasons. The table shows that the largest and quickest gain for the feed consumed was made during the first winter. During the first winter an average of 5.674 pounds of grain and 4.266 pounds of hay were required per pound of gain. The second winter-feeding period required an average of 9.228 pounds of grain and 12.99 pounds of hay, the average grain requirement per pound of gain being at this time almost twice as much and the hay requirement slightly over three times as much as it was during the first winter. The table showing the results in detail follows.

"A study of these figures would seem to show the fallacy of attempting to make good draft horses by roughing weanlings through the winter, with stunted yearlings as a result. Continued liberal feeding: through the summer and the succeeding winter made big, growthy, two-year-old fillies that were much nearer maturity than if they had been forced to subsist on a ration too limited in either or both the quantity and quality of the nutritients which it contained. It is of particular advantage to have purebreds well grown at two years of age, because wellgrown individuals of both sexes are in good demand at that age.

"The average weight of the lot at 12 months of age was 1,112 pounds; at 24 months of age, 1,548 pounds. The average weight of 8 head (the two youngest fillies being excluded) at corresponding ages was 1,128 pounds and 1,578 pounds. The 


\begin{tabular}{|c|c|c|c|c|c|c|c|c|}
\hline \multicolumn{2}{|c|}{ 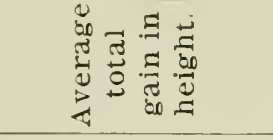 } & $\begin{array}{l}\dot{\varphi} \\
\stackrel{\Xi}{0} \\
\dot{\Xi} \\
\dot{\Xi}\end{array}$ & $\stackrel{\text { II }}{=}$ & $\stackrel{8}{\circ}$ & • & $\begin{array}{l}\mathbb{\infty} \\
\dot{0}\end{array}$ & $\stackrel{0}{-}$ & $\stackrel{8}{\&}$ \\
\hline \multicolumn{2}{|c|}{ 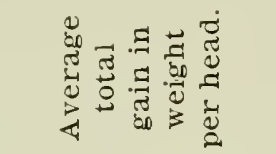 } & $\frac{\dot{0}}{3}$ & $\begin{array}{l}\circ \\
\dot{8}\end{array}$ & 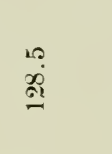 & $\begin{array}{l}0 \\
0 \\
i=1 \\
6 i\end{array}$ & $\begin{array}{l}10 \\
\text { i⿱ } \\
\text { in } \\
\text { in }\end{array}$ & $\begin{array}{l}0 \\
\dot{80} \\
0\end{array}$ & : \\
\hline \multicolumn{2}{|c|}{ 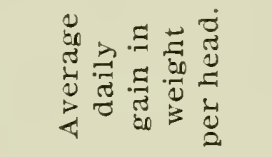 } & 离 & 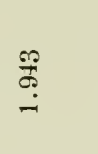 & $\overrightarrow{0}$ & $\begin{array}{l}\overrightarrow{\sigma^{2} ?} \\
\stackrel{?}{?}\end{array}$ & $\stackrel{ \pm}{*}$ & $\stackrel{5}{5}$ & 舀 \\
\hline \multirow{2}{*}{ 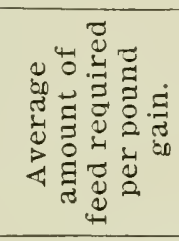 } & 密 & $\stackrel{\infty}{\frac{\infty}{3}}$ & 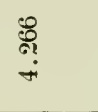 & $\stackrel{\infty}{=}$ & $\begin{array}{l}8 \\
8 \\
.:\end{array}$ & $\begin{array}{l}\text { 踶 } \\
10 \\
10\end{array}$ & 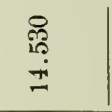 & $\stackrel{\substack{8 \\
:}}{:}$ \\
\hline & 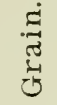 & $\stackrel{\dot{D}}{\stackrel{0}{~}}$ & 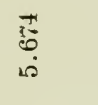 & $\underset{\substack{9 \\
\mathrm{~g}}}{\mathrm{~g}}$ & 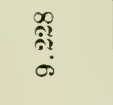 & 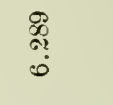 & $\begin{array}{l}\text { i? } \\
\stackrel{0}{9}\end{array}$ & ?ִ. \\
\hline \multirow{2}{*}{ 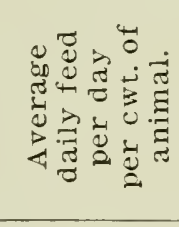 } & 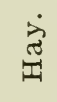 & $\frac{\dot{m}}{\vec{H}}$ & $\begin{array}{l}\text { 유 } \\
\text { 范 }\end{array}$ & 总 & $\stackrel{8}{\stackrel{2}{2}}$ & $\overrightarrow{\mathrm{g}}$ & क्. & $\begin{array}{c}10.0 \\
0.0 \\
0.0\end{array}$ \\
\hline & 苛 & 客 & 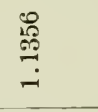 & 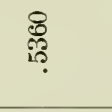 & 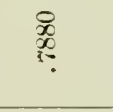 & $\frac{\stackrel{s}{\frac{\pi}{\alpha}}}{\alpha}$ & 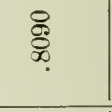 & $\stackrel{\circ}{\stackrel{0}{0} .}$ \\
\hline \multirow{2}{*}{ 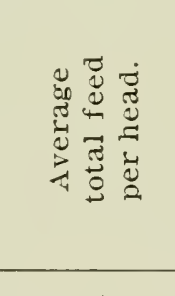 } & 悹 & 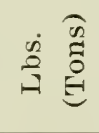 & : & 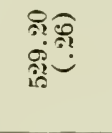 & 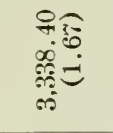 & 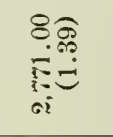 & 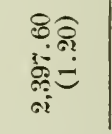 & 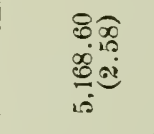 \\
\hline & 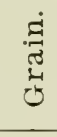 & 总产 & 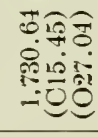 & 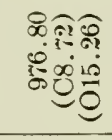 & 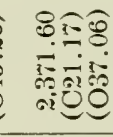 & 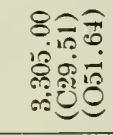 & 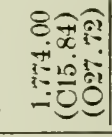 & 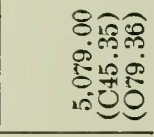 \\
\hline \multirow{2}{*}{ 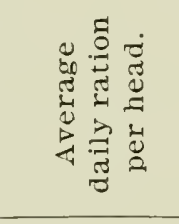 } & 离 & 离 & $\begin{array}{l}8 \\
60 \\
6 ! n \\
\infty \\
\infty\end{array}$ & م" & $\begin{array}{l}0 \\
\infty \\
\infty \\
: \\
0\end{array}$ & $\begin{array}{l}\frac{m}{0} \\
:-1\end{array}$ & $\begin{array}{l}\text { 总 } \\
10 \\
10 \\
.0\end{array}$ & $\begin{array}{l}\infty \\
1 \\
\infty \\
\infty \\
0\end{array}$ \\
\hline & 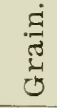 & 官 & $\begin{array}{l}\stackrel{a}{0} \\
\stackrel{0}{0} \\
=\end{array}$ & $\begin{array}{l}\stackrel{8}{0} \\
\stackrel{0}{0}\end{array}$ & 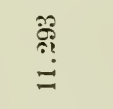 & $\begin{array}{l}\stackrel{0}{0} \\
\dot{0}\end{array}$ & $\stackrel{\frac{0}{10}}{=}$ & $\begin{array}{l}13 \\
\infty \\
\infty \\
\infty\end{array}$ \\
\hline \multicolumn{2}{|l|}{$\underset{\Xi}{\stackrel{\Xi}{E}}$} & & 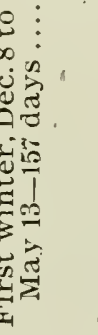 & 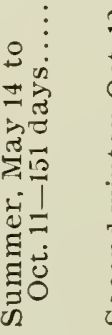 & 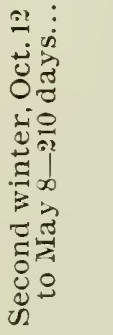 & 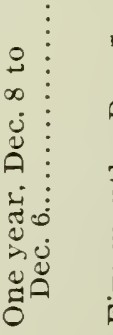 & 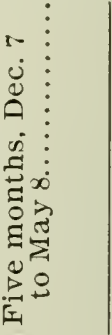 & 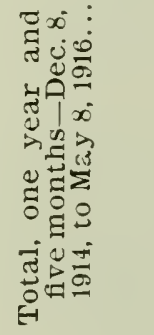 \\
\hline
\end{tabular}


growthiest filly of the lot weighed 1,260 pounds at 12 months of age and 1,775 pounds at 24 months. "The three sets of prices used in obtaining the feed costs of growing these fillies during the time of the experiment were as follows: \$86.88, when afalfa was $\$ 16$ per ton; corn, 56 cents per bushel; oats, 40 cents per bushel; pasture, $\$ 2$ per calendar month per head. \$105.50, when alfalfa was $\$ 14$ per ton; corn, 65 cents per bushel; oats, 40 cents per bushel; pasture, $\$ 1.50$ per 28 days per head. $\$ 108.49$, when alfalfa was $\$ 11$ per ton; corn, 50 cents per bushel; oats, 35 cents per bushel; pasture, $\$ 10$ per acre, for 8 acres."

\section{Buying, Feeding, and Selling Draft Geldings.-} Mr. Mat Biers is known throughout the entire United States as one of the most successful buyers and feeders of the draft gelding. His long and successful experience renders the following statement particularly valuable. He says:

"I was born and brought up on a farm in northcentral Illinois and began buying draft geldings 22 years ago. For 2 years I worked for a man named Peterson, who bought and fed good draft horses. I began to admire good horses while working with Peterson, and during the time when I was feeding cattle and horses for him I occasionally bought a good gelding, took it home and fed it out. Peterson bought nothing but good grade draft horses, the bigger the better.

"Shortly after I got married I began to trade in draft horses and bought very good thin geldings. These I fed out and sold. After about three years I formed a partnership with Peterson and we began to buy draft horses for Rosenberg. Horses were extremely cheap then and we were buy- 
ing on a commission of $\$ 5$ per head. After we had followed this plan for some time, we quit and began to ship and feed for ourselves. We usually shipped about 3 loads per week. This was some 15 years ago, and I have been located in Mendota, Ill., for the last 19 years. In more recent years I have been operating alone.

"The first and most important consideration in feeding draft geldings is to buy the right kind at a price that will permit a profit. A horse well bought is well sold. It is unwise to buy a horse that is too low in condition, it requires too much time to get him in shape. I prefer to select only those horses which can be sold at any time after purchase at a fair profit. I aim not to buy horses that will not finish out satisfactorily within 60 days, as I do not believe it pays a dealer to feed longer than 2 months. Horses that have to be fed 3 or 4 months to get them in shape for market cost too much in the way of feed.

"The second important point in making purchases of draft geldings is to buy them at the right time. The demand for drafters is a seasonable one. They will not sell to good advantage except during the late spring and early summer months and again in the early fall months. I like to have my heavy geldings ready to sell during the latter part of April or early in May, or if I do not wish to market them at this time I want geldings that I can turn off late in August or early in September. There is a relatively light demand for the very heavy draft geldings at other times of the year, and many men lose money on the draft geldings they purchase on account of buying them at the wrong time of the year. They are then compelled to sell them when draft geldings are not in strong demand, or if they 



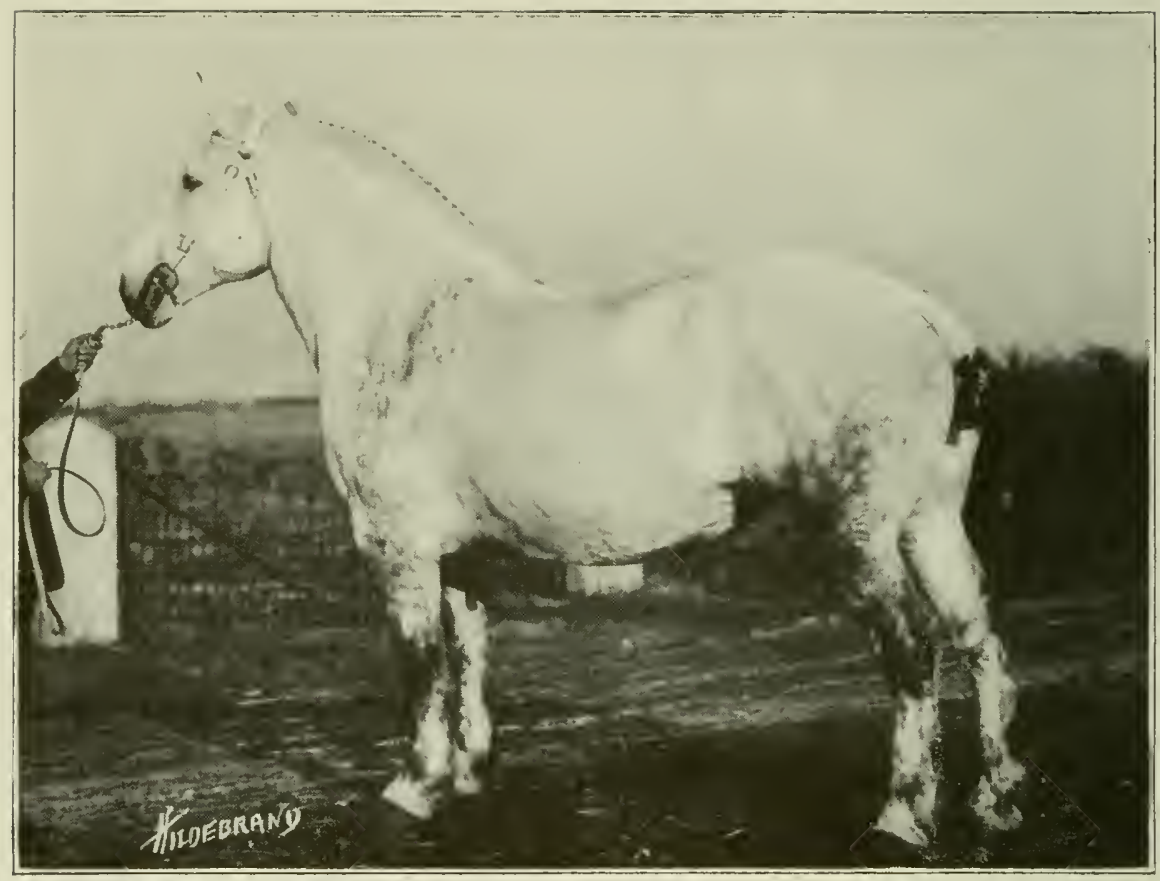

PINK BRILLIANTE 57897-CHAMPION MARE CHICAGo INTERNATIONAL, 1916.

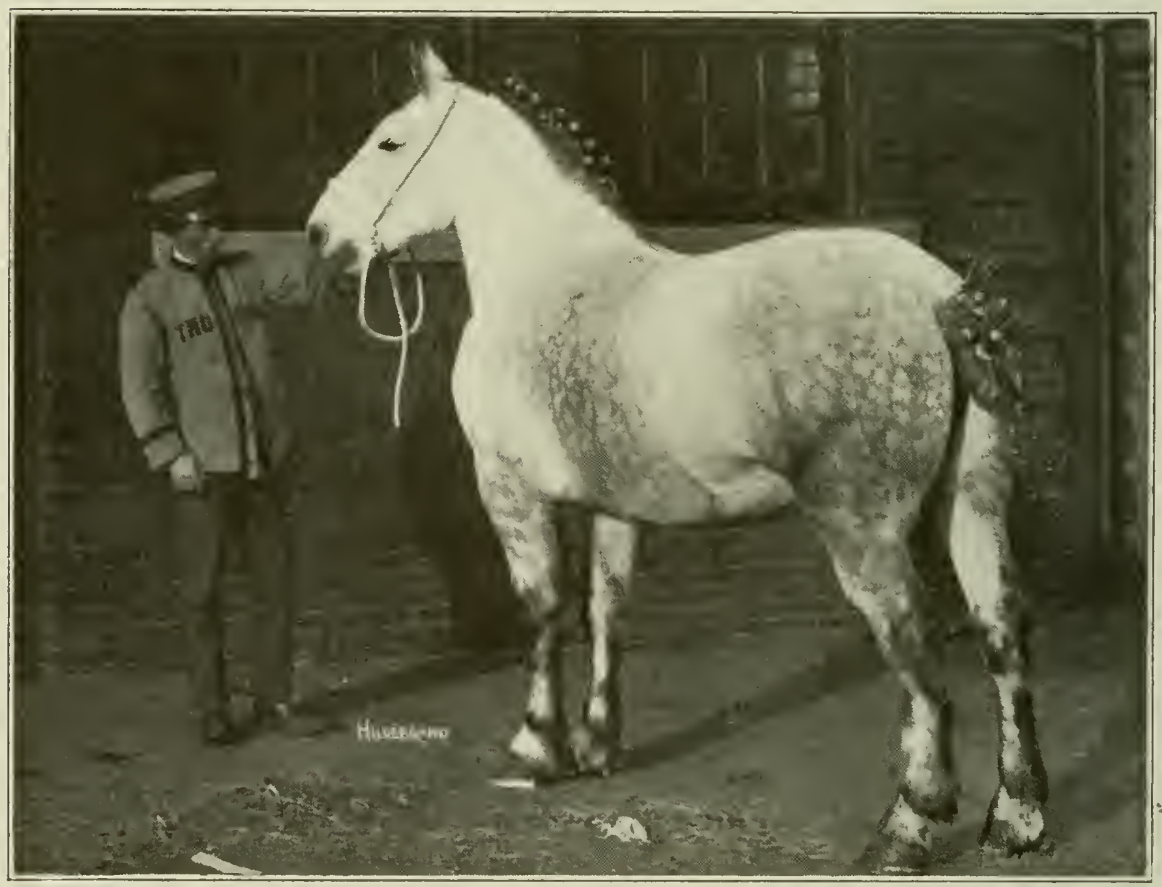

HYSOPE 89487 ( 74401 ) CHAMI'ION MARE INTERNATIONAL EXPOSITION, 1912. 
do not sell them, they are obliged to carry them so long that the profit is taken up in extra feed bills.

"Farm chunks weighing from 1,200 to 1,500 pounds sell to the best advantage during the months of December, January, and February, and there is no market of any consequence for horses of any kind during June. This, of course, has not been true during the last two years, as the war demand has been heaviest during the summer, but I am speaking of the general commercial demand.

"In selecting heavy draft horses for feeding, I aim to buy about 60 days before I want to place the horses on the market. I look for a big horse, preferably one standing from 16.2 to 18 hands high. Of course, anything from 16.1 up can be made into a big horse, if he has the right proportions and is given the feed necessary to finish him out. Eighteen hands is too high, unless the horse is well proportioned. A good draft gelding should have depth of chest equal to one-half his height, and have the spread of rib, depth of flank and other parts in proportion. In buying horses for the heary gelding trade, they should weigh from 1,600 to 1,650 pounds to start with, and have the height mentioned. They can be fed out to 1,900 or 2,000 pounds.

"My ideal horse to put on feed is one that stands around 17 hands high and is well proportioned, weighing about 1,650 pounds in moderate condition. Such a horse on feed 60 days will increase at least an inch in height on account of the fact that the flesh fills up over the withers and the feet grow out longer. I want a horse that has a good big head, clean-cut and wide between the eyes, with well-set ears and reasonably long neck, clean-cut in the throttle, with fairly sloping shoulders and a full 
breast. I want my horse to be heavy through the shoulders, deep through the heart, with a short back, well-sprung rib, and good length of rib, so as to give a deep middle. One should always buy a horse with a big chest and should never select one that is not short-coupled and heavily muscled over the loin; he should be wide and heavily muscled over the croup, thighs, and in the haunches, and should be massively muscled in the stifles. I prefer to have the croup slightly drooping rather than too straight; horses that are very straight in their croup are inclined to be narrow through the stifle and thighs. The underpinning receives close attention, as I want my horses to stand squarely on their legs from front, side and rear. The pasterns should not be too straight, nor do I want a horse that is down too much on his pasterns; a medium slope is desired.

"The feet should be of good size and medium in height. Of the high-walled foot and the low-walled foot I prefer the high-walled foot, although I like to have a happy medium between the two. The foot that is low-walled is apt to be flat and widespread at the heels, and such feet go to pieces altogether too rapidly in city service.

"A sickle hock or a curby-formed hock is extremely undesirable and should be avoided under all circumstances, particularly in heavy geldings, because the heavy pulling that must be done is sure to make such hocks curby. The hock should be wide and clean-cut. I like to have geldings that will measure about $13 \frac{1}{2}$ inches of bone below the hock. They should have heavy bone, with the tendons standing well back in the forelegs. A little hair on the legs is not objected to, but very much feather is to be avoided. A little filling in the hocks does not cut the price of a big gelding to any 
extent, but large puffs or any indication of a bog spavin must be avoided.

"A horse should have a good, big eye, preferably brown in color, and should be wide between the eyes. The eye orbits should be prominent, so that the eye sets well out on the side of the head. The small, hog eye always is to be avoided; that kind of an eye indicates a bad disposition and never lasts so well as a big, open eye.

"Under no circumstances would I buy a horse with a small sheath; such a one is usually light in the middle and a poor feeder. Occasionally one will get hold of a horse with apparently ideal conformation for feeding that has a small sheath. While I cannot explain just why such horses are poor feeders, I have always found that they are poor doers. I always pay close attention to the sheath in purchasing thin gelding's for feeding purposes.

"There are more good feeders among' the grade Percherons and Belgians than among those of other breeding. I prefer geldings sired by Percheron and Belgian sires. It is difficult to describe the kind of thin horse that will grow out into a big horse of the right kind, but above all, he must have height, heavy bone, and the proper proportions in frame work. If he does not have these, no amount of feed will ever make the right kind of a horse out of him.

"After buying the right kind of horses, I make it a rule to have them vaccinated as soon as they are brought in to town. They are treated with a hypodermic injection of any of the good polyvalent bacterins before they are put into any livery stable or allowed to stand around a stockpen. I have found that if one can vaccinate horses before they 
are exposed to shipping fever he will have very little trouble. In addition to this, I make it a rule to keep a shipping fever medicine on hand, and if the geldings show any symptoms of fever, I can usually break it within 24 hours by using this medicine. I find that vaccination is a great help where I have to bring horses in from all parts of the country and put them in the same barn for feeding. I do not physic a horse when it is starting on feed, unless it appears unhealthy, in which case I usually give a physic ball once or twice at the beginning of the feeding period.

"As soon as I start the horses on feed, I tie them up in single stalls just wide enough so that they may lie down comfortably. I tie my horses in the stalls and never take them out from the time I put them in until they are ready to market. We even carry the water to them. A thin horse that has been working steadily will begin swelling in the legs, after being tied up in these single stalls and put on heavy feed. In fact the legs swell up until a man who did not know would think that the horses were utterly ruined. This swelling starts a short time after the horses are tied in, but will come down within 2 or 3 weeks; no one should be disturbed over this temporary swelling that occurs during the feeding period.

"Long experience has convinced me that horses will fatten a great deal more quickly when tied in single stalls than when loose in box stalls or rumning out in yards or sheds. I have paid enough for my experience to satisfy me that there is no other method of feeding horses which is so economical and so conducive to quick results as keeping them tied in single stalls and never moving them out from the time they are started on feed. Not even 



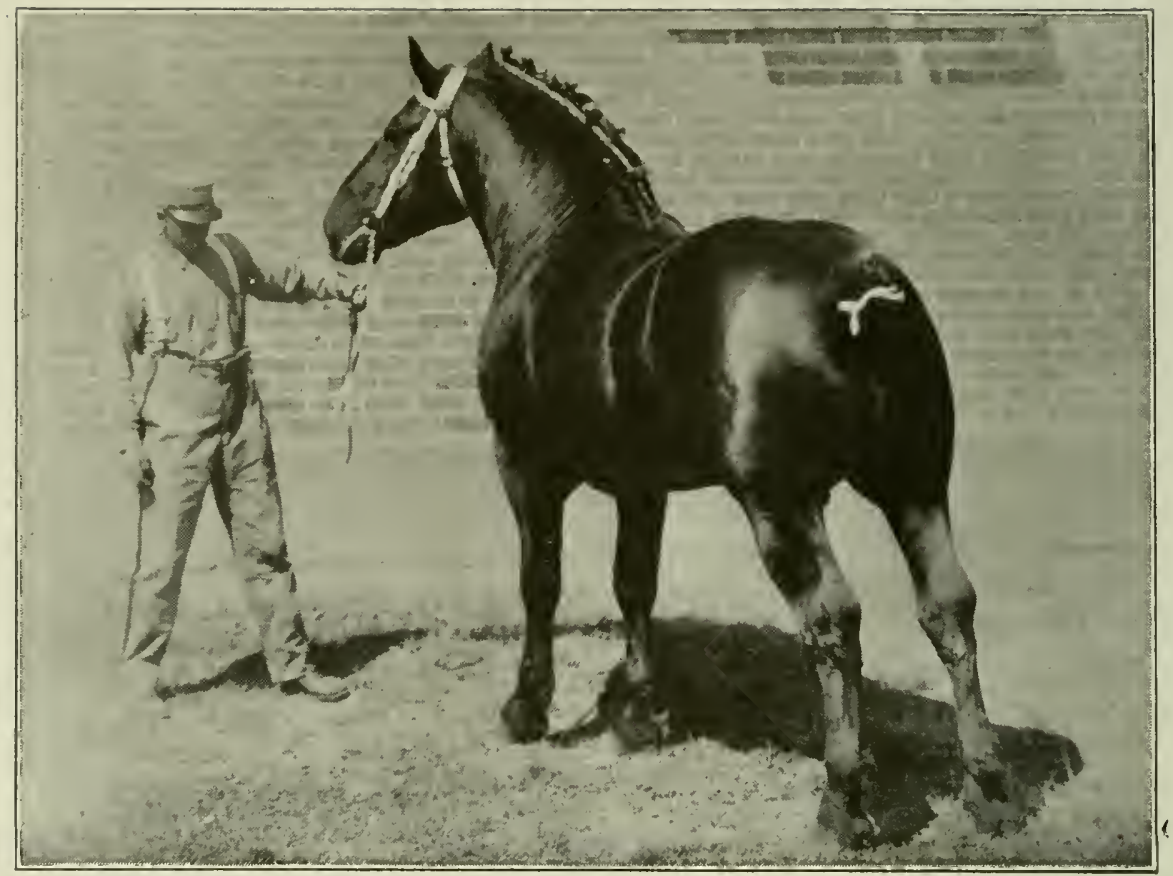

KEUTA INSIGHT 107242, RESERVE CHAMPION STALLION BRED BY EXHIBITOR. IOWA STATE FAIR, 1916.

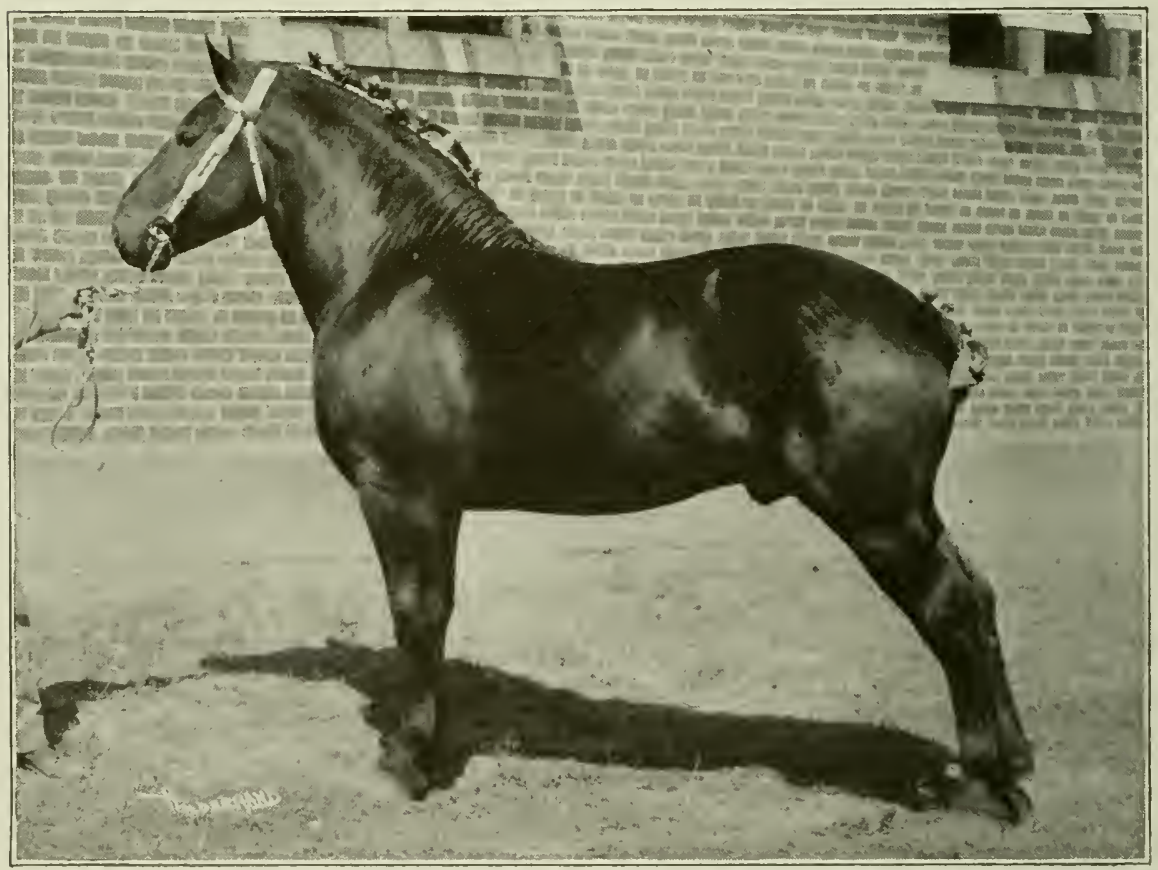

FAIR HOPE 117379, AMERICAN-BRED RESERVE JUNIOR CHAMPION STALLON, CHICAGO INTERNATIONAL, 1916; SOLD FOR $\$ 5,000$. 
should they be taken out to lead or show; moving them even 100 yards when they are on this heavy feed is apt to induce azoturia.

"First and foremost, one must see to it that the horses are allowed plenty of salt, all the good fresh water they can possibly use, and an abundance of good hay. I always water my horses before feeding. They should never be watered immediately after being fed. Our experience has been that the water has a tendency to carry the feed through before it is thoroughly digested.

"I prefer to feed five times a day, beginning at 6 o'clock in the morning, feeding again at 10 o'clock, 2 o'clock, 6 o'clock, and 9 o'clock at night. They should be fed at the same time every day. I consider regularity in the feeding of the gelding's almost as important as any other one thing. If they are fed promptly, they will not fret and will do much better than if any irregularity in their hours of feeding is allowed.

"I like to keep salt before my gelding's at all times, to give them all the fresh water they can use, and to feed all the hay that they will clean up. I make it a rule to allow them all the grain that they will clean up within 25 or 30 minutes. One shonild not feed horses so much as to cause them to be indifferent to the feed when it is placed before them the next time. On the other hand, I aim to feed just up to the limit, so that the horse is always anxious for his feed at the next feeding period and yet is receiving about all that he will clean up. I prefer to feed ear corn, and with this I give bran and oats, preferably crushed oats and dry bran. I feed this in about equal proportions by measure. I have, however, had good results by feeding corn and oats in equal parts, and then giving the Inrse 
a bran mash twice a week at the evening feed. I nse a little molasses in the wintertime, it hastens the gains on the horses by increasing their appetites and it also adds bloom to a horse's coat of hair. It should be thinned with hot water, and then sprinkled over the grain feed and over the hay. Never feed molasses in the summertime, however, as it only attracts the flies, and one cannot keep the feedboxes clean when using molasses.

"So far as hay is concerned, I prefer bright clover hay, but clover and timothy mixed make excellent feed. I do not like alfalfa for fattening geldings. While the first and second cuttings of alfalfa, if properly cured, make very good horse feed, one can never be sure whether he is obtaining the earlier cuttings or the later cuttings. The last cuttings are always too soft and cause too much work for the kidneys, and my observation has been that one is apt to have more trouble with the hocks filling up when alfalfa is used than when the other hays are fed. Besides this, I have found that my horses do not ship so well when fed alfalfa hay as when I have used the bright clover or the clover and timothy mixed. Do not use straight timothy, however; this will bankrupt any man who undertakes to do it. I never use timothy alone, even in preparing horses for shipment or in shipping 'them, as it causes them to appear light in the middle and cut up in the hind flank.

"During the late summer and early fall I feed some green corn, but it should be fed sparingly, as it is too soft as a rule to feed to horses that have not been on grain very long. Green corm is a excellent feed, however, on which to start thin horses; it tones up the system and gets them in good condition to start fattening. I have fed some silage and find it very 
satisfactory, providing it has been put in when the corn is fairly well hardened and is good and clean-smelling, without the acid condition that is too often found in silage from corn that is not suffciently matured. Extreme care must be exercised, not to give any silage that contains the least evidence of mold; moldy silage will kill horses as quickly as any feed I know of.

"Be careful about using" shredded fodder. If it could be shredded before being rained on and after it had become thoroughly cured, it would be excellent feed, but it is almost impossible to get shredded fodder in that condition. I have found it very difficult to avoid colic when shredded fodder is fed.

"I like to feed a tablespoonful of ashes made from ash or hickory wood twice a week, mixing it in with the ordinary feeds, but I do not feed any stockfoods or patent medicine tonics. I am afraid of them and do not believe there is any advantage in using them. If a man has bright clover hay and gives plenty of salt and water, his horses will keep in healthy condition and will not need tonics or salts to keep them from becoming unduly constipated.

"So far as the amount of feed to be given is concerned, no hard and fast rules can be laid down. This is a matter that must rest in the discretion of the feeder, and the aim should be to give the horses all the feed that they can stand without overdoing it so as to cause them to lose their appetites. Some horses will consume a great deal more feed than others and will make much more rapid gains. I have had horses that have gained as much as 150 pounds in a month, but that is very unusual and ordinarily we figure on a gain of about 3 pounds a day on geldings being fed for the market. 
"There are some incidentals that contribute to success in feeding operations. Horses should be fed on dirt floors, if possible. When a barn is well drained and good dirt floors have been properly built in the stalls, no better foundation can be obtained. The stalls should be kept carefully cleaned out, occasionally disinfected, and well bedded, so that the horses will feel disposed to lie down and rest frequently and for considerable periods.

"We do not blanket our draft horses in the winter, unless we are preparing them for some special sale and want to get a little extra bloom on their coats. In the summer we darken the stable, have screen doors, and also use large fly traps so as to keep the flies out of the barm as completely as possible.

"I prefer open mangers, and would emphasize the fact that it is very necessary to keep mangers and feedboxes scrupulously clean. When our horses are ready for shipment, we reduce the amount of grain for the last 3 days before shipping and do not feed any grain at all on the day we ship, depending simply on hay and water.

"I prefer to sell my horses at my own barns and have always found it best to get the big eastern buyers to come direct to my place whenever I have a carload of good horses for sale. During the last year it has been decidedly injudicious to ship geldings to the large commercial markets. The tremendous tracle in war horses and the large amount of shipping back and forth horses that did not pass inspection has spread influenza and shipping fever. If the gelding's are taken directly from the barns where they are fed to the point where they are to go to work they are likely to get through in healthy condition and without any trouble of any kind. 
"So far as the trade is concerned, the chief demand for good, big horses comes from the eastern states. The big packing companies of Chicago are about the only ones that will take first-class geldings, as most of the Chicago trade is for a rather common class of big horses which can be bought more cheaply. The packing companies will not take a horse that is in the least degree unsound, but a small sidebone will pass the eastern buyer's without much objection, and some of the eastern buyers will take a horse with a hock that is a trifle coarse, providing he does not go lame on it. We do not find many horses that are wrong in the wind, but can sell a horse on the eastern market that is a little off there if he will take a big load and walk along at a reasonable gait and make no noise about it. But if he does make a fuss, a $\$ 300$ horse would bring not more than $\$ 150$.

"Geldings on feed will make much more satisiactory progress if they are well curried every day, as this loosens up their skins, cleans out the scurf and makes them feel better. A stiff brush should be used, with plenty of elbow grease put behind it.

"Never try to feed horses where there are chickens, because with chickens there will be lice and they will get on the horse in spite of everything one can do. If you buy a horse that has lice, use kerosene and lard, half and half; kill the lice just as quickly as possible.

"Close attention should be given to the feet of the horses that are on feed, particularly in the summer, when the atmosphere is hot and dry. I prefer to pack my horses' feet in packing clay, but the ordinary kind of blue clay will serve the purpose. Make a good paste and plaster it over the horse's feet on the frogs. It is well to use some 
good hoof ointment. Rub it into the hoofs and the coronets, as this tends to stimulate the growth of the hoof and helps to keep it in good condition.

"Care should be taken to give the horses plenty of fresh air. The barns or sheds should be well ventilated. The barns must be kept clean and well disinfected so that the stalls will not betray stable odors. Above all things get the horse to lie down as much as possible. Keep his stall in such shape and so well bedded that he will be encouraged to lie down and rest. Good rye straw is the best kind of bedding, and good wheat straw comes next.

"Good, big, draft gelding's, well proportioned and sound, will always bring a good price if properly fitted. Any farmer who has good corn and oats and first-class clover hay can well afford to feed out the surplus geldings which he has for sale, as it will add much more to their value than the cost of feeding amounts to. In buying geldings for feeding purposes, however, one must have at least a $\$ 50$ spread between purchase price and the price he expects to get when they are sold in order to be at all safe, and I prefer to have a little more than this where possible. Whenever I buy a thin gelding for feeding purposes, I have a mental picture of the kind of gelding he will look like when he is finished. I usually try to have in mind the buyer who will want just that kind of gelding, so that in my buying and feeding operations I am selecting horses for certain specific purposes and certain particular buyers. No farmer should undertake to buy gelding's for feeding purposes until he has had some experience in finishing out his own surplus horses, or has acquired some familiarity with the task by feeding out small bunches, say 2 or 4 hor'ses. Experience is a most valuable asset." 



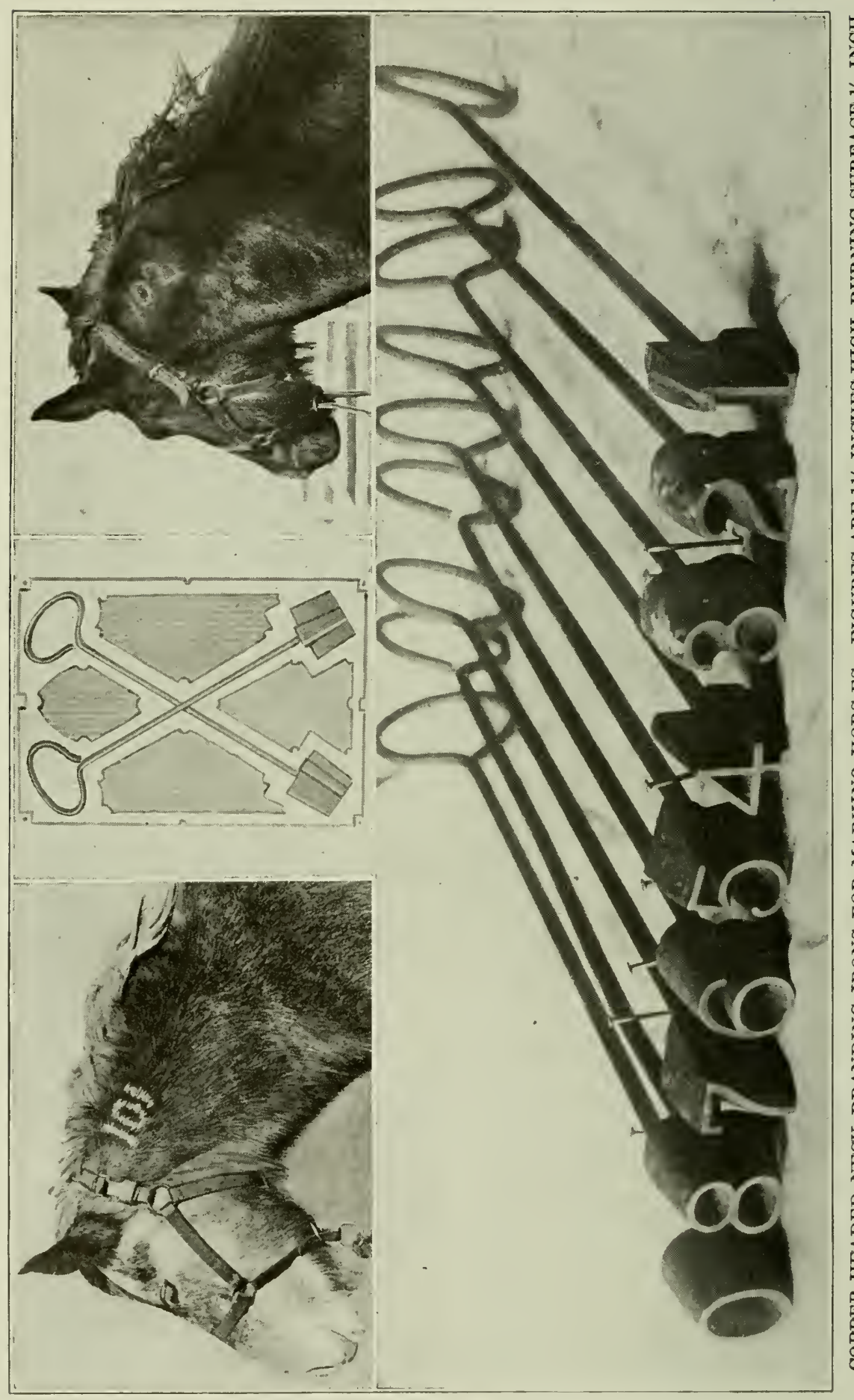

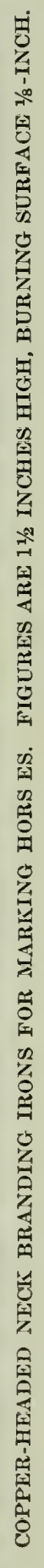


Permanent Marks For Percherons.-The successful management of Percherons requires a method of positive identification of the individual animals. Satisfactory results can best be attained by permanent marks. On this subject we quote from the following authorities:

TV. S. Corsa says:

"I am convinced after" years of trial of other systems that the only satisfactory solution is in branding the horses with plain figures on the neck. Properly branded, no scar results and the animals are identified for life. I have within the past year adopted this plan with all my horses, and I am gratified with the resulting ease and certainty of keeping my records. Hereafter I shall include the brand for each individual as a part of the description in the pedigree. By this system all doubt is removed, and in case of my death any administrator can go in and handle my stud of Percherons with the same certainty regarding each individual that I have myself. It also removes the possibility of error on the part of grooms in keeping service and foaling records."

Lambert Keffeler, with more than 60 Percherons, states:

"I would not think of being" without brands on my Percherons. Each animal has its own number, which is embodied in the pedigree. Errors are made impossible."

U. L. Burdick says:

"I consider a set of branding irons indispensable. It is a guarantee that the breeder's records are properly kept and that each animal is absolutely true to pedigree." 
George Lane, owner of the largest stud of Percherons in the world, says:

"Branding Percherons in plain figures, so that each animal has its own distinguishing number, is essential to any man who undertakes systematic Percheron breeding. It is the best possible evidence that the breeder is careful in his operations and that the animal is bred as represented. For the benefit of those not familiar with details of the work, I am pleased to give the following instructions:

"The branding irons must be of copper. The sample set shown in the illustration is correct in all respects. The colts to be branded should be blindfolded and the hair be clipped from the neck where the brand is to be applied. If the skin seems dirty, it should be washed clean and allowed to dry thoroughly before the brand is applied. This will result in a clear, plain brand. If you are in doubt about being able to apply the brand in the correct position, take a piece of chalk and lightly mark the figures on the neck, then apply the brand on the figure outlined. This will insure getting the brand on straight. The hair must be clipped to permit of clean, quick branding. Blindfold the colt and stand. him beside a fence or gate, so that he cannot crowd away. The iron should be heated in a small charcoal burner, or in any other small, clean fire. Keep a coarse brush at hand, so that the face of the branding iron can be brushed off before applying it. This is done to make certain that there are no specks of dirt or cinders adhering to the face of the brand when it is applied. The presence of any such particle blurs the brand and spoils the results. The copper head should not be heated red hot, but should be just turning from a bluish tinge to a faint red when removed from the fire. It should be allowed 
to cool for at least a minute after this, and will still be hot enough for use. Experienced branders do not heat their irons even this hot. They heat them until there is a bluish tinge running over the face of the branding instrument, but beginners will have to work as indicated. At the beginning it is best to test the irons on some grade horses imtil you have determined the proper heat and time. The numbers are $11 \%$ inches high and the burning face is barely $1 / 8$ of an inch. The copper branding instruments must be carefully handled; for when hot they are very soft. If thrown down carelessly, or struck against one another, they will be bent out of shape and ruined.

"Step up beside the colt, and if you are a short man step on a box, so that you will be up on a level with the neck. Then apply the brand to the neck on the spot desired with one straight movement, making sure that all of the branding surface of the iron comes in contact with the neck. If this is not done, one part of the brand will be deep while the other will be barely touched. It is sufficient to bring the iron against the neck and take it away. A second is all that is required. If the hair has been clipped, a second's touch with the hot brand will burn the hair roots and turn the skin to a light-brown color. Do not try to re-apply the brand; if you do you will simply blur the figure and spoil the mark. The chief danger with men who are inexperienced in branding is that they have the iron too hot, or apply it too long. This results in too deep a burn, and in the case of such figures as 8 or 0 may burn out the entire center core, leaving a blotch on the neck, so that the figure is indistinguishable. If the irons are hot, as directed, a single straight application for a second is sufficient to burn the hair 
roots and turn the skin brown, and this is ail that is needed. The operation is so quickly done that the colt or horse will not wince appreciably, and there is no difficulty in doing the work.

"Probably the most satisfactory plan is for each man to select some letter as his own, and then brand from 1 to 1,000. Thus C 101 might stand for Corsa 101, indicating that this was an animal bred or owned by $\mathrm{Mr}$. Corsa and that the identification was 101. The breeders who adopt this system can number 999 animals, without using more than 4 characters, and as the figures are small the animals will not be disfigured. Where it is preferred, the brands may be applied under the mane and will not be at all noticeable.

"I formerly used hoof brands, but since adopting this system I would not depend on the other under any consideration. With my present arrangement I am absolutely certain at all times as to the identity of any animal that I have. I might die and my entire force might be swept out of existence, but any stranger could step in and take the records and the pedigrees and identify every Percheron that I ornn. The individual neck brand is carried on the pedigrees, on the produce cards, and in my record books. It is also carried in my memorandum book, so that I can at any time distinguish any animal in pasture, barns or lots, and determine in a second the registered name, number and breeding.',

J. P. Gammon, with approximately 100 Percherons, says:

"Long experience has satisfied me that there is no system for identifying Percherons equal to the plan of branding each one in plain figures, so that each animal has its individual mark. It does not 



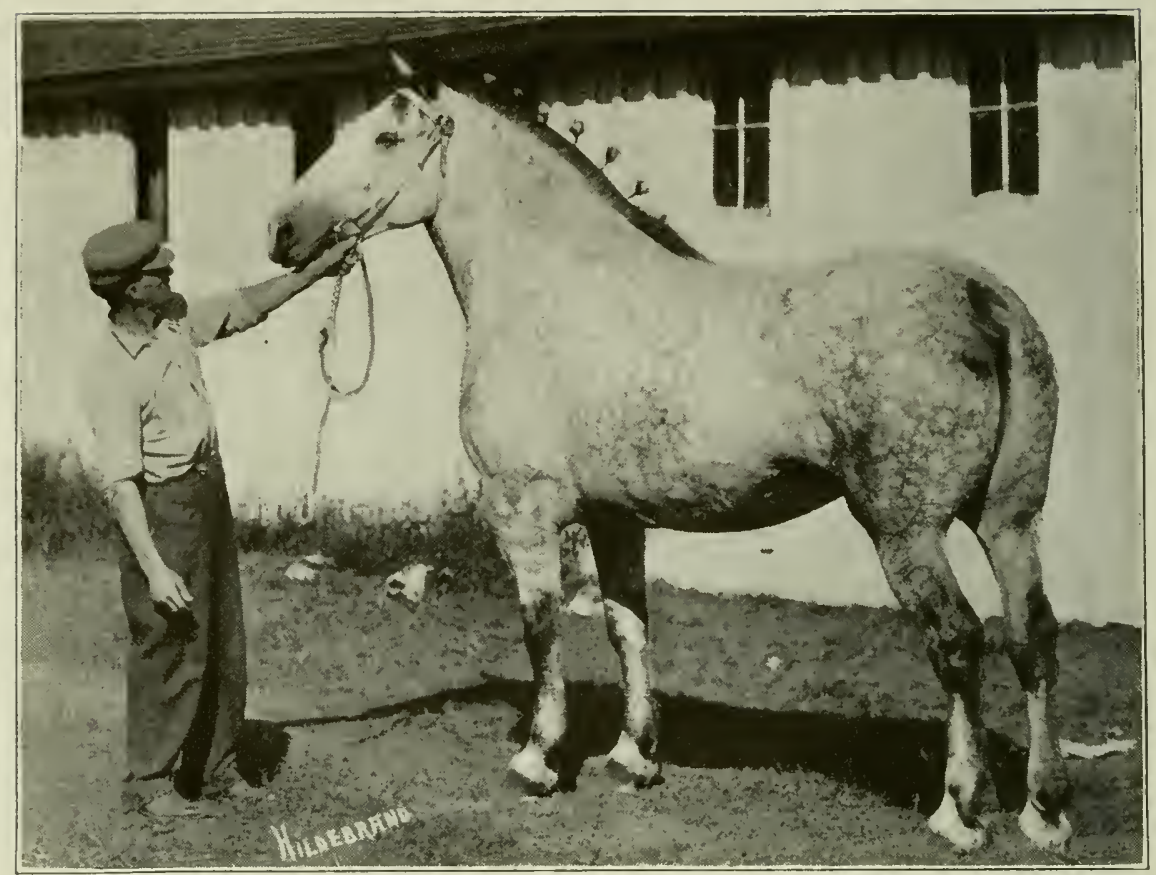

AMORITA 61314, CHAMPION MARE AT CHICAGO INTERNATIONAL, 1909.

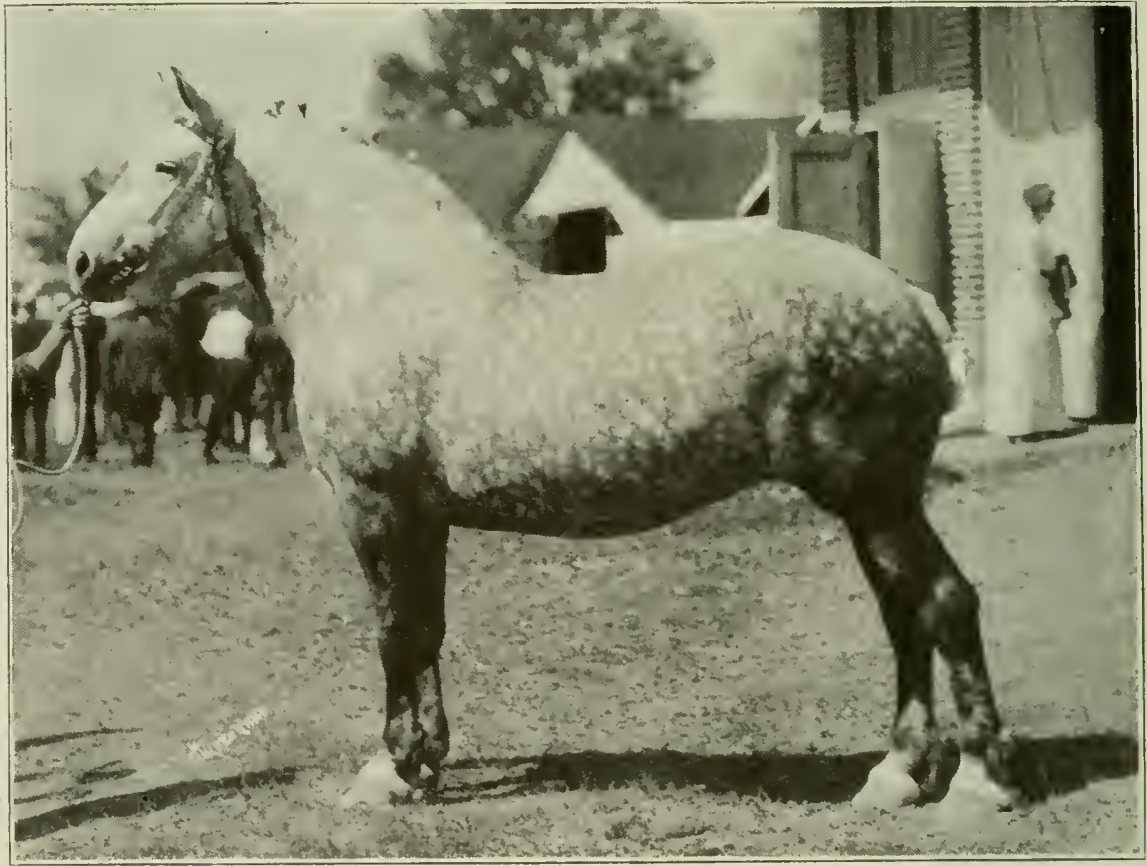

HERMINE 102198 (76134), CHAMPION MARE AT IOWA STATE FAIR, 1914. 
disfigure the animal, but is on the contrary a mark of merit, as it is evidence as to the identity of the breeder and the care used in his breeding operations.

"Almost all the states have statutes governing" brands, providing for legal records of same, and stipulating heavy penalties, usually a penitentiary sentence, for those who seek to deface or alter brands. Illinois has such statutes, and I see no reason why the Percheron Society of America should not have regulations providing that each breeder may adopt and have registered in the records of the society some specific brand which shall belong to him, and which shall not be infringed upon by any other breeder. John Brown might adopt the maple leaf as his symbol, and use it, with numbers following, to identify all his horses. In time the breeder of good horses would find the brand to be a valuable trademark, advertising him as the breeder wherever the horses might be used or shown. The careful, conscientious breeder has everything to gain by the adoption of a distinguishing brand to mark animals of his breeding. This, together with individual numbers for each Percheron, will make errors on the part of grooms impossible, will eliminate doubt or disputes as to the identity of animals, and will give intending purchasers added confidence in purchasing from a breeder who follows the system of branding all foals at weaning time in such manner as to give each individual identification numbers which are incorporated in the certificates of pedigree as a part of the description. I have used the plan for years, know it to be successful, and would not think of depending on any other system. Every breeder, for his own protection in dealing with employes and for the protection of his estate in 
case of his death, should adopt permanent marks for his Percherons. There is no system equal to copper branding irons, properly used." 



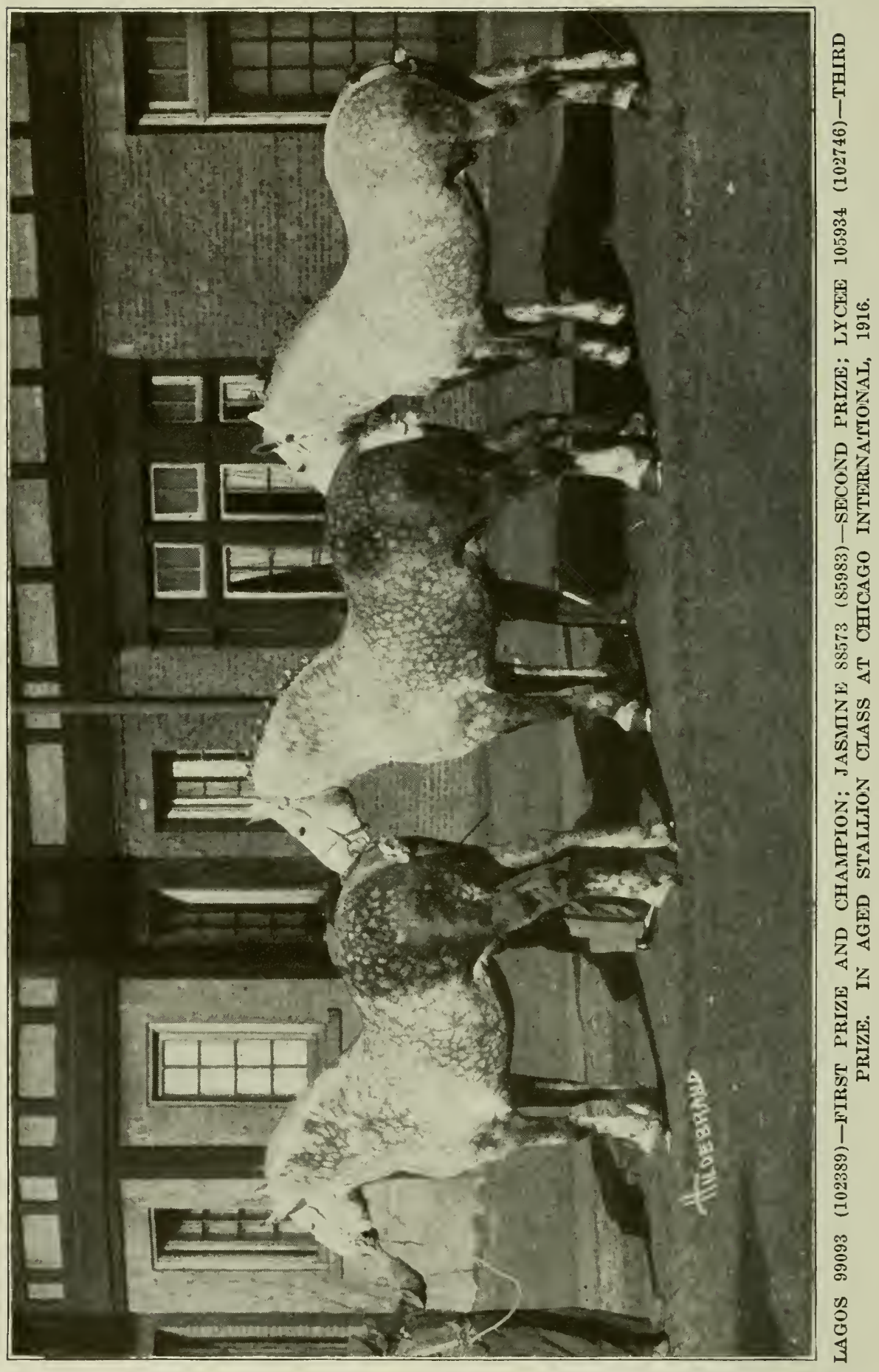




\section{GHAPTER XV.}

\section{BLOODLINES IN THE SHOWRING.}

We come now to the matter of an examination of the blood elements most largely represented in the breeding of the leading prizewinners of recent years at the two most important shows of France and the United States. This was undertaken not with a view to demonstrating the truth or falsity of any particular proposition, but merely as the presentation of the record as it actually exists. A study of these tabulations and summaries should prove of interest and value to present-day Percheron breeders.

The Breeding of Leading Winners.-The showring is to Percherons what the racetrack has been to Thoroughbreds and Standardbreds. It is the fiery crucible wherein the gold is separated from the alloy. When leading shows are considered, the winners represent the highest type which Percheron breeders have been able to produce. A Percheron of surpassing excellence in type, conformation and quality can no more escape the showring than a race horse of extraordinary speed can escape the racecourse, because hundreds of men are seeking out the most excellent animals to prove their merit by open competition in the showring. If successful, 
their value is greatly enhanced and their opportunities in the stud are widened. Sentiment among breeders is so strong, alert and well informed that the judging at the leading shows is in the long run representative of the best thought of the breeders of the period. Analysis of the showyard records and of the breeding of the winners is of great interest to all intelligent, thoughtful breeders.

An exhaustive study of the winning horses at the shows held in the Perche under the direction of the Société Hippique Percheronne de France from 1901 to 1910 inclusive discloses 1,418 which were awarded prizes in the individual classes. The large number is due to the French system of awarding several third and fourth prizes in each class. Only one first prize is awarded, but two second, two third, six fourth, seven fifth, and fifteen sixth prizes, so called, have sometimes been awarded. This is a scheme to aid sales, and wholly unjustified.

The names and numbers of the prizewinning horses at all these shows were tabulated, and opposite each was placed the name and numbers of the sire, grandsire and great-grandsire in the paternal line. It was found that 476 stallions appeared but once each in the 10 years as great-grandsires of winners. These were therefore eliminated from consideration. The 942 animals remaining trace to only 80 different great-grandsires, some of which appeared more frequently than others. The number of times each great-grandsire appeared during the 10 years is shown by the following summary: 
SUMLIARY NO. 2-1901 TO 1910 INCLUSIVE.

RANK OF STALLIONS ACCORDING TO THE NUMBER OF TIMIES THAT THET APPEARED AS GREAT-GRANDSIRES OF PRIZEWINNERS DURING THE 10 YEARS.

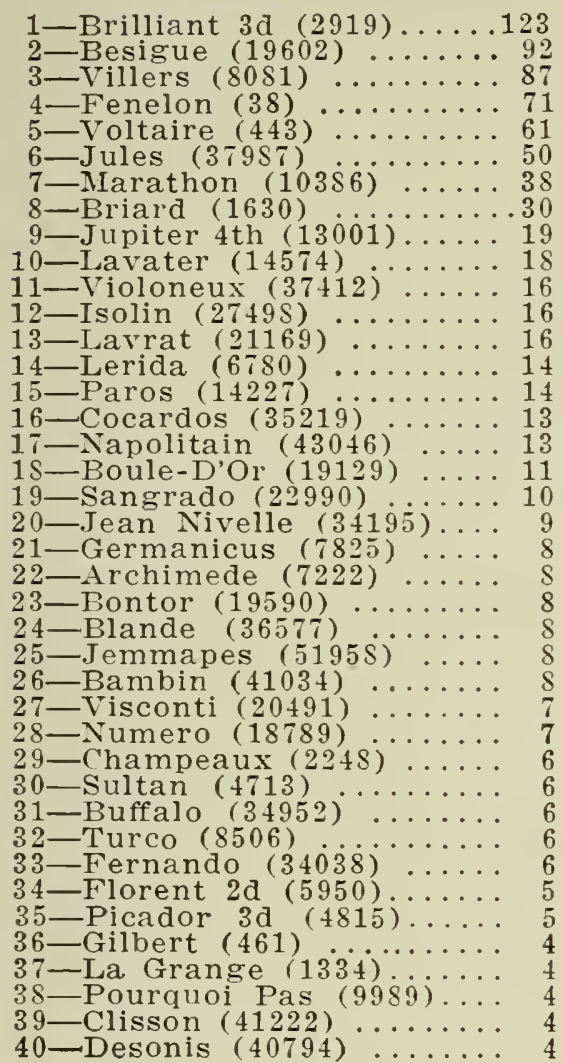

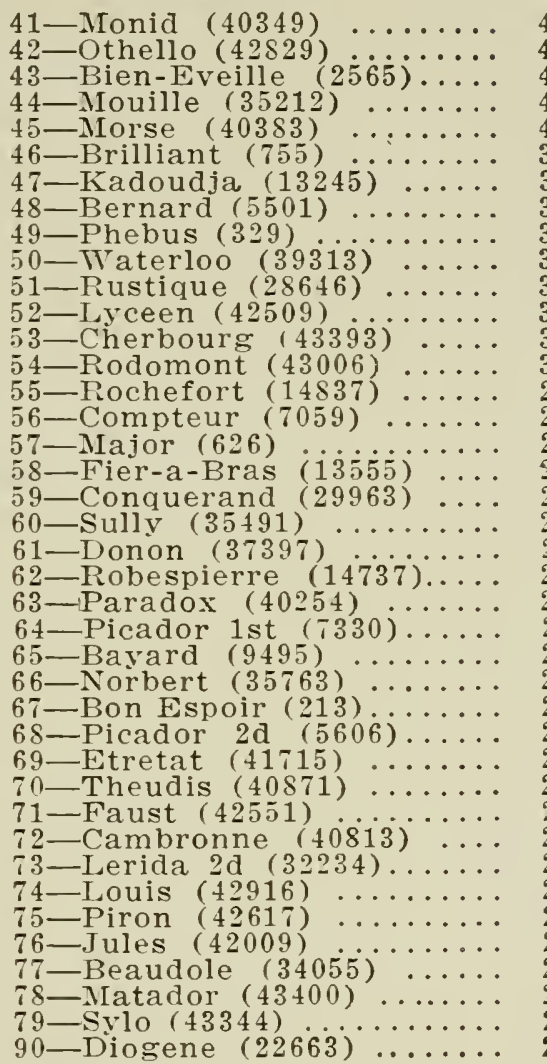

SYNOPSIS OF SUMMARY NO. 2

26 great-grandsires appear

9 great-grandsires appear

10 great-grandsires appear

2 great-grandsires appear

5 great-grandsires appear

2 great-grandsires appear

6 great-grandsires appear

1 great-grandsire appears

1 great-grandsire appears

1 great-grandsire appears

2 great-grandsires appear

2 great-grandsires appear

3 great-grandsires appear

1 great-grandsire appears

1 great-grandsire appears

8 great-grandsires appear
2 times

3 times

4 times

5 times

6 times

7 times

8 times

9 times

10 times

11 times

13 times

14 times

16 times

18 times

19 times

more than 20 times,

ranging from 30 to 123 
Of the 80 great-grandsires that appeared two times or more at any one show during the 10 years, 46, or 57 percent, were of Brilliant breeding.

Of the 1,418 animals at these shows, 942 trace directly to these 80 great-grandsires through their sire's line. The remaining 476 animals are unaccounted for ; they did not have a great-grandsire that appeared more than once at that year's show.

Of the 942, 724, or 76.8 percent, carry Brilliant blood. No doubt a great many of the animals trace to Brilliant blood in the succeeding generations beyond their great-grandsires. It is true that a great-grandsire might appear once at each show during the entire 10 years and yet not receive credit in this list.

The basis of this tabulation is the appearance of a great-grandsire at least two times in one show.

An interesting feature, not disclosed by this summary, but shown by the more extended figures, is that the stallion classes, while only slightly larger in number, carry a much larger percentage of the prominent bloodlines than do the mare classes.

Of the 8 stallions that ranked highest in the total of 80 common progenitors, all are of Brilliant breeding. To these particular great-grandsires stands the credit of having 58 percent of the total number of prizewinners whose great-grandsires are included in this list of common progenitors.

Brilliant $3 \mathrm{~d}^{\prime} \mathrm{s}$ * right to premier rank as a sire is

* The sire referred to throughout the text as Brilliant $3 d$ is Brilliant III 11116 (2919). 
abundantly proved by the showyard records. He appears as the great-grandsire of 123 of the winners, and his son Besigue stands second with 92 to his credit. The high estimate placed on Villers is also borne out by his appearance in third place, as the great-grandsire of 87 prizewinners. ' Fenelon, sire of Brilliant $3 d$, comes fourth, appearing as the great-grandsire of 71 of the winners. All of the first 8 horses appearing in this roll of honor are sons, grandsons, or great-grandsons of Brilliant 1271 (755), the sire that joined with his own sire, Brilliant 1899 (756), in founcling the Brilliant strain, dominating blood in the Percheron breed.

The most noted of these great ancestors did not win their high rank by heavy winnings of their descendants in any one or two years. On the contrary they have appeared as great-grandsires of winners year after year. This is shown by the following summary:

\section{SUMMLARY NO. 3-1901 TO 1910 INCLUSTVE}

RANK OF STALLIONS ACCORDING TO NUMBER OF SHOWS AT WHICH THEY APPEARED MORE THAN ONCE AS GREAT-GRANDSIRES OF PRIZEWINNING ANIMALS.

1. Brilliant $3 \mathrm{~d}$ (2919), in '01, '02, '03, '04, '05, '06, '07, $08,{ }^{\prime} 09,{ }^{\prime} 10.10$

2. Villers (8081), in '01, $02,{ }^{\prime} 03,{ }^{\prime} 04,{ }^{\prime} 05,{ }^{\prime} 00^{\prime}, 07,,^{\prime} 08,{ }^{\prime} 09, ' 10 \ldots 10$

3. Toltaire (443), in '01, '02, '03, $04,{ }^{\prime} 05,{ }^{\prime} 07,{ }^{\prime} 08,{ }^{\prime} 09, ' 10 \ldots . . .99$

4. Marathon (10386), in '01, '02, '03, '04, '05, '08, '09, '10.... 8

5. Fenelon (3S), in '01, $02,{ }^{\prime} 03,{ }^{\prime} 04,{ }^{\prime} 05,{ }^{\prime} 06,{ }^{\prime} 07 \ldots \ldots \ldots \ldots \ldots 7$

6. Besigue (19602), in '04, '05, '06, '07, $08,{ }^{\prime} 09,{ }^{\prime} 10 \ldots \ldots \ldots \ldots 7$

7. Lavater (14574), in '01, $02,{ }^{\prime} 03,{ }^{\prime} 07$, 'OS ............. 5

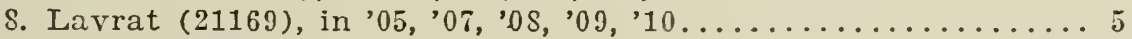

9. Cocardos (35212), in '04, $05,{ }^{\prime} 07,{ }^{\prime} 08,{ }^{\prime} 00 \ldots \ldots \ldots \ldots \ldots \ldots . \ldots$

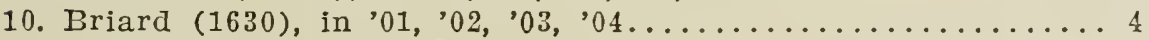

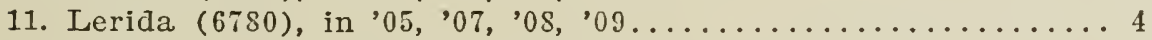

12. Jupiter 4 th $(13001)$, in '04, '0s, $09,10 \ldots \ldots \ldots \ldots \ldots \ldots$

13. Boule D'Or (19129), in '04, '06, '07, '10........... 4

14. Jules $(37987)$, in 07 , $08,{ }^{\prime} 09,{ }^{\prime} 10 \ldots \ldots \ldots \ldots \ldots \ldots \ldots$ 
SUMMART NO. 3-1901 TO 1910 INCLUSIVE (Continued).

15. Violoneux (37412), in $07,{ }^{\prime} 08,{ }^{\prime} 09,{ }^{\prime} 10 \ldots \ldots \ldots \ldots \ldots \ldots \ldots \ldots 4$

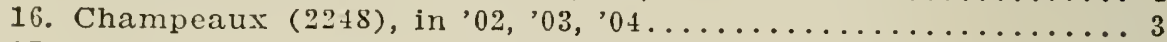

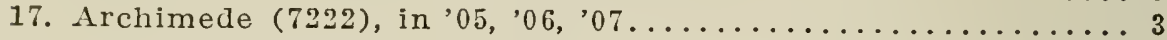

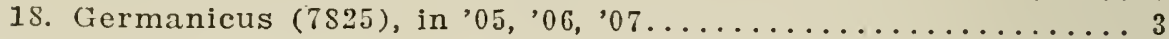

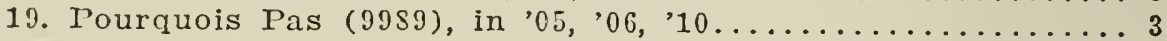

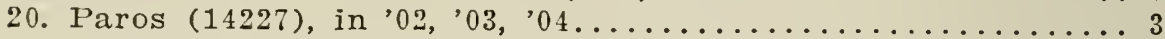

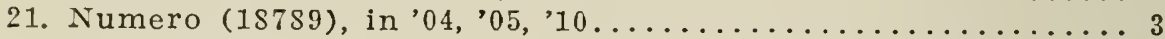

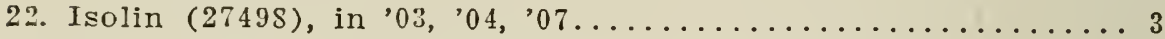

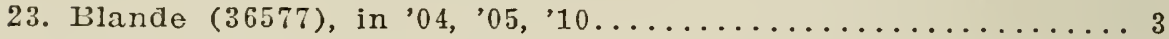

24. Jean Nivelle (34195), in '06, '0s, $09 \ldots \ldots \ldots \ldots \ldots \ldots \ldots \ldots$

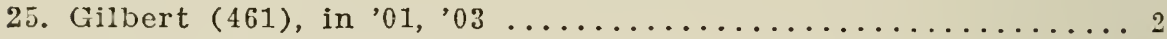

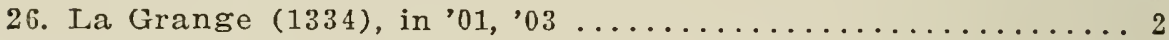

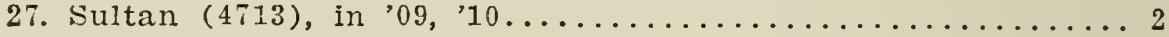

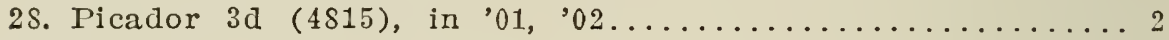

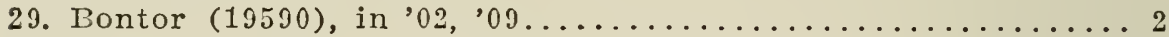

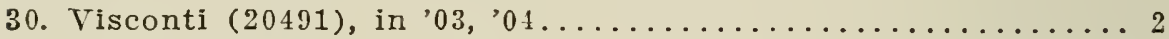

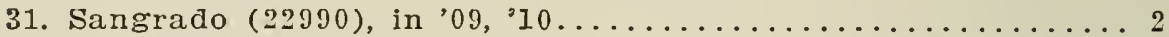

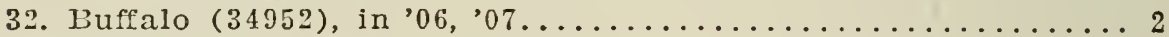

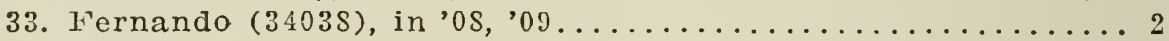

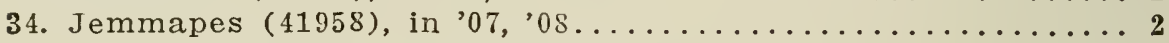

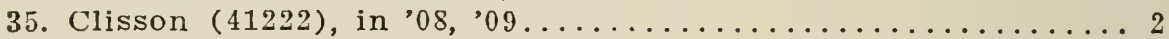

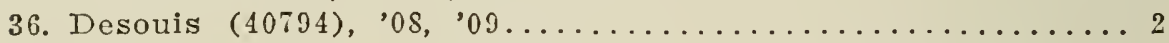

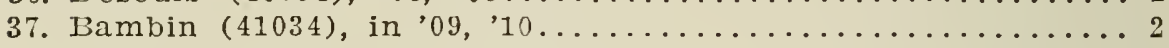

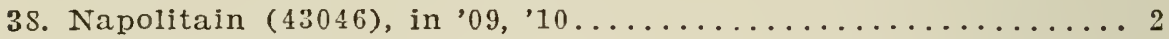

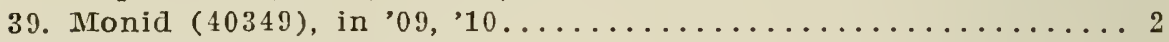

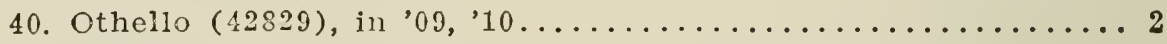

\section{Breeding of Prizewinners at French Shows.-}

For the benefit of students of animal breeding, the first-prize winners at the shows held under the auspices of the Percheron Society of France from 1901 to 1910, inclusive, were selected and their breeding traced out in detail to the eighth generation, or, where the breeding did not extend so far, to its uttermost limits. There were three stallions and four mare classes at each of these shows.

The detailed breeding of the seventy animals in question was submitied to Prof. E. N. Wentworth, of the Kansas Agricultural College, for analysis as to the percentages of blood of the leading strains represented, the total shown on each pedigree being 
taken as 100 percent. This is not absolutely accurate, but is near enough for all practical purposes.

In computing the proportion of blood of the leading sires, duplications were avoided, and where, as in the first instance given, a pedigree is said to contain 12.5 percent of the blood of Brilliant 1271 (756) and 18.75 percent of the blood of Brilliant 1899 (755), we mean that the particular animal involved carries 18.75 percent of the blood of Brilliant 1899 (755) through other lines than Brilliant 1271 (756). Where Coco 2d (714) is listed, his blood comes down through other strains than the Brilliant, every precaution being taken to avoid duplications in these calculations. The figures show the percentage of the blood of leading sires carried:

TABLE I.-WINNERS AT THE 1901 SHOW.

Class 1.-Stallions.

CHAMBELLAN 27349 (46787).

Brilliant 1271 (756) ...12.5

Brilliant $1899(755) \ldots 18.75$

Coco 2d (714) .......6.25

Farori 1st ( 711$) \ldots \ldots .7 .8125$

Class 2.-Stallions.

SCIPION 27123 (43667).

Brilliant $1271 \quad(756) \ldots 21875$

Brilliant $1899 \quad(755) \ldots 6.25$

Coco 2d (714)....... 3.125

Favori 1st (711)..... 1.5625

Class 3.-Stallions.

ORANGISTE 29606 (45088).

Brilliant 1899 ( 755$) \ldots 6.25$

Brilliant 1271 (756) . . 3.125

Favori 1st (711)..... 3.90625
Class 1.-Mares.

EGLANTINE $30011(48070)$.

Percent

Brilliant 1271 ( 756$) \ldots 20.3125$

Brilliant 1899 ( 755$) \ldots 9.375$

Coco 2d ( 711$) \ldots \ldots \ldots 7.8125$

Favori 1st (711).... 7.03125

Class 2.-Mares.

DOCILE (35823).

Brilliant 1271 ( 756$) \ldots 12.05$

Class 3.-Mares.

REINE (48062).

Brilliant 1271 (756) ...12.5

Brilliant 1899 ( 755$) \ldots 9.375$

Coco 2d (714)....... 7.0312.

French Monarch (734) 4.6875

Favori 1st (711) ..... 3.5156

Class 4.-Mares.

TENEBREUSE 30013 (45615).

Fercent

Brilliant 1899 ( 755$) \ldots 12.5$

Favori 1st (711)...... 7.8125

Brilliant 1271 (756) ...66.25

Champeaux (2248)...6 6.25

Coco 2d (714)....... 1.5625 


\section{TABLE II.-WINNERS AT THE 1902 SHOW.}

Class 1.-Stallions.

PIRRHUS 29563 (44643).

Percent

Brilliant 1271 (756) . 3.6575

Coco $2 \mathrm{~d} \quad(714) \ldots \ldots .3 .515625$

Brilliant 1899 (755) . 3.125

Favori 1st (711).... 3.125

Class 2.-Stallions.

ORANGISTE 29606 (450S8).

See Table I.

$$
\text { Class 3.-Stallions. }
$$

PAUL 29885 (47477).

Percent

Brilliant 1271 (756) ...15.625

Favori 1st (711)..... 7.8125

Brilliant $1899(755) \ldots 6.25$

Coco 2d (714)....... 4.6875
Class 1.-Mares.

EGLANTINE 30011 (48070).

See Table I.

Class 2.-Mares.

DOCILE (35823).

See Table I.

Class 3.-Mares.

TENEBREUSE 31501 (48069).

Percent

Champeaux (2248)... 6.25

Favori 1st (711) ..... 4.6875

Coco 2d (714)........ $\mathbf{1 . 5 6 2 5}$

Brilliant $1271(756) \ldots 1.5625$

Class 4.-Mares.

OMBRELIE $30010 \quad(50329)$.

Percent

Champeaux (2248)...6 6.25

Brilliant 1271 (756) ... 4.6\$75

Brilliant 1899 ( 755$) \ldots 3.125$

Favori 1st (711)..... 3.125

TABLE III.-WINNERS AT THE 1903 SHOW.

Class 1.-Stallions.

TELEMAQUE 34104 (44762).

Champeaux (2248)...18.75

Favori 1st (711)...13.671875

Brilliant 1271 ( 756$) \ldots 6.25$

Brilliant 1899 (755) . 3.125

Coco 2d (714) ..... 3.125

Class 2.-Stallions.

UNIVERS 33977 (47622).

Brilliant 1899 (755) ..18.75

Brilliant 1271 (756) ..15.625

Favori 1st (711)....14.84375

Coco $2 \mathrm{~d}(714) \ldots \ldots .390625$

Class 3.--Stallions.

CASCADEUR 33977 (53120).

\section{Percent}

Coco 2d (714)......11.71875

Brilliant 1271 ( 756$) \ldots 6.25$

Brilliant 1899 ( 755$) \ldots 6.25$

Favori 1st (711) .... 5.859375

French Monarch (734) 1.5625
Class 1.-Mares.

DOCILE (35823).

See Table I.

$$
\text { Class 2.-Mares. }
$$

CASTILLE 344SS (47121). Percent Brilliant 1899 (755) ...18.75

Favori 1st (711).....14.0625

Brilliant 1271 (756) .. 9.375

Coco 2d (714)....... 7.8125

Class 3.-Mares.

FAISANT 41215 (46330).

Favori 1st (711) .. 6.25

Brilliant 1899 ( 755$) \quad 6.25$

Coco 2d (714).... 5.46875

Brilliant 1271 (756) 3.125

French Monarch (734) .73415625

Class 4.-Mares.

ERMANTRUDE 41203 (51\$27).

Percent

Brilliant 1271 (756) . 4.6875

Favori 1st (711).... .390625 
TABLE IV.-WINNERS AT THE 1904 SHOW.

Class 1.-Stallions.

ELECTEUR 41264 (46264).

Brilliant 1899 (755)..12.5

Brilliant 1271 (756) ..12.5

Coco $2 \mathrm{~d}$ (714)......6. 6.25

Favori 1st (711).... 3.90625

Class 2.-Stallions.

VICTOR HUGO (52791).

Brilliant 1271 ( 756$) \quad 20.3125$

Brilliant 1899 (755) . 15.625

Favori 1st (711)....99.76592j

Coco 2d (714).....6.6.640625

Class 3.-Stallions.

CHICHI ( 54591 ).

Brilliant 1271 (756) $\begin{array}{r}\text { Percent } \\ \text { B } 10.4375\end{array}$

Brilliant 1899 ( 755$) \ldots 9.375$

Coco 2d (714)....... 5.46875

Favori 1st (711).... 3.515625

French Monarch (734) 1.5625
Class 1.-Mares.

ROSETTE 52054 (4.8054).

Brilliant 1271 ( 756$) \quad \begin{aligned} & \text { Percent } \\ & 9.375\end{aligned}$

French Monarch (734).. 9.375

Brilliant 1899 (755) ... 6.25

Favori 1st (711) .....6. 6.25

Coco $2 \mathrm{~d}(714) \ldots \ldots \ldots .3 .125$

Class 2.-Mares.

DOCILE (35823).

See Table I.

Class 3.-Mares.

BLANCHETTE (51576).

Coco $2 \mathrm{~d}$ (714)...... 3.515625

Brilliant 1899 ( 755$) \ldots 3.125$

Favori 1st (711)..... 1.953125 Class 4.-Mares.

XERES (54751).

Brilliant 1271 ( 756$)$

Brilliant 1899 ( 755$) \ldots 7.8125$

Favori 1st (711)...4 4.296875

Coco $2 d(714) \ldots \ldots \ldots 2.34375$

TABLE V.-WINNERS AT THE 1905 SHOW.

Class 1.-Stallions.

RATISSANTE (46514).

Brilliant 1899 (755)..12.5

Brilliant 1271 (756) .. 6.25

Favori 1st (711)..... 5.46875

Coco 2d (714)....... 3.125

Class 2.-Stallions.

FLAMBART (54628).

Brilliant $1271 \quad(756) \quad \ldots 15625$

Champeaux (734).....6. 6.25

Brilliant 1899 ( 75$) \ldots \ldots .3 .125$

Favori 1st (711)...... 3.125

Coco $2 d \quad(714) \ldots \ldots \ldots .3 .125$

Class 3.-Stallions.

MONACO 45896 (58631).

Favori 1st (711) ...... 9.375

Coco 2d (714)....... 9.375

Brilliant 1271 (756) .... 9.375
Class 1.-Mares.

FOSSETTE 46039 (4522J).

Percent

Brilliant 1271 (756)..10.9375

Favori 1st (711)......10.15625

Brilliant 1899 ( 755$) \ldots 9.375$

Coco 2d (714)......6. 6.25

French Monarch (731) 3.125

Class 2.-Mares.

PAQUERETTE (4\$593).

French 70 arch $(734)$.

Brilliant 1271 (756)...4.6875

Brilliant $1899 \quad(755) \ldots 3.125$

Favori 1st (711).... 3.125

Coco $2 \mathrm{~d}$ (714)........ 1.5625

Class 3.-Mares.

XIMENES (55074).

Brilliant 1899 (755).14.0625

Brilliant 1271 ( 756$) .9 .375$

Favori 1st (711)...6. 6.8359375

Coco 2d (714)..... 2.34375

Class 4.-Mares.

LISETTE 85118 (58368).

Percent

Brilliant 1271 ( 756$) \ldots 4.6875$

Brilliant 1899 ( 75$) \ldots \ldots 6.25$

Favori 1st (711)...... 6.25 
TABLE VI.-WINNERS A'T THE 1906 SHOW.

Class 1.-Stallions.

BIBI 95697 (52612).

Brilliant 1271 (756) 10.9375

Favori 1st (711) ....99.375

Coco $2 \mathrm{~d}(714) \ldots \ldots . \$ .59375$

Brilliant 1899 (755) . 6.25

Class 2.-Stallions.

DIMITRI (58251).

Brilliant 1271 (756) Percent

Favori 1st (711)....12.109375

Brilliant 1899 (755) . 10.9375

Coco 2d (714)...... .78125

Class 3.-Stallions.

GUERIDON (64253).

Brilliant $1899(755) \ldots 15.625$
Brilliant $1271 \quad(756) \ldots 11.71875$
Favori 1st $(711) \ldots \ldots 6.640625$
Coco 2d $(714) \ldots \ldots .2 .34375$
Class 1.-Mares.

MARTHA (43811).

Brilliant $1271 \quad(756) \ldots 3.125$

Favori 1st (711)....2. 2.31375

Class 2.-Mares.

BICHE (50061).

Champeaux (734)...12.5

Brilliant 1271 (756) . 9.375

Favori 1st (711)..... 7.03125

Brilliant 1899 (755) ..6 6.25

Coco 2d (714)....... 1.5625

Class 3.-Mares.

DEMOISELLE $4622 \mathrm{~S}$ (58468).

Percent

Brilliant 1271 (756)..22.65625

Brilliant 1899 (755)..20.3125

Favori 1st (711)...8 8.54375

Coco $2 d \quad(714) \ldots \ldots 6.640625$

Class 4.-Mares.

ETONNANTE 46233 (63090).

Brilliant 1899 (755)..18.75

Percent

Brilliant 1271 (756)..17.1875

Coco 2d (714)......99.76562 b

Favori 1st (711).... 9.375

TABLE VII.-WINNERS AT THE 1907 SHOW.

Class 1.-Stallions. COCO $\$ 3035$ (60171).

Brilliant 1271 ( 756$) \ldots 6.25$

Coco $2 \mathrm{~d}$ (714)...... 1.171875

Class 2.-Stallions.

MYLORD 54216 (64236).

Percent

Brilliant 1899 ( 755$) \ldots 21.875$

Brilliant 1271 (756)..15.625

Favori 1st (711).... 9.765625

Coco 2d (714)...... 2.34375

Class 3.-Stallions.

ATOCAT (66303).

Percent

Favori 1st (711)... 7.2265625

Coco 2d (714)..... 4.296875

French Monarch (734) 1.5625

Brilliant 1899 (755) $\mathbf{1 . 5 6 2 5}$

Brilliant 1271 (756) 1.5625
Class 1.-Mares.

BICHE (50061).

See Table VI.

Class 2.-Mares.

ROSETTE 52054 (4S054).

See Table IV.

Class 3.-Mares.

COQUETTE (69196).

Percent,

Favori 1st (711)... 7.421875

Coco 2d (714)...... 2.34375

Brilliant 1271 (756) . 1.5625

Class 4.-Mares.

MIRZA 51879 (67199).

Brilliant 1899 (755).. 9.375

Favori 1st (711)...6 6.640625

Coco 2d (714).....6 6.640625

French Monarch (734) 5.46875 
TABLE VIII.-WINNNERS AT THE $190 \mathrm{~S}$ SHOW.

Class 1.-Stallions.

ETUDIANT 70S02 (59291). Percent

Brilliant 1899 (755).10.9375 Brilliant 1271 (756). $\$ .59375$

Favori 1st (711)... 4.4921875

Coco 2d (714)...... 1.953125 Class 2.-Stallions.

AVOCAT (66303).

See Table YII. Class 3.-Stallions.

GRENADIER 55941 (70250).

Favori 1st (711)...4 4.1015625

Picador 1st ( 7330$) \ldots 3.125$

Coco 2d (714)..... 2.5390625

Brilliant 1271 (756). 2.34375

Brilliant $1899 \quad(755) \quad 1.625$

French Monarch (734) 1.625 Class 1.-Mares.

MAUDE (51487).

Favori 1st (711) ..... Percent

Brilliant 1271 (756) .. 3.125

Coco 2d (714)........ .78125
Class 2.-Mares.

XANTHOUETTE (55429).

Favori 1st (711) ..... 8.59375

Champeaux (734).... 6.25

Brilliant 1899 ( 755$) \ldots 3.125$

Brilliant 1271 ( 756$) \ldots 3.125$

Coco 2d (714)....... 1.5625

Class 3.-Mares.

LEVRETTE (6\$225).

Percent

Brilliant 1271 ( 756$) \ldots 4.6875$

Picador 1st (7330)... 3.125

Favori 1st (711).... 3.125

French Monarch (734) 1.953125

Brilliant 1899 (755).. 1.5625

Coco 2d (714)...... .390625

Class 4.-Mares.

GAULOIS 55284 ( 75180$)$.

Brilliant $1271(756) \cdot 7.8125$

Brilliant 1899 (755). 6.25

Favori 1st (711).... 5.6640625

French Monarch (734) 4.6875

Coco 2d (714)..... 3.515625

TABLE IX.-WINNERS AT THE 1909 SHOW.

Class 1.-Stallions.

ETUDIAN'T (70802) (59291).

See Table VIII.

Class 2.-Stallions.

GALOP (69sss).

Percent

5.90625

Coco 2d (714)..... 3.515625

Favori 1st (711)... 3.3203125

Brilliant 1271 (756). 2.34375

Picador 1st (7330).. 1.5625

Class 3.--Stallions.

HONORABLE 64381 (74813).

Percent

Favori 1st (711) ...6.73828125

Brilliant 1271 ( 756$) \quad 6.25$

French Monarch (734)......... 5.46875

Brilliant 1899 (755) 4.6875

Coco 2d (714).... 1.7578125
Class 1.-Mares.

HERMINE 61987 (74197).

Percent

Brilliant 1271 (756).25.7\$125

Favori 1st (711) .... 9.1796875

Brilliant 1899 (755) 7.8125

Coco 2d (714)..... 1.953125

French Monarch (734) $\quad .78125$

Class 2.-Mares.

GAULOIS 61979 ( 75176$)$.

Brilliant 1271 (756).10.9375

Brilliant 1899 ( 755$)$. 6.25

Favori 1st (711)...5 5.07\$125

Coco 2d (714)..... 4.1015625

Picador 1st (7330).. 3.125

Champeax (734)... 3.125

Class 3.-Mares.

ERICA (68318).

Percent

Brilliant 1271 (756). 4.6875

Favori 1st (711).... 3.125

Brilliant 1899 (755).. 1.5625

Coco 2d (714)...... .7\$125

French Monarch (734) .390625

Class 4.-Mares.

DOCILE (69234)

Percent

Picador 1st (7330).....6.25 
TABLE X.-WINNERS AT THE 1910 SHOW.

Class 1.-Stallions.

FIER-A-BRAS (65250).

Coco $2 \mathrm{~d}$ ( 714$) \ldots \ldots$. Percent

Brilliant 1271 (756). 5.45425

Brilliant 1899 ( 755 ) 4.6875

Favori 1st (711)...4 4.296875

Class 2.-Stallions.

HELIX 70340 ( 75752$).$

Favori 1st (711) Percent

Brilliant 1899 ( $755 j \cdots 5.646875$

Brilliant 1271 (756) . 3.125

Coco $2 \mathrm{~d}(714) \ldots \ldots \ldots .78125$

Class 3.-Stallions.

INCOMIPRISS 78960 (79751).

Coco $2 d$ (714) ..... 7.8125

Favori 1st (7ii) ...66.4453125

Brilliant $1271(756)$. 3.90625

French Monarch (734) 3.515625

Brilliant 1899 ( 755$)$. 3.125

Class 1.-Mares.

INFRANCHISSABLE 70267 (82233).

Picador 1st (7330).6.25 Percent Brilliant 1271 (756): 3.515625

Favori 1st (711)...2 2.9296875

Brilliant $1899(755)$. 2.34375

Coco $2 \mathrm{~d}(714) \ldots . . .78125$
Class 2.-Mares.

PIOCHETTE 70479 (75519).

Brilliant 1271 (756) $\$ .59375$

Brilliant 1899 (755) 7.8125

Coco 2d (714).... 7.03125

Favori 1st (711)... 5.46875

French Monarch

(734)......... .73446875

Class 3.-Mares.

FAVORITE 70281 (87784).

Percent

Brilliant 1899 (755).17.1875

Coco 2d (714)......10.7421875

Brilliant 1271 (756) . 9.375

Favori 1st (711)...7 7.03125

Class 4.-Mares.

ALISE 79311 (58009).

Brilliant 1899 (755) 7.8125

Brilliant 1271 (756) 7.8125

French Monarch

(734)......... 7.8125

Favori 1st (711)..66.4453125

Coco 2d (714).... 1.97265625

\section{Breeding of International Prizewinners.-The} breeding of the imported horses that appear as prizewinners at the International Live Stock Exposition from 1900 to 1910 inclusive corresponds so closely to the French records just discussed as to require no further comment. An analysis has been made. however, of the breeding of all American-bred horses winning prizes at these International shows, and as a matter of interest the sires, grandsires, and great. grandsires appearing two or more times in the pedigrees of the winners are given, with the number of prizes won by descendants. It will be noted that the ranking sire is by the ranking grandsire, and he by the ranking great-grandsire, and that the second 



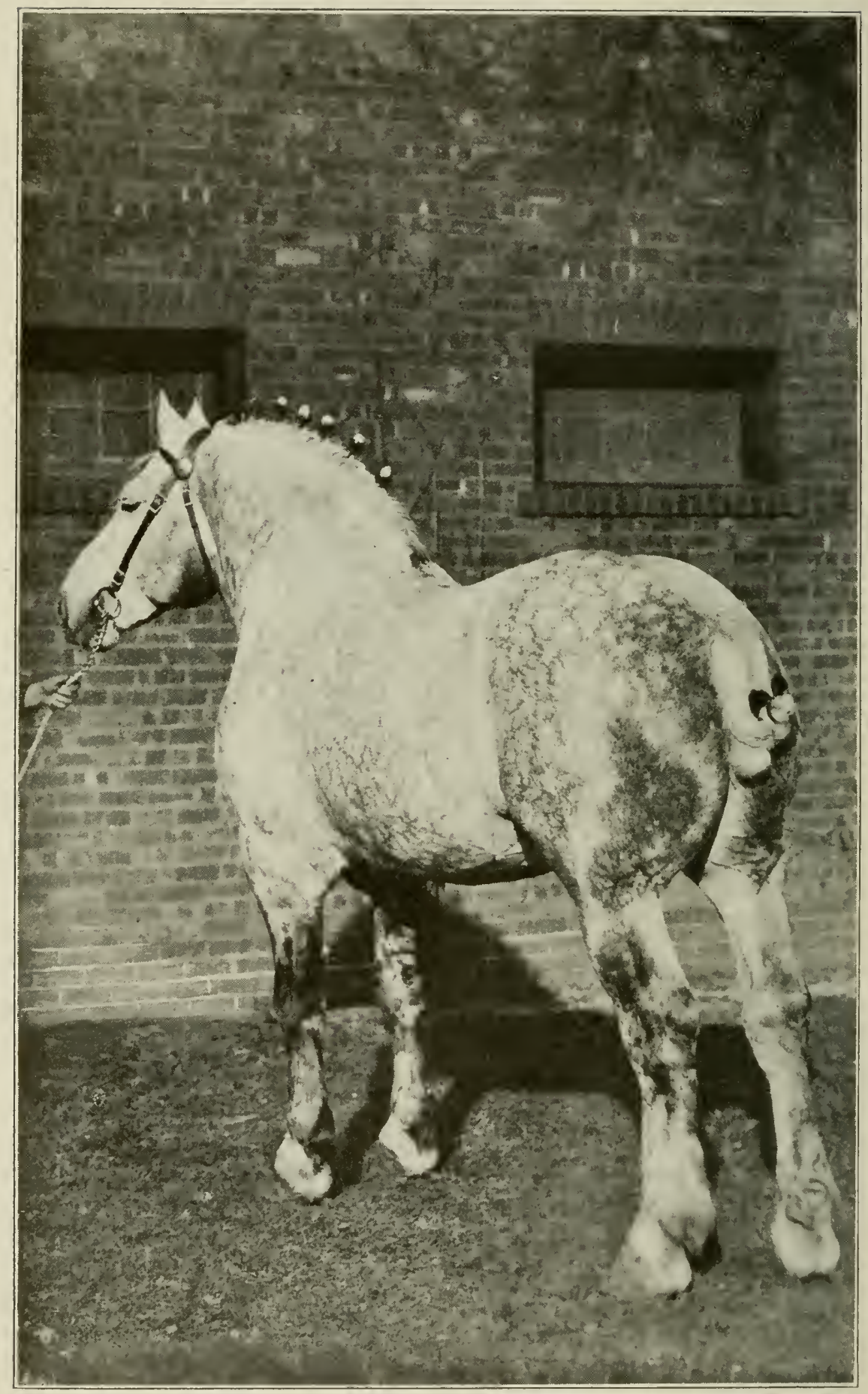

JALAP 80583 (85614)-CHAMPION AT 1915 IOWA SPRING STALLION SHOW: PROGENY WON GET-OF-SIRE PRIZE AT PANAMA-PACIFIC INTERNATIONAL EXPOSITION, 1915. 
highest sire of winners is by the second highest grandsire. Here the consistency ends, however, as Marathon is the second highest great-grandsire, but is not the sire of Highland Chief.

Prizes won by

American-bred

Sires

Calypso 25017 (44577) .......38

Superior $40605 \ldots \ldots \ldots \ldots . \ldots 15$

Salvanos $10827(20922) \ldots \ldots \ldots 12$

Rhum Jr. $21627 \ldots \ldots \ldots \ldots . . .99$

Cadmus $2162(92 \dot{9}) \ldots \ldots \ldots \ldots . .8$

Boer $24267(44611) \ldots \ldots \ldots \ldots 7$

Aride $25056(45424) \ldots \ldots \ldots \ldots .7$

Villers $13169(8081) \ldots \ldots \ldots \ldots$

Picador $27370(48373) \ldots \ldots \ldots$

Olbert $42815 \quad(53109) \ldots \ldots \ldots \ldots$.

Brunelles $11415(12162) \ldots \ldots .5$

Volage $48578(55179) \ldots \ldots \ldots .5$

King of Highland $16341 \ldots \ldots$.

Ali 20012

Putnam 2 $\dot{3} \dot{2} \dot{i}$

Pink $24765(47513) \ldots \ldots \ldots \ldots \ldots$

Constantin $35228(4 \$ S 90) \ldots . .4$

Hercules $21564 \ldots \ldots \ldots \ldots . \ldots 3$

Iorse $22714 \quad(40 \dot{0} \dot{\delta} \dot{3}) \ldots \ldots . . . .$.

Saphir $32834(46498) \ldots \ldots \ldots \ldots 3$

Lamy $46057(56473) \ldots \ldots \ldots \ldots 3$

Brilliant $1271(755) \ldots \ldots \ldots \ldots 2$

Fils de Jupiter 11413 (9992) ..

Sansonnet $4300(1990) \ldots \ldots \ldots$.....

La Grange $20372 \ldots \ldots \ldots \ldots . . . .2$

Invincible $22715(3 \dot{s} 107 j \ldots . .2$

Highland Monarch $40607 \ldots .$.

Soldat $31084(47533) \ldots \ldots \ldots .2$

Hyacinthe $26723(4 \$ 386) \ldots .$.

Kimberly $25726(44616) \ldots \ldots .2$

Villageois $27423(44898) \ldots . .$.

Kabyle $24761 \quad(44167) \ldots \ldots \ldots . .2$

Artiste $31529 \quad(47528) \ldots . . . \ldots$

Paquebot 35048 (47609)....... 2

Armor $46682 \ldots \ldots \ldots \ldots$

Russo $45802(61861) \ldots \ldots \ldots \ldots .2$

Brocanteur $30393(51632) \ldots \ldots .2$

Breslie 43904 (59812)....... 2

\section{Grandsires}

Theudis 25015 (40871)......40

Highland Chief $23744 \ldots \ldots \ldots 15$

Fernando (3403s) ......................

Grevin $6846(6892) \ldots \ldots \ldots \ldots 12$

Rhum 11288 (13173) ......... 9

Victoria $24449(42905) \ldots \ldots . .99$

Brilliant $1271(755) \ldots \ldots \ldots \ldots 8$

Besigue $(19602) \ldots \ldots \ldots \ldots . . . . .8$

Dominant $5146(2017) \ldots \ldots \ldots 6$

Briard $5317(1630) \ldots \ldots \ldots \ldots 6$

Brutus $(34739) \ldots \ldots \ldots \ldots 6$

Aiglon $13145(8187) \ldots \ldots \ldots \ldots$

Scheret 8948 (15793) ....... 5

Han Brion $10708(19918) \ldots \ldots 5$

Blande $29259(36577) \ldots \ldots \ldots 5$

Artilleur $27348(46769) \ldots \ldots \ldots 5$
Prizes won by

American-bred descendants

Orpin 24388 (43279).......4

Confident $3647(397) \ldots \ldots \ldots . .3$

Mirabeau $(34778) \quad \ldots \ldots \ldots \ldots . . .3$

Napolitain $22882(43046) \ldots \ldots 3$

Charlemagne $22713(40167) \ldots 3$

Brilliant $1899(756) \ldots \ldots \ldots .2$

Jupiter $4301(2243) \ldots \ldots \ldots \ldots . .2$

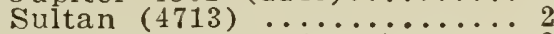

Producteur 1st $(7657) \ldots . . .2$

Porthos 6823 (10594).........

Parfait $3 \mathrm{~d} 10727(12939) \ldots . .2$

Baccarat $11326(18639) \ldots \ldots \ldots 2$

Black Diamond $26279 \ldots \ldots \ldots 2$

Myron $(20690) \ldots \ldots \ldots \ldots . . . . .2$

Beaudole $(34055) \ldots \ldots \ldots . . \ldots 2$

Diogene $(41294) \ldots \ldots \ldots \ldots 2$

Casino $40580(468 \div 5) \ldots . . . .2$

Raphael $25047(43483) \ldots \ldots \ldots 2$

Olga $22736(43283) \ldots \ldots \ldots 2$

Rivoli $33848(46722) \ldots \ldots \ldots 2$

Rayon D'Or $(\$ 4266) \ldots . . . .$.

Great-grandsires

Besigue (19602) ..........52

Marathon (10386) $\ldots \ldots \ldots \ldots 16$

Sensation $22544 \ldots \ldots \ldots \ldots 15$

Brilliant $3 d$ (2919)..........13

Brilliant 1271 (755) ............

La Grange $3065(1334) \ldots \ldots \ldots 12$

Chicago $6947(74 \$ 5) \ldots \ldots \ldots . .99$

Bienfaisant (1397) ........6 6

Monarque $5149(2428) \ldots \ldots \ldots 6$

Brilliant 1899 (756)........6. 6

Germanicus (7825) ........6

Gilbert (461) ......... 5

King of Perche $4975(6738) \ldots 5$

Ney $(40287) \ldots \ldots \ldots \ldots \ldots \ldots 4$

Jules (37987) ….........

Saint Germain 6252 (4315)...3

Donon $(37397) \quad \ldots 3 \dot{9} \times \ldots \ldots 3$

Malakoff 15753 (29888)......

Rochambeau (13\$2) .........

Vaillant $(404) \ldots \ldots \ldots \ldots \ldots 2$

Coco 2d (714)............

Jean Bart (716) ...........

Favora $1542(765) \ldots \ldots \ldots \ldots 2$

Bayard (9495) $\ldots \ldots \ldots \ldots \ldots 2$

Cheri 6024 (6903) $\ldots \ldots \ldots \ldots 2$

Fils de Jupiter 11413 (9992) . 2 2

Parfait 3d 10727 (12939)...2 2

Patache (42261) …일..

Charlemagne $2271 \dot{3}(40167) \ldots 2$

Mery $(29834)$. $\ldots \ldots \ldots \ldots \ldots$.

Paumier $(24581)$
Victoria $24449(42905) \ldots \ldots \ldots$. 
This table shows the rank of the sires, grandsires and great-grandsires of the American-bred Percherons winning prizes at the International from 1900 to 1910 inclusive. Group awards are not included in this list. This calculation takes into account every sire, grandsire or great-grandsire that appeared more than once in the pedigree of an American-bred International winner during the 10 years. The number opposite each name represents the number of prizes awarded to sons or daughters, grandsons or granddaughters, or great-grandsons or great-granddaughters of the stallion in question. 





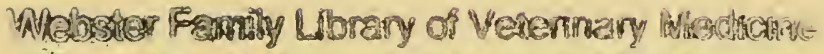
Cumwings School of Vesterinany Medichns a Tuits University 200 Westboro Roxa

Norfoth Gration, MP. OM 5. 

